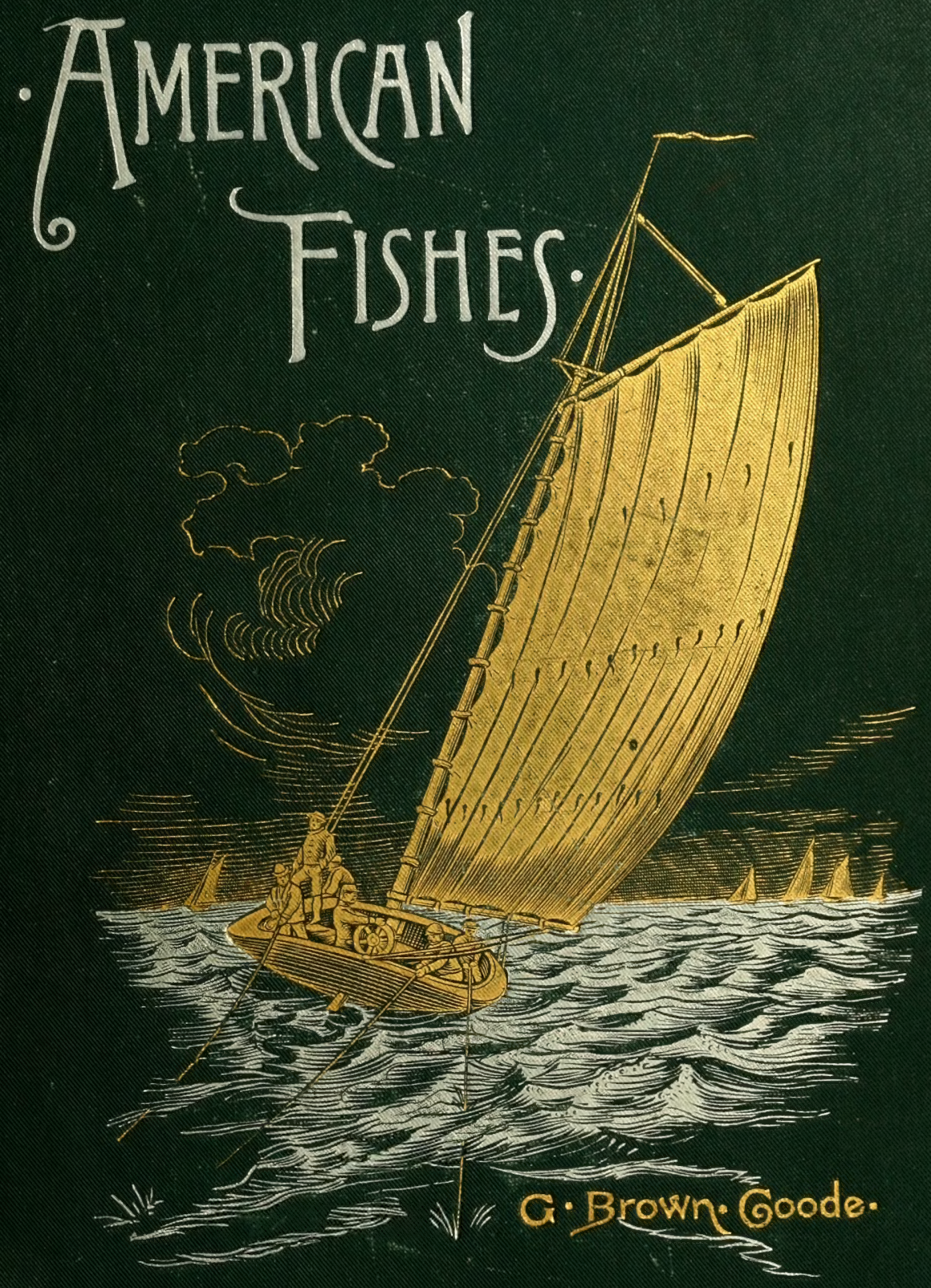




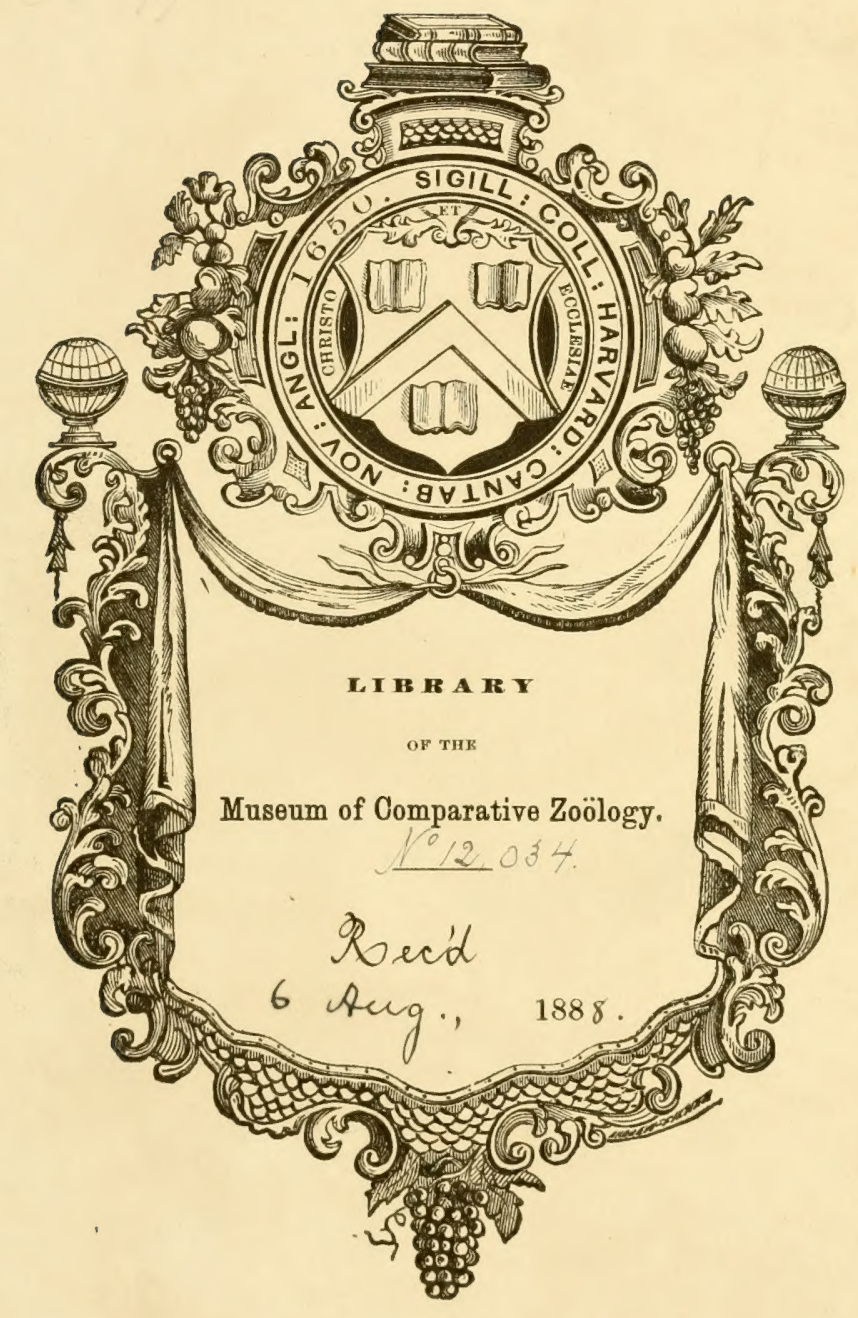



AMERICAN FISHES. 






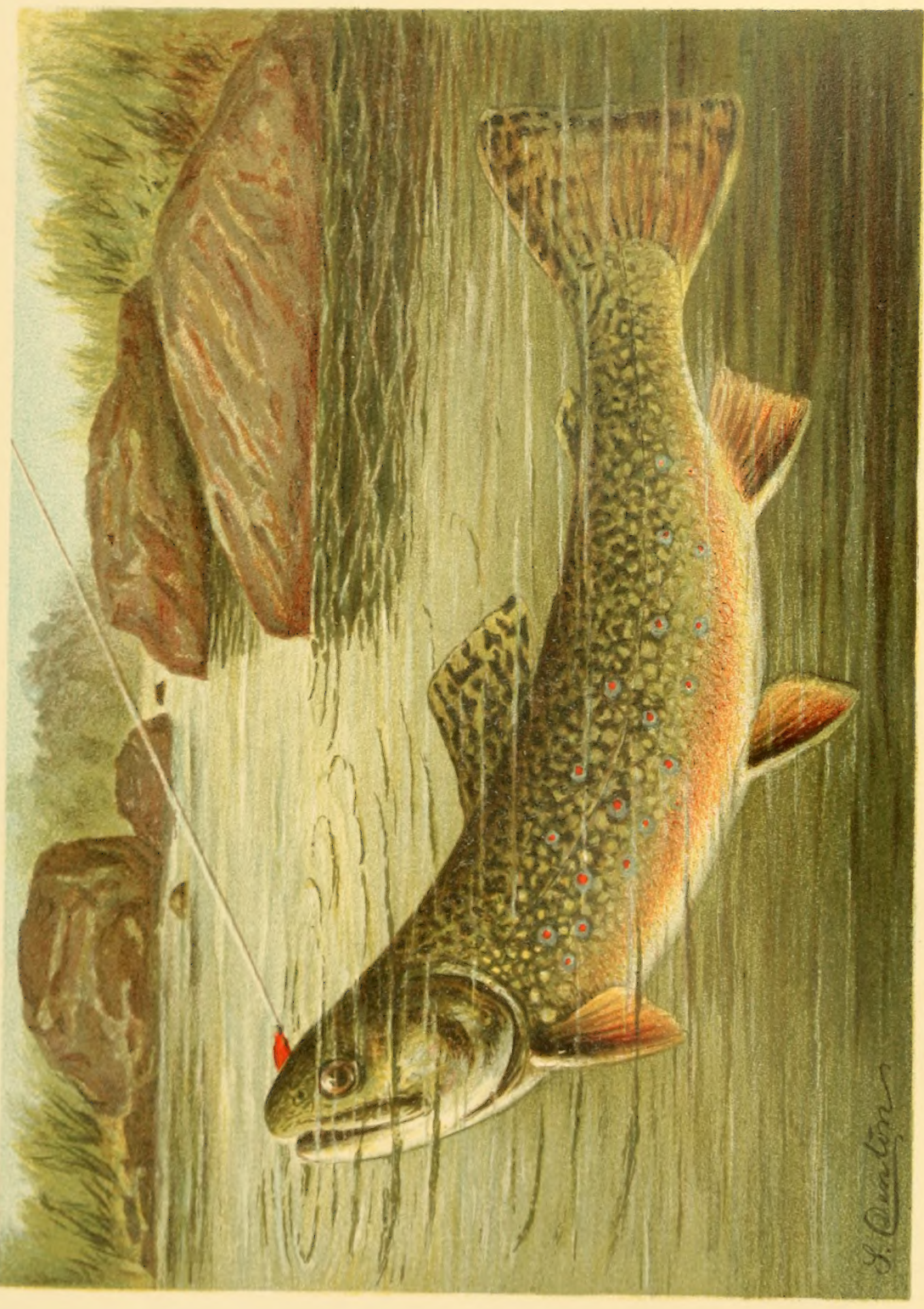




\section{AMERICAN FISHES}

A POPULAR TREATISE

IION THI:

\section{(rIME AND PO()D FISHES}

(1) I

\section{NORTH AMERICA}

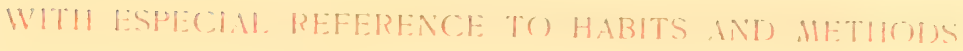
() ${ }^{2}$ (APTITRE

IBY

\section{G. BROWN GOODE}

Assistant Secretary of the Smithsonian Institution; Corresponding Member of the Zoological Society of London, the Deutsche Fischerei Vorein, the Nutional Fish-Culture Association of Great Britain, the Northern Fisheries Sociely of Japan, etc., etc.; late United States

Commissioner of Fisheries, and Commissioner to the International Fisheries Exhibitions in Berlin and London.

WITH NLAHEROLS H.L.USTRATIONS

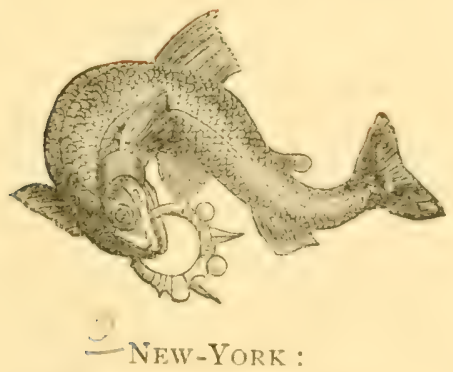

STANDARD BOOK CO. I8S8. 
COPYRIGHTED, I 887 . 


\section{DEDICATION.}

This little book on the fishes of America, is dedicated to my Brother-Ichthyologists in other lands

DR. NICHOLAS APOSTOLIDES, of Athens;

DR. ROBERT COLLETT, of Christiania ;

DR. FRANCIS DAY, of Cheltenham, England;

Prof. ENRICO H. GIGLIOLI, of Florence;

Dr. ALBERT C. L. G. GÜNTHER, of the British Museum;

DR. JAMES HECTOR. of New Zealand;

Prof. A. A. HUBRECHT, of Utrecht;

Dr. FRANZ M. HILGENDORF, of Berlin;

Messrs. K. ITO, and S. MATSUBARA, of Japan;

DR. CHRISTIAN LÜTKEN, of Copenhagen;

DR. ANDRE-JEAN MIALMIGREN, of Helsingfors;

Prof. PIETRO PAVESI, of Pavia;

DR. EMILE SAUVAGE, of Paris;

PROF. F. A. SIIITT, of Stockholm;

DON FELIPE POEY, of Havana ;

DR. FRANZ STEINDACHNER, of Vienna;

DR. DECIO VINCIGUERRA, of Rome;

PROF. OSCAR voN GRIMII, of St. Petersburg-

in memory of much pleasent intercourse in the past, especially. during the recent Fisheries Ex-hibitions in Borlin and London, and with the hope that its publication may lead to a aider popular appreciation, in Imerica, of the importance and interest of Ichthyological Science.

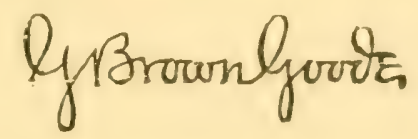


A je recongmieu, somant sa grosse conche, Glauque, Protée, Nerée, et mille autres dieux et monstres marins. Teismes aussi nombre infiny de poissons, en especes diverses, dancants, volants, woltigeants, combattants, mangeants, respirants, belutants, chassants, dressants escarmouches, faisants embuscade, composants trefoes, mar. chandants, jurants, sèbuttants.

En un coing la pres veismes Aristoteles, tenant une ianterne, expiant, considerant, le tout redigeant far escript.

PANIAGRUEL, V.g Xxxi. 


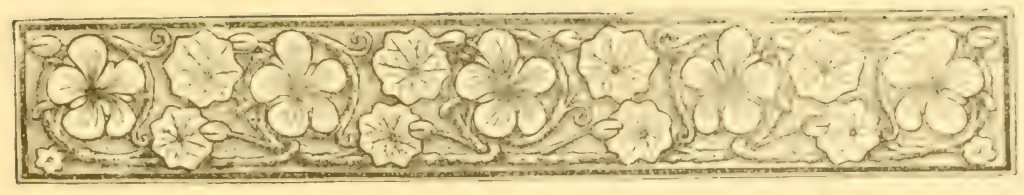

Quis, nisi ridisset, pisces sub undas natare crederet. LiNN.ieus.

\section{CONTENTS.}

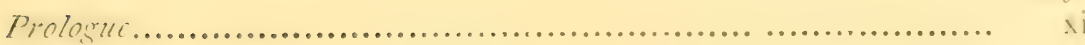

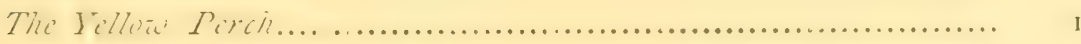

Thi Pilie Pirihis................................................ I

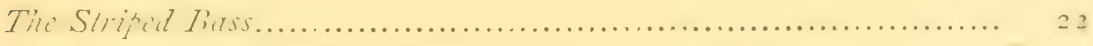

The Thite Bass and the Yellow Bass............................. 32

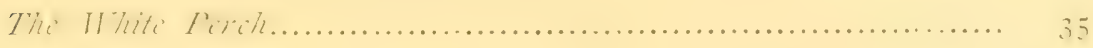

The Sea Basses................................................... 39

The Groupers and the Jew Fish................................... 47

The Black Basses .............................................. 54

The Suil Fishes and thitr Mllies..................................... it

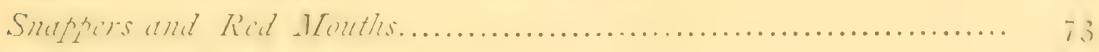

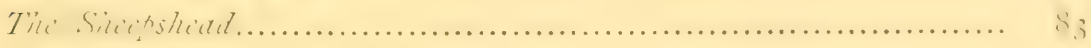

The Scuppaug and the Fair Maid .................................. 92

The Red Drum..................................................... I I

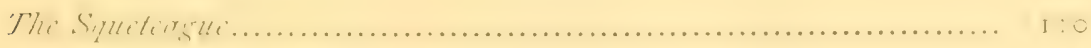

The King and (llith Fishes.........................................

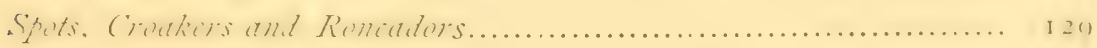

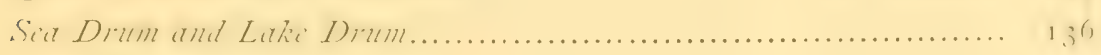

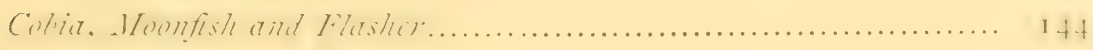

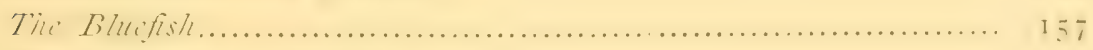

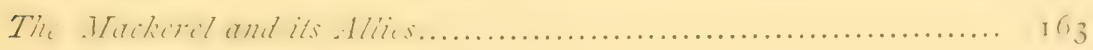

The Spanish Mackerel and the Ceroes.................................. I $S_{4}$

The Pompanoes..................................................... I

Bonitoes and Tumies............................................ 206 
The Hariest Fishes............................................ $22 \mathrm{I}$

The Cureally and other Carangoids................................. 226

Sword Fish, Spear Fish and Cutlass Fish............................ 239

The Rose Fish and its Allies......................................... 257

Pike, Muskellunge and Pickerel..................................... 274

Tautog, Chogset and Parrot-fish................................... 287

Sculpins and Gurnards......................................... 307

Italitut, Flatfish and Fluindir.................................... 307

Cod, Pollock, Haddock and Hake.................................. 333

The Hillets................................................. ${ }_{3}^{6}{ }_{5}$

The Cut-fish or Bull-hidt...................................... 376

The Herring and its Allics........................................... ${ }_{3} 8 \mathrm{r}$

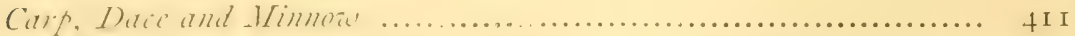

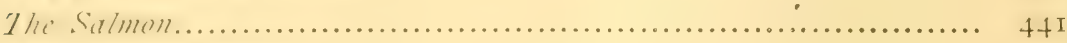

The Sirlmon Trouts......................................... $+5+$

The Lake Trouts................................................ $4^{6} 2$

The Brook Trouts or Chars....................................... 469

The Parifie Silmens ............................................ tiso

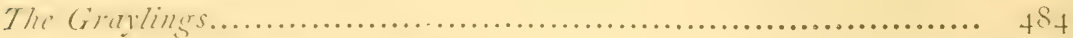

The White-fishes and the Smelts................................. 488

Index............................................................ 493

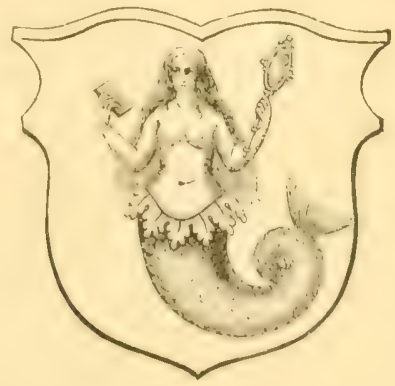




\section{PROLOGUE.}

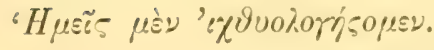

Athenæus: Deipnosophia.

66 COME, let us discourse about fish," saicl Athenæus, in his "I)eipmosophia," and so said Mr. A. R. Hart, coming into my study last January. "Write us a book about fish and fishing in America," he urged, and since, as it happens, I know more about fish and fishing in America than I do about anything else, I consented.

This volume has been prepared for the use of the angler, the lover of nature, and the general reader. It is not intended for naturalists, and the technicalities of zoological description have therefore been avoided ; for the concise and precise phraseology of science, admirable though it be for the use of those who have been trained to employ it, is to others not only misleading, but it may be, repulsive.

I have aimed to include in my discussion every North American fish which is likely to be of interest to the general reader, either because of its gameness or its economic uses. All others are excluded, because, from the standpoint of scientific interest, every one of the seventeen hundred and fifty species indigenous to our continent has equal claim to consideration, and to discuss, or even casually mention them all, within the limits of a book of ordinary size, would be next to impossible. President Jordan's recent pamphlet, entitled "A Catalogue of the Fishes Known to Inhabit the Waters North of the Tropic of Cancer, with notes on the Species Discovered in $\mathrm{I} 88_{3}$ and $\mathrm{r} 88_{4}$," " contains, with its indexes, I $\delta_{4}$ pages, and this is merely a list. His " Synopsis of the Fishes of North. America," which simply enumerates and gives brief diagnoses of the fourteen hundred or more species known in I 882 , contains Ior 8 pages. The former of these works is published by the United States Fish Commission, the latter by the National Museum, and to these and to the numerous monographic papers published in the transactions of learned societies and scientific institutions in America and abroad, I would refer the student 
who desires to make a serious study of the technical portion of American ichthyology. My own little library of works on fish and fishing is far from complete, yet it includes over two thousand volumes and pamphlets, and my "Bibliography of American Ichthyology," which I hope to publish within the next two years, comprises nearly ten thousand titles of books and papers. It is evident that it is impossible to make a book on American fishes which shall include more than a very small part, indeed, of what might be said upon the subject. I hope that the readers of this volume will feel that a judicious selection of topics has been made.

Only the most important species are referred to, and in the discussion of them all descriptive matters are omitted save those which relate to color. There is an Oriental proverb to the effect that, "Though the distance between the ear and the eye is very small, the difference between hearing and seeing is very great."

Acting in the spirit of this wise saying, a figure of almost every species* discussed is presented, by the aid of which any one interested in fishes can determine the correct zoological name of the form before him, and by referring to the accompanying text can learn what is known about its geographical range, halbits, methods of capture and economical uses. Exact bibliographical references are given in footnotes, to direct the reader to fuller discussions of subjects referred to when there are such in existence.

In the preparation of this book constant use has been made of my own frevious writings, and especially to the quarto work on Food Fishes, published by the Government in $\mathrm{I}_{8} 8_{5}$. Upon that work, in fact, this one is based, being essentially a rearrangement in condensed form. The text has, however, been for the most part rewritten, and much new matter has been added. One of my chief motives in preparing this volume has been the desire to see some of the results of twenty years' study of fishes printed in substantial and dignified form, in a book which shall not look cut of plake on a library shelf; for it has been my lot hitherto to have all the prorlucts of my pen published in those dismal looking bunches of papers known as public documents, which of necessity must be classified among Charles lamb's "books which are not books."

The author acknowledges his extended and continued indebtedness, in

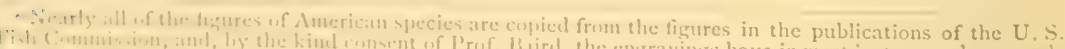

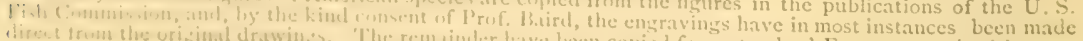

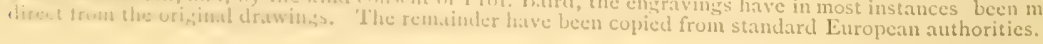


the first place to his teacher and master, Prof. Baird, and secondly, to his colleagues in the preparation of the quarto volume just referred to, especially to Dr. Jordan, Dr. Bean, Capt. Collins, Mr. Earll and Mr. Stearns. If in some instances the quotation marks have been omitted in connection with statements derived from their pen, it is simply because in the work of abridgment certain changes have been made in their phraseology, for which it seems hardly proper to hold them responsible. It is proper to say that all the biographies of the fishes of the Pacific, and the minor freshwater species, are due to Jordan, and that Stearns is equally responsible for what is said of the fishes of the Gulf of Mexico. With Bean the writer has long sustained a partnership in all matters ichthyological; with Collins and Earll similar relations in matters connected with the study of fishery economy, and in such associations it is not always possible to separate interests in such a manner as to place credit where it properly belongs. The classification followed is the system elaborated and ad vocated by Dr. Gill, undoubtedly the most erudite and philosophic of living systematic ichthyologists.

Perhaps some may feel aggrieved because there are no discussions of rods, reels, lines, hooks and flies, and no instructions concerning camping out, excursions, routes, guides and hotels. To such the author would say that he has at present neither time nor inclination to enter upon these subjects. Men who know them better than he have already written what should be written. Thaddeus Norris's "American Angler's Book" is an excellent guide in the selection and construction of tackle. Roosevelt's "Game Fishes of the North" and "Superior Fishing" are full of good suggestions, and Scott's "Fishing in American Waters," and even the works of Brown and Frank Forrester, are at times useful. Hallock's "Sportsman's Gazetteer" points out distant localities for sport to the few who are not satisfied with home attractions.

The files of "Forest and Stream," "The American Field" and "The American Angler"' are treasuries which cannot be exhausted, and the back volumes of the monthlies, "Harpers," "Lippincott's" and the "Century ", are full of finely illustrated essays, of interest to fishermen and anglers.

The English "Field," "Land and Wrater" and "Fishing Gazette" are also full of interest for Americans.

Prof. Mayer's "Sport with Gun and Rod in American Woods and Waters" is a charming and instructive book made up chiefly of reprinted magazine essays. 
The Reports and Bulletins of the United States Fish Commission must not le overlooked, and the reports of the State Commissions, the reports of the Canadian Department of Fishery, the bulletin of the French Society of Acclimation, the circulars of the German Fischerei-Verein, and the pulplications of the London and Berlin Fisheries Exhibitions are worthy of study.

I do not think that the term "game fish" has ever been properly defined. It is grenerally supposed to apply to fishes which are active, wily and couraceous, and whose capture requires skill or cunning-those, in short, which afford sport to the sportsman. As a matter of fact, although most food fishes are not game fishes, no fish which is not of the highest rank as a table delicacy is rated by Americans as a game fish. The barbel, the dace and the roach, the pets of the father of angling, classical in the pages of sportsman's literature, are despised by new world authorities, and are now considered "coarse fish" even by English writers. Yet they afford excellent sport-sport which in England tens of thousands enjoy to every one who gets the chance to whip a salmon or trout line over preserved waters.

"Game" in law and every day usage is a term employed to describe wild animals-fere nature, in which no man holds personal title of possession. Game birds are those which can only be obtained occasionally and with difficulty, and which, having been obtained, are worthy the notice of the epicure. Game fishes are rated in much the same manner, it appears to me. If not, why were the Pompano; the King-fish and the California Salmon and the Spanish Mackerel included among the twenty selected to be painted ly Kilbourn for Scribner's atlas of the game fishes of the United States. Surely not because they afford sport to the sportsman. Some years ago I defined the term as follows:

Ciame fishes are those which by reason of the courage, strength, beauty and the sapidity of their flesh are sought for by those who angle for sport with delicate fishing tackle.

Xow I should simply say that-

A gime fish is a choice fish, a fish not readily obtained by wholesale methexls at all seasoms of the year, nor constantly to be had in the markets-al lish, furthermore, which has some degree of intelligence and cunning. and which matches its own wits against those of the angler, requiring sliill, forcthought and ingenuity to compass its capture. 
Many writers, especially those of America, show a disposition to deny the rank of "game fishes" to all species which will not rise to a surface lure. This is illogical such, if it were strictly insisted upon, sheepshead and sea-bass would be counted out, while the shad and even the gar-pike must needs be allowed at least humble positions among the game fishes.

I hope that the readers of this book will freely communicate to me any new facts concerning American fishes, or any criticisms of erroneous statements, for use in preparing such fuller and better editions of this book as it may be decided in future to publish.

It is a great satisfaction to feel that this little volume will probably be the companion of men whom I know, or should like to know, in numerous delightful excursions to lake, brook and sea. In closing this prologue I feel disposed to repeat the prayer at the end of Walton's immortal pastoral: "That the blessing of St. Peter's master be upon all that hate contentions, and love quietnesse, and virtue, and go a-angling."

G. B. G.

Simthsonian Institution,

Washington, Dec. I, I 886. 
IN win had God stor'd Fleav'n with glistring studs,

The plain with grain, the mountain tops with woods, Sever'd the Aire from Fire, the Earth from Water,

Had he not soon peopled this larse Theatre

With living creatures: therefore he began

(This-Day) to quicken in the Ocean

In standine Pools, and in the strageling Rivers

(Whose folding Chanell fertill Champain severs,

So many föshe's of so many fuatures

Tlant in the Waters one may see all Creatures

And all that in this All is to be found:

As if the World within the Deeps were drown'd.

One (like a I'irat) onely lives of prizes,

'That in the Deep he desperately surprises ;

Another haunts the shore, to feed on foam :

Another round about the Rocks doth roam,

Xibbling on Weeds; another hating theeving,

Eats nought at all, of liquor onely living :

For the salt humor of his element

Servs him, alone, for perfect nourishment.

Some love the clear streams of swift tumbling torrents.

Which through the rocks straining their struggling currents

Ireak Banks \& liridges; and do never stop

Till thirsty Summer comes to drink them up ;

Some almost alwaies pudder in the mud

Of sleepy I'ools, and never brook the flood

Of Chrystall streams, that in continuall motion

Bend toward the bosom of their Mlother Ocean.

O watry Citizens, what Umpeer bounded

Vour liquid Livings? O! what Mlourch mounded

With walls your City? what severest Law

Keeps your lugge armies in so certain aw,

That you encroach not on the neighboring Borders

Of your swim-brethren?

What cumning Prophet your fit time doth show?

What Heralds trumpet summons you to go?

What Guide conducteth, Day \& Night, your Legions

'Through path-less l'ath in unacquainted Kegions?

Surely the same that made you first of Nought

Who in your Nature some Idiczs wrought

()f (Good and Evill; to the end that we

Following the Good might from the Evill flee.

Du bartas His First Wick; or The Birth of the IVorla, I005 


\section{AMERICAN FISHES.}

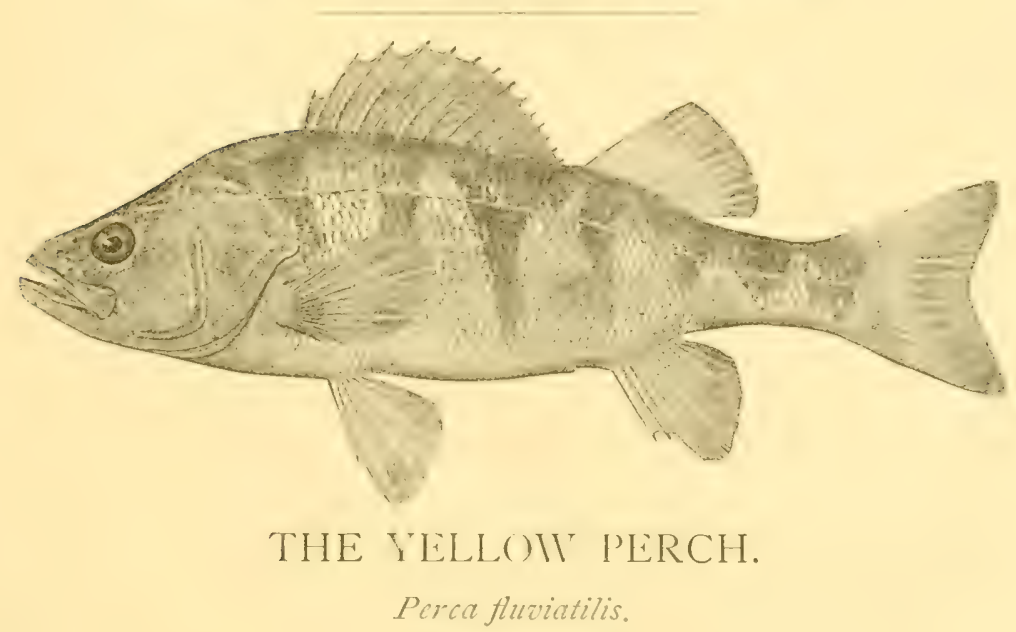

It is a true fish, such as the angler loves to put into his basket or hang on top of his willow twig on shady afternoons, along the banks of the streams.

Thoneau, Halde'n Pond. HE PERCH is a member of a very ancient race. A closely related
form has been found fossil in the tertiary deposits of CEningen, and its wide distribution throughout the northern hemisphere testifies to its existence in its present form at a remote period. Additional evidence of the antiquity of the species is found in the fact that its common names are much the same in many European languages which diverged from a common stock, thousands of years back in history.

The Perch is found almost everywhere in Europe, though it is said to be rare in the north of Scotland. It ranges to Lapland and Siberia, and ascends the slopes of the Alps to the height of more than 4000 fect. It inhabits the sea of Azor, and the brackish waters of the Caspian an? Baltic, and is everywhere a well-known and useful species.

In America it exists in all the waters of the Atlantic slope, from Labrador to Georgia, throughout the Great Lake region, and in the upper part 
of the Mississippi valley, especially in the tributaries of the Mississippi in IVisconsin and Minnesota, and of the Ohio, in Indiana and Ohio. It does not occur in the lower Mississippi basin, nor on the western slope of the Alleghanies.

There is no representative of the genus in the tributaries of the Pacific, either American or Asiatic, but the allied Percichthy's replaces it in temperata South America (Patagonia, Peru and Chili), while in northern China Siniperca fills its stead. The Stone-perch, Pope, Ruffe, Kaulbarsch or Gremille, of Europe, Accrina cermua, which somewhat resembles the Perch, though more nearly related to the Pike-perches is, perhaps fortunately, not found in America.

Authorities are not harmonious in opinion as to the specific identity of the American and the European Perch. Günther, Steindachner and Day maintain that they are the same, while Jordan is equally positive that the Perca americana or P. flavescens of American writers is at least a distinct sub-species. It is my own impression that the American Perch cannot be positively separated from that of Europe, which, as Day has shown, is extensively variable in form and color.

Perch frequent quiet waters of moderate depth, pools under hollow banks, eddies and expansive shady reaches in the meadow brooks, creeks and canals, preferring the sides of the stream to swift currents, and sandy and pebbly rather than muddy bottoms. In mill-ponds they are likely to be found in the deep water just above the dam, and in the vicinity of piles of locks, bridges and sluice gates. They sometimes descend into the brackish water of estuaries, where they become large and very firm fleshed. In muddy pools they often assume a golden color, but in such situations are soft and rarely well flavored.

"As a still-water pond fish," writes Abbott, "if there is a fair supply of spring-water, they thrive excellently; but the largest specimens come either from the river or from the in-flowing creeks. Deep water of the temperature of ordinary spring-water, with some current, and the bed of a stream, at least partially covered with vegetation, best suits this fish." They are gregarious, and there is an Old-country saying that when the angler meets a school of Perch he may capture every one, if he be wary and noiseless.

"Perch, like the Tartar clans, in troops remove,

And urged by famine or by pleasure rove ;

But if one prisoner, as in war, you seize, 
You'll prosper, master of the camp with ease ;

For, like the wicked, unalarmed they view'

Their fellow's perish, and their path pursue." $\%$

Day tells us that in the famous Norfolk Broads the fish assemble in shoals according to their sizes, the smaller and larger indivicuals keeping to themselves, and repelling the intrusion of those that materially differ from themselves in this respect. The writer has observed a similar natural association in the lakes of the Hudson and Housatonic basins. In winter they retreat to the deepest parts of their domain. Here they adajt themselves to circumstances; if the temperature of the water approximates the freezing point, they become torpid; if it remains above $38^{\circ}$ or $40^{\circ} \mathrm{F}$., they do not suffer any inconvenience. Dr. Abbott found a large number of them in December and January, in a deep hole in the bed of a tide-water creek, about half an acre in extent and twenty feet deep; they were in moderately good condition, active and in high color, with empty stomachs, and refusing to feed, a habit by no means invariable, however, at this season.

As spring advances they assume their ordinary mode of life. With the warming of the waters the eggs begin to swell in the ovaries, the colors brighten, particularly in the males, and the lower parts of the body in both sexes assume a ruddy hue. Spawning time varies in different localities. It is of course largely dependent upon the temperature of the water, though the requisite standard of heat most probably changes with latitude. In New Jersey, according to Abbott, it comes in May, with the water at $55^{\circ} \mathrm{F}$, and in Sweden, by Malm's observations, in May, also, at $50^{\circ} \mathrm{F}$. In Virginia and Maryland Perch spawn in March and April ; in France and Austria, from March to May; in England and Sweden, in April and May. When the Marsh/ Marigold, or "Cowslip," Caltha palustris, blooms in the wet meadows, the spawning time of the Perch is near at hand. That Perch spawn twice in the year, is a popular belief in Europe. This idea must have originated in the fact, well known to students of fish, that many individuals retain their eggs long after the end of the normal spawning time.

Among some Perches, twenty millimeters long, taken late in September, I 866, in the Rhine, a French naturalist found three males prepared for breeding as well as a female with ovaries hardly visible.

The proportion of males to females varies curiously with locality. Out of one hundred taken at Salzburg only ten were males, and Cuvier stated 
that the proportion of males was as one to fifty. Von Siebold found one-third males at Munich, and Manley in England one-tenth. It would be well worth while for American anglers to continue these observations, as well as to make some new counts of the number of eggs. The only reliable recent enumerations appear to be those made by Buckland in $\mathrm{s} 868$. He found I 27,240 eggs in a fish of 2 pounds II ounces, and I 55,620 in one of 3 pounds 2 ounces. Iacépède put the figure at $\mathrm{I}, 000,000$, Bloch at 28,000, and Abbott at 8,000.

The eggs are from 2 to $21 / 2 \mathrm{~mm}$. in diameter, or about as large as poppy seeds. They are of the adhesive class, and cling together in beautifully interlaced bands, like pearl necklaces, five or six feet long and an inch or two in width. These glutinous masses adhere to twigs and stones in shallow water, and are devoured by birds and all kinds of aquatic animals. The eggs begin to expand soon after fertilization. At a temperature of $59^{\circ}, \mathrm{F}$. Malm hatched some eggs in four days and nine hours; at the end of a week or ten days after the eggs were laid, Abbott frequently found minute Yellow Perch, associated with little Sun-fish, tangled in among the water plants, active as their strength permitted, and darting voraciously at almost invisible specks, that seemed to serve them for food. The little perchettes grow very fast, and in a year or two they have reached maturity. Edward Jesse observed a fish three inches long which was full of spawn.

Perch rarely exceed a pound or two in weight. "Une Perche de deux kilogrammes est un phenix tres-rare," says De la Blanchere. Some large ones are on record. An individual taken in Delaware Bay, by Abbott, weighed four and one-quarter pounds. In England three-pounders are thought large; but Pennant mentions one of nine pounds, taken in the Serpentine in Hyde Park. Günther puts the limit at four pounds, but Seeley states that in Russia, in Lake Seligher they reach eight pounds.

The artificial propagation of the Perch was accomplished as early as I 856 by Malm, a Swedish naturalist, and is said to have beeen repeated in this country. Many ponds have been stocked with grown fish, Dr. S. L. Mitchill transplanted them from Ronkonkoma Pond in Suffolk County to Success Pond in Queens County, N. Y. The species is very properly excluded from waters in which trout and carp are to be cultivated. It is said that poachers often revenge their grievances by stocking trout ponds with Perch. They have been known to deposit their eggs in aquarium tanks, where, with care, they will doubtless hatch their young. 
The Saxons, it is said, represented one of their gods standing with naked feet on the back of a Perch, as an emblem of constancy in trial and patience in adversity. With his bristling array of thorny fin-spines, the Perch is a fair type of sturdy independence, a Diogenes of the brooks and ponds, well described by Drayton in his "Poylyolbion :"

"The Perch with prickling fins against the Pike prepar'd As nature had thereon bestow'd this stronger guard His daintiness to keep."

The angler cannot be too careful in unhooking these spike-armed heroes, for the armature of the fins inflicts wounds painful and clifficult to heal.

They feed on worms, grubs, insects and even small fishes of their own species and are voracious in the extreme. "In feeding," writes Dr. Abbott, "Yellow Perch chase small minnows instead of waiting for a single fish to come near enough to seize by a single dart upon it, as the Pike does. They are not rapid in their movements, but seem to dart with open mouth at several minnows, as though trusting to catch some one of the number they pursue."

They are pirates, as voracious in proportion to their size as the Black Bass and the Pike.

The claims of this fish to popular favor have been strangely overlooked in America, owing perhaps to the fact that anglers, like other men, have their specialties, and that most of our writers upon this subject have had hobbies other than that of Perch fishing. Surely no inhabitant of our brooks and ponds has higher claims on the score of beauty than-

"The Perch with fins of Tyrian dye."

Its graceful movements and beautiful colors, its hardiness and intelligence makes it particularly desirable for aquarium culture. In the sunlight the scales reflect delicate hues and golden glints which are deliciously tempered by the dusky bands upon the sides and the ruddy tones of the quivering fins, which have been well compared to the reds sometimes to be seen in the glass of very old church windows.

Its rank as a game fish is thus estimated by J. P. Wheeldon, angling editor of Bell's Life: "A gloriously handsome fish, the Perch, when in condition affords excellent sport, and is a deserved favorite with each and every fisherman, be he young or old." It is mentioned as a faroritc in the first of all treatises on angling-that printed in Antwerp in $\mathrm{I}+92$, - and is eulogized by scores of later European authorities, as well as in the "Complete Angler:", 
"I pray you, sir," said Viator, "give me some observations and directions concerning the Pearch, for they say he is both a very good and in bold-biting fish, and I would fain learne to fish for him."

Although Norris and Scott and Roosevelt and Forester pass the Perch by with contempt, and Jordan has pronounced it "soft, coarse and insipid," it is not without its advocates in America. Seth Green admits that it is an "excellent fish for the people," and a "superior table fish," and that when taken on light tackle with an artificial fly it affords not a little sport,* and H. H. Thompson, in the American Angler for June 2, I $88_{3}$, has made an eloquent plea for this worthy little species, in which he is supported by such eminent anglers as D. W. Cross and A. N. Cheney.

I venture the prediction that before many years the Perch will have as many followers as the Black Bass among those who fish for pleasure in the waters of the Eastern United States. A fish for the people it is, we will grant, and it is the anglers from among the people, who have neither time, money nor patience for long trips and complicated tackle, who will prove its steadfast friends.

As an article of food a Perch taken from clear, cool water is undoubtedly superior to many popular marine species. Ray tells us that it was formerly called Perdrix aquarum - the partridge of the waters, and Ausonius thus sounds its praise:-

"Nor will I pass thee over in silence, O Perch, the delicacy of the tables, worthy among river fish to be compared with seafish; thou alone are able to contend with the Red Mullets." $†$

In Venner's "Via Recta ad Vitam Longam" printed in 1650 , we are told that Perch taken in pure water are for taste and nourishment equal to Trout or Pickerel. "Perch," adds this writer, "is usually sauced with butter or vinegar, but add thereto the flavor of nutmeg, which to this fish is very proper, it becomes delectable to the taste and grateful to the stomach. The spawn of Perch is of delicate and wholesome nourishment, very good for the weak."

A recent British authority writes that it is unsurpassed by any nonmigrating species, except the eel, and that it more closely resembles the sole than any other fresh-water fish.

There are in America many who prefer the Perch to the bass, and even to the brook trout, and among them are some independent enough to 
say so. Frank Buckland writes: "Our friend, the Perch, is one of the most beautiful fish which it has pleased Providence to place in our waters. Not only does he afford the angler excellent sport, but to the professed cook his arrival in time for the menu is most welcome, as witness water souché, as served at ministerial dinners, city banquets or private parties at Richmond and Greenwich." *

The simplest way to catch Perch is with the boy's standard outfit: a "pole," a stout line, a large float and heary sinker and a worm or minnow for bait. This is effective when the water is muddy and the Perch are numerous and hungry.

For wary fish in clearer water more delicate tackle is necessary. The line should be fine, and a simple reel may be used; the float should be small and well balanced, and the shot used for sinkers only heary enough to keep the float steady. The float should be adjusted so that the bait may be suspended about a foot from the bottom, and a gentle motion upwards and downwards may advantageously be employed.

A favorite gear for Perch in England and France is the "pater noster." This name was always a puzzle to me until I saw the apparatus in its French form, when its origin was at once intelligible. The gutta-percha beads and round sinkers of wood and lead suggested at once a rosary. The pater-noster used in England at the present day is much more simple. It is thus described by Francis Francis:

"For Perch fishing the pater-noster simply consists of a line of gut about 4 or 5 feet long; at the bottom of this is a leaden bullet or plummet to sink it to the bottom; about 6 or $S$ inches above this a hook on some

* How to Cook Perch.-This famous dish, water souché, souchy or sokey, does not scem to have been naturalized in America. 'The following recipe from an old angler's manual seems more practicable than others given by later authorities: Scale and wash your Perch; put salt in your water: when it boils put in the fish with an onion cut in slices; put in chopped parsley enough to turn the water white: season with salt and pepper, and as soon as the fish is done serve it in a deep dish, pouring a little water over it, with the parsley and onions. Melted butter and parsley should be served in a tureen. Slices of brown bread and butter generally accompany this dish. The writer has tasted a water souche prepared by a famous London cook, but does not remember it with rapture. The favorite American method is to fry the Perch to a crisp, with salt pork rather than with butter. In summer, when the skin is slightly bitter, it may advantageousty be removed, at other times the fish is better simply scaled. This method is hearty and best adapted to the needs of hungry anglers. Many will prefer the contmental method of stewing them in vinegar or lemon juice, or in some kind of sour sauce. In Italy they are roasted on the spit without removing the scales, and bathed while roasting with vinegar or lemon juice, a method not unsuitable to camp life in the woods. The following directions are taken from the "International Fishery Exhibition Cookery Book:

Boiled Perch. - Lay the fish in boiling water, with a $1 / 4$ pound of salt to each gallon, and simmer gently for about ten minutes. Garnish with parsley and serve with plain melted butter. (This resembles the water souché.)

Fried Perch.-Brush the fish over with egg, and sprinkle bread crumbs over it. Have ready boiling lard: put the fish in and fry a nice brown. Serve with anchovy sauce.

Perch Stezued with Wine. - Lay them on a stew pan with sulficient stock and sherry to cover them. Put in a bay leaf, garlic, parsley, two cloves and salt, and simmer till tender, then remove she fish, strain the liquor, add a thickening of butter and tlour, pepper, nutmeg and anchovy sauce; sit it over the fircuntil somewhat reduced, pour over the fish and serve. "Broiled 'erch flitters" are spoken of with enthusiasm by" early" gourmets. 
6 inches of gut is fastened; a foot above this another hook is fixed on, and a foot above that again a third. This third hook is often a gimphook when pike and Perch are found in common, so that if a pike should come to the bait there may be a fair chance of capturing him. A minnow being hooked through the lips on each of the other hooks, the tackle is dropped into an eddy where Perch is supposed to be, and the three baits swim round and round the main line; so that, no matter whether the fish are resting at the bottom or searching for their prey in mid water, they may be attracted. As soon as there is a bite from a Perch the angler feels it at the rod point, slackens line for two seconds to let the fish get the minnow well into his mouth, and then strikes. Should the immediate neighborhood not afford a bite the tackle is cast to a distance, and after being allowed to rest for a minute it is drawn in a few feet, when another cast is made and then another draw, until the tackle is worked up on the boat or the bank. In the winter, after the floods, very many Perch are caught in this way on the Thames, from one hundred to two hundred in a day being not very uncommonly taken."

Pater-nostering is said to require much skill, but this method is surely worthy of more general use in America. It may, perhaps, be preferable to hook the bait though the dorsal fin, or to use a "tail-hook" to avoid the risk of losing the minnow without gaining the Perch.

The French gear is more complicated than the English, the hooks being attached to long bristles, which are tied to beads of wood, rubber or iron, kept in place upon the line by means of split shot. The use of supplementary floats, or "'postillions," is recommended to keep the line from sinking. This apparatus is very heavy, and is more of the nature of a set line than of an angler's apparatus.

The "ledger" is another method sometimes employed in Perch fishing, especially in rapidly running streams, where it is not convenient to use a float.

"This," says Francis, "consists of a gut line a yard or two long, run through a bullet or lump of lead pierced with a round hole. On the hook side of the line an obstruction is fastened, so that the lead cannot slip down to the hook, but the line is free on the rod side of the lead, the lead is dropped into the water and rests on the bottom, a tight line between the rod top and the lead being kept. The instant a fish bites at the hook, the line being. free in that direction, it is felt at the rod top, and the angler, yielding a little line to let the fish get the bait and hook well in his mouth, strikes, lifting the lead and hooks the fish."

In France are employed various modifications of the ledger, some of 
them, especially the piche aux geux in its different forms, very complicated, and hardly to be recommended for use in America.

The Perch, it is said, will also rise to an artificial bait, or to a fly, natural or artificial, especially at the end of spring, when the Eplemeras are abundant and they are preying upon surface life. Some authorities say that a gray fly is preferable; others that there is nothing equal to a red hackle. An imitation of the insect upon which they are known to be feeding at the time, or better still, the natural insect, will undoubtedly be the most effective bait. In fly-fishing for Perch a strong trout rod, or light bass rod may be used. The leader should be of gut, and may advantageously be rendered inconspicuous by staining a deep blue or reddish brown-so say the experts.

The flavor of the Perch is said to be finest when they are full of spawn and milt, but directly after spawning for two or three weeks, although at this time they bite ravenously, their flesh is often soft and watery. They are active and voracious throughout the summer, but in the fall months are more wary and require the exercise of the angler's highest art. Walton observed that, though abstemious in winter, they would bite at the middle of the day even then, if it were warm. Many Perch are taken by fishing through the ice on the northern lakes.

This, the only peculiarly American method of Perch fishing, is well described by Mr. A. N. Cheney, of Glen's Falls, N. Y.:

"The Perch retire to deep water with a bottom of fine grass as cold weather approaches, and there they are found in February and March, which is the time for ice fishing. The tools required are an ice chisel for cutting the holes, a hand-line and sinker, fixed with a 'spreader,' and snells, and though it does not come under the head of tools, a fire.

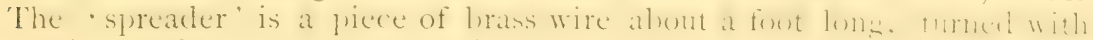
a pair of pliers to form an eye in the middle, to attach the line, and an eye in each end to fasten the snells. Spreaders may be obtained at the tackle shops, that have a swivel in the middle of the wire, and underneath it an eye so that three snells may be used. The bait is the small white grub, most easily found in dead and partly rotted second-growth pine trees or logs, from which they have to be cut out with an ax. The man who catches Perch for market does not trouble himself to provide more than two or three grubs, for as soon as he catches one fish he has two baits. It seems cruel, however, to tear the eyes out of a fish that has scarcely ceased to quiver, and I could never bring myself to do it thus hastily. When the spreater is thrown through the here at in the hee, there is nothing to do but to wait for a bite. If a Perch takes one bite 
the matter is settled, and it is only necessary to bait and lower the hooks, for each time without fail there will be a fish brought up for each hook baited.*

To the words of instruction and advice already written, I would add a sentence of warning to him who angles for Perch. Do not yield too unreservedly to the fascination of the pastime. Remember the unfortunate angler in Bulwer's "My Novel."

"Young man, listen!" said Burley. "When I was about your age, I first came to this stream to fish. Sir, on that fatal day, about 3 P. M., I hooked up a fish-such a big one, it must have weighed a pound-and-a-half. And just when I had got it nearly ashore, the line broke, and the Perch twisted himself among those roots and-cacodremon that he was-ran off, hook and all. WVell, that fish haunted me; never before had I seen such a fish. Ninnows I had caught, also gudgeons, and occasionally a dace. But a fish like that-a PERCH - all his fins up, like the sails of a man-ofwar-a monster Perch, - a whale of a Perch!-No, never till then had I known what leviathans lie hid within the deeps. I could not sleep till I had returned; and again, sir-I caught that Perch. And this time I pulled him fairly out of the water. He escaped; and how did he escape? Sir, he left his eye behind him on the hook. *** I gazed at that eye, and the eye looked as sly and wicked as if it was laughing in my face. Well, sir, I had heard there is no better bait for a Perch than a Perch's eye. I adjusted that eye on the hook and dropped in the line gently. In two minutes I saw that Perch return. He approached the hook; he recognized his eye,-frisked his tail,-made a plunge-and, as I live, carried off the eye, and I saw him digesting it by the side of that water lily. The mocking fiend: Seven times since that day in the course of a varied and eventful life, have I caught that Perch, and seven times has that Perch escaped.

* * * Good Heavens! If a man knew what it was to fish all one's life in a stream that has only one Perch, to catch that Perch nine times in all and to see it fall back into the water, plump. Why then, young sir, he would know what human life is to vain ambition." 


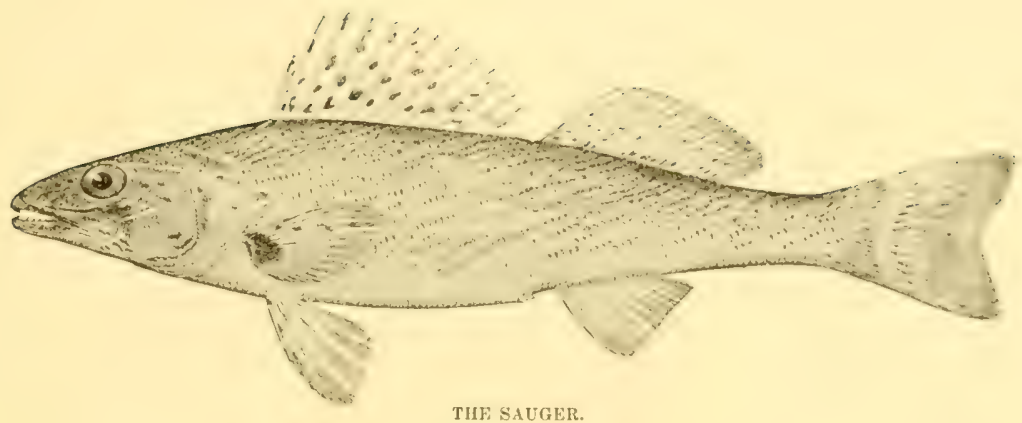

THE PIKE-PERCHES.

Stizostedion vitremm and $S$. canadense.

The surest way

To take the fish, is give her leave to play,

And yield her line.

Quakles, Shephoard's Eclogues, ibłs.

$\mathrm{T}$

HE Pike-Perches have been known to the inhabitants of Continental Europe for many centuries, and on account of their elongated form and large teeth were described by Gesner and other medixval naturalists under the name Lucioperca-a name intended to describe their general appearance, since their proportions resemble those of the pikes, while their structure resembles that of the perch, to which they are closely allied.

Linnæus in his ichthyological system, named the Scandinarian species Perca Lucioperca, and placed it in the same genus with the perch, where it remained until the time of Cuvier and Rafinesque. The former set aside this group of fishes in I 8 I 7 , under the group name of "Les Sandres," but neglected to formally propose the genus named Incioperca, until the publication of the second edition of his "Animal Kingdom" in r 829 . In the meantime the Sicilian explorer, Rafinesque, had published in I 820 , his "Ohio Ichthyology," and named the fish. Stianstidien, an alpreflation which. however meaningless and cacophonous, priority requires shall always be

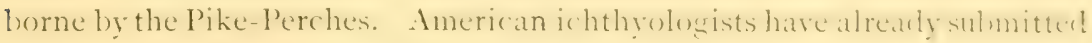
this necessity, but those of the old world still cling to the venerable and euphonious Lucioperca.

The Pike-Perches are distributed throughout the waters of the northern hemispheres in much the same manner as the perch, though absent from 
certain areas within the limits of its range. The British Isles, France, the Rhine valley and Switzerland, New England and the South Atlantic states, are without it, and its distribution in Asiatic Russia is more restricted than that of Perca.

This form is more subject to variation than the Perch, and probably a more recent product of evolution, and it has become differentiated into several fairly well-marked types.

The North American species may be divided into two groups: (I) the typical form, most closely related to those of Europe, and (2) the form with small eyes, slender body, pointed head, smaller second dorsal and with pyloric coeca set aside by Gill and Jordan in the subgenus Cynoperca.

In the latter category is placed $S$. canadense, having its spinous dorsal fin ornamented with two or three rows of round black spots, and without a blotch posteriorly, but with a dark patch at the base of each pectoral: within the limits of this species, Jordan recognizes three varieties or subspecies which intergrade to some extent, but which by old-school naturalists would have been regarded as valid species. The first of these is the Sauger or Pickering of the St. Lawrence region, S. canadense canadense, with the opercles and bones of the head considerably rougher, the number or opercular spines, (which are merely the free ends of the strix), increased, and the head more closely and extensively scaly.

The second is the common Sand Pike, or Sauger, of the Great Lakes, S. canadense griseum, the Lucioperca grisea of DeKay's "New York Fauna," and many other ichthyologies. This form is now plentiful in the Ohio River into which it is supposed to have made its way since the construction of the Ohio and Erie Canal.

The third is the Sand Pike of the upper Missouri, S. canadense borem. which is rather slenderer than that of the Great Lakes, having a long slender nose and a head more flattened and snake-like.

A certain type of coloration is characteristic of $S$. canadense in all its forms, and it has fewer rays in the second dorsal fin, there being only i $\delta$, more scaly cheeks, a more prominent armature of the operculum and most significant of all, the pyloric coeca are small and unequal in length and are never less than four in number, and sometimes as many as seven. In the other American species these number only three, and are nearly equal in length and about as long as the stomach. Whoever wishes to identify our Pike-Perches accurately must not fail to dissect them and examine this feature of internal structure. 
The largest and most important form is Stizostedion vitreum, generally' referred to by recent writers upon fishes as the Wall-eyed Pike. This well-known species is found in nearly all the water systems frecuented by $S$. canadense, and in many others, its geographical range being much more extended. It inhabits the Great Lakes and their confluents, * and occurs in most of the little lakes of Western New York,-Cayuga, Seneca, Chatauqua, Oneida and many others. It ranges north to the fur countries, and is doubtless widely distributed through British America. It is found in the Susquehanna and the Juniata, in the Ohio River, and many of its tributaries, in Western Virginia and North Carolina, in Kentucky, in Rock Castle River and elsewhere in Tennessee, especially in the French Broad and at least as far south as Memphis, in Georgia in the Oostanaula river and it is said, in Arkansas. Its range to the south and southwest deserves careful investigation.

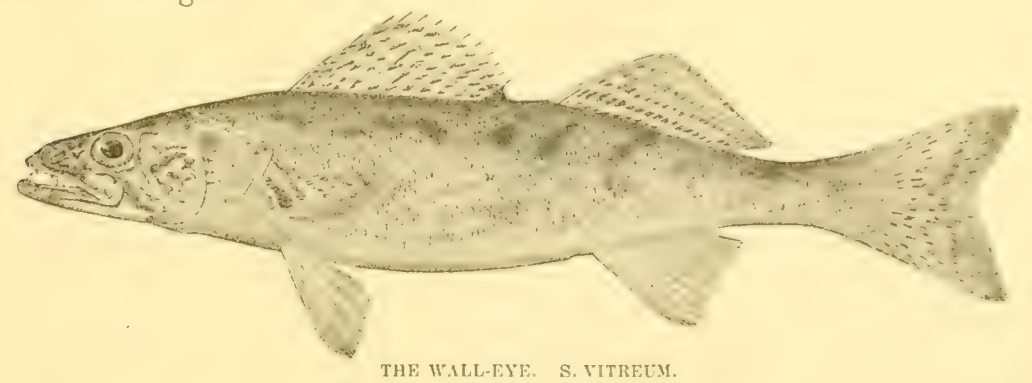

Jordan recognizes two subspecies of Stizostedion vitreum-the typical form $S$. vitrcum vitreum, and a smaller, heavier bodied form which is bluer in color and is generally known as the Blue Pike, S. vitrcum salmoncum. This, he states, is a local variety in Ohio and southward. It has been considered a distinct species by many naturalists since the days of Rafinesque.

The geographical range as well as the classification of the American Pike-Perches, as the reader must have inferred from what has been said about them in these pages, need to be studied much more exhaustively before a satisfactory essay can be written upon them. Their habits are very imperfectly understood, and it will be necessary to refer to what is known of their kindred in Europe, in order to give even a partial idea of their lifehistory.

In the Old World, as in the New, there are two well marked species,

*A specimen was taken in April, I887, in the Connecticut river at Portland, as recorded by Professor Wil. liam North Rice. 
the Zander, or Schill, S. lucioperca (L), ${ }^{*}$ and the Berschick, or Sekret, S. volgensis, (Pallas), the former distributed through a large part of Northern, Eastern and Central Europe, the latter, in the south of Russia, especially in the Dniester and the Volga.

The popular nomenclature of the various American forms is in a most perplexing state.

In the upper lakes where the true Pike, Esox lucius is known as the pickerel, Stizostedion aitreum is called the "Pike," with such local variations as "Blue Pike," "Yellow Pike," "Green Pike" and "Grass Pike."

In Ohio, Tennessee and western North Carolina, it robs Esox of another of its names, and is called "Jack." In Lake Erie, however, it is generally known as the "Pickerel."

The name "Salmon," is quite generally applied in rivers where no member of the family Salmonida is found. This is notably the fact in the tributaries of the Mississippi and Ohio, and in the Susquehanna: hundreds of cases of the capture of salmon, supposed to have developed from fry planted by the fish commissioners, have been reported in the newspapers during the past ten years, and almost always, when the matter has been investigated, a Pike Perch has been found the innocent cause of the false report. "White Salmon" is a local name at the Falls of the Ohio ; Jack Salmon" is another bad name. "Okow," sometimes heard in the lake region is evidently a corruption of "Okun" and "Okunj," Polish and Russian names for the common perch, introduced by immigrants. The French Canadians on the lakes call it "Doree," and "Dory" is a name which has found its way into the books.

"Glass eye" and "Wall-eyed Pike" are names peculiar to this species, and the former has been perpetuated in the specific name vitreum. The name "Wall-eyed Pike" is coming into favor, and has already replaced some of the misnomers long prevalent. On the Susquehanna, for instance, it is rapidly taking the place of "Salmon." If it must be used, "Wall-eye" is of course to be preferred to the misleading "Wall-eyed Pike." 'To me it seems a most repulsive and undesirable name, but others find it appropriate. Listen to an ardent admirer:- "Look at this beautiful fish! as symmetrical in form as the salmon. Not a fault in his make-up, not a scale disturbed, every fin perfect, tail clean cut, and his great big wall-eyes stand out with that life-like glare so characteristic of the fish."

\footnotetext{
* Zander, Zant, Sander, Sannat, and Sandart in Northern Germany, Anaul, Nagemaul, Schiel, Schill and Fogosch in Southern Germany, Sander and Sandel in Austria, Sandre or Sandat in France, Santart in 1)enmark, Goes in Sweden, Gjory in Norway, Sudak in Russia, Sterkas in Lithuania, Sendacz in Poland, Sullo and fiogrs in Hungary.
} 
The phrase "Wall-eyed" is good old English to be sure, but it brings to mind the invective of Lucius reviling the Goth in Titus Andronicus:

"Say, wall-eyed slave, whither wouldst thou convey

This growing image of thy fiend-like face." *

If "Wall-eye" is to be the name of $S$. griseum it is evident that "Sauger" must be that of the other species, for it is not claimed by any other fish, and is probably of Indian origin, which is a recommendation. $S$. canadense is also called in various localities "Pickering," "Pickerel," "Horse-fish," "Gray-pike" and "Ground-pike."

The Pike-Perches resemble the yellow perch in their habits, but though epually vivacious are usually less sprightly and pugnacions, esperially when inhabiting quiet waters. The Swedes have a proverb_-As stupid as a PikePerch "- not particularly applicable to our American species.

Their greater size debars their occupancy of the creeks and pools in which perch so often congregate, and it is said that they are rarely found on bottoms of clay or mud. In lakes they retire to waters of considerable depth, but in running streams are partial to rapids, and whirling pools among the rocks. In Lake Pepin, according to Dr. Estes, they seek out the purest water, and their favorite feeding grounds are at the ends of projecting points where the bottom has been washed clear by the waves, and at the mouths of streams where the current breaks into the still waters of the lake. They delight to run up the larger streams until they encounter an impassable fall or dam, and in rivers where there are no falls they frequent deep rolling foot-pools, or deep dark holes, where the current is strong under old logs or drift piles. At the foot of Lake Pepin, just at the point where the still water of the lake begins to flow into the river, they are found in great numbers, associated with the black-bass and the striped lake-bass. At the junction of the Chippewa with the Mississippi is another great feeding grounds where the Pike-Perches are especially abundant under the great rafts of lumber and accumulation of logs which are always there in summer. Concerning their association, Dr. Estes writes: "In these waters the Walleye $f$ is seldom found associated with any other fish than the sand-pike." I It is true, however, that in swift-rolling waters, especially under falls we find him in company with the black-bass, but I believe that the force of the fall and the tumbling waters in a measure destroy the pugilistic nature of the bass, or he would not suffer the wall-eye to remain in his company. In

* Titus Andronicus, Act $\mathrm{v}$, Scene $\mathrm{r}$.

†S. vitreum. IS. cancedense boreum: this form was named Lucioperaz pipinus by Dr. Estes. 
other locations the bass easily drives the wall-eye from his feeding grounds."

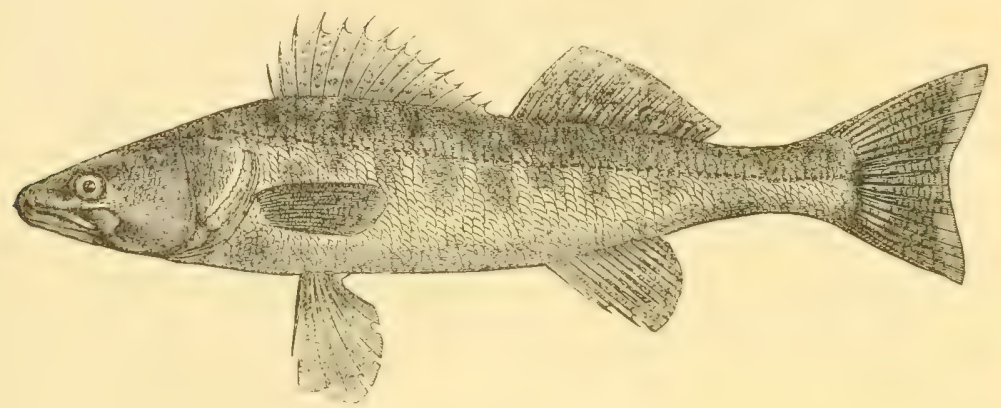

THF ZANDER. S. LECIOPERCA.

They feed upon every kind of small fish, and do not even spare their own offspring. In the sea-going rivers of Germany they prey largely upon the smelt, and in our own waters upon the various small cyprinoids. Insects, larvæ, crawfish and worms are also devoured in great numbers, and even trogs and snakes.

Their eggs are from I to I $1 / 2$ millimeters in diameter, and light golden yellow in color, and are adhesive like those of the sea-herring, clinging to stones, roots and the stalks of water plants where they are deposited at a depth of from three to ten feet. They begin to spawn when less than a pound in weight, and each female deposits from two to three hundred thousand ova. This great fertility is serviceable, for no fresh water species is more subject to the fatalities incident to the spawning season. After storms the shores of lakes are said to be often bordered by windrows of the stranded ova of the Pike-Perch. Dr. Estes well describes the destructive inroads of sturgeon, cat-fish and suckers upon the spawning beds in Lake Pepin. He estimates that not one-fourth of the eggs remain to be hatched.

Wenzel Horack, who has studied the habits of the Zander in Southern Bohemia, finds that the time of spawning is so intimately connected with the temperature of the water and the air that it sometimes begins in March, though it usually occurs in April and May; the season of oviposition continues through the summer and into October. In the north of Germany the Zander spawns in May and June; in southern Germany earlier, begining in April. Eckström states that in Sweden they spawn only at night.

The fullest description of the breeding of the American species is that by 
Dr. Estes: "They spawn," he writes, "from the first to the fifteenth of April, in Lake Pepin sometimes earlier. One season the spawning was all done by the third of April, and every fish had left the beds. Just as soon as the lake is well closed over with ice, they leave the deep water and resort to the sand-bars where they remain until the spawning time in the spring. It seems a fact that they select and take possession of the spawning beds fully three months before they are needed for use. I have carefully observed this habit for more than twenty-five years, and each year's observation is confirmatory. In the first place, we do not take them on these bars in summer, and again two-thirds of all that are taken from the beginning of winter to spring are females, proving conclusively that they thus early select these bars as spawning grounds. I have often visited them as early as May, but failed to find the fish, while, from the closing of the lakes to March, they are often found in great numbers.

"The beds are made on sandy bars, in water from four to eight feet deep). The bottom must be clean, well-washed sand, free from gravel, rocks, mud or grass. The eggs are mixed with the sand. but not covered over, and consequently many of them fall an easy prey to the numerous fishes which are on the hunt for them." *

Little is known of their rate of growth. Heckel and Knerstate that the Zander grows rapidly with abundant food, especially if it remains in the marshy districts, attaining in the first year a weight of a pound-and-a-half, in the second two pounds-and-a-half, and in the third, from five to six pounds. In the lower waters of the Danube, however, its weight in the first year is only three-quarters of a pound, and in the second, two pounds.

They also say that the Zander lives only from eight to ten years. Dr. Estes tells us that in Lake Pepin the yearling fish are only about two inches long, a story which seems much more credible than that told by the Austrian naturalists just quoted. The Wall-eye does not often exceed ten pounds in weight, though giants of thirty-six inches or more, weighing from twenty to thirty pounds, are on record. $\uparrow$ The Sauger is smaller, rarely exceeding eighteen inches in length. Zanders sold in the German market:; range from one to four pounds in weight; the Pike-Perch which come to Washington and New York are usually not larger.

The Pike-Perch was one of the first species experimented upon by American fish culturists. In May, IS 57 , it is said, Mr. Carl Muller of New York 
and Mr. Henry Brown of New Haven, artificially fecundated twenty million eggs, which they transferred from Lake Ontario to Lake Saltonstall in Connecticut. There is no evidence that the eggs ever were hatched.* Seth Green has experimented in the same direction. He states that the eggs may be hatched either in the box which bears his own name, or in the Holton box, and that they require thirty-one days for development in water at a temperature of $34^{\circ}$, though in warmer water they will mature in ten days. $\nmid$ Max Von dem Borne gives the details of some further experiments made in Pomerania, prior to r 881 . f

It seems probable that whenever it shall be determined to disseminate this fish more widely through American waters, the object may be accomplished, as has been so often done with the black-bass, by transplanting individuals of considerable size. The Zander was successfully acclimated in England by the Duke of Bedford in I 878 . Twenty-eight individuals, averaging about two pounds in weight, were taken across from Germany by Herr Dallmer, a Prussian fishery officer.

Elaborate instructions for the transplanting of this fish, and its care in captivity, are given by my friend Max Von dem Borne, in his "Fischzucht."

Wherever the Pike-Perch is known it is very highly prized. In the Great Lake regions $S$. vitreum ranks next in value to the white fish and lake trout, though $S$. canadense is not so well esteemed. At Sandusky, Toledo and Cleveland, where all market-fishes are classified-in the two categories "hard-fish" and "soft-fish," the two species are assorted into distinct classes, the Sauger being placed in the inferior, or "soft" group.

The flesh is hard, white, flaky and easy of digestion, and has a distinctive flavor of its own, which renders it especially available for boiling, though often stuffed and baked. Its capabilities are equal to those of fresh-caught cod or turbot. The Pike-Perch, as it comes to our tables, through the mediation of the fish-mongers, is by no means so palatable as the Zander, when served in the restaurants of Berlin, Dresden or Nunich-plainboiled with a simple sauce of drawn butter. This is not the fault of the fish so much as of the fish-markets. In Germany they are sold alive, and it is a most satisfactory experience to see the clean, plump fishes, eels, carp and Zander, swimming about in the great wooden tubs, of which there are scores in the great stone-paved squares every market morning.

Report U. S. Commissioner of Patents, 1859 , p. 227.

$\dagger$ Iish Ifatching and Fish Catching, 1879,1 , $x 73$.

$\ddagger$ fischaucht, p. 149 . 
I have an impression that the delicacy of the Zander in Germany is greatly due to the fact that the fish are bled, when taken from their tubs to be delivered to the purchaser. In Sweden the fishermen are said to pierce their tails, to allow the blood to escape and thus blanch the flesh.

In the south of Russia one of the Pike-Perches, the Berschick, is exceedingly abundant. In former years it was held in low esteem and used in the manufacture of oil, but of late, Astrakhan has been sending annually to Turkey and Greece about eighty millions of pounds of this fish, salted and two or three million pounds of a kind of caviar, called tchastikovi, made for the most part from its roe.

Travellers in Austria and Russia tell of the great piles of salted PikePerch, stacked up like cord wood along the banks of lakes and rivers.

In angling for Pike-Perch, a bass-rod, reel and float are generally used by American anglers. In quiet waters live minnows are preferable for bait, but in rapid.currents slices of fish are quite as good, especially if these are trimmed so as to spin nicely. Bischoff, a Bavarian authority, recommends the use of long thin strips, fastened to the hook at one end so as to wriggle like snakes. European anglers generally prefer live bait, with the paternoster or even with the simple float-line.

In fishing in rapids the bait should be allowed to run down with the current, guiding it as far as may be in and out among the largest rocks. Genio Scott found this method effective at the Little Falls of the Mohawk River.

It should always be remembered that the Pike-Perch rarely leaves the bottom, and the line should always be baited with reference to this fact.

The artificial fly is sometimes used. A correspondent of the American Angler* wrote sometime ago to that journal that he had fished the streams and lakes of southern Wisconsin for twelve years, and had found no fish which afforded him better sport than the Pike-Perch. It will take the fly as readily as the brook-trout or the black-bass. and while it will not light as lons as the bass, it furnishes the fly-fisher with a fair amusement, and as a table fish is infinately its superior. With a light rod, weighing from five to nine ounces, a four foot leader, and a bass-fly, this fish may be readily taken. The angler should whip the white foaming water below a dam, on some frosty morning, using a dark fly, or cast upon the same water toward evening with a light fly. He will learn that there are new possibilities for him in the way of sport with a rod.

* Anerican Angler, Oct. 7,1882 . 
There is probably no better Pike-Perch fishing in the world than that which may be had in the vicinity of Lake City, Minn., in Lake Pepin and the adjacent waters. The name of Dr. D. C. Estes is as closely identified with the Pike-Perch as that of Norris with the grayling, of Henshall with the black-bass, or of Cholmondeley-Pennell with the pike. His essay published in the fourth volume of the American Angler, * from which extracts have been made, is the only careful study of the American species and is well worth the attention of naturalists as well as of anglers.

The tackle which he recommends for boat or raft fishing consists of a three-jointed bamboo rod, about twelve feet long; a click reel placed in front of the hand and on top of the rod, thirty or forty yards of braided silk or linen line, and a Sproat-bend hook, No. $3^{-0}$, tied to a single length of twisted double gut or to gimp.

For wading the bars he uses a much longer rod, often a whole bamboo, so pliable that long casts may be made into deep water. More than twothirds of the fish caught in the main body of Lake Pepin are taken within four rods of the shore, off the ends of the sandy points, in water from five to ten feet deep.

The Pike-Perches are never taken in large numbers for use in commerce, except during the spawning season, or immediately before it, and like the perch, they are in the finest condition when full-roed. In Balaton Lake and elsewhere in Hungary, there are extensive fisheries with bag-nets under the ice, and they are caught chiefly in winter in our own lake region. I have never seen a description of the manner in which the Berschick, S. volgensis, is captured in Astrakhan, but the statistics indicate that it is carried on during the spawning season, since three or four per cent. of the weight of the fish exported is in the form of salted ova.

A good type of winter fishing through the ice is that practiced on Lake Pepin. Holes are cut through the ice over the bars from three to ten rods from the shore. The hook is baited with a live minnow. A very simple device is used to signal a bite. A piece of lath about two feetlong, with a hole in it a little nearer one end than the other; through this hole in the lath is run loosely a cross-bar which is laid across this hole on the ice. To the short end of the lath the line is attached. The moment the bait is seized by a fish below, the end of the lath flies upright, and so remains as long as the fish pulls. The fisherman seeing it, hastens to rescue his fish.

\footnotetext{
* American Angler IV, $1883, \mathrm{pp} .145,161,177,191$.
} 
When there are from fifty to one hundred lines out, and the fish are biting freely, it is exciting sport to fly from one quivering signal to another, for it is often that four or six are in the air at one time. The number of fish thus taken every winter is very great, amply supplying local demands, and the fish are much larger than those caught in summer.

"As an angler and naturalist," continues Dr. Estes, "it was many years before I became reconciled to catching the wall-eyed pike from off their spawning beds in the winter and spring. Three considerations finally forced reconciliation. (I) There existed in the lake a great number of these fishes, (2) comparatively few could be taken in summer by the approved method of angling, (3) unless taken through the ice a great amount of cheap and wholesome fish-food could not be utilized.

"Notwithstanding these arguments I cannot but feel condemned for my conclusions, when I see hundreds of these fishes daily, every one filled with spawn enough to stock an inland sea.

"One other method is resorted to. This is the Indian plan of spearing through the ice from under a teepe or daily shanty. A decoy minnow is kept in motion until the fish is enticed into sight, when the cruel and deadly spear descends and fastens its barbed truss firmly in the flesh. 'The method is worthy alone of the Indians who invented it. *",

Closely allied to the Pike-Perches is the log-perch, Pcrcina caprodes, also known as the "Rock-fish," and "Hog-fish." It is the largest of a large group of little perch-like fishes called "Darters" or Ethcostomatidc. "These fishes" writes Jordan, "may be described as little perch, reduced in size and compacted, thus fitted for a life in rocky brooks, where the water is too shallow, swift and sterile to support larger fish. All the Darters are brilliantly colored, and all have a way of lying quiescent on the bottoms, resting on their large fins, and then suddenly darting away for a short distance when disturbed. They are carnivorous, feeding chiefly on insects and crustaceans. Only one of them, Percina caprodes, is large enough to take the hook. This one is often found on the urchin's string, but it cannot be said to have any economic value. The others are too small for the urchin even, and although, according to Rafinesque, "they are good to eat fried,' few people think it worth while to cook them. Darters are found in all fresh waters of the United States east of the Rocky Mountains, but all the species are peculiar to America." 


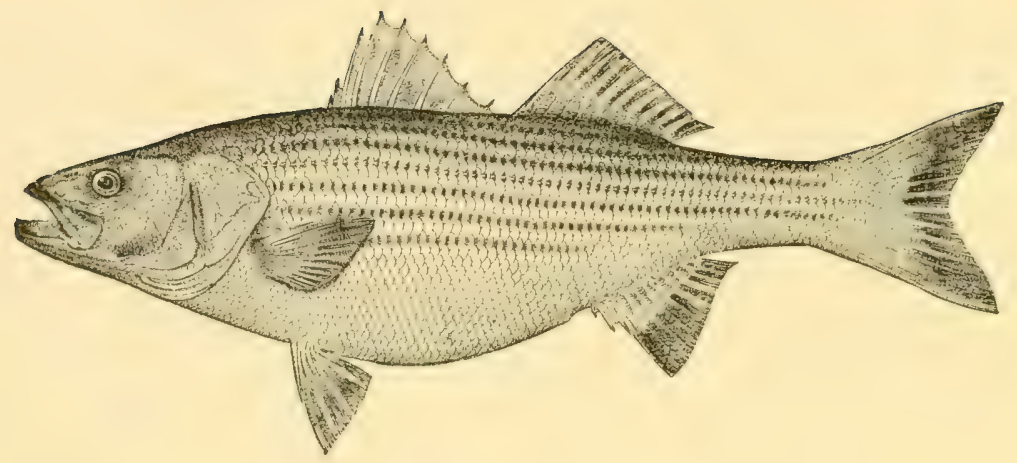

THE STRIPED BASS.

Roccus lineatus.

The stately Bass, old Neptune's fleeting Post

That tides it out and in from sea to coast.

Wood, New England's Prospect: 1634.

$\mathrm{B}^{\mathrm{Y}}$ the Greeks, it was so highly esteemed that Archetratus termed it, or one of the two other closely allied species taken near Miletus, "the offspring of the gods:" So writes Günther, concerning the Bass of Europe, the Ao $\beta_{1} 0 u_{s}$ and the Lupus of classical literature, which ascended the Tiber, and entered the Acherusian marshes, and gladdened the palates of the gourmets of Rome and Athens.

The European Bass, Roccus labrax* is found from the Mediterranean, to Tromsoe in Norway; the American species ranges from the Gulf of St. Lawrence to the Gulf of Mexico. The two species are similar in form, but very unlike in color; ours being conspicuously striped, while that of Europe is silvery grey. The American form is the largest, most active, and on account of its greater abundance, by far the more important.

In the North it is called the "Striped Bass," in the South the "Rock Fish," or the "Rock." The neutral territory where both these names are in use appears to be New Jersey. The fisherman of the Delaware use the latter name, those of the sea-coast the former. Large sea-going individuals are sometimes known in New England by the names "Sipuid-hound"

* Bass, Sea-Perch, White Salmon, Salmon Dace and Sezvin, in England, Gape-mouth in Scotland, Draenog in Wales, ( This means hedgehog. Compare with the Breton Dreinee.) Bar and Bars in France, Yan and Dreinee in Brittany, See-Barsch in Germany, Hav-Bars and Bars in Denmark, Spinola, Spigola, Branzine, Varola, Baciola, Ragus and Labrace in Italy, Luben in Croatia, (compare Latin Lupus.) 
and "Green-head." In old books it is sometimes called the "Streakedlass."

The generic name, Roccus, a barbarous derivative from the common name of the fish, originated with Professor Mitchill, who described the species in his "Fishes of New York," in I $\mathrm{S}_{4} 4$.

There is still some uncertainty regarding the southern limits of the distribution of this species. In the St. Joln's River, Florida, they are very unusual. Though familiar with the fisheries of that region since ${ }^{8} 873$, I have known of the capture of only two individuals. Mr. Stearns has obtained one or two specimens in the vicinity of Pensacola, and gives an account of the degree of their abundance in the Gulf of Mexico. He writes: "They are occasionally caught on the northern shores of the Gulf, and are evidently more common about the mouths of the Mississippi River than elsewhere, since they are taken in this region only in seines, and in shallow water their abundance cannot be correctly determined. The earliest account I have been able to obtain of the capture of the Striped Bass in Pensacola Bay is that of Capt. John Washington, of Mystic, Connecticut, who states that in 1850 , while seine-fishing from the smack 'Francis Parkes,' he surrounded with his seine a large school of fish, which were quite unmanageable; a few of them were saved, and proved to be large Striped Bass, weighing from fifteen to forty pounds. At long intervals since, solitary individuals have been taken at various points on the coast. At New Orleans it is found in the market quite often. An eighteenpound specimen was sold there in March, ISSo."

In Hallock's "Sportsman's Gazetteer" the following statement occurs: "It is constantly seen in rivers of fresh water at great distances from the ocean, even as far up the Mississippi as Saint Louis, and it is common in White River, Arkansas, and in all the rivers of the Southern States.' While there can be no question that straggling individuals of this species have been taken in the Gulf of Mexico, it seems probable that both Mr. Stearns and Mr. Hallock have been mistaken by the resemblance of this species to the Brassy Bass, Roccus intermptus, which abounds throughout the Lower Mississippi Valley.

Canadian authorities inform us that, though the Bass still occur along the New Brunswick and Nova Scotia shores of the Gulf, they are much less abundant and of smaller size than formerly. They have been known to ascend the Saint Lawrence as far as Quebec, and Mr. Roosevelt has seen a 
specimen, a female fish, which was taken in the Niagara River, near Lewiston. The Bass is most abundant in the bays and inlets about Cape Hatteras, in the Chesapeake and Delaware Bay region, and in the protected waters of Long Island and Southern New England. In winter it occurs in considerable numbers in the Altamaha River, and is not unusual in the markets of Charleston, South Carolina.

The species was introduced into California some years ago, and Jordan reported, in $\mathbf{I} 880$, that several specimens had been captured along the coast.

It is particularly abundant in the great estuaries and the open stretches of large rivers. It ascends the Potomac to the Great Falls, twelve miles above Washington, the Hudson to Albany, the Connecticut to Hartford, and the Saint Lawrence to Quebec. Before the erection of the dam in the Susquehanna individuals were taken as high up as Luzerne. It is very curious that Günther should state that the European species of Bass are "almost exclusively inhabitants of the sea, entering brackish but never fresh waters, whilst the American species seem to affect principally fresh waters." It is true that America has species of Roccus exclusively fluviatile in distribution, but not true that the European form does not ascend rivers. Badham, who is a sufficiently accurate commentator on the classical authorities, remarks: "Though born, and in a great measure, bred at sea, it was only those taken in fresh waters which fetched fancy prices, for most rivers were thought to impart flavor and to improve the condition of his solids; but as tawny Thames has a pre-eminence among rivers for the quality of its Perches, so had tawny Tiber for the quality of its Basses. Many went so far as to ignore the existence of this fish from any other stream."

The young fish may advantageously be confized in "stews" or artificial enclosures. This was done successfully by Arnold on the Island of Guernsey, and the experiments of Clift at Mystic, Connecticut, were, I am told, reasonably satisfactory.

No one species among the many which they encountered, seems to have astonished the early colonists of America by its abundance and choice qualities so much as did the Bass. Capt. John Smith in his "New England's Trials," wrote:

"The Basse is an excellent Fish, both fresh \& salte, one hundred whereof salted (at market) have yielded 5 pounds. They are so large, the head of one will give a good eater a dinner, $\&$ for daintinesse of diet they excell the 
Marybones of Beefe. There are such multitudes that I have seene stopped in the river close adjoining to my house with a sande at one tide so many as will loade a ship of roo tonnes. I myselfe, at the turning of the tycle have seene such multitudes passe out of a pounde that it seemed to me that one mighte go over their backs drishod."

Skeptical historians of to-day say that John Smith was a liar. I don't believe it, and I quote in his support from the words of a "reverend Divine," his contemporary :

"There is a Fish called a Basse, a most sweet \& wholesome Fish as ever I did eat, it is altogether as good as our fresh Sammon, \& the season of their comming was begun when we came first to New Lngland in June and so continued about three months space. Of this Fish our Fishers take many hundreds together, which I have seene lying on the shore to my admiration; yea, their Netts ordinarily take more than they are able to hall to Land.'

It is by no means strange that the Virginians believed it possible to establish commercial fisheries which should rival those of Newfoundland. Indeed the bass fishery has, for two hundred and fifty years, been a very important resource of the coast states from Massachusetts to the Carolinas, and to the present day the annual captures in certain localities are enormous. The following are extracts from an old note book:

In December, I874, three fishing-gangs near Bridgehampton, N. Y., took over I 8,000 pounds in less than a week, Captain Charles Ludlow securing at one set of his seine I , 672 Bass, or about three and one half tons. * Shortly after this a New London fisherman brought in 4 I 9 Bass, I 85 of which had been caught with a hook in three hours. Near Norfolk, Va., i, 500 have been taken at a single set of the seine; a few years ago 600 were thus taken which averaged 80 pounds each. The most successful fishery is on the plantation of Dr. IV. R. Capehart, in Bertie County, N. C. At the approach of spawning time, and during the continuence of the shad and herring fishery, the bass congregate near the head of Albemarle Sound, where they are taken in great numbers. Dr. Capehart writes: "We usually catch from 20,000 to 40,000 pounds of Striped Bass in a season of fifty days, - in March, April, and early May. Gecasionuiy ise make an immense catch. In $S_{5} 8$, I took alout 30.000 pounds in onc hut. Many

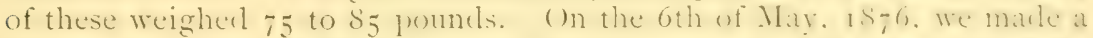
hatul of 820 Bass, weighing 37.000 prounds: sis of this lue weighed o5 pounds, average, a great many $S_{5}$ pounds, and a few 90 pounds. In the

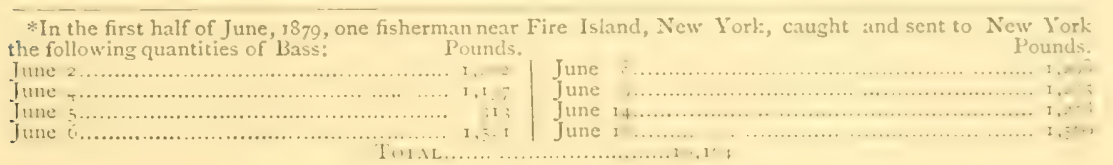


next haul we caught I3,000 pounds more, or 50,000 pounds altogether within six hours. This was at the Black Walnut Point fishery. At my Avoca Beach fishery a haul was made in 1844 , which was supposed to amount to 100,000 pounds, but this was not accurately counted. Many of the individual fish weighed 95 pounds." A Hessian officer, stationed at New York during the Revolutionary war, recorded that great quantities were at that time sold in the markets. In the year ending March, I879, over 800,000 pounds of bass were sold in New York, the greatest number being recorded for Noveminer.

The Baltimore Gazetle, in May, $18_{34}$ had this item: "Some fishermen at Carpenters Point took a single haul, upwards of 800 rock fish of the largest size we ever saw. Some of them weighed upwards of 100 pounds, and the most of them averaged from 50 to roo pounds."

The annual consumption of this fish in the United States is estimated at not less than 200,000 pounds.

I have found no very reliable evidence to show that the species is decreasing in numbers. They are not taken by unfair means, nor captured by wholesale upon the spawning beds or in narrow waters. The citizens of New York a century and a quarter ago were apparently more concerned about it than at present, for in $175^{8}$ they passed a law prohibiting their sale during the winter months, on account of the "great decrease of that kind of fish." An offender was to be fined forty shillings and forfeit his fish, and if he were a negro, mulatto or Indian slave, to be punished at the whipping post, unless his fine were paid by his master or mistress.

The European Bass is probably quite as abundant on the west coast of Spain and Portugal as anywhere within its range.

Like other representatives of the perch family not exclusively marine in habit, the Striped Bass are resident in our waters throughout the year. They appear to avoid a temperature higher than $65^{\circ}$ or $70^{\circ}$, and are not sensitive to cold, but their movements are not related to the changes of the seasons, and there is no evidence that they seek to avoid the approach of winter by southward migration like bluefish and Spanish mackerel, or by moving out into the temperate strata of mid-ocean, like shad, salmon, menhaden, and mackerel. Nor is it probable that they voluntarilyenter upon a state of torpidity in winter, as some writers have supposed. Several authorities state that they go into fresh waterstreams in winter for shelter, and De Kay's opinion was that, entering bays and ponds, they embed themselves in the mud. We know, however, that hibernation of this kind is rarely voluntary; as a rule, fish retreat, with a falling temperature, into 
the deepest waters, and never become torpid until they are benumbed by the cold, when they sink to the bottom, and possibly rest on a bed of mud. It is easy, however, to understand that individuals may occasionally be penned up in this way. Mr. Genio C. Scott is responsible for the statement that the ponds formed by the back water of the Seconnet River, in Rhorle Island, were one winter so full of Striped Bass that they were discovered by their dorsal fins projecting from the ice where they had been frozen by too close packing. Most of our Bass doubtless avoid such ignominious captivity as this by retreating to the deeper parts of the sea, or the rivers, where they remain in a state of partial activity, at least, and have occasional opportunity for feeding. Since 1875 there have come to my notice instances of their capture in Long Island and Block Island Sounds, and in the Merrimac River in December, in Martha's Vineyard Sound and the lower part of Hudson River in January. Chesapeake Bay and the Potomac yield considerable quantities all winter. In the rivers of New Brunswick quantities of them are speared through holes in the ice, as they lie close to the bottom.

The Bass are most voracious feeders. When in the rivers they prey upon small fishes, which are always a favorite, and at this time their exclusive diet. C. C. Abbott, once saw a Bass, a foot in length, devour a dozen silver-finned minnows in four minutes. "A Rock-fish," writes he, "will frequently cormer up a small school of minnows, and then pick them up as rapidly and easily as a fowl will pick up grains of corn, and while devouring them will keep them in a small place, close together, all the time." They also frequent the surf along the ocean beaches, and near rocky shores at high tide, hunting for crabs, shrimps, squids, and other invertebrate animals.

Oppian and Alian tell astounding stories about European Bass, and how they choked themselves to death with their prey.

"The Lupus's foible," writes Badham, "is an inordinate greediness which, when choice fish can be obtained, renders all his cunning of no avail; and his death is often brought about by means of a very insignificant enemy."

They spawn. in the late spring and early in the summer, some of them in the rivers, others probably at sea, although this has not been definitely ascertained. The European Bass are said to deposit their spawn near the mouths of rivers, in the summer months. From North Carolina to New 
Jersey the spawning time appears to be in May; in New Brunswick in June. Dr. Blanding, many years ago, estimated the number of eggs at 2,248,000. Seth Green puts the figures at 500,000.

The experiments of Major Ferguson on Albemarle Sound, in May, I879, resulted in the artificial fecundation and hatching of many thousands of the eggs. These were smaller than shad eggs, but after fecundation they increased considerably in size, and assumed a light green color. They hatched in about twenty-four hours. About 400,000 young fish were liberated in Salmon Creek. Mr. Holton made similar experiments at IVeldon, N. C., in May, I873. He observed that the eggs did not come to maturity until the fourth or fifth day. This difference in the time of hatching was possibly due to the cooler temperature of the water in the Roanoke river.

In the North Carolina waters they spawn in early May; in the Potomac also in May. Dr. C. C. Abbott for five successive years found in the Delaware River young an inch long in the second week of June. Professor Leith Adams observed bass spawning in the St. Johns River, N. B. about the middle of June.

Their rate of growth is not certainly known. Dr. Abbott's inch-long fry of June measured four and one-half inches by the middle of October. Great quantities of young fish, from five to nine inches long, are taken in the Potomac in February and March. I believe them to be the young of the previous year.

Capt. Gavitt, of Westerly, Rhode Island, has caught Bass in June that weighed from one-half to one pound, put them into a pond and taken them out in the following October, when they weighed six pounds. The average size of this fish probably does not exceed twenty pounds. In the Potomac, Hudson, and Connecticut rivers the largest seldom exceed thirty or forty pounds, though in the Potomac fifty-pound fish are not unusual. The Fish Commission has for several years had a standing offer of a reward for a sixty-pound fish from the Potomac, but none has been forthcoming as yet. Dr. Henshall states that he once saw a Striped Bass weighed in the Baltimore fish market, which went several pounds over one hundred. In 1860 one was taken at Cuttyhunk, which weighed ro4 pounds. The largest on record was one weighing one hundred and twelve pounds, titien at Orleans, Massachusetts, in the Town Cove. Such a fish must have measured at least six feet in length. A fairly proportioned Bass thirty-six inches long should weigh at least eighteen pounds. 
In Great Britain a Bass of ten or twelve pounds is considered a fine example, but there are instances on record of individuals weighing 22 and $2 S$ pounds, and those in Southern Europe do not appear to grow much larger.

Few of our food-fish are more generally popular. The small ones, weighing less than a pound are fried, and are excellent pan-fish. Those from one to three pounds, are recommended for broiling, and from five to eight pound-fish are considered the best to boil. The very large ones are cut in transverse sections for boiling, and never lack purchasers. De Voe says that lass are in the best condition in September, ()ctoler and November.

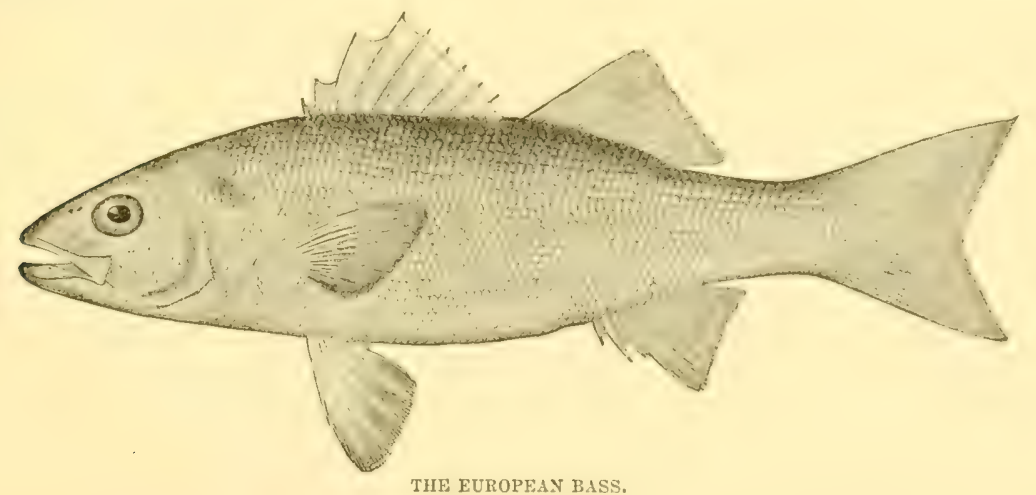

In Great Britain the Bass is not highly esteemed, but in France, Spain, Italy and Greece, is considered one of the finest of fishes.

"He is a gallant fish and a bold biter," said Frank Forester; and Genio Scott puts him first among the game-fishes of coast and estuary. 'The Striped Bass is deservedly a favorite with the ander, whether he fishes with shrimp or clam bait in the brackish creeks, entices with the artificial fly at the Little or Great Falls of the Potomac, trolls in the swift tideways, tolls with menhaden bait from the stages at Pasque and Cuttyhunk, stillbaits in the bays, or "heaves and hauls" in the wild surf of the outer shores. The last mentioned method is perhaps the most peculiar, and deserves a few words of description. In Scott's "Fishing in American Waters," and in Roosevelt and Green's "Fish Hatching and Fish Catching," may be found descriptions of the various kinds of tackle used in Bass-fishing, and graphic, breezy stories of adventurous days passed in this pursuit. Mr. Scott does not hesitate to claim for his favorite the first 
place on the list of American game-fishes. After devoting several chapters to other methods of capture, he continues: "Casting menhaden bait for Striped Bass, from the rocky shores of the bays, estuaries, and islands along the Atlantic coasts constitute the highest branch of American angling. It is, indeed, questionable-when considering all the elements which contribute to the sum total of sport in angling-whether this method of Striped Bass fishing is not superior to fly-fishing for salmon, and if so, it outranks any angling in the world. The method is eminently American, and characteristic of the modern angler by its energy of style, and the exercise and activity necessary to success." The rods used in this kind of fishing must not exceed nine feet in length, and are very light, often less than a pound in weight, the lines of linen or hemp, two to three hundred yards long, must be of the utmost strength and elasticity, the reels must represent the perfection of the tackle-maker's skill, triple-multipliers, with jewelmounted wheels and delicately adjusted balance-cranks. The unsuspecting Basses are lured in by the use of a toll bait of chopped menhaden, which is cast upon the water until an oily surface or slick is produced which extends half a mile or more from the shore. This attracts the fish, which swim toward the angler, stopping now and then to seize the floating bits of fish. When they come within reach of the fisherman's line a strong hook, delicately baited with a bit of menhaden, pork, or parchment, is quickly offered them. "With a dexterity which practice alone can assume," writes Mr. Hallock, "the experienced anglers carefully sway the rod until the squid describes its slowly moving circle around the head, and then, by a quick, inexplicable movement, cause it to dart like an arrow, straight out far over the sea, and the reel whizzes and whirls until it seems to flash fire, and you wait long and patiently for the cessation of the hum, which indicates that the squid has dropped full one hundred feet, perhaps one hundred and fifty feet away. The pleasure and excitement of capture are intense, and often the struggle lasts for an hour when the fish is large."

On Pasque and Cuttyhunk, two of the Elizabeth Islands, lying between Buzzard's Bay and Martha's Yineyard Sound, are several club-houses. sustained by wealthy gentlemen from New York who resort to this region in summer to enjoy this amusement. Long stages project from the rocks into the sound and bay, and from these the anglers cast their squids and play their fish, attended by their " baiters," who do their full share of labor in finding bait, baiting hooks, and gaffing the fish. Ill-natured rumor 
whispers that for every pound of Bass brought to shore by these hard-working club-men, hundreds of pounds of menhaden are cast in to the sea.

An obliging correspondent furnishes the following description of one of these clubs: "The Island of Cuttyhunk is about sixteen miles from New Bedford, at the extreme southwesterly boundary of Buzard's Bay, whose foaming billows wash its northern shore, while the ocean itself beats upon the south. 'The Cuttyhunk Club own about three hundred acres of land, and have the exclusive right to fish on the shores and in the ponds of the island. When the club was first formed they stocked one of the ponds on the island with black bass, and these have multiplied so plentifully that they are now caught in large numbers. No fishing was allowed for three years from the time the pond was stocked. Perch and trout are also plenty in ponds on the island. Twenty-six fishing stands have been built at Cuttyhunk, and they extend completely round the island. These stands are built upon prominent rocks, and are supported above the breakers by iron rods. Foot bridges, supported in the same way, are built from the shore to the stands. The stands are all named or numbered, and are drawn for every night by the members of the club. A member drawing a stand can fish from it the next day, or it can be used by any one else by his permission. 'The stands bear such names as 'Nashawena Point,' 'Canepitset,' 'Old Water Line,' 'Cove Point, 'Little Bass,' 'Big Bass,' and 'Gull Rocks.' The stands are all removed after the season is over, to be put up again the next year. 'Central Park' seats have this season been placed on the bluffs round the island at convenient points, from which to watch the fishing at each stand, so that members who are not lucky enough to secure favorite stands can sit with ease and enjoy the sport of their fellow-members. The farorite fishing is for Striped Bass, and, during the best of the season, the sport is commenced as early as three o'clock in the morning. A record is kept at the club house of the daily catch, by whom caught, where taken, on what station, the number of fish, weight, and date. Some members of the Cuttyhunk Club also belong to the West Island Club, which controls only five acres of land. The West Island Club is limited to thirty members, with an admission fee of $\$ 1,000$."

Professor Leith Arlams has drawn a vivid gen-gicture of Inulian Bhas-lishing in New Brunswick.

"The Indians (on the St. John's River) pursue them at spawning time. The scene on a beautiful summer afternoon is extremely exciting. There a few canoes containing remnants of the Melicita tribe may be seen dropping quietly down the river, each with an Indian in the prow, spear in hand, and another at the stern paddling gently; then a sudden splash close by calls for his utmost exertions, and like an arrow the birch-bark skiff is shot towards the spot, when the man in front, resting on his knees, with much force and dexterity sends his three-pronged harpoon straight on the fish." 


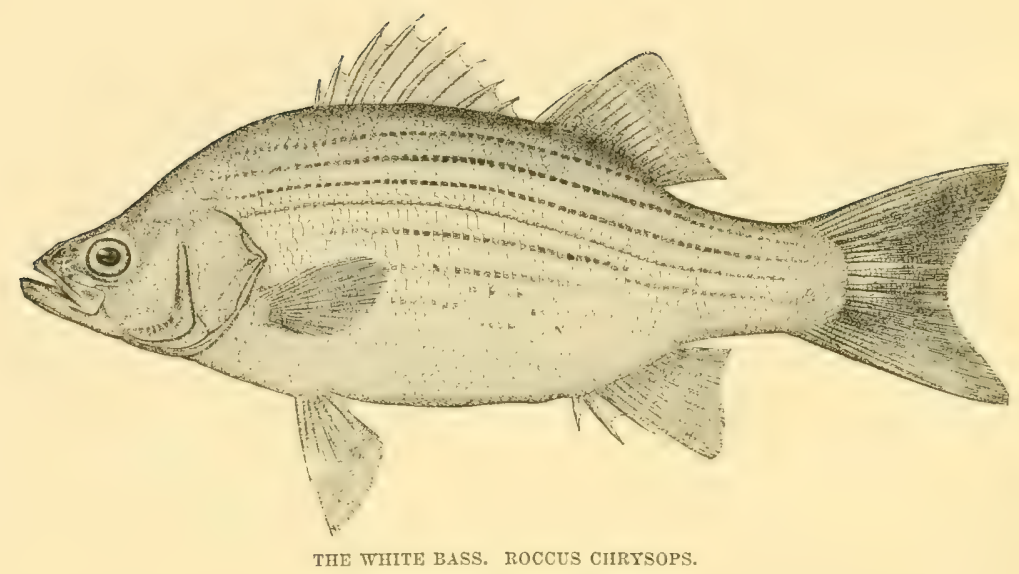

\section{THE IVHITE BASS AND THE YELLOW BASS.}

Subtle. Has he bit? Has he bit?

Face. And swallowed too, my Subtle. I have given him line, and now he plays i' faith. Subtle. And shall we twitch him?

Face. Through both the gills.

Ben. Jonson, The Alchemist, 1611, Act. ii, Sc. r. HE White Bass, or Striped Lake Bass, Recius chysofs, is often con-
founded with the Striped Bass, which it closely resembles. It may easily be distinguished by the presence of thirteen, instead of eleven, soft rays in the anal fin, as well as by the greater size of its scales, of which there are about fifty-five rows, instead of sixty or more.

It is most abundant in the Great Lake region, although it has a wide distribution in the Ohio and upper tributaries of the Mississippi, and is found in many streams farther south. It frequents chiefly the lakes and ponds and the deeper parts of the rivers. It feeds upon minnows and the like, usually taking the hook readily, and is considered gamy by the angler. As a food-fish it ranks high, being little inferior to the blackbass. Its usual weight is from one to three pounds. The White Bass is said to be an excellent fish for cultivation in artificial ponds. Like most of its relatives, this species spawn in late spring.

"It is often taken in the Ohio River," writes Jordan, " and frequents chiefly deep or still waters, seldom ascending small streams. 
This is doubtless the Silver Bass of Canada (Ie Silver Bass du Canade), the details of whose introduction into France, and successful propagation by M. Carbonnier, from $\mathrm{i} 877$ to $\mathrm{i} 879$, are recorded by that experimenter in the Bulletin of the Society of Acclimation for $\mathrm{x} 8 \mathrm{~S}_{\mathrm{r}}$ * $^{*}$

The species at one time attained to commercial importance in the Lake Region, but has now greatly decreased in numbers. It is especially admired by the anglers of Lake Pepin.

Another species which closely resembles the Striped Bass is the Morone interrupta, generally known as the Yellow Bass, but sometimes called



Bar-fish in the South. It is found throughout the lower course of the Mississippi, ascending the tributaries which are deep and sluggish, but not running past rapids or into the upper courses of the rivers. Jordan states that its range extends up the Ohio to the mouth of the Wabash or beyond, though it does not seem to be common anywhere except in the Lower Mississippi. It probably enters salt water, but of this we have no certain information. It is taken in considerable numbers in the regions where found, and is graded with the White Bass, which it much resembles in size and color. Little is known in regard to its habits. The criterion by which it may be distinguished from the White Bass is the low membrane connecting the two dorsal fins. Its color is yellow, not silvery, and the black stripes are very prominent. 
In Louisiana this species is called "Bar-fish" probably on account of its stripes. "The appellation," says Hallock, "is equally appropriate as applied to its habit of congregating in great numbers upon the shoals of clear water branches and bayous which empty into the Mississippi. The minnows and shiners seem to seek the bars at night. In early morning the water is alive with Bar-fish and trout (black-bass) in pursuit of the minnows until it fairly boils. This is the time of day to go fishing."

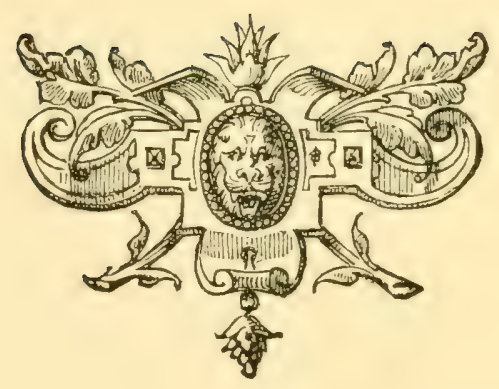




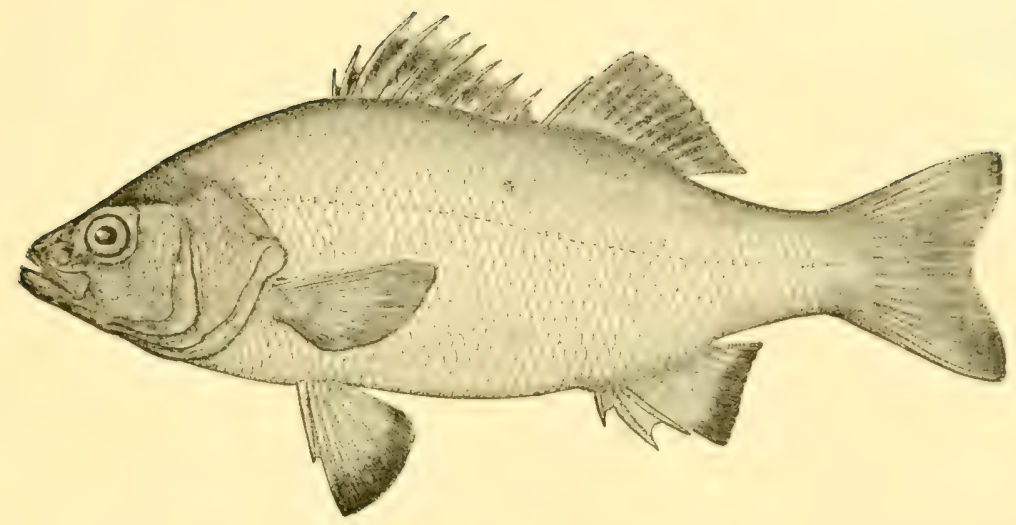

THE WHITE PERCH.

Morone americana.

Nor let the Muse, in her award of fame,

Illustrious Perch, unnoticed pass thy claim,

Prince of the prickly cohort, bred in lakes,

To feast our boards, what sapid boneless flakes

Thy solid flesh supplies ! though overfed,

No dantier fish in ocean's pastures bred

Swims thy compeer.

Ausonius, The Moselle.

THE apostrophe of Ausonius was prophetic, for his words apply much more exactly to the species of Morone now under discussion than to the Perca which the poet had in mind.

This fish, closely related to the Yellow Bass, occurs in brackish water in the mouths of rivers, and even, in many instances, in fresh-water ponds, where it had become land-locked, and all along the coast from Georgetown. S. C., to Nova Scotia. Dr. Yarrow states that it abounds in the Tar and Neuse Rivers, N. C. In the Chesapeake and tributary streams it is exceedingly abundant. It also abounds in the lakes and streams of the St. John River, New Brunswick, and in the vicinity of Halifax, Nova Scotia. It has been claimed by certain observers in Florida that White Perch were formerly abundant in that region, and the marketmen of New Orleans state that they were common in Lake Pontchartrain until the Bonnet Carré Crevasse changed the water from salt to fresh. Mr. Stearns and Prof. Jordan having inrestigated the subject, are of the opinion that these theorists are mistaken. 
The habits of this fish have been but little observed; in fact, it has been the custom of nearly all writers on game fishes to speak lightly of it. It found an earnest advocate in Mr. Thaddeus Norris, who, after protesting strenuously against the statement of various writers that it is rarely brought to market for food; that it is only fit for chowder; that it is not of sufficient importance to merit particular notice, and so on, goes on to state, what is undoubtedly true, that in season the White Perch is the panfish, excelled by none in the Philadelphia, Baltimore, Washington, Norfolk and Richmond markets; and he might have added, had he been writing at the present time, of the New York market also, for there is, probably, no fish of its size which is more universally popular throughout the Eastern States than the White Perch.

In a single paragraph, Mr. Norris, who, making no professions of scientific skill, has been one of our best observers of fishes, has given almost the only reliable information which has ever been collected regarding this species. "Its most natural habitat is in fresh tidal rivers, where it is found on flat clay and muddy bottoms, and in shallow water. It is frequently found far above the terminus of the tide, and is often more abundant in fresh than in brackish water in the season of the year when sought for by anglers. This fish, when found in salt water creeks, is darker in color, but there is no specific difference. The White Perch is a congener of the magnificent rock-fish, and is frepuently found feeding in the same place and in his company. Its average length is eight or nine inches; it is not often more than twelve, though in rare instances it is found fourteen inches long. White Perch hibernate in the deep waters of our bays, and ascend the fresh tidal rivers soon after the ice and snow-water have run off. They feed greedily on the spawn of other fish, particularly that of the shad; on insects, crabs, minnows and on the migratory schools of young eels which are found in the months of April and May in great numbers at any rapid or dam obstructing the upward flow of the tide. Perch usually spawn in May, and then resort to deeper waters to recuperate, and all summer long are found by the angler, ever swimming around the deep-sunk pier or the timbers of the rickety old bridge, snapping at shrimps or chasing the minnows; at flood-tide high up amongst the waterlilies, and never refusing a bait, if of the right sort and properly presented."

Dr. C. C. Abbott has added some important observations. He found female fish heavy with apparently ripe ova as late as June io. The largest 
specimens of White Perch taken in the Delaware weighed, respectively, one pound nine ounces, one pound thirteen ounces, and two pounds one ounce. 'These were caught in a shad net in May, I865, at the fishery opposite Trenton. The average adult fish may be said to measure eight inches and weigh from seven to nine ounces. He continues: "I believe, for reasons to be given, that the growth of the young is very rapid, and that the August Perch are young, hatched late in the preceding May and April; in June these August Perch measuring about two-and-a-half to three inches in length. . . . I should judge that spawning occurred between May io and June Io, usually nearer the former than the latter date. This is based on the fact of having gathered very young fish, the age of which I guessed from the general condition and amount of development of the specimens. After the middle of June the White Perch are found in localities widely different; even waters with a dense growth of lily and river weed are found to contain them in apparent health and vigor-spots where the Rock fish could not live a day. Still later in the summer, as the young Perch become quite strong and of some size, the river, although in and above tide-water, fairly teems with them. At this season they go in schools, sometimes of large size. I have known of twelve, fifteen and twenty dozen August Perch being taken with a line in as short a time as from three to five hours. Fishing in this way a line with half a dozen hooks is used, and worms, sturgeon spawn or live minnows are used as bait. These schools of small Perch I supposed to be broods of the preceding May, and that they kept together until late in November. They pass down to the salt water and there separate. Larger adult fish are not as restless as these smaller ones, and are found in deeper water, and usually in the tide-waters. In their feeding habits the White Perch agree very closely with the rock-fish. In all their habits, in fact, the two fish are much alike, and in the Delaware they are always associated, the most noticeable difference in their habits being the ability of the Perch to remain and thrive in warmer waters than the rock-fish is ever found frequenting."

Harris, in his "Game Fish of Pennsylvania," writes: "When taken with a skittered minnow or bright fly on a light rod, we do not hesitate to class as a game fish the White Perch. Large individuals are caught on the edges of the splatterdocks and in the eddies around the piers of the bridges spanning the numerous creeks that flow into the Delaware, the bait being a live minnow. At night, in the incoming tide, large Perch 
are caught in great numbers with the worm, in the waters below and above Philadelphia. The angler sits in the stern of the boat and fishes with a short rod and line. Perch caught by the above methods run large and are gamy, and those caught on rod and reel at Pennsgrove, Salem ancl other places further down the bay give great sport on light-running tackle. I see nothing to commend in the method of fishing for Perch as practiced by the "bow-line" fishers for the fingerlings which swarm in great schools upon the bars of the river above and below the tide-waters of the Delaware. It takes a basketful to make a breakfast for a small family. I have seen and counted a catch of I,300 small Perch made with worm bait by three lines in two hours' fishing at Titusville, N. J., nine miles above tide-water."

It seems very strange that no attempt should have been made to introduce the White Perch into Europe. It would thrive admirably in the estuaries and sluggish streams, and would be far more worthy of the attentions of the British angler than various species of so-called "coarse fish" which he now pursues. It would be a great boon to the easy going British angler of the Waltonian type, to whom the pleasure of the rural scenery and quiet outing is of more moment than the strength and voracity of the fishes which chance to encounter his lures.

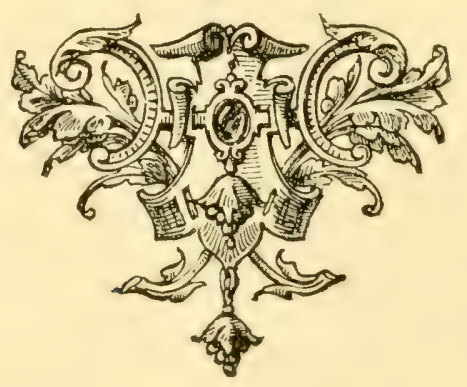




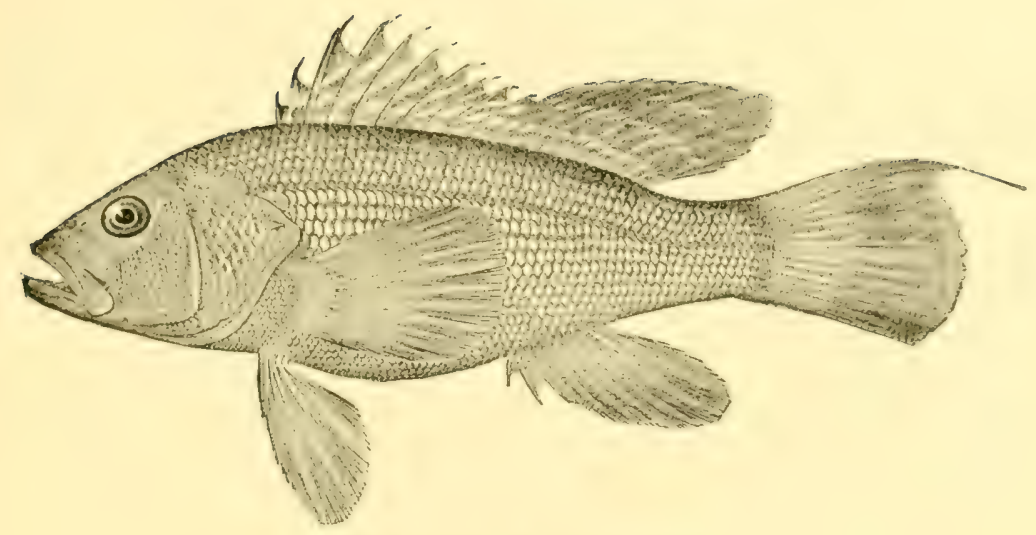

\section{THE SEA BASSES.}

So gaat het hier : dat's Werelts overvloed, (Waar mee de Mensch word koninglijk gevoed Door gulle gunst des milden gevers) doet Hem vaak vergeeten.

Steenbrassem, Steur en Dartien en Knor-haan. En Zee-Baars die geen vorst sal laten slaan En Kabellau: en Salm, die (wel gebraan). Is vet, en voedig. Jakob Steendam, $t^{\prime}$ Louf van Niew Nederland, $166 \mathrm{r}$.

6 THE SEA BASS is another gentleman among his finny comrades," wrote Frank Forester. He belongs to the family Serranida, the members of which are similar in form and habits to the Perches, from which they are distinguished by certain anatomical characters, scarcely tangible to persons not expert in ichthyology. This family contains a very large number of species, some of which are to be found in all the tropical and temperate seas. On our Atlantic coast there are over twenty kinds, while in California, there are four, at least, which are of economic: importance.

The Sea Bass is also known south of Cape I Iatteras as the ". I3latktish,", and is the most important species on our coast. In the Midelle states the Sea Bass is called "Black Will," "Black Harry," and "Hannahills ;" about Newport and New Bedford, "Bluefish," and at New Bedford also, "Rock Bass." Curiously enough, the Southern name, "Blackfish," is in use at ()ak Bluffs, on Martha's Tineyard, and, it is said, also in New Jer- 
sey. In Gill's "Catalogue of the Fishes of the East Coast," and in Storer's "Fishes of Massachusetts," I find the statement that it is known as the "Black Bass." If this was true at any time, the usage has since undergone a very considerable change. The species should be carefully distinguished from the Blackfish of Long Island Sound, which is the tautog, a member of a very different family.

Under the name Sea Bass, are included two species, so similar in general appearance that it is scarcely necessary to discriminate between them,so similar, indeed, that for a score of years after the differences had been pointed out by Holbrook, the Carolina ichthyologist, naturalists refused to believe in their existence.*

The habits of the two are so similar that they will be treated as one throughout this essay.

The combined range of the two species embraces the Cape Ann, Massachusetts, and the northern part of the Gulf of Mexico. It has not yet been determined where the dividing line in their distribution should be drawn. It is probable, however, that it is somewhere in the neighborhood of Hatteras, since the atrarius type prevails about Charleston, where indeed Dr. Garden obtained the specimens which he sent to Linneus to name and describe. There is doubtless a neutral ground occupied by both species, and the determination of its limits would be a capital subject for some enterprising angler to investigate.

The extreme southern limit of the Sea Bass appears to be the sandy coast of Texas, where Jordan ascertained that it is rarely if ever seen. Silas Stearns informs us that it is rather abundant in certain rocky localities along the Gulf coast of Florida. In Pensacola Bay it is seen about the piles of stone ballast that lie in shoal water, and also at sea on the fishing grounds near the entrance. It also occurs in St. Andrew's, St. Joseph's, and Apalachicola Bay ; and to the southward, where there is more or less rocky bottom, showing either in reefs or in channel-beds, it is found in abundance. In the vicinity of St. Mark's, Cedar Keys, and St. Martin's Reef are other prolific Bass reefs.

It has only recently been found to occur north of Cape Cod. Previous to 1878 , there were on record only four instances of its occurence east of Nantucket, but in the summer of ${ } \delta_{7} 8$ several were taken in the Milk Island weir, off Gloucester. This weir, which lies on the west side of Milk

* S. furvus, the northern form, has the air bladder simple, and the pectoral as long as the ventral fin; $S$. atrarius, the southern form has the air bladder sacculated, and the pectoral longer than the ventral. 


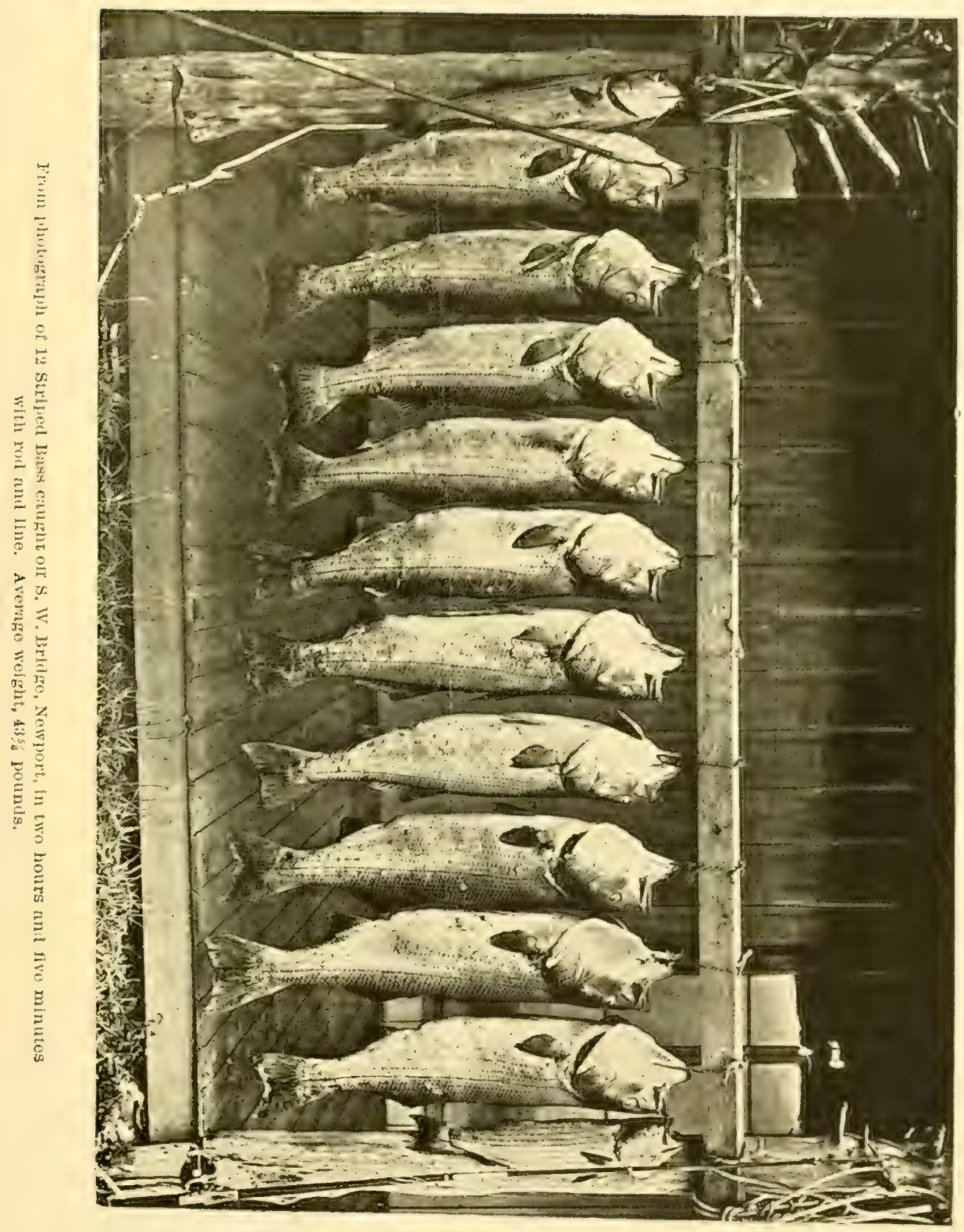



Island, almost under the shadow of the twin light-houses of Thatcher's Island, waylaid many southern species never before known to enter Massachusetts Bay, among them the kingfish and the Spanish mackerel. At some future time the Sea Bass may become abundant in these more northerly waters. Like the scuppaug, the Spanish mackerel, and the bluefish, it was at one time almost unknown to New England. In the "Catalogue of the Fishes of Connecticut," published in $\mathrm{x} 842$ by Linsley, the species is described as a great novelty. However strange to the people of Connecticut at this time, it is said by Storer to have been so abundant, between I 850 and I 860 , that fifty or sixty vessels were accustomed to obtain full fares in summer about the Vineyard Sound. This statement is probably somewhat of an exaggeration.

The "Zee-Baars" mentioned in the verse of Steendam's poem, "In Praise of New Netherland," which stands at the head of this chapter may or may not have been Centropristis. Mr. Murphy, in his translation, gives the exact equivalent of the Dutch words. :-

"The bream, and sturgeon, drumfish and gurnard

The Sea-Bass which a prince would not discard

The cod and salmon cooked with due regard, Most palatable."

Schoepf, writing of the fishes of New York in 1787 , stated that the "Blackfish." was rarely brought to New York, and the species does not appear to have been at all prominent among the New England food fishes of the last century. A diligent search through the works of the early writers fails to bring to light any definite allusions. It would be interesting to know whether there has actually been an increase in their abundance, or whether the apparent increase has been, as with the Spanish mackerel, due to the introduction of new modes of fishing, or the discovery of new fishing grounds.

The favorite haunts of the Sea-Bass are among the rocky ledges and "spots of ground" which are so abundant in the bays and sounds, and are scattered at intervals along the outer Atlantic coast. Among the boulders and ledges, full of cracks and crevices, which mark the position of these localities, there grow, in the greatest profusion, invertebrates of every order. A haul of the dredge over a good fishing ground often brings up tens of thousands of minute animals. A hundred species have often been recorded from a single dredging by the Fish Commission. Upon such feeding grounds the Sea-Bass congregate in great herels. rooting 
and delving among the holes, in search of delicacies. 'The best Bass gromds in the North are usually covered by water twenty to fifty feet deep, while off Charleston they are from sixty to one hundred and twenty feet below the surface.

Throughout the whole region of its distribution the species usually occurs near the shore, and also in spots of medium depth, where suitable feedinggrounds occur. In the Gulf of Mexico they are often found in very shoal water; indeed, all along the Southern coast the young fish are found close in to the shore, and I have seen a great many taken with hook and line from the sea-wall at St. Augustine. The temperature of the water affected by this species and by the red snapper corresponds very closely, and in most instances is probably not less than $50^{\circ}$, though on the coast of Connecticut and New York it may be slightly lower.

The Sea-Bass is a bottom-feeding and a bottom-loving fish, and, it may be said, rarely comes to the surface. This rule has exceptions, however, for Mr. Charles Hallock writes: "Although the Sea-Bass is a bottom fish, yet once on an outward-bound voyage to the southward of the Gulf Stream we made fast to a ship's lower mast, found drifting on the surface, which was covered with clams and baınacles and surrounded with Sea-Bass. We caught all that we wanted and cut loose. They weighed from five to twelve pounds each, and were all male fish." Whether or not those occurring in northern waters migrate southward in winter, or merely go into deeper water, is not yet ascertained. According to Capt. Edwards and Capt. Spindle, they make their appearance in the Vineyard Sound from the ist to the 20 th of May up to the roth of June. Capt. Spindle states that no stragglers are ever seen in April. Capt. Edwards declares, on the other hand, that they are found in that region in the winter, and I find in my note-book a statement that they have been taken in the Vineyard Sound in the winter by Thomas Hinkley and others. A careful study of their habits would form an important contribution to zoölogy.

They are somewhat sluggish in their habits. 'The temperature of the body is low, being very nearly that of the surrounding water, and their digestion is slow. Although very eager feeders at times, they seem much less fat than bluefish of the same size, and their growth is less rapid. They seldom leave the bottom, and there is as yet no evidence that cold weather drives them far from their summer haunts. They retreat, in all probability, into water of greater depth, where they pass the winter in a somewhat 
torpid state. Like the tautog, they appear to have a habit of lying under loose stones and in cavities among the rocks. I have observed this habit in the tanks of the New York Aquarium, my attention having been called to their movements by Mr. Fred. Mather. In the South they are feeding all the year. I have seen them taken in February on the Snapper Banks at the mouth of the St. Johns, at St. Augustine, and along the wharves of Charleston.

The food of this species, as of its associates upon the same grounds, consists of crabs, shrimps, squids and small fish. It is stated that the intestines of mackerel and the stomachs of menhaden are considered the best bait about Wood's Holl, Mass., while further south, shrimps and pieces of the flesh of fishes, such as small sharks, are frequently used. They are voracious feeders and readily attracted; their mouths are tough and leathery, so that when once hooked they are not easily lost.

Scott states that their feeding time is during the lull of the waters between the turn of the tides, when they are easily taken by the angler. In the North the Sea-Bass occupies the feeding grounds in company with the scuppaug or porgy, the flounder and the tautog, while in the South its associates are the red snapper and the various species of grunt, and on the inshore grounds, among the rocks, it occurs in company with the sheepshead and the king-fish.

The breeding time is believed to occur in July and August. Mr. Dyer, of Naushon, states that the Sea-Bass, when they come into the pounds in the spring, are full of spawn, ready to shoot. Young fish, one or two inches long, are abundant among the eel-grass along the shores of southern New England. In the Gulf of Mexico, according to Stearns, they spawn in early summer, and the young are caught in July and August.

The average size of the fish in New England is about one-and-one-half pounds. A Sea-Bass nine inches longr weighs about five ounces; ten inches long, six to ten ounces; eleven inches long, nine to twelve ounces; twelve inches long, ten to sixteen ounces; while the length of a three-pound fish varies from eighteen to twenty inches. They occasionally attain the weight of four or five pounds, but this is unusual. In the South they are, as a rule, much smaller than in the North. This is especially the case in the Gulf of Mexico. In these waters, and along the southern part of the South Atlantic coast, they rarely exceed a pound in weight. Large male fish are remarkable on account of the presence of a large hump upon the 
top of the head. This is particularly prominent during the breeding season, and at this time the colors of the whole body are much brighter. The colored plate of this species, drawn by Mr. Kilburn for Scribner's "Game Fishes of the United States," represents a large male at the breeding season, the only picture of this kind which has ever yet been made.

The Sea-Bass is of interest to fish culturists as being the first marine fish upon which the experiment of artificial propagation was tried in this country. This was in June, I874, when Mr. Mather fertilized a number of eggs at the station of the United States Fish Commission at Noank, Conn. These eggs were placed in shad boxes and were watched for several days, as they passed through the early stages of segmentation. A storm interfered with the completion of the experiment, and it has never been repeated.

The Sea-Bass is without many rivals as a chowder fish, and for boiling. Its flesh is firm, flaky, and very sweet. The hardness of the flesh makes it desirable for packing in ice, and prevents rapid deterioration in hot weather. The head is so large that half the weight of the fish is lost in the process of dressing for the table.

There are excellent fishing grounds on the Savannah Bank and others near Charleston, at the mouth of the Chesapeake and the Delaware Bays, off the coast of New Jersey and the entrance to New York harbor and in Long Island Sound, and Buzzard's Bay. The latter are frequented in summer by ten or twelve Connecticut smacks, which purvey for the New York market. The fish are carried in the wells of the smacks to Noank or New London, where they are kept alive in fluating cars until needed for shipment. It is one of the chief recommendations of this fish that it is so hardy and tenacious of life that it can be kept any length of time in confinement. Thousands of them may be seen, swimming in perfect health in the cars, crowded together until their sides are in contact, and thus they are often kept for weeks. Before they are placed in the wells the fisherman has recourse to the expedient of thrusting an awl into the side of the fish so as to puncture the air-bladder. Otherwise they would float on the surface, on account of the expansion of air in the bladder after the removal of the pressure of the weight of water under which they are accustomed to live. Several of the Noank smacks are usually employed from November to April in fishing for Sea-Bass on the Southern coast. These supply the Charleston market. 
In summer several steamers make daily trips from New York to the fishing banks off Sandy Hook and Long Branch. They are patronized by thousands of amateur fisherman, who seldom fail to bring back trophies of Sea-Bass and scuppaug.

In the summer of $\mathrm{x}_{32}$, Captain Lyman Bebe of the fishing smack Mary, of New York, discovered a notable fishing bank about twenty miles to the eastward of Sandy Hook. I 832 was the year of the "great cholera," and its progress was the one topic of conversation, and Captain Bebe named his new-found fishing ground the "Cholera Banks."

Another famous reef, known as the "Fishing Banks," extends from off the Highlands of Navesink, past Long Branch, to a point about opposite Squan Beach. Both of these are favorite resorts for New Yorkers, who visit them on the small excursion steamers.

An artist, visiting the Cholera Banks thus records his experience:

"Starting so early in the morning that his eyes are still heavy with unexpended sleep, he soon finds himself on the steamer in company with a hundred more fellow passengers, some of whom are heavy-eyed and inclined to grumble about the hour of starting, while others are cheerful, and full of excitement at the prospect of the day's sport. 'Down the bay, through the Narrows, across the lower bay, and out to sea, steams the little craft on which they are embarked. Past the red light-ship, and twenty miles due east from Sandy Hook, she runs, and then begins the search for the Banks. The pilot takes ranges by several of the big hotels, of which so many have been erected during recent years along the south shore of Long Island; a man in the bows takes soundings; and if the day be clear, the steamer is soon brought to anchor directly above the reef, and a hundred eager lines are dropped overboard.

"Once at anchor the fun and trouble begin together. It is fun to catch fish; but seasickness is among the saddest of human experiences, and many of those who have bravely endured the pitching to which the steamer has been treated ever since she left Sandy Hook succumb at once to the motion that succeeds it as soon as she comes to anchor, and rises and falls with regular, ceaseless monotony on the long swells.

"Apart from these and ridiculing their wretchedness, stand the professionals and toughened amateurs, smoking short pipes, hauling in fish, making cruel jokes upon the condition of the novices, and thoroushly enjoring themselves. They bait their hooks with hard-shell clams, skillfully toss their leaden sinkers far out from the steamer's side, let run fourteen fathoms of line, and haul in Sea Bass, black-fish. flukes, rock cod, weak fish, porgies, or whatever else comes to hand. Once in a while a line goes whizzing through the water with a wild rush, there is a protracted struggle, and an ugly customer in the form of a shark either breaks the line and escapes, or is hauled on board amid much rejoicing. 
The first catch of the day is always watched for with the greatest interest, for upon it depends the ownership of a number of small pools that have been made up among the passengers. Other points to be scored are the largest catches of the day in numbers and weight, and the catching of the heaviest single fish.

Late in the afternoon the anchor is lifted, lines are drawn in, and the steamer is headed toward home. Then comes a time of great interest. The fish are cleaned, sorted, weighed, examined with care, passed around for inspection, and commented upon. Special lots are laid aside for home consumption and for distribution among friends; and frequently those who have made the large catches, and have more than they know how to dispose of otherwise, raffle them off or present them to the crew of the steamer." **

This species is captured in great quantities in the pounds and traps of Rhode Island and Southern Massachusetts. Its distribution is wide, many of its haunts are unfrequented by fishermen, and it is probable that its importance as a food fish will increase in years to come. In I 880, over 350,000 pounds were sold in New York city.

There is a small species, Serrams trifurcus, resembling the Sea-Bass which has been found only in the vicinity of Charleston, S. C., and Pensacola, Fla., where it is called the "Rock Black-fish." It occasionally finds its way to the Charleston markets.

The Squirrel fish, Serranus fascicularis, is a beautifully colored species, usually to be seen in the markets of Charleston, north of which locality it has not been found. The following paragraph from Holbrook's "Ichthyology of South Carolina," contains all that has been observed regarding its habits: "Little can be said of the habits of this fish. It, however, appears in our waters in May and June, and remains until November. It is occasionally taken with the hook on the black-fish grounds, but is never abundant. Southward it ranges at least to Brazil."

* Harper's Weekly, Nov, x, 1884. (With illustrations.) 


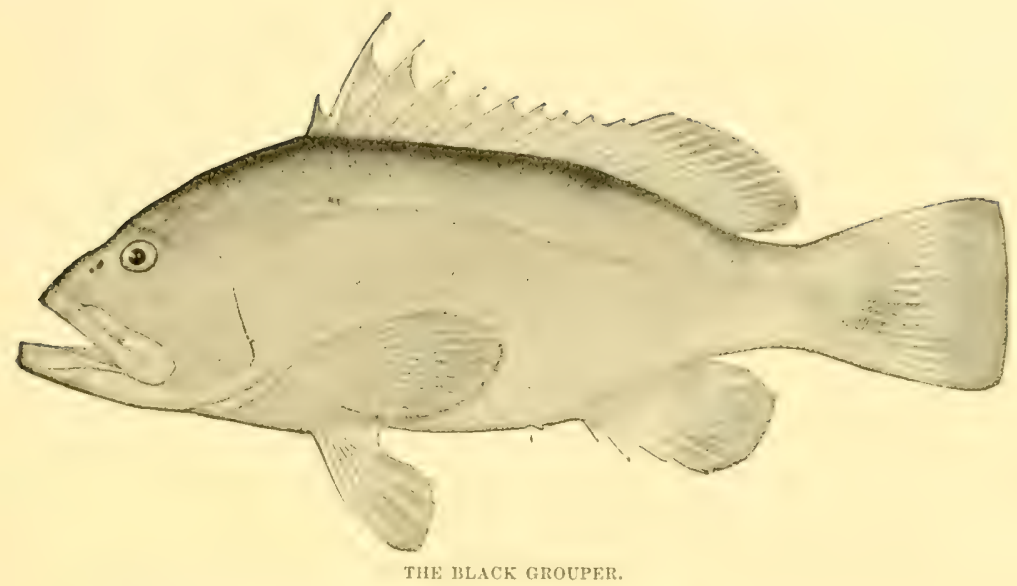

THE GROUPERS AND THE JEIT FISH.

\author{
Hugest of all are fish in sea \\ For they were formed by heaven's great King \\ Before all other earthly thing. \\ The Voyage of St. Brandon (Mediaval)
}

\title{
$\mathrm{T}$
}

$\mathrm{HE}$ various species of Grouper are already of importance, and will be still more highly appreciated by the anglers of future generations. They are members of the genus Epinephelus, and other closely related genera. The Red Grouper, Epinephelus morio, is a large species, sometimes attaining the weight of forty or fifty pounds. There is no certain record of its having been captured north of Florida, where it is called the "Brown Snapper" or "Red-bellied Snapper." DeKay, writing in I 842 , stated that it was not unusual in the New York market in June and July, where it was called by the fishermen 'Groper,' or 'Red Groper'; that it is a Southern species and is hrought from the reefs of Floridia lout that he had been informed by West Indian fishermen that it is occasionally, but rarely, taken off the coast of New York; he added that Dr. Holbrook informed him that it was brought into the Charleston markets from Floricla in the months of January, February, and March.

Holbrook wrote: "The Grouper is so seldom seen on our coast that nothing can at this time be said of its habits; but in confinement, as it is brought to us from Key West, it appears very voracious and bold, taking 
food even from the hand when offered, and always injuring such other species of fish as may be its fellow-captives."

It is often taken in the Gulf of Mexico and about the Florida Keys, and it is said also to be abundant along the whole coast of East Florida, and is often taken on the St. John's bar. Mr. S. C. Clarke writes that it occurs in the vicinity of New Smyrna, Fla., where it spawns in bays and inlets in the months of May and June, as does also the Black Grouper. The only reliable study of its habits which has been made we owe to Mr. Silas Stearns, whose biographical sketch of this species may here be quoted in full:

"The Red Grouper is extremely abundant in the Gulf of Mexico in company with the red snapper. It is most abundant on the South Florida coast, and is found throughout the year on the 'grounds' at sea, and in summer in some of the bays. It probably spawns in both places, and in June and July. The young are often caught in Pensacola Bay. In June, r880, I obtained a young one about one inch in length. The Grouper is more of a bottom fish than the red snapper, for it swims much more slowly and very seldom rises to the surface. It is very voracious, consuming, as is shown by an examination of the contents of its stomach, enormous quantities of crustaceans and small fish. Large horny crabs, in almost perfect condition, are often found inside of it. Its movements are rather slow, and when hooked it is hauled up more like a dead-weight than like a live fish. In South Florida it is extensively eaten when procurable, and at Key West it is particularly important, since a large fleet of smacks is constantly employed in carrying fares of Grouper to Cuba. In West Florida, where red snappers are more abundant, Groupers are not in demand and have but a small market value. After being taken from the water, the Grouper is remarkably tenacious of life, and will live several hours, even though exposed to considerable heat. This is one reason why the Key West fleet prefer Groupers for transportation to Cuba, since they are obliged to go a long way to market and through warm water, and no other fish of the kind would bear crowding and chafing in the wells of the smacks. The Grouper attains the weight of forty pounds, and is an excellent food fish."

In Cuba, this fish is called by the Spanish name "Cherna." The name "Grouper" is a corruption of Garoupa, a name given by the Portuguese to similar species. In DeKay's time, as has been remarked, this fish was not unusual in the New York market, where it sold for from six to 
twelve cents a pound, though its flesh was considered tough, and not very highly esteemed. Gill, writing of the same market in ${ } S_{5} 6$, said : "This species is sometimes sent to our market from Key West and the reefs of Florida in May and the summer months. I have never seen more than two or three exposed for sale at a single time; it appears to be considerably esteemed, and is sold at from twelve to fifteen cents a pound."

Genio Scott writes: "The Grouper is an excellent dinner-fish, and when boiled and served with drawn butter and shrimp or lobster sauce is said to fully equal the turbot."

The Black Grouper, Epinephelus nigritus, is called in Florida and 'Texas the "Jew-fish," and at Pensacola, known by the name "WVarsaw," evidently corruption of the Spanish name Guasa. It was first brought to notice by Holbrook, who had received one specimen from the vicinity of Charleston; north of that point it had not yet been observed, though it appears to be abundant along the coast of East Floricla and in the Gulf of Mexico. Mr. S. C. Clarke has observed it in the Indian River region, and communicated the following notes to Professor Baird:

"The Black Grouper is resident all the year, though not abundant. The greatest size attained is about fifteen pounds. They pass the winter in the salt-water rivers, living in holes in the rocks and under roots and snags and about piles. They are solitary in their habits. They feed on small fish, particularly mullet, and on crustaceans, and breed in the salt rivers in May and June. Their spawn is very small, and pale yellow. They are taken with hook and line by the use of mullet and crab bait, and are seldom seen except when thus captured. They are much esteemed as food.',

In an essay on "Florida Game Fishes," published in The American Angler, the same writer says:- "From a deep hole in the Halifax River, two of us took in one morning, seven groupers, from four to eight pounds in weight, and lost three larger ones which broke our lines. That hole had not been fished for years, and although I have often fished it since, I have never taken another from it."

Mr. Stearns remarks that it is a common fish at sea along the Gulf coast, living chiefly on the same spots with snappers and Groupers. At some places it is found in abundance in the bays, and lives on the bottom, feeding upon small fishes, crabs, etc. On the fishing grounds when fish are being caught rapidly it is not of unusual occurrence. 
A very large Jew-fish will follow and finally swallow a hooked firh, usually a red snapper, with hooks, lead, line and all. If the line does not then break the fish may be hauled in with gaffs. The Jew-fish attains an enormous size, and specimens weighing from eighty to one hundred pounds have been caught. The smaller fish are quite choice, but large ones are too coarse and tough to be salable.

There is another fish which is also called "Jew-fish," or "Warsaw," and "Black Grouper," of which only enormously larga specimens have been obtained, and which is entered upon our catalogues under the name Promicrops suasa. It is a fair question whether this great fish be not the adult of the common Black Grouper or some closely allied species, the appearance of which has become somewhat changed with age. A large specimen, weighing about three hundred pounds, was taken near the St. John's bar in March or April, I 874, by James Arnold. It was shipped by Mr. Hudson, a fish dealer in Savannah, to Mr. Blackford, who presented it to the Smithsonian Institution. A fine cast of this specimen graces the Fisheries Hall of the National Museum. Professor Poey, by whom the species was named, states that in Cuba it attains to the weight of six hundred pounds. An old Connecticut fisherman, who was for many years engaged in the Savannah market fishery, states that the Havana smacks often catch Jew-fish. They are so voracious that when put into the well with the Groupers they would do much damage. The fishermen have found it necessary therefore to sew their jaws together before placing them with other fish.

The Spotted Hind of the Gulf of Mexico, Epinephelus Drmmond-Hayi, has been found only in the Gulf of Mexico and at the Bermudas. It was observed at the Bermudas in ${ } \$_{5} \mathrm{I}$ by Col. H. M. Drummond-Hay, of the British army. It is there called "John Paw." Specimens were sent to the National Museum in 1876 and 1877 , by Mr. Blackford and Mr. Stearns. It is one of the many important species which have been brought to notice by the labors of the United States Fish Commission. Although it is an excellent food-fish, it is, even now, not well appreciated.

Mr. Stearns records the following facts concerning its habits: "The Spotted Hind is common in company with the Grouper and Jew-fish, and is most abundant in South Florida about the reefs. Off Pensacola it lives in the deep fishing grounds, in seventeen, nineteen and twenty-two fathoms. It swims close to the bottom, and is of sluggish movements. I 
have not known of its occurrence in the bays, and believe that it spawns at sea. Specimens weighing fifty pounds have been caught, but that is fully four times the average size. It is seen daily in the Key West market and sells readily, but at Pensacola, Mobile and New Orleans it is hardly marketable. Its color varies very considerably with the different colored bottoms on which it lives.'

The Coney of Key West, Epinephelus apua, the "Hind" of Bermuda, is an important food-fish which occurs throughout the West Indies. Specimens have been sent by Mr. Stearns, who remarks that it is common in South Florida among the reefs, and is often seen in the Key West market, where it is readily sold.

The Bermuda Grouper, Epinephelus striatus, one of the most important food-fishes of those islands, is sure to be found in the vicinity of Key West, and will probably prove to be one of the important fishes of our own southern coasts. About Key West and in the Gulf there are several species of the sub-genus Mycteroperca, which may be grouped together under the name "Rock-fish," the name by which all fishes of this genus are also known in Bermuda. They are large fishes of excellent food quality, similar in habits to the others of the family which have already been discussed. The material at present on hand is not sufficient to admit of satisfactory identification of all the species. The "Black Grouper" of Pensacola, which has been variously named Mycteroperca brunnea, $M$. microlepis, and M. stomias, is said by Mr. Stearns to be common in company with the Red Grouper, although not so abundant. It spawns in June and July, at sea and in the inlets. As a food-fish it is considered superior to the Red Grouper, although it is not more readily sold. It attains a weight of fifty pounds. Professor Jordan is of the opinion that the form recently described by Goode and Bean as M. stomias, the "Gag" of Key West, is the adult of that previously characterized by them under the name $M$. microlepis.

The Rock-fish of Key West, which has not yet been identified, is said by Mr. Stearns to be very common, and is sold almost every day in the market. The average weight is four or five pounds, the maximum twentyfive to thirty. There appear to be at Key West, as well as at the Bermudas, various forms known as "Rock-fish."

An allied species, Mycteroperca falcata, is called at Pensacola by the name "Scamp." It is common off the Florida coast, living near the bottom in 
company with the other species of Groupers. It is found on the coast all the year round, and is caught with the hook and line. It seldom exceeds the weight of twenty pounds, and the average size is much smaller. It is considered an excellent table fish. The Spanish fishermen of Key West call it "Baccalao"' (Cod fish.)

S. C. Clarke refers to a fish which he calls the "Mangrove Snapper or Red Grouper," to which he attributes gamey qualities far in excess of those mentioned by Stearns. It is probable that he has in mind this grouper and not a snapper.

Several of these fishes, whose relations have not yet been determined, have been taken abong the Atlantic coast, particularly at the mouth of the Chesapeake and at Wood's Holl, Massachusetts.

There are several other species belonging to this family which have been observed, none of which, however, are of any economic importance.

The Pacific Jew-fish, Stereolepis gigas, is one of the principal serranoid fishes of the Pacific coast. It is also sometimes called the "Black Sea Bass." It reaches a weight of five hundred pounds, being the largest food-fish on the coast. It ranges from the Farallones to below San Domingo, and is generally abundant in deep water about the islands, but from its great size is seldom taken. It feeds upon smaller fishes, and is voracious. It is often taken by swallowing a white-fish when the latter is on the hook. Its flesh is of excellent quality, and those small enough to be available always brings a very high price in the market.

The Cabrilla, Serramus clathratus, is called at Monterey, where it is not common, the "Kelp Salmon"; further south it is known to the Americans usually as "Black Bass," and to the Italians and Spaniards as "Cabrilla," a name applied to other species of Serranus in the Mediterranean. The Chinese call it "Lockee Cod" (Rock Cod). It reaches a length of eighteen inches and a weight of about five pounds. It ranges from San Francisco to Cerros Island, being very abundant about the Santa Barbara Islands, where it is taken in large numbers. It lives in water of no great depth, chiefly about the rocks. It feeds on squid, crustacea, and small fishes. It is an excellent food-fish, similar in quality to the related Atlantic species.

The Johnny Cabrilla, Serranus nebulifer, receives the name "Rock Bass" and "Cabrilla" with the other species. The distinctive Spanish name of "Johnny (Juan) Verde" is also in frequent use, especially at San 
Pedro. It reaches a length of twelve to twenty inches and a weight of about five pounds. It has been taken at Monterey, but is common only from San Pedro southward to Magdalena Bay. So far as known to us, it agrees in habits and value with the preceeding.

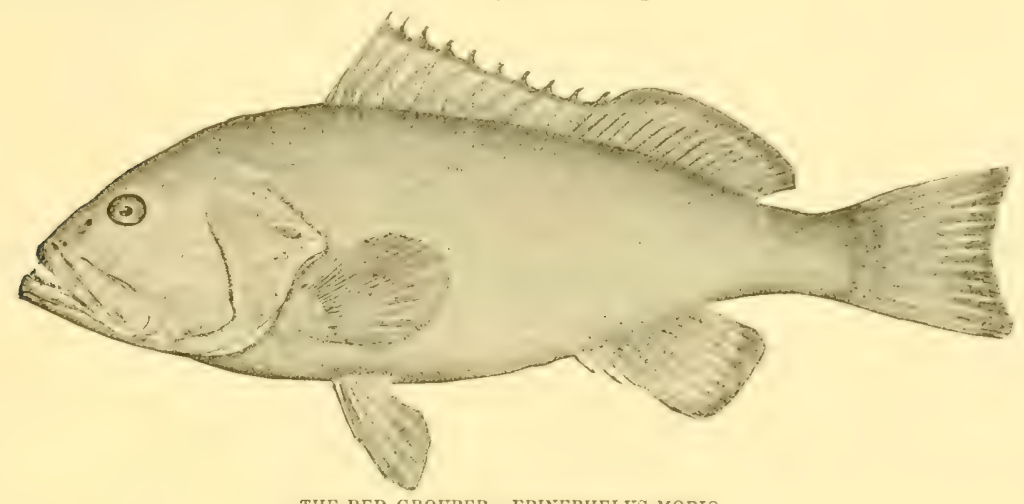

THE RED GROUPER. EPLNEPHELUS MORIO.

The Spotted Cabrilla, Serramus maculofasciatus, receives the same names, "Rock Bass" and "Cabrilla," as others. It agrees with the preceeding in value, distribution, and habits, so far as is known, but is rather smaller in size. It is an excellent food-fish, and from its great abundance about San Diego it may become of considerable economic importance. Its range extends southward to Mazatlan, it being one of the very few California fishes which extend their range to the south of the Tropic of Cancer.

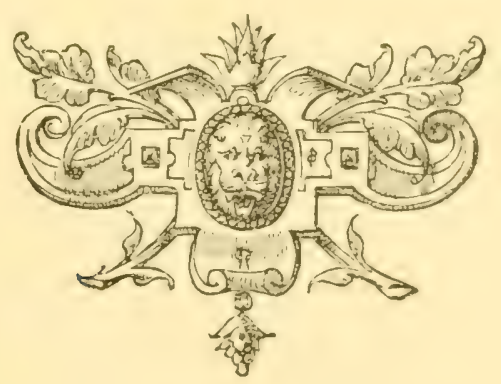




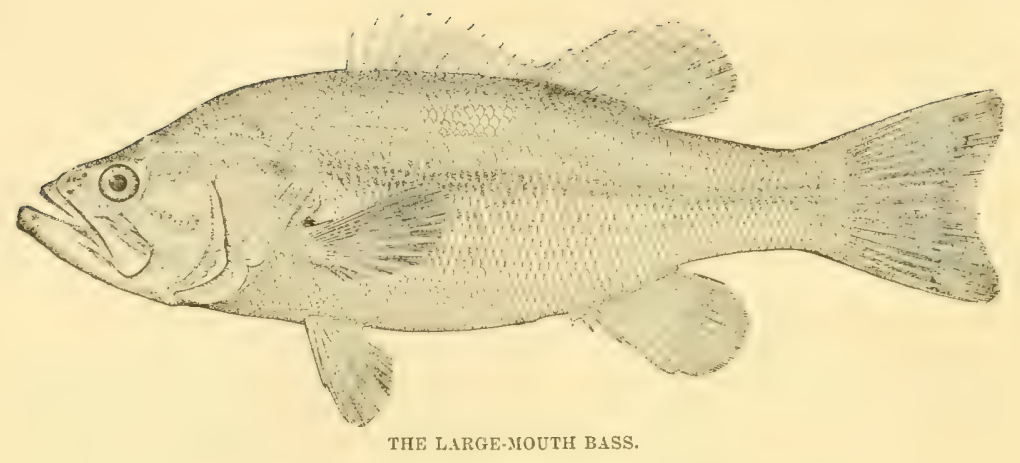

\title{
THE BLACK BASSES.
}

\author{
Fishing, if $\mathrm{I}$, a fisher, may protest \\ Of pleasure is the sweetest, of sports the best \\ Of exercises the most excellent; \\ Of recreation the most innocent, \\ But now the sport is marde, and wott ye why. \\ Fishes decrease and fishers multiply.
}

De Piscatione, $\mathbf{1 5 9 8 .}$

$\mathrm{U}$

NTIL recently, we supposed that there were many kinds of Black Basses. Different communities christened them to their own liking, and naturalists, misled by the numerous popular names, described, as distinct, forms which, had they been seen side by side, they would have considered the same. Twenty-two separately named species are on record. In I873, Prof. Gill, after studying specimens gathered from all parts of the United States by the Smithsonian Institution, came to the decision that there were only two species, the Large-mouthed and the Small-mouthed bass. This was easy work for so accomplished an ichthyologist as Gill, but the difficulty was to determine the ownership of the many names already established in the literature of ichthyology. After five years of uncertainty, and several changes, thirteen of these have been allotted to the Small-mouth, and the remainder of nine to its cousin with the long jaw. The oldest name for the Large-mouth is Micropterus salmoides, and for the Small-mouth, as Henshall has prover, Micrepterus Dolemici: it is hoped that this decision, which is grounded upon a firm foundation of priority, may be permitted to stand unchanged. Gill's paper, in which he defines the differences between the two species, was published in $\mathrm{I}_{73}$ in the Proceedings of the American Association for the Adrancement of Science. 
This volume is, however, not easily accessible, and the important differences are therefore repeated in this place. In the Large-mouth the upper jaw extends far behind the eye; in the other to a point below it. The Large-mouth has from sixty-five to seventy rows between the gillopening and the base of the tail, instead of seventy-two or more, while on the cheek there are about ten oblique rows instead of seventeen, also sevenand-a-half to eight instead of eleven rows between the lateral line and the dorsal. There are other distinctions, such as the absence, in the Largemouth, of scales on the bases of the dorsal and anal fins, the smaller number of rays in the pectoral fins (there being thirteen or fourteen instead of sixteen or seventeen), and the lesser height of the spinous dorsal. (In the Large-mouth the first dorsal spin is one-half; in the Small-mouth, onethird of the height of the third dorsal spin).

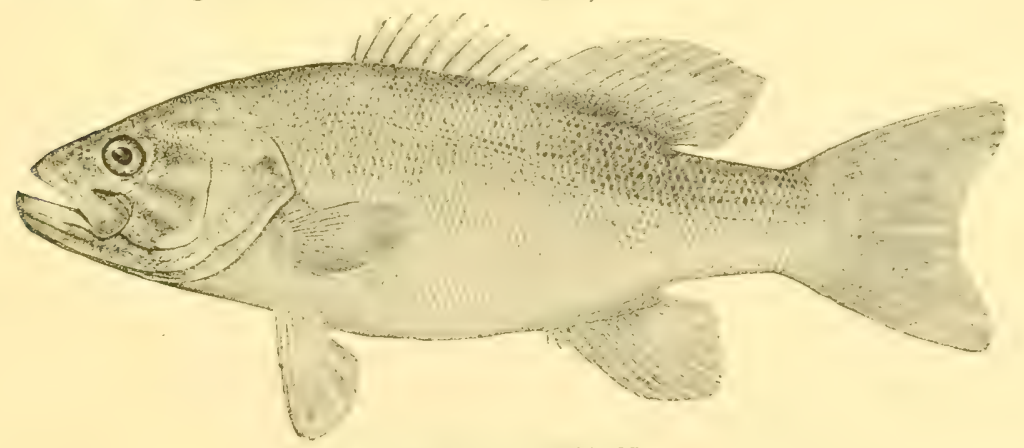

THE SMALL-NOUTH BASS.

Numerous as have been the zoölogical names, they are outnumbered liy the popular names still in use in different localities. Charlevoix, a Jesuit missionary, who explored Canada in $172 \mathrm{r}$, mentions a fish called ". Achigan." which is thought to have been the Large-mouth. An earlier allusion to this species, which in the Southern States is still called "Trout," occurs in the writings of Réné de Laudonnière, who described the incidents of the first Huguenot expedition to Florida in $\mathrm{I}_{5} 2$, under the command of Jean Ribault. The Large-mouth is known in the Great Lake Region, especially in Northern New York, as the "Oswego Bass." This name should not be confounded with "Otsego Bass," a local name for the common whitefish. In Kentucky, and possibly in Florida, it is called " Jumper;" in Indiana, "Moss Bass ;" in the Southern States generally, "Trout," though on the Tar River of North Carolina, it is called "Chub," and on the Neuse, "Welshman." 
The Small-mouth shares with the Large-mouth in the Southern States the names "Jumper," "Pearch" and "Trout," and in Alabama, according to Prof. Jordan, it is called the "Mountain Trout. "Bronze-backer" is one of its pet names among the anglers.

"Marsh Bass," "River Bass," " Rock Bass," " Slough Bass," " White Bass," "Green Bass," "Spotted Bass," "Green Perch," "Yellow Perch," "Black Perch" and "Speckled Hen " are other names applied to one or both species. A comedy of errors this hath surely been, and the colloquy between the Duke and the Dromios comes pat to the pen :

"Duke. One of these men is genius to the other;

And so of these. Which is the natural man,

And which the spirit? Who deciphers them?

Dromio of Syracuse. I, sir, am Dromio ; command him away.

Dromio of Ephesies. I, sir, am Dromio ; pray let me stay."**

Both species are very widely distributed over the Atlantic slope of the continent east of the Rocky Mountains, and their range is probably much wider than is now supposed, for many of our northern and western waters are still unexplored. The Large-mouth and Small-mouth dwell together in the Great Lakes, and in the upper parts of the St. Lawrence and Mississippi basins. The Small-mouth is found north to latitude $47^{\circ}$ and west to WVisconsin, while southward it ranges to latitude $33^{\circ}$, where Prof. Jordan found it in the headwaters of the Chattahoochee and Ocmulgee Rivers, this being the only instance of its presence in a stream emptying east of the Alleghanies, into which it is not known to have been introduced by man. The Large-mouth ranges further to the west and north, occurring in the Red River of the North, perhaps as far as Manitoba, in latitude $50^{\circ}$. It abounds in all the rivers of the Southern States, from the James to the St. John, and in the lower reaches of the streams and bayous connected with the Gulf of Mexico, around to Texas, in latitude $27^{\circ}$.

To the waters of New England and the eastern part of the Middle States they are not native. The Small-mouths found their way into the Hudson in 1825 or soon after, through the newly-opened Erie Canal, and they have since been introduced by man into hundreds of eastern lakes and rivers. Many circumstances suggest the idea that in early days, before

* For fuller information upon this and other matters connected with the species the reader is referred to Dr. J. A. Henshall's elaborate and exhaustive illustrated treatise, entitled "Book of the Black Bass," published in $188 \mathrm{r}$ by Rcbert Clarke \& Co., Cincinnati. "Fly fishing for Black Bass," a serial publication by W. S. Norris, in The American Angler, is an exceedingly well-written sketch in the American style. 
the various drainage systems were connected by canals, the distribution limits of the two species were much more sharply defined, the Large-mouth inhabiting, perhaps, the upper part of the basin of the Great Lakes and St. Lawrence and the rivers of the southern seaboard, while the Smallmouth was found chiefly in the northern part of the Mississippi basin. This theory can never be demonstrated, however, for the early ichthyologists had not adopted the accurate methods of study now in use, and their descriptions of the fish they saw are scarcely good enough to guess by. The mingling of the two forms might have been accomplished in an incredibly short time. A few young Bass will multiply so rapidly as to stock a large lake in five years. The Potomac and its tributaries swarmed with them ten years after their first introduction.

A very suggestive incident occurred at the Brookline Reservoir, near Boston. Nine Bass were introduced in July, IS62. Four or five years after, in examining the water-pipes leading thence to Long Pond, Bass in considerable numbers and of large size were found; and what is still more strange, they had, either as young fish, or in the egg state, gone through the screen at the mouth of the pipe and found their way into the pond itself, having accomplished an underground journey of fifteen miles through a brick aqueduct nowhere more than six feet in diameter.

Gill states that the two forms of Micropterus have long inhabited the waters of the cismontane slope of the United States, except those of the New England States and the Atlantic seaboard of the Middle States. Only one, however, the Small-mouth, appears to have been an original inhabitant of the hydrographic basin of the Ohio River.

The Bass do not seem to depend closely on temperature. Having no opportunity of avoiding the cold, they sink to the deepest part of their watery domain at the approach of winter, and if the chill penetrates to their retreat, their vitality is diminished, their blood flows more slowly, they feel no need of food, and forthwith enter into a state of hybernation. Mr. Fred. Mather kept one in his aquarium nearly all of one winter. It ate nothing, and seldom moved any members except its eyes. In deep lakes, however, they can sink below the reach of surface chills, and here they are sometimes caught with a hook through the ice. In the South their activity never ceases. Any one who has seen Black Bass feeding must have been impressed with their immense power of movement. They soon become masters of the waters in which they are placed. Sun-fish, 
perch, troat, young salmon and even the ravenous pickerel, are devotired. They feed at the surface on moths, flies and frogs; they turn over stones in search of crawfish and insect larvæ. Rats and snakes have been seen in their stomachs. A correspondent of Forest and Stream relates that once, while fishing in the Chicago River, one of the small frogs used for bait escaped and perched on a portion of an old wreck above the water. A Black Bass came along, and, lifting his head from the water, picked off the frog, and descended to the depths below. The angler finds them at the proper seasons equally eager for fly-hook, trolling-spoon, or still-bait, and always ready for a struggle which puts his rod and line to a severe test. Their leaps are almost as powerful as those of the salmon. The negro fishermen of Florida often surround a body of Large-mouths with a seine, but as the lines are hauled in and the arc grows smaller the dark forms of the "Trout" begin to appear, springing over the cork-line and returning, with a splash and a jet of spray, to liberty. I have seen them rise five or six feet above the water. They are said to be taken best at night, or when the river is high and the water muddy. Otherwise they leap over the seine. Expert seiners coil their nets in such a manner as to prevent the escape of part of the school. The Small-mouths are said, generally, to prefer deep or swift, cool waters, while the Large-mouths live in muddy, black pools, or in the shelter of old stumps and ledges. In Florida they lurk among the lily-pads and aquatic plants in shallow, dark streams, where they feed on a grub called the "bonnet-worm," which burrows in the flower-buds of the "bonnets" or yellow water-lilies, Nuphar adàna.

The account given by Laudonniere of the abundance of this fish in Florida nearly two-and-a-half centuries ago, is well worth quoting:

"Having passed," he writes, "most part of the day with these Indians (at Cape Francois), the captain imbarked himiselfe to pass over to the other side of the river, whereat the king seemed to be very sorrie ; nevertheless, being not able to stop us, he commanded that with all diligence they should take fish for us, which they did with all speede. For, being entered into their weares, or inclosures made of reeds and framed in the fashion of a dalyzintto or maze, they loaded us with trouts, great mullets, plaise, turbuts and marvellous store of other sorts of fishes altogether different from ours."

The spawning season occurs on the approach of warm weather. Its date does not vary much with latitude. In Florida, in Virginia and in Wisconsin they build their nests in May and June. The oldest fish, we are 
told, sometimes anticipate the ordinary season, while many late spawners are occupied with family cares until the last of July, and some young fish are not ready until October and November. After the spawning is over the Bass are "in season." They take the hook eagerly from July till November. In the winter they are lank and black, though in season till the ice comes.

Concerning their spawning habits, Mr. Hallock, of the Blooming Grove Association, wrote in 1875 : "Four years ago, one hundred and thirteen Black Bass from Lake Erie were placed in Lake Giles, and their progeny has increased so fast as to insure good sport to the angler at any time. The late spawners are now (early July) in the gravel beds, in the shallow waters along shore, protecting either their spawn or their newly-hatched fry, as the case may be. It is interesting to note the pertinacity with which they guard their precious charges, and the vigor with which they drive away depredators and intruders of all kinds. They will frequently allow a boat to pass over them, scarcely six inches above their backs, and obstinately keep their ground. Sun-fish and such are compelled to keep their distance. There are hundreds of these bowl-shaped excavations, eighteen inches or so in diameter, all along the sandy shallow shores of this lake, which is very clear, and in the center some seventy feet deep, fed by bottom springs."

The eggs are much smaller than those of a trout, and, being heavier than the water, rest on the bottom within the limits of the nest. The only estimate of their number with which I am familiar is that made by Mr. E. L. Sturtevant, who found about 17,000 in a Large-mouth weighing two and one-half pounds.

The length of time required by the eggs in coming to maturity is estimated at from eight to ten days, the hatching being somewhat accelerated in warm weather. The young fish, when first hatched, are about threeeighths of an inch long. They are very active, and at once begin to feed. One observer describes them as darting rapidly about, looking like black motes in the water; while another has seen them lying motionless near the bottom, the school appearing like a floating vail of gauze. For a few days they may be seen playing about the nest, but they soon disperse, to find lurking places among the grass and pebbles near the margin of the water, and to begin their corsair career by preying upon the larvæ of insects and the minute crustaceans which abound in such localities. 
They have another reason for seeking a shelter in the shallow water, for their parents are surely guilty of inconsistent conduct. They are said to care tenderly for their callow brood, and even teach them how to eat; but this must be a mistake : for although it cannot be denied that they patiently mount guard over their nestful of eggs, they are often seen derouring their new-born offspring, who thrive in the very teeth of their piratical relatives.

The rate of growth of the young has been studied in artificial ponds. In Granby, Conn., four-pound fish were taken in 1874 , the progeny of two hundred and fifty fish placed in the pond in $\mathrm{S} S 6 \mathrm{~S}$. The eggs require two or three weeks to hatch. In September the young are about two inches long; when well fed they grow to four inches the first season. At two years of age they weigh about a pound, few caught in the North weighing more than four pounds. Leaving the egg in June, they grow to two or three inches before cold weather begins-trim, sprightly little darters, with black bands across the bases of their tails. Another twelvemonth finds them in the garb of maturity, eight or nine inches long, and with their organs swelling in preparation for the act of spawning, which they are said to undertake at the age of two years, and when less than a foot long. The ordinary size of the adult fish is two and one-half to three pounds, though they are sometimes taken in the North weighing six or seven pounds. In Florida the Large-mouths grow larger. A seven or eight-pounder is not unusual in the St. John's; and I was told that in March, 1875 , a fish weighing nineteen and one-half pounds was caught in the lake at Gainesville, Fla.

Fish culturists have made many efforts to hatch the eggs of the Black Bass, and have never succeeded. One reason for their failure, perhaps, lies in the fact that, while in the shad and salmon the eggs fall from the ovaries into an abdominal cavity, whence they are easily expressed, in the Bass and other spiny-rayed fishes they are retained until the parent fish are ready to deposit them. This failure is the less to be regretted since the young Bass may easily transported from place to place in barrels of cool water, and, when once introduced, they soon multiply, if protected, to any desired number.

Black Bass are very tenacious of life. A Germantown correspondent mentions some taken at Io o'clock a. m., sold and wrapped in paper, left in a warm room till $5 \mathrm{p}$. $\mathrm{m}$., when they were found to be alive and well. 
The first experiment in their transportation seems to have been that mentioned by A. M. Valentine, who states that a pond near Janesville, Wis., was stocked with Black Bass about $\mathbf{I} \delta_{47}$. In I $\delta_{50}$ Mr. S. T'. Tisdale carried twenty-seven Large-mouths from Saratoga Lake, N. Y., to Flax Pond, in Agawam, Mass. The manner in which the Potomac was stocked with Small-mouths is also well known. It was in $18_{53}$, soon after the Baltimore and Ohio Railroad was finished, that Gen. Shriver, of Wheeling, carried a number of young fish from the Ohio to Cumberland, Md., in the water-tank of a locomotive engine. These he placed in the basin of the Chesapeake and Ohio Canal, whence they soon penetrated to all parts of the Potomac basin, and as far down the river as Mount Vernon. The custom of stocking streams soon became popular, and through private enterprise and the labors of State Fish Commissioners nearly every available body of water in New England and the Middle States has been filled with these fish. This movement has not met with unmixed approval, for by the ill-advised enthusiasm of some of its advocates a number of trout streams have been destroyed, and complaints are heard that the fisheries of certain rivers have been injured by them. The results have been on the whole very beneficial. The Bass never will become the food of the millions. The New York market receives probably less than 10,000 pounds of them annually, and they are nowhere very numerous. Yet hundreds of bodies of waste water are now stocked with them in sufficient numbers to afford pleasant sport and considerable quantities of excellent food.

The flesh of the Bass is hard, white and flaky, and not particularly remarkable for its flavor. When sufficiently large, it is perhaps better that it should be broiled, and served with white sauce. The smaller Bass may be treated as pan-fish. They are not well suited for broiling, except in the hands of the most judicious of cooks.

The Black Bass is one of the most universally popular of American fishes. Even those who know the joys of trout and salmon angling do not disdain it. For one man who can go forth in search of salmon, and twenty to whom trout are not impossible, there are a thousand who can visit the Bass in his limpid home. There are many methods of angling for Bass. Those who use rod and reel are perhaps not unreasonable when they profess to pity their uncultured brethren who prefer the ignominious method of trolling with hand-line and spoon-bait. 
I shall not attempt to discuss the merits of various kinds of tackle. The dealers in angling apparatus can usually give advice both timely and suitable to the locality. Those who wish to enter into the extreme refinements of the art of Bass fishing must read the writings of Dr. Henshall, and then learn for themselves by long years of observation and experiment, for to no one is book-knowledge less valuable than to him whose desire it is to catch a fish.

Bass may be caught by the use of artificial flies or artificial minnows, with live bait, consisting of minnows, chubs, young perch and many other small fishes, frogs, helgramites, crawfish, shrimps, grasshoppers, crickets or worms, or by the use of spoon-bait or trolling spoon.

In bait fishing a light rod, about eight-and-one-half feet long is used with a multiplying reel to insure the delivery of the bait at long distances. In fly-fishing a more flexible rod, eleven feet long, with a click-reel, is preferred. Strong lines, preferably of braided raw silk, are used, and too much care cannot be given to the strength of leaders and snells, and to the perfection of the hooks. Of the various forms of the latter, Henshall puts the "Sproat bend" first and the "O'Shaughnessy" second, using Nos. 4, 5 and 6 for bait fishing and Nos. 2 and 3 for fly-fishing.

In trolling from a boat at least 300 feet of line should be used. Trolling with the rod "skittering" and "bobbing" are other modes of local popularity.

The Small-mouth is the angler's favorite in the North, being the more agile and pugnacious; but in Florida, the paradise of the Big-mouths, few complaints are heard as to the character of the sport which they afford. "J. W.," writing to the American Angler, June 3 $\mathrm{I}$, I862, reported as follows the weights of sixteen taken in the Homosassa River, Hemard Co., Fla., in one-and-a-half hour's fishing: $7 \mathrm{~T} / 4,61 / 2,5 \mathrm{~T} / 2,5 \mathrm{~T} / 4$, $5,4^{\mathrm{I}} / 2,4,4 \mathrm{~T} / 2,4 \frac{1}{2}, 4,3,23 / 4,2,1 \mathrm{I} / 4$; total, 68 pounds.

The introduction of the Black Bass into England by the Marquis of Exeter has caused great consternation among British anglers, who fear that its rapacity may lead to the destruction of trout and salmon. It has many friends and advocates, however, not the least powerful of whom is Mr. R. B. Marston, editor of the Fishing Gazette. It is, I believe, intended only to place it in streams inhabited by "coarse fish," and the waters of England would surely be the better for the destruction of a goodly percentage of their breams, roaches and barbels. 
I have already often quoted the opinions of that wisest of anglers, Charles Hallock, and I cannot otherwise than repeat in this place his prophecy concerning the future estate of the Black Bass.

"No doubt the Bass is the appointed successor of the trout; not througn heritage, nor selection, nor by interloping, but by foreordination. Truly, it is sad to contemplate, in the not distant future, the extinction of a beautiful race of creatures, whose attributes have been sung by all the poets; but we regard the inevitable with the same calm philosophy with which the astronomer watches the burning out of a world, knowing that it will be succeeded by a new creation.

"As we mark the soft vari-tinted flush of the trout disappear in the eventide, behold the sparkle of the coming Bass as he leaps into the morning of his glory! We hardly know which to admire the most - the velvet livery and the charming graces of the departing courtier, or the flash of the armor-plates on the advancing warrior. The Bass will unquestionably prove himself a worthy substitute for his predecessor, and a candidate for a full legacy of honors.

"No doubt, when every one of the older States shall become as densely settled as Great Britain itself, and all the rural aspects of the crowded domain resemble the suburban surroundings of our Boston; when every feature of the pastoral landscape shall wear the finished appearance of European lands; and every verdant field be closely cropped by lawnmowers and guarded by hedges; and every purling stream which meanders through it has its water-bailiff, we shall still have speckled trout from which the radiant spots have faded, and tasteless fish, to catch at a dollar per pound (as we already have on Long Island), and all the appurtenances and appointments of a genuine English trouting privilege and a genuine English 'outing.'

"In those future days, not long hence to come, some venerable piscator, in whose memory still lingers the joy of fishing, the brawling stream which tumbled over the rocks in the tangled wildwood, and moistened the arbutus and the bunchberries which garnished its banks, will totter forth to the velvety edge of some peacefully-flowing stream, and having scatcel himselt on a convenient point in a revolving easy chair, placed there by his careful attendant, cast right and left for the semblance of sport long dead.

"Hosts of liver-fed fish rush to the signal for their early morning meal, and from the center of the boil which follows the fall of the handfuls thrown in, my piscator of the ancient days will hook a two-pound Trout, and play him hither and yon, from surface to bottom, without disturbing the pampered gourmands which are gorging themselven upon the disernsting viands; and when he has leisurely brought him to hand at last, and the gillie has scooped him with his landing-net, he will feel in his capacious pocket for his last trade dollar, and giving his friend the tip, shuffle back to his house, and lay aside his rod forever." 


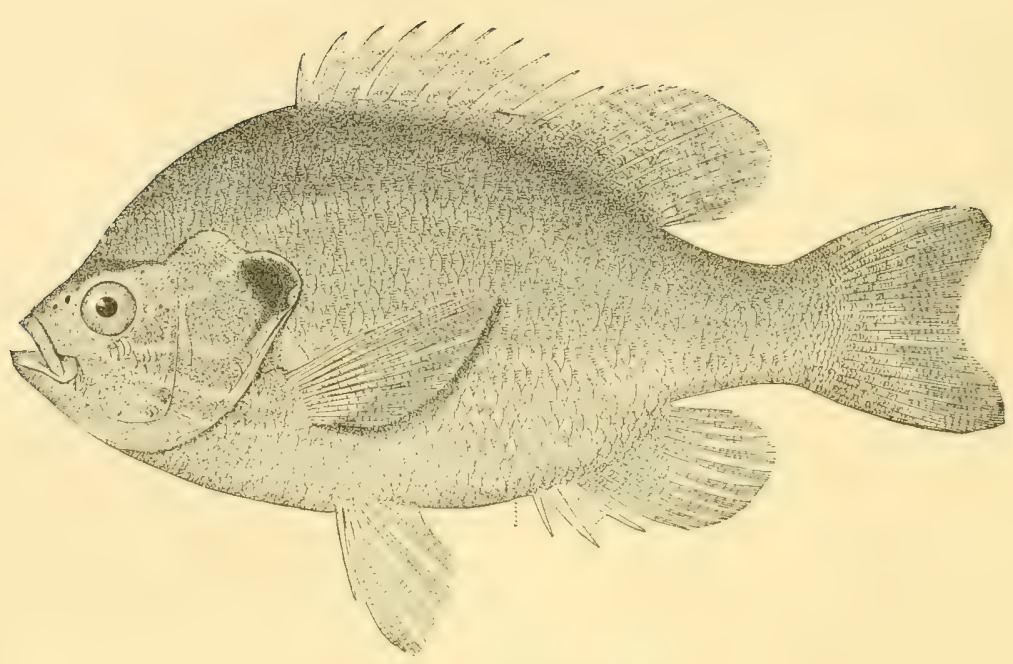

THE SUX-FISH, LEPOMIS GIBBOSUS.

\section{THE SUN-FISHES AND THEIR ALLIES.}

Slowly upward, wavering, gleaming Rose the Ugudwash, the Sun-fish Seized the line of Hiawatha, Swung with all his weight upon it.

But when Hiawatha saw him . Slowly rising through the water,
Lifting up his disk refulgent, Loud he shouted in derision 'Esa! esa! shame upon you. You are Ugudwash, the Sun-fish; You are not the fish I wanted; You are not the King of Fishes.'

LoNGFellow, Hiawatha's Fishing.

THE "Pumpkin seed" and the perch are the first trophies of the boy angler. Many are the memories of truant days dreamed away by pond or brook side, with twine pole and pin-hook, and of the slow homeward trudge, doubtful what his reception will be at home; pole gone, line broken, hooks lost, the only remnant of the morning's glory a score of lean, sun-dried perches and Sunnies, and, mayhap, a few eels and bull-heads, ignominiously strung through the gills upon a willow withe, and trailing, sometimes dropping from weary hands, in the roadside dust.

Then in later youth came the excursion to some distant pond; thr 
early start, long before sunrise, the cane rods trailing over the tail-board of the wagon, the long drive between fresh forests and dewy meadows, the interested faces at the wayside windows. Then at the pond the casting of the seine for minnow-bait, the embarcation in the boat, the careful adjustment of sinker and float, and the long, delightful, lazy day, floating over jungles of eel-grass and meadows of lily pads; now pulling in by the score the shiners, Pumpkin seeds and perches; now passing hour after hour without a bite.

Just as the nightingale and the lark, though eminent among the lesser song-birds of Europe would, if native to America, be eclipsed by the feathered musicians of our groves and meadows, the perch and Sun-fish yield to the superior claims of a dozen or more game fishes. The Sunfish and the perch must not be snubbed, however, for they are prime favorites with tens of thousands of anglers who cannot leave home in quest of sport. They will thrive and multiply, almost beyond belief, in ponds and streams too small for bass, and too warm for trout and landlocked salmon; and I prophesy that they will yet be introduced in all suitable waters throughout the continent, which they do not now inhabit.

The Sun-fish, Lepomis sibbosus, is the common "Pumpkin-seed," or "Sunny" of the brooks of New York and New England. It is everywhere abundant in the Great Lake region and in the coastwise streams from Maine, to Georgia. It is never found in the Mississippi Valley except in its northernmost part, its distribution corresponding precisely to that of the perch. Its breeding habits are thus described by Dr. Kirtland :

"This fish prefers still and clear waters. In the spring of the year the female prepares herself a circular nest by removing all reeds or other dead aquatic plants from a chosen spot of a foot or more in diameter, so as to leave bare the clean gravel or sand; this she excavates to the depth of three or four inches, and then deposits her spawn, which she watches with the greatest vigilance; and it is curious to see how carefully she guards this nest against all intruders; in every fish, even those of herown species, she sees only an enemy, and is restless and uneasy until she has driven it away. from her nursery. We often find groups of these nests placed near each other along the margin of the pond or river that the fish inhabits, but always in very shallow water; hence, they are liable to be left dry in times of great drought. These curious nests are most frequently encircled by aquatic plants, forming a curtain around them, but a large space is invariably left open for the admission of light." 
So far as known, the breeding habits of the other species of Sun-fishes agree with those of Lepomis gibbosus.

It reaches, in the lakes, a weight of about one-and-a-half pounds, and as usually taken is of not over a pound weight. Its flesh is of good quality, similar to that of other Sun-fish of the same size, and is graded as superior to that of the perch, but inferior to the black bass and white bass. It takes the hook freely, and to the small boy is the perfection of a game fish, while even the experienced angler does not despise it.

W. C. Harris, in his "Game Fishes of Pennsylvania," remarks: "I confess to a fondness for catching the 'pumpkin-seed' upon the lightest of light fly rods with leader and line of a spider-web consistency. I hare caught them, averaging a half pound in weight, by the dozen, with black and brown hackles, and when they reach that size they are so sprightly in their play, when hooked on trout tackle, that we cannot deny them a niche in the gallery of game fishes."

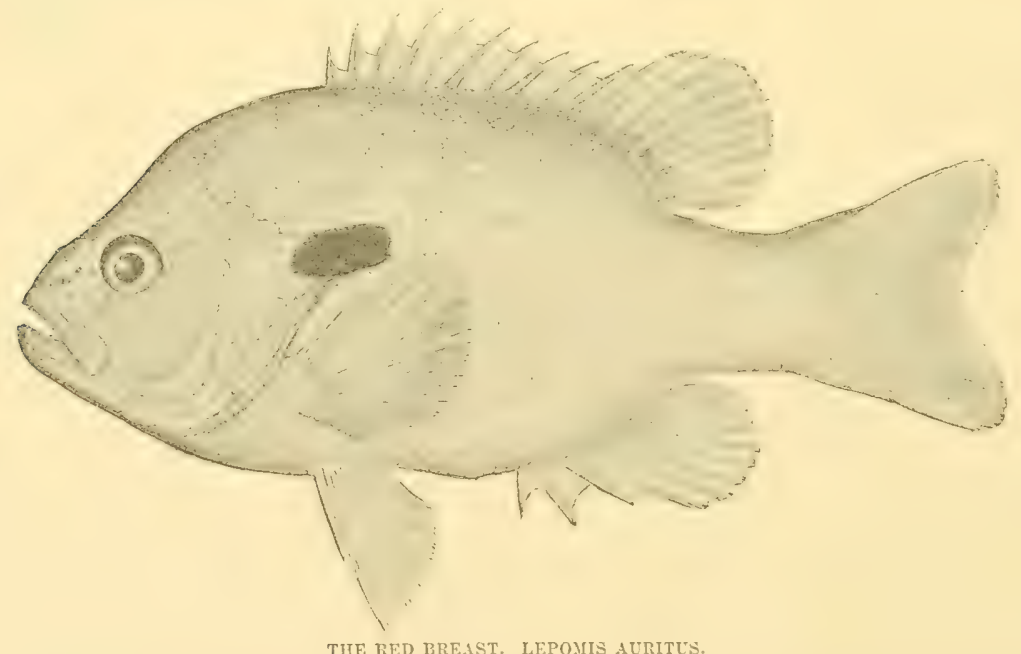

The long-eared Sun-fish, Lepomis auritus, like its relatives, receives the general name of "Sun-fish," "Brim" (Brcam), and "Pearch" (Perch). In Pennsylvania it is called "Sun Perch" and "Red Headed Bream," elsewhere it is the "Red Breast," "Red Bellied Bream" and the "Red Bellied Perch."

It is found in all coastwise streams from Maine to Louisiana, but does 
not penetrate far into the interior. It seldom reaches a weight of much over a pound, but from its abundance becomes in the rivers of the South a food-fish of some importance. Like the others, it feeds on worms: crustacea and small fishes, and spawns in early summer.

The Blue Sun-fish, Lepomis pallidus, is also known as the "Blue Bream" and "Copper-nosed Bream," and in Kentucky sometimes as the "Dollardee." This is the most widely distributed of our Sun-fishes, ranging from New Jersey and the Great Lakes to Florida and Mexico. It reaches a weight of one-and-one-half to two pounds, and, in some regions, is an important market fish. Its havits adapt it especially for cultivation in ponds.

Many other species of similar size abound in the fresh waters of the Mississippi Valley, and are known as "Sun-fish," "Bream" and "Perch." $L$. cyanellus and $L$. megalotis are universally abundant both North and South; the others are chiefly Southern. All take the hook readily, and are good pan-fish, but from- their small size they have no economic importance, and are valued chiefly by urchins and negroes.

The Warmouth, Chanobryttus gulosus, is well-known throughout the South. The names "Perch," "Sun-fish," "Goggle-eye" and "Redeye " it shares with others of its relatives. It is found in all the lowland streams from Virginia to Texas, and in all the Southern States, and is generally abundant. In habits, food, size and value it agrees closely with the Rock Bass.

The Black Warmouth, Chanobryttus antistius, a species also called "TVarmouth," "Big-mouth," "Sun-fish" and "Goggle-eye," abounds in the tributaries of the Upper Mississippi, and is often taken in Lake Michigan. In Illinois it is an important food-fish. In size, habits and ralue it is sufficiently similar to the Rock Bass.

The Sacramento Perch, Archoplites interruptus, known only by the name of "Perch," a name applied in the San Francisco markets to many very" different fishes. It has been thus far found only in the Sacramento and San Joaquin Rivers and tributaries. It is abundant in the lower parts of these rivers, large numbers being shipped to the market in San Francisco. It is there bought and consumed mainly by the Chinese, who value it highly, paying for it more than for any other fish which they consume. Although it is an excellent pan-fish, very similar to the black bass, we have never seen any of them bought by Americans. It reaches a weight 
of little more than one pound. Nothing distinctive is known of its habits.

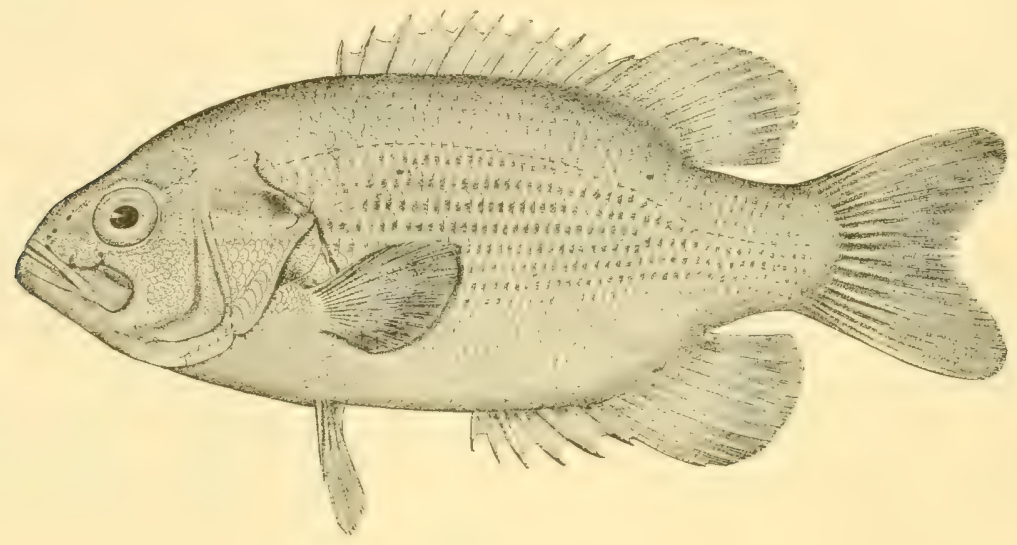

THE ROCK B.ISS.

The Rock Bass, Ambloplites mpestris, is also known as the "Goggleeye" and "Red-eye." All these names are in general use, the first being most common in the Lake region, the last further south. It is everywhere abundant in lakes, ponds and larger streams throughout the Great Lake region and the Mississippi Valley. It prefers clear waters, and is not often found in muddy bayous. it is a hardy and gamey fish, and takes the hook readily, and it is a good pan-fish, though not large, its weight seldom exceeding one-and-a-half pounds. Like other Sun-fishes, they spawn in early summer, and about the same time as Black Bass; and keep much about sunken logs and roots.

The Mud Bass, Acantharchus pomotis, is found only in the coastwise streams of the lowlands from New Jersey to North Carolina. Its habits are similar to those of the Warmouth, but it is similar in size, and has little value as a food-fish.

Contrarchus macropterus has no name more distinctive than "Sun-fish" or "Perch." It is found throughout the lowland streams of the South from North Carolina to Florida, Southern Illinois and Iexas, preferring generally rather deep, clear waters. It is rarely seen in upland streams. It is a fish of good quality, but small, rarely weighing more than half a pound. Little is known of its habits.

The Strawberry Bass, Pomoxy's sparoides. is a beautiful fish known by a 
many names. In Lake Erie, and in Ohio generally, it is the "Strawberry Bass," "Strawberry Perch" or "Grass Bass." 'The names "Bitter Head" and "Lamplighter" are also ascribed to it by Mr. Kippart, and "Bank Lick Bass", by Dr. Kirtland, and it is also called "Bar-fish," "Razor Back," "Chinquapin Perch," "Silver Bass" and "Big Fin Bass." In Lake Michigan the name "Bar-fish" is in general use, giving place in Illinois to the name "Calico Bass." "The latter is among the most appropriate of these designations, having allusion to its variegated color. In the South, like Ambloplites mpestris, it becomes a "Goggle-eye" or "Goggle-eyed Perch." The Strawberry Bass is found in abundance in all the lakes and ponds of the Great Lake region and the Upper Mississippi. It is also diffused throughout the Mississippi Valley, and appears in the streams of the Carolinas and Georgia east of the mountains. Its preference is for quict, clear waters, with a bottom covered with grass; and in the muddy sloughs and bayous, where the Crappie is abundant, it is rarely seen. It is an excellent pan-fish, reaching sometimes a weight of two or three pounds, although usually weighing not more than a pound. It is, like its relatives, gamey; but it is not so voracious as most of them. The following notes on its habits and value are from the pen of Prof. Kirtland:

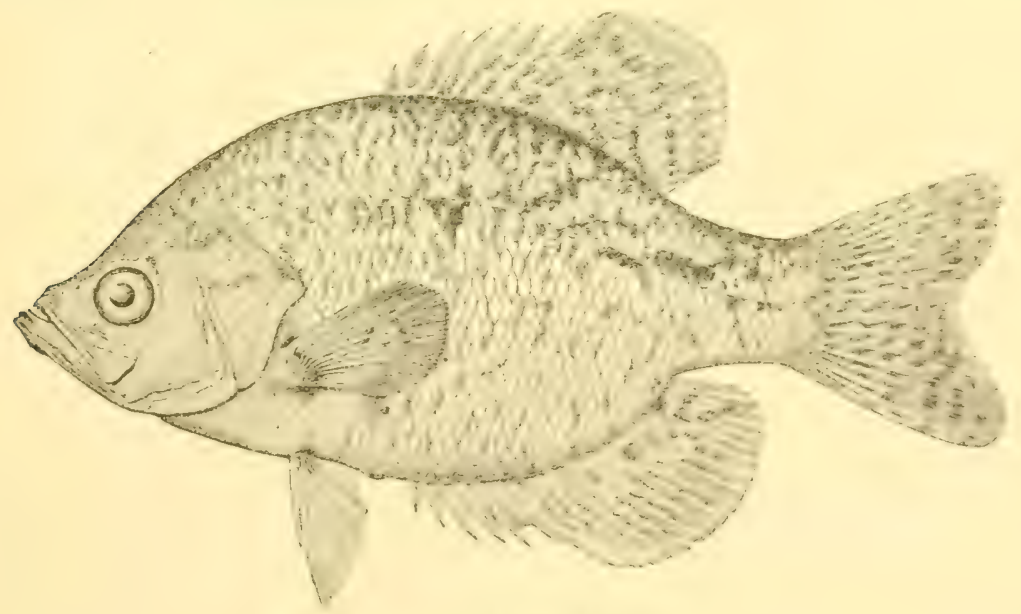

THE STR.WBEHRT b.1SS.

"The Grass Bass has not hitherto been deemed worthy of consideration by fish culturists; yet, from a long and intimate acquaintance with 
its merits, I hesitate not to pronounce it the fish for the million. It is a native of our Western rivers and lakes, where it usually resorts to deep and sluggish waters; yet in several instances, where it has found its way into cold and rapid streams, and even small-sized brooks, by means of the constructing of canals or by the hand of man, it has adapted itself to the change, and in two or three years stocked to overflowing these new locations. As a pan-fish, for the table, it is surpassed by few other freshwater species. For endurance and rapidity of increase it is unequaled. * * * The Grass Bass is perfectly adapted to stocking ponds. It will thrive without care in very small ponds of sufficient depth. **** It will in nowise interfere with the cultivation of any number of species, large or small, in the same waters. It will live harmoniously with all others, and while its structure and disposition restrain it from attacking any other but very small fry, its formidable armature of spinous rays in the dorsal and abdominal fins will guard it against attacks of even the voracious pike."

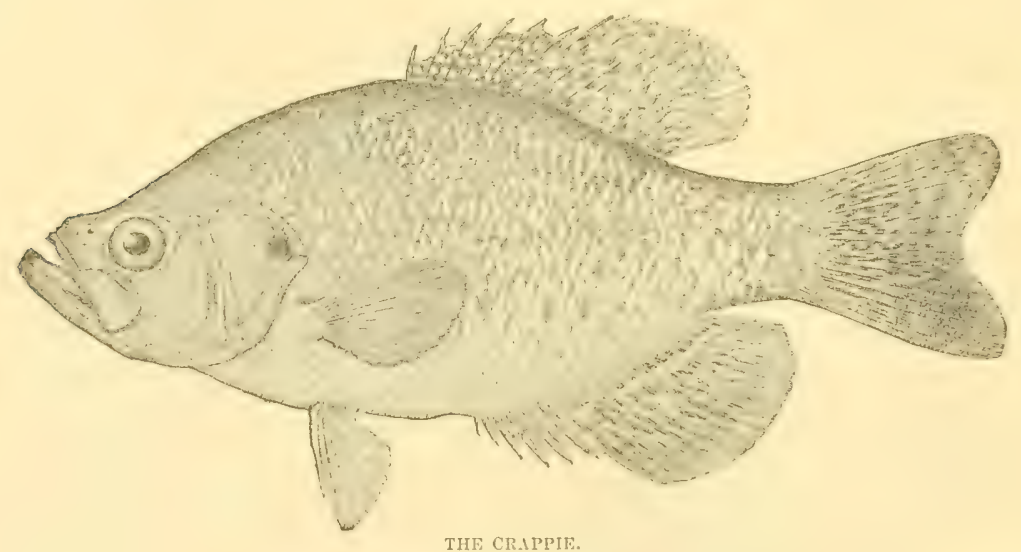

Closely related to the Strawberry Bass is the Crappie, Pomoxy's anmularis. It is the form almost universally called Crappie in the Mississippi Valley. Dr. Henshall has proposed that it shall be called the "Southern Crappie," reserving the name "Northern Crappie" for the Pomoxy's sparoides." It is not such an easy matter to change the popular names of fishes, however flexible may be the terminology of the ichthyologist. Strawberry Bass

*American Angler, III, 167 
and Calico Bass seem to be very appropriate designation for Pomoxy's sparoides, and has the additional adrantage of being already generally in use in a larger clistrict.

Pomoxy's anmlaris is also known by such names as "Bachelor" in the Ohio Valley, "New Light" and "Campbellite" in Kentucky, Illinois and Indiana, names given to it by the irreverent cluring the great Campbellite movement in the West nearly half a century ago. It is also called "Sac-a-lait" and "Chinquapin Perch" in the Lower Mississippi, and has other names of local application as "Tin Mouth," "Bridge Perch,", "Goggle Eyc," "Speckled Perch," "John Demon" and "Shad."

It is also often confounded with the preceding species, and some of the names of the two are interchangeable. This species is not often seen in the Great Lake region, but throughout the Lower Mississippi and its tributaries it is very abundant. Its young swarm in all the muddy bayous along the rivers, and great numbers of them are destroyed in the fall when these bodies of water clry up. With the exception of its predilection for muddy waters, I know little in its habits distinctive from those of the Strawberry Bass. Like the latter, it is said to be an excellent fish for ponds. Both take the hook, feed upon small fishes and crustaceans, and spawn in spring. They grow to be about twelve inches long and to the weight of a pound. Exceptionally large individuals have been known to weigh three pounds.

Among the Louisiana anglers, especially about Lake Pontchartrain; the Crappie is a prime favorite, for it will take a minnow bait as promptly as a black bass. It is not very pugnacious, howerer, and will not fight as long as the bass, and is also more easily frightened, repuiring greater caution on the part of the angler.

A correspondent of the Angle ${ }^{*}$ describes the fishing in Cedar Lake, Incliana. Angling is carried on from little flat-bottomed skiffs and from sail boats, with bait of minnows, worms or pieces of fish. In five hours two men caught fifty-seven bass and eighty-two Crappies. Trolling is a favorite mode of fishing among the people who live near the lake, who, using two lines with spoon-baits or "whirl," and fishing from a sail boat, frequently take two hundred or more Crappies in a clay, besides occasional pickerel, perch and bass. Two men fishing for pleasure, took in June, ISS 2 , in the course of threedays, a thousand Crappies, weighing from four

«Jap" in Anterican Angler, ii, $\mathrm{S}_{7}$. 
to twenty-four ounces each. Another correspondent of the same journal writes as follows concerning Crappie fishing near St. Louis.*

" Our 'Croppie,' the greatest pan-fish of the WVest, is highly esteemed by us for the table. We have seen a monster Croppie this spring, weighing over three pounds, taken at Murdock Club Lake, near St. Louis, on the Illinois side. We consider one of one-and-a-half to two pounds a large one. They are taken about logs and tree tops, on the water's edge, in our rivers and sloughs. They are greedy fellows, but as soon as hooked, step right into the boat without a struggle for liberty.

"A gentleman of this place, a member of one of our old French families, who turned the scale at about three hundred pounds, was noted for his success in Croppie fishing. He would have his large flat towed to a tree; when, tied to a limb, he would settle himself for the day, on a pillow, placed in a large split-bottom chair. Hauling his live box and minnow pail alongside, he would bait two hooks attached to a strong line, using a weak snell, so that in case the hook should foul, he could break it loose. He used a float and short, stout bamboo rod and, shaking the bushes a little, 'to stir up the fish,' would select an opening and carefully drop in the minnow, two feet below the surface, pass the end of the rods through rings in the side of the boat, light his pipe, and wait for something to happen. It was not long, and after the fun began, it was the same monotonous lifting out of fish, and dropping them into the live-box all the day long, and was continued on the next, until he had brought to creel over three hundred.

"I have always associated in my mind the Croppie, and the love of ease and quiet of our old French inhabitants. Nothing could more truly represent contentment and ease than the picture of this simple-minded old gentleman, on his annual Croppie fish at King's Lake.' 




THE RED SX.PPPER.

\title{
SNAPPERS AND RED-MOUTHS.
}

\author{
The island's edges are a-wing \\ With trees that overbranch \\ The sea, with song-birds welcoming \\ 'The curlews to green change, \\ And doves from half-closed lids espy \\ The red and purple fish go by.
}

Mis. Brownisg, fin Island.

$\mathrm{T}$

HE Snappers and the Grunts belong to Gill's family, Pristipomatida. Jordan puts them with the Sparide, or Sea-Breams, while Günther includes them in his much more comprehensive perch family. They are among the most wholesome and abundant of the food-fishes of tropical waters. There are numerous species in the West Indian fauna, but only a small number are sufficiently abundant on the coast of the United States to merit discussion in this book.

The Snappers and Grunts are among the most highly colored of the tropical fishes-the tanagers and grosbeaks of the coral reefs.

The Red Snapper, Lutjams Blackfordii, although it has been for many years a favorite food-fish of the Gulf of Mexico and Eastern Florida, has but recently become known in Northern markets. About $S_{7}+$ individuals of this species were occasionally seen in New York and Washington, and they began shortly after to come into notice in the cities of the Mississippi Valley. It was not eren described and named until i 878 , when a study 
of the notes and measurements obtained in Florida confirmed my suspicion, which had been growing for years, that the species was new to science. The name Lutjanus Blackfordii was chosen in compliment to MIr. Eugene G. Blackford, Commissioner of Fisheries of New York, whose enthusiastic labors have greatly aided all students of American ichthyology, and who has added several species of fishes to the fauna of the United States. The genus Lutjamus was founded in $I_{7} 87$ by Bloch, who derived its designation from Ikan Lutjang, an Asiatic name for a kindred species of the group. Its color is bright crimson, and it is the most conspicuous fish ever to be seen in our markets.

Seven years ago the geographical range of this species was supposed to be limited at the north ly Savannah Bank, but during the summer of I SSo several specimens were taken along the coast of the Middle States; one, nine-and-a-half pounds in weight, off Point Monmouth, New Jersey, October 5 ; another, about August Io, near Block Island. This northern extension of its range is quite unexpected, and the fact that even stragglers find their way into the northern waters suggests great possibilities for the future in the way of their artificial propagation and introduction along the coast of the United States. In the South it is found on the same grounds with the sea-bass, a species which is abundant as far north as Cape Cod, and it is hard to understand why the banks which are farorite haunts of this fish should not also be shared by the Red Snapper. In the Gulf of Mexico the Red Snapper is exceedingly abundant in suitable localities from Key West to the Rio Grande.

"About the Florida reefs," writes Silas Stearns, "and as far north as Temple Bay, where there are reefs and rocks, they live in holes and gullies where all kinds of marine animals and fish are most abundant, and sometimes, as I have noticed, off Charlotte Harbor numbers of them will congregate about a solitary ledge protruding over a level bottom of white sand. Throughout this southern district the fishing spots are small, but rery numerous; and away from the reefs, where the bottom is chiefly sand, it is only necessary to find rocks or rocky bottom to find Red Snappers. Since it is impracticable to make use of bearings by which to find the fishing grounds, the fishermen sail about, throwing the lead continually until it indicates the proper bottom. Along the coast from 'Temple Bay to Texas the bottom declines very gradually to the hundred-fathom curve, forming vast, almost level plains of sand. In these barren wastes there are gullies 
of variable size, having rocky bottoms and teeming with animal and vecretable life. These gullies occur at a depth of from twelve to forty-five fathoms, the water in them being sereral fathoms cleeper than the surrounding bottom, and more rocky, and in the deepest parts richer in animal life. Red Snappers are exceedingly abundant in these places, which are the so-called 'snapper banks.' From 'Temple liay to Cedar Keys the gullies are numerous in sixteen, eighteen, and tirenty fathoms; from Ceclar Keys to Saint Mark's, in fifteen and sixteen fathoms; off Saint Mark's and Dog Island there are a few in five and ten fathoms. From Cape San Blas to the mouths of the Mississippi River occur the best fishing grounds in the Gulf, so far as is now known; gullies ten and fifteen fathoms in depth are especially abundant fifty miles west from the cape. West of the Mississippi, and on the Texas coast, there are a few which are in twelve and fifteen fathoms. These grounds are found by the use of the soundinglead, which shows every position by the sudden increase in the depth of the water. Red Snappers live in such places all the year, except, perhaps, in some of the five and ten fathom ones, which are nearly deserted in winter. Off Pensacola there seems to be quite a movement inshore in fall. In South Floricla they are usualiy associated with the groupers. which occur in the proportion of about three to one, while in W'est Florida the case is reversed; not more than one fish in ten of those caught is a grouper.'

Red Snappers are also known to be abundant on the Sarannah Bank and on the Saint John's Bank, off Eastern Georgia and Florida.

The Red Snappers are strictly carnivorous, feeding upon small fish, crabs, and prawns. The temperature of the water in which they live probably rarely falls below $50^{\circ}$. They have no enemies except sharks and two or three enormous spiny-rayed fishes such as the jew-fish or warsaw (Guasa). The only reliable observations upon their breeding habits have been made by Mr. Stearns, who states that they spawn in May and June in the bays and at sea. In June, July, and August they are found in some of the bays of the Northern Gulf, about wrecks and rock-piles, in considcrable numbers, and none are taken but the larger adults and the young from one to eight inches long. The spawning season probably extends over a period of several months, Mr. Stearns having found well-developed ovaries in them from April to July. Nothing is known of their rate of growth. They attain to the size of forty pounds. In East Floricla, however, the aver- 
age is much less. Mr. Stearns remarks that in the Gulf of Mexico they very seldom exceed thirty pounds weight, though he has seen several of that size, while the average is eight or nine pounds, and in a large lot may usually be found individuals weighing from two-and-one-half to twenty pounds.

Red Snappers from Florida are frequently quoted in the New York market returns. In 1879 about 12,000 pounds were there sold. They are also shipped to Boston, Washington and Baltimore in winter, the supply in these cities being derived chiefly from Pensacola. Mobile and New Orleans consume considerable quanities, and from these ports they are shipped up the Mississippi River to the principal cities of the West, where the fish is growing to be a staple of much importance. In Saint Louis and New Orleans it is one of the most highly esteemed food-fishes.

Snappers should always be boiled or cooked in a chowder. Thus treated they are equal to the striped bass, sea bass or turbot, in flavor and texture. The Court-Bouillon of the New Orleans cooks is made of Snappers, and is very delicious.*

Snapper-fishing is usually carried on with a bottom bait of skip-jack, bluefish, or young shark. The Snappers will sometimes bite at a white rag. Norris, the only sporting authority who has written about them with a clear understanding as to what species he was dealing with, states that. they bite readily at a silver or pearl squid. I am inclined to believe that this is a mistake. Their habits are closely similar to those of the sea bass and the sheepshead, and they seldom rise to the surface.

A trip to the Snapper banks is a favorite summer recreation for the gentlemen of Jacksonville. A tug is chartered for the day, and usually returns to the city with flags flying, whistles triumphantly sounding, and gorgeous festoons of red fish hanging over the bows.

My friend, Dr. C. J. Kenworthy, has kindly given me the foilowing memoranda concerning such a trip :

"Eighteen of us left Jacksonville at two o'clock in the morning, reaching Mayport before daylight. Before the sun rose we were twelve miles from the shore, and near the banks. The second cast of the learl furnished

* Court-Bonillon. "This preparation gives boiled fish a better flavor than cooking in clear water does, Many cooks use wine in it, but there is no necessity for it. Four quarts of water, one onion, one slice of carrot, two cloves, two table-spoonfuls of salt, one teaspoonful of pepper, one table-spoonful of vinegar, the juice of half a lemon and a bouquet of sweet herbs are used. 'Tie the onion, carrot, cloves and herbs in a piece of muslin, and put in the water with the other ingredients. Cover, and boil slowly for one hour. Then put in the fish and cook as directed for plain boiling." -Miss I'ARLOA. 
unmistakable evidence of rocks, and over-board went the lines. They scarcely touched bottom before the cry 'Snapper!' 'Snapper!' was hearl, and a crimson beauty graced our deck.

"All were soon engaged, foreward, aft, starboard, and port. 'To feel the bite of a twenty-five pound Snapper at a depth of twelve fathoms causes a sensation never to be forgotten. As the line is pulled in and the fish is first seen at a depth of several fathoms, he looks like silver and not larger than one's hand. As he comes nearer his tints deepen, as he struggles at the surface to escape, all his rich, brilliant colors are displayed, and when he reaches the deck every one exclaims, "What a beauty!' For a few minutes the shouts resound from all sides, but a change soon occurs. Each man labors as if the number to be captured depended upon his individual exertions, and no breath or time could be spared to cry 'Snapper!' or indulge in fisherman's chaff. In less than two hours the whistle sounds 'Up lines' for we must cross the bar at a particular stage of the tide. The fish are biting rapidly, but our tired arms and blistered fingers induce us all quietly to obey the warning.

"On the home-trip our captures are counted; - not sea bass, porgies, and small fry, but fish worth counting, - and it is found that the party has captured one grouper weighing thirty-five pounds, two of eighteen pounds, and two hundred and eight snappers averaging twenty-five pounds each, the entire catch weighing two and one half tons."

One April day, some years ago, the writer and a party of friends were passengers on the little steamer which plied between Jacksonville and the mouth of the St. Johns. After leaving Mayport on the return trip, we were hailed by a party of men from a large sail-boat laying-to in the micidle of the river. We threw them a line, and they gave us a deck-load of stout fishes,-shapely, bright-eyed, and crimson. We learned that the boat had left Mayport on the previous afternoon, carrying six men, who had, in three hours, taken ninety Red Snappers, weighing in the aggregate over a ton, besides quantities of sea bass. Their brilliant liues were a great surprise to those of our party who were acquainted only with the neutral colors of the common northern market fishes, or pertiaps had even seen the dull red color of the Snappers hanging in the markets. The ladies were eager to possess some of the "lovely scales," but soon learned one of the first lessons of ichthyology, that scales are always white, whatever may be the color of the fish which wear them.

The writer also learned a lesson in ichthyology, on the same occasion, The opportunity to examine so many specimens of this fish, gave him the clew to the fact that it was an undescribed species and led to its descriptions by Goode and Bean under the name Lutjams Blackfordii. 
The genus Lutjanus is found everywhere in tropical waters, and fish resembling the Red Snapper occur everywhere throughout the West Indies. There is one which is abundant on the Bahama Banks and in South Florida. 'This is L. campechiams, Poey, perhaps also accompanied by $L$. torridus, Cope. Two other brilliant red species occur with $L$. Blackfordii in the Gulf of Mexico-the Pensacola Snapper, L. Stcamsii, and the Mangrove Snapper, Rhomboplites aurorubens. On the Bermuda reefs occurs a small but brilliant species, still undescribed, which I propose calling $L$. autolycus.

The Pensacola Snapper might fairly be compared with $L$. Blackfordii, although its color is somewhat less vivid. Concerning this species, Mr. Stearns, whose name it bears, writes: "It is abundant on the Gulf coast, and lives in the bays all the year. In summer it is to be found about stone-heaps, wharves, and old wrecks, where it obtains crustaceous food in abundance. In winter it returns to the deeper places in search of food, and to escape from the cold surface-water. During a cold snap in I 876 a great many of these fish were benumbed and floated at the surface, until the sun appeared and warmed them, when they revived and sought the bottom. They spawn in May and June. They are very cunning, and will not readily take the hook. Those commonly seen in the bays are quite small, averaging ten inches in length, while those taken with the Red Snappers at sea are from twenty to twenty-four inches long. It is an excellent food-fish, generally thought to be superior in flavor to the Red Snapper." 'This fish has as yet been found only on the Gulf coasts of the United States, where it is known as the "Mangrove Snapper." Since this name is used on the Atlantic coast for another species, and has been so used since the time of Catesby, it seems desirable to designate Lutjanus Stearnsii by another name, and "Pensacola Snapper" has been suggested.

The Mangrove Snapper, Rhomboplites aurorubens, of Charleston, called at Pensacola the "Bastard Snapper," is a much more slender and elegantly formed fish than either of the Snappers already described. Its color is less vivid, being somewhat more russet, and is enlivened by the presence of narrow, oblique lines, with gold and yellow upon the sides. It is a swift-swimming fish, probably less given to bottom feeding, and more partial to a diet of living fish. It has been found at famaica, and as far north as Charleston. S. C.

"In the Pensacola region," writes Stearns, "it is well-known, but not 
a common species." Single individuals are occasionally brought in from the sea with the Red Snappers and groupers. It is caught at all depths, from ten to thirty-five fathoms, and seldom exceeds eighteen inches in length. As a food-fish it is equal to the Red Snapper.

The Gray Snapper, Lutjams caxis, is similar in form to the others, but not red in color. It is called the "Gray Snapper" in South Florida, and the "Black Snapper" at Pensacola; is abundant about the Bermudas, and has been found on the cast coast of Florida, in tropical South America, in Western Africa, and about the Bermudas, where it attains the enormous size of sixty to eighty pounds, and is known as the "Gray Snapper," and also, on account of its sly, cunning habits, the "Sea Lawyer."

Mr. Stearns writes: "It is most abundant in South Florida, living in deep channels, on rocky bottoms, about old wrecks, stone-heaps, and wharves; it is considered the most cunning fish on the coast, and extremely difficult to catch. 'T'he young may be seen about the wharves, and the breeding grounds are probably near by. Those usually observed are from ten to twelve inches in length, but I think I have seen specimens which would measure two feet."

The Red-mouths or Grunts, small fishes belonging to the genus Diabasis, are found in the inshore waters of the Southern Atlantic and Gulf States. 'they are closely related to the Snappers, which they resemble in form, and have remote affinity, with the perch, the bass, and the porgy and sheepshead. Their colors are usually striking, and without exception, they are distinguished by the brilliant red color of the inside of the mouth and throat, from which they have sometimes been called Redmouths, or Flannel-mouths. From their habit of uttering a loud, rather melodious sound when taken from the water they have acquired the name of "Grunts" and "Pig-fish." In some localities they are called also "Squirrel-fish," in allusion to the same habit. They are, for the most part, bottom feeders, preying chiefly upon crustaceans and small fish. In fact, they are, in most respects, miniature counterparts of the Red Snapper. In many localities they are in high favor as foocl-fish. They have not yet been very carefully studied, but so far as they are now understood the following species are known to occur in sufficient numbers to prove of commercial importance.

The Black Grunt, Diabasis Plumieri, has a brownish body, lighter upon the sides, and has the sides of the head ornamented with numerous hori- 
zontal stripes of bright blue, while the posterior half of the lower lip is red. It occurs as far north as Charleston, and Dr. Yarrow claims to have seen it at Beaufort, North Carolina, though there is some question whether this species was not mistaken for another. Holbrook records that it has been observed on the Atlantic borders of South Carolina, Georgia, and Florida. I noticed several small individuals in the markets of Saint Augustine in March, 1877. Stearns mentions the Black Grunt as abundant at Key West among the reefs, and as frequently seen in the markets. It is there known as the "Ronco Grande," $D$. albus being called the "Margate Fish," and D. chromis the "Sailor's Choice."

The Red-Mouth Grunt, Diabasis aurolineatus, is probably the "Flannelmouthed Porgy," familiar to Florida fishermen, and often taken. on the St. Johns bar. It has recently been found to be common in Charleston in summer. This species was mentioned in Catesby's great work, published in I643, under the name of "Margate-fish." When alive its color is bright silvery, but it soon becomes, when taken from the water, of a dull amber-brown, with a slight brazen tint along the back and sides, though the belly remains white. The upper jaw, within, is white; the palate is salmon-colored; the lower jaw and mouth below are also white in their interior third; the posterior two-thirds, both within and without, are red, and the mouth below; the tongue and fauces are of a similar color. This fish occurs in Northern Brazil and throughout the West Indias, and specimens are recorded from Jamaica, Trinidad, and the Bahamas ; it is found in the Bermudas and on our coast at least as far north as Charleston. Stearns writes: "It is quite common on the Gulf coast of Florida from Pensacola to Key West. It is caught with hook and line, and is eaten as a pan-fish. I took an extremely large specimen from the snapper ground between Cedar Keys and St. Marks in fifteen fathoms of water. It is not found in the vicinity of Pensacola." Holbrook writes: "The Red-mouthed Grunt is occasionally taken in our waters at all seasons of the year, but is never abundant, as seldom more than a dozen or two are met with in the market at one time. It is not highly esteemed for food, since its flesh lacks both firmness and flavor."

Uhler and Lugger say that it occurs occasionally in the lower part of the Chesapeake Bay, where it is not considered to possess great economical value. The occurrence of this species so far north needs confirmation.

The Norfolk Hog-fish, Pomodasys fulvomaculatus, belonging to a 
closely related genus is the "Hog-fish," or "Grunt," of the Chesapeake, and called also "Pig-fish" "or "Grunt" in the Gulf of Nexico, and "Porkfish" and "Whiting" at Key West, and known in South Carolina and the St. John's River, Fla., as well as in Bermuda under the name of "Sailor's Choice. Its colors are as follows: Above, pale brown: belly, silvery; sides marked with numerous orange-colored or yellow spots; those above the lateral line disposed in irregular oblique lines, those below it in horizontal rows. Dorsal, anal and caudal fins with similar spots; sides of the head pale bluish with a silvery tint and marked with yellow spots; lower jaw, orange at the angle of the mouth; internal surface of the gill membrane bright orange."

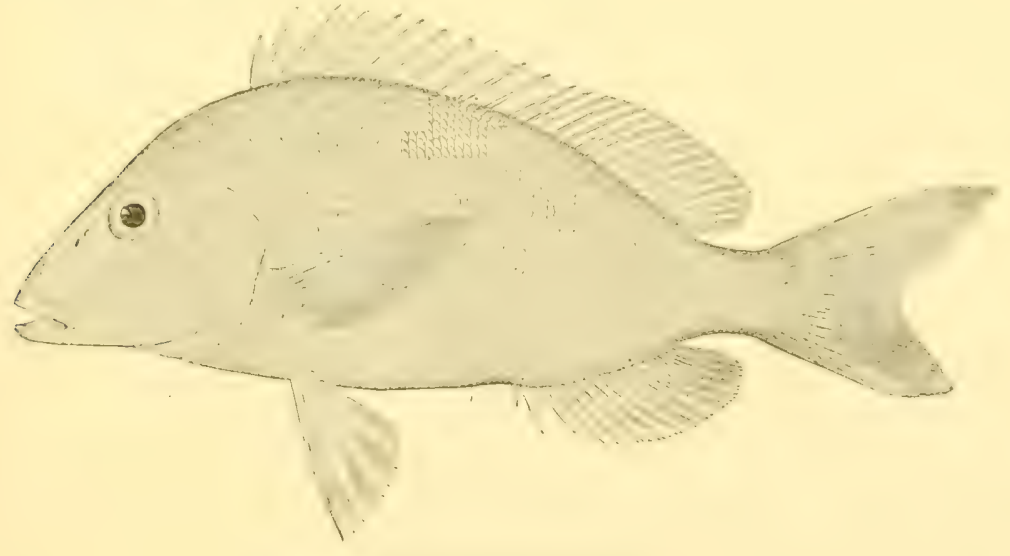

TIIE YORFOLK HOG-FISH.

This species was first described by Mitchill from a specimen taken in the bay of New York. The National MIuseum has many specimens from various parts of the Southern coast and the Gulf of Mexico. "In New Tork," wrote Dekay in I $S_{+2}$, "this is a rare fish, but occasionally appearing, as I am informed, in our harbor in consiclerable numbers. It is a very savory food." Prof. Baird did not find it on the coast of New Jersey in $\mathbf{I}_{54}$. It occurs in the salt water of the lower part of the Chesapeake Bay, and is much esteemed for food, being perhaps the most popular pan-fish of the Lower Chesapeake.

At Beaufort, N. C., where it is also called "Hog-fish," according to Jordan, it is extremely common everywhere in the harbor. Holbrook wrote about I 860 : "The 'Sailor's Choice' makes its appearance in our 
waters about the month of April and continues with us until November, when the largest are taken. I have found in the stomach of this animal only the remains of small fish, and yet it takes hook readily when baited with shrimps and clams. It is found along the coast from Georgia to Virginia, where it is called "Hog-fish," and is held in great estimation by epicures."

"On the Gulf coast," writes Stearns, "it is common everywhere and throughout the year it lives in shallow water among the grass, feeding upon small crustaceous animals. It spawns in April and May, and is a choice food-fish. The average length is about ten inches." Stearns also refers to three species known respectively as the "White," "Yellow" and "Black" Grunt, which are found at Key West and upon the neighboring reef in great abundance. He states that "they are taken with hook and line, and are brought daily into market. Before the poisoned water visited that neighborhood the Grunt was the most important as well as the favorite food-fish in the market, but since then they have been scarce, and other fish, to a great extent, have taken their place."

On the coast of California, especially southward, occur two species of this family; one, known by the name "Sargo," Pristipoma Davidsoni, is found from San Pedro southward to Cerros Island, chiefly about the islands, and is nowhere common. It feeds on crustaceans, and is a a good pan-fish, but is too scarce to have much economic value. It reaches a length of about fifteen inches. Still another, Xenistius californiensis Steindachner, occurs from San Diego to Cape San Lucas. It is too scarce to be of any importance for food. 


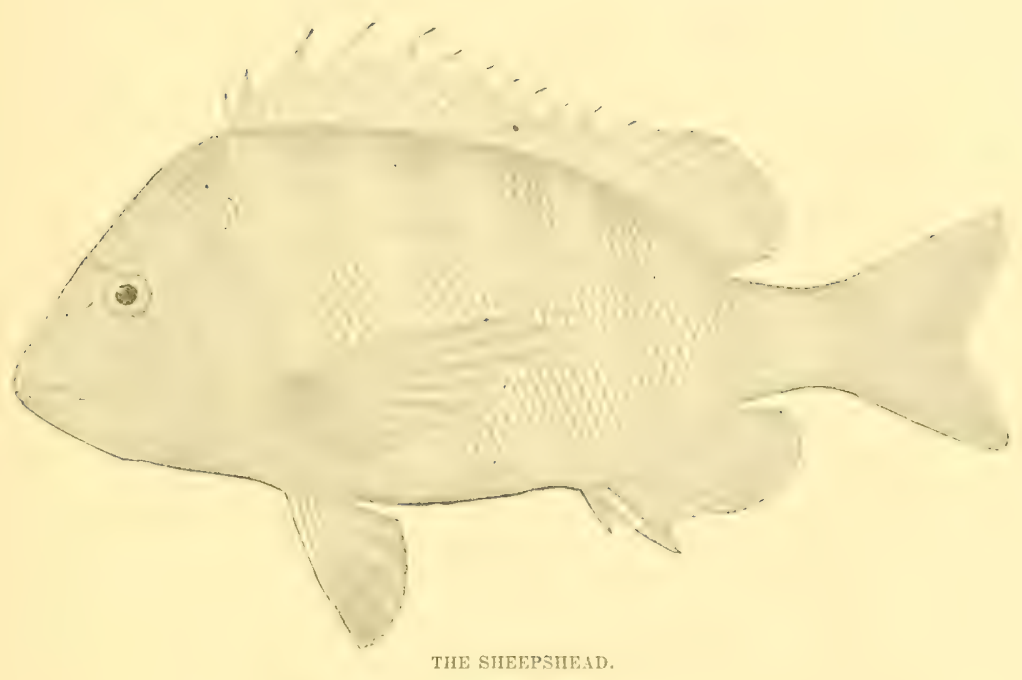

THE SILEPSHEAD.

The pleasantest angling is to see the fish Cut with her golden oars the silver stream And greedily devour the treacherous bait.

Shakespeare, Much Ado About Wothing, Act IIT, Scene $r$.

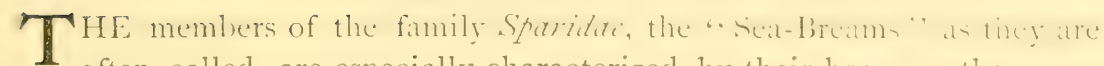
often called, are especially characterized by their heavy, rather compressed bodies, their large heads, and strong jaws and teeth. In addition to one or more series of teeth in the front of the jaws, either conical or incisorial in shape, adapted for tearing their food from its lodging places, they always have a set of heary, flat, grinding-teeth in the back of the mouth, which are often in double or triple rows on each side and are closely set, like the stones in a mosaic. Their use is to crush hard shells of mollusks and of barnacles, and other crustaceans. They are sedentary in their habits, living close to the bottom and browsing among the rocks and piles. Their colors are usually inconspicuous and their motions sluggish. Representatives of this family are found throughout the world in temperate and tropical waters everywhere, and were numerous in the seas and lagoons of the Tertiary and Cretaceous periods.

The most important representatives of the family in America, are the 
Sheepshead and the Scuppaug or Porgy. There are several others inhabiting our southern coast, of which the Sailor's Choice, Lagodon rhomboides, and the Bream, or Bastard Snapper, Sparus aculeatus, are the best known, but these are of little importance to either fisherman or economist. On the Pacific side are others, which will doubtless be better known in the future than they are at the present time.

The Sheepshead, Archosargusprobatocephalus, is one of the choicest fishes of our waters. It derives its name from the resemblance of its profile and teeth to those of a sheep, and also from its browsing habits. Unlike most of those fishes which are widely distributed along our seaboard, it has only one name, and by this it is known from Cape Cod to the Mexican border. The negroes of the South, however, frequently drop the sibilant sound from the middle of the word and call it "Sheephead."

Several other species are called by the same name, but there is little danger of confusion except in the case of the so-called "Sheepshead" of the Great Lakes, which is similar to the well-known "Drum ;" this fish is occasionally sold to the unwary on the recommendation of its good name.

This fish has never been known to pass tu the north of the sandy arm of Cape Cod, and its northern range is at present somewhat more limited than it was eighty years ago. In the records of Wareham, Massachusetts, they are mentioned as having been somewhat abundant in $\mathrm{r}_{\mathrm{SO}} 3$, and in Narragansett Bay there is a tradition that they began to disappear in 1793 , when the Scuppaug commenced to increase in abundance. In 187 I, E. E. Taylor, of Newport, testified before the U. S. Commissioner of Fisheries, that his father caught Sheepshead in abundance forty-five or fifty years previous. In $\mathrm{I} 870$ and $\mathrm{I} 87$ I the species was coming into notice in this region, though neither at that time nor since has it become common. On the south shore of Long Island it is quite abundant, and in New York harbor and its various approaches, at times, may be taken in considerable numbers. On the coast of New Jersey it is also abundant, and between Cape May and Montauk Point the species is said to attain its greatest perfection as a food-fish. Lugger states that it frequents the oyster localities of all parts of Chesapeake Bay, but is now more common among the southeastern counties of Virginia, where it comes in considerable numbers to feed upon the animals which live on the oyster bars. It is found about wrecks of old vessels, on which barnacles and mollusks live. About Beaufort, N. C., it is also abundant, and also along the entire coast of the South Atlantic and 
Gulf States, where it frequently ascends, especially in Florida, high up the fresh-water rivers. In the Gulf, according to Stearms, it is abundant on the coast from Southern Florida to Mexico.

The Sheepshead is a bottom-loving species, quiet in its habits, and little given to wandering. North of Charleston it is absent from the inshore waters during the winter season, but it is probable that its migrations do not carry it far. Holbrook records that it has been taken in Port Royal Sound as early as January, while in Charleston it makes its appearance in April and continues until November. Dr. Mitchill, whose observations on this species in the vicinity of New York, made sixty years ago, are perhaps as satisfactory as any which have been made, remarked that its term of continuance was from the beginning of June to the midclle of September. He had, however, known it to stay later, for one of the most numerous collections of Sheepshead he ever saw was on the $4^{\text {th }}$ of October, I 8 I 4 ; he had observed it as late as the I 7 th of October.

In Florida the Sheepshead is found along the shores throughout the entire year, and also in the Gulf of Mexico.

It is curious to see how much at variance were the statements of early observers concerning its habit of entering fresh-water streams. Mitchill states explicitly: "He confines himself strictly to the salt water, never having been seen in the fresh rivers." Holbrook, speaking of the vicinity of Charleston, says: "It enters shallow inlets and mouths of rivers, but never leaves the salt for fresh water." In the St. John's and other rivers of Florida the Sheepshead becomes almost a fresh-water species, and the young, especially, are constantly taken in seines in company with bass, perch and suckers, far above the limits of perceptibly brackish water. It is not yet possible to infer with any certainty what the temperature limits of this species may be, but it would seem probable that they never willingly encounter water colder than $60^{\circ}$, except perhaps in fall, when they are reluctant to leave their feeding grounds.

The statement just made, however, requires a certain qualification. No - one knows whether the Sheepshead of our Northern waters go south in winter or whether they simply become torpid and remain through the season in deep holes near their summer haunts, their presence unsuspected. Perhaps it would be wiser to say that they are not actually engaged in feeding when the temperature is lower than $60^{\circ}$, and that their winter habits are entirely unknown. Where the water is warmer than $60^{\circ}$ throughout the 
year, they are constantly active. The Sheepshead feeds almost exclusively upon hard-shelled animals, mollusks and barnacles, and particularly on young oysters as they grow, attached to stones and sticks of wood. With its strong cutting and grinding teeth and powerful jaws it easily rips off thick bunches of shells, which are quickly triturated by the mill-stone like jaws. The anglers of the South take advantage of their knowledge of its habits.

The Hon. William Elliot, in his "Carolina Sports by Land and Water," describes the peculiar methods employed in Port Royal Sound, South Carolina :

"They are exceedingly choice in their feeding, taking no other bait but shell-fish. Their favorite food is the young oyster, which, under the form of barnacles, they crush with their strong teeth. Of course they frequent those shores that abound with fallen trees. On the Florida coast they are taken in great quantities among the mangrove trees, whose roots growing in the salt water, are covered with barnacles. Formerly they were taken in considerable numbers among our various inlets. Wherever there were steep bluffs, from which large trees had fallen in the water, there they might confidently be sought. But as these lands have been cleared for the culture of sea-island cotton, the trees have disappeared, and with them the fish; and it has been found necessary to renew their feeding grounds by artificial means. Logs of pine or oak are cut and framed into a sort of hut without a roof. It is floored and built up five or six feet high, then floated to the place desired, and sunk in eight feet of water by casting stones or live-oak timber within. As soon as the barnacles are formed, which will happen in a few weeks, the fish will begin to resort to the ground. It is sometimes requisite to do more before you can succeed in your wishes. The greatest enemies of this fish are the sharks and porpoises, which pursue them incessantly and destroy them, unless they can find secure hiding-places to which to retreat. Two of these pens, near each other, will furnish this protection; and when that course is not adopted, piles driven near each other, quite surrounding the pen, will have the same effect. Your work complete, build a light staging by driving down four upright posts at a distance of fifteen feet from the pen, and then take your station on it, provided with a light, flexible, and strong cane reed, of twenty feet length, with fourteen feet of line attached, a strong hook and a light lead. Instead of dropping your line directly down and poising it occasionally from bottom, I prefer to throw the line out beyond the perpendicular and let the head lie on the bottom. The Sheepshead is a shy fish, and takes the bait more confidently if it lies on the bottom. When he bites you perceive your rod dipping for the water; give a short, quick jerk, and then play him at your leisure. If the fish is large, and your jerk 
too violent, the rod will smap at the fulcrum-the grasp of your left hand. It has happened that, at one of these artificial gromds, I have taken sixteen Sheepshead at one fishing. What was unusual was that they were taken in liebruary, when no one thinks of fishing for these or any other sea-fish within the inlets. I ascertained, from the continued experiments of several years, that they could always be taken at this season, and, frequently, January also. 'The difficulty is to find bait, for neither shrimps nor crabs are then in season. In the case referred to the difficulty was thus removed: The lines were rigged with two hooks; upon one was placed an oyster taken fresh from the shell, on the other an oyster boiled. The scent of the first attracted the fish, but so little tenacity was found in it that, before the fish had taken hold of the hook, the oyster was detached; but when, encouraged by the taste of the first, the fish advanced to the second, that having acquired toughness from boiling, would adhere until the hook was fairly taken into the fish's mouth. They clearly prefer the uncooked to the cooked oyster, but the latter was more to the fisherman's purpose. Their fondness for this food suggested the expedient of breaking up the live oysters in the shell and scattering them in the vicinity of the ground; also that of letting down the broken oysters in a wicker basket. Each plan is found effectual in attracting the fish.

"The blufts, in their primitive state, in which trees enough are found fallen to give the fish both food and protection against their enemies, are only to be met with now among the Hunting Islands, where the barrenness of the land had secured them against cultivation. On two occasions I have enjoyed excellent sport at such places. On one I took twenty-three to my own rod; on another, twenty-four, and desisted from fatigue and satiety. They are never taken in such numbers when fishing from a boat with a drop-line on the rocks. It is very rare that as many as twenty are taken in one boat."

In New Jersey, Sheepshead pens are made by forming enclosures of long stakes driven into the sandy bottom of bays and inlets.

In the North, the Sheepshead is equally a great favorite, and the instructions to anglers written nearly a hundred years ago by Mitchill is better than any by more recent writers.

"This noble fish visits the neighborhood of Long Island annually, emerging from the depths of the ocean. He feeds in the recesses and inlets upon the clams and mussels, which are abundant and on which he loves to feed. He confines himself strictly to the salt water, never having been seen in the fresh rivers. His term of continuance is only during the warmest season; that is, from the beginning of June to the middle of September. He then disappears to the unknown depths of the Atlantic, and is seen no more until the ensuing summer. The Sheepshead swims in shoals, and is sometinıes surrounded in great numbers by the seine; several 
hundreds have often been taken at a single haul with the long sweeping nets in use near Rayner Town, Babylon and Fire Island. They even tell of a thousand brought to land at a draught. 'He also bites at the hook, and several are not unfrequently thus caught in succession. The outfitting of a Sheepshead party is always an occasion of considerable excitement and high expectation, as I have often experienced. Whenever a Sheepshead is brought on board the boat more joy is manifested than by the possession of any other kind of fish. The sportsmen view the exercises so much above common fishing that the capture of the Sheepshead is the most desirable combination of luck and skill; and the feats of hooking and landing him safely in the boat furnish abundant materials for the most pleasing and hyperbolical stories. The Sheepshead is a very stout fish, and the hooks and lines are strong in proportion; yet he frequently breaks them and makes his escape. Sheepshead have been caught with such fishing-tackle fastened to their jaws. When the line or hook gives way, the accident makes a serious impression on the company. As the possession of the Sheepshead is a grand prize, so his escape is felt as a distressing loss. I know an ancient fisherman who used to record in a book the time, place, and circumstances of every Sheepshead he had caught. This fish is sometimes speared by torchlight in the wide and shallow bays of Queens County and Suffolk."

Dr. Mitchill concludes his naive remarks by the mournful words: "It is to be regretted that the Sheepshead too often corrupt for want of ice."

Schoepf, writing of the same region forty years before, states that during the period of the Revolutionary war the Sheepshead was very abundant in the summer months and was a very highly prized species. In 1773 the New York Chamber of Commerce offered a prize of twenty pounds sterling to the crew of the ressel which should bring to the city markets, "the greatest quantity of live Sheepshead, from the ist of May, I773, to the Ist of May, I 774." Some unknown writer contributed to Brown's "American Angler," in i 846 , the following memorandum :

"These noble fish have become quite scarce in our harbor. The writer has taken them repeatedly near Governor's Island, opposite the Battery, but this was in days long since gone by. Still, they are still taken, occasionally, at Caving Point and at the Signal poles, at the Narrows, also at Pelham Bridge and Little Hell Gate.'

Scott gives the following advice to Sheepshead anglers:

"If a resident of New York, you will find Canarsie on the Old Mill, near East New York, the most convenient place from which to take a sailboat; a boat is generally at hand at either place. Sail down the channel above the inlet toward Near Rockaway, about a mile below Remson's Ho- 
tel; feel by sounding for a mussel-bed (they are numerous for a mile along shore), about two hundred yards from which, when found, cast anchor far enough away so that, when the boat toles round from the tide toward the feeding-ground, the cast required for dropping your anchor will be about fifty feet. 'The water should be about seven feet deep at low tide, and it rises there from four to six feet. The best time is cluring the period between high and low tides when the water is slack, and until it runs at the rate of five miles an hour, or one hour after it begins to run; for when the tide runs out it is then considered that Sheepshead seek some still-water ground and wait for a moderate motion of the waters. At the right times of tide the location of the mussel-beds is plainly indicated by a fleet of fifteen to twenty sail-boats or hand-line fishermen. Many of them are farmers, who, residing near the shore of Jamaica Bay, employ the interregnum between hay and grass, uniting their profits, and earning from $\$ 3$ to \$IO a day, by fishing for Sheepshead.

"There are many places along our shores better than Jamaica Bay. The Hand-line Committee makes it pay at Fire Island, and there are many superior feeding places in the South Bay; about the wreck of the 'Black Warrior,' near the Narrows, is celebrated for its great numbers of them ; in truth, our whole coast south of Long Island is rendered inviting by this delicious fish."

The favorite resorts of northern Sheepshead anglers are among the rocks about Jamaica Bay, South Bay, and Fire Island, and in various parts of New York Bay, as well as in similar localities on the coast of New Jersey.

The Sheepshead of the North is generally considered much finer in flavor, as well as larger than its southern brethren, but I can speak from experience of the delicious quailities of these fish taken in the St. John's River, Fla., at the upper limit of brackisly water, and am inclined to doubt the vaunted superiority of those of New York.

In Florida, and as far north as Port Royal, S. C., the Sheepshead is a winter resident. Mr. Elliott tells of his success in fishing for these species in January and February, despite the scarcity of bait. At Charleston the fish is scarce in winter. At the mouth of the Chesapeake it appears in early April, in New Jersey in May, and at about the same time in the ricinity of New York. In mid-summer it is seen in southern New England. It leaves New Jersey about September, and Virginia in October. Its preferred temperature is, probably, not below $60^{\circ}$ or $65^{\circ} \mathrm{F}$. Frank H. Allen in the American Angler, (I, 55) states that at Indian River Inlet, Fla., three men at one tide took one hundrel and sixty Sheepshead, using roasted oysters for bait. He states that Sheepshead may, as a rule, be 
taken wherever the mangrove roots extend out into the water, but in shallows they are frightened away.

Little is known of its reproduction. When they first appear on our northern coast we are assured by several writers, they are always thin and unfit for food; it would seem from this that if their spawning season must then have just come to an end. No one, has made any careful observations upon this point north of Florida however.

Mr. S. C. Clarke has observed that about New Smyrna, in the Indian River region of Florida, they spawn at the mouths of rivers and inlets in March and April, the sexes mixing together in schools. The eggs are deposited in shallow water near the shore, and are about the size of mustard seed, and dark. At the spawning season the fish play near the surface and become thin and unfit for food. The young fish are abundant in shallow water among the rocks."

Silas Stearns writes from Pensacola:

" The Sheepshead spawns in April and May, in the bays. On June is, I 878 , and in June, I 879 , I caught young Sheepshead, measuring a quarter of an inch, in Pensacola Bay. It lives about wharves, rock-piles, old wrecks, oyster-reefs, and, in South Florida, about the roots of the mangrove tree, feeding upon the barnacles that grow in such places. It is caught with hook and line, in fall and winter, at which seasons it is in its best condition. Its average weight is three or four pounds, and its maximum twenty pounds."

Those taken about New York sometimes weigh from twelve to fifteen pounds, though the average size is not more than six. All authorities. agree that the Sheepshead is one of the very finest food-fishes in our waters, many persons prefering it to the salmon, while others compare it to the English turbot, which, in the writer's judgment, it excels in flavor.*

How ro lort Frsi.- The art of boiling fish is so little understood, that it is deemedproper to insert the following instructions, derived from the writings of Georgiana Hill of London. The method of boiling usually practiced is simply to place the fish in salt water, which should be cold if the fish is large, and hot for small-sized fish; in the latter case, two or three minutes in the boiling water will be sufficient, and a sheepshead or bass of four or five pounds will not require more than about ten minutes from the time the water begins to boil. Whenever practicable, use a strainer whercon to place the fish in the sauce-pan.

Some kinds of fish may le first skimed, but carp should retain its skin.

When only salt is added to the water, the fish is said to be a l'cau de sel. When sea-water is used, the fish is understood to be dressed a l'Hollandaise. When white wine or vinegar and spices and shred onions, are employed to flavor the water, the fish becomes au court bouillon, and should the fish be simmered in a small quantity of water, to which is added a savoury seasoning of herbs, it is known as being $a$ la bonne cau; in this case it is generally served in the liquor in which it was dressed; done in equal quantitics of red wine and water, strongly impregnated with aromatic herbs the fish is described as being $a u b l e w$, and is almost 
The Pin-fish, Diflodus Holbrookii, which is abundant at Charleston and about Beaufort, N. C., was first scientifically described by Dr. Bean from specimens obtained in Charleston market, in March, I 878 . Tordan founc it abundant everywhere near the shores of Beaufort, N. C., in which region it reaches but a small size, and is not used for food. It is confounded by the fishermen with the Sailor's Choice, Lagodon rhomboides.

invariably served cold; only the best kinds of fish, such as striped-bass, sea-bass, sheepshead, moonfish, red smaper, squetengue, salmon \&ic, are treated in the last way.

Salmon, and all dark-lleshed fish require much more boiling than the white-fleshed kinds.

When possible, some vinegar should be rubbed on the outside of fish before it is boiled, by which means the skin is prevented from cracking, but the introduction of much flavoring in the liquor in which it is lressed is principally neccssary when the fish has been some time out of the water, and is consequently deficient in natural tlaver.

It is considered preferable to serve boiled fish upon a napkin, rather than have a sauce poured over it in the dish: and with salmon it is thought better taste to have a plain white sauce, instead of anything less simple; cucumber or melon in slices may be served apart.

No positive rules can be given as to the length of time fish should be boiled, as everything depends upon the size and kind of fish you have to dress.

Salmon, usually, should be allowed at least ten minutes to each pound, while two or thrce minutes per pound will be ample for haddock, cod, \&c.: a mackerel needs about a quarter of an hour to do it properly; herrings, and many other sorts of fish, scarcely half so long.

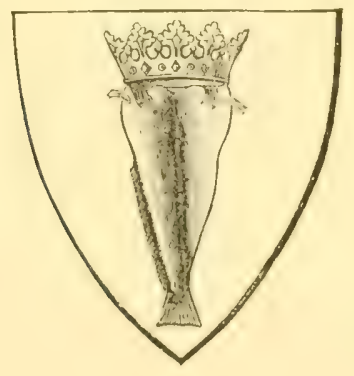




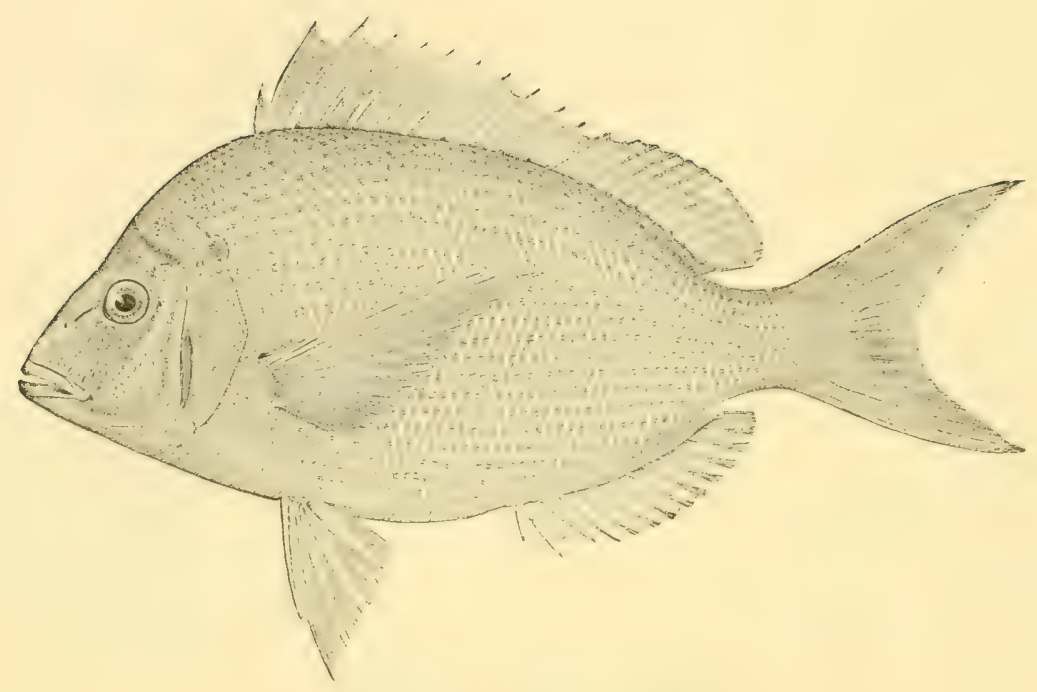

THE SCUPPAUG. STEXOTOMUS CHRYSOPS.

\section{THE SCUPPAUG AND THE FAIR MAID.}

Bait the hook well; this fish will bite.

Shakespeare, Miuch Ado About Nothing, Act ii, Scene iii.

SCUPPACG, the name of this fish, is an ablureviation of Mishuppanes, $S$ an appellation used by the Narragansett Indians, which has unfortunately been corrupted to form two others, neither of which is euphonious or significant. In New England it is generally called "Scup," while about New York the second syllable of the abbreviated Indian name has been lengthened into "Paugy" or "Porgy." The latter name is particularly objectionable because it belongs to an English fish, and its proper etymology as a fish-name is very different. Another Indian word, "poghaden," a corrupt form of the Abnaki name for the menhaden, or moss-bunker, has been changed to "pogy" and "porgy," thus leading to much confusion. "Scuppaug" is an excellent name for the fish, and its claims for general adoption will be recognized ly all who wish to preserve the memory of the aboriginal languages of America. 
Tautog, chogset, squeteague, mummichog, mattawacca, menhaden, siscowet, tullibee, quinnat, oulachan, oquassa and namaycush are among the best of them ; their number is few, and they need careful guardianship.

Until very recently only one species of the genus Stenotomus was known to occur in our waters. Dr. Bean has, however, shown that there are two on the Atlantic coast of the United States, in addition to the unimportant species, S. caprimus, recently dcscribed from the Gulf of Mexico.

The "Scup" of the North, Stenotomus chry'sops, is by far the most important, though the Southern species, S. aculeatus, has considerable commercial value. The former, which is distinguished by its larger teeth and more abrupt profile, is abundant between Cape Cod and Cape Hatteras; the latter has its metropolis on the Carolina coast, but has been found sparingly as far north as Wood's Holl, Mass.

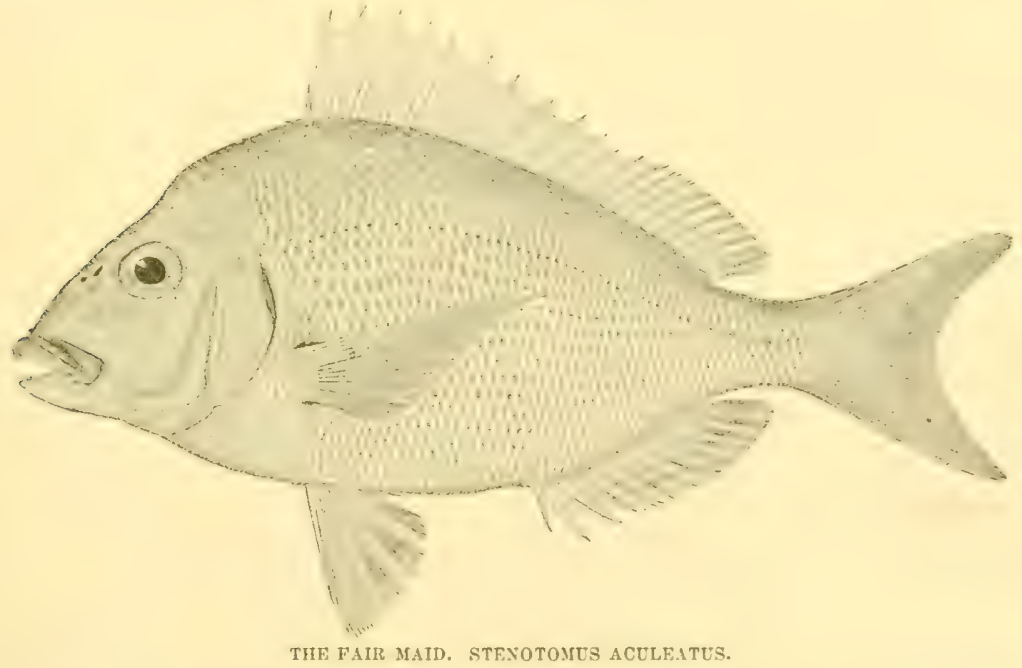

On the Virginia coast the Southern Scup is known as the "Fair Maid." The name "Porgy" is in use about Charleston, S. C., but is not distinctive, being applied to sevcral allicd forms. Their range is much more limited to the south and extends farther to the north than that of the Sheepshead. Holbrook wrote in I860: "The Porgy is found along our consts at all seasons of the year, though most abundant in June and July." He further states that its southern limit on the Atlantic border is Cape Florida, a statement probably not susceptible of proof. 
The Northern Scup rarely passes the boundary of Cape Cod; in 1878 , however, thirty-seven were taken at the Milk Island weir off Thatcher's Island, Cape Ann, Mass, and they appear to be increasing in abundance.

This species does not appear to be indigenous north of Cape Cod. Storer states that in the year $\mathrm{I}_{3} \mathrm{I}_{\mathrm{I}}$ or $\mathrm{I}_{3} 3_{2}$ a smack-load of Scuppaugs arrived in Boston. A portion of them were purchased by subscription among the fishermen in the market and thrown into the harbor, and that in 1834 or 1835 Capt. Downes carried a smack-load from Vineyard Sound and threw them overboard in Plymouth Harbor. From i 860 to 1867 small numbers appeared north of Cape Cod, and were yearly captured at Wellfleet and Sandwich.

Judging from the rare occurrence of the species thus introduced, it can hardly be considered to have become naturalized; the few which have been taken were doubtless summer stragglers, although in $8_{7} 8$ over one hundred were taken at Capt. Webb's weir on Milk Island.

The life history of the Scuppaug has been thoroughly worked out by Prof. Baird, and from his paper published in the first volume of the report of the U. S. Fish Commission, the following life-history is compiled:

"It makes its appearance, at least in considerable quantity, on the coast of New England about the middle of May, although the advanceguard of very large fish arrive sometimes as early as the middle of April ; and it is most abundant toward the Ist of June, and arrives in successive detachments or 'runs' differing in size, the smallest fish coming last. The first run on the southern coast of New England, as stated, takes place about the beginning of May, and consists of large breeding fish, weighing from two to four pounds, and measuring up to eighteen inches or more in length. The spawn is quite well developed at that time, and is said to be at first red, but gradually to become light yellow as it matures. The particular time and place, however, of laying the eggs is not yet known, although it is probable that this occurs early in June, since the schools are said to break up about the middle of that month, and the fish to scatter. It is thought probable that the spawning takes place in the eel-grass which covers the shoal water of Narragansett Bay and Vineyard Sound.

"According to the fishermen generally, the Scup on first coming into the shores do not take the hook readily, being apparently too much occupied in the business of reproduction, and two weeks usually elapse before they can be caught in this way. They present themselves in large schools of immense extent, and moving very slowly, at about the rate of three miles an hour. From the testimony presented before the committe of investigation of the Rhode Island legislature, they appear to come from the south and west, as when they enter Narragansett Bay they strike the 
western shore and move up along its edge. 'They are said, however, to drift slowly backward and forward with the tide, especially at the entrance of this bay. At this time they are very sluggish, and are said sometimes to appear as if blind, and can frequently be taken with the hand, or a very short scoop-net.

"According to Capt. Edwards, of Wood's Holl, in proceeding to their breeding-grounds, on the coast of New England, they are taken at Montauk Point three weeks earlier than at Wood's Holl, and a week earlier at ITood's Holl than at Hyannis, still farther east.

"The Scup feed upon a great varicty of marine animals, such as worms, small crustaceans, mollusks, \&c., and take the hook very freely during the greater part of their stay; in fact, the smaller ones become veritable nuisances to the fishermen, from the readiness with which they pounce upon the baited hook whenever thrown overboard.

"The flesh of the Scup is very much prized by most persons, as it is firm and flaky, and usually sweet, although occasionally a bitter flavor detracts from its palatalifity. Since the settlement of the coast lis the whites, it has been by far the most important food-fish of Fisher's Island and Vineyard Sound, Narragansett Bay and of Buzzard's Bay; and the rapid diminution in number has caused the greatcst solicitude.

"Of their abundance on the south coast of New England in former times, almost incredible accounts are given. They swarmed to such a degree that their capture ceased to be a matter of sport. The line when thrown overboard could be immediately withdrawn with the assurance of having a fish on each one of two hooks. Any number of fishermen from boats could take five hundred to one thousand pounds a day without the slightest difficulty, the limits of the catch being simply the ability to find a sale.

"In flavor the flesh of this fish is surpassed by very few others on the coast, although its superabundance caused it to be undervalued. The period of greatest development in number of this fish coincided with that of the absence of the bluefish, and since the return of the latter to the coast of New England the Scup has become scarce, although still a very important object of pursuit.

"The Scup is a fish that grows with rapidity, and at two years is almost of sufficient size to be marketable. Throughout the summer young fish of the spring spawning are to be seen floating around in the eel-grass and over the sandy bottoms, having attained a length of from two and a half to three and a quarter inches by the ist of October. When these fish reappear the next season, thus completing one year of existence, they measure about six inches, six to eight or nine weighing a pound; and by the ist of September attain an average length of eight inches, including the tail, and a breadth of three inches. In the third year of existence, or at the age of two years, they have increased considerably, though not so rapidly as was once supposed, measuring, on their reappearance, about 
ten inches, with an average weight of one-half pound. After this they grow more quickly. One hundred and ninety-nine, presumed to be three years' fish, weighed on the 6 th of September, averaged one and a half pounds each, and measured about twelve inches in length by four and a half inches in width, some individuals being larger and some smaller. The female fish of the second year not unfrequently contains mature eggs. It is in the fifth year, or after the lapse of four years from birth, that the Scup presents its finest development; specimens believed to be of this age measured fourteen or fifteen inches by five to six inches or more, with a weight of two-and-a-half to three pounds. They, however, still continue to grow, specimens being not unfrequently met with eighteen inches long, and weighing four pounds and even more. The dimensions may belong to fish of six or more years of age; more probably, however, of five years.

"As a general rule, in their movement along the coast the Scup are not found in water shallower than a few fathoms; and it sometimes happens, in the course of heavy storms, that in consequence of the discoloration of the water near the shore the fish move farther out to sea, and on such occasions measurably escape falling into the traps.

"The Scup is very largely a bottom feeder, and depends very much upon mollusks or shell-fish for subsistence. I have been informed by the fishermen that they may frequently be seen feeding upon small bivalves of different species, rooting them ont of the sand or mud. The stomachs of about two hundred one and one-half pound Scup were examined at one time in the beginning of September. These almost exclusively contained shells of various genera, with some worms and a few amphipods. Its especial food appears to be small shells, crabs, shrimps and possibly small fish. The abundance of such food on the south coast of New England must be prodigious to support the swarms that even now are found there. It is in regard to this species that a close time appears desirable, so that access to the spawning-grounds and freedom from disturbance may be enjoyed by a sufficient number to maintain the species.

"Like all other small fish, they are devoured by their more rapacious fellows, and very largely by bluefish, notwithstanding a general impression to the contrary. The extent to which this takes place will be considered under the head of the bluefish. Halibut, cod, sharks and other ground-feeders likewise use them up in great numbers.

"As already remarked, the breeding fish do not appear to feed on their first arrival, being then too much occupied in carrying out the reproductive function. As, however, they can be taken with the hook about the Ist of June, we may infer that this is about the time they begin to feed for themselves. The younger fish probably feed as soon as they reach the shores. No remains of fish have hitherto been found in the stomachs of Scups, and we may conclude that they are not piscivorous.

"The Scup remain along the northern coast until about the middle of October, when the larger ones, at least, begin to leave the shores and 
more out into deeper water. Mr. Vinal Edwards has, however, taken younger fish at Wood's Holl as late as the roth of December, and Capt. John Rogers, of Noank, states that, in fishing for cod on Nantucket Shoals late in November, their stomachs are occasionally filled with small Scup, which drops out of their mouths when hauled on deck, found to be to the extent of five or six at a time. It is quite possible that they, as well as other fish, seek in winter that portion of the Gulf Stream that corresponds in temperature to that of their summer abode; and as the mean summer temperature of the waters of Southern Massachusetts and Rhode Island amounts to about $63^{\circ} \mathrm{F}$, they must go nearly to the latitude of Norfolk, Va., before they can find that same temperature in the winter season."

This species has a certain interest derived from its connection with an early and important incident in the history of the market fisheries, for we are told that the smack "Amherst," launched July 23, I $7 \sigma_{3}$, was the first fishing boat provided with a well for the transportation of living fish; and that she was intended for the "porgy" fishery. In the New York Gazette of January 30,1764 , were printed some lines beginning thus:

"Since on our banks the porgys found

A smack they've built to try the ground." etc., etc.,

The "porgy" soon became too common for profit or pleasure, and the fishing was abandoned. *

Immense numbers of Scup are caught in the pounds and traps in Rhode Island and Massachusetts, and for several weeks in each year the market is usually glutted, a barrelful being frequently sold for twenty-five to fifty cents, or a small fraction of a cent a pound. It is extremely doubtful whether any part of the more northern coast of North America can furnish, within three miles of the shore, as large a weight of fish in mackerel, herring and cod as has been furnished by the Scup, sea-bass and tautog alone in the waters of Rhode Island and Massachusetts. Mr. William Davol, of Rhode Island, with his " gang," caught 2, 400 barrels of Scup, valued at \$I,200, at Secomnet, in May, IS60. Fish were purchased by Messrs. Reynolds, Young \& Co., of Fall River, and shipped to Philadelphia.

In the summer of 1880 over 2,500,000 pounds were sold in New York city alone, and the product of the New England fishery amounted to at least double the quantity. As many as ro, oo barrels have been taken at once in a single pound in Narragansett Bay. The Scup is not especially 
in favor as a food-fish, although when very fresh it is entitled to a middle rank. Large ones should be broiled with rich sauce, small ones treated as pan-fish. The flesh is somewhat dry, and without distinctive flavor.

I was greatly surprised to find this species exposed for sale in the markets of Paris and Rouen in $I S S_{3}$, and meeting with a ready sale. A large quantity had been sent in ice from New York to France.

The European analogue of our American Scup or Porgy is the Sparus auratus, the Braize or Becker, sometimes Bream, of the fishermen. This fish frequents the European coast in summer, and is said to have much the same habits as our American species. They are eaten only by the poorer classes.



The Sailor's Choice, Lagodon rhomboides, is found in very great abundance from Cape Hatteras south, and around the Gulf coast; also occasionally north of Cape Hatteras; it is known in the lower part of the Chesapeake Bay, and two or three stragglers have recently been taken at Wood's Holl, Massachusetts. It is not uncommon in the Bermudas. It may readily be recognized by the longitudinal stripes of iridescent color upon the sides, and by the peculiar character of the teeth, each having a prominent notch on either edge.

The "Sailor's Choice," as it is called in the St. John's River, at 
Brmswick, Ga., and about Key West, hears several other names, being known about Cape Hatteras as the "Robin " and "Pin-fish," at Charleston as the "Salt-water Bream," at Brunswick, Ga., as the "Squirrelfish" and "Sailor's Choice," in the St. John's River as the "Sailor's Choice" and "Porgy," in the Indian River region as the "Sailor's Choice," "Scup," and "Yellow-tail," at Cedar Keys as the "Porgy " and "Shiner," and at Pensacola as the "Chopa Spina."

South of Cape Hatteras this fish is exceedingly abundant, and is usually found in company with the sheepshead, which it much resembles in habits. Its jaws, however, are not so strong as those of the sheepshead, by reason of which it is debarred from feeding upon the stronger shelled mollusks and crustaceans, which constitute the principal diet of the latter.

On the Atlantic coast the largest individuals rarely exceed ten inches in length, the ordinary size in Eastern Florida being six or eight inches, with the weight of five or six ounces.

The Sailor's Choice is one of the most deliciously flavored fishes of our coast, being preferred to the young sheepshead by many of those who are familiar with its good qualities. Lugger states that it enters the clrains of the ocean coast of Maryland, and is occasionally caught in the lower part of the Chesapeake Bay. According to Jordan they are excessively abundant everywhere in the harbor of Beaufort, N. C., where they are taken by the thousand by boys with hook and line from the wharves, but are seldom used for food, and are found equally numerous through the Gulf States coast.

At Charleston, according to Holbrook, this fish is taken at all seasons of the year, though most plentiful in May and June. No reference is made by this author to its value as an article of food. At Brunswick, Ga., the Sailor's Choice is highly esteemed; in the St. John's it is very abundant, and is taken in company with the sheepshead far up the river. It is easily captured with hooks baited with shrimp, and is considered to be a very superior pan-fish, its flesh resembling that of the scuppaug, though much sweeter and harder.

In the Indian River region, according to Mr. S. C. Clarke, this fish is resident all the year, and is very abundant. 'The weight of the largest observed by him was one pound. The average weight is about five ounces. They are found in the deep water, or salt water, feeding upon minnows, small crabs, and shrimps. The spawn is pale blue, and of the size of 
mustard sced. Young fish are seen in great abundance. They are taken by hook with mullet or clam bait, and also in cast-nets and seines. One hundred are often taken by a fisherman in a day. They are highly prized for food, and are occasionally salted. They are sometimes sent in ice to Savannah and Charleston. "On the Gulf coast," writes Mr. Stearns, "they are very abundant, living and breeding in the bays and bayous. They spawn in winter or early spring, and the young of different sizes may be seen in May and June. The adult fish live in deep water, while the young remain near shore. Many are caught by hook and line, and with the seine."

A fish known as the "Sheepshead Porgy" is said by Stearns to be common in the Gulf of Mexico and about the Florida Reefs. It is caught with hook and line, and is sold in the markets of Key West. There are other species, known by the name "Porgy," which are found in this region, such as Calamus bajonado, common also at Charleston, where it is called the "White-boned Porgy," the "Jolt-head Porgy," of Key West, C. megacephalus, C. arctifrons, the "Shad Porgy" of "Grass Porgy" of Key West, and C. macrops.

California has two important species belonging to this family, concerning which Professor Jordan has communicated the following information:

The Blue-fish, Girella nigricans, inappropriately so called, reaches a length of about fourteen inches, and a weight of three or four pounds. It ranges from Monterey southward, and is very abundant about the Santa Barbara Islands. The young of this species are common inhabitants of the rock-pools. The Bluefish is entirely herbivorous. It is a food-fish of good quality, but the flesh softens sooner after death than is usually the case with related fishes. It is very tenacious of life.

The Half-moon, Scorpis californicnsis, more commonly known by its Spanish name, Medialuna, reaches a length of more than a foot, and a weight of three or four pounds. It ranges from Point Conception southward, chiefly about the Santa Barbara Islands, where it is exceedingly abundant, and, in the winter, forms the greater part of the catch at San Pedro. It feeds chiefly upon crustaceans, but is, to some extent, herbivorous. It takes the hook readily, is an excellent food-fish, and, in the Los Angeles. market, is second only to the barracuda in importance. 


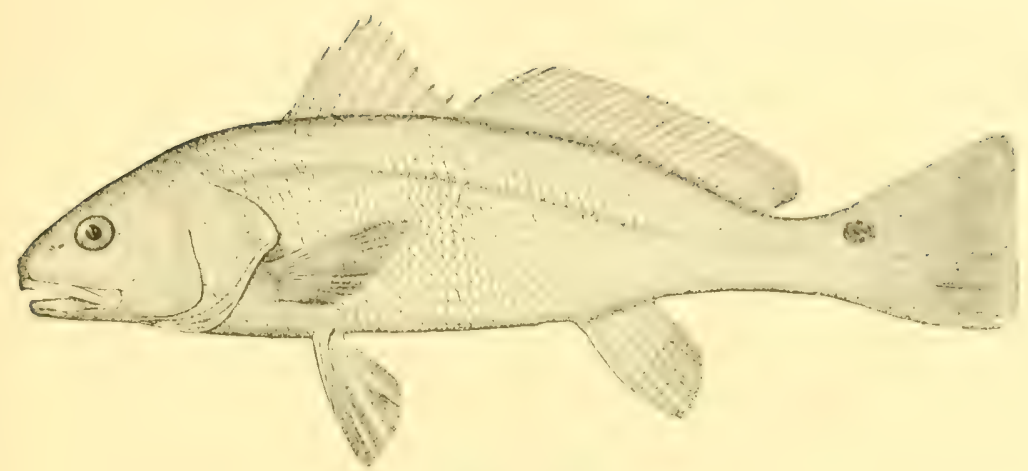

THF, RED DRUM.

\section{THE RED DRUM.}

Long as a salmon, if not so stout,

And springy and swift as a mountain trout,

INNES RANDOLPI, The Drum-fish.

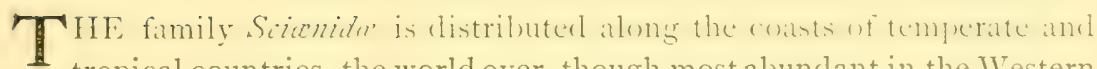
tropical countries, the world over, though most abundant in the Western Atlantic, the Eastern Pacific and Indian Oceans, and in the Nediterranean Sea. In general form many of the members of this family are not unlike the salmon, and are sometimes mistaken for it. They are, however, true spiny-rayed fish, and they may be distinguished from all others by the presence of the comparatively short, spiny, dorsal fin, and a very long, soft-rayed fin upon the posterior portion of the back.

Many of them are ground-loving species, are provided with barbels by which they feel their way over the bottom, and with strong, parementlike teeth for crushing shell-fish and strong shelled crustaceans. To this group belong the fresh-water Drum, the King-fish, and others.

Another group, typified by the Squeteagues, are without the barbels and possess long, sharp teeth, being rapid swimmers, and roracious surface feeders.

Many of the species are most abundant about the mouths of rivers, and there are several species, such as the fresh-water Drum, Haploidonotus smmmiens, of the Mississippi Valiey, which are found only in fresh water. Nearly all have the power of uttering loud sounds. 'This, as has been demonstrated by M. Dufossé, is accomplished through a peculiar structure of the air-bladder. 
Scaena ocellata is greatly in need of a good English name. Other forms more widely distributed or better known seem to have substantial claims of priority upon all its appellations. In the Chesapeake and south to below Cape Hatteras it is known as the "Drum;" but, Pogonias chromis, is called by the same name from Provincetown to Texas, and is the possessor of a much more musical organ. Some of the old writers coined names for it like "Beardless Drum", and "Branded Drum," referring to the brand-like spots upon the tail; but these are of no value for common use. In the Carolinas, Florida and the Gulf we meet with the names "Bass," and its variations, "Red Bass," "Sea Bass," "Reef Bass," "Spotted Bass" and "Channel Bass." Many persons suppose "Channel Bass" to be a characteristic name, but this is a mistake, for the term is applied properly only to large individuals which are taken alone or in pairs in the channels of streams and sounds; wherever this name is used, the smaller fish of the species are called simply "Bass" or "School Bass ;" even if the word "bass" could be so qualified as to be applicable to the species, there is an insuperable objection to its use for any fish of this family.

"Spot" sometimes corrupted to "Spud" is another name erroneously applied to this fish, and which is the property of a much smaller species of the same family, otherwise known as "Lafayette" or "Cape May Goody."

Finally, we have the "Red Fish" and "Red Horse" of Florida and the Gulf States, the "Poisson Rouge" of the Louisiana Creoles, and "Pez Colorado" of the Mexicans. This is perhaps best for general use, if modified to "Southern Red-fish or "Red Drum." The chief objection is that the fish is not always red; in the young there is not a suggestion of this color, while in the adult it is more a tint, an evanescent, metallic reflection of claret from the scales, which is often absent, and at all events soon disappears after life is gone. The number of spots on the tail is variable; usually there is one or two, but sometimes as many as eight or ten, and their arrangement is a matter of chance, while occasionally they are absent. A facetious friend suggests that "Bass Drum" would not be inappropriate, because of all the drum family it is "hardest to beat."

The Southern Red-fish is among the important species upon the coast of the United States from the Chesapeake to the Mexican boundary. 
Abundant as it is in the Carolinas, in Florida and in the Gulf of Mexico, the limits of its range appear to be very sharply defined, there being little tendency on the part of individuals to stray away from their wonted pastures. Although the species has long been commonly found in the Chesapeake, I am unable to find any record of its capture north of Cape Charles previous to 3880 , though since that date the species has been rather abundant along the coast of New Jersey. Mitchill and DeKay refer to it in their books on fishes of New York, but their descriptions were based upon market specimens, probably brought from more southern localities, and Prof. Baird obtained none in his exploration of the New Jersey coast in I 854 , nor can it be found in Webster's collections from the Atlantic side of the Virginia Peninsula. Its range to the south seems to terminate with equal abruptness. Stearns states that from Tampa Bay and northward to the Mississippi River it is one of the most common edible fishes, while west of the Mississippi River it is more abundant than any other sea-fish, evidently increasing in numbers as the Texas coast is approximated. On the Texas coast it is more abundant than all other food-fishes together. IVest of the mouth of the Rio Grande the species has not been recorded, chiefly, no doubt, for the reason that no explorations have been made along the shores of Mexico. The fish fauna of the Caribbean coast of Panama has, however, been carefully studied, and the species not found. It seems probable that its southern range is limited by the peninsula of Yucatan. It is a noteworthy fact that it does not wander more; for every other species, I think, without exception, which is abundant north of Cape Hatteras, is occasionally met with in Buzzard's and Narragansett Bays.

Its movements and breeding habits are not well understood. "In the spring," Stearns writes, "they are seen in large numbers in the Gulf, swimming in shoal water near the coast. This is usually in March and April, though the weather and the temperature of the water seem to influence the time of their arrival. Arriving at the entrance of a bay, their migratory movement ceases, and for days and weeks they may be seen in shoal water near the inlet swimming lazily about in search of food, or lying quite still in deep holes between shoals, where there is comparatively little current and few enemies can reach them. Some seasons immense numbers of Red-fish gather about the inlets before any are noticed inside or coming in, while in other seasons there is but slight accumulation, the 
schools working in as fast as they arrive. By the Ist of June the 'run' is over, and the fish are believed to have all come in. When once inside, the schools break up into small squads, which proceed to the weedy bottoms of the bayous and to the heads of the bays. About the river mouths, where the water is brackish, and even in fresh water, they are found through the summer. While at sea their color is light, and they are so thin in flesh that they are far from desirable as food. In the bays they become very fat and their colors are much darker. In September spawn is found in them in a half developed state. In October and November they again form in schools and are observed moving out of the inlets to the sea. They do not leave the coast immediately, but follow the beach for some days. At this time they contain spawn which I should think to be three-fourths developed. Many reliable fishermen here have observed that the Red Fish go to sea with spawn in them."

S. C. Clarke has observed their habits in the Indian River region, and says: "They enter the rivers and creeks from the sea. The young fish are here all the time. The adults leave the shore in a body when done spawning. They are first seen off the coast in January and February, and remain in the rivers until late in the spring. The males and females swim together, frequenting localities on shoals and sand-banks, where the water is from one to four feet deep and warm. After spawning they scatter. They begin to breed in August and September in the shallow bays and inlets, at which time both sexes are poor and unfit for food. The spawn is small, brown, about as large as No. 5 shot, and floats. 'The young are found abundantly in the creeks and bays.

I have been told by fishermen on the St. John's that in November, when schooling begins, the fish are full-roed, but that in December the eggs have all been spent.

I have never found the young in the north less than ten inches long, but, in Pensacola Bay, Jordan and Stearns secured numerous young in the seine in April, the smallest measuring two and a half inches. Jordan supposes that they spawn in water of no great depth. They swim in scattered schools at times, probably in the spawning season, and they may occasionally spring above the surface while feeding. At this time the fish are taken in large gill-nets, which are set around them by the fishermen. The food consists chiefly of the crustaceans and small fish with which Southern waters are filled. It undoubtedly gathers much food from the 
bottom, although it connot be so much of a grubber as many other members of the same family, better provided for this kind of foraging by the tactile organs under the chin, and a set of grinding teeth with which to liberate the shells of muscles and barnacles. An accurate observer describes them as swimming along close to the bottom, with head down and body obliquely upward, wriggling through the water, rooting up the weeds and grass, among which are found quantities of shrimps and crabs. One observer found ten or twelve eels of a foot in length in the stomach of a Redfish. 'Their enemies are sharks, porpoises and saw-fish.

'The Redfish attains a weight of forty pounds, and a length of four or five feet. In the markets of New York and Washington small ones are often seen. The average size of those exposed for sale is perhaps ten pounds.

The chief demand in the South is for local consumption, though a few thousand pounds are sent every year to New York and other cities of the North.

S. C. Clarke, in his "Game Fishes of Florida," expresses this opinion: "Take it all in all, it is the favorite game-fish of the South-a hard, honest fighter, which makes long runs in open water, seldom skulking or hiding in holes, and never giving up the battle until fairly beaten."

In discussing this species as a game-fish, I cannot do better than refer to the experiences of $\mathrm{H}$. S. Williams in the Indian River region:

"I have seen them," writes Mr Williams, "swimming in shallow water by the hundreds, sometimes ten and twenty, moving with almost the regularity of solid columns of infantry; all apparently of the same size. The Red Fish are in season at all times, but best from the ist of April until January $I$. In size they run up to forty, and even fifty, pounds. They readily take mullet bait, and when securely hooked furnish fine sport. for the kerl Fish is cmphatically a game fish. I shall norer forter mis first experience in this line, a day or two before the full of the moon in November. I concluded to try a new hook just sent me by a distant friend. Just at dusk I went down to the river, and balting my hook with

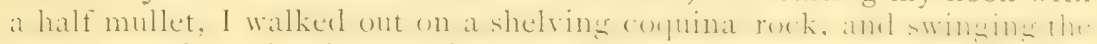
houk around my hearl a fell times sent it out into the risce to she full length of the line; then filling and lighting my pipe I took a seat and quietly awaited results. The moon, nearly full, was half an hour or more high, not a cloud obscuring its brightness, and it made a highway of silver

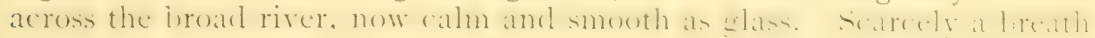
of air stirred the leaves of the huge live-oaks above my head, and everything was so still that I could distinctly hear the fish in shallow water a 
mile away as the small-fry dashed and jumped in their frantic endeavors to escape from the ravenous jaws of their pursurers; in fact, everything was so still that I remember to have heard the sound of a cow-bell, two miles away, as its low, mellow tones were borne over the broad expanse of water. I had occasionally taken a whiff or two at my pipe and watched the fleecy clouds of smoke float slowly upward and dissolve into space, before something sent an electric message to my finger from the other end of the line. It was a faint message, scarcely felt, but distinct enough to tell me what was there. A moment's pause and then it was repeated; this time it was emphatic, for the fish picked up the bait in its mouth as daintily as a neatly-gloved lady would pick up an orange, and then let it fall again. Aha! my boy. You are an old hand at the business, and know by past experience that sometimes even the most tempting morsels are dangerous. A moment more it is picked up again, and yet again, and it is carried a couple of yarels or so before it is dropped; and then back again; then further off. Our fish is playing with the bait as a coquette with hearts. The very moment a novice would think that he was going to take it, 'tis dropped and he is gone again. No, not gone, only swimming around in circles, keeping one eye on the prize and keeping away all such intruders as sharks and cat-fish.

"Now for it. The bait is picked up, seized with a vim, as though he meant business, and away he starts with it. Here the inexperienced would jerk the line and perhaps lose the fish, or at least have the whole formula to go over again. But wait; the successful sportsman must practice patience. Again the bait is dropped, but not for long. In a moment it is seized, and this time there is not feint about it. He darts off, the line is drawn tight, then a sudden jerk and a wild plunge tell that the game is safely hooked. And now commences the struggle for life. Away he goes up the stream for fifty yards or more, straining every nerve to get free; then down, then back again, while the line is pulled just hard enough to draw him in a little nearer the shore; then up and down, each time a still shorter distance. At each effort I feel his powers give way, and then as he makes a turn we pull his head toward the shore and keep it there. Now is the critical period; now, if at all, the line will part or the hook break. I haul the line in rapidly, hand over hand, keeping it taut, for the least slack or a failure to grasp the line firmly would perhaps lose the game. Swerving to and fro, I chraw him rapidly in, and with such force does he come that far up the shelving rocks we land our prize, a thirty pound Bass, a magnificent fellow, his scales glistening like burnished silver in the moonlight."

At Mayport, Fla., in summer, "heaving and hauling in the surf" is practiced for the capture of this fish, just as it is for bluefish and striped bass in New England. Chumming in the Cuttyhunk and Newport style would doubtless be very effective. 
Dr. C. J. Kenworthy, in the American Angler, gives an excellent (lescription of the methods of fishing in Florida.

"This fish resembles in its habits its congener the striped bass of Northern waters. It is an excellent biter, and makes a noble fight for liberty. As a table fish, up to say ten pounds, it is an excellent one, but large specimens are rather coarse. The back of the fish is of a beautiful bronzed hue, shading off to a silvery lustre on the sides and belly. It has usually one or more black spots at the junction of the tail with the body, but these sometimes extend upwards for one third of the length of the fish. In a specimen I recently captured the spots numbered seventeen on one side and twenty-three on the other. It is a salt water fish, but is occasionally captured in fresh water; at times a long distance from the ocean, as in Crescent Lake and Lake George. In its habits it appears to differ in different localities. In the St. John's River it frequents the deeper portion of the stream, with rock, shell or hard sandy bottom, but on the southwest coast it is generally captured in shoal water, on sand bars, edges of grassy flats and near points at inlets. In the northeasterly portion of the State the large fish put in an appearance in June and July, but the main run enter the St. John's River in August and September, leaving for the sea in November. They visit the bays, estuaries, and rivers of the southwest coast in the fall and winter, and, from the best information I can obtain, school in June, and probably retire to the ocean.

In the Halifax River, and the tributaries of the Indian River and on the southwest coast, they greedily take a spinner or fly, but in the St. John's River these baits have proven a failure. In Lake George and Crescent Lake large fish have been captured with a spinner. At the mouth of the St. John's River small specimens take shrimp, and the large fish, cut mullet bait, or the half of a hard-back crab. At the mouth of the river large fish prefer mullet to crab. But what is somewhat remarkable, in the autumn after a severe northeast gale they ascend the river to Jacksonville, twentyfive miles from its mouth, and will not look at cut mullet bait, and fishermen are forced to tempt them with hard-back crabs.

These fish vary in size in different streams. In the St. John's River near its mouth, the summer and autumn run of fish range froin eighteen to sixty pounds. The smallest specimen thus far captured by the writer weighed nineteen pounds. The usual average will be found to be about thirty-five pounds. My friend Mr. B., who is familiar with the fishing on the Halifax River, informed me that the largest specimen that he heard of being captured in that stream weighed thirty-five pounds; and from the best information we have been able to secure, they seldom exceed this weight on the Indian River. We have captured many Bass on the southwest coast, but none to exceed thirty pounds in weight. Some years since one was caught on the Homosassa River with spinner and hand line weighing thirty-four pounds. Several years since a visitor at Homosassa 
offered a prize of a camping axe for the largest fish captured during the season. In the company of Charles Hallock I visited the locality, and having a day to spare I entered the lists. Provided with a mullet for bait, I visited Ship Rock, and with rod and reel soon brought to gaff a Channel Bass weighing twenty-four and one-half pounds. This proved to be the largest fish of the season, and a few months later I received by express a nicely finished camping axe with silver plate and appropriate inscription. At one occasion at Homosassa I trolled with rod, reel and spinner, and landed fourteen Bass ranging from nine to nineteen pounds. From my own experience and such data as I have been able to collect, Channel Bass visiting the St. John's River excel in size those of other streams of the State.

During the summer months at the mouth of the St. John's River, fishermen wade in the surf, use a stout hand line, a heavy sinker, and mullet for bait, throw their lines beyond the breakers and capture great numbers of Bass ranging from thirty to sixty pounds. I have not heard of any one using the rod and reel in surf fishing, but am satisfied that if tested it would afford exciting sport. During the latter part of August, September and October superior Bass fishing can be secured at the shells opposite the old lighthouse at Mill Point and Shell Bank. Owing to the rapidity of the current, and the size of the fish, stout cable line or braided cotton lines with large hooks are used. At slack water, or if the anchor is raised when a large fish is hooked, a stiff bass rod, with a large reel and Cuttyhunk line will be found sufficient to bring these noble fish to gaff. Midway between Jacksonville and the mouth of the river is a deep back channel where there is but little tide, where large Bass congregate, and where a rod and reel can be successfully used. At almost any time during August, September or October the fishermen may capture during a day's fishing from three to fifteen of these fish, and at times their numbers seem to be endless."

From the same excellent journal I quote the opinions of a New Jersey drum-fisherman :

"I fish for the Red Drum here from askiff anchored at sea in four fathoms of water, a mile and a-half from the beach, and use the plaited cotton cod line and the Virginia drum hook, letter " A," No. 4. Use menhaden bait; anchor the skiff and chum as for striped bass. I believe a hook suspended so as to hang a foot above the sinker is most successful, though I take them also from the bottom. They are indiscriminate feeders, smashing clams and catching menhaden with equal avidity, but I think the oil of the menhaden attracts them from a distance, and the latter is therefore the best bait. I have taken them upon all sorts of cut bait-Lafayettes, weak-fish, etc.

Brigantine Beach just now is level as a table, the surf breaking on it for several hundred yards. This is its normal condition, and it cannot now 
be fished with comfort or success, as you cannot reach the fish with your line after the tide begins to rise.

Oftentimes the current cuts out a deep "slough," or sluice, within reach of high water mark. In this the fish are apt to congregate. It forms a space of smooth water between the outer and inner breakers, through which the current flows, carrying in clams, crabs and sand-flies, and in which the fish can lie and feed quietly. In these I take the black drum, and in the autumn of I880 I took three Red Drum in one day on Brigantine while fishing for the other species.

In the surf the Drum nudges like the sheepshead when he first takes the bait; in the deep water he bites like a shark of the large species slowly and heavily, but can be distinguished from the shark when he is hooked by his habit of shaking his head in the effort to throw the hook out."

The European representative of our Sciana is the Scicna aquila, called "Maigre" by the French on account of the whiteness and bloodlessness of its flesh. This fish has been found from Sweden to the Cape of Good Hope and Australia, but is most abundant in the Nediterranean, and is comparatively rare in northern Europe. The Dutch fishermen believe that they can discern the image of the Virgin in each scale. It is said that in Languedoc it is called the "Royal Fish" (Peis-re) a name which calls to mind the American "King-fish," applied to a closely related form. The ear-stones or otoliths, which are very similar to those of our species, were formerly considered a sovereign remedy for colic, and in the middle ages were set in amulets, to serve as prophylactics.

The Maigre, the "Sciæna" of the classical opsophagists, the "Onitra" of Venice, the "Fegars" of Genoa, the "Figou" of Nice, is still highly esteemed, as it was in the days of Ancient Rome and Greece, by the inhabitants of southern Europe. The head and shoulders are prized for broiling, as in centuries long gone by when this part of the fish was a farorite tribute from the Roman fishermen to the civic magistrates. 


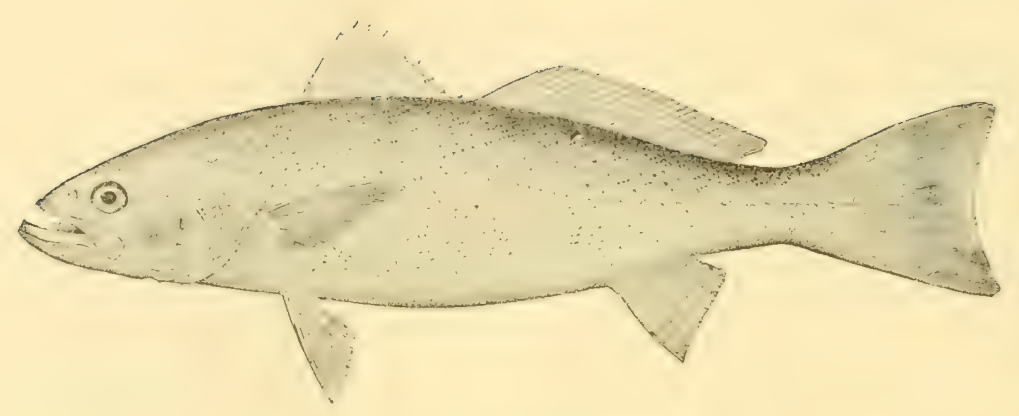

THE TEAK FISI OR SQUETEAGUE.

\section{THE SQUETEAGUES.}

Weekvis, en Schol, en Carper, Bot, en Snoek, Ja gy en hebt geen poel, geen water-hoek, Of't krielter vol von Visschen; die (te soek)

Ticht zinj te vinden.

Jacos Steendam, 't Louf wan Niew Nederland, $166 \mathrm{x}$

You've weak-fish, carp and turbot, pike and plaice;

There's not a pool, or tiny water-trace

Whereswam not myriads of the finny race Easily taker.

Praise of New Netherland, translated by HoN. H. C. MIUрннs.

THE genus Cynoscion, is represented on our Atlantic coast by three Il species. Cynoscion regale, the Weakfish, or Squeteague, is found: from Cape Ann to the mouth of the St. John's River, Fla., and possibly to the Gulf of Mexico. Cynoscion carolinense, the Spotted Squeteague, or Southern Sea Trout, ranges from the Chesapeake to the Gulf of Mexico and Lake Pontchartrain. The Silvery Squeteague, Cynoscion nothum, is a fish of somewhat unusual occurrence, observed at Charleston and in East and West Florida. There was still another, described by Holbrook under the name Cynoscion thalassinum, which has not been seen by other naturalists, and which is probably not a valid species.

Like all of our important fishes, which have no European representative, the Squeteague are known by a great variety of names. About Cape Cod they are called "Drummers;" about Buzzard's Bay and in the vicinity 
the largest are known as "Yellow fins;" in New York and in New Jersey, "Weak-fish;" from Southern New Jersey to Virginia, "Bluefish." The name "Squeteague" is of Indian origin, and "Squit," "Succoteague," "Squitee" and "Chickwit" are doubtless variations of this name in different ancient and modern dialects. In the Southern Atlantic States it is called "Grey Trout," "Sun Trout" and "Shad Trout," and with the other members of the genus is spoken of under the name "Sea Trout" and "Salt-water Trout," though, of course, distinct from the "trout" of the fresh waters of the South, which is a Black Bass. The name "Squeteague," since it is the aboriginal Indian term, seems most characteristic, and is well worthy of being permanently retained.

"Weakfish" appears to be a legacy from the Dutch colonists of Manhattan, as may be inferred from the use of the word in the poem quoted at the head of this essay. It means a soft fish, but whether, like Miossbunker, this name was transferred from some species known to them in Holland, I have not been able to learn. Some old authorities use the name "Wheatfish," and Brown in the "Angler's Guide," accounts for this by the theory that in former days the fish made its appearance in harvest time. It is, in all likelihood, however, a corruption of the Dutch name. This etymology resembles those suggested for "Weakfish," "because he does not pull very much after he is hooked," or, as others allege, "because the laboring men who are fed upon him are weak by reason of the deficient nourishment in that kind of food."

The Squeteague is found on the Atlantic coast from Cape Cod to Eastern Florida, where I observed it, sparingly, in 1878 . Its extreme southern distribution has not yet been indicated. Some writers have claimed that it occurs at New Orleans, but Mr. Stearns did not succeed in finding it in the Gulf, and Prof. Jordan writes that it is certainly not found in the Gulf of Mexico, unless as a stray.

The Squeteague is abundant throughout the above range, except in the regions where its productiveness is interfered with by the bluefish. In Massachusetts Bay, according to Dr. Storer, it is very rare, but scattering individuals have been found as far north as the Bay of Fundy. The early annals of New England make frequent mention of this fish and of its variations in number with that of the bluefish. Thus, according to Dr. Storer, it was very abundant in the Vineyard Sound in the early part of the present century, but gradually became more scarce, until about 
1870 , when it was no longer to be met with, and for several years it was entirely unknown in these waters: so much so, indeed, that fishermen of many years' experience were totally unacquainted with its characteristics. In 1867 or I 868 , however, scattering individuals were taken on the south coast of Massachusetts, and in I 870 they were quite abundant and have since held their own. But they are nowhere at any season so abundant as in summer along the stretch of shore from Norfolk to Nantucket. "They arrive with the bluefish in late May and early June, are most abundant in August, and depart in advance of the bluefish at the very beginning of autumn. They swim in large schools at the surface, pursuing the menhaden and scup, on which they savagely feed. I have frequently seen a thousand or more taken in one night in one of the weirs on Martha's Vineyard Sound.

The most remarkable draft on record is that referred to in July, I $88_{\mathbf{I}}$, by Mr. Barnet Phillips in the New York Times:

"A great catch of Weakfish was made yesterday about two miles off Rockaway Beach, by the steam smacks "E. T. DeBlois," Capt. J. A. Keene; "Leonard Brightman," Capt. Elijah Powers, and "J. IV. Hawkins," Capt. J. IV. Hawkins. These smacks are engaged in the menhaden or " mossbunker" fishery for the oil-rendering and fish-scrap works on Barren Island, and were cruising off Rockaway. yesterday in search of schools. About noon a vast school of what the fishermen supposed at first to be menhaden was discovered stretching along the coast for miles. To borrow their language, 'The water was red with the fish, but they didn't break the surface as menhaden always do.' The boats were lowered, the seines spread, and then it was discovered that the school was of Weakfish and not menhaden. 'I have been in the business for twenty years,' said the mate of the 'Brightman,' ' and I never saw anything like it before.' The fish varied in length from one and a half to three feet, and in weight from three to seven pounds. The 'DeBlois' took over 200 barrels, the 'Hawkins' I 50 barrels, and the 'Brightman' 350 barrels. The entire catch was estimated at something over 200,000 pounds, which, at the ordinary market price for Weakfish-seven cents a pound-would amount to $\$ I_{4}, 000$. But, of course, the market price could not be maintained in the presence of such a catch as this."

The Squeteague comes on the coast of New England in summer in pursuit of food. Its wanderings do not often carry it north of Monomoy. "In the days of my boyhood," said Capt. Atwood, when before the Rhode Island Legislature in IS7 I, "my neighbors often spoke of a fish called the 'drummer,' which is the same variety that you call the Sque- 
teague, which were so plentiful that they could be taken by the boat-load. But in $\mathrm{S}_{16} 6$, when I first went into a fishing boat, they had disappeared, and I did not see a single specimen for many years. Since that time, however, they have commenced returning in considerable numbers." The pioneer of this return came to Provincetown June $23,18_{47}$. Capt. Atwood's prediction of their abundant return has not yet been verified. Their movements further south have been no less eccentric; and this species illustrates in a very forcible manner the axiom of the ichthyologist, that the morements of the oceanic fishes are the effect of laws, as yet but little understood, upon which the feeble efforts of man have no appreciable effect. Col. Theodore Lyman has written: "This fish is highly interesting as one of those which has appeared and disappeared alternately on our coast. In $\mathrm{I}_{80} 3$ it was abundant in Rhode Island, and very plenty at Provincetown as late as $\mathbf{I}_{\mathbf{2}} \mathbf{2 0}$. In $\mathbf{I}_{32}$ it deserted Vineyard Sound (and the northern part of the Cape even before that), $* * *$ and now $\left(I 8_{72}\right)$ for five or six years it has grown abundant, apparently increasing as the bluefish decreased, until this season when the weirs have taken hundreds at a haul." Capt. Atwood tells me that in $S_{45}$ he noticed them in New York, when the weekly supply would not have exceeded one thousand pounds, while thirty years later he found them coming in by the ton. Mr. David T. Church wrote in I 87 I : "Scup have disappeared from Narragansett Bay, but Squeteague have taken their place, and where ten years ago there were millions of scup, now there are almost none, but millions of Squeteague. Hundreds of acres could be seen any clear day between Point Judith and Providence."

There has been a curious relation between the periodical variations in the abundance of bluefish and Squeteague, the latter having been most numerous when bluefish were least so, but no one fully understands its cause. The habits of the two species are very similar; their times of coming and going, and probably their favorite water temperature, nearly identical. They feed in the same manner and upon the same animals, and the bluefish being the swiftest swimmer and the most voracious feeder, its presence in large numbers possibly interferes with the food supply of the Squeteague. It is not impossible that, though both species much prefer menhaden, the bluefish may frequently vary its diet by feeding on its weaker comrade.

Some inexplicable cause had a similar influence upon the bluefish, 
which became scarce in turn; thus the Squeteague was enabled to recover its ground, and to resume its place in the food economy of the coast. To what extent the disappearance or reappearance of the Squeteague is actwally connected with that of the bluefish it is impossible at present to state. It is quite likely that other causes, at least, are concerned, with which we are now unacquainted.

The striped hass is also an associate of the Squeteague, which, though essentially a coast and salt-water fish, occasionally runs into tidal waters, and on the coast of New Jersey is thought to prefer the vicinity of streams where there is a mixture of fresh and salt water. "He never goes into fresh streams or ponds," wrote S. L. Mitchill, "but within the limits of salt water is taken in almost all the places where the rock-fish is caught. The Weakfish is so much the companion of the bass that I once gave him the specific name of Comes." Prof. Baird has recorded that in Southern New Jersey, where, at times, in consequence of drought there is less water brought into Egg Harbor than usual, they are known to move to a considerable distance up towards the head-waters, and to leave in a great measure their ordinary grounds more seaward.

We have intimations, in the writings of the early historians of New England, of the disappearance and returns of the Weak-fish, like those referred to in the present century.

It is said that when they appear off the coast of New Jersey, about the middle of June, they are found to be filled with spawn, and that the early fish in Narragansett Bay have not spawned. This statement requires confirmation. Thousands of individuals have been examined by the Fish Commission naturalists at different times in the summer, and it is but rare that traces of spawn have been found. The precise period of spawning along the coast and the localities where the eggs are laid, as well as the habits of the fish during that period, are but little known, and are well worthy of careful investigation.

At Beasley's Point the young fish of the year have in August attained a length of about four inches, and differ from the adults in lacking entirely the characteristic spots, these being replaced by broad, vertical bands, which, together with their more compressed form, render their appearance very unlike that of the adult.

The young are rarely seen in New England. Dr. Bean obtained a single individual three and one half inches long in Herring River, 
Waquoit, Mass., August 9, $\mathrm{r} S 75$, the only instance of such a capture in the course of many years' careful exploration of that region. Young fish, four inches long, are common in Southern New Jersey in August. The growth of the species is quite rapid, the weight of four pounds apparently being attained in about three years. The largest I remember to have seen weighed about ten pounds, though this is not an unusual size.

The Squeteague, as well as the bluefish, varies in size with the locality. While on the coast of New Jersey they do not average much over one pound, they are stated to occasionally attain the weight of from six to ten pounds, and have even been known to weigh thirty.

The Squeteague in the South is a resident fish, although said by Holbrook to be most abundant and largest in the autumnal months, when, in his opinion, they come from the north. It is not satisfactorily ascertained, however, whether these fish, leaving the northern coast during winter time, migrate southward or more towards the warm waters of the Gulf Stream. They return to the coast of the Middle or Northern States early in the spring, the first being taken in May, and are most abundant from June to September.

Although its flesh is soft, it is delicately flavored, and is one of the farorite food-fishes of the South Atlantic and Gulf States, its chief rivals being the pompano, the whiting, the sheepshead and the red snapper. In the North the Squeteague is in moderate demand, particularly at the close of the shad season.

Among anglers, according to the late Genio C. Scott, this fish is considered as second in interest among those of the coasts and estuaries. In the opinion of this eminent authority, the striped bass holds the highest rank.

Prof. Baird has written: "The sport of catching the Squeteague is very great, and is highly enjoyed by many fishermen, on account of the great number that can be taken in a very short time. They swim near the surface and require a line but little leaded. 'They take almost any kind of bait, especially clams, soft crabs or pieces of fish. 'They take the hook with a snap, rarely condescending to nibble, and constant vigilance is necessary, as well as extreme care in hauling them out of the water, on account of the extreme tenderness of the mouth. During the flood tide they keep in the channel-ways of the bays, and at the ebb they generally settle in some deep hole, where they remain until the flood entices them out again. 
In the night they are much in the habit of running up the creeks in the salt meadows, where they are sometimes taken in great numbers by interposing between them and the sea, just before the period of high water. This experiment is not a very satisfactory one on the coast of New Jersey, in consequence of the abundance of crabs. The smaller fish become gilled in the net meshes, thus inviting the attacks of the crabs, which cut the nets to pieces, often ruining them in a single night."

When taken, the Squeteague makes a peculiar croaking, audible at a considerable distance; and it is said that this is not unfrequently heard from a boat when passing over a school of them in the water beneath.

The Sea Trout, or Deep-water Trout, of Charleston, described by Holbrook under the name Otolithus thalassinus, is without much question identical with the Northern Squeteague, although that author states that it differs from this fish entirely in its habits, since it is only found in the ocean and deep water, and never approaches the bays and inlets along the coast, while it is a larger animal.

The few specimens which Holbrook saw were taken off Charleston Bar, about twenty miles from land and in about fifteen or twenty fathoms of water. The very peculiaritıes which he mentions are characteristic of the adult Squeteague.

The Spotted Squeteague, Cynoscion maculatum, is a species associated with the Squeteague in the waters off the coast of New Jersey and on the eastern shore of Virginia. It belongs to the same genus, but somewhat different, being characterized by the presence of well-defined dark spots. It becomes more abundant as we proceed southward, until off the coasts of North Carolina and Georgia, where it is one of the most abundant foodfishes. Owing to its shape and the presence of well-marked spots on the sides it is usually known on the southern coast as the "Salmon" or "Spotted Trout," and there are not wanting sportsmen in the Southern States who maintain with dogmatic earnestness the existence of a true Salmon Trout in the waters of their coast. The early colonists of the Carolinas knew full well that the trout was a spotted fish, and that it was a most desirable fish withal ; their warm streams had no genuine trout, and they could not carry in their untrained minds the image of the trout of England, so very different from Cynoscion. A much better name for it would be "Spotted Squeteague." It is difficult, however, to bring about a change in a name which has been in use for several generations, 
and it is probable that the name "Sea Trout" will alway be used. Genio Scott proposed the name "Spotted Silver-sides," which is not particularly appropriate, and which no one but himself has ever used.

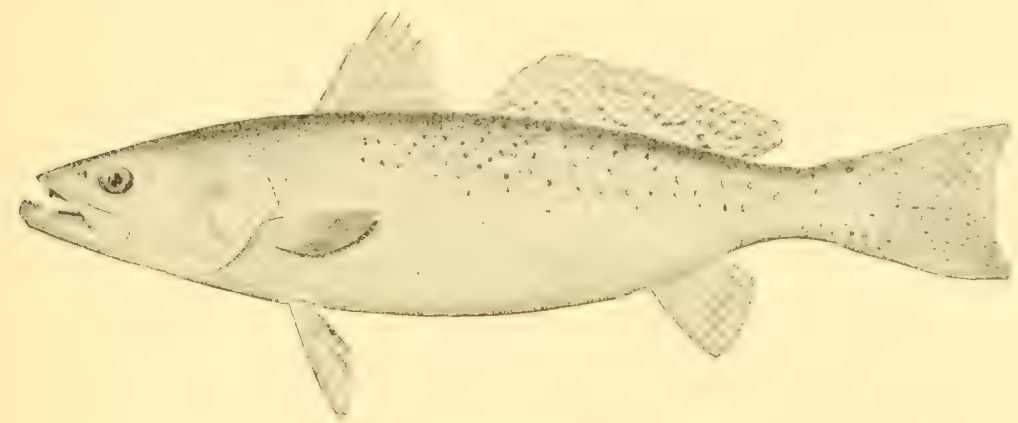

THE SPOTTED SQUETEAGUE.

The history of American fishes contains very little respecting the habits of this species, although it is so important an element of food to the inhabitants of the Southern coast. We have, however, been farored by Dr. H. C. Yarrow with notes made at Fort Macon, N. C., in which many of the deficiencies in our information are supplied. According to his account, the Spotted Trout is not found in that locality during the winter, or only in small numbers, making its first appearance in February on its way from the south, and attaining its greatest abundance about the middie of April.

Little is known of its rate of growth, although, according to some observers, this increase amounts to about six inches per annum; so that a fish of average size, or eighteen inches, may be considered as three years old. There is no perceptible difference in the sexes as to rate of growth or general appearance, excepting in the fuller belly of the female.

Dr. Yarrow states that they come from the south in the spring and pass through the inlets on the flood tide, the date of their first appearance varying with that of the opening of spring. They remain in the vicinity of the inlets and sounds on the coast of North Carolina until about May, when they gradually proceed northward, extending their journey as far as the shores of Long Island, where a few only are taken, although, perhaps, their number may be considerable. They reappear on the coast of North Carolina in September, and thence proceed south, following the same course as that by which they came, but leaving on the ebb instead of the 
flood tide. They are found in the winter as far south as St. Augustine, and possibly below this point, although we have no positive assurance of this fact.

At present they are thought to be more abundant than any other fish on the Carolina coast, with the exception of the mullet, having increased in numbers largely (at least twofold) within the last fifteen years, possibly in consequence of the intermission of capture during the war. The average length is about eighteen inches, with a weight of two pounds, although they are not unfrequently found three feet in length and ten pounds' weight. They are often found outside of the beach in great numbers in January, coming in to the shore when the water is warm, about February, as stated. School follows school at intervals of about four or five days, when they seem to go northward and to be absent from the Southern coast for several months. On their return in September, after a short stay, they gradually leave the coast until they finally disappear for the season. Their return season by season is very regular and definite, being relied upon with much confidence. The successive "runs" do not seem to be classified in any particular way, large and small fish of both sexes coming in together. The colder the weather the less tendency they appear to exhibit to come towards the shore.

At their first appearance in the spring the spawn is not appreciable, nor, according to Dr. Yarrow, do they have any development of the ovaries during their stay on that coast; and he is under the impression that they breed during their autumnal and winter stay farther south. This, however, is scarcely probable, it being more likely that their spawning ground is more to the north, perhaps off the coast of Virginia.

Their presence is generally made known by the schools of porpoises which follow and feed upon them. Swimming low in the water, they make no ripple on the surface, as is the case with mullets. The time of their capture is usually on the young flood, as in their movements along the shore they come in on the rising tide and depart on the ebb.

Like their representatives in the north, these fishes are fond of penetrating, for a short distance at least, into the mouths of rivers, remaining, however, only about a week; this, according to Dr. Yarrow, is their habit on the coast of North Carolina, before leaving for the North.

A singular phenomenon illustrating the delicate organization of this and the related species, is described by Mr. N. E. Armstrong, of On- 
slow, Co., N. C. "When we have extremely cold and cloudy weather, and I believe also windy weather for three or four days, the Trout at the mouth of New River are benumbed, and on the first sumny day rise to the surface, and after a day or two die and sink to the bottom or are washed ashore. As soon as they rise, there are generally hundreds of men ready with nets, dip nets, gigs, and in some instances, nothing but their hands and boats, to pick them up. They are sometimes washed ashore in long heaps, two and three feet deep, for a considerable distance. When these 'numbs' occur, it is generally known through this and the adjoining counties, and carts and wagons come for the fish by hundreds-sometimes from a distance of fifty or sixty miles. 'The New River is a wide and very shallow bay for the distance of twenty miles from its mouth. There was a 'numb) in January, $x 877$, and another in the winter of 1879 , about the same time, but they do not occur frequently.'"

They prefer sandy and grassy bottoms, and are particularly fond of shallow water, four or five feet deep, especially in still waters and eddies. Their favorite food is small mullet and other diminutive fish, as well as still more iargely shrimps and small crustaceans; while, on the other hand, they are eaten voraciously by Weak-fish, blue-fish, drum and porpoises.

In market fishing, nets are generally employed, though some fish are occasionally speared. They are taken in seines, usually having a mesh of about one and one-half inches, made of No. \& cotton twine, about one hundred yards long and ten feet deep. When the fish first begin to make their appearance the fishermen establish themselves in their boats, just outside the surf, and watch along the crest of the breakers. When the fish are seen the net is paid out from the stern of the boat, one man leaping overboard with a rope attached to one end of the net, while a man in the boat pulls rapidly around the school so as to inclose it. The net is then drawn carefully to the shore. The average catch of two men for a day may be set at about three hundred pounds, although a much greater amount than this could be taken if desirable.

They are used when fresh, and sent up into the small towns in the interior in large numbers. The flesh is of an excellent quality, much superior to that of the Weak-fish, being firm, white, and flaky, and will keep well for three or four days, unless the weather be too warm. It is sometimes salted down for home use by the inhabitants along the coast, and much esteemed. Dr. Yarrow estimates that about two hundred barrels 
were salted during the season of I $87 \mathrm{I}$ by the fishermen, in his vicinity.

The fish bring about $\$ 3$ per hundred at wholesale, and $\$ 5$ at retail, this being equal to the average for the last ten years.

Silas Stearns writes:

"The Spotted Trout is abundant from Key West to Mexico. In the Pensacola region it is present all the year, although most abundant in summer. It prefers to remain in shoal waters on grassy bottom, where it finds small fish and shrimps in abundance for food. It breeds in inside waters in July and August. Quantities of the fry are seen in August and September. They do not often form in schools in the bays, but in some places are so plentiful that it is not unusual to catch five or eight barrels at one drag of a seine. One man fishing with hook and line sometimes catches one hundred in less than a day. The Trout is an excellent foodfish, and of considerable importance to the fish trade. The demand for it would be much greater if it was not so hard to preserve in this climate."

S. C. Clarke writes that it is more of a game fish than the Squeteague, active, vigorous and voracious, and capturable with similar fishing gear. He recommends a bamboo rod of eight or nine feet, a multiplying reel with drag, and Ioo to I50 yards of fifteen thread flax line, with hook of the Cuttyhunk pattern, and ounce sinkers of hollow lead.

The Silver Squeteague, Cynoscion nothum, called at Charleston the "Bastard Trout," while resembling in shape the two species already described, is easily distinguished from them, being of a uniform silvery hue, the back being slightly darker than the rest of the body.

One or two individuals have been taken in Chesapeake Bay, but it has rarely been observed north of South Carolina, whence Holbrook obtained the specimens from which the original description was made. I have obtained one or two individuals from the mouth of the St. John's River, where they are not distinguished by the fishermen from the "Shad Trout," or Northern Squeteague. In the Gulf of Mexico, according to Stearns, it is common in company with the Spotted Squeteague, and, as far as has been observed, its habits are similar. It is, however, according to Jordan, less abundant, and is not to be found at all seasons. It is most abundant in September and October, but no spawning fish or young have been seen. The "White Trout," as it is called in Pensacola, is caught with hook and line in company with the Spotted Trout.

On our Pacific coast there are several species of Cynoscion. The most 
important of these are undoubtedly Cynoscion nobile and $C$. parvipinne. Jordan thus describes their habits:

"Cynoscion nobile is everywhere known as the Sea-bass and the Seatrout, sometimes as 'White Sea-bass,' to distinguish it from the Black Sea-bass or Jew-fish. The young, while yet banded, are known as 'Sea 'Trout,' and generally considered a distinct species, and both are frequently' called 'Corvina' and 'Caravina.'

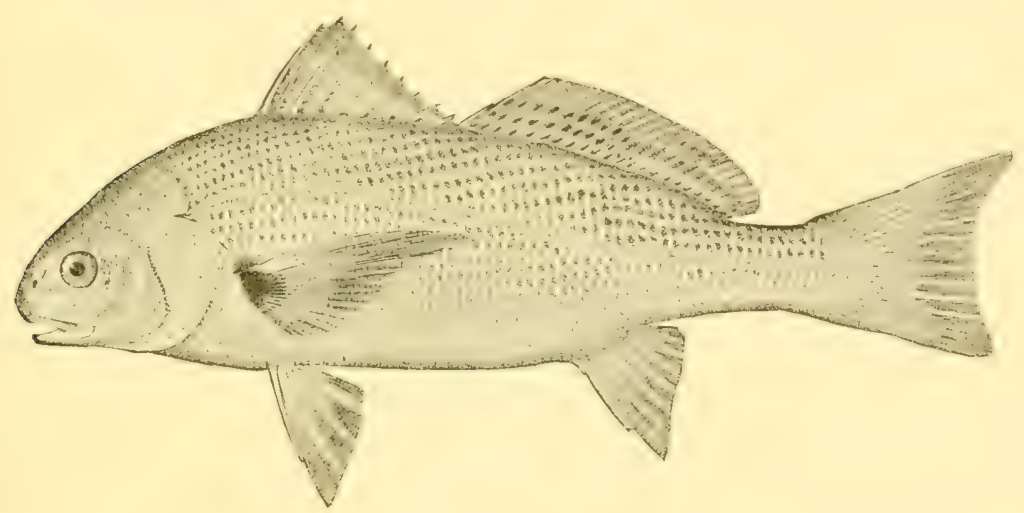

THE RONCADOR.

"It reaches a length of four to six feet and a weight of fifty to seventyfive pounds, perhaps more. Those usually seen in market average about fifteen.

"It ranges from Cape Mendocino southward to below San Diego, being especially abundant from Santa Barbara to Monterey in spring and summer. It is not often seen in winter. Only adults are taken in spring, and it probably comes to the shore from deeper water for the purpose of spawning. It goes in small schools, and its movements are irregular. Its food consists of crustaceans and fishes. It spawns in June or July. It is one of the most important food-fishes of the coast. Its flesh is excellent, firm and well flavored, and its great size renders it a very valuable species. In the firmness of its flesh it differs strikingly from most of the other species of the genus.

"Cy'noscion parvipinne, is usually known as the 'Corvina ' or 'Caravina.' It is also occasionally called Bluefish. It reaches a length of about two feet, and a weight of eight pounds. It is found from San Pedro southward to the Gulf of California, rarely straying to the north. In San Diego Bay it is abundant. It feeds on crustaceans, and especially on small fishes, as 
anchovies and sardines, and is very voracious. It spawns in July or August. Its flesh is tender, being very similar to that of the weak-fish (C. regale). It softens soon, but, when fresh, is of a fine, delicate quality, and scarcely surpassed by any fish on the coast. Several other species of this genus occur southward along the Mexican coast, where they are among the most important of the food-fishes."

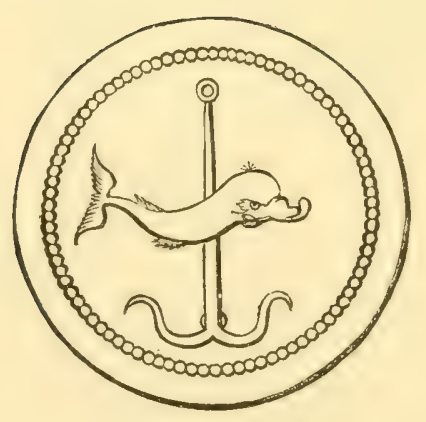




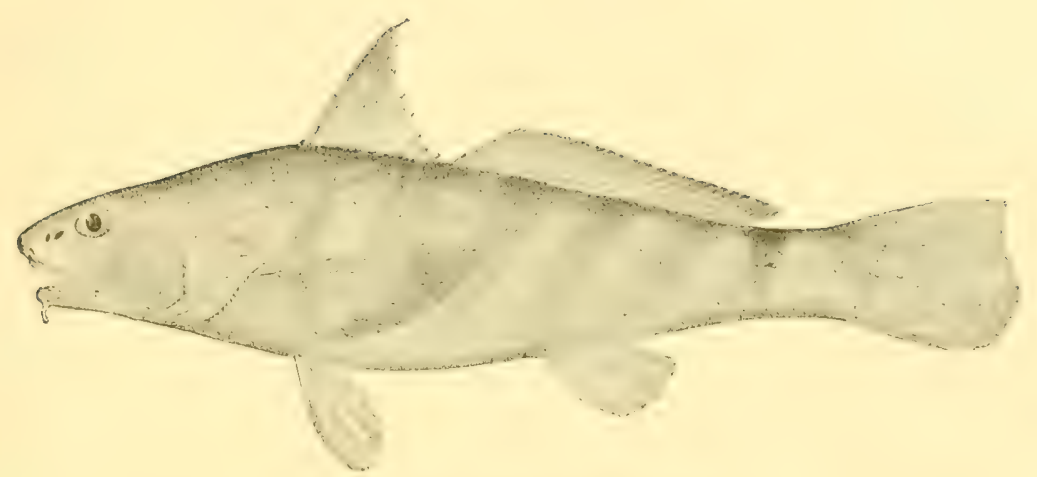

THE KING.FISH. MENTICIRRUS NEBULOSCS.

\title{
THE KING AND QUEEN FISHES.
}

\author{
These be the hills, (quoth he) the surges hie, \\ On which faire Cynthia her heards doth feed ; \\ Her heards be thousand fishes with their frie, \\ Which in the bosome of the billowes breed. \\ Of them the shepheard, which hath charge in chief, \\ Is Triton, blowing loud his wreathed horn \\ At sound whereof, they all, for their relief, \\ Wend too and fro at evening and at morne.
}

Spenser. Colin Clouts Cone Home Agant. 1591.

HE KixG-Fish, Menticirms nebulosus, also known as the "Hake"
on the coast of New Tersey and Delaware, and as the "Tom-cod" on the coast of Connecticut, the "Barb" about Barnegat, the "Black Mullet" in the Chesapeake, the "Sea Mink" in North Carolina, and sometimes also in the South as the "Whiting," ranges from Cape Ann south at least as far as the mouth of the St. John's River, Fla., although in the southern part of its range it is frequently confused with the Whiting. It has been obtained by Jordan and Stearns at Pensacola; though it is rare in the Gulf. Its great gaminess, its beauty of color and form, and its excellent flavor, Mr. Cheney assures us, caused the loyal citizens of New York in colonial days to call this species the "King-fish" and in former times, when it was abundant in New York bay, the King-fish and the small striped bass were the crowning glory of the old time fishing.

It is discussed as follows by Professor Baird:

"This species, well worthy of the name which has been given it, and 
the estimation in which it is held by New York epicures, as it is certainly savory when taken fresh from the water, leaves nothing to be desired in the way of a fish diet. It is quite abundant off the Middle States, but is rare much to the eastward. A few specimens are occasionally taken in Buzzard's Bay and Vineyard Sound, and Dr. Storer mentions four as having been captured in Massachusetts Bay. It is almost as capricious in its occurrence in the more northern waters as the Lafayette, sometimes being scarcely met with for several successive summers, and then suddenly reappearing, as if migrating from more southern waters. At Beesley's Point, N. J., where I have had most opportunity of studying its habits, it appears quite early in the spring with the squeteague, and is found a good deal in company with it, like that fish seeming to prefer a slight mixturc of fresh water, as shown by its keeping in the mouths of rivers and running farther up during the dry season. It takes bait readily and affords excellent sport to the fishermen, although not caught in anything like the same number in a given time as the squeteague, thirty or forty at a single tide being considered an excellent catch for one boat.

"Nothing has been recorded in regard to the precise time of their spawning or the places where they lay their eggs. The young are met with at Beesley's Point in immense numbers on the sandy bottom as well as in the surf. The smallest were about an inch long. I have taken the young also in considerable number in Vineyard Sound at a time when the old fish were scarcely known. They occasionally run to a considerable distance up the rivers, as I have caught young fish of this species at Sing Sing, on the Hudson, where the water is scarcely brackish. The Kingfish run much in schools, and keep on or near a hard, sandy bottom, preferring the edge of channels and the vicinity of sand bars; and they congregate about oyster-beds, especially when the oysters are being taken up, and may be seen under the boats, fighting for the worms and crustaceans dislodged in the operation. They bite readily at hard or soft clams, or even pieces of fish, and are taken most successfully on the young flood. Like the squeteague, they will occasionly run up the salt creeks at night, and may be captured in gill-nets as the water recedes. This, however, is not so common a habit with them as it is with its associate.

"The price of this fish varies at different seasons of the year, but it is always well maintained, and it is generally valued at nearly as high a figure as the Spanish mackerel. The European analogue of this species, Um- 
Brina cirrhosa, is somewhat similar in general appearance, and its flesh is highly esteemed. This feeds on small fishes, mollusks, and, according to Yarrow, on sea-weed, sometimes attaining a weight of forty pounds. This magnitude I have not seen approximated by our species, although it is possible that it may occasionally reach a large size. Of its distribution southward I can find no satisfactory account."

In 1879 numerous small individuals of this species appeared in the harbor of Provincetown, Mass.; they seemed however, to be out of their proper habitat, and many were chilled by the coldness of the water and cast up on the beach. In $\mathrm{I} 880$ and $\mathrm{r} 88 \mathrm{I}$, the species is said to have been particularly abundant on the coast of New Jersey, and to have afforded much sport to anglers of that vicinity, many of whom had not been familiar with it in previous years.

Mr. A. N. Cheney gives the following instructions for King-fish angling:

"A light rod and multiplying reel, a strong and very light line, a swivel sinker and two rather small hooks are what is required in the way of tackle; much the same rig as is used in weakfishing. The bait is either shedder crab or sand-worm. The King-fish is thoroughly game; he seizes the bait eagerly and then goes to the bottom, following up this movement with long runs from right to left ; it is really remarkable what a determined resistance the little King-fish will make. In size he varies from one to six pounds, the average being two or three pounds. The time to fish for them is when the tide is running in. Kingfish can be caught along the south side of Long Island, off the Jersey coast at Atlantic City, Long Branch and Barnegat Inlet, and further south they are very common."

The Whitings, favorite food-fishes of the Southern coast, embrace the two species, Menticirmus alburnus and $\boldsymbol{M}$. littoralis, both closely allied in general character to the King-fish of more northern waters. They are said to occur abundantly from Cape Fear River, N. C., to the Rio Grande, in Texas. Uhler and Lugger claim that they inhabit the salt water of the Chesapeake Bay and its estuaries, but it is not probable that they are at all abundant. On the coast of South Carolina, according to Dr. Holbrook, the Whiting remains all the year round, and although few are taken in December and January, yet they are sufficient to prove themselves constant residents. Near Charleston in the spring and summer months they are very abundant; they enter the mouths of bays and rivers, and are captured in great numbers. They take the hook readily; their faror- 
ite bait is the drum, and being strong, lively and active in habit, they afford great sport to the fishermen. They prefer deep and running waters, and seldom approach so near the shore as to be taken in seines. Their ordinary food seems to consist of various species of small shell-fish.

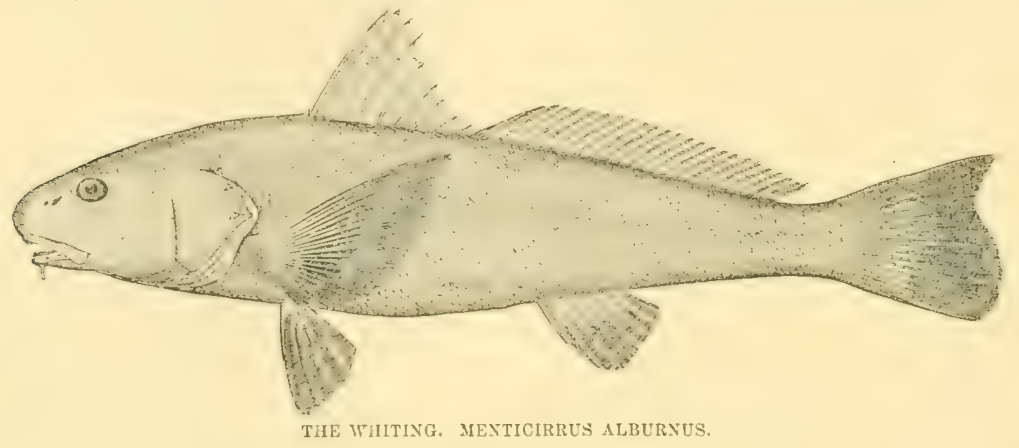

Speaking of the "Surf Whiting," of Charleston, Holbrook remarks: "This species makes its appearance on the coast of Carolina in the month of April, and continues with us during the entire summer, though very few are taken in July or August. It is only found in shallow water where the bottom is hard and sandy, often forming, when the tide is out, an extensive beach. Its favorite resort. is in the neighborhood of the shore where the surf can roll over it from the ocean and bring with it doubtless the animals on which it feeds. In such localities many are captured with the seine and are sold in the market under the name 'Surf Whiting,' in contradistinction to the other species which is called the 'Deep-water Whiting.' Its food seems to be similar to that of the Deep-water Whiting, judging from the contents of its stomach, and yet it is seldom taken with the hook. Hitherto I have only seen this fish in the immediate neighborhood of Charleston. This fish is very commonly supposed to be the adult male of the common Whiting, approaching the shoal water to deposit its spawn. I believed it, from common report, to be such, until frequent dissections proved to me that there are both males and females among them. The flesh of this species is good, but by no means so finely flavored as that of the Deep-water Whiting."

At Mayport, Fla., the Whiting is abundant, and also at the mouth of the St. John's. The largest observed by me measured ten inches, and in the first week of April was within two or three weeks of spawning. A few 
are taken in the St. John's as high up as Arlington. They are abundant in the Indian River. About New Smyrna, Fla., according to Mr. S. C. Clarke, it is called "Whiting," "Kingfish," "Barb" and "Bull-head Whiting." They occur in the winter and spring, though seldom in sum. mer. The largest reached the weight of one and a half pounds. Ther average three-quarters of a pound, the female being usually the larger.

They appear about the last of November, and spend the winter in bays and still rivers. They bite in strong currents, not in slack water. 'They prefer deep channels and sandy bottoms. They are found in the deepest water and prefer cold water. 'Their food consists of crabs, shrimps, and small crustaceans, and they feed at the bottom. Half-grown to fullgrown fish contain spawn. They spawn in the sea in May. They are taken with a hook by the use of mullet or clam bait at half-tide. They bite best in a strong current in winter and spring and fifteen or twenty may be taken in one tide. In the Gulf of Mexico, according to Stearns, they are abundant from Key West to the Rio Grande, and are known as the "Whiting," though at Pensacola the name "Ground NIullet" is in use. He writes :

"There are two varieties, which, if they have no specific differences, have at least, different habits. One variety lives exclusively in very shoal water along the sandy beaches, appearing to take pleasure from the action of the surf, and swimming in small schools. The other inhabits deeper waters; is found singly, and is of much darker coloring. 'The former seldom leaves the sea-water, while the latter are often found in brackish and fresh water. I have found ripe spawn in the surf variety in April, and believe they deposit it on the sea-beach. Large specimens of the dark variety were taken in September, IS79, in the Apalachicola River, where the water is fresh. The Whiting is an excellent food-fish.',

The two varieties thus referred to by Stearns have been identified by Jordan as the two species $\boldsymbol{M}$. albumms and $\boldsymbol{M}$. littoralis, the latter being the surf-loving species first mentioned.

The Whiting is a delicious pan-fish, sweet and hard, though soon losing its delicate flavor. In Charleston it is regarded as a great dainty. According to Colonel Lyman, when Charleston was closely blockaded and fishing was a hazardous occupation, the commandant of the garrison, who was a bon rivant, gave \$Ioo in Confederate money for a string of Whiting. Some of the early writers called this fish the "Bermuda Whiting," for 
what reason it is difficult to understand, for the Whiting of Bermuda at the present day is a fish very unlike that of our Southern coast.

The "Surf Whiting," according to Jordan, is not rare at Charleston, and in the Gulf of Mexico is as common as the other species, but is chiefly found in the surf, and hence is less frequently brought into the markets.

Speaking of the game qualities of the two species, S. C. Clarke writes that they bite much like the trout, seizing the bait with a rush - that they are strong and active, and make a good fight for their size. He recommends a trout bait rod, fine line, reel, and two small hooks. For bait he uses cut mullet and fishes on or near the bottom of a sandy strong-tided channel, at half tide.

The Bagre, Menticirmus undulatus, is an allied form, member of our Pacific family. It reaches a length of twenty inches, and a weight of four or five pounds. It is found close to shore from Point Conception southward to Cerros Island, and is generally abundant. It feeds on crustacea, spawns in July, and is a food-fish of fair quality. In appearance and in value it approaches closely to the Surf Whiting of the Atlantic, $M$. littoralus.

The Queen-fish, Seripluus politus, is also known as "King-fish" in California. It reaches, says Jordan, a length of eight inches, and a weight of half a pound. It ranges from Tomales Bay southward, and is abundant in summer, when it is found in great numbers in the surf along sandy shores. Enormous numbers of them are sometimes taken in seines, especially at Santa Barbara and Soquel. It is not often brought into the San Francisco market. It feeds on small fishes and crustaceans. It spawns in summer. It is a food-fish of excellent quality, but is too smail to possess much economic value. 


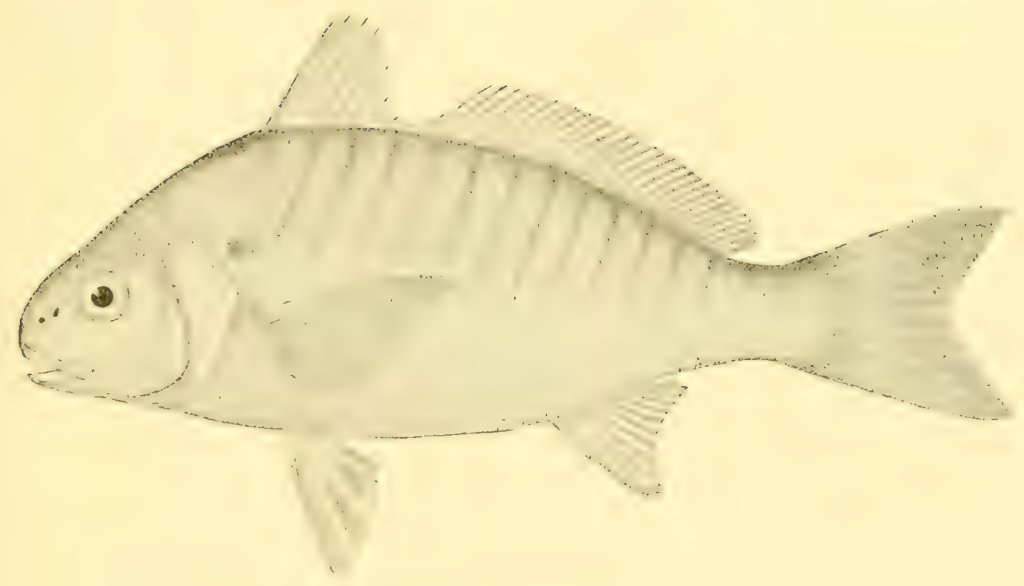

THE SPOT OR LAF.ATETTE.

\title{
SPOTS, CROAKERS AND RONCADORS
}

\author{
Man's life is warm, glad, sad, 'twixt loves and graves, \\ Boundless in hope, honoured with pangs austere, \\ Heaven gazing; and his angel wings he craves: \\ The fish is swift, small-needing, vague yet clear, \\ A cold, sweet, silver life, wrapt in round waves, \\ Quickened with touches of transporting fear.
}

Leigix Hunt, The Fish, The Afun and the Spirit.

1 HE Spot, or Lafayette, Liostomus xanthurus, is found along our
coast from New York to the Gulf of Mexico, and is known in New Tork and elsewhere as the "Spot," on the coast of New Jersey as the "Goody" and sometimes as the "Cape May Goody," in the Chesapeake region also as the "Spot" and the "Roach," at Charleston, S. C., as the "Chub," in the St. John's River, Fla., as the "Masooka" - this name being probably a corruption of a Portuguese name, "Bezuga" - and at Pensacola as the "Spot" and "Chopa blanca." The name "Lafayette" is used for this fish in New York even to the present day. This name was given it by the New York fishermen in consequence of its reappearance in large numbers in that region having been coincident with the arrival of Lafayette in this country in $S_{34}$. It had been known before that time, but only in scattering numbers.

Although they sometimes enter the large rivers of the South, such as 
the St. John's, which they ascend as far as Jacksonville, Günther is by no means justified in his statement that this is "a fresh-water fish inhabiting the rivers of North America."

Like the other bottom-feeding members of this family, their food consists chiefly of the smaller mollusks and crustaceans. Little is known about their breeding habits in the North. Mr. S. C. Clarke states that at New Smyrna, Fla., they breed in the bays and inlets in November and December, while Stearns remarks that they spawn in the lower bays and inlets about Pensacola late in the fall, while the young of all sizes are very abundant in the spring.

Concerning this species Prof. Baird writes:

"Of the smaller pan-fish of our coast, in excellence of flavor none is considered superior to that known as the 'Lafayette.' Its precise eastern range is not well ascertained, although it is occasionally taken in great numbers off Long Island and the coast of New Jersey. It is most plentiful off the coast of Virginia.

"According to Dr. Holbrook, it is not much esteemed for food at Charleston, owing to a want of flavor. In the case of this species, as in many others, it is probable that the colder waters of the North impart a superior flavor and excellence to the flesh. This is well known to be the case with the sheepshead, as well as many other species.

"At Beesley's Point, N. J., where I have had an opportunity of studying its habits, it makes its appearance in large numbers in August, the first school being composed of small fish, large ones following them. A short time later they ascend the creeks in great numbers and are taken there in company with the white perch. Their usual size in New Jersey is about six inches, although occasionally measuring ten inches. They do not make their appearance in the New York markets in any abundance until towards the Ist of September, and remain until the end of October, when they disappear. I did not succeed in finding any very young fish, and am unable to state whether they actually spawn on the New Jersey coast, or whether the supply found there and further north consists of a 'run' from the more southern waters of fish migrating northward, perhaps to escape the increased heat of the southern coast."

Mr. L. O. Van Doren in the American Angler, gives an account of its merits as a game and food fish.

"It swarms on the eastern coast during the hot months of July and August, and is caught even in September. 
"In the Harlem and East Rivers and in Long lsland Sound, where I have caught them, they run very small indeed, and it requires great patience and small hooks to take them in. They keej up a constant nibbling, and the angler is so busy pulling his line up every minute or two that he wishes he luad not fallen in with the silvery pests.

"Like the bergall the Spot bites at the hook with a sly tentative nibble and immediately darts away, as is proved by their being frecuently hooked in the back, sides or tail. But there is this difference between cunners and Lafayettes; the latter are good to eat and the former are worthless. I know of no daintier morsel than a big, fresh Lafayette. nicely fried and served hot. They are the most tasteful of all the salt water pan-fish with the exception of the Stonington eel.

"Few would care to go out especially for Spots, but if you do have a lot of fine, sharp hooks, put four on your line above a light sinker, bait with small pieces of clam or saddworm, and fish on the first of the flood or at dead high water in about fourteen feet. It is great fun to take them with a very light rod. They can be caught in great numbers at Rockaway, Cape May, Atlantic City, in fact, everywhere on the coast.'

The Spot is abundant at Mayport, Fla., in spring and summer. In the Gulf of Mexico, according to Stearns, it is present in the bays all the year, living in shoal water, feeding upon the bottom upon the small invertebrate animals, and taken with hook and line and seine. It is extremely abundant, and is considered a good food fish.*

There is a rare species, allied to the Spot, recorded from Charleston, S. C., and St. George's Island, Tex., known by naturalists under the name Stclliforus lanceolatus. It is found in deep water, and is not sufficiently abundant to have acquired a common name.

The Yellow Tail, Bairdiella chrisura, known as "Silver Perch" on the

*: How TO FRY FAN-FISH - "To fry is to boil in fat, therefore the fat must boil, and it must coverwhatever you wish to fry. When fat boils it is quite still, lenves off moving or bubbling, and a thin blue smoke or vapor rises from it. Fat can be kept for a long time to fry in; it should be strained after using, and it car: be clarified often, provided it is not allowed to burn." -(Fniti CLAkE.)

After being cleaned and wiped perfectly dry, fish for frying should be rubbed over with llour, or dipped once or twice into egg and bread crumbs, or passed through a regularly-made batter. Fry it in plenty of very hot oil or friture; drain it thoroughly from grease; sprinkle fine salt upon it, and serve it upona damask napkin folded in a dish tastefully garnished; serve a sauce apart. Chopped onions are generally fried and served with fresh herrings. If a sufficient quantity of fat be employed, a good thick fisli will not need more than ten minutes's frying; smelts and such-like small fish are done in five minutes, or even lcss. Finely-shred herbs may be sprinkled over somesorts of fish, such as eels or mackerel, previously to frying them, but soles, or in short flatfish generally, should be only done with bread crumbs and egg, so as to send them to table looking of a clear golden yellow." - GI:ukgiANi HiLL.)

To fry fish in the Virginia style:- "Choose middle-sized fish; clean them, scale and wash them: then with a very sharp penknife score them on the sides, but not verv deep nor very close; dredge them with flowr; then fry them in oiled butter. When they are well done and brown serve them up garnished with fried parsley, and send up with them plain melted butter. This give; the fish its true flavor, and many, for that reason, prefer it to any other way of dressing."-(MIRS. SMiTH.)

To fry fish in the angler's style :- "Never put your fish in the pan till the fat is boiling hot. $\mathrm{Always}$ cut your pork small, and don't try it out or otherwise cook it too fast, as it will lose much of its sweetness. Score the fish and roll them in four before laying them in the sparkling fat. In using lard, a table-spoonful of salt to a pound is a fair average." - (Gexio C. Scotr.) 
coast of New Jersey, is quite an important food fish in the Southern States. But little has been written regarding it, and its excellent qualities are not yet thoroughly appreciated. In fact, it has been confused with other species by both Holbrook and Gunther. This fish has not been observed north of New York, where it was recorded by Mitchill and DeKay, the latter of whom stated that it was no: uncommon in the summer season.

Prof. Baird found the young very abundant about Beesley's Point. in 1854 , though the adults were unknown to the fishermen. Uhler and Lugger, who, following the mistaken nomenclature of Holbrook, confused this with a species of Liostomus, say it is common in the Chesapeake and Lower Potomac. It is also abundant about Beaufort, N. C., and in the vicinity of Charleston.

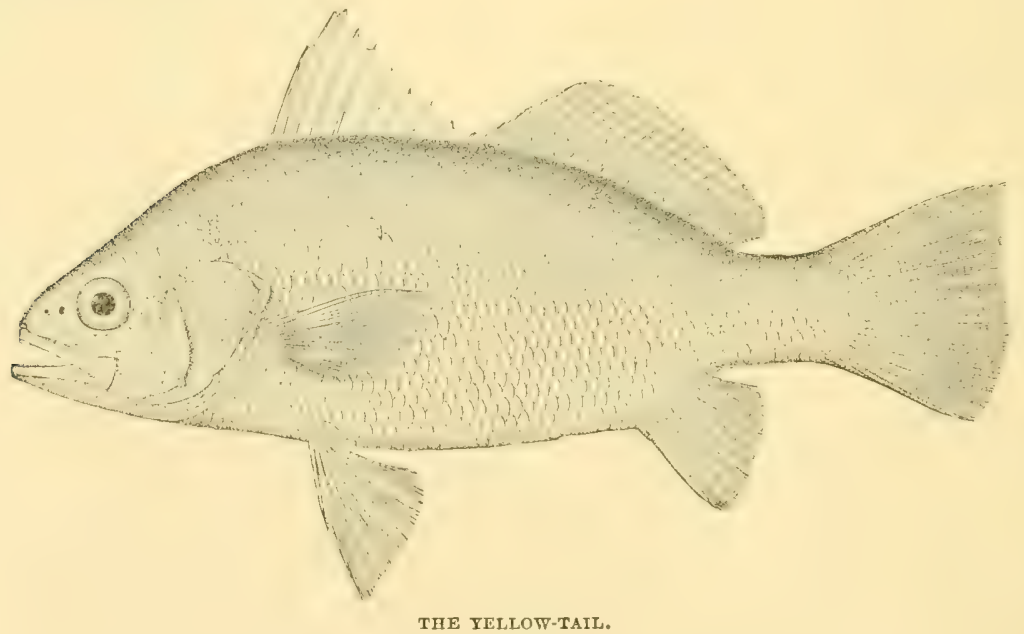

According to many observers, Yellow-tails are highly esteemed for food at St. Simon's Island, New Brunswick, Ga., and in the Lower St. John's River. They probably never ascend the river much above Jacksonville, though in 1877 great quantities were taken, in the month of April, at the mouth of the Arlington River. In I878 the water was so fresh at this point tinat none could be taken there, though I saw them at Yellow Bluffs in water not perceptibly brackish to the taste. A large majority of those observed at Mayport on April 7, I875, were full grown and taken at the point of spawning. Others taken by fishermen at Nay- 
port, $A_{\text {pril, }}$ 5, I 878 , had the spawn running free from them. The largest adult did not exceed eight inches in length.

On the Florida coast of the Gulf of Mexico, according to Stearns, they are very common. They were found by Jordan to be very abundant along the shores of Louisiana and Texas. At Pensacola they are known by the name "Mademoiselle." They are present throughout the year, but most plenty from May until November, and are found in company with the trout and the Spot on the grassy shoals of the bays where they feed and spawn. The time for spawning is in June and July. They feed chiefly upon small fishes and shrimps. They do not school, but swim singly or in pairs. Their extreme length does not exceed ten or eleven inches, the average being about eight. They are regarded as excellent pan-fish.

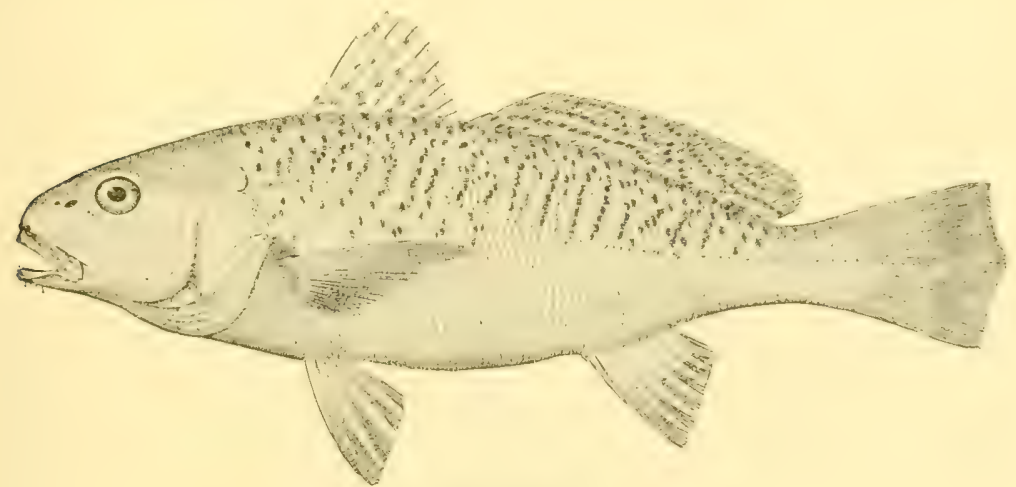

THE CROAKER.

The Croaker, Micropogon undulatus, ranges from New York at least to the Gulf of Mexico, although rarely seen north of Delaware. It occurs also in some of the West Indian islands and south of Brazil. Its name refers to the peculiar grunting sound which it utters, but in the Chesapeake this name has been corrupted into "Crocus." In Texas it is called "Ronco."

At Beaufort, N. C., according to Jordan, it is very abundant, and, next to the mullet and the Spot, is the most common food-fish of the region. Iílbrook states that the Croaker makes its appearance off Charleston in the month of May, but becomes common in shallow water in June and July, and is most abundant and attains its largest size in October and 
November. It is not much esteemed as food, and is only used as a panfish.

It is abundant and highly esteemed at Brunswick, Ga., and everywhere in Eastern Florida, in company with the Spot, ascending the St. John's as far as Jacksonville.

Stearns writes: "In the Gulf of Mexico it is very common. Is found everywhere in the bays and bayous throughout the year. Lives mostly in shoal water or grassy bottoms. Feeds upon crustaceous animals. Breeds in the bays in November and December. The young are seen in the spring, having grown to a size of two or three inches in length. Is caught with hook and line and seine. It sells with other pan-fish for a low price. It is an excellent food-fish; average length ten inches. At Sarasota Bay, December $8, \mathrm{I} 879$, I caught two specimens of spawning croakers that were each fully eighteen inches long-the largest that I have ever seen."'

An allied species is Larimus fasciatus, which is called "Chub" in Charleston.

Prof. Jordan supplies the following notes upon allied species native to the Pacific waters:

Corvina saturna, is known wherever found as the "Red Roncador," less commonly as "Black Roncador" or "Croaker." It reaches a length of sixteen inches and a weight of three or four pounds. It is found from Point Conception southward in moderate abundance. It feeds largely on crustaceans and spawns in July. It is a food-fish of good quality.

Roncador Stearnsi, is generally known as the "Roncador" or the snorer, from the Spanish roncar, to snore. It makes a very distinct grunting noise, probably with its air-bladder, on being taken from the water. It reaches a length of over two feet, and a weight of six to eight pounds. It is found from Santa Barbara southward, usually in abundance. It feeds on crustacea and spawns in July. It is a food-fish of excellent quality. It is named in honor of that eminent naturalist, Prof. R. E. C. Stearns, so long identified with the scientific interests of the Pacific coast.

Genyonemus lineatus, is known about San Francisco as the Little Bass. Southward it is called the Little Roncador. 'The name "Cognard," said by Dr. Ayers to be given to it in San Francisco, is unknown to us. It reaches a weight of little over a pound, and a length of a foot; it is found from Tomales to San Diego, being most abundant from Santa Barbara to San Francisco. It often comes into the markets in large numbers; it 
feeds chiefly on crustacea and spawns in July. It is a food-fish of good quality when fresh, but its flesh becomes soft in the market sooner than that of most species. Many are dried by the Chinese.

Umbrina roncador, generally known as the "Yellow-tailed" or "Yellow-finned Roncador." It reaches a length of more than a foot, and a weight of two or three pounds. It is found from Santa Barbara southward, and is generally abundant, especially in summer. It feeds on crustacea and spawns in July. It is a food-fish of good quality. Many are split and salted. 




SEA DRUM AND LAKE DRUM.

His drumming heart cheers up his burning eye.

SHAKESPEARE, Rape of Lucrece.

NEXT to the sword-fish, tunny, jew-fish, and halibut, the Drum is 1 perhaps the largest of the food-fishes of our coast. It is most abundant in the Gulf of Mexico and in the Southern Atlantic States, though nearly every summer a few specimens appear on the south coast of New England. In one or two instances individuals have been observed as far north as Provincetown, Mass. In the Gulf it is common ererywhere, even to the southern boundary of Texas; how much further south it goes there is at present no means of determining. Ichthyologists formerly supposed that there were two species, one of which, of small size and conspicuously banded with brown and white, was called the " Banded Drum," $P$. fasciatus, or "Little Drum." This is now well-known to be the young of the $P$. chromis. It seems curious that the changes of color in relation to age, although known to Cuvier forty years ago, should have ween overlooked by American naturalists, and that the species $P$. fasciatus should have stood as valid until $\mathrm{s} \delta 73$.

The name "Drum," as everyone knows, alludes to the loud drumming 
noise which is heard, especially in the breeding season, and is doubtless the signal by which the fish call to their mates. This habit of drumming is shared by many fishes of this family, but appears to be most highly developed in the Drum, and in a European species known as the Maigre, Sciana aquila. M. Dufossé has investigated, very thoroughly, the physiological causes of these sounds, which appear to depend largely upon the action of the air-bladder.

The northern limit of the species appears to be defined by Cape Cod. In 1873 , Mr. James H. Blake captured one at Provincetown. Another, of twenty-five pounds' weight, was secured by Vinal Edwards for the Fish Commission from Rogers's pound, Quisset, Mass., July, I874; another large individual, of sixty pounds' weight, was taken near Noank, Conn., July Io, I874, the third instance of its capture known to the fishermen of that vicinity.

Schoepf, writing about the year i 786 , says that they were at that time very rare about New York, though he had occasionally seen them at the city market, where they met with sale, though their flesh was none of the hardest.

The Drums captured north of Sandy Hook have been, so far as I can learn, large adult fish. Prof. Baird found the young fish of this species very abundant in August in the small bays along the shores of Beesley's Point, N. J., though few were seen in the rivers. Its southern limit is somewhere in the Gulf of Mexico, but has not been accurately ascertained.

The young are very dissimilar to the adult fish, though the fishermen in Florida and elsewhere recognize the actual relations. In this respect they are more discriminating than the ichthyologist Holbrook, who described them as distinct species. The adult is known as the "Black Drum," the young as the "Striped Drum." In addition to the marked differences in color, the young has a much more shapely body than the adult, much higher in proportion to its length. The full-grown fish sometimes weigh eighty pounds, though the average is perhaps not more than one-quarter as large. They are sluggish swimmers, and are especially adapted to life on the bottom, where their long, sensitive barbels aid them in their search for buried treasures of food. They feed upon all bottom-dwelling invertebrates. Their teeth are extremely heavy and pavement-like; their jaws are provided with very powerful muscles, by means of which they can crush with great ease the shells of the most strongly protected invertebrates. 
It is claimed by oyster-planters that the Drum is very destructive to the oyster-beds. Mr. Stearns writes: "Oysters are their favorite food on the Gulf coast, and they destroyed a great many at Apalachicola, St. Andrews, Mobile, and Galveston Bays. The Mobile oyster-planters attribute the bulk of their losses to Drums. At Pensacola I have known a boat-load of oysters, fifty barrels, that were thrown overboard to be preserved, to be entirely consumed in eight or ten days by them, leaving but a heap of broken shells."

While it is probable that the Drum feeds upon oysters as well as upon crabs or shrimps, it is probable that the extent of their destructiveness has been somewhat exaggerated; for instance, it was claimed a few years ago that oysters in New York Bay to the value of hundreds of thousands of dollars were destroyed by Drums. This seems quite unlikely, since the Drum is by no means a common fish so far north as New York.

Concerning its relation to the oyster-culturist, I cannot do better than to quote the words of Mr. Ernest Ingersoll :

"Knowing the carnivorous propensity of the fish, one can easily imagine how an inroad of such a host must affect an oyster-ground. They do not seem to make any trouble, however, north of New York City, and rarely along the south side of Long Island. At Staten Island and Keyport they come in every few years and devastate thousands of dollars worth of property. Such a memorable visitation happened about $\mathbf{I} 850$, in July. The following summer the planters in Prince's Bay, fearing a repetition of the onslaught, anchored shingles and pieces of waste tin on their beds, scattering them at short intervals, in the hope that their dancing, glittering surfaces might act as 'scare-crows' to frighten the fish away. Whether as an effect of this, or because of a general absence, no more Drums appeared. In New York Bay, off Caven Yoint, where the old 'Black Tom Reef' is now converted into an island, one planter of Keyport lost his whole summer's work-material and labor-in a single September week, through an attack by Drums. A City Island planter reported to me a loss of \$I0,000 in one season a few years ago; but the East River is about the northern limit of the Drums, at least as a nuisance to oyster-culture, so far as I can learn. The vexation of it is, too, that the Drum does not seem to eat half of what he destroys; but, on the contrary, a great school of them will go over a bed, wantonly crushing hundreds of oysters and dropping them untasted, but in fragments, on the bottom."

The size of the schools in which they go is shown by the following records from contemporary newspapers: "On Monday last, John Earle and sons caught, at one draught, in Bristol Ferry, 7 rg Drum-fish, weigh- 
ing upwards of fifty pounds each." Niles' Weckly Registcr, July, x $\delta_{33}$, also says: "Some days ago a haul was made in Great Egg Harbor Bay, near Beesley's Point, Cape May, at which 2 I Drum-fish was caught, their entire weight being from 8,000 to 9,000 pounds. This is said to be the largest haul of that description of fish ever made in that bay."

Another still larger, noticed as a great haul of Drum-fish: "On Weclnesday, June 5, I 804 ," says the postmaster of Oyster Ponds, I.ong Island, "one seine drew on shore at this place at a single haul i 2,250 fish, the average weight of which was found to be thirty-three pounds, making in the aggregate 202 tons $25^{\circ}$ pounds. This undoubtedly is the greatest haul of this kind ever known in this country. A hundred witnesses are ready to attest the truth of the above statement. They are used for manure." (The fish, I suppose, and not the witnesses, remarked Ingersoll.)

Mr. S. C. Clarke has made some interesting communications regarding their breeding habits. The male he informs us, is the larger, and is more brightly colored, particularly at the breeding season. The male drums very loud, the female in a softer tone. Fish under twenty pounds in weight do not breed. About the Halifax Inlet, Southern Florida, they spawn in March in the salt-water rivers. The ova sink to the bottom. They are as large as B-shot, dark brown in color, and are often seen to run from the parent fish when it is captured. In a large fish the roe sometimes weighs six or seven pounds. In the northern part of the Gulf of Mexico, according to Silas Stearns, they spawn in April and May in inside waters.

My own observations upon the Drum have been made chiefly in Florida. Specimens of ten and fifteen inches are abundant in the Lower St. John, and are frequently taken at Jacksonville, even as high up the river as Doctor's Lake. Large ones are seldom known to pass the bar at Mayport.

They are sometimes caught in seines in great numbers and retained living in the seines until disposed of. Drum-fishing with hook and line is one of the most exciting exploits of the sportsmen of this region. In the Nassau River, large Drum which are sold at Fernandina, are taken with hook and line in the spring.

The young are often taken in seines at the St. John's River and sold in the Jacksonville market, and are excellent pan-fish, as my own experience testifies. Their flesh is coarse, but tender, and it is thought to compare favorably with any of the salt-water fishes of the region. The large ones 
are often eaten, but are not so much sought after; perhaps the cause of this is that they are liable to be infested by parasitic worms. A Drum of sixty pounds, taken at Wood's Holl, Massachusetts, I 864 , was completely ridAled by nematode worms, neatly encysted among the layers of muscle. Some of them were two feet long, with heads larger than large buck-shot.

In the Indian River, according to Mr. Clarke, Drum are taken with hooks and crab bait, and with cast-nets. In summer they are caught in the open ocean ; in the winter, in the bays and inlets. Four or five a day is considered good fishing luck. Tides do not affect the fishing. Their flesh is not greatly esteemed. They are sometimes salted, but are chiefly used for compost. "In the Gulf of Mexico," says Stearns, "the Drum is often caught in seines and gill-nets, but is very rarely eaten, as the flesh is dry and tasteless."

I have often caten the young fish in Florida. When very fresh, the flavor is sweet and agreeable, though the flesh is very soft.

In the Carolinas, according to a statement of a correspondent, the roes are considered very delicious, and it is customary for the residents of the coast to salt and dry them and send them "up country" to their friends as a very acceptable present.

North of Maryland the fish is of little economical importance. In the Chesapeake region, according to Uhler and Lugger, its flesh is much esteemed, and its roe is a great delicacy ; considerable numbers are brought to the Baltimore markets in spring and fall.

The scales of the Drum are extensively used in the manufacture of the sprays of flowers and other articles of fancy work which are sold, especially in Florida, under the name of "fish scale jewelry." They are large and silvery, and so hard that it is necessary to remove them from the fish with an axe or hatchet.

The Drum was known to the Dutch colonists of New York as early as the middle of the seventeenth century, as is shown by references in Steendam's poem "In Praise of New Netherland," already referred to. Its name was "Dartien," while the bass was "Twalft," and the shad "Elft" - facts which give endorsement to the old tradition that the early colonists of New Netherland knew only ten kinds of fish and that when the shad came they called it the eleventh kind (Elft) the bass the twelfth (Trualft) and the Drum the thirteenth (Dartien or Derticnen). It is interesting to speculate as to which were the ten they first knew. The 
following list is probably not far from right, and is useful from its suggestions as to the origin of some of the names now in use :
I. Baars.
Perch, (white and yellow).
2. Aal.
Eel.
3. Haring.
Herring.
4. Makrecl.
Mackerel.
5. Stenbrassem and Carper.
Bream and Sucker.
6. Masbank.
Mossbunker or Menhaden.
7. Schol and Bot.
Flatfish and Flounder.
8. Steur.
Sturgeon.
9. Prik.
Lamprey.
ro. Knorhaan.
Gurnard or Sea Robin and Sculpin.

The IVcekvis (Weakfish or Squeteague), the Roch (Rock-fish), the Somne wis (Sun-fish), Swart wis (Black-fish or Tautog), were probably later discoveries, and if the New Netherlanders had been less imaginative, might have been called numbers fourteen to seventeen. The principal difficulty with this myth is that Alosa has long been known in Holland as the "Elft." Perhaps the double meaning of its name was what suggested an arithmetical nomenclature for the others.

Another historical incident is connected with Pogonias. The legend of Pascagoula and its mysterious music, deemed supernatural by the Indians is still current. "It may often be heard there on summer evenings," says a recent writer. "The listener being on the beach, or, yet more favorably, in a boat floating on the river, a low, plaintive sound is heard rising and falling like that of an Eolian harp, and seeming to issue from the water. The sounds, which are sweet and plaintive, but monotonous, "ease as soon as there is any noise or disturbance of the water."

Bienville, the French explorer, heard the music of Pascagoula, when he made his voyage in $\mathbf{I} 699$ to the mouths of the Mississippi, and his experiences are recorded in his narrative.

Mr. A. W. Roberts gives in the American Angler the following interesting notes upon observations of the Drum in confinement:

" When curator of the New York Aquarium, several small specimens of the so-called "Banded Drum" were brought to the establishment by the regular collectors. At first they were placed in the medium-sized tanks. where they increased in size so rapidly that in course of time it was found necessary to remove them to more roomy quarters, where they remairen 
up to the time of the closing up of the establishment, having been in confinement over three years, and by which time they had become the blackest of black drum; all the bands that were so conspicuous in their younger stage having disappeared entirely, although, for the last two years, the shark tank, (some seventy feet in length), in which they had been kept, was always flooded with strong sunlight in the morning and strong daylight during the afternoon, not to mention a flood of gaslight during the evening. The bottom of this tank consisted of clean and white shingle, so that a great deal of reflected light was the result, and yet these "banded drum" seemed to become blacker and blacker black drum every month. Mussels and scollops, in the shell, were their particular delight, and they always had plenty as long as I was their keeper. The bull-nosed clam was too much for their pharyngeal teeth, consequently I had them partially opened before feeding them out.

"During the spring months the males constantly pursued the females, and, on such occasions, both the males and females gave out a series of very musical and liquid drum-like sounds, which could be distinctly heard in any part of the aquarium. Often, when dredging at night-time at Princess Bay, Staten Island, I have heard the constant drumming of the drum at different points about my boat; they were evidently having a big oyster supper."

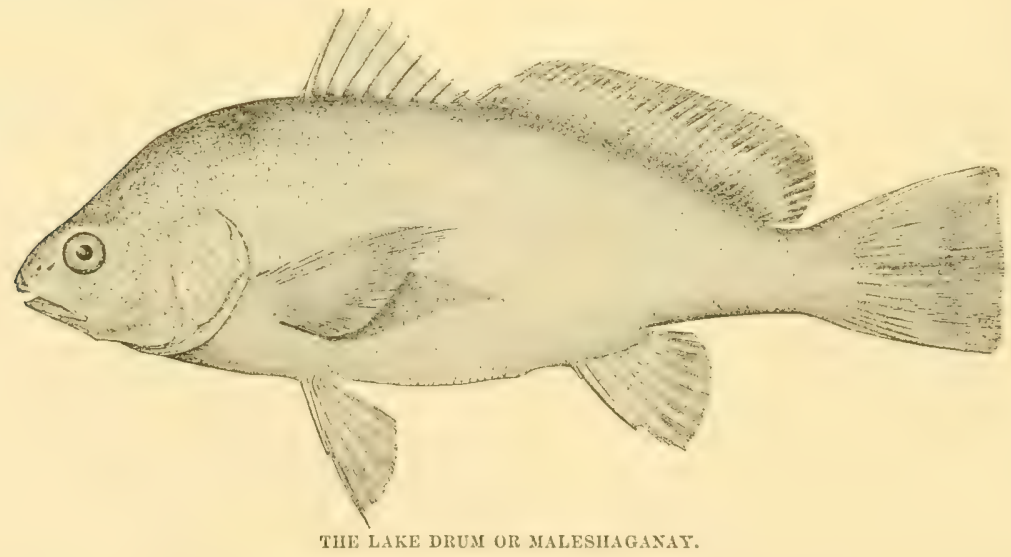

The fresh-water Drum, Haploidonotus grmnicns, is always known in the Great Lakes by the name "Sheepshead." In the Ohio River it is usually called "White Perch" or "Gray Perch," often simply "Perch." In the lakes of Northern Indiana it is called " Crocus," evidently a corruption of "Croaker." In the Southern States the name "Drum" predominates; that of "Thunder-pumper," also used for the bittern, Botau- 
mus lentiginosus, is heard along the Mississippi River. Southwestward, in Louisiana, Texas and Arkansas, it is always known as the "Gaspergou." "*

These names, "Croaker," "Drum," "Thunder-pumper," etc, refer to the croaking or grunting noise made by this species in common with most Scirnoids. This noise is thought to be made in the air-bladder by forcing the air from one compartment to another. Another name used in the southwest is "Jewel-head."

"This species," writes Jordan, "is very abundant in all large bodies of water throughout the Western States, from the Great Lakes to the Rio Grande. It seldom enters small streams. It feeds largely upon crustaceans and mollusks, but sometimes swallows other fishes. It is rather a bottom fish than otherwise. Its value as a food-fish depends on the water and food, and, unlike most fishes, its quality seems to improve to the southward. Although from its size and abundance it becones an important market fish, it cannot at best be considered one of high quality. Its flesh is tough and coarse in fiber, and often of a disagreeable shark-like odor, particularly in the Great Lakes, where it is never eaten. The flesh of partly grown specimens is better than that of the adult. It reaches a length of four feet and a weight of forty to sixty pounds. Those usually seen in market are much smaller. Nothing is known concerning its breeding habits.

The ear bones or otholiths of the Lake Drum are large and have a texture like ivory. They are often carried as amulets by the negroes of the South, and are also prized by boys in Wisconsin and elsewhere in the West, who call them "lucky stones," perhaps in allusion to the fact that they are marked by a figure which resembles the letter L. The name "Jewelhead " refers, of course, to these bones, and Jordan's generic name Eutychelithus, proposed for a form of the Lake Drum, supposed to inhabit Lake Huron, is a translation of the words "lucky stone." The Lake Huron form is in all probability identical with that of the other lakes, and it is hoped that the Indian name "Maleshaganay" may be preserved in connection with these lacustrine sciænoids.

*Mr. Norman Walker, in a recent paper on "Outdoor Life in Louisiana," published in Outins, informs "us that "gaspergou" is an Indian word, meaning "fish," and is applied by Louisianians to anything fishy" from the sheepshead to the mudsucker. 


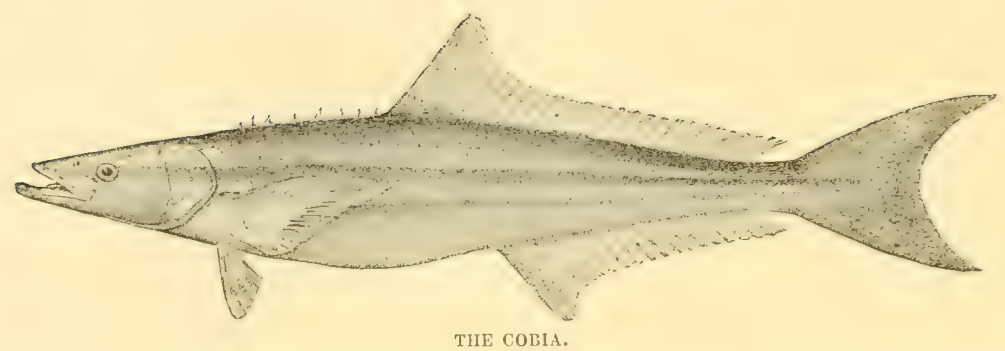

COBIA, MOON-FISH AND FLASHER.

\begin{abstract}
You strange, astonished-looking, angle-faced,
Dreary-mouthed, gaping wretches of the sea, Gulping salt-water everlastingly,

Cold-blooded, though with red your blood be graced, And mute, though dwellers in the roaring waste, What is't you do? what life lead? eh, dull goggles? How do ye vary your dull days and nights? How pass your Sundays? Are ye still but joggles, In ceaseless wash? Still nought, but gapes, and bites, And drinks, and stares, diversified with boggles.
\end{abstract}

Leigh HUnt, The Han to the Fish. 1 HE Colia or crab-eater, Elacate camada, known in the Chesapeake
Bay as the "Bonito" or the "Coal-fish," as the "Sergeant-fish" in Southern and Eastern Florida, and in parts of Florida as the "Ling" or "Snooks," is considered one of the most important food-fishes of Maryland and Virginia, though it is but little known elsewhere. Like the Bluefish, it is cosmopolitan in its distribution, having been recorded in the seas of China and Japan, in Southeastern Hindostan, in the Malay Archipelago, on the coast of Brazil, in the West Indies and the Bermudas, where it is called the "Cubby-yew," and along our own shores from the Gulf of Mexico to Cape Cod. DeKay speaks of the capture of a single individual in Boston Harbor. The species was originally described by Linnæus from a specimen sent to him from South Carolina by Dr. Garden. The name "Sergeant-fish" refers to its peculiar coloration, several stripes of brown and grey being visible on the sides of the body. The name "Crab-eater" appears to have been ascribed to the fish by Dr. Mitchill. What is known of its habits may be very shortly told. Holbrook remarked: "The Crab-eater is a solitary fish; it prefers deep and clear water and is 
only taken singly with a hook. It lives on the coast of Carolina late ir May, and is occasionally captured mutil September, when it is no longer seen in our waters. It is exceedingly roracious, and destroys many smaller fish, which make its ordinary food, though it does not reject crustaceous animals."

Mitchill dissected a specimen caught in New York Bay obtained by him in the city market in Jume, $\mathbf{S}_{\mathbf{1}} 5$. He found its stomach distended with food of various sorts, including twenty spotted sand-crabs and several young flounders. DeKay tells us that the specimen from which his description was taken was captured in a seine in the harbor of Boston and placed in a car with other fish. It was soon discovered that it had destroyed and eaten every fish in the car. These fish were chiefly sculpins and porgies. Mr. S. C. Clarke, speaking of the fish fauna of Florida, remarks: "This fish I have never seen except in the Indian River, where it is a common species, lying under the mangrove bushes in wait for prey like a pike, which it much resembles in form and in the long under jaw full of sharp teeth." The size is from two to three feet. It attains the length of five feet and the weight of fifteen or twenty pounds.

The Cobia breeds in the Chesapeake Bay, where in ISSo Mr. R. E. Earll succeeded in artificially fertilizing the eggs. Dr. Mitchill speaks of its availability as a food-fish in the highest terms.

It is occasionally taken by trolling lines in the Gulf, and seems to be regarded with favor by the anglers who have made its acquaintance. Mr. IV. C. Prime, whose charming book, "I Go a Fishing," has become one of the classics of Waltonian literature, writes:

"In shape he may be roughly likened to the great northern pike, with a similar head, flattened on the forehead. He is dark green on the back, growing lighter on the sides, but the distinguishing characteristic is a broad, dark collar over the neck, from which two black stripes or strajs. parting on the shoulders, extend, one on each side, to the tail. He looks as if harnessed with a pair of traces, and his behavior on a fly-rod is that of a wiid horse. The first one that I struck, in the brackish water of Hillsborough River at Tampa, gave me a hitherto unknown sensation. The tremendous rush was not unfamiliar, but when the fierce fellow took the top of the water and went along lashing it with his tail, swift as a bullet, then descended, and with a short, sharp, electric shock left the line to come home free, I was for an instant confounded. It was all orer in ten seconds. Nearly every fish that I struck after this behared in the 
same way, and after I had gotten 'the hang of them' I took a great many."

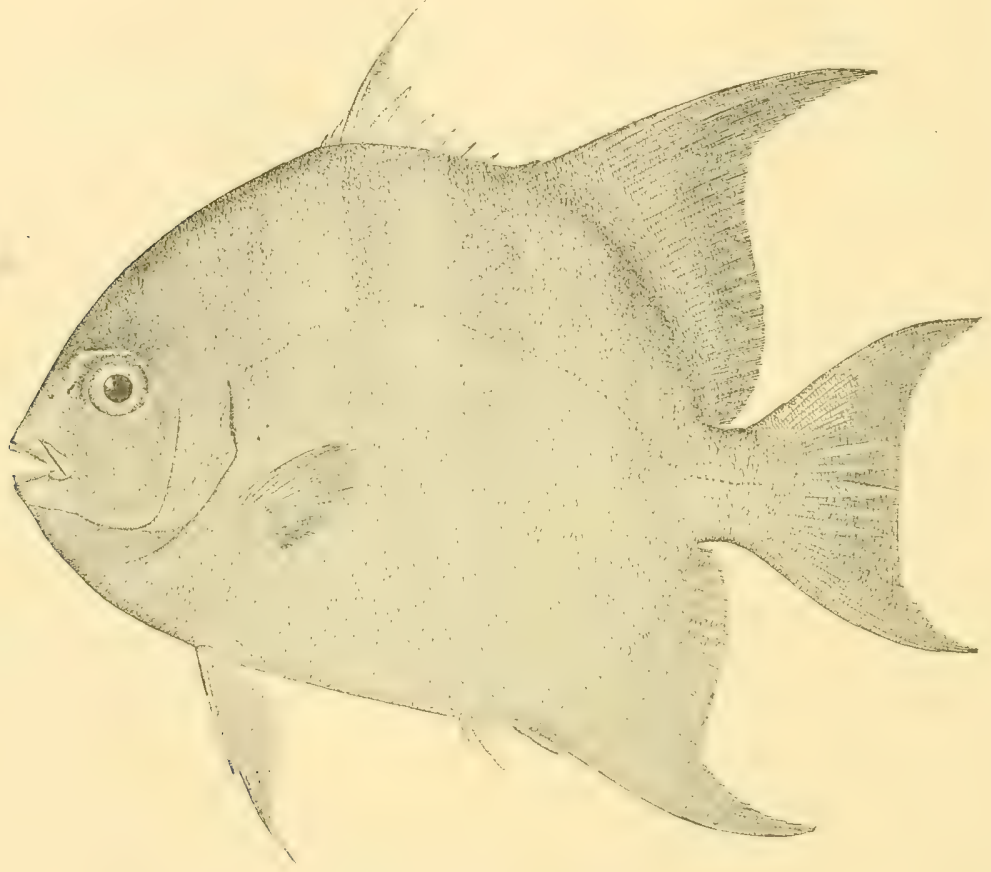

THE MOON-FISII OR SPADE-FISH.

The Moon-fish, Chatodipterus father, is one of the rarer species on our coast, and has recently come so much into faror in New York that among connoisseurs it is one of the most highly esteemed food-fishes. It is also greatly valued by residents of Washington who know it, being abundant in the markets of that city in summer. In the northern parts of the Gulf of Mexico it is called the "Spade-fish"; from Florida to Charleston the "Angel-fish," a name which, according to Schoepf, appears to have been current during the last century at Beaufort, N. C., where it is called the "Porgee" or "Porgy," and at New York, where it is stated to be found in summer. "Three-tail Sheepshead" and "Three-tailed Porgee" are names which are said to have been formerly in use among the New York fishermen. 
'The range of this species along our coast is very wide. It has loeen found in Guatemala, and perhaps farther south, and the Ijritish MIuseum has specimens from 'Texas, Santo Domingo, and Jamaica. It is said to be somewhat abundant on the coast of South Carolina, and not uncommon at the entrance to the Chesapeakc Bay. They are occasionally taken about New York, and several indiriduals have becn obtained by the Fish Commission at Woods Holl. It is occasionally taten in Southern California, about San Diego. It attains the length of eighteen inches and the weight of several pounds. The large adult specimens have a peculiar globular bone in the head, unlike anything which has been found in any other fish. Two species have been recognized by American ichthyologists. It secms probable that these represent different ages of the same fish. The only. study of its habits in existence is the following, which is quoted from Mr. Stearns' excellent journal of observations.

"The Spade-Fish, Chatodipterus fater, is common on the IVest Filorida. Alabama, and Louisiana coasts. I have not observed it in South Florida. It is found throughout the summer and fall in the bays, alout wharres, rock-piles, and old wrecks, where crustaceous animals are abundant. In October and Norember large schools are seen along the sea-beaches, eridently leaving the coast for warmer waters, at which time many are caught by seine fishermen. It spawns in early summer, and the young are seen until October. I have seen specimens of Spade-fish fifteen inches long ; but the average size is not more than eight inches. It is an excellent pan-fish, selling readily in market."

This species is known to the fishermen of the St. John's and Indian Rivers, Fla., under the name "Angel-fish." Holbrook states that it appears on the shores of South Caizlina in May and June, and is then taken in considerable numbers with the seine. Jordan states that it is common at Beaufort, N. C., where it is used as a food-fish. Lugger remarks that it is not uncommon in the salt-water region near the entrance to Chesapeake Bay, but is seldom, if ever, brought to the Baltimore markets. DeKay remarks that in the waters of New York it only appears periodically, and occasionally in great numbers during the summer months. About I 822 they were caught here in seines in great numbers, and exposecl in the markets for sale. I am not aware that any such incursion has since Leen observed. On the coast of California, where, according to Jondan, it is occasionally taken about San Diego in the kelp, it is too rare to be of commercial importance. 


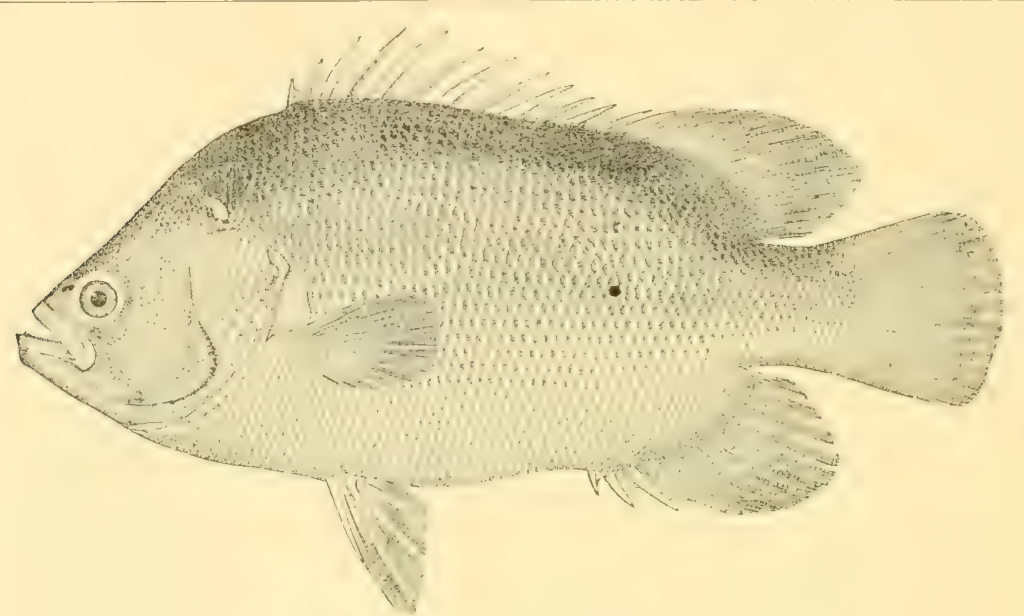

THE FLASHER.

The "Flasher" or "Triple-tail" of New York, Lobotes surinamensis, known in South Carolina as the "Black Perch," and to the fishermen of St. John's River as the "Grouper," is spoken of by various authors as the "Black Triple-tail," and in 1856 , according to Gill, was called in New York market the "Flasher." It is remarkable on account of its extraordinarily wide range, having been found in China, the Malay Archipelago, at Sunda and Molucca, in the Bay of Bengal, and in the Mediterranean about Sicily, at Ceylon, in the West Indies about Cuba and Jamaica, on the coast of South America, and in Surinam, whence the first specimen was derived, and from which locality the species takes its scientific name, and along the coast of the United States from St. John's River to Woods Holl, Mass. The Triple-tail is a short, thick, heavily built fish. The dorsal and anal fins project backwards towards the base of the caudal so prominently as to give origin to the common name. When alive it is a very beautiful species, silvery and grey in color, but after death it soon becomes dingy-so dingy, in fact, that many of the common names are prefixed by the adjective "black." I saw four specimens at Jacksonville, Fla., on the $5^{\text {th }}$ of April, 1875 . The largest weighed about ten pounds and measured nearly two feet in length. The species is abundant about Charleston, where, according to Holbrook, it appears in June and remains until September. It feeds upon small fishes and mussels, and is said to take the hook readily when baited with clams or with shrimps. It is 
occasionally taken in the lower part of the Chesapeake Lay, and Prof. Baird obtained specimens about three inches long in August among the eel-grass on Tuckahoe River, in New Jersey. Stragglers have been taken at New York, and even as far north as Wood's Hall, Mass. They are occasionally brought to the New York market, where they are highly esteemed. Gill, writing in $\Sigma_{5} 6$, said: "I saw a single specimen of this species in Fulton market last year, which remained exposed on the stall from August 30 to September 6. It did not seem to be known. It was about fifteen inches in length, and one dollar was demanded for it." De Voe saw one in Catherine market, in August, IS64, taken in a net on the Long Island coast, near Flatlands. He speaks of its excellence as a fish for boiling, comparing it to the Sheepshead. By the fishermen of St. John's River, Fla., it is considered one of the finest food-fishes, and its large silver scales command a high price at the fancy shops, where they are sold to be used in the manufacture of scale works.

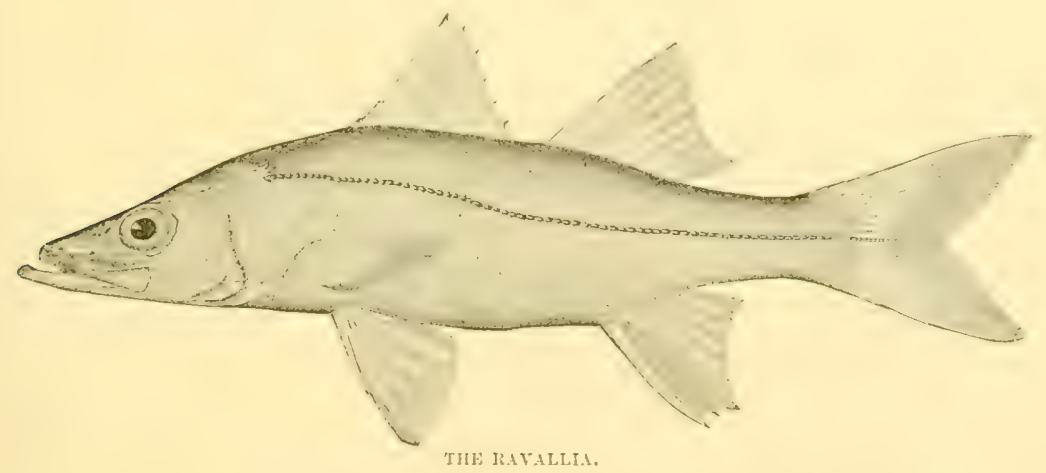

The Ravallia or Snook, Centropomus undecimalis, is a fish which has only recently been added to the fauma of the United States.

It occurs only along the Gulf coast, where it is known by the Spanish name, "Robalo," with such variations as "Ravaljo," "Ravallic" and "Ravallia." It ranges from Florida to Rio Janeiro, and occurs in the Pacific from the Gulf of California at least to Callao. The "Robalo" of Chili is quite another fish, the Pinguipes chilcnsis, of Curier. A closely allied species, Centropomus robaleto, is the "Constantine" or "Robaleto" of the Mazatlan fishermen.

The Centropomus is a perch-like fish, and is not unlike Stizostedium in appearance and structure. Its habits are very like those of its fresh- 
water ally, and it may appropriately be considered the pike-perch of the sea coast. It occurs in the sea and also in brackish estuaries. The Robalo attains the length of about three feet, and is exceedingly strong, active and voracious, feeding upon all kinds of small fishes. It is undoubtedly a good fish for the sportsman, though the "Ravallia" or "Snook" usually referred to in the chronicles of angling is Elacate.

President Jordan gives it an unqualified endorsement: "A rigorous gamy fish it must certainly be, from its build and food, though I nerer took it on the hook. I have eaten them baked, and I know them to be good, and the Creole Spanish hold them in high esteem. In structure they much resemble the striped bass, and Robalo is the Spanish name for the European bass. Probably the objection is simple prejudice. I once heard a darky, who had never before seen a Robalo, say of a twentypounder, that 'he would rather eat the devil than such a looking fish.' It is much valued on the Mexican coast and is occasionally taken about Galreston in summer. It becomes much more abundant southward along the Texas coast, and is one of the staple food-fishes about Brazos Santiago."

There is reason for caution in speaking about this fish by its common names, since we are assured by Dr. Henshall that the name "Ravallia" is very commonly applied to the Cobia, and that the name "Snooks" is the one in common use for Centropomus on the west coast of Florida. This is of course a corruption of Snoek, the Dutch name for the Pike (Esox lucins), and was used in Dampier's list of fishes printed in the seventeenth century. 


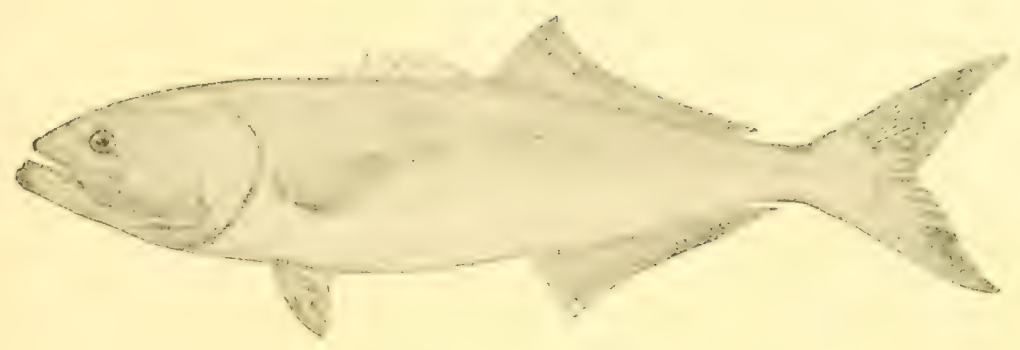

THE BLLEIISH.

And, as he darts, the waters blue

Are streaked with gleams of many a hue

Green, orange, purple and gold. MAtruew G. Lewis.

Call them Sir, by whatever name we please; whether blue-fish, of Massachusetts Bay ; snapper, of New Bedford; horse-mackerel, on the shores of Rhode Island; or tailor, in Delaware Bay, they are the same Tomnodon saltator still, and deal out destruction and death to other species in all the localities they visit.

Speech of Hox. N. E. ATwood, of the Cape District, 18;o.

THIS fish, which on the coast of New England and the Middle States is called the Bluefish, is also known in Rhode Island as the "Horse Mackerel "'; south of Cape Hatteras as the "Skipjack ;" in North Carolina, Virginia, and Maryland it is sometimes known as the "Green-fish." Young Bluefish are in some parts of New England called "Snapping Nackerel" or "Snappers;" about New Bedford "Blue Snappers;" to distinguish them from the Sea Bass they are sometimes spoken of as the "Bluefish." About New York they are cailed "Skip Mackerel," and higher up the Hudson River "White-fish." In the Gulf of Mexico the name "Mluefish" ' is in general use.

Pomatomus saltatrix is widely distributed-in the Malay Archipelago, Australia, at the Cape of Good Hope, at Natal and about Madagascar: in the Mediterranean, where it is a well-known and highly-prized foodfish in the markets of Algiers, though rare on the Italian sicle. It has been seen at Malta, at Alexandria, along the coast of Syria, and about the Canaries. It has never been seen on the Atlantic coast of Europe, and, strangely enough, never in the waters of the Bermudas or any of the Western Islands. On our coast it ranges from Central Brazil and the 
Guianas through the Gulf of Mexico and north to Nova Scotia, though never seen in the Bay of Fundy. From Cape Florida to Penobscot Bay, Bluefish are abundant at all seasons when the temperature of the water is propitious. It is not yet known what limits of temperature are the most farorable to their welfare, but it would appear, from the study of the dates of their appearance during a period of years in connection with the ocean temperature, that they prefer to avoid water which is much colder than $40^{\circ}$. It is possible that the presence of their favorite food, the menhaden, has as much influence upon their movements as water temperature. Certain it is, that few Bluefish are found on our Middle and Southern coast when the menhaden are absent; on the other hand, the Bluefish do not venture in great numbers into the Gulf of Maine at the time when menhaden are schooling and are at their greatest abundance. Their favorite summer haunts are in the partially protected waters of the Middle States from May to October, with an average temperature of $60^{\circ}$ to $75^{\circ}$. The menhaden, or certain schools of them, affect a cooler climate and thrive in the waters of Western and Central Maine in the months when the harbor temperatures are little above $50^{\circ}$ and $55^{\circ}$, and that of the ocean considerably lower.

Since Prof. Baird wrote in $187 \mathbf{1}$, there has been no great change in the abundance of Bluefish. They are quite sufficient in number to supply the demand for them and to make great inroads upon the other fishes, some of which, like the menhaden and mackerel, would perhaps, if undisturbed by the Bluefish, be more valuable than they are at present. They have now been with us for fifty years. Their numbers are subject to periodical variations, of the causes of which we are ignorant. It is to be regretted that there are no records of it in the South Atlantic States. If such existed, we might, perhaps, learn from them that the Bluefish remained in those waters while absent from the northern coasts. Only one statement is to be found which covers this period, although Lawson, in his "History of North Carolina," published in I 709 , and Catesby, in his "Natural History of the Carolinas," published in I 743 , refer to its presence. In "Bartram's Travels," published in I 79I, the "Skipjack" is mentioned as one of the most abundant fish at the mouth of the St. John's River. When Bluefish again became abundant their presence was first noticed at the South, and they seem to have made their inroads from that direction. The Bluefish was unknown to Schoepf, if we may judge from 
his work on the "Fishes of New York,", published in $17 \mathcal{S}_{7}$. Dr. Mitchill recorded their frequent capture about New York in IS I t though before $\mathbf{I} S \mathbf{I}$ they are said to have been unknown there. In IS25 they were very abundant and in $\mathrm{I} 84 \mathrm{I}$ immense numbers were captured in the Vineyard Sound, while about Nantucket they were on the increase from I 820 to 1830 . It is certain that they had not reappeared in $8_{22}$ in Narragansett Bay, for in "Dwight's 'Trarels," it is stated that, though formerly abundant, they had not been seen in that region since the time of the Revolution.

The first one which was noticed north of Cape Cod was captured in October $1 \delta_{37}$, though we have no record of their appearance about Cape Ann before 1847 .

The Bluefish is a carnivorous animal of the most pronounced type, feeding solely upon other fish. Prof. Baird remarks :

" There is no parallel in point of destructiveness to the Bluefish among the marine species on our coast, whatever may be the case among some of the carnivorous fish of the South American waters. The Bluefish has been well likened to an animated chopping-machine, the business of which is to cut to pieces and otherwise destroy as many fish as possible in a given space of time. All writers are unanimous in regard to the destructiveness of the Bluefish. Going in large schools, in pursuit of fish not much inferior to themselves in size, they more along like a pack of hungry wolves, destroying everything before them. Their trail is marked by fragments of fish and by the stain of blood in the sea, as, where the fish is too large to be swallowed entire, the hinder portion will be bitten off and the anterior part allowed to float away or sink. It is even maintained, with great earnestness, that such is the gluttony of the fish, that when the stomach becomes full the contents are disgorged and then again filled. It is certain that it kills many more fish than it requires for its own support.

"The youngest fish, equally with the older, perform this function of destruction, and although they occasionally devour crabs, worms, etc., the bulk of their sustenance throughout the greater part of the year is derived from other fish. Nothing is more common than to find a small Bluefish of six or eight inches in length under a school of minnows making continual dashes and captures among them. The stomachs of the Bluefish of all sizes, with rare exceptions, are found loaded with the other fish, sometimes to the number of thirty or forty, either entire or in fragments. 
"As already referred to, it must also be borne in mind that it is not merely the small fry that are thus devoured, and which it is expected will fall a prey to other animals, but that the food of the Bluefish consists very largely of individuals which have already passed a large percentage of the chances against their attaining maturity, many of them, indeed, having arrived at the period of spawning. To make the case more clear, let us realize for a moment the number of Bluefish that exist on out coast in the summer season. As far as I can ascertain by the statistics obtained at the fishing stations on the New England coast, as also from the records of the New York markets, kindly furnished by Middleton \& Carman, of the Fulten Narket, the capture of Bluefish, from New Jersey to Monomoy, during the season, amounts to not less than one million individuals, averaging five or six pounds each. Those, however, who have seen the Bluefish in his native waters, and realized the immense number there existing, will be quite willing to admit that probably not one fish in a thousand is ever taken by man. If, therefore, we have an actual capture of one million, we may allow one thousand millions as occurring in the extent of our coasts referred to, even neglecting the smaller ones, which, perhaps, should also be taken into the account.

"An allowance of ten fish per day to each Bluefish is not excessive, according to the testimony elicited from the fishermen and substantiated by the stomachs of those examined; this gives ten thousand millions of fish destroyed per day. And as the period of the stay of the Bluefish on the New England coast is at least one hundred and twenty days, we have in round numbers twelve hundred million millions of fish devoured in the course of a season. Again, if each Bluefish, averaging five pounds, devours or destroys even half its own weight of other fish per day (and I am not sure that the estimate of some witnesses of twice this weight is not more nearly correct), we will have, during the same period, a daily loss of twenty-five hundred million pounds, equal to three hundred thousand millions for the season.

"This estimate applies to three or four year old fish, of at least three to five pounds in weight. We must, however, allow for those of smaller size, and a hundred-fold or more in number, all engaged simultaneously in the butchery referred to.

"We can scarcely conceive of a number so vast ; and however much we may diminish, within reason, the estimate of the number of Bluefish and 
the average of their captures, there still remains an appalling aggregate of destruction. While the smallest Bluefish feed upon the diminutive fry: those of which we have taken account capture fish of large size, many of them, if not capable of reproduction, being within at least one or two years of that period.

"It is estmated by very good authority that of the spawn deposited by any fish at a given time not more than thirty per cent. are hatched, and that less than ten per cent. attain an age when they are able to take care of themselves. As their age increases, the chances of reaching maturity become greater and greater. It is among the small residum of this class that the agency of the Bluefish is exercised, and whatever reasonable reduction may be made in our estimate, we cannot doubt that they exert a material influence.

"The rate of growth of the Bluefish is also an evidence of the immense amount of food they must consume. The young fish which first appear along the shores of Tineyard Sound, about the middle of August, are about five inches in length. By the beginning of September, however, they have reached six or seven inches, and on their reappearance in the second year they measure about twelve or fifteen inches. After this they increase in a still more rapid ratio. A fish which passes eastward from Vineyard Sound in the-spring, weighing five pounds, is represented, according to the general impression, by the ten to fifteen pound fish of the autumn. If this be the fact, the fish of three or four jounds which pass along the coast of North Carolina in March return to it in October weighing ten to fifteen pounds.

"As already explained, the relationship of these fish to the other inhabitants of the sea is that of an mmitigated butcher; and it is able to contend successfully with any other species not superior to itself in size. It is not known whether an entire school ever unite in an attack upon a particular object of prey, as is said to be the case with the ferocious fishes of the South American rivers; should they do so, no animal, however large, could withstand their onslaught.

"They appear to eat anything that swims of suitable size-fish of al! kinds, but perhaps more especially the menhaden, which they seem to follow along the coast, and which they attack with such ferocity as to drive them on the shore, where they are sometimes piled up in windrows to the depth of a foot or more. 
"The amount of food they destroy, even if the whole of it be not actually consumed, is almost incredible. Mr. Westgate and others estimate it at twice the weight of the fish in a day, and this is perhaps quite reasonable. Capt. Spindle goes so far as to say that it will destroy a thousand fish in a day. This gentleman is also of the opinion that they do much more harm to the fishes of the coast than is caused by the pounds. They will generally swallow a fish of a very large size in proportion to their own, sometimes taking it down bodily; at others, only the posterior half. The peculiar armor of certain fish prevents their being taken entire; and it is not uncommon to find the head of a sculpin or other fish, whose body has evidently been cut off by the Bluefish. In the summer time the young are quite apt to establish themselves singly in a favorite locality, and, indeed, to accompany the fry of other fishes usually playing below them, and every now and then darting upward and capturing an unlucky individual, while the rest dash away in every direction. In this manner they attend upon the young mullet, atherinas, etc. They are very fond of squid, which may very frequently be detected in their stomachs. In August I 870 , about Fire Island, Mr. S. I. Smith found their stomachs filled with marine worms, a species of Heteronereis, which, though usually burrowing in the mud, at that season swims freely toward the surface in connection with the operation of reproduction. This, like the squid, is a favorite bait for the Bluefish; and they appear to care for little else when these are to be had. This fact probably explains the reason why, at certain seasons, no matter how abundant the fish may be, they cannot be taken with the drail or squid boat."

The Bluefish are believed to have had a very important influence upon the abundance of other species on some part of the coast. This has been noticed especially on the north side of Cape Cod. South of Cape Cod the small fish occur in such enormous abundance that even the voracity of millions of Bluefish could hardly produce any effect upon them. Capt. Atwood has recorded his belief that the advent of the Bluefish drove away the plaice or large flounder from those waters, not so much by their direct attacks upon them as by destroying the squid upon which the latter formerly subsisted. He is also of the opinion that the mackerel, once, for a time, were affected by them. The mackerel have since returned to those waters in their wonted numbers, but the Bluefish are not now sufficiently plenty north of Cape Cod to interfere with them. The flight of the 
mackerel was not an unmitigated evil, however, since, as Capt. Atwoorl pointed out, the number of lobsters for a time was very considerably increased. The mackerel fed upon their eggs, and when they were diven away by the Bluefish the lobsters had a better chance to multiply.

The Bluefish sometimes make their way up the rivers to a considerable distance, the adults, however, apparently never entering the perfectly fresh water. 'They are found in the Potomac as far north as Acquia Creek, and also far up the Hudson; indeed, the young of the year are taken as high as Sing Sing on the Hudson and in other tidal rivers, where the water is entirely fresh.

Summing up all the evidence in regard to the periodical appearance of the Bluefish, we find notice of its occurrence in 1672 , or even I659, and up to I $_{7} 64$. How long it existed in the waters prior to that date cannot now be determined. The oral testimony of Mr. Parker refers to its occurrence at Wood's Holl in 1780 or 1790 ; and it is mentioned by Mr. Smith as being at Newport in I 800 , and at Edgartown, Mass., about the same time, by Capt. Pease. Mitchill testifies to its occurrence in New York, of very small size, in $\mathbf{8} 8 \mathrm{Io}$; and it is recorder as existing again in Nantucket in 1820 , and about Woods Holl and Buzzard's Bay in 1830 to $183 \mathbf{I}$, and a little later at Hyannis. In 1830 it had become abundant about Nantucket, and in the fall of $\mathbf{I} \$_{37}$ it was first noticed in Massachusetts Bay, and then year by year it became more and more numerous, until now it is very abundant. Several accounts agree in reference to the very large size (even to forty or fifty pounds) of those taken in the last century.

Further research into ancient rccords may tend to throw more light on the early history of the Bluefish, and even materially to change the conclusions already reached. It will be observed that the references to its occurrence, from I 7 So to I 800 , are on the testimony of aged persons who have heard their fathers speak of it, although I find no printed records anywhere in reference to it between 1764 and $I 8 I O$. The rate of progression to the north of Cape Cod I have at present no means of indicating, although they probably gradually ranged further and further north, and very possibly occurred much further east than we have any mention of at present.

During the present century the maximum of abundance of these fish off the middle coast of the United States appears to have been reached from 
I S ro to I 860 . The testimony elicited from various observers, as well as from printed records, indicates a decrease since that period much greater in some localities than others. About New York they are said to have been unusually plenty in the summer of $\mathbf{I} 87$ I, but farther east the diminution which had been observed in previous years appeared to continue.

Diligent research by numerous inquirers during a period of sixteen years has added little to what Prof. Baird has stated and it may be regarded as almost certain that Bluefish do not spawn in our inshore waters. The only important contribution to our knowledge on this subject is found in the notes of Mr. Silas Stearns, who believes that he has abundant evidence of their spawning in the Gulf of Mexico. His remarks are quoted in full below. The Hon. Robert B. Roosevelt records that he observed the Bluefish fry less than an inch in length in the inlet of Far Rockaway, N. Y., on the roth of July:

Little is known of their reproduction. Dr. Yarrow does not give any facts in regard to this subject, at Fort Macon, except that spawn was seen to run out of a small female caught July I 4. Dr. Holbrook is also silent on this head. Mr. Genio C. Scott says the spawning beds are visited by the parent in June, and consists of quiet nooks or bays. Mr. R. B. Rooserelt states that very diminutive young occur in immense numbers along the coast at the end of September or beginning of October ("Game Fish of America," I S62, ' 859. .) Prof. Baird found the young fish at Beesley's Point, N. J., in July, I $\$_{54}$, two or three inches in length, and more compressed than the adult; but farther east, on Vineyard Sound, although diligent search was conducted, between the middle of June and the $\mathrm{s}$ st of October, with nost efficient apparatus in the way of fine-meshed nets, I met with nothing excepting fish that made their appearance all at once along the edge of the bay and harbor.

According to Capt. Edwards, of Woods Holl, a very accurate observer, they have no spawn in them when in Vineyard Sound. 'This statement is corroborated by Capt. Hinckley; and Capt. Hallett, of Hyannis, "does not know where they spawn.". 'The only positive evidence on this subject is that of Capt. Pease, who states it as the general impression about Edgartown that they spawn about the last of July or the ist of August. He has seen them when he thought they were spawning on the sand, having caught them a short time before, full of spawn, and finding them afterward for a time thin and weak. He thinks their spawning ground is on 
the white sandy bottom to the eastward of Martha's Vineyard, toward Muskeeget. While not discrediting the statement of Mr. Pease, it seems a little remarkable that so few persons on the eastern coast have noticed the spawning in summer of the Bluefish; and, although there may be exceptions to the fact, it is not impossible that the spawning ground is in very early spring, or even in winter, off New Jersey and Long Island, or farther. south. It is not impossible that, at a suitable period after spawning, the young, in obedience to their migratory instinct, may move northward along the coast, growing rapidly as they proceed. This explains the almost sudden appearance of fish of five inches about Wood's Holl.

We have the statement of Dr. Yarrow that vast schools of small Bluefish were met with in Beaufort harbor during the last week in December. is 7 I. These were in company with small schools of young menhaden and yellow-tailed shad, and were apparently working their way toward the sea by the route of the inlet. When observed, they were coming from the southward through the sound, moving very slowly, at times nearly learing it, and then returning. The largest were about four inches in length, and others were much smaller; and as many as twenty schools were observed from the wharf at Fort Macon, each of them occupying, an area of from sixty to eighty feet square, and apparently from four to six feet in depth. I would not be much surprised if these fish should prove to have been spawned late in the year off the southern coast.

The size of the Bluefish varies with the season and locality, those spending the summer on the southern coast, according to good authority, rarely exceeding two or three pounds in weight, and being generally considerably less. The largest summer specimens are those found farther to the eastward, where they are not unfrequently met with weighing from ten to fifteen pounds, although this latter weight is quite unusual. Mr. Snow, of Nantucket, mentions having seen one of twenty-two pounds, and others give as their maximum from fourteen to twenty. The average size of the schools in Vineyard Sound, during the early season, is from five to seven pounds. The schools, however, that make their appearance in October embrace many individuals of from ten to fifteen pounds. It is, therefore, not improbable that the difference between the first-mentioned average and the last represents the increase by their summer feeding. As already remarked, Bluefish in the last century sometimes attained a weight of forty or fifty pounds in Vineyard Sound; according to Zaccheus Macy, thirty of them would fill a barrel. 
Forest and Stream, June 25, I 874 , stated that L. Hathaway, Esq., a veteran fisherman, while fishing from the bridge at Cohasset Narrows, Mass., with rod and reel, captured a Bluefish weighing twenty-five pounds. The largest previously caught weighed seventeen pounds.

On getting back to the Carolina coast in the early part of November, according to Dr. Yarrow's statement, they are from three to five feet in length and weigh from ten to twenty pounds. What becomes of these large fish, that so few of them are seen in the early spring, it is impossible to say. If it be really true that they are much scarcer than in the fall, we may infer that their increased size makes them a more ready prey to the larger fish and cetaceans, or that they have accomplished their ordinary period of life; possibly that they have broken up into smaller parties, less conspicuous to observation, or that they have materially changed their locality. The average length of the fish that appear in the spring oft the coast of Virginia and the southern part of New Jersey, according to Dr. Coues, Dr. Yarrow and Prof. Baird, is about one foot, being probably about one year old. As a general rule, those of the smaller size keep close to the shore and can always be met with, while the larger ones go in schools and remain farther outside.

Prof. Baird obtained no very young fish at Woods Holl in $187 \mathrm{r}$, the smallest found making their appearance quite suddenly along the coast, especially in the little bays, about the middle of August, and then measuring about five by one and one-fifth inches. By the end of September, however, these had reached a length of seven or eight inches, and at the age of about a year they probably constitute the twelve or fourteen inch fish referred to as occurring along the southern coast. The fish of the third year, or those two years old, are possibly the three-pound fish, while the five to seven pound fish may be considered a year older still. Accurate observations are wanting, however, to determine these facts; as also whether they require two years, or three or more, to attain sufficient maturity for breeding. As far as I know, there is no appreciable difference between the sexes in their rate of growth or weight, excepting that the female is likely to be a little deeper in the body.

A Bluefish weighing one pound measures about fourteen inches; two pounds, seventeen inches; three pounds, twenty-one inches; four pounds, twenty-four inches; five pounds, twenty-six inches; six pounds, twentysix to twent $\mathrm{v}$-seven inches, and eight pounds, twenty-nine inches. 
The Bluefish is one of our most important of sea-fishes, and surpassed in public estimation only by the Spanish mackerel and the pompano. It may be said to furnish a large part of the supply to the Middle and Northern States. It is a standard fish in New York, Boston and other seaports, and is carried in great numbers into the interior. Its flesh is very sweet and savory, but it does not keep very well. In the Vineyard Sound the fishermen are in the habit of crimping their fish, or killing them, by cutting their throats in such a manner that they bleed freely. Every one who has opportunities for observing admits that fish thus treated are far superior to any others. Great quantities of Bluefish are frozen in New York for winter consumption. They are stili considered unfit for food on our Southern coast, and even in the markets of Washington, D. C. I have frequently been stopped by fish-dealers who asked me to assure their customers that Bluefish were eatable. They are growing in favor everywhere, however, just as they did in Boston. Capt. Atwood tells me that in $186_{5}$ but very few were sold in Boston, and that the demand has been increasing ever since. When he first went to Boston with a load of Bluefish he got two cents a pound for them; the second year they were scarcer, and he got two and one-half cents, and the year afterward three cents.

Within a few-years the reputation of the Bluefish among anglers has decidedly improved. Norris wrote in $\mathrm{I} 86_{5}$, that the Bluefish was seldom angled for, and that it was not esteemed as food: in I879, Hallock declares that the Bluefish and the Striped Bass are the game fish, par excellence, of the brine, just as the salmon and black bass are of fresh water. The favorite mode of capture is by trolling or squidding, a process already described. This amusement is participated in every summer by thousands of unskilled, but none the less enthusiastic, amateur fisherman, who in their sail-boats, trail the tide-rips from Cape May to Cape Cod. Many professional fishermen also follow this pursuit, especially in the Vineyard Sound, about Nantucket and along the south shore of Cape Cod, a region famous for its swift cat-boats and fat Bluefish.

Another mode which is growing in favor is that of heaving and hauling in the surf, which has been already described in writing of the Striped Bass. No rod is used, but the angler, standing on the beach or in the breakers, whirls his heavy jig about his head and casts it far into the sea, and having hooked his fish puts his shoulder to the line, and walks up the 
beach, dragging his prize after him to the shore. This is practiced everywhere on exposed sand beaches, such as are found at Montauk, Monomoy, Newport, and Barnegat.

Other anglers prefer to use a light rod and an artificial minnow from a stationary skiff near where Bluefish are breaking, or to fish with shrimp bait from the wharves in quiet bays where the young "snappers," six to ten inches in length, abound. I have seen this kind of fishing at various points, from the mouth of the Florida St. Johns to Nantucket.

The Bluefish has also an important rank among the commercial species. The wholesale dealers of New York city handle nearly 4,000,000 pounds annually. The yearly consumption of Bluefish probably does not fall much below $8,000,000$ pounds, valued at $\$ 500,000$. The markets are supplied, for the most part, from three sources. Large quantities are taken in the weirs, forty or more in number, planted on the northern and southern shores of Cape Cod, in Buzzard's Bay, Martha's Vineyard, Narragansett Bay, Peconic Bay, and at Block Island. 'The yield of these is estimated at I,300,000 pounds. Gill-nets on the southern New England coast are supposed to take about $3,000,000$. Enormous quantities are also obtained by line fishermen about Hyannis, Edgartown, Nantucket, and Eastham, and on the shores of Long Island and New Jersey.

On the igth of August, I 874 , I saw I 2,000 taken from the long pound on the west shore of Block Island.

The line-fishery is probably not less productive than gill-netting. In I 875, we were cruising about Martha's Vineyard in the Fish Commission yacht "Mollie." Off Cape Pogue we noticed at least thirty cat-boats drailing for Bluefish. These boats were about twenty feet in length, square-sterned and well housed over. Each carried three lines, one at the stern and two at the end of long rods projecting over each quarter. When we anchored at dusk in Edgartown harbor, these boats were coming in, dropping alongside of a New York market boat, which lay at the wharf. The bright lantern under the deck awning, the black forms of the fishermen, the busy changing of the little sails, the eager voices of bargaining, gave an impression of brisk trade. The same scene is repeated day after day, from July to October, in scores of New England seaport towns. 


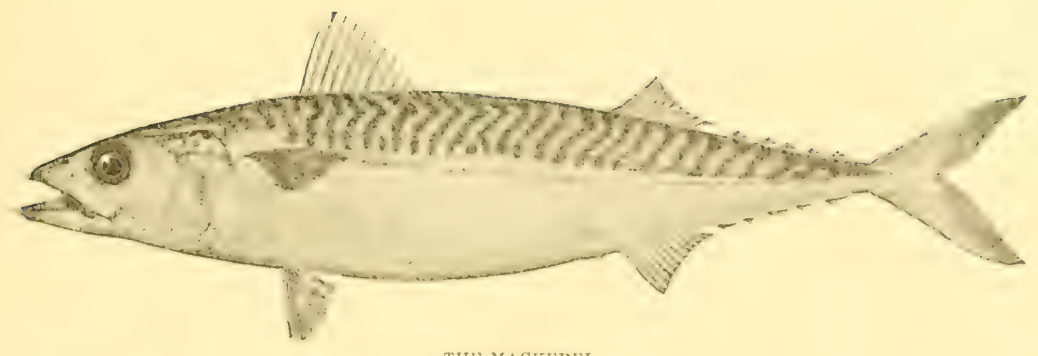

TILE M.ACKLRYL.

\title{
THE MACKEREL AND ITS ALLIES.
}

\author{
A reef of level rock runs out to sen, \\ And you may lie on it and look sheer down \\ Just where the 'Grace of Sunderland' was lost, \\ And see the elastic banners of the dulse \\ Rock softly, and the orange star-fish creep \\ Across the laver, and the Mackerel shoot \\ Over and under it, like silver boats \\ Turning at will, and plying under water.
}

Jean Ingelow, Brothers and a Sermon. HE common Mackerel, Scomber scombrus, is an inhabitant of the
North Atlantic Ocean. On our coast its southern limit is in the neighborhood of Cape Hatteras in early spring. The fishing schooners of New England find schools of them in this region at some distance from the shore, but there is no record of their having been taken in any numbers in shoal water south of Long Island. A. W. Simpson states that the species has been observed in the sounds about Cape Hatteras in August, September and October. R. E. Earll finds evidence that stragglers occasionally enter the Chesapeake. Along the coasts of the Middle States and of New England Mackerel abound throughout the summer months, and are also found in great numbers in the Gulf of St. Lawrence, where in past years fishermen of the United States congregated in great numbers to participate in their capture. They are also found on the coast of Labrador, though there is no evidence that they ordinarily frequent the waters north of the Straits of Belle Isle.

They appear also at times to have been abundant on the northeastern coast of Newfoundland, though their appearance there is quite irregular. Mackerel do not occur in Hudson's Bay nor on the coast of Greenland. 
It seems probable that the natural northern limit of the species in the IVestern Atlantic is not far from the Straits of Belle Isle. Prof. Packard, who visited this region in I 866 , recorded that a few Mackerel were taken in August in Salmon Bay and Red Bay, but that the Straits of Belle Isle is evidently the northern limits of the genus, while Fortin, one of the best Canadian authorities on fisheries, in his annual report for I 864 , stated that in summer they appear in some places, such as Little Mecattina, on the adjoining coast, latitude $50 \mathrm{I} / 2^{\circ}$ north, and even sometimes enter the Straits of Belle Isle.

The Mackerel, then, would appear to be a shore-loving fish, not addicted to wide wanderings in the ocean, and with range limited in the Western Atlantic between latitudes $35^{\circ}$ and $56^{\circ}$; in the Eastern Atlantic. between $36^{\circ}$ and $71^{\circ}$.

The migrations of the Mackerel, the causes of their appearance and disappearance at certain seasons at different points along the coast, the causes of their relative abundance and scarcity in different years, have previously been discussed by numerous writers. The subject has received special attention on account of the disputes between our own and the Canadian Government concerning the value to our fishermen of the right to participate in the mackerel fisheries in the Provincial waters.

Notwithstanding the great amount of paper which has been covered with theories to explain the various mooted questions, it cannot be said that the habits of the Mackerel are understood at all better than those of other fishes which have not attracted so much attention. The most voluminous writer upon this subject has been Prof. Henry Youle Hind, who devotes many pages of his book, "The Effect of the Fishery Clauses of the Treaty of Washington on the Fisheries and Fishermen of British North America," to the attempt to prove that the Mackerel which have been at certain seasons in the past so abundant in the Gulf of St. Lawrence and on the Atlantic coast of Nova Scotia remain there throughout the year, hibernating in deep waters not very remote from the shore. I have attempted to show the weakness of his arguments in an essay published in the Fifth Annual Report of the United States Commissioner of Fisheries for the year $\mathrm{I} \$ 77$, Pp. 50-70. It is by no means demonstrated that certain schools of Mackerel do not remain throughout the year in waters adjacent to the coast of Canada, but the weight of evidence at present seems to rest with those who believe that the Mackerel are given 
to extensive migrations north and soutl along our coasts. These migrations are believed to be carried on in connection with another kind of migration which I have called "bathic migration," and which consists in a movement, at the approach of cold weather, into the deeper waters of the ocean. The menhaden and many other fishes have these two kinds oi migrations, littoral and bathic. The sea-herring, on the other hand, has extensive littoral migrations and probably very slight movements of a bathic nature. In some the latter is most extended, in others the former. Anadromous fishes, like the shad and the alewife, rery probably strike directly out to sea without ranging to any great degree northward or southward, while others, of which the Mackerel is a fair type, undoubtedly make great coastwise migrations, though their bathic migrations may, without any great inconsistency, be as great as those which range less.

Upon this point I cannot do better than to quote from a manuscript letter from Prof. Baird to the Hon. Hamilton Fish, Secretary of State, dated July 2 I, I873. Having expressed certain views concerning the well-known phenomenon of the migration of the herring and shad, he continues:

"The fish of the Mackerel family form a marked exception to this rule. While the alewife and shad generally swim low in the water, their presence not being indicated at the surface, the Mackerel swim near the surface, sometimes far out to sea, and their movements can be readily followed. The North American species consist of fish which as certainly, for the most part at least, have a migration along our coast northward in spring and southward in autumn, as do the throngs of pleasure-seekers, and their habit of schooling on the surface of the water enables us to determine this fact with great precision. Whatever may be the theories of others on the subject, the American mackerel-fisher knows perfectly well that in the spring he may find the schools of Mackerel off Cape Henry, and that he can follow them northward day by day as they move in countless myriads on to the coasts of Maine and Nova Scotia.'"

The movements of the mackerel schools, like those of the menhaden. appear to be regulated solely by the temperature of the ocean.

In my essay upon menhaden, which has just been referred to, I have attempted to show, in a preliminary way, the relations of the movements of the menhaden schools to the temperature of the water at different stations along the coast in accordance with certain crude observations, which at present constitute the only material available as a basis of such 
generalizations. I have there claimed that menhaden make their appearance near the shore in the spring as soon as the temperature of the water in the harbors has reached a weekly average of $50^{\circ}$, and that they disappear in the fall soon after the waters have again cooled down to the same average temperature.

The Mackerel are partial to much colder waters. They range ten to fifteen degrees farther to the north, and their southern limit is proportionally high. They appear earlier in the spring and disappear later in the fall, and their presence is nearly synchronous with the time when the water temperatures of the harbor have reached a weekly average of $45^{\circ}$. It has been remarked that the presence of the menhaden depends upon a weekly average of the harbor temperature of $50^{\circ}$ or more. These harbor temperatures are several degrees - it is not known exactly how manyhigher than those of the open ocean at the same latitude, and there can be no question that the menhaden thrives in water as cold as $45^{\circ}$. Mackerel will remain active and contented in a temperature of $40^{\circ}$, or even less. The normal time of the departure of Mackerel from the coast is, therefore, a month or two later than that of the menhaden.

There are well recorded instances of the capture of menhaden in Massachusetts Bay as late as December, and there are also many instances where Mackerel have been taken not only on the New England coast, but also in the Gulf of St. Lawrence, in midwinter.

Basing their arguments upon such occurrences as these, Canadian writers have attempted to prove that large bodies of Mackerel hibernate along their shores in the winter months. It is still believed by many fishermen that the Mackerel, at the approach of cold weather, go down into the mud and there remain in a state of torpidity until the approach of warm weather in spring. All that can be said regarding this theory is that, although we do not know enough about the subject to pronounce this impossible, American ichthyologists think they know enough to be of the opinion that it is very decidedly improbable.

The appearance of the mackerel schools at the appearance of summer in ordinary years has been noticed somewhere in the neighborhood of the following dates: At sea, off Cape Hatteras, March 20 to April 25 ; off Norfolk, Va., March 2 to April 30 ; off the Capes of Delaware, April 15 to May I ; off Barnegat and Sandy Hook, May 5 to May 25, and at the same date along the whole southern coast of New England, and as far 
east as Southern Nova Scotia, while in the Gulf of St. Lawrence they appear late in May, and in abundance early in Junc.

There appears to be a marked difference between the movements of Mackerel and the menhaden, for while the menhaden are much more gradual in their approach to the shore, and much more dependent upon a small rise of temperature, the Mackerel make their appearance almost simultaneously in all the waters from New Jersey to Nora Scotia at about the same time. Stragglers, of course, appear much earlier than the dates just mentioned; a few Mackerel were observed at Waquoit, Mass., as early as April i 9, I 87 I.

In the fall the Mlockerel disappear as suddenly as they came in the spring, but they have only in one instance been observed off the Carolina coast, except durirgs the spring run. This is very probably because no fishing vessels ever visit this region later than June.

The very vaguteness of the statements just made is sufficient to show how little is aclually known about the movements of these fish. The subject must be studied long and carefully before it can be understood, and the interests of the American fishermen demand that it should be thus studied

The Maciserel belongs to what may technically be termed pelagic or wandering fish, as their movements, something like those of the herring, are apparently more or less capricious, though probably governed by some definite law, which has not yet been worked out. It moves in large schools or bands, more or less isolated from each other, which sometimes swim near the surface and give distinct evidence of their presence, and at others sink down into the depths of the ocean and are entirely withdrawn from observation. The army of fish, however, moves along with a rery broad front, a portion coming so close to the shore as to be taken in the weirs and traps along the coast of the Middle States, especially in Vineyard Sound and on Cape Cod; while at the same time other schools are met with from twenty to fifty miles, or even more, out to sea. It is, however, still a question whether the fish that skirt the coast of the United States enter the Bay of St. Lawrence, or whether the latter belong to another series, coming directly from the deep seas off the Newfoundland and Nova Scotia coast. Until lately the former has been the generally accepted theory, in view of the alleged fact that the fishermen of the Nova Scotia coast always take the fish coming from the west in the spring and from the east in the fall. 
Capt. Hanson B. Joyce, of Swan's Island, Me., one of the most expert and observing mackerel fishermen of New England, thinks that the movements of the spring schools of Mackerel are very much influenced by the direction and force of the prevailing winds while the fish are performing their northerly migration. He has generally found, he says, that when there has been a continuance of strong northerly winds about the last of May and early in June, the season at which the Mackerel are passing the shoals of Nantucket and George's Bank, the schools have taken a southerly track, passing to the southward of George's Shoals and continuing on in an easterly direction to the coast of Nova Scotia, and thence to the Gulf of St. Lawrence.

When southerly winds or calms prevail at that season the Mackerel are carried into the waters of the Gulf of Maine, and in consequence are much plentier off the New England coast than in the St. Lawrence Gulf.

On this theory Capt. Joyce bases his actions in cruising for Mackerel, always fishing off the New England shores when southerly winds have predominated in the spring, and going to the St. Lawrence if northerly winds have been exceptionally strong and continues about the last of May.

The movements of the fish, as already stated, season by season, are quite uncertain, sometimes being very abundant in one direction and sometimes in another, and occasionally, indeed, they may disappear almost entirely for several years, subsequently reappearing after a considerable absence. In some years the fish are very abundant on the coast of the United States, and at others rare; the same condition applying to the fish of the Bay of St. Lawrence. It is not certain, of course, that this indicates an entire absence of the fish from the locality referred to, but they may, possibly, for some reason, remain in the depth of the sea, or some change in the character of the animal life in it, which constitutes the food of the fish, may produce the changes referred to. A notable instance of a somewhat permanent change in the migration of the Mackerel is found in the entire failure since $1 \delta_{7} 6$ of the mackerel fishery in the Bay of Fundy, which, a few years ago, enabled a merchant of Eastport to employ successfully as many as a dozen ressels, especially in Bigby and St. Mary's Bay, but which is now abandoned. There are indeed faint suggestions, in the early history of the country, of their total absence from the whole coast for several years, as was also the case with the bluefish. 
The wonderful abundance of Mackerel in the Western Atlantic has always been a subject of remark. Francis Higginson, in his "Journal of his Voyage to New England, 1629," speaks of seeing "many schools of Mackerel, infinite multitudes on every side of our ship," off Cape Ann on the 26 th of June; and Richard Mather, in his jourmal, I 635 , states that the seamen took abundance of Mackerel off Menhiggin (Monhegan). In Gov. Winthrop's journal, speaking of the year 1639 , he remarks: "There was such a store of exceeding large and fat Mackerel upon our coast this season as was a great benefit to all our Plantations, since one Boat with three men would take in a week ten hogsheads, which were sold at Connecticut for $£ .3$ i2s. od. per hogshead."

'Their abundance has varied greatly from year to year, and at times their numbers have been so few that grave apprehensions have been felt lest they should soon depart altogether.

As early as 1670 , laws were passed by the colony of Massachusetts forbidding the use of certain instruments of capture, and similar ordinances have been passed from time to time ever since. The first resource of our State governments has always been, in seasons of scarcity, to attempt to restore fish to their former abundance by protective legislation. It seems to us at the present day absurb that the Massachusetts people should have supposed that the use of shore-seines was exterminating the Nackerel on the coast of Massachusetts, but it is a fair question whether their apprehensions were not as well grounded as those of legislators of the present century who have endeavored to apply a similar remedy for a similar evil. In the author's writings upon "The Mackerel Fishery" published elsewhere, is shown a diagram, which, by means of curves, exhibits the catch of Mackerel in New England for a period of seventy-five years.

From a study of this it seems quite evident that the periods of their abundance and scarcity have alternated with each other without reference to overfishing or any other causes which we are prepared to understand. In the year $3^{8} 3,548 \mathrm{~s} / 2$ barrels of Mackerel were caught by the citizens of Massachusetts. In ISSI the number of barrels salted was 269,495 ; to this, however, should be added I 25,000 barrels caught and marketed fresh by the Massachusetts fleet, making an aggregate of 394,495 barrels.

The stories which are told by experienced fishermen of the immense numbers of Mackerel sometimes seen are almost incredible. Capt. King Harding, of Swampscott, Mass., described to me a school which he saw 
in the South Channel in I 848 : "It was a windrow of fish," said he ; " it was about half a mile wide and at least twenty miles long, for vessels not in sight of each other saw it at about the same time. All the vessels out saw this school the same day." He saw a school off Block Island, I877, which he estimated to contain one million barrels. He could see only one edge of it at a time.

Upon the abundance of Mackerel depends the welfare of many thousands of the citizens of Massachusetts and Maine. The success of the mackerel fishery is much more uncertain than that of the cod fishery, for instance, for the supply of cod is quite uniform from year to year. The prospects of each season are eagerly discussed from week to week in thousands of little circles along the coast, and are chronicled by the local press. The story of each successful trip is passed from mouth to mouth, and is a matter of general congratulation in each fishing community. A review of the results of the American mackerel fishery, and of the movements of the fish in each part of the season, would be an important contribution to the literature of the American fisheries.

The food of the Mackerel consists, for the most part, of small species of crustaceans, which abound everywhere in the sea, and which they appear to follow in their migrations. They also feed upon the spawn of other fishes and upon the spawn of lobsters, and prey greedily upon young fish of all kinds. In the stomach of a "Tinker" Mackerel, taken in Fisher's Island Sound, November 7, I877, Dr. Bean found the remains of six kinds of fishes-of the anchovy, sand-lants, the smelt, the hake, the barracuda and the silver-sides, besides numerous shrimps and other crustaceans. Capt. Atwood states that when large enough they devour greedily large numbers of young herring several months old. Specimens taken July i 8 , I 87 I, twenty miles south of Noman's Land, contained numerous specimens of the big-eyed shrimps, Thysanopoda, larval crabs in the zoea and megalops stages, the young of hermit crabs, the young lady crabs, Platyonichus ocellatus, the young of two undetermined Macrura, numerous Copepoda and numerous specimens of Spirialis Gouldii, a species of Pteropod. They also feed upon the centers of floating jelly-fishes (discophores). In Gaspé the fishermen call jelly-fishes "mackerel bait."

The greed with which Mackerel feed upon the chum, or ground menhaden bait, which is thrown out to them by the fishing vessels, shows that they are not at all dainty in their diet, and will swallow without hesitation any kind of floating organic matter. 
Large Mackerel often eat smaller ones. Capt. Collins has frequently found young Mackercl three or four inches long in the stomachs of those full grown. This is generally noticeable only in the fall, and the young fish are probably those which have been hatched in the spring.

In the fall of $\mathbf{I} 87$ the writer made a trip upon a gill-net schooner to the grounds off Portland, Me., some distance to sea, for the purpose of studying the food of the Mackerel, and found their stomachs full of a species of Thysanopoda and of a large copepod crustacean. The greater part of the food of Mackerel consists, however, of minute crustaceans. Owing to the infinite abundance of these in the sea, Mackerel probably have very little difficulty in finding food at almost any portion of the ocean visited by them, whether on the edge of the Gulf Stream or near the shore.

In an interview with Capt. King Harding, of Swampscott, one of the most experienced mackerel catchers on our coast, I obtained the following amusing observations: "He described one kind of crustacean Mackerel food which looked like spiclers, which were red, and crawled over his hand when he took them up. They look like spiders; the Mackerel are especially fond of them. At Boone Island, Me., in July, r $85^{\circ}$, the water all around the island was red for one hundred yards from the shore; these crawled up the rock-weed on the shore until it was red. He took the sprays of rock-weed in his hands and pulled them slowly to him, and the Mackerel, one and a half pound fish, wouid follow in quite to the rocks. He killed three with his oar, and tried to catch some in a basket by trolling them over it, but they were too quick for him. He asked his old skipper, Capt. Gorham Babson, what they were, and was told that they were "Boone Island bedbugs." And, said he, "Young man, when you see this kind of bait, no matter if you don't see any fish, never leave; the fish will be there in a few days."

'Then there is another kind, called "snappers." These are white, and dart rapidly about in the water; they are doubtless small crustaceans. He says that sometimes they swim at the surface, where the Mackerel follow them. A few days before he had been standing on the stern of his vessel, and though he could see nothing under the water he knew the snappers were there about two feet below the surface, for he could see a school of Mackerel swimming along, opening their mouth and taking in their food, and then letting the water out through their gills. 
When the Mackerel are trolled up from twelve or fifteen fathoms below the surface theirstomachs are often full of bait; so it is certain that these little animals swim at all depths.

Another kind of food is red, and is hot to the hands. This is called "Cayenne ;" and it spoils the fish.

Years ago, according to Capt. Harding, Mackerel did not school as they do now.

When you see pollock jumping near the shore, it is a pretty good sign that there is plenty of mackerel food.

The presence of abundance of mackerel food is indicated by the great schools of sea-birds, particularly by the flocks of phalaropes, or sea-geese, as the fishermen call them, which congregate together, floating upon the water, and when seen in summer give a sure sign of the presence of Mackerel also.

The various invertebrate animals preyed upon by Mackerel are known to the fishermen by such names as "shrimp," "red-seed" and "Cayenne."

The winged pteropods very probably form an important part of the mackerel food, as they sink and rise with changes of the temperature of the zone or sheet of water in which they are feeding.

Although little is actually known concerning the spawning habits of the Mackerel compared with those of fish which, like the shad and the salmon, have been artificially propagated, it is perhaps safe to say that the subject is understood in a general way. The testimony of reliable observers among the fishermen of our coast and the coast of the British Provinces indicates that the spawning takes place in rather deep water along the shore from the eastern end of Long Island to Eastport, Me., along the coast of Nova Scotia, and in the Gulf of St. Lawrence. The spawning season occurs in May in Southern New England, in May and June in Massachusetts Bay, and in June in the Gulf of St. Lawrence, and on the Bradley Banks and about the Magdalenes early in the month, and according to Hind, on the northeast coast of Newfoundland toward the end of the month.

We are indebted to Capt. N. E. Atwood for the most complete series of observations upon the spawning of the Mackerel which has ever been made, and what he has seen he shall be allowed to tell in his own words: 
"I have many seasons been engaged in fishing for Mackerel in our bay with gill-nets. I watched the Mackerel more particularly in regard to their time for spawning. In $1 \delta_{5} 6$, owing to the fact that a measure had passed the Massachusetts legislature authorizing the appointment of three commissioners to make investigations with regard to the artificial propagation of the fish, and that I expected to be named one of the commissioners, I went to the upper part of Massachusetts Bay, where it is about twenty miles broad, and I found these spawning Mackerel there near the bottom. This year the Mackerel came in about the middle of May; few at first. On the zoth I went out for the first time with my drifting-nets all night in the bay; I caught 2,250 Mackerel; on the following I caught 3,520. WThen I first began to catch them I observed that the spawn had come to its full size, though it was not free to run from them, not being yet fully matured. On or about the ist of June we found that some of them were depositing spawn, and as I took them from the nets the spawn ran freely. On the $5^{\text {th }}$ of June I took the mature eggs as they came from the fish and put them in alcohol, marking the date, as I considered this time the middle of the spawning season. (By the roth of June the fish had all deposited their spawn, and they then proceeded to the grounds where they expected to meet with better food in order to fatten and recruit. The spawning takes place at a depth of from five to fifteen fathoms.) Thirty days after I went out in the bay and found any quantity of schools of little Mackerel which were, I should think, about two inches long, though their length might have been a little less. I took a number of specimens and put them in allcohol, marking the date. Twenty-five days later I procured another lot of them which had grown to double that size. I don't mean to imply that they were twice as long, but twice as heary. I put them also in alcohol, marking the date. The first time I subsequently went to Boston I called on Prof. Agassiz and gave him the specimens. Fie said that he had never before been able to ascertain these facts so clearly and so well, and that he was very much pleased with them. I watched the growth of these young Nackerel all along, and I saw them grow considerably from month to month, so much so that the same fall, in the latter part of October, I caught some of them with a very small mesh net and found they had grown to a length of six and a half or seren inches. I kept a small quantity of them, split, salted and packed them, in accordance with the Massachusetts inspection law, as No. 4's, and since Mackerel were then scarce and very high in price, I sold them for as much as $\$ 6$ a barrel."

"Much yet remains to be learned in regard to the spawning season of the American Mackerel," writes Prof. Baird, " and little more is known of this except in regard to the European variety. It is, however, well established by the researches of Sars that this fish, like the cod, and many 
of the flat fish, etc., spawns in the open sea, some times at a great distance from the land, at others closer inshore." Sars found them on the outer banks of the coast of Norway; and Mr. Matthias Dunn, of Mevagissey, England, communicates to Land and WVater his observations of Mackerel found, with ripe spawn, six miles from the coast.

The fish taken in the weirs and pounds on Vineyard Sound and about Cape Cod in the early spring are filled with ripe spawn; and that the operation of spawning takes place on the American coast is shown by the immense schools of small fish that are taken throughout the summer, of various sizes, from a few inches up, and from Buzzard's Bay to Portland and Penobscot Bay. No species of young fish is, at times, more abundant throughout the summer season than the Mackerel.

The egg of the Mackerel is exceedingly minute, not larger than that of the alewife or gaspereau. It appears to be free from an adhesive envelope, such as pertains to the egg of the herring, and in consequence of which it agglutinates together, and adheres to gravel, the rocks or the seaweed at the bottom. As with the egg of the cod, that of the Mackerel is provided with an oil globule, which makes it float nearly at the level of the surface.

I am indebted to Mr. Frederick WV. True for an enumeration of the eggs in two Mackerel taken at Wood's Holl, Mass., in May, I873; one of these contained $36_{3}, 107$, the other 393,887 .

The only previous record of the number of eggs yielded by Mackerel is that made by Thomas Harmer, in I 764, and published in the "Philosophical Transactions" of London, Vol. 57, p. 285. He found in one large Mackerel, weighing one and a quarter pounds, 454,99I eggs; in a second, of much the same weight, 430,846 , and in a third, weighing about one pound two ounces, 546,68 I.

The growth of the Mackerel has been studied by Capt. Atwood, and the same authority has, perhaps, more satisfactorily than any other, interpreted the facts from which may be deduced the conclusions as to their growth year by year.

Referring to the small fish, six and a half or seven in length, which he believed to be the young of the year, caught by him in October, $1 \$ 56$, he says: "Fish of this size are sometimes called "Spikes,' but I do not know their proper name. The next year I think they are the 'Blinks,' being one year old; the following year they are the 'Tinkers,' two years old, and the year after they return to us as the sccond size, three 
years old. It is probable that the fish reaches its full maturity in four years." He continues: "The first Mackerel that come in are very large and spawners, but these do not bite at the hook; and you don't catch them with the seine, because they don't show themselres. You would not know of their presence if you did not set nets for them. When they are taken in nets set anywhere along the coast, at Provircetown, etc., a good many people imagine that they are the remnant of the Mackerel which were there the year before, and which have been imbedded in the mud; and when they taste these fish they fancy that they taste mud. When the next school arrives there appear Mackerel of different sizes, which take the hook. They are carried to Boston market and are sold fresh in their season. They are not sold by weight, but are culled, and are denominated as follows: Large ones, second size, 'Tinkers,' and 'Blinks.' When the large ones are worth twelve cents, the others may sell, second size, eight cents; Tinkers, four cents, and Blinks, one and a half cents. These prices may fluctuate when there occurs a large proportion of one or more of the above-named kinds at the same time. Any man who is well acquainted with them will make the same culling, as there seems to be a line of demarcation between the different kinds which stands out prominently.

"Admitting this to be the fact, those that come as Blinks are from the spawn of the year before, while those which are called 'Tinkers' are from the Blinks of the year previous, being the two-year-old fish; and those that are called second size are from the Tinkers of the year before; when they grow up and mix with the bigger ones, I don't know how they live, or much about them. This is my opinion about these matters. You will find that fishermen will tell you they think that Mackerel are six or seven years in getting their growth."

Mackerel, when full grown, are from seventeen to eighteen inches in length; sometimes they attain a larger size. In August, I8So, a school of Mackerel was taken in the vicinity of Plymouth; they weighed from three to three and a half pounds each, and were from nineteen to nineteen and a half inches long. They were regarded as extraordinary large, and a barrel of them were sent to the Fishery Exhibition at Berlin as an illusIration of the perfection to which the Mackerel attains in this country. Although the size mentioned is unusual at present, in past years many thousands of barrels have been taken nearly, if not quite, as large. The 
size varies from year to year, sometimes very few barrels which can be rated as No. I's being found in our waters. A No. I Mackerel, according to the Massachusetts inspection laws, measures thirteen inches from the tip of the snout to the crotch or fork of the caudal fin. The average length from year to year for the whole coast is probably not far from twelve inches in length, and a weight of twelve to sixteen ounces.

The gannet is one of the most destructive enemies of the Mackerel. These birds are often seen so heavily weighted with these fish that they are unable to rise on the approach of the vessel until they have disgorged from two to four good-sized Mackerel. This is so common an occurrence that there are but few fishermen who have not witnessed it.

Porpoises and whales may also be included in the list of enemies of the Mackerel. It is by no means an unusual sight on the fishing grounds to see hundreds of the former rushing and leading among schools of Mackerel, scattering them in every direction.

The shark known to fishermen as the "mackerel shark" is one of the principal enemies of the Mackerel. I have often seen them chasing Mackerel, and, when jigging was practiced, it was a common occurrence for sharks to drive off a school from alongside of a vessel.

Dogfish often hover around the outside of large schools of Mackerel, and doubtless feed on them. Great difficulty is sometimes experienced in saving fish that have been inclosed in a purse-seine, owing to the immense numbers of dogfish that gather around and, in their efforts to eat the Mackerel, which they see through the meshes, bite off the twine, making large holes in the seine through which the inclosed fish escape.

Among the other principal enemies of the Mackerel are the bluefish, and the cod. The appearance of a school of bluefish in waters crowded with $M$ Iackerel is an almost sure signal for their disappearance.

The young Mackerel are eaten by squids also. Prof. Verrill has recorded the following account of the maneuvers of the squid known to zoölogists by the name Ommastrephes illecebrosus:

"Messrs. S. I. Smith and Oscar Harger observed it at Provincetown, Mass., among the wharves, in large numbers, July 28 , engaged in capturing and devouring the young Mackerel, which were swimming about in 'schools,' and at that time were about four or five inches long. In attacking the Mackerel they would suddenly dart backward among the fish with the velocity of an arrow and suddenly turn obliquely to the right or left 
and seize a fish, which was almost instantly killed by a bite in the back of the neck with the sharp beaks. The bite was always made in the same place, cutting out a triangular piece of flesh, and was deep enough to penetrate to the spinal cord. The attacks were not always successful, and were sometimes repeated a dozen times before one of these active and wary fishes could be caught. Sometimes after making several unsuccessful attempts one of the squids would suddenly drop to the bottom, and, resting upon the sand, would change its color to that of the sand so perfectly as to be almost invisible. In this way it would wait until the fishes came back, and when they were swimming close to or over the ambuscade, the squid, by a sudden dart, would be pretty sure to secure a fish. Ordinarily when swimming they were thickly spotted with red and brown, but when darting among the Mackerel they appeared translucent and pale. The Mackerel, however, seemed to have learned that the shallow water is the safest for them and would hug the shore as closely as possible, so that in pursuing them many of the squids became stranded and perished by hundreds, for when they once touch the shore they begin to pump water from their siphons with great energy, and this usually forces them farther and farther up the beach. At such times they often discharge their ink in large quantities. The attacks on the young Mackerel were observed mostly at or near high water, for at other times the Mackerel were seldom seen, thongh the squids were seen swimming about at all hours; and these attacks were observed both in the day and evening."

The dog-fish is doubtless a dangerous foe to the Mackerel weakened by the act of spawning and remaining near the bottom. An old fisherman has described to me with great animation how greedily the dogfish devour the Mackerel which have become gilled in the nets, how they follow them to the surface and linger about the vessel while the process of cleaning is going on, drinking the blood of the fish as it flows from the scuppers.

The Chub Mackerel, Scombor colias, or, as it is called, the "Thimbleeye," "Big-eyed Mackerel," or "Bull Mackerel," closely resembles in feneral appearance the common Markerel, from which it is distinguisheel chiefly by the presence of an air-bladder, and also by the occurrence of a row of indistinct circular spots upon the sides below the lateral line. This is the fish which is called "Spanish Mackerel" in England, and the name was brought to us by the early English fishermen of New England. It has been found at Pensacola and Charleston, as well as in New England. There is another fish closely related if not identical with $S$. colias, which Prof. Jordan found to be abundant in California, which corresponds to the S. fnimmatophorus of the Alediterranean, and has licen elescribed from 
the Pacific as S. aiego. Prof. Jordan considers it to be the S. grex of various authors, but writes that he is not yet prepared to accept as final the judgment of Steindachner and Taillant that it is the young of $S$. colias. The lower half of its sides is silvery and without any gray spots, such as are conspicuous in $S$. colias. Jordan has specimens of the unspotted form much larger than his smallest specimens of the true $S$. colias.

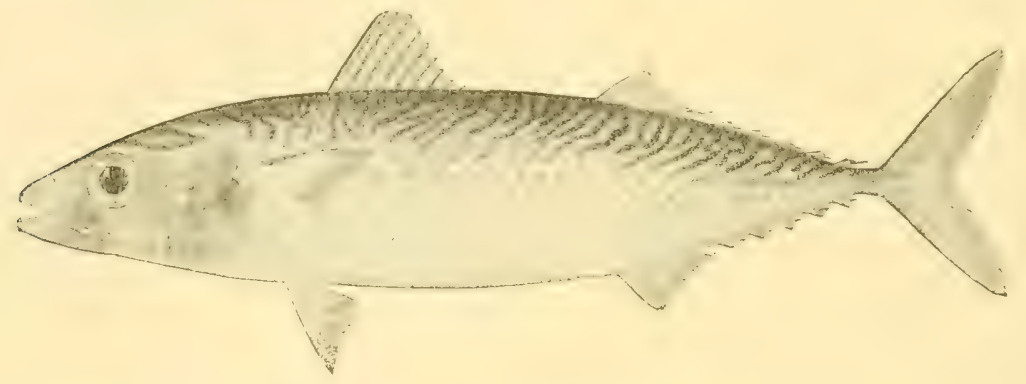

THE CHUB ALACKEREL.

The history of the Chub Mackerel on our coast is a peculiar one. At the beginning of the present century it was exceedingly abundant all along the coast of New England and New York. Mitchill remarked that it "comes occasionally in prodigious numbers to the coast of New York in autumn. This was memorably the case in $I_{7} 8 I_{1}$ and $I_{8} I_{3}$, when the bays, creeks and coves were literally alive with them, and the markets full of them."

DeKay states that in early November, $\mathbf{I} 8_{2} 8$, they were very abundant, and many persons were poisoned by eating them.

Capt. Epes W. Merchant, of Gloucester, a veteran fishing skipper, who has been familiar with the fisheries of Massachusetts Bay for the past seventy years, told me that the Thimble-eye were so abundant from i $\mathrm{S}_{\mathrm{I}} 4$ to I 820 that with three men and a boy and a small vessel he could catch ten barrels of them, or about three thousand fish, in a day.

From these testimonies it would appear that between I 840 and I $S_{50}$ the species, formerly so abundant, had disappeared along the whole coast line. In an essay by the writer, written in the spring of $x \delta_{79}$, this sentence occurs: "For ten years past the Smithsonian Institution, with its collectors stationed at various points from Halifax to Galveston, has tried in vain to secure one of them, and it is probable that no museum in the world possesses a species of this fish, once so common." 
In the summer of IS79, however, during the stay of the Fish Commission at Provincetown, a considerable school of these fish came into the harbor and were taken in company with the Tinker Mackerel. None were observed there in I 880 , however, and it remains to be seen whether they have returned to be again counted among the permanent members of the fauna. 'This fish, during the period of its abundance on our coast, was considered an excellent article of food, and was by many preferred to the common Mackerel. On account of its small size, however, it was not so much sought after by the fishermen.

Concerning the Mackerel of the Pacific coast, which Prof. Jordan considers to be identical with the Scomber pneumatophoms of the Eastern Atlantic, this authority writes:

"The Tinker Nackerel, S. pncumatophoms, is known as 'Nackerel,' 'Easter Mackerel,' 'Tinker Mackerel' and 'Little Mackerel.' It reaches a length of about fourteen inches. It ranges northward to Monterey Bay, appearing in the fall in irregular and often large schools, usually disappearing in November. Some years few or none are seen. It is a good food-fish, but little attention is paid to it, on account of its small size and irregular occurrence."

The Mackerel is the principal rival of the cod in the claim for highest rank among the food-fishes of North America. Nany thousands of men and many hundreds of vessels are employed in their capture, and their migrations in which they are followed by fleets of swift schooners, are the subject of annual discussion in the halls of Congress, and the disputes of the sallor-fishermen of Canada and New England have long been made the subject of treaty and international convention.

The statistics and methods of the commercial fisheries have been fully discussed in a volume entitled "Materials for a History of the Mackerel Tishery," prepared by Messrs. Goode, Collins, Earll and Clarke and printer? by the U. S. Fish Commission in $\mathrm{I} S 8_{3}$, and will be but briefly alluded to here. It seems proper, however, to refer to the history of the various modes of capture employed by our fishermen.

The method chiefly practiced by the colonists of New England was that of drag-seining, and we find as early as 1626 a record of the establishment, by Isaac Allerton, of a fishing station at Hull, where mackerel were seined by moon-light. There can be little doubt that the practice of fishing with baited hooks were also early introduced, and that in the 
seventeenth and eighteenth centuries groups of boats might have been secn, as at the present day, clustered together in the harbors, or near the outer shores, their crews busily engaged in hauling in the tinkers, and, occasionally, larger mackerel, which during the summer season found their way into those protected waters. It is not known when the custom of drailing for mackerel was first introduced, but it was, beyond question, the common method at the close of the last and the beginning of the present century, as it is in the present day in England, under such names as "whiffing," " railing," "drailing " or "plummeting."

Captain Atwood writes: "In my boyhood, when I caught my first mackerel, nobody thought of jigging them. We then took them in the some way as bluefish are caught. My first experience in mackerel fishing took place when I was a little boy, about ${ } S_{5} 5$. I went out with two old men. One of them fished in the stern of the boat, and when it did not sail fast enough the other and myself-I was eight years old at the time-had to row, in order, by the more rapid motion of the boat, to induce the fish to bite. They would not bite unless the line was towed. Two great long poles were run out, one just forward, in such a manner that our vessel had the appearance of a long-armed spider. The poles were straight, and one line was fastened at one part, and another line on the end of the pole, in order to have them separated."

"The present mode of catching mackerel by drifting and tolling with

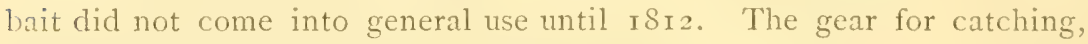
previous to that, was a white hempen bob-line, as it was called, and the style of fishing was called 'bobbing' mackerel. 'These lines were some seven fathoms in length, with a leaden sinker two inches long and shaped like a pea-pod. At one end was a ganging about a foot long, for the hook. Every few minutes off would go the hook, and extra hooks were always in readiness to replace those lost. This mode continued until the year isi6, when Abraham Lurvey, of Pigeon Cove, discovered a method of running lead around the hooks, and which were afterward called jigs. This he kept secret for many months. The hooks then in use were nearly as large as the haddock hooks of to-day. The small lines and fly-lines did not come into use until about $\mathrm{r}_{23}$. About this time the gaff was introduced, and was abandoned after being used some ten years.* 
The mackerel fishery at the time of its highest developement, from r 820 to $S_{7}$, was carried on almost exclusively by the use of little hooks with heavily weighted shanks, known as "mackerel jigs." For many years there were from six-hundred to nine-hundred vessels, chiefly from Cape Cod and northward, engaged in this fishery; and in the year $r \delta_{3}$ I the total amount of mackerel salted in Maine, New Hampshire and Massachusettes was 450,000 barrels.

The jig has now been almost entirely superseded by the purse-seine, and this radical change in the method of catching mackerel has caused the desertion, by the mackerel fleet, of the Gulf of St. Lawrence, and the practical futility-to benefit our fishermen-of the fishery clauses of the Treaty of Washington. All attempts, with very few exceptions, to use the purse-seine in the Gulf of St. Lawrence have been failures.

The purse-seine has come into general use since $\mathrm{x} 850$, and with its introduction the methods of the mackerel fishery have been totally revolutionized. The most extensive changes, however, have taken place since 1870 , for it is only during the last ten years that the use of the purse-seine has been at all universal. As late as I 873 and 1874 a few ressels have fished with the old apparatus in the Gulf of St. Lawrence, and also a few on the coast of New England. Such changes in the manner of fishing for mackerel have brought about also a change in the fishing grounds. Vessels fishing in the old style were most successful in the Gulf of St Lawrence, but the purse-seine can be used to very much better advantage along our own shores between Cape Hatteras and the Bay of Fundy.

Considerable quantities of Nackerel are sometimes caught in gill-nets at various points along the New England coast from Vineyard Sound to Eastport. For the most part, however, they are taken west of Momt Desert. This fishery is carried on in two ways: The gill-nets may be anchored and left out over night, as is the custom about Provincetown, or they may be set from a boat or vessel. The latter method is called "dragging;" the vessels are called "draggers," or "drag-boats," and the fishermen "mackerel draggers." The Mackerel gill-nets are 20 to 30 fathoms long, $2 \mathrm{I} / 2$ fathoms deep, with a mesh varying from $2 \mathrm{I} / 2$ to 3 inclies. In Provincetown harbor they are set in the following manner:

Active and beautiful, strong, hungry and courageous, the Mackerel possesses all the attributes of a game fish, and were it not so abundant it 
would be one of the angler's prime favorites. Some of the sportsmen ignore the Mackerel, but Hallock and Scott are broad-minded enough to speak a word in its favor. Hallock says that it affords most excellent sport to the rod and reel. "Bass tackle of the lightest description, with wire gimp snood, is required: caplin, porgy and clams are used for bait, and no float is necessary, and when the fish are biting sharply, the bait will be taken the instant it touches the water."

Scott is even more decided in his approval.

"Hook-fishing for Mackerel," remarks he in his Fishing in American Waters, is very exhilarating sport. A brisk breeze, sky mellowed by fleecy clouds, gulls swooping and screaming, everything in excitement. Under such circumstances and surroundings, it is not strange if the troller, whiffer or still-baiter should inflate his lungs and feast his soul until the waning sun warns him to desist and retire. Excellent sport is sometimes to be had by rowing or sculling a boat into a thick shoal and trolling for them with feathered squid, or twirling spoon or casting to them a white artifi(ial fly.'"

And then-when the Mackerel is caught-trout, bass and sheepshead cannot vanquish him in a gastromonic tournament. In Holland, to be sure, the Mackerel is not prized, and is accused of tasting like rancid fish-oil, and in England, even they are usually lean and dry, like the wretched skeletons which are brought into market in April and May by the southern fleet, which goes forth in the early spring from Massachusetts to intercept the schools as they approach the coasts of Carolina and Virginia. They are not worthy of the name of Nackerel. Scomber is not properly in season until the spawning season is over, the schools begin to feed at the surface in the Gulf of Maine and the "North Bay."

Just from the water, fat enough to broil in its own drippings, or slightly corned in strong brine, caught at night and eaten in the morning, a Iackerel or a bluefish is unsurpassable. A well-cured autumn Mackerel is perhaps the finest of all salted fish, but in these days of wholesale capture by the purse-seine, hasty dressing and careless handling, it is very difficult to obtain a sweet and sound salt Mackerel. Salt Mackerel may be boiled as well as broiled, and a fresh Mackerel may be cooked in the same manner. Americans will usually prefer to do without the sauce of fennel and gooseberry which transatlantic cooks recommend. Fresh and salt, fat and lean, new or stale, Mackerel are consumed by Americans in 
immense quantities, as the statistics show, and whatever their state, always find ready sale.

The mackerel fishery is peculiarly American, and its history is full of romance. No finer vessels float than the American mackerel schoonersyachts of great speed and unsurpassed for seaworthiness. 'The modern instruments of capture are marvels of inventive skill, and require the highest degree of energy and intelligence on the part of the fishermen. The crews of the mackerel schooners are still for the most part Americans of the old colonial stock, although the cod and halibut fisheries are to a great extent given up to foreigners. It is particularly appropriate that the mackerel fishermen of New England should have found a bard in one who is above all others the poet of old New England. Whittier's "Song of the Fishermen" celebrates the days in the early part of the century when our fleet went yearly to the Gulf of St. Lawrence and the coast of Labrador :

Where in mist the rock is hiding, And the sharp reef lurks below, And the white squall smites in summer, And the autumn tempests blow;

Where through gray and rolling vapor, From evening into morn,

A thousand boats (were) hailing, Horn answering unto horn.

There we'll drop our lines, and gather Old Ocean's treasures in, Where'er the mottled mackerel Turns up a steel-dark fin, The sea's our field of harvest, Its scaly tribes our grain ;

IVe'll reap the teeming waters As at home they reap the plain!

Hurrah !-Hurrah !-the west-wind Comes freshening down the bay.

The rising sails are filling,-

Give way, my lads, give way!

Leave the coward landsman clinging To the dull earth, like a weed,-

The stars of Heaven shall guide us, The breath of Heaven shall speed! 


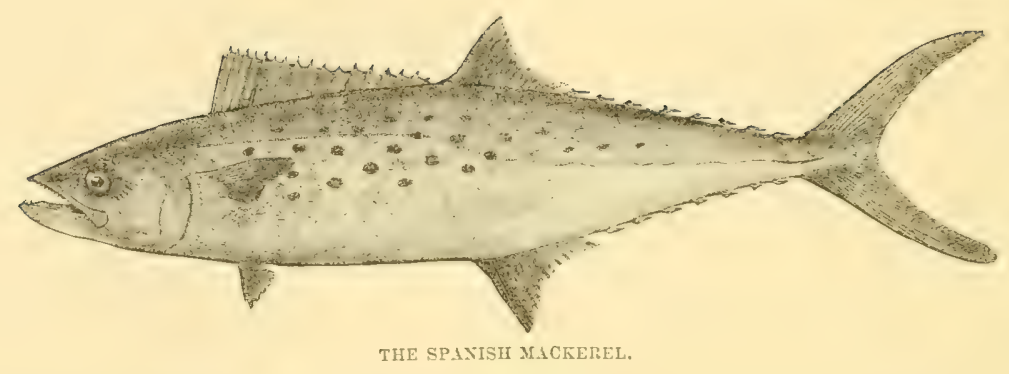

\section{THE SPANISH MACKEREL AND THE CEROES.}

Sooner shall cats disport in water clear
And speckled mackrels graze the meadows clear
Than I forget my shepherds wonted love.

Gay. Pastorals, I7 4 .

Next morn they rose and set up every sail

The wind was fair, but blew a mackrel gale.

DRYDEN. The Find and the Panther, I687.

THE Spanish Mackerel is surely one of the most graceful of fishes. It appeals as scarcely any other can to our love of beauty, when we look upon it, as shown in Kilbourn's well-known painting, darting like an arrow just shot from the bow, its burnished sides, silver flecked with gold, thrown into bold relief by the cool green background of the rippled sea; the transparent greys, opalescent whites and glossy blacks of its trembling fins, enhance the metallic splendor of its body, until it seems to rival the most brilliant of tropical birds. Kilbourn made copies of his large painting on the pearly linings of sea-shells, and produced some wonderful effects by allowing the natural lustre of the mother-of-pearl, to show through his transparent pigments and simulate the brilliancy of the life-inspired hues of the quivering, darting sea-sprite, whose charms even his potent brush could not properly depict.

It is a lover of the sun, a fish of tropical nature, which comes to us only in midsummer, and which disappears with the approach of cold, to some region not yet explored by ichthyologists. It is doubtless very familiar in winter to the inhabitants of some region adjacent to the waters of the Caribbean or the tropical Atlantic, but until this place shall have been discovered it is more satisfactory to suppose that with the blue-fich 
and the mackerel it inhabits that hypothetical winter resort, to which we send the migratory fishes whose habits we do not understand-the middle stratia of the ocean. the floating beds of Sargassum, which drift hither am thither under the alternate promptings of the Gulf-stream currents and the winter winds.

Sisty-two years ago, Mitchill, in his "New York Fauna" said all that was known of this fish in two short sentences:- "A fine and beautiful fish. Comes in July."' Seven years ago, when the writer was called upon to prepare its biography for his "Game Fishes of the United States," he was compelled to admit that later naturalists had added very little to this tersely expressed story. The admirable studies of Earll and Stearns have since been made, and the habits of the Spanish Mackerel are now fairly well understood.

It is a member of the Mackerel family and of the genus Scombcromorus, established in ISoz by Lacépède, and subsequently re-named by Cuvier, Cybium. European naturalists still cling to Curier's name for the genus, which is composed of twelve or more species inhabiting the warmer portions of the Atlantic and Inclian oceans. The species under discussion was described by Mitchill under the name Scomber maculatus. For nearly half a century it stood upon our books as Cybium maculatum, but our progressive American school of ichthyologists now insist that for the sake of a consistent nomenclature, we must catalogue this lovely species under the unlovely name Scomberomorus maculatus.

The Spanish Mackerel is not the only representative of the genus Scomberomorus which occurs in American waters. There are two closely allied forms in the Atlantic, which are gigantic in comparison. In the Gulf States they are called King-fish and are highly esteemed by lorers of good sport and delicate food. Both of these forms have been occasionally observed as far north as Cape Cod, and it is quite possible that their abundance along our eastern coast is greater than is at present suspected. The three species are very similar in form, and their distinctive characters are of such a kind that they might readily be overlooked by ordinary observers. It is my own opinion that they are sold in large numbers with the Spanish Mackerel, and under the prestige of its name. The fish-mongers, the only persons likely to notice the differences, would, for obvious reasons, not be likely to call attention to them.

The distinctive characters, though not obtrusive, are strong and con- 
stant and he who chooses to do so may soon learn to discriminate between the Spanish Mackerel and its allies.

The Spotted Cero, or King Cero, Scomberomorus regalis, has seventeen dorsal spines, and upon the front of the first dorsal, which is white, is a spot of deep blue, which is prolonged far back upon the upper edge of the fin. The sides are marked with broken longitudinal bands of gold, interlined with brown and golden spots.

It differs from $S$. maculatus, which also has seventeen dorsal spines, in the form of its teeth and in its coloration. In the Spanish Mackerel the teeth are somewhat conical and very pointed, the first dorsal has a black blotch. and the spots upon the sides are golden brown nearly circular and not arranged in band like series.

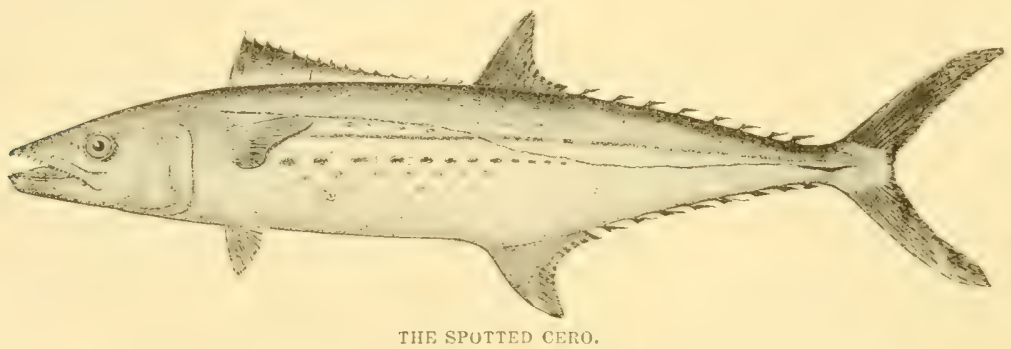

The King Cero is a magnificent fish which grows to be five or six feet in length and attains a weight of twenty to thirty pounds. It is abundant in the IVest Indies, and has been recorded from Cuba, Santo Domingo, Jamaica, Barbadoes, Key West, and Brazil. The Silver Cero, Scomberomomis caballa, has fourteen spines in its full dorsal fins, which is immaculate in color. The young fish have the sides of the body marked with indistinct spots, circular in form, and tawny in color, which disappear with age ; the lateral line is very sinuous upon the posterior portion of the body.

It is a West Indian species, which has already been observed at Santo Domingo, Jamaica, Cuba, Martinique, Porto Rico, and Brazil, and a few specimens have been captured as far north as Wood's Holl, Mass. Prof. Jordan states that they are caught with trolling hooks on nearly every summer trip of the steamer from Savannah to New York. This is a magnificent fish, which often attains the weight of twenty-five pounds. Its habits are doubtless like those of the Spanish Mackerel. The name Cero is commonly accepted in the United States; it is a corruption of the 
Spanish sierra, which is in fact the name applied to the species by the Spanish people of Mexico.

King-fish, according to Silas Stearns, are very abundant in the southem part of the Gulf of Mexico, and are common in some localities along the coast of our Gulf States. They live at sea and are caught by the use of trolling-lines. At Key West, large quantities are sold in the markets. Two men in a small sall-boat sometimes catch a hundred or more in a day.

The Pacific species, Scomberomorus concolor, has been called the "Monterey Mackerel." It attains a length of about thirty inches and a weight of about five or eight pounds. It has only been seen in the Monterey Bay, where from five to forty individuals are taken each autumn, most of them at Soquel. They appear in September and disappear in November. Nothing is known of their distribution or habits. They always command the high price of from thirty to fifty cents per pound. The flesh is similar to that of the Spanish Mackerel, which it closely resembles. The male is silvery blue, without spots, but the female has a double row of alternately roundish blotches upon each side.

The Spanish Mackerel is a species smaller and more delicately formed than the others which occur in the Atlantic. Its normal range, as now understood, is from Cape Cod to the Gulf of Mexico. It is possible, indeed probable, as has already been suggested, that it occurs in the waters of South America, though the statement that Agassiz recorded it from Brazil is based upon an erroneous reading of his statement in his book on the fishes collected by Spix. Poey had it from Cuba. Solitary individuals have been taken north of Cape Cod, one at Provincetown in August, I $8_{47}$, one at Lynn in July, $\mathrm{I}_{44 \mathrm{I}}$, and one at Monhegan in Maine. I am clisposed to question the official statement of the Canadian fisheries department that one was taken at New London, in September, ISSo, which, if true, would extend the range of the species several hundred miles. The author of this report justly remarks: "It is rare to find this fish in so high a latitude." ** The identification should be verified.

Though abundant in the north-eastern portion of the Gulf of Mexico, few individuals have as yet been observed off the east coast of Florida.

The species also occurs along the Pacific coast of Mexico, and in great abundance in the Gulf of California.

* Supplement No. 2 to the Eleventh Annual Report of the Minister of Marine and Fisheries for the year I 880 , p. 229. 
Spanish Mackerel visit the shores of our Atlantic states, on a mission of feeding and breeding.

In early spring they appear in schools off our southern coast, appearing in the waters of West Florida early in March, or even in the latter part of February, reaching Pensacola about the beginning of April. Off the Carolinas, their coming is a little later, for they do not reach Charleston before the end of March, and really enter the sounds of Pamlico and Albemarle until a month later. By the 20 th of May, they are rounding the capes of Virginia, and the schools rapidly increase in number in the inland sea of the Chesapeake, until the middle of June, and their abundance continues through the summer and early autumn. In July and August they are most abundant off the coasts of New York and Southern New England, where they remain in considerable numbers through the early part of September-just as they did in the days of Mitchill, and, so far as we can know, in the seventeenth century when Josselyn described the fishes of New England.

With the approach of the autumnal equinox, their southward migrations begin. The first of October finds them absent from the region north of New Jersey, and by November they have deserted the waters of the United States, unless perchance, a few may still remain among the reefs and sand-beds of the Florida Keys.

They are lovers of warm waters, even more so than the blue-fish, for they precede in the fall migration the schools of menhaden, while the blue-fish follow them. Their breeding season in the Chesapeake occurs when the temperature of the water ranges from $78^{\circ}$ to $84^{\circ}$, and it is believed that they do not willingly enter water colder than $60^{\circ}$

Their habits are much like those of the blue-fish, with which they are aaid to associate. They are much more active in their movements, and sport and dance between sky and water almost like swallows skimming over a lake. No oceanic fishes which I have seen are so admirably built for springing. Their tails are muscular, shapely, provided with oar-like fins, formed like the crescent moon. Their bodies are conical, arrow-like, smooth as burnished metal, and their speed must be as matchless as that of the dolphins. When the blue-fish leaps, it is with more deliberation and noise, falling back into the water with a splash, while the sharp head of the Spanish Mackerel cuts the water like the stem of a yacht. Mr. Earll tells me that the Chesapeake fishermen can indentify the species by its movements as far as the eye can see. 
In Genio C. Scott's "Fishing in American Waters" is an interesting little picture of a school of Spanish Mackerel feeding, which is worthy of examination.

Both Earll and Stearns agree in the statement that this is a fish which lives almost entirely at the surface. On a calm bright day in summer, the surface of the Chesapeake or the Gulf of Mexico is sometimes broken up for miles by the movements of large schools of these fishes, while the air is enlivened by the screaming flocks of terns, which follow them, to gather up the fragments of their feasts. Similar scenes may occasionally be witnessed off the coast of New Jersey and the Carolinas, but further to the southward their abundance is less.

The schools are frequently observed at a long distance from the shore, especially when they are first approaching in the spring. Mr. Earll has also called attention to the fact that they avoid brackish waters, and thus accounts for their abundance on the eastern side of the Chesapeake, and their comparative absence near the opposite shores where the salinity of the waters is lessened by the inflow of the Potomac, Rappahannock, the Tork and the James. During the spawning season they frequent tle warmest and shoalest waters to which they can gain access.

The diet of the Spanish Mackerel is like that of the bluc-fish, entircly carnivorous, and there is no reason to doubt that the menhaden or mossbunker is its principal quaving. Mackerel, mullet, silversides and all our other schooling species contribute also a share to its support.

The breeding habits of this fish were never understood until the spring of I 880 , when, to the astonishment of everyone, it was found by Mr. Earll that their spawning grounds are in the Chesapeake Bay and at other localities on the middle Atlantic coast, while Mr. Silas Stearns, almost simultaneously discovered a breeding place in the Gulf of Mexico. MIr. Earll, to whom science is indebted for a most thorough and comprehensive study of the reproductive habits of this fish, has published a full account of his observations, and of his experiments in practical fish-culture in one of the annual reports of the $\mathrm{U}$. S. Fish Commission, * to which the reader is referred for detailed statements, since it is not the purpose of this book to enter into prolonged discussions of such a character.

Mr. Earll found evidence that the species spawns not only in the Sandy

*R. E. Earli. The Spanis/ . Mackerel. Keport U. S. Comm. Fisheries, xS8o. (1883) pp. $395-426$. 
Hook and Chesapeake regions, but also on the southern shore of Long Island, and in the sounds of the Carolinas.

In the Carolinas, he tells us, the spawning season begins in April, in the Chesapeake region from the first to the middle of June, in the Sandy I-Took region and about Long Island, from the latter part of August to the first of September. In the Gulf, according to Stearns, the season is in July. The season continues in any given locality from six to ten weeks, and the spawners, contrary to what occurs in shad, salmon and white-fish, require several weeks rather than a few days only to deposit their individual building of eggs. A one pound Spanish Mackerel will yield about 300,000 eggs, a six pounder scarcely less than I,500,000; the species being much more prolific than salmon, shad or white-fish, though less so than the members of the cod family. The eggs are minute, from ${ }_{22}^{1}$ to 1 of an inch in diameter, and over a million can be held within the walls of a quart measure. Their specific gravity is such that they will sink in fresh water and float in the sea.

When first hatched, Mackerel is very small, and the length of the cm. bryo scarcely exceeds one-tenth of an incl,, while its diameter, even with the comparatively large yelk-sac, is so small as to allow it to pass through wire-cloth having thirty-two wires to the inch. For several hours it remains quiet at the surface in an almost helpless condition, small oil globule in the yelk-sac causing it to lie belly uppermost. Later the sac is absorbed, and the little fish manifests greater activity, and by vigorous and spasmodic efforts swim to the depth of an inch or so below the surface. In a few hours it finds no difficulty in swimming at various depths, and begins to lie upon the bottom of the vessel, darting off with surprising rapidity when disturbed.

The rate of growth has not been studied. Earll supposed that the yearling fish are not more than six inches long, and those of two years, to be the young fish of a half-pound weight, observed by Genio C. Scott in the Long Island region. It is scarcely probable that the species attains full size in less than four years. The annual growth of so voracious a species is doubtless considerable after the first two years. The species sometimes attains the weight of eight or nine pounds, though it rarely exceeds three or four pounds. A specimen taken off Block Island, July 8 , I 874 , the first of the season, measured twenty-six and one-fourth inches and weighed three pounds and five ounces. It is said to be the largest 
crer taken in this section, and was a female with the ovary spent. In the Gulf States, according to Mr. Stearns, the Spanish Mackerel are in great demand, though but few are caught in the Gulf of Mexico, on account of the absence of proper nets.

"In the Chesapeake region the catch has increased rapidly from year to year, until in I $S_{79}$ it amounted to fully $I, 000,000$ pounds, and in I SSO the quantity was increased to $\mathrm{I}, 609,66_{3}$ pounds. 'The average daily catch for the pound-nets about Cherrystone, $\mathrm{Va}$., is fully 500 fish; while as many as 4,000 have been taken at a single 'lift,' and hauls of 2,500 are not uncommon during the height of the season. At Sandy Hook the catch is quite large; in $\mathbf{I} 879,3,500$ pounds were taken at one haul in a pound-net at Seabright, and the average stock for the pound-nets in that locality often exceeds $\$ I, 000$ for Mackerel alone, while the catch of other species is proportionally large.

The species is common in New Orleans and Mobile markets. Although those taken on the coast of New Iersey and farther to the eastward are considered much more delicately flavored than the Chesapeake fish, and command a higher price in the market. The Spanish MIackerel served at the best restaurants in New Orleans are delicious in the extreme, and fully equal to the best to be found in New York. It is pre-eminently suited for broiling and grilling, and is rarely prepared in any other manner.*

In the Chesapeake and about Cape Hatteras, they are extensively salted, and in the Gulf of Mexico pickled king-fish is regarded as a delicacy of the first degree of excellence.

The Spanish Mackerel ought surely to rank with the "game-fishes," but unfortunately does not come fairly within the designation. It is occa-

\footnotetext{
* How to Brorr, Frsir. _ "Take the fish you intend to broil, see that it is properly clcaned, and cither rub it with vinegar, or simply dry it and dredge it with flour, then dip it into olive oil, or eger and breadcrumb it, or roll it well in chopped herbs, then place it upon a heated gridiron well rubbed over with fat. Mackerel may be stuffed, but their heads should be taken off. When the fish is thick, score it here and there, or split down the back. Broiled fish, according to its kind, may be either masked with a sauce, or served upon a purèe of sorrel, tomatoes, or haricots, or upon an oil or caper sauce, Soaking fish in a marinade previously to broiling it is a considerable improvement, as it eats shorter and better flavoured; the French: steep it in olive oil, made savoury with spices, \&c.

"For the more delicate kinds of fish the gridiron may be stewed with bunches of aromatic herbs (tresh), the fish well oiled being laid thereon; do it very slowly, and only turn it once while being cooked. Fish first crimped ia boiling water and then broiled is excellent. No fixed rules can be given as tri the time required to broil fish, so much depending upon the state of the fire and the size and sort of the fish. Smoked salmon should be merely made hot through."-(GEORGiasa HrL.)

"Wipe the fish cleen and dry, after taking out the gill and insides. Open the back, and put in a little pep" per, salt, and oil; broil it over a clear fire, turn it over on both sides, and also on the back. IIhen the flesh can be detached from the bone, which will be in about 15 uninutes, it is done. Chop a little parsley into the butter, with pepper, salt, and lemon juice. Serve before the butter is quite melted, with a matire d'lotel sauce." - Fisheisies Eximirion CuOK Book.)
} 
sionally taken on trolling tackle in use in blue-fishing, but is never so far as I am aware, a definite object of pursuit.

Genio C. Scott wrote, in I875: "My experience in trolling for Spanish Mackerel off the inlets of Fire Island has convinced me that the fish is as numerous as the blue-fish, and more so than the striped bass, at certain seasons, and is found a little farther seaward than either of those fishes."

"Every year the shoals of Spanish Mackerel become more and more numerous, and more are taken, but never in sufficient nembers to reduce the average price below sixty cents per pound. The shoals which $I$ saw when last trolling for them would have formed an area nearly five miles square, and still the most successful boat did not take more than a dozen in three days. They will not bite freely at any artificial lure, and though numbers came near leaping on the deck of our yacht, they treated our lures with an indifference which savored of perverseness."

Trolling seems to be more productive in the Gulf of Mexico than farther north.

Mr. Thaddeus Norris states that in the Gulf of Mexico, they are sometimes taken by hook and line, with shrimp-bait at the end of the long piers where the steamers land in Mobile to New Orleans.

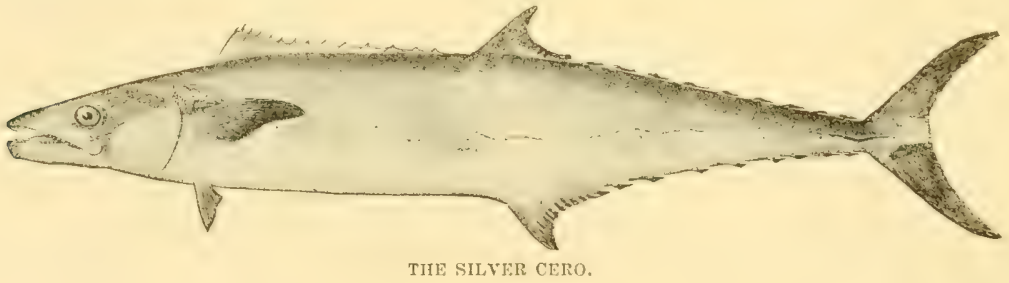

The early chronicles of the colonies seem to contain no references to the Spanish Mackerel under its present name, but it seems certain that this fish was the speckled hound-fish, spoken of in that renowned work, "New England Rarities, Discovered in Birds, Beasts, Fishes, Serpents and Plants of that country, etc., by John Josselyn, Gent," published in 1672 . Josselyn wrote of "Blew-fish or hound-fish, two kinds, speekled houndfish, called horse-fish." 'The blue-hound-fish can be nothing else than the common blue-fish of our coast, (Pomatomus saltatrix), and no species in the western Atlantic, other than our Spanish Mackerel, sufficiently resembles the blue-fish to warrant the use of so similar a name. Mitchill referred 
to the species in $\mathbf{I S}_{\mathbf{5}}$, in a manner which seems to indicate that it was not of rare occurrence, but from his day to $\mathrm{i} \$ 70$, it seems to have attracted but little attention.

Even Mitchill's published description does not seem to have satisfied contemporary ichthyologists of the existence of such a fish, for some of them did not hesitate to express the opinion that Dr. Mitchill had been deceived by accidental differences of color at different seasons of the year, and that there were not so many varieties of Mackerel as he imagined.*

In an essay on the fishes of New York market, published in i $8_{54}$, Prof. Gill referred to the Spanish Mackerel as a species of slight importance.

The quantity taken with hook and line is quite insignificant; they are caught almost entirely in traps and weirs, and these contrivances were not employed in Narragansett Bay before $\mathrm{r} 845$, and did not come into general use clsewhere on the coast until many years later. Many experienced fishermen are, however, of the opinion that they have been rapidly increasing of late, and this is strikingly confirmed by the marketmen.

DeKay in his "New York Fauna," I $S_{42}$, mentioned that he had seen this fish in New York market, in August and September, but that it was not common.

Prof. Baird, who was one of the first to speak of the abundance of this species and to testify to its excellent qualities, wrote in 1854 : "But two specimens were taken during my stay at Beesley's Point, and the species is scarcely known to the fishermen. It was more abundant at Greenport, L. I.; in the Peconic Bay, towards Riverhead, four hundred were caught st one haul of the seine. The fish bring a high price in the New York market, where it has been but recently sold at from fifty cents to one dollar a pound, the prices varying with the season. It has been more abundant off our coast than ever before, and in the lower part of the Potomac numbers have been taken."

The Gloucester "Telegraph" of August I 7 , I 870 , stated that the Newport epicures were in ecstasies over the fact that Spanish Mackerel, the most delicious fish caught in the sea, were taken there in seines, and remarked that it was only by southerly winds that they were tempted so far north.

Mr. J. M. K. Southwick states that the first Spanish Mackerel taken in 
the vicinity of Newport were found in the summer of 1857 . No one knew what they were.

Mr. Earll writes as follows concerning the history of its increase :

"About Sandy Hook prior to $\mathbf{I} 850$, almost nothing was known of the fish, as shown by the fact that about this time Mr. Robert Lloyd, a fisherman at Seabright, was engaged in trolling for bluefish, having a contract with one of the hotels to take his entire catch. He secured a number of Spanish Mackerel (these being the first he had ever seen), which were carried with the bluefish to the hotel; but the proprietor knew nothing of their value, and buying them.

"From this date they were taken more frequently, and soon were highly prized. They were caught wholly by trolling, the average catch being from ten to twenty fish to a boat daily. They continued to increase in number, or at least were more generally noticed by the fishermen, until I 866 , when they were quite plentiful, becoming most abundant between $I S 70$ and $I 875$. During that period it is said that they were often nearly as plenty as the bluefish, though comparatively few were taken, owing to the lack of suitable apparatus. It was not until the introduction of properly arranged gill-nets and pound-nets that the fishermen succeeded in securing considerable quantities.

"It is claimed that their numbers have, since 1875 , gradually decreased on the inshore grounds, though they are said to be as numerous as formerly, eight to ten miles from land, where they remain beyond the reach of gill-nets and pound-nets.

"Many of the fishermen of Chesapeake Bay never saw the species before 1875 , though there are authentic records showing that individuals were occasionally taken in the haul-seines along the Eastern shores as early as 1860 , and hauls of one and two hundred are reported by Dr. I. T. Wilkins in I $866 .^{*}$ It is very easy to explain the ignorance of the fishermen as to the abundance of the species in that region, for, until recently, the fisheries of the Chesapeake appear to have been of small commercial importance, having been prosecuted only during the spring and fall by means of gill-nets and haul-seines. During the summer months, when the Mackerel are most plenty, no fishing of importance was done. Poundnets were introduced into the Chesapeake region in $\mathbf{I} 875$, and it was through their use that the fishermen came to know of the abundance of the species in these waters.

"On the North Carolina coast most of the fishermen, and, indeed, a majority of the dealers, are still unacquainted with either the name or the value of the Mackerel, and when, in 1879 , several thousand pounds of them were brought to Wilmington, the dealers refused to buy them, sup-

\footnotetext{
Prof. Baird, as we have seen, referred to extensive captures of this species in the lower Potomac and Chesapeake in 1854 , and called attention to the fact that they were to be had salted in the Washington. city fish market.
} 
posing them to be a species of horse-mackerel (Orcynus), which they understood had no value as a food-fish. Since no purchasers could be found for them, they were finally thrown away. Farther south few have been taken, owing to the lack of suitable apparatus, as well as to the fact that the fishermen seldom fish beyond the inlets. The smack fishermen of Charleston catch a few on troll-lines during the pleasant weather of the spring and early summer, but they fish only occasionally in this way.

"Though the fishing is at present limited to certain localities, there is no reason to believe that the fish are absent from other places; on the contrary, it seems probable that, should proper apparatus be employed, the species could be taken at almost any point along the outer shore where the menhaden are abundant."

C. R. Moore, of Johnsontown, Va., wrote in I 874 : "Spanish Mackerel come in September and October and stay until frost. They are most numerous about the mouth of the York River, where a large number are caught in seines and salted. They bring about \$40 a barrel."

There is no reason to believe that the present fishery will affect the future abundance of the species; for the catch is necessarily insignificant when the immense number of individuals in our waters is taken into account. There is no doubt that there have been important fluctuations in abundance in the past, and natural causes are certain, cause a like variation in the future.

It is particularly important therefore, that the experiments which the U. S. Fish Commission has already made upon the artificial propagation of this species shall be as soon as possible brought to some practical outcome.

The Spanish Mackerel of New England was a fish with spotted sides. The people of New England found a spotted mackerel and called it by the old familiar name; the people of the Middle States did likewise with a different kind of spotted mackerel. In like manner the names herring, alewife, shad, salmon, trout, perch, chub, and bass are applied to several different kinds of fish in different parts of the United States. There is only one clew to the manner in which the Spanish Mackerel of England was named. Rondeletius, who wrote in 1554 , a book on marine fishes, "Libri de Piscibus Marinis," speaks of this fish as occasionally occurring on the coast of France, but particularly abundant in Spain.

How did our Spanish Mackerel get its name? English colonists, the world over, have always given to the native animals of the new continent, the names of those with which they were familiar in their ancestral home. 
The only other spotted fish which has been known to frequent our coast is the " chub mackerel " or "thimble eye," a species closely allied to the common mackerel, but smaller, and distinguished by having larger eyes and less distinct dorsal markings, as well as by other characters. This was the "Spanish Mackerel" of New England fifty years ago. Its name must have come to it from the "Spanish. Mackerel" of England, the Scomber colias, described by Gmelin, with which, indeed, some authorities believe it to be identical, and which also is very similar to the common mackerel, Scomber scombrus, though smaller, with fewer stripes upon its back, and with circular spots of grey or brown upon the white sides, which in the common mackerel are pearly and immaculate. The question of the identity of the Spanish Mackerel of New England, with that of Old England, is not likely to be decided at present, for the former has entirely deserted our waters, though at one time extremely abundant.

The origin of the name "Mackerel" is in itself a curious subject of inquiry. Certain authorities derive it from the Old French maquercau, signifying a pander or go-between, from a popular tradition in France, that the Mackerel in spring follows the female shads which are called vierges, and leads them to their mates. Skeat and other modern etymologists reject this idea, and decide that the name comes from the Latin macus or maca, signifying a spot or stain.

Still another theory is advocated by Dr. C. D. Badham, in his " Prose Halieutics."

"The word Mackerel is one of very old standing in our own vocabulary, and has most probably a northern origin; but whether this be so or not, both the usually assigned Greek and Latin etymologies are equally inadmissible; the Greek, which, either from the excellence of the flesh, its own personal happiness, or that which it confers on so many Mackerel-

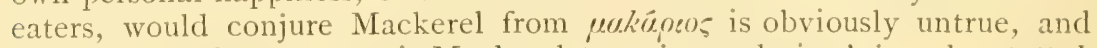
particulary unhappy; nor is Mackerel 'quasi macularius,' $i$. $c$. the spotied, in lieu of what it is, a striped fish, a less unfortunate attempt to fish out a meaning from the Latin. If we are to adopt any etymology where all are doubtful, Aldrovandi's 'magarellos seu nacarellos e corporis nacritudine,' seems the most plausible; the shot, lustrous surface of the belly and sides is certainly nacreous; while we are distinctly taught in our Church catechism that in regard to a name, an $\mathrm{M}$ or $\mathrm{N}$ are indifferent, and in fact the change of one of these liquids into the other never offers any real difficulty in etymology. Touching the nomenclature of that particular hind called sometimes Spanish, sometimes Horse-Mackerel, though the latter adjunct 


\section{THE SPANISH MACKEREL AND THE CEROES. IOT}

often expresses no more than size or coarseness-as in qualifying the words laugh, mushroom, chesnut, or radish, -it is quite possible in this case that it may merely be the translation of cavallo, which in that language not only means horse, but Mackerel as well. Concerning the opprobrious employment of this word to designate a certain class of villains, called in Latin lenones, ard ruffani in Italian, M. Lacépède, after Belon, gives the following interpretation - 'C'est à raison de la rencontre des maquereaux avec les petits aloses ou pucelles vers le temps ou celles-ci vont frayer avec les mâles, qu'on a donné ce vilain nom (maquererau), qu'il porte en France et dans quelques autres pays.' "' 


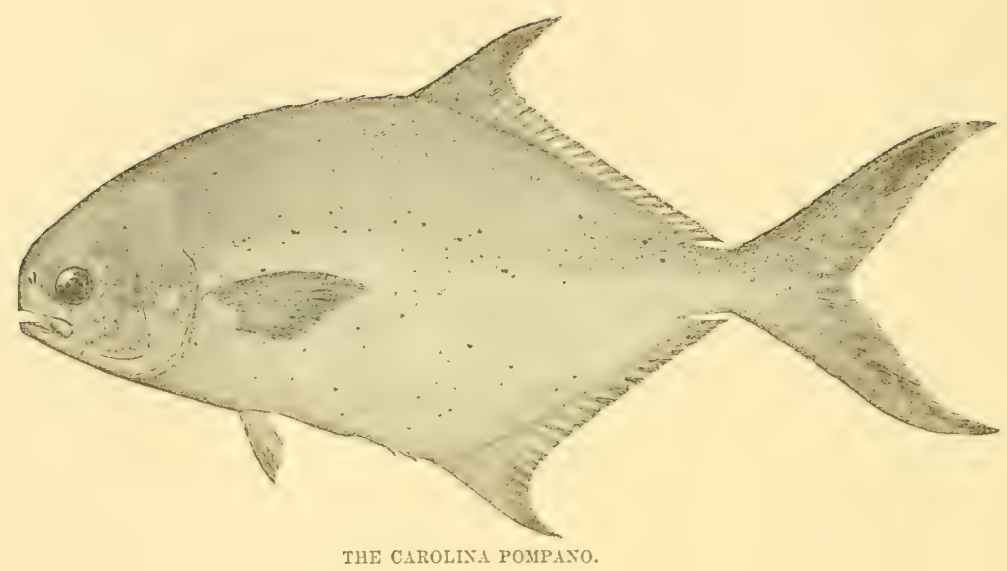

THE POMPANOES.

\author{
" Lightly and brightly they glide and go \\ The hungry and keen on the top are leaping \\ The lazy and fat on the depths are sleeping."
}

William Mackworti Praed, The Red Fishierman.

\begin{abstract}
7 HE Pompano, with its pleasing contours, its banner-like fins, and its scales glistening with the brilliancy of polished silver and gold, is one of the loveliest of our summer visitors. It is not an angler'sfish, nor is it a food-fish of importance from the commercial stand-point, yet it is confessedly the king of table-fishes, commanding almost fabulous prices in the markets of our great cities, and esteemed more highly than salmon or bass, moon-fish or Spanish mackerel. It figures in angling literature as "the wood-cock of the seas" - wherefore, the writer is unable to say.

The genus Trachynotus, to which our Pompanoes belong, is widely distributed through the warmer parts of the Atlantic and Indo-Atlantic regions. Three species are peculiar to Asiatic waters, three have been found only on our own Pacific coast, one is limited to the waters of western Africa, one to those of the Caribbean, while of the four which are abundant on the Atlantic coast of North America, one ranges the wide world over, occurring in warm waters everywhere, one is found on the California coast, and one in Africa. The genus is entirely unknown in the waters of Europe. The species of the Pacific coast, Trachynotus
\end{abstract}


rhodopus, 7 . fasciatus and $G$. Kimncili, are chiefly interesting to naturalists, and will not be discussed at length. 'The Pompanoes of our Atlantic waters, belonging as they do to a small, strongly specialized genus, are separated from each other by characters not likely to be noticed by casual observers. It is probable that the most unusual of them is mo:c abundant than is now supposed, and that a more careful study of the faun of the South Atlantic and Gulf States will show that they are frequent risitors. I have myself seen the Carolina and the Round Pompano sold under the same name in Charleston market, just as I have seen the young of four species of the herring family sold together indiscriminately in Fulton market, New York.

The four species, though similar in general appearance, may easily be distinguished by differences in proportions and in the number of fin-rays.

The commonest and by far the most important form, the Carolina Pompano, Trachynotus carolinus, has the height of the body contained two to two and two-thirds times in the total length; the length of the head five to five and one-third times; one of the caudal lobes four times. It has twenty-four to twenty-five rays in the second dorsal, while the anterior rays of the dorsal and anal fins, if laid backward, reach to the middle of the fin.

It occurs in both the Atlantic and Pacific waters of the United States. On our castern coast it ranges north to Cape Cod, south to Jamaica, east to the Bermudas, and west in the Gulf of Mexico, at least as far as the moutl of the Mississippi River. In the Pacific it is rare, and as yet known only from the Gulf of California, where it has recently been observed by Mr. C. H. Gilbert.

Like the Spanish mackerel, the squeteagne, and the bluefish, it is a summer visitor, appearing in southern Massachusetts in June and July, departing in September. It is emphatically a warm water species. Although it is at present impossible to ascertain the lower limit of its temperature range, it is probable that this corresponds very nearly to that indicated by a harbor temperature of $60^{\circ}$ to $65^{\circ}$ Falhr.

The Pompano has never been known to pass the boundary defined by the low, sandy barrier of Cape Cod and its submarine extension, the Georges Bank. Like the shoals of Hatteras, the broad, slightly submerged sands of this region, with their swirling tides and fuctuations of temperature, forbid the passage of many specier. abundant either to the North or 
South. Both of our common Pompanoes were described by Linnaus from South Carolina, but had never been observed north of Cape Hatteras until the summer of $\mathbf{1} 854$, when Prof. Baird, at that time carrying on the first of the ichthyological investigations which have since made his name famous all the world over, discovered it near Great Egg Harbor. In his Report on the Fishes of New Jersey, he states that he had seen them taken by thousands in the sandy coves of the outer beach, near Beesley's Point. These, however, were all rather small, scarcely exceeding a quarter to half a pound in weight. In $I_{8} 6_{3}$ he obtained both species in Southern Massachusetts, where in subsequent year's they have frequently been captured.

"My first acquaintance with the Pompano in New England," writes Prof. Baird, "was in $I \delta 6_{3}$, during a residence at Wood's Holl, where I not unfrequently caught young ones of a few inches in length. I was more fortunate in the summer of $187 \mathrm{I}$, which I also spent at Wood's Holl; then the Pompano was taken occasionally, especially in Capt. Spindle's pound, and I received at different times as many as twenty or thirty, weighing about one and one-half or two pounds each. Quite a number were caught in Buzzard's Bay and Vineyard Sound in $1872 . "$

It is a fair question whether the Pompano has recently found its way into northern waters, or whether its presence was unknown because nobody had found the way to capture it. When Mitchill wrote on the fishes of New York in 1842 he had access to a single specimen which had been taken off Sandy Hook about the year i 820 .

I quote in full the observations of Mr. Stearns :

"The common Pompano is abundant on the Gulf coast from the Mississippi River to Key West, and, so far as I can learn, is rare beyond this western limit until the Yucatan coast is reached, where it is common. It is considered the choicest fish of the Gulf of Mexico, and has great commercial demand, which is fully supplied but a few weeks in the year, namely, when it arrives in spring. The Pompano is a migratory fish in the Pensacola region, but I think its habits on the South Florida coast are such that it cannot properly be so classed.

"At Pensacola it comes in to the coast in spring and goes away from it in fall, while in South Florida it is found throughout the year. In the former section it appears on the coast in March in schools varying in numbers of individuals from fifty to three or four thousand, which continue to 'run' until the latter part of May, when it is supposed that they are all inside. Their movement is from the eastward, and they swim as near to 
the shore as the state of the water will permit, very seldom at the surface so as to ripple or break the water, although sometimes while playing in shoal water they will jump into the air.

"Before any schools enter the bays certain ones will remain for days, or even weeks, in a neighborhood, coming to the beach during the flood tide to feed on the shell-fish that abound there and returning again to deeper water on the ebb-tide. The holes or gullies in the sand along the beach are their favorite feeding grounds on these occasions. Sharks and porpoises pursue the Pompano incessantly, doubtless destroying many. The largest numbers come in April, and sometimes during that month the first schools are seen entering the inlets, others following almost every day, until about June I, when the spring run is said to be over. Every year they appear in this way at Pensacola and adjoining bays, although there are many more some years than others. As the abundance is judgred by the quantity caught I think that the difference may lie more in the number of fishing days (pleasant ones) than in the real numbers of fish present. The sizes of Pompano that make up these schools are large or adult fish averaging twelve or fourteen inches in length, and small fish (probably one year old) averaging eight inches in length. The largest Pompano that I have seen measured nineteen and a half inches in length, and weighed six and a quarter pounds, the extremely large fish called Pompano of two or three times that size probably being another species. After entering the bays the schools of Pompano break up and the fish scatter to all parts where the water is salt and there are good feeding grounds. Except single individuals that are taken now and then, nothing is seen of Ponpano until late in the fall, when they are bound seaward. In regard to its spawning habits nothing very definite has been learned. It has spawn half developed when it arrives and has none when it leaves the bays. Large quantities of the fry are seen in the bays all summer, which is some proof of its spawning inside. In June, is 78 , I caught specimens of the fry varying in size from three-quarters of an inch to three inches in length. Very many schools of these sizes were also observed in July and August of the same and following years of $1879^{-}$'So.

"The schools of fry go to sea in August and September. The older or adult fish leave the coast in September and October in small schools, that are only seen and caught at the inlets where they happen to cross shoals or follow the beach. These Pompano of the fall are very fat and in every way superior to those caught in the spring. As before mentioned, the Pompano is found on the South Florida coast all the year. The sea-beach, from Tampa Bay to Charlotte Harbor seems to be its favorite feedingground owing to the quantity of shell-fish that occur there. It does not form in large schools as in the Pensacola region, and therefore is not taken in such large quantities by seine fishermen.

"Smacks from Mobile and Pensacola sometimes go to Tampa Bay for them. I have been told that Pompano are caught at Key West in con- 
siderable quantities by hook and line, and I have known of a few being taken in that manner at Pensacola. It feeds entirely upon small shellfish, which are crushed between the bones of its pharyngeal arch."

The Round Pompano, T. rhomboides, has the height of the body contained two to two and one-third times in the total length; the length of the head five to five and one-fourth times; one of the caudal lobes three and a-half to four times. In the second dorsal are from eighteen to twenty-one rays, in the second anal from sixteen to nineteen, while in the Carolina Pompano there are twenty-one to twenty-two.

In the south it is sometimes called the "Shore Pompano," and is known in the Bermudas by the name "Alewife."

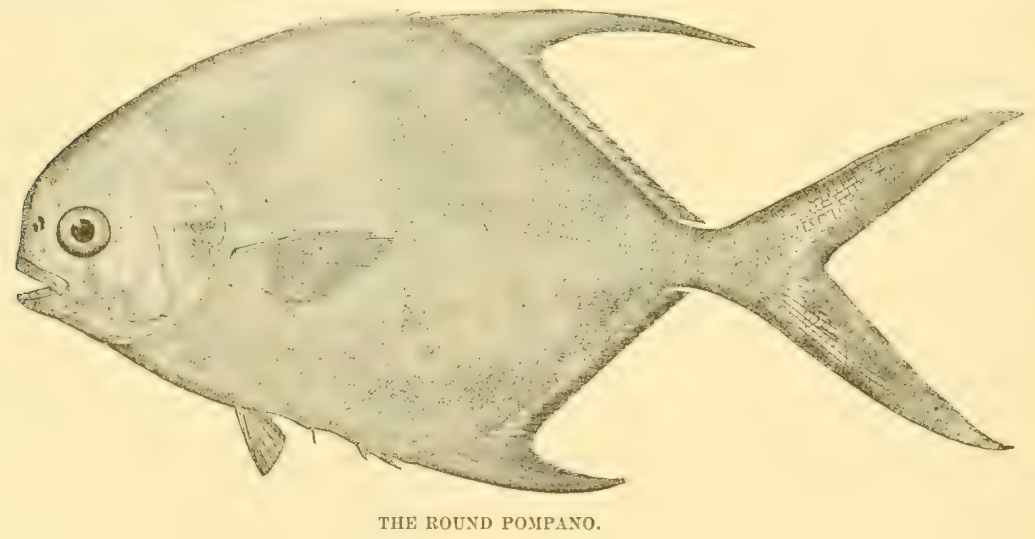

The Round Pompano is cosmopolitan in its distribution, occurring in the North and South Atlantic, and in various parts of the Indian Ocean. The young have been obtained in the harbor of Vineyard Haven, Mass., and at Beaufort, S. C. It is probable that the species is far more abundant in our waters than we now suppose it to be.

The only well authenticated instance of the capture of the Pompano with hook and line are those recorded by S. C. Clarke. During ten winters of Florida angling he writes: "I have only once seen this fish taken with the hook. My fish was taken on a rod with clam-bait, while fishing for sheepshead in April, I 875 , in the Hillsboro River, near New Smyrna." B. C. Pacetti, a veteran fishermen, assured Mr. Clarke that during forty years'experience, he had only known of two similar instances.

The African Pompino, T. gorecnsis, originally described from the 
Island of Gorea, on the west coast of Africa, resembles in general form the Round Pompano, though somewhat more elongate, while the head is larger, being contained four and a half times in the total length. The anterior rays of the dorsal and anal extend beyond the middle of the fin, if laid backward. In the number of the fin rays it corresponds most closely with the Round Pompano. I first became familiar with the species through examining a small specimen in the collection of my friend, J. Matthew Jones, Esq., of "The Hermitage," Smith's Parish, Bermuda, in I $\$ 76$, has since been repeatedly observed on our own coast. It is the largest of the Pompanoes. Dr. J. W. Velie obtained two large specimens in West Florida, and in I879, Mr. Blackford sent to the National Muscum a giant of the same species, taken at Jupiter Inlet, about two feet long, and weighing twenty-three pounds. It has since become evident that the species figured by Girard in the ichthyology of the United States and Mexican boundary, under the name Doliodon carolinus, is really Tracliy'notus goreensis, and that its occurrence in the Gulf of Mexico is not unusual.

In the Gulf of Mexico it is not unusual, being known at Key West as the. I'ermit."

Stearns informs us that this fish is rather common along the lower end of the the Florida Peninsula, and is often taken in seines at Cedar Keys, and at the mullet fisheries of Sarasota and Charlotte Harbor, as well as about Key West.

The Banner Pompano, $T$. glaucus, has a somewhat elongate body and a small head. It is much thinner than either of the other species. Its silvery sides are marked with four blackish vertical streaks; the best distinguishing mark is in the length of the first rays of the dorsal and anal, which extend back nearly to the tip of the caudal fin.

It is a member of the West Indian fauna, and is represented in the National Museum by specimens from Pensacola, Key West, the Bahamas and the Bermudas. Stearns remarks that it is obtained frequently at Pensacola with the other species, but is never very common, is seen only in the spring, and is not valued as a food-fish. Professor Jordan tells me that it is not rare along the Carolina and Gulf coasts, and that at Pensacola, wherever it is known as the 'Gall-topsail Pompano, it is held in low esteem. 'The allied species, Trachynotus fasciatus, has lately been noticed by Jordan and Gilbert on the Pacific side of the Isthmus of Panama. 
Linnæus classed the Pompano with the stickleback on account of the sharp spines on its dorsal fin. The young, like that of the swordfish, have along the posterior edges of the opercular bones, rows of strong spike-like spines, which entirely disappear with advancing age.

The spawning grounds and breeding times of these fishes are not well known. Mr. Samuel C. Clarke states that the common Pompano spawns in March, in the open sea, near the inlet to Indian River, Fla. Mr. Stearns' statement concerning the occurrence of the young about Pensacola has already been quoted. It is supposed that those visiting our northern coast breed in winter, at a distance from the shore, the eggs, like those of the mackerel, being lighter than the water and floating at or near the surface. The Pompanoes may, however, be truly migratory fishes, seeking the waters near the equator in winter, to follow a long coastwise migration, north and south in summer. They are rapid, powerful swimmers.

Their food consists of mollusks, the softer kinds of crustaceans, and probably the young of other fishes. S. C. Clarke states that they have been known to bite at a clam bait. Scott remarks: "It is mulletmouthed; never takes a bait except by mistake." Their teeth are rery small and are apt to disappear with age.

They are caught in set nets and Spanish cast-nets. Great quantities are secured in the Gulf of Mexico and in Mobile Bay. A few are taken every year in the traps on the New Jersey coast. The local demand for them is so great that they are not usually sent far away from the place where they are taken. In New Orleans, Mobile, Savannah, Charleston, or New York, they readily command the price of $\$ I$ to $\$ I .50$ a pound. The entire quantity sold annually in New York probably does not exceed three thousand pounds.

Pompano means "grape leaf," and in Western Europe is appropriated by a very different fish. This name was applied to our fish by the Spanish colonists of America. The Cubans call the Pompano "Palometa." In South Carolina it is known as the "Crevalle" or "Cavally," a corruption of Caballa, (horse). La Roche, in his "Voyage to Canada," published in I 542 , wrote of "salmons, mullets, sturgeons, surmullets, bass, carps, pimperncaux, and other fresh water fish." This is the earliest use of this name for an American fish; the writer cannot have been acquainted with what we now call Pompano, but it is impossible to understand his meaning. 
In August, is $\%$, a party of the Fish Commission hauled a hundred fathom seine on the beach at Watch Hill, R. I., and much to our surprise a number of young Carolina Pompanoes were landed. They were less than two inches long, and were exceedingly graceful in their movements. They were kept alive for some weeks in aquaria. At a short distance they looked like silver dollars swimming about on their edges.

Twelve months later we were still more successful, obtaining the young of both species in Holmes' Hole. 'The small Round Pompanoes, an inch or two in length, were very beautiful, their burnished sides shaded with tawny golden tints.

In 1876 , I became familiar with three species in the Bermudas, the most common of which was the Round Pompano. In the winter of I\$75 a school of six or seven hundred were seined on the south shore of the islands. A large one was confined in the aquarium at "Wistow Lodge," the residence of Hon. C. M. Allen. This aquarium is unique, being a circular basin, embowered in tropical vegetation, and aerated by a powerful fountain of sea water, forced up by a ticle-wheel. In this limpid pool were many gorgeously-colored species, the angel-fish, the parrot-fish, the rainbow-fish, the Spanish-lady, the surgeon, the porcupine, and the sergeant-major. Among them, as they softly floated, moving like soaring birds, flashed in and out the Pompano, with black-tipped, streaming fins, only plainly visible when momentarily at rest in some secluded corner of the basin. It was the only fish I have ever seen which appeared to possess the power of becoming phosphorescent at will. At night we could trace its nervous movements by occasional gleams of light, as the fish, turning one side toward us, touched with the other the floor of the basin. 


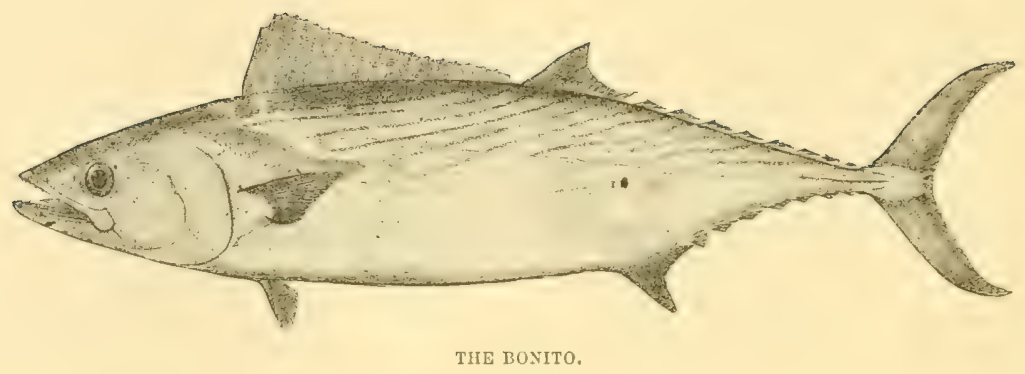

\title{
BONITOES AND TUNNIES,
}

\author{
Vext with the puny foe, the Tunnies leap, \\ Flounce on the stream, and toss the mantling deep, \\ Ride o'er the foamy seas, with torture rave, \\ Bound into air, and dash the smoking wave.
}

Oppian, Translated by Jones.

7 HE Bonito, Sarda mediterranea, is one of those fishes which appear to live chiefly in the open ocean, wandering hither and thither in large schools, preying upon other pelagic fishes, and approaching land only when attracted by abundance of acceptable food. Several of the smaller species of the group of Tunnies, to which it belongs, are known to sailors by the same name. The common "Bonito" of England, Orcymus pelamys, two or three specimens of which have been detected in our waters since 1876 , is what is here called the "Striped Bonito," but the fish which most frequently and in greatest numbers approaches our shores is the one which is named at the head of this section. Almost nothing is known of its habits, and it is even impossible to define its geographical range with any degree of certainty, its distribution being very unlike tha: of any other fish with which we are acquainted. It may be said, howevi. that it is found only in the Atlantic basin. On our coast it occurs in summer between Cape May and Cape Sable, though rarely north of Cape Ann; occasionally off Cape Hatteras and the mouth of the Chesapeake and in the Gulf of Mexico. Specimens have been taken about the Canaries and Madeira, at the Cape of Good Hope and in the Mediterranean. It has not been observed on the coast of Europe north of Gibraltar, no? at the Bermudas. 
The Bonito does not appear to have been abundant in former years; it attracted but little attention in our waters before 1860 , although it was

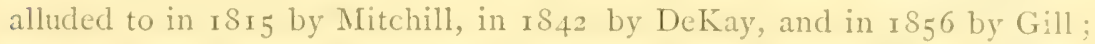
none of these authors, however, regarded it as a common form, or cited any considerable number of instances of its presence.

A note from Prof. J. Hammond Trumbull states: "This fish used to be quite common, in some years, in the Stonington market. I have a note of a considerable number in market July $22, \mathrm{I} 842$, their first appearance for the season."

Storer remarked in 1846 : "This species, called by the fishermen in Boston market the 'Skipjack,' and by those at the extremity of Cape Cod the 'Bonito,' is very rarely met with in Massachusetts Bay. It is occasionally taken at Provincetown, and even at Lynn. At some seasons it is frequently caught at Martha's Vineyard with trailing bait."

One of these fishes is a marvel of beauty and strength. Every line in its contour is suggestive of swift motion. The head is shaped like a minie bullet, the jaws fit together so tightly that a knife-edge could scarcely pass between, the eyes are hard, smooth, their surfaces on a perfect level with the adjoining surfaces. The shoulders are heavy and strong, the contours of the powerful masses of muscle gently and evenly merging into the straighter lines in which the contour of the body slopes back to the tail. The dorsal fin is placed in a groove into which it is received, like the blade of a clasp knife in its handle. The pectoral and ventral fins also fit into depressions in the sides of the fish. Above and below, on the posterior third of the body, are placed the little finlets, each a little rudder with independent motions of its own, by which the course of the fish may be readily steered. The tail itself is a crescent-shaped oar, without flesh, almost without scales, composed of bundles of rays flexible, yet almost as hard as ivory. A single sweep of this powerful oar doubtless suffices to propel the Bonito a hundred yaris, for the julished surfaces of its body can offer little resistance to the water. I have seen a common dolphin swimming round and round a steamship, advancing at the rate of twelve knots an hour, the effort being hardly perceptible. The wild duck is said to fly seventy miles in an hour. Who can calculate the speed of the Bonito? It might be done by the aid of the electrical contrivances by which is calculated the initial velocity of a projectile. The Bonitoes in our sounds to-day may have been passing Cape Colony, or the Land of Fire, day before yesterday. 
In 1875 , the earliest Bonito was taken in the Robinson's Hole weir July 7 , and two more came along July 24. They were not abundant until August, when many more were taken in Vineyard Sound by Oak Bluffs boats, trolling. The fishermen then believed that they were gradually increasing in numbers and importance and taking the place of the squeteague which was disappearing. August 7 the weir at Cedar 'Tree Neck had taken nothing but Bonitoes, while those farther west at Menemsha Bight had taken only squeteague.

The Bonito is not so great a favorite with the angler as it deserves to be. It is caught in the vicinity of Block Island with trolling-hooks. He bites sharply, like a bluefish. The best bait is an ordinary bluefish hook with a petticoat of red and white flannel, though the fish will also take any bluefish lure.

In I 877 four smacks were constantly running between Block Island and New York, carrying each from 4,000 to S, 000 Bonitoes a week, or perhaps 20,000 pounds. The yield of Block Island alone that summer was probably not less than $2,000,000$ pounds. In one haul of the purseseine by the schooner "Lilian," of Noank, 1,500 were taken ; and in August, I874, I, 200 in one pound-net.

On the eastern shore of Virginia, Bonito are caught by harpooning, says Mr. C. R. Moore, and also with the hook. They are most numerous about the mouth of the York River. They come in June and leave in September. It is quite possible, however, that the Bonito referred to by Mr. Moore is quite another fish-the Cobia, Elacate atlantica.

When tested side by side with the bluefish, at the same table, the Bonito seems not much inferior, though the flesh is somewhat softer and more perishable.

The Bonito may be ranked among the many excellent food-fishes of our coast, and, in any country not so abundantly suppiied with finely-flarored kinds, it would be considered of the highest value. Their vitality is so great and their supply of blood so abundant that unless bled immediately after capture their flesh, especially in warm weather, is apt to deteriorate. Great quantities of them are taken to New York, and there, as well as in Rhode Island and Connecticut, they are sold exclusively under the name of "Spanish Mackerel," at prices ranging from thirty-five to fifty cents a pound. This was the common practice in 1874 , and has continued since. The statement made by Scott in $\mathrm{I} S 75$, that on account of their rarity 
they were preferred to the bluefish and striped bass, would not now be true; his prediction that they would in time become as abundant as the bluefish seems, however, during some years to have been almost verified. The dealers, by the change of name in the market above referred to, are able to obtain a high price for a fish which, under its own name, would be looked upon with suspicion. In absurd report that the Bonito was poisonous was current in $\mathrm{I} \$ 74$, probably owing to the fact that similar fish taken in warm climates are sometimes deleterious.

In $\&_{75}$ the ordinary price in New York was one cent apiece, though in the wholesale markets they commanded the same price as bluefish, and many were sold, as has been stated, at the high rates of Spanish Mackerel. The market was so glutted that many of the vessels could not dispose of their cargoes.

According to Stearns, our Bonito occurs also in the Gulf of Mexico, where it is everywhere abundant, and is found in the bays on the Florida coast. It usually moves, according to the same authority, at the surface of the water in small schools. At sea it is found throughout the year, and along the shore only in the summer. Small schools are sometimes taken in clrag-seines in shallow water. Its market value at Pensacola is not great, although it has become an article of food.

A writer in the Providence fournal July, I S7 I, remarked: "Last night I had a fish on-my table which they said was a kind of Spanish Mackerel; the moment I tasted it I said it was a Bonito, having eaten it thirty years since, on my first voyage to India, and the taste had never been forgotten. It is the salmon of the sea. Mark its solidity of flesh, its great weight, its purity of taste, entire absence of the slightly decayed taste all fish has during warm weather. It is as nourishing as beef, and Bonito is the worthy rival of the Spanish mackerel and the sheepshead."

They seem first to have attracted the attention of New England authorities about $\mathrm{I}_{86}$. Genio C. Scott, writing in 1875 , remarks : "His first arrival along our beaches and in our bays was about eight years ago, and his shoals have increased remarkably fast ever since his advent. As a table luxury it ranks, with epicures, below the striped bass and bluefish, but because of its comparative rarity it commands a price rather above either. The numbers of this fish annually taken about the approaches to our harbors with the troll and in nets has increased so much that it bids fair to become nearly as numerous as the bluefish." 
Each summer the schools now range the ocean between Cape Cod and Cape Hatteras, and about Block Island and the eastern end of Long Island fabulous quantities are often captured.

The habits of the Bonito are similar to those of the bluefish, though it is, if possible, even more active and more an embodiment of perpetual and insatiable hunger. They come at the same time, they leave the coast simultaneously, they prey in company upon menhaden and mackerel, and together they are often caught in the fisherman's gill-net or are detained in the labyrinths of the pound-net. The two kinds of fish do not, it is supposed, mingle, but the regiments rush to battle side by side.

Sometimes two lines in one boat will fasten at the same time a bluefish and a Bonito. The Bonito, like the bluefish, appear to be attracted to our waters by the great schools of mackerel and menhaden, upon which they feed.

Schools of Bonitoes cause more commotion than those of bluefish; they spring out of the water, and are visible at long distances. They are attended by the same schools of screaming gulls and terns, and leave in their track similar "slicks" of oil and blood.

The Bonito is an alien in our seas. It comes here only for food, and in winter disappears entirely. It does not, like the bluefish, follow the trend of the coast to the south, to pass the cold months off the shoals of Hatteras. No very young individuals of this kind have ever been obtained in the western Atlantic, although young bluefish, from two to eight inches long, may be caught in summer by tens of thousands on any sand beach south of Monomoy. Genio C. Scott records the capture of one in Jamaica Bay in 1874 weighing less than a pound, and which he believes to have been hatched the previous year. The Fish Commission also has one of the same size taken off Southern New England. Charles Potter, of Norwalk, Conn., states that small specimens, six inches in length, were from 1870 to $\mathrm{r} 874$ frequently taken late in the fall in the weirs at Fisher's Island.

A fish weighing ten pounds measures twenty-eight to twenty-nine inches; eight pounds, twenty-seven to twenty-eight inches; seven pounds, twenty-six to twenty-seven inches; six pounds, twenty-five to twenty-six inches; four pounds, twenty-two to twenty-three inches. There have not yet been found in the adults any traces of mature spawn, though one taken off Norwalk July 23, 1874, had the eggs well formed though not nearly 
mature. 'The breeding grounds of the Bonito, like those of the swordfish, are doubtless in some remote quarter of the globe. The swordfish spawns in the Mediterranean, if nowhere else. The species is cosmopolitar, and occurs in nearly every quarter of the globe, though perhaps nowhere in greater abundance than along our own shores.

On the California coast occurs a closely related species, the Pacific Bonito, Sarda chilcnsis, which is thus described by Prof. Jordan:

"This fish is everywhere known as the Bonito. The names 'Spanish Mackerel,' 'Skipjack' and 'Tuna' are also sometimes applied to it. It reaches an average weight of about twelve pounds, but the body is considerably longer and more slender than that of an Albicore of the same weight. It ranges from San Francisco southward to Chili, being abundant in Monterey Bay and about the Santa Barbara Islands in the summer and fall. It approaches to within half a mile of the shore, where, in company with the barracuda, it is taken in great numbers by trolling. It spawns in August or September. Its arrival is in early summer and its departure in the fall, at which season the young are said to be found abundantly in the kelp. It feeds chiefly on anchovies and squids. As a food-fish it is not held in high esteem, the fish being coarse. Great numbers are salted and dried, and are in that state considered far inferior to the barracuda and yellow-tail."

The Striped Bonito, Orcymss pelamys, already mentioned, is distinguished from other species by the presence of four dark lines, which begin at the pectoral fin and run along the side of the belly to the tail, the sides of the common Bonito being of a silvery white. This species, is occasionally taken on the European coast, but has rarely been known to enter the Mediterranean. It is found in the Pacific on the coast of China and Japan, and is the species most commonly known to mariners as the Bonito, or Albicore, of the activity and voracity of which, as observed from the decks of ressels at sea, so many descriptions have been written. The first individual on our coast was that seen by Mr. Barnet Phillips in 1876 . Another was taken by Mr. J. H. Blake at Provincetown in July, I 877 . Others have since been observed at Woods Holl and in the New York markets. The capture of the Striped Bonito is a favorite subject with Japanese artists. I have seen many drawings and prints in Japanese books, in which the characteristic form and markings of this fish are faithfully delineated. The Japanese appear to catch it in great quantities, with rod, line, and hook. 
One of the American men-of-war of Revolutionary times was named "Bonetta," after the fishes of this group.

In addition to the Striped Bonito, which is, properly, a Tunny, we have in American waters two other small Tunnies-the Long-finned Tunny, Orcymus alalonga, and the Silver-spotted Tunny, Orcymus argentivittatus-which have since $\mathrm{x}_{77}$ been added to the fauna of the United States.

The former of these two occurs in considerable abundance on the coast of California, and is there also known as the Albicore. Concerning it Prof. Jordan writes: "This fish reaches a weight of about twelve pounds, and is much shorter and deeper than the Bonito of the Pacific. It is found from San Francisco southward, but is abundant only in the channels about the Santa Barbara Islands. It seldom comes within six miles of the shore, and it is taken by trolling. It spawns about the middle of August, its arrival on the coast being determined by the spawning season. It usually is present in June and July and disappears in the fall. It feeds chiefly on anchovies and squids, and various deep-water fishes (Merlucius, Sudis, Myctophum) are found in its stomach. As a food-fish it is even less valued than the Bonito, rarely selling for more than twenty to twentyfive cents. It is abundant, but of little economic importance, being usually fished for by sportsmen."

The Albicore, Orcymus alliteratus, known in the Gulf of Mexico, where it is confounded by the fishermen with other similar species, as the "Bonito," and in the Mediterranean by the names "Tonnina" (Trieste), "Carcane" (Venice), and "Tauna" (Nice), has a geographical range very similar to that of the Bonito, except that it is found in the Pacific on the east coast of Japan, and in the Malay Archipelago. It has also been recorded from Cuba, Brazil and the Bermudas. This activespecies, which attains the weight of from thirty to forty pounds, first made its appearance in our waters in $\mathrm{I} 87 \mathrm{I}$, when several large schools were observed by the Fish Commission in Buzzard's Bay and the Vineyard Sound. Nearly every year since they have been seen in greater or less numbers; but, as they are of iittle value for food, no effort has been made to capture them, nor are they often brought to the markets. 'This species, known at the Bermudas as the "Mackerel," is frequently seen in the markets at Hamilton and St. Georges.

In the Mediterranean its flesh is considered to be very excellent. My 
own experiments with it are hardly confirmatory of this statement, but in Southern Europe all the fishes of this family are very highly esteemed, and that it is not appreciated with us is perhaps clue to the fact that we do not know how to cook them. I firid the following note by Prof. Baird: "Flesh, when cooked, dark brown all around the backbone, elsewhere quite dark, precisely like horse-mackerel. Flesh very firm, compact and sweet."

Stearns records its frequent occurrence in the Gulf of Mexico, where he has observed individual specimens at Pensacola and Key W West.

The habits of this fish have not been specially studied, but there is no reason to doubt that they correspond closely with those of others of the same family.

The Frigate Mackerel, Auxis thazard, is a species which has lately made its appearance in our waters, none having been observed before r $8 S 0$, when they came in almost countless numbers. It is yet to be determined whether it is to be a permanent accession to our fauna. The United States Fish Commission obtained numerous specimens, twenty-eight barrels having been taken in a mackerel seine ten miles east of Block Island on August 3, I880, by the schooner "American Eagle," Capt. Joshua Chase, of Provincetown, Mass.

The Frigate Mackerel resembles, in some particulars, the common Mackerel; in others, the Bonito, the genus Auxis being intermediate in its character between the Scomber and the related genera Pclamy's and Orcymus. It has the two dorsal fins remote from each other as in Scomber, and the general form of the body is slender, like that of the Mackerel. The body is, however, somewhat stouter, and, instead of being covered with small scales of uniform size, has a corselet of larger scales under and behind the pectoral fins. Instead of the two small keels upon each side of the tail, which are so noticeable in the Mackerel, it has the single, more prominent keel of the Bonito and the Tunny. Its color is greyishblue, something like that of the pollock, the belly being lighter than the back. Under the posterior part of the body, above the lateral line, are a few cloudings or maculations resembling those of the Mackerel. The occurrence of a large school of this beautiful species in our waters is very noteworthy, for the fish now for the first time observed are very possibly the precursors of numerous schools yet to follow.

The Frigate Mackerel has been observed in the West Indies, and other 
parts of the tropical Atlantic, as well as on the coast of Europe. In Great Britain it is called the "Plain Bonito." It is not unusual in the Bermudas, where it is called the "Frigate Mackerel," a name not inappropriate for adoption in this country, since its general appearance is more like that of the Mackerel than the bonito, while in swiftness and strength it is more like the larger members of this family. It is the "Timberello" of the Adriatic fisher-folk.

In the Mediterranean there is a regular fishery for this species, which is prosecuted from May until September, and they are also taken in great numbers in the Tunny nets.

Since the first appearance of this fish many new observations of its abundance have been received. These fish appeared to have come in immense schools into the waters between Montauk Point and George's Bank; and from Mr. Clarke's statements it appears that they have been observed in small numbers by fishermen in previous years. Several vessels have come into Newport recently reporting their presence in immense numbers in the vicinity of Block Island. It will interest the "ichthyophagists" to know that several persons in Newport have tested the fish, and pronounce it inferior to the bonito. Part of the flesh, that on the posterior part of the body, is white, but behind the gills it is black and rank, while the meat near the backbone is said to be of disagreeable, sour flavor.

It is hard to predict what its influence will be upon other fishes already occupying our waters. Its mouth is small and its teeth feeble, so that it is hardly likely to become a ravager, like the bonito and the bluefish. There is little probability, on the other hand, that its advent will be of any special importance from an economical point of view, for its oil does not seem to be very abundant, and it will hardly pay at present to capture it solely for the purpose of using its flesh in the manufacture of fertilizers.

It is very important that any observation made upon this species in years to come should be reported to the United States Fish Commission. The length of those $I$ have seen ranges from twelve to sixteen inches, and their weight from three-quarters of a pound to a pound and a half or more. Those sent to New York market were part of the lot taken by the schooner "American Eagle" and brought into Newport, whence they were shipped by Mr. Thompson, a fish dealer of that place. It would require from eighty to one hundred of them to fill a barrel; so the estimate of Capt. 
Riggs, that there are a thousand barrels in one of the schools, shows how exceedingly abundant they must be.

Capt. N. E. Atwood, of Provincetown, Mass., the veteran fishermanichthyologist, has examined the specimens, and is satisfied that they belong to the same species with a fish which he found abundant in the Azores in I 840 , when, led by the reports of Cape Cod whalers, he went to these islands in search of the Mackerel, the mackerel fishing leing por at home. No Mackerel were found except the Frigate Mackerel. Reports in 1887 , concerning this occurrence of Mackerel in the Eastern Atlantic are very probably inspired by the presence of this fish.

The Horse Mackerel, so-called, Orcymus thymmus, is the most important of the Tunnies, the "Ton" or "Tuna" of the Mediterranean, and the "Tunny" of English-speaking people.

The distribution of this fish corresponds more closely with that of the ordinary species of the Atlantic, since it occurs not only in the Mediterranean and the Western Atlantic north to the Gulf of St. Lawrence, but also on the coast of Europe to the Loffoden Islands, latitude $69^{\circ}$.

Of this fish, as found in American waters, our naturalists have not much to say, the species, although abundant at certain seasons of the year off particular parts of the coast, being not a very familiar one to our writers. They seem to be rather a northern fish, and are said by Storer to make their first appearance on our shores about Provincetown early in June, remaining until October. Of late years they seem to be increasing in abundance northward, becoming more and more common during the summer season at Newfoundland.

In 1878 Capt. Henry Webb, of Milk Island, near Gloucester, harpooned and killed thirty of these monsters, weighing in the aggregate at least thirty thousand pounds. They had entered his pound in pursuit of small fish, cutting without difficulty through the netting. (One hat his stomach full of small mackerel.

According to Capt. Atwood, on their first appearance in Massachusetts Bay they are very poor, but by the beginning of September become quite fat and are very much hunted for the oil, the head and belly especially furnishing sometimes as many as twenty gallons. They are harpooned on the surface of the water, much like the Sword-fish.

The early traditions of this fish in Massachusetts Bay speak of them as being sometimes so tame as to take food from the hand; but they have 
long since given up this engaging habit. This species attains a very great size. One specimen, taken in $\mathrm{I}_{3} 8 \mathrm{~S}$ off Cape Ann, measured, according to Dr. Storer, fifteen feet in length, and weighed one thousand pounds, while still larger individuals than this are known to have been captured.

Their food while in our waters consists, it is said, mainly of menhaden, of which they destroy a vast number. Their inclosure in the fishermen's nets is not much desired, as they are apt to become entangled in them and to do much injury in their efforts to escape. They are pursued by the killer whales, before which they flee in great terror. A graphic description of this pursuit is given below in the words of Capt. Atwood.

Strange to say, although highly prized in the Old World from the time of the ancient Romans to the present day, they are seldom, if ever, used for food in the United States, where their flesh is not esteemed, being rarely, if ever eaten, although much used for mackerel bait. It is, however, more in favor in the Provinces. Although occurring in large numbers and of remarkable size, no effort is made toward their capture; and though not unfrequently taken in weirs and pounds along the coast, they are always allowed to rot on the shore. Occasionally a portion of the flesh may be used as food for chickens, but seldom, if ever, for human consumption.

In the Mediterranean the Tunny is taken in large nets, known as "madragues," similar in many respects to the so-called "traps" of Seconnet River in Rhode Island. The fish are used partly fresh and partly salted, and they are put up in oil to a considerable extent and largely consumed in all the Latin countries of Europe. Considerable quantities are salted and canned, and canned Tunny of European manufacture is imported to New York in small quantities. The flesh is dark and not usually attractive, although wholesome. They appear to attain a greater size in America than in Europe, one of five hundred pounds in the Mediterranean being considered rather a monster, while in America their weight is not unfrequently given at from twelve to fifteen hundred pounds.

Nothing definite is known in regard to their mode of reproduction. The eggs are said to be deposited early in June, and the young at hatching, according to Yarrell, weigh an ounce and a half, reaching a weight of four ounces by August, and thirty ounces by October.

Mr. Matthew Jones, of Halifax, Nova Scotia, writes: "The Tunny is very common on the eastern coast of Nova Scotia in summer, and is known to fishermen and others as the 'Albicore.' The Rer. J. Ambrose 
informs me that it regularly visits St. Margaret's Bay every summer, several specimens being taken and rendered down for oil. They were particularly abundant in 1876 . They are not seen in the Basin of Minas."

According to Dr. Fortin the Horse Mackerel is quite abundant in the Gulf of St. Lawrence, especially in the Days of Chaleur and of Gaspé, and also in the Straits of Belle Isle and Blancs Sablon Bay. It is taken in increasing numbers in the gulf, partly by spearing and partly by baiting. For this latter purpose strong steel hooks are used tied to solid lines and baited with herring. This fishing is prosecuted more particularly in the Bay of Chaleur and off Caraquette, where in $186_{3}$ over one hundred were captured. The fishing is quite exciting, although tiresome and requiring a good deal of skill, as in the efforts of the fishes to escape they pull with such violence as to endanger the lives of the fishermen by dragging them werboarl.*

Capt. Atwood contributes the following note on Horse Mackerel in Cape Cod Bay:

"They don't come till the weather gets warm. We don't see them at first when we begin setting mackerel nets, but about June they are liable to appear, and we find holes in the nets. Sometimes in September they gill them for the sake of their oil. My brother had forty-seven holes through one eighty-yard net in one night. When they strike a net they go right through it, and when they go through it the hole immediately becomes round. It looks as if you could put a half bushel through it. I said in my Lowell Institute lectures that a shark in going through a net would roll himself up in it, but the Horse Mackerel get right through, and the hole they cut could be mended in five minutes. The fishermen don't dread them much because they do the nets so little injury. They remain with us through the summer and early autumn, when they are killed for the oil. When they are here they fced upon any small fish, and when menhaden were here I have seen them drive the harbor full of them. I have seen the Horse Mackerel swallow dogfish whole weighing eight pounds. As fast as we got out the livers of the dogfish they would catch them and eat them. There was a great deal of whiting here at that time. They have almost totally disappeared. The Horse Mackerel seems to be the enemy of all kinds of fish. There is nothing to trouble the Horse

\footnotetext{
* Canadian Fishery Report for $1862-63$.
} 
Mackerel until the killer comes, and then they know it, I tell you. Then the Horse Mackerel will run! Some fishermen say that they have seen a killer poke his head out of the water with a Horse Mackerel in his mouth. I have known a Horse Mackerel to yield twenty-three gallons of oil. The average size is about eight feet in length."

This is a book devoted to American Fishes, but the Tunny, though an American fish, is not the foundation of an American fishery. In time we shall no doubt have a tunny fishery of our own, and as a step toward the consummation of that result, I quote a description of madrague fishing in Sicily, from the ever-delightful pen of Dr. Badham :

"It was early in the morning of a lovely August day-never since we had been in Sicily had the water looked more blue, nor the cactus-crowned heights of Monte Pelegrino more inviting - that we put off in a boat from the Bay off Palermo, and ordered our barcaroles to pull for the tonnaro, or place where the madrague lay, about a mile from shore; to seaward all was smooth; not a ripple broke the oleaginous expanse stretched before us, mapped with floating corks, and indicating, as accurately as on a ground-plan, the whole extent and figure of the mighty decoy-a town indeed in size; having pulled from one end to the other of the long faubourg, to the first submarine barrier, and then glided over it, we rowed with increased speed between battlements of cork and motionless buoys, and soon came to the spot, towards which some boats a little in advance of our own had been driving a shoal of thunnies, like a flock of timid sheep. 'Ecco la camera della morte ; siamo giunti!' exclaimed both rowers at once, shipping their oars, and staring down into the depths to see what might be there : we did the same ; but not discovering anything, the men resumed the oars, and in a few seconds laid us alongside an anchored barge, - one or two, which were placed as guards over each end of the 'chamber of death.' The first served as the point $d$ 'appui for the nets, which were being worked up from the near side of the opposite vessel. A crowd of fishermen were busy tugging away at what seemed to our impatience an endless cordage ; by the shortening of which, however, as the boat duly received it, layer after layer, coil upon coil, and fold upon fold, they were slowly bringing up the reticuled wall from the bottom. Whilst waiting the result we had time to notice the fine proportions of the men, who, leaning over the sides of the boat, or standing on its benches, exhibited their athletic and agile forms picturesquely grouped and engaged in all those varieties of muscular action which each man's share in the labors severally demanded. A fine figure is, according to Oppian, a prime qualification in a fisherman:

First be the fisher's limbs compact and sound,

With solid flesh and well-braced sinews bound: 
Let due porportion every part commend,

Nor leanness shrink too much, nor fat distend.*

And more perfect figures than theirs poetry could not describe, nor the classic chisel of Greece portray; every man was an Academy model; to perfect symmetry of limb were added dark flashing eyes, jet black hair, beard, and moustache; irreproachable noses, ivory teeth, and the richcolored complexion of the South. What a contrast to a body of santl-hairul, freckled, hard-featured, stockingless Highlanders, landing from a sicotch steamboat, and challenging, by their self-satisfied air, attention to an ungainly gait and knock-kneed deformity of person!

Presently a simultaneous shout proclaimed, 'La pipa! la pipa!'-our own boatmen, after repeating the cry, informed us that a sword-fish, or pipa, as the Palermo sailors designate it, had been seen to enter the decoy with the thunny, and must now be in the net, as the flooring had been drawn up several fathoms, the pipa presently swam towards the surface, to see what was the matter, and some well-practised eyes having caught a first glimpse of him, the crews testified their delight by three loud vociferations. Frightened by the noise and the confused scene above, the long form of the fish might soon be distinguished, shooting now here, now there, athwart the hempen court; he rose at last, in much agitation, to the top, but instantly dived down again, scattering the spray far and wide with a lash of his powerful tail. This plunge only carried him among the trembling thunnies, pelamyds, and alalongas, which covered the bottom of the net; then up he came again, to find every eye looking fishy, and every hand ready to deal the fatal blow. Like a startled horse in a highfenced paddock, the sword-fish now careered round and round the enclosure, vainly seeking an exit by which to bolt, but finding none, he backed a moment, then, swifter than thought, rushed on the net, ran his long weapon through, and made a large hole in the meshes; but becoming hopelessly entangled, his fate was sealed, and death followed fast; one lusty arm throws a heavy harpoon, and misses; another with more steady aim, and a lighter missile, hits and wounds the fish, who, staggered at the blow, flounders from side to side, while the clear blue waves are stained all round with his blood; in a few seconds a dozen barbed poles lie deep in the poor pipa's flank, and after throwing up a whirlpool of discolored water, as the blows of the fishermen rain faster and faster upon their victim, the crimson of the flood deepens, and in less than a minute from the first wound the gashed carcass of the great scomber is poised up safely into the boat, with a triumphant shout. 'Five scudi, my lads, for our share!' exclaims one of the excited mariners, as they lay him at last at the bottom : and 'Bless the Virgin and St. Anthony,' says another, 'there is not much damage done this time to the net.' 'Now, signor, we shall presently see the thunny,' cried out our barcaroles; and accordingly, as

\footnotetext{
* Oppian, J. Jones's translation.
} 
the sieve-like flooring of the 'camera della morte' was drawn within a few feet of the surface, a mixed multitude of large fish, chiefly of the scomber family, all in violent agitation at what they saw and heard (for the men were now gaily singing at the ropes), dashed and splashed about, till the whole enclosure was covered with foam. The work of slaughter soon commenced, and these great creatures, despatched by blows, were hauled without difficulty on board the barge.* The chamber being now empty, was let down again for new victims, while we followed the cargo just shipped to the land-place ; thence, preceded by two drummers, off we went in a procession to the Mercato Reale, where we found many great zyeless thunny (the produce of a still earlier haul) already piled up in bloody heaps on the flags. $\uparrow$ Besides these, there were alalongas, whose long pectorals had been draggled in the mire, with many other large and curious fish, and the formidably armed heads of two or three sword-fish, fixed on end in the upper part of the woodwork of the same stalls, where their huge bodies were exposed for sale below, cut up into bloodless white masses, like so many coarse fillets of veal; while whole hampers of labridæ attracted the least attentive eye by their lovely variegated and ever-varying tints.

* Sometimes, we are told, when a very colossal thunny is caught, one of the crew mounts his back, and will ride him, as Arion did the dolphin, several times round the inner enclosure, patting and taming him before he is stabbed like his smaller companions.

t The eyes, being a perquisite of the crew, are torn out the first thing, to make oil for their lamps: the gills also and the roes, which are eaten fresh, are commonly ripped out nnd deposited in baskets by themselves. These various mutilations of the thunny render its appearance in tuc markets at all times unsightly and uninviting. In some cases, however, the fish are transferred in the first instance into an inner shed or shamble, where a whole troop of them is speedily cut to pieces, and the sections (each of which has a name and a market price of its own) are then exposed for sale. 'The young thunnies do not appear in public at all till they have been first carefully boiled in sea-water, and become thon marine.

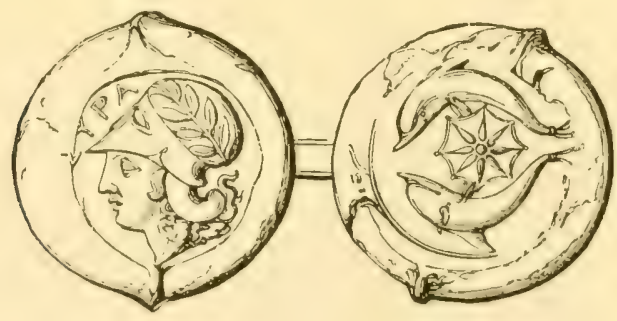




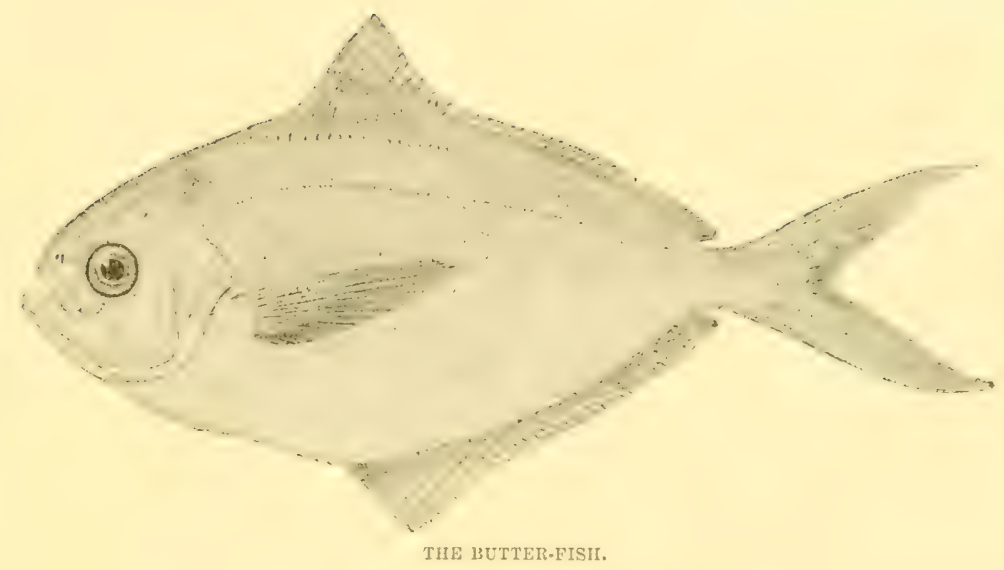

TIE HARVEST FISHES.

After the battle, the peace is dear.

After the toil, the rest;

After the storm, when the skies are clear, Fair is the ocean's breast.

Out in the gold sunshine

Throw we the net and line ;

The silvery chase to-day

Calls us to work away,

So throw the line, throw-Yo, heave ho!
Fishers must work when the treacherous sea Smiles with a face of light,

Though the deep bed, where their fortunes be, May be their grave ere night.

Out in the gold sunshine

Throw we the net and line;

The silvery lines to-day

Flash in the silvery spray,

So throw the line, throw-Yo, heave ho!

Herman Merivale, The Fisherman's Song.

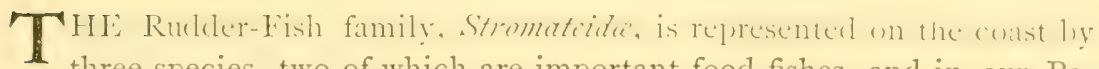
three species, two of which are important food-fishes, and in our $\mathrm{Pa}$ cific waters by one species, the so-called "California Pompano." The family is a small one, and is widely distributed throughout warm seas.

The "Butter-fish" of Massachusetts and New York, Stromatens triacanthus, sometimes known in New Jersey as the "Harvest-fish," in Maine as the "Dollar-fish," about Cape Cod as the "Sheepshead," and "Skipiack," in Connecticut as the "Pumpkin-seed," and at Norfolk as the "Star-fish," is common between Cape Cod and Cape Henry. It has been observed south to South Carolina and north to Maine. It has been found in some abundance along the north side of Cape Cod in nets with bass and mackerel. It is a summer visitor, appearing in our waters in company 
with the mackerel and disappearing about the same time. It appears to breed in the sounds and in the open ocean in June and July, and the young are found in great abundance in July, August, and September, swimming about in company with certain species of jelly-fishes. During these months several large species of jelly-fish, or sun-squalls, are found abundantly floating about in waters near the shore, and each one of these is almost invariably accompanied by ten or twelve, or more, young Butter-fishes, which seem to seek shelter under their disks, and which, perhaps, may obtain a supply of food from among the numerous softbodied invertebrates which are constantly becoming attached to the floating streamers of their protecters. The young fish, thus protected, range from two to two and a half inches in length. I have seen fifteen, and more, sheltered under an individual of Cyanea arctica not more than three inches in diameter. This refuge is not always safe for the little fishes, for they sometimes are destroyed by the tentacles of their protector, which are provided, as every one knows, with powerful lasso cells. The little fish seem to rise at the approach of danger and seek refuge among the lobes of the actinostome. They are thus protected from the attacks of many kinds of larger fishes which prey upon them, though they themselves often fall victims to the stinging power of the jelly-fish and are devoured. The habit of thus seeking shelter is very much like that of the rudder-fish. The Butter-fish attains an average size of seven or eight inches in length, and is very often taken in the pounds. The fishermen of Noank, Conn., tells me that a barrelful of them is often taken in one haul of a pound-net. They are much valued for food at New Bedford. When sent to New York they command a good price, and the poundmen at Lobsterville sometimes eat them and consider them better than scup. Their flavor is excellent, resembling that of the mackerel, though less oily; they are very palatable when nicely boiled. At many places, for instance, Noank, and Wood's Holl, they are thrown away. Storer stated that they were extensively used as manure in certain parts of Massachusetts. No observations have been made upon their food, though, since their mouths are nearly toothless, it seems probable that they subsist, for the most part, upon minute vertebrates. These fishes are remarkable on account of their brilliant, iridescent colors, which, in freshly caught individuals, are as beautiful as those of a dolphin.

The Harvest-fish, Stromateus alepidotus, has not been observed north of 
New York. Mitchill referred to it in his work on the fishes of New York, published in $\mathrm{I} 8 \mathrm{I} 5$, saying that it derived its common name, "Harvestfish," from the fact that it usually appeared during harvest time. DeKay, too, mentions having had several specimens in his possession. It is somewhat abundant at the mouth of the Chesapeake, and along the Southern coast. In the Gulf of Mexico it is rather rare; occasionally it is taken in seines at Pensacola. Dr. Günther, in his "Catalogue of the Fishes of the British Museum," makes the astonishing statement that he has seen specimens from Lake Champlain. The species ranges south to Bahia, Brazil. It is not commercially valuable except at Norfolk, Va., where it is consumed for food in large quantities, its market name being "Whiting."

The California Pompano, Stromatcus simillimus, is thus described by Prof. Jordan :

"This species, known here as the Pompano, reaches a length of eight inches, and a weight of rather less than half a pound. It occurs along the entire coast of California and Oregon, being most abundant about Santa Barbara and Soquel, and is not known from farther south than San Diego. It appears in schools chiefly in the summer and fall; occasionally, also, during the winter, its times of arrival and departure leing puite variable. It is said that it was an extremely rare visitant till about $\mathrm{r} \delta$ \% , and that its abundance since then has steadily increased, it being now often found in greater quantities than can be readily sold. It feeds on worms, small crustacea, \&c. Nothing special is known of its breeding habits. As a food-fish it is held in the highest repute, the price of individual fish ranging from two to four for a 'quarter.' Its flesh is fat, rich, and excellent."

The Black Rudder-fish, Limus perciformis, is also called by the fishermen "Log-fish" and "Barrel-fish." It has been noticed at various points along our coast from New Jersey to Nova Scotia, where schools of them were several times observed off Halifax in 1877 . It has hitherto been considered very rare north of Cape Cod. I cannot doubt that it will be hereafter found at least as far south as Cape Hatteras, and probalily along the whole length of our Atlantic coast. The halsits of this lish are peruliar in the extreme. They are almost always found in the vicinity of floating barrels and spars, sometimes inside of the barrels; hence the fishermen often call them "Barrel-fish," though the most usual name is " Ruduler- 
fish." They are occasionally taken in lobster-pots. When cruising in Fish Commission yacht "Mollie," off Noman's Land, July I3, I875, we observed numerous specimens swimming under floating spars and planks. Sometimes as many as from fifty to seventy-five were obseryed under a single spar, a cloud of shadowy black forms being plainly visible from the deck. We went out to them in a row-boat and succeeded in taking thirteen of them in the course of a day. After the first thrusts of the dipnet they grew shy and sought refuge under the boat, under which they would sink far below our reach. A lull of a few moments would bring them back to the log under which they had clustered until disturbed again. When the boat was rowed away they followed in a close-swimming school until we gained full speed, when they suddenly turned, as if by one impulse, and swam back to the log or spar. Once they followed us about two hundred yards from the spar, and then leaving us retreated to their old shelter, reaching it some time before we could turn the boat and row back to it. I had before this supposed them to be quite unusual, but on that one day we must have seen, at the lowest computation, two hundred or two hundred and fifty. They doubtless have been given the name of Rudder-fish by the sailors who have seen them swimming about the sterns of becalmed vessels.

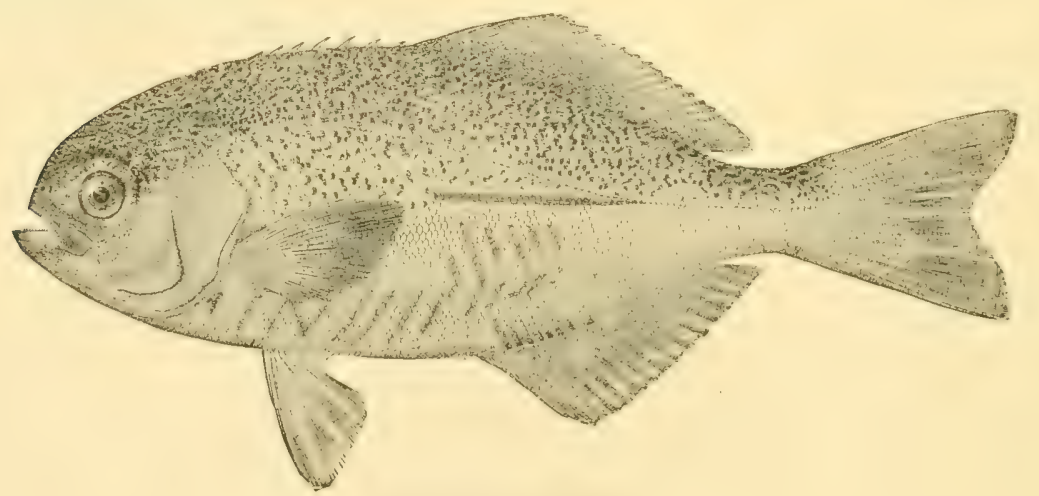

THE BLACK RUDDKR.FISH.

When the Fish Commission steamer has been dredging off Halifax, I have several times noticed schools of them hovering around her sides. They doulstless gather around the logs for the purpose of feeding upon the hyclroids and minute crustaceans, and perhaps mollusca which accumulate 
around them. Their stomachs were found to contain amphipod crustaceans, hydroids, and young squids. They are doubtless to some degree protected by the spars under which they congregate, in the same manner as their kindred, the Butter-fish, which swim under the disk of the jelly-fish. Their colors undergo considerable change from time to time, possibly at the will of the fish.

The Rudder-fish attains the length of ten or twelve inches, and is cxcellent eating. DeKay states that the fishermen of New York, in ${ }^{8} \delta_{42}$, called this species the "Snip-nosed MIullet," but this name does not appear to have become permanent.

The Rudder-fish occasionally follows ships across the Atlantic. A single individual was taken at Penzance, in Cornwall, in October, r879, and is now in the collection of Sir John St. Aubyn, at "Michaels Mount."

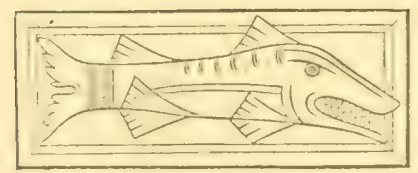




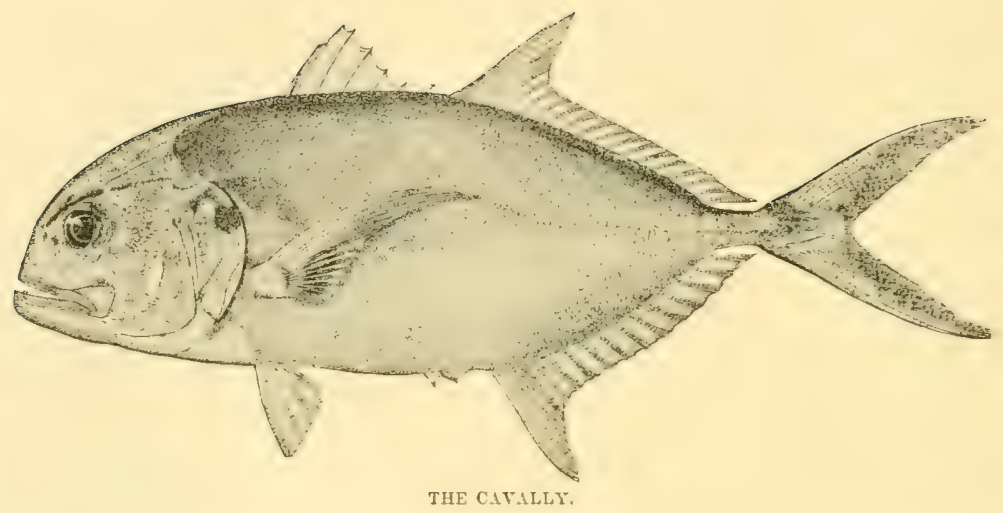

THE CAI ${ }^{\dagger}$ ALLI AND OTHER CARANGOIDS.

Swift speed crevalle over that watery plain,
Swift over Indian River's broad expanse.
Swift where the ripples boil with finny hosts,
Bright glittering they glance;
And when the angler's spoun is over them cast,
How fierce, how vigorous the fight for life!
Now in the deeps they plunge, now leap in air
Till end's the unequal strife.

I AAC MCLELLAX.

$\mathrm{T}$

HE members of the family Carangida, which is closely allied to the mackerel family, are distinguished chiefly by the form of the mouth, and by the fact that they have uniformly but twenty-four vertebra, ten abdominal and fourteen caudal, while the mackerel have uniformly more, both abdominal and caudal. They are carnivorous fishes, abounding everywhere in temperate and tropical seas. On our own eastern coast there are at least twenty-five species, all of them eatable, but none of them of much importance except Pompanoes. On the California coast there are two or three species of this family, of small commercial importance.

Caranx hippos, the Cavally of the Gulf of Mexico and Eastern Florida-the "Horse Crevallé" of South Carolina-occurs abundantly on our Southern coast, and has been recorded by Prof. Poey from Cuba and by Cope from St. Christopher and St. Croix. It is generally distributed throughout the West Indies, and is found along the Pacific coast the Gulf of California to Panama. The sjecies was originally described 
from specimens sent from South Carolina by Garden to Linnxus. 'The name of this fish is usually written and printed "Crevalle," lut the form in common use among the fishermen of the South, "Cavally," is nearer to the Spanish and Portuguese names, Cacalla and Caballa, meaning "horse." 'The name as used in South Carolina is a curious reduplication, being a combination of the English and Spanish names for "lhorse." It should be carefully remembered that in South Carolina the name Crevalle is most generally applied to quite another fish, the Pompano.

'The Carally, as it seems most appropriate to call Caranx hippos, though in individual cases occurring as far north as Cape Cod, and even, in one instance, at Lynn, Mass., is not commonly known in the United States north of Florida. Storer remarks: "This fish is so seldom seen in the waters of South Carolina that we are unacpuainted with its habits." I observed a specimen in the Jacksonville market in April, $8_{74}$. Concerning the Cavally of Southern Florida, which is either this or a closely allied species, Mr. H. S. Williams writes:

"In the Indian River this is one of the best of the larger varieties. Its season is from the Ist of May to November. It ranges in weight from three to twenty pounds, being larger and more numerous to the southward toward the Mosquito Inlet. 'The south end of Merritt's Island and the inlets opposite old Fort Capron seem to be a sort of headquarters for the Cavalli. When in pursuit of prey they are very ravenous and move with the rapidity of lightning. They readily take a troll either with bait or rag. The favorite mode of capturing them, as well as all other large fish that feed in shallow water or near the shore, is with a rifle. The high, rocky shores afford an excellent opportunity for this sport, though the rapid movements of the fish render them very difficult target." S. C. Clarke says: "It will take a spoon or other troll, and would no doubt rise to a fly. When hooked it makes long and vigorous runs, and fights to the last."

Mr. Stearns writes: "The Crevalle is common on the Gulf coast. In West Florida it appears in May and remains until late in the fall, and is equally abundant in the bays and at sea. In the bays it is noticeable from the manner in which it preys upon fish smaller than itself, the Gulf menhaden and mullet being the most common victims. On arrival it contains spawn which it probably deposits in the salt-water bayous, for in the fall schools of young are seen coming out of those places on their way 
to the sea. These young are then of about one pound weight, appearing to the casual observer like pompano, and I am told that they equal it for edible purposes. They are caught accidently by seines and trolling-lines. Large ones are not considered choice food, the flesh being dark and almost tasteless. The average weight is twelve pounds; occasionally they attain the size of twenty pounds."

Prof. Jordan found this species abundant in Lake Pontchartrain.

Caranx cmuncnophthalmus, called in the Bermudas, where it is of some importance as a food-fish, the "Goggler," or "Goggle-eyed Jack," and in Cuba the "Cicharra," occurs in the West Indies and along the Atlantic coast of the United States north to Vineyard Sound. . It is also found at Panama and in the Gulf of California, and in the Indian Ocean, the Red Sea, and off the coast of Guinea, while, as has been remarked, it is abundant in the Bermudas. Its large, protruding eyes are very noticeable features, and the Bermuda name seems appropriate for adoption, since the fish has with us never received a distinctive name. In form it somewhat resembles the species last discussed, with which it is probably often confused. Stearns speaks of a fish, common at Key West, which is known as the "Horse-eyed Jack," and this may prove to be the same species.

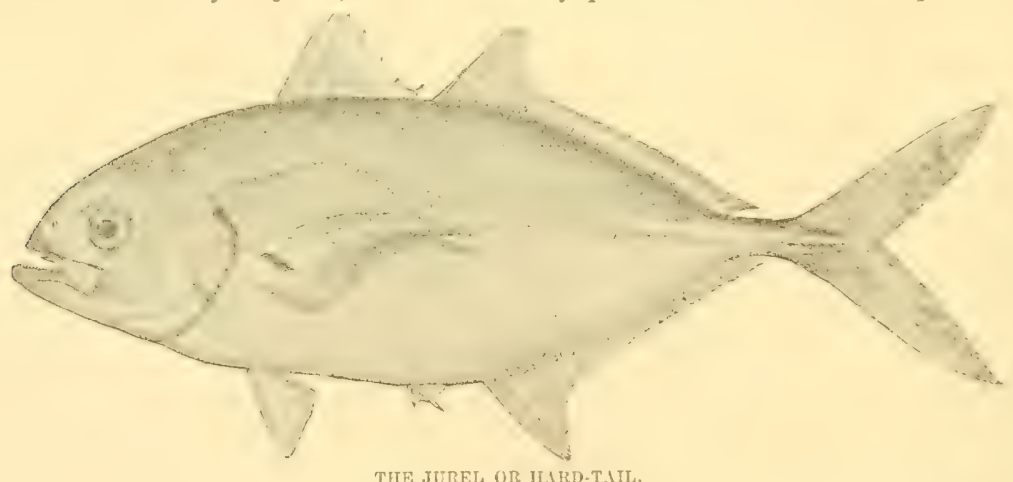

Caranx pisquetus, known about Pensacola as the "Jurel," "Cojinua," and "Hard-tail"; along the Floricla coast as "Jack-fish" and "Skipjack"; in the Bermulas as the "Jack" or "Buffalo Jack"; in South Carolina as the "Horse Crevallé"; at Fort Macon as the "Horse Mackerel"; about New York and on the coast of New Jersey as the "Yellow Mackerel," is found in the Western Atlantic from Brazil, Cuba, and 
Hayti to Halifax, Nova Scotia, where specimens were secured by the United States Fish Commission in 1877 . It is one of the commonest summer visitants of the West Indian fauma along the whole coast of Southern New England and the Niddle States, being especially abundant in the Gulf of Mexico, and one of the commonest fishes in the Bermudas. This fish is occasionally brought to the New York market, but is of no special importance as an article of food north of the Gulf of ILxico. Concerning its habits in those waters, Mr. Stcarns has contributed a very interesting series of notes. They are especially instructive, since nothing has previously been known of its life-history.

"It is extremely abundant everywhere on the Gulf coast of Florida, Alabama, and Mississippi. At Pensacola it is one of the important fishes of trade, and is highly prized for food. It is one of the class of migratory fishes of this coast, like the pompano, mullet, Spanish mackerel, and redfish, having certain seasons for appearing and disappearing on the coast, and also has habits during these seasons that are peculiar to themselves or their class. It appears on the coast in April, in large schools that swim in shoal water near the beach during pleasant weather, when there is little or no surf, in eight or ten feet of water, and in stormy weather some. little clistance from the breakers. Their movement is from the eastward to the westward. As they scldom swim at the surface, their movements can be watched only when in shoal water. The schools 'running' in April and first of May are usually smaller than those of a few weeks later, but the inclividuals of the first are somewhat larger. The mass, or largest 'run,' comes in May, and it is on the arrival of these that schools are first seen coming in the inlets.

"A noticeable peculiarity of the Hard-tail compared with some other common migratory fishes is that the first schools do not stay about the mouths of an inlet and along the beach weeks before coming inside as those of the latter do, but continue their westwarct movement, without seeming to stop to feed or play, until the time has come for a general movement towards the bays. In this way they must be distributed along the coast, with no unequal accumulation at any one point. When once inside, the numerous schools break up into smaller ones of a dozen or two fish, which are found in all parts of the bay during the summer. On their arrival the larger fish contain spawn, and become quite dull, in July and August; after this none are seen but the young fish of about ten 
inches in length, until there is a general movement towards the sea. It is believed that the adult fish spawn in the bays, but the only evidence to support that belief is that they come inside with spawn, go away with it, and that very young fish are found there. In October and November small Hard-tails are caught in Santa Rosa Sound, measuring five and six inches in length.

"The smallest of the spring run are nine or ten inches long. Adult fish measure twelve, fourteen, and fifteen inches in length, very rarely more than the last. During the months of October and November, Hard-tails leave the bays, formed in small schools and swimming below the surface in deep water. The only time that they can then be seen is when they cross the 'bars' at the inlet or sandy shoals in the bay. A few stragglers remain in Pensacola Bay and Santa Rosa Sound all winter, which are taken now and then with hook and line. I have found them in abundance in winter on the South Florida coast, where, owing to less variable conditions of the water, their habits are decidedly different. The Hard-tail is a most voracious fish, waging active war upon the schools of small fish. Its movements are rapid, and sometimes in its eagerness it will jump high out of the water. It has its enemies also, for I have seen whole schools driven ashore by the sharks and porpoises; a great many are destroyed in this way. Hard-tails are caught for the market in seines."

The occurrence of the Cuba Jurel, Caranx latus, on our coast was first announced by a drawing made by Mr. J. H. Richard of a fish taken in South Carolina. Upon this drawing Holbrook founded his species, $C$. Rickardii. Caranx latus occurs abundantly throughout the West Indies and along the Gulf coast of the United States, and it is by no means impossible that stragglers should have found their way to Charleston. According to Prof. Poey, this fish has been prohibited from sale in Cuba from time immemorial, and with good reason, since many disastrous cases of sickness have followed its use as food. This species occurs, according to Jordan, from the Gulf of California to Panama, and also in the East Indies.

The Round Robin, Dccaptcrus punctatus, called at Pensacola, the "Cigar-fish," occurs in the Bermudas, where it is an important food-fish; it occurs also in the West Indies and along the coast of the United States north as far as Woorls Holl.

A closely related species, Decapterus macarellus, is found also in the 
West Indies and along the eastern coast of the United States. According to Stearns, individuals of this species are rather rare in the northern part of the Gulf, but more common along the South Florida coast. They live in shallow water and in harbors, usually moving about in small schools. At Key West they are caught in seines, and are eaten.

The Scads, known in England as the "Horse-Mackerels," appear to occur in all temperate and tropical waters. The distribution is given by Günther as follows: "From the coasts of the temperate parts of Europe, along the coasts of Africa, round the Cape of Good Hope into the East Indian seas, to the coasts of New Zealand and West America." As has been shown by Lütken, Steindachner, and Jordan and Gilbert, three distinct species are confounded by Günther under the name Trachums trachurus.

In Europe our scad ranges north to the Trondhjem Fjord, latitude $65^{\circ}$, and is said to occur as far south as Portugal. On the coast of Holland it is known as the "Marse Banker," or "Hors." It is interesting to American ichthyologists, since the similarity of its habits to those of the menhaden, so important in our waters, caused the latter fish to be called among the early Dutch colonists of New York by the same name. Euro. pean writers describe the Scads as occurring upon those coasts in schools of immense numbers, and it would seem. that although their manner of swimming resembles that of the menhaden, in their other habits they more closely resemble our bluefish. They are considered to be food-fishes of fair quality, and attain the length of about twelve inches. They are supposed to spawn about the same time as the mackerel. Only three specimens of this species have ever been taken in the United States, one by the Fish Commission in Southern New England in 1878 , and subsequently two others by Jordan and Stearns, at Pensacola. In California, according to Jordan, the allied species $T$. picturatus occurs and is known as the "Horse- Mackerel." He remarks: "It reaches a length of about a foot and a weight of less than a pound. It ranges from Monterey southward to Chili, appearing in California in the summer, remaining in the spawning season, and disappearing before December. It arrives at Santa Barbara in July, and at Monterey in August. In late stmmer it is exceedingly abundant. It forms part of the food of larger fishes, and great numbers are salted for bait. As a food-fish it is held in low esteem, but whether this is due entirely to its small size we do not know. It is identical with the well-known Mediterranean species." 
The Horse-fish, Selene setipinnis, known in North Carolina as the "Moonfish" or "Sunfish," and in Cuba by the name "Jorobado," was called by DeKay "Blunt-nosed Shiner," and since this name, sometimes varied to "Pugnosed Shiner," is in common use in the New York market and in Narragansett Bay, while the other names are shared by other species, similar and dissimilar, it seems the most suitable for general adoption. The fish is found everywhere throughout the West Indies, as well as in Northern Brazil and in the Gulf of Guinea, the Gulf of Mexico, the Gulf of California, and southward along the coast to Panama, but has not been found in Europe. In Eastern Florida it is not very unusual, being frequently taken in the Lower St. John's, and sometimes driven up as far as Jacksonville by easterly storms. Here and in the Indian River it is known as the "Moonfish." It is a frequent summer visitor all along the coast as far north as Woods Holl, Mass., where it has a peculiar name, the people there calling it the "Hump-backed Butterfish." The species attains the length of ten or twelve inches, and is esteemed an excellent article of food. Considerable numbers are brought yearly to New York, but elsewhere it rarely appears in the markets. Young from three inches in length upwards are found, but we have no definite knowledge as to its breeding habits.

The Silver Moon-fish, Selene argentea, is almost certain to be confused by fishermen with the one last described, which it resembles, and is often spoken of under the same names. It occurs abundantly on our coast as far north as Woods Holl, and is found in the West Indies, in Brazil, and in the Gulf of Mexico, as well as in the Pacific, from the Crulf of California to Panama.

The young of the Silver Moon-fish is abundant in our waters, and has been frequently taken in Massachusetts Bay, and, in one or two instances, as far north as Halifax, Nova Scotia. Their bodies are so thin that they can be dried in the sun without the use of any preservatives, without loss of form and color. They are, consequently, of no importance for food. In the Chesapeake this fish is often called by the names "Horse-head," and "Juok-down."

The Amber-fish. Scriola carolinensis, is quite common off the West Florida coast, occurring in from ten to thirty fathoms of water on or near the 'snapper banks' throughout the year. It is an active species, swimming just below the surface, and preying upon schools of small fish. 
It is a good food-fish, but is rather shy of a baited hook, and but few are taken. It attains a size of forty inches in length and fifteen pounds

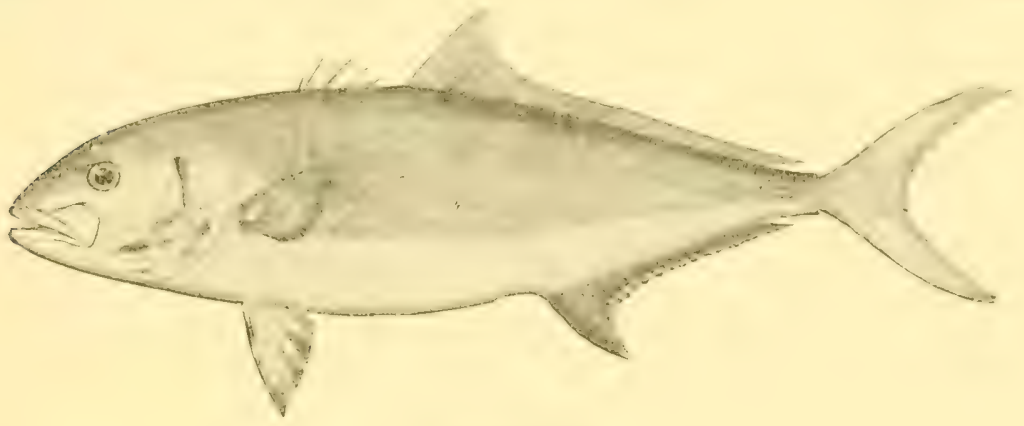

THE AMLER.FISH.

weight. It is also, according to Jordan, rather common on the Carolina coast, where it is known as the "Jack-fish."

The "Rock Salmon" of Pensacola, Scriola falcata, is recorded by Stearns as occasionally occurring near Pensacola in company with the preceeding species, which it resembles in habits. It is caught with hook and line and is eaten; in his opinion, it attains a larger size than the Amber-fish. There is a third species of Amber-fish of which the National Inseum has, received a single specimen from South Florida. It is closely related to the fish described by Cuvier under the name Scriola Lalandii. The same species is some sent to the New Orleans market, where an example was seen by Prof. Jordan.

Another closely allied species, Seriola dorsalis, occurs on the coast of California, where, according to Jordan, it is known under the names "Yellow-tail," "White Salmon," and "Carasina."

Of the "Yellow-tail," Prof. Jordan says: "It reaches a length of four to five feet, and a weight of thirty to forty pounds, and individuais of less than fifteen pounds weight are rarely seen. It ranges from Cape San Lucas northward to the Santa Barbara and Coronados Islands, where it is found in great abundance in the spawning season, arriving in July, and departing in early fall. It spawns about August is. It is caught chiefly by trolling. It feeds on squid and such fish as the anchory and sardine. As a fresh fish it ranks high, although large individuals are sometimes coarse and tough. When salted and dried it is inferior to none on the coast, ranking with the white-fish and barracuda." 
The Banded Rudder-flsh, Seriola zonata, has been observed as far north as Salem and Beverly, Mass. Several specimens have been taken north of Cape Cod during the past forty years. It is a small fish, rarely exceeding six or eight inches in length, conspicuous by reason of its brilliant and beautiful colors, and good to eat, though rarely saved by the fishermen who accidently capture it. It is called in Southern New England the "Rudder-fish" on account of its resemblance to the Rudder-fish of the ocean, Naucrates ductor.

Seriola fisciata, called in Cuba the "Medregal" and in Bermuda the "Bonita," has been observed in South Florida and along the coasts of the Carolinas. It is apparently exceedingly rare in the waters of the United States. In Bermuda it attains a length of two feet or more, and is highly esteemed as a food-fish.

The Leather-jacket, Oligoplites saurus, which is found throughout the West Indies and south as far as Bahia, and on the Pacific coast of Mexico and Central America, has since i 875 been severel times observed between Florida and Newport, R. I. It is known to fishermen as the "Skipjack," sharing this name with a number of other scombroid fishes, which leap from the water as they pursue their prey. It is one of the most beautiful and graceful fishes in out waters, but at present is of no economic importance, its flesh being hard and dry.

"The Runner, Elagatis pimulatvs, known at Key West as "Skipjack" or "Runner," and at Pensacola as "Yellow-tail" or "Shoemaker," is, according to Stearns, abundant on the western and southern coasts of Floricla. At Pensacola it spawns in spring; the young fish are seen in July and August. It is found in the bays and along the sea-beaches, seeming to prefer clear salt-water, swift currents, and sandy bottoms. It usually moves in small schools of a dozen or two individuals. It feeds upon small fishes and crustaceans. When pursued by larger fish it jumps repeatedly from the water, very much in the same manner as the flying fish, only its flights are much shorter and oftener repeated. This habit has given it the names of 'Skipjack' and 'Runner' at Key West, where it may be seen at almost any time. It is sometimes eaten at Key West, and at Havana is quite an important fish in the markets, being also exposed for sale at stands on the streets, cooked and ready for use.

The dolphins, Coryphanide, are found usually in mid-ocean, where they feed upon other pelagic fishes, such as the flying-fish. They are strong, 
rapid swimmers, and are widely distributed throughout all temperate and tropical waters. The name Dolphin is unfortunately applied, this being

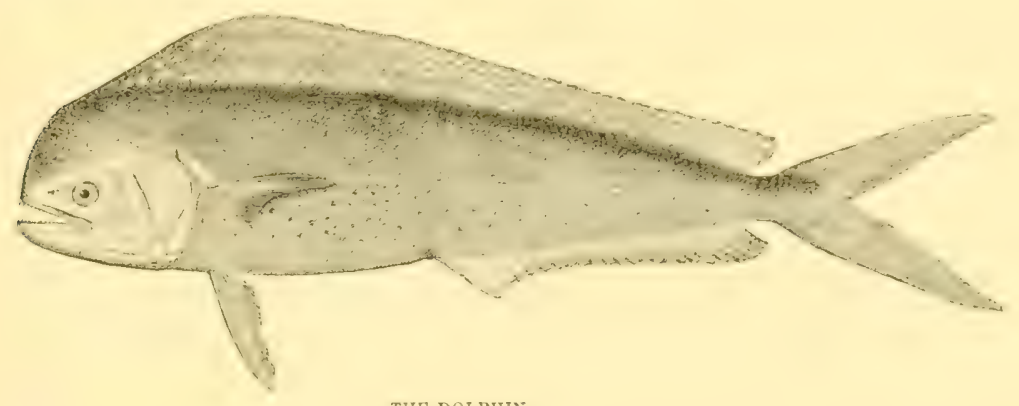

THE DOLPIIN.

the peculiar property of a group of small cetaceans. They are often caught by sailors at sea, and are considered most excellent food. It is an almost universal custom before eating them to test the flesh by putting a piece of silver into the vessel in which they have been cooked, it being a common belief that if the flesh is poisonous the silver will turn dark. Narratives of ocean voyages abound in descriptions of the beautiful colors of the Dolphin and the brilliant changes of hue exhibited by the dying fish, but none so eloquent as that in Montgomery's "Pelican Island."

\section{"A shoal of dolphins, tumbling in wild glee,}

Glowed with such orient tints, they might have been

The rainbow's offspring, where it met the ocean.."

There are in the Atlantic two species of Dolphins, though the number was, until lately, supposed to be very much greater. But one of these, Coryphena hippurus, is definitely known from our shores.

The young, less than two feet in length, are beautifully marked with numerous small circular spots, and have, until lately, been considered by many writers to belong to a distinct genus and species. Dolphins are abundant also, it is said, in the Gulf of Mexico.

The Pilot-fish, Naucrates ductor, though of little or no economic importance, deserves passing mention, since it is so frequently referred to in literature. It is occasionally taken on our coast. Capt. Atwood mentions a specimen which was taken in a mackerel net in Provincetown Harbor, in October, $18_{5} 8$. A whale-ship had come in a few days before, and he supposes that the Pilot-fish had followed it into the harbor. 
The Pilot-fish, $N$. ductor, is a truly pelagic fish, known in all tropical and temperate seas. Its name is derived from its habit of keeping company with ships and large fish, especially sharks. It is the Pompilus of the ancients, who describe it as pointing out the way to dubious or embarrassed sailors, and as announcing the vicinity of land by its sudden disappearance. It was therefore regarded as a sacred fish. The connec-

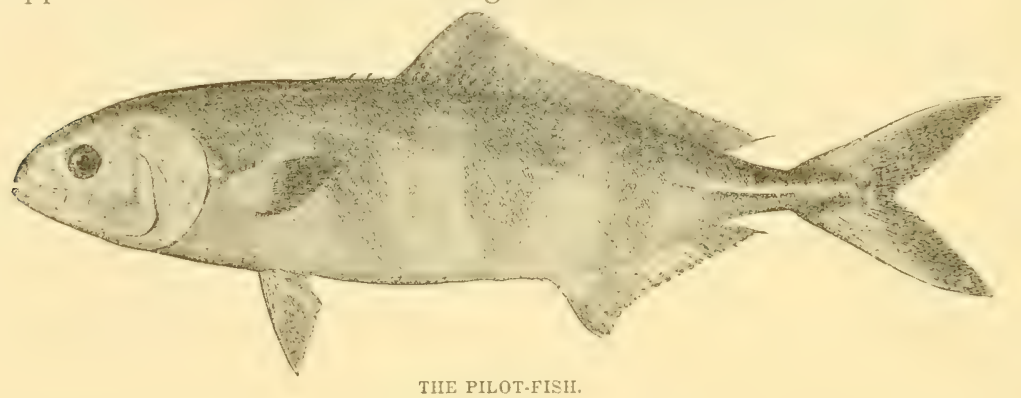

tion between the shark and the Pilot-fish has received various interpretations, some observers having, perhaps, added more sentiment than is warranted by the actual facts. It was stated that the shark never seized the Pilot-fish; that the latter was of great use to its big companion in conducting it and showing it the way to food. Dr. Meyer, in his "Reise um die Ercle," states: "The Pilot swims constantly in front of the shark; we ourselves have seen three instances in which the shark was led by the Pilot. When the shark neared the ship the Pilot swam close to the snout, or near one of the pectoral fins of the animal. Sometimes he darted rapidly forwards or sidewards, as if looking for something, and constantly went back again to the shark. When we threw orerboard a piece of bacon fastened on a great hook, the shark was about twenty paces from the ship. With the quickness of lightning the Pilot came up, smelt at the dainty, and instantly swam back again to the shark, swimming many times round his snout and splashing as if to give him exact information as to the bacon. The shark now began to put himself in motion, the Pilot showing him the way, and in a moment he was fast upon the hook. * Upon a later occasion we observed two Pilots in sedulous attendance on a blue shark, which we caught in the Chinese Sea. It seems probable that the Pilot feeds on the shark's excrements, keeps his company for that purpose, and

In this instance one may entertain reasonable doubts as to the usefulness of the pilot to the shark. 
directs his operations solely from this selfish view." I believe that Dr. Meyer's opinion, as expressed in his last words, is perfectly correct. The Pilot obtains a great part of his food directly from the shark, in feeding on the parasite crustaceans with which sharks and other large fish are infested, and on the smaller pieces of flesh which are left unnoticed by the shark when it tears its prey. The Pilot, also, being a small fish, obtains greater security when in company of a shark, which would keep at a clistance all other fishes of prey that would be likely to prove dangerous to the Pilot. Therefore, in accompanying the shark, the Pilot is led by the same instinct which makes it follow a ship.

With regard to the statement that the Pilot itself is never attacked by the shark, all observers agree as to its truth; but this niay be accounted for in the same way as the impunity of the swallow from the hawk, the Pilot-fish being to nimble for the unwieldy shark.

I quote at length the remarks of my friend, Dr. Francis Day:

"This fish has long been celebrated as the companion and guide of sharks, as it was formerly said to be of whales, and also the friend, or at least close attendant, on ships while sailing over the ocean. Although some consider the pilot-fish to be the friend of the shark, others have thought such open to suspicion, while Cuvier has even suggested downright enmity or rather treachery in its actions. M. Geoffrey tells how two of these fishes were observed to lead a shark up to a baited hook which by their importunities they induced him to gorge. Or as Cuver pithily puts it, that this tale if true should occasion them to be tcrmed "deceivers" rather than "pilots." Capt. Richards once observed upon a blue shark attended by four pilot-fishes following his vessel in the Mediterrancan; a bait was displayed, but the little pilot-fishes pertinaciously came to the front and with their snouts thrust the bait hook away. All at last swam away together, but suddenly the shark changed its mind, turned and rushed forwards with all speed at the bait, leaving his faithful attendants far behind, and which only arrived as the body of their companion was being hauled up on board, to which one is said to have clung, until it was half above water, when it fell off leaving it doubtful if it was not a sucking fish. Why the shark does not prey on its companions is amystery. Lacépède thought their agility saved them, and that their flesh is not worthy the eating.

"In the Naturalists' Note-book (IS69, p. 255), a writer (J. D. S. IV.) mentions "we frequently threw pieces of flesh into the water to them. The pilot-fish first came up and smelt the meat, and then went away and led the shark to it, who always swallowed the whole and left none for his little companions. On a dark night you can see the entire shape of the 
shark in the water below, shining all over with phosphorescence. Now this phosphorescence is considered by most naturalists to be due to the presence of animalcules, and if so, it may reasonably be presumed that the pilot-fishes live on these animalcules, for they are frequently seen clinging to the sides of the shark."

The Pilot-fish does not always leave the vessels on their approach to land. In summer, when the temperature of the sea-water is several degrees above the average, Pilots will follow ships to the south coast of England into the harbor, where they are generally speedily caught. Pilot-fish attain a length of twelve inches only. When very young their appearance differs so much from the mature fish that they have been described as a distinct genus, Nauclerus. This fry is exceedingly common in the open ocean, and constantly obtained in the tow-net; therefore the Pilot-fish retains its pelagic habits also during the spawning season, and some of the spawn found by voyagers floating on the surface is, without doubt, derived from this speries.*

The Pilot-fish has been observed in one or two instances about New York, and also has been recorded from South Carolina. It is, however, rare in the Western Atlantic, and our museums have very few specimens.

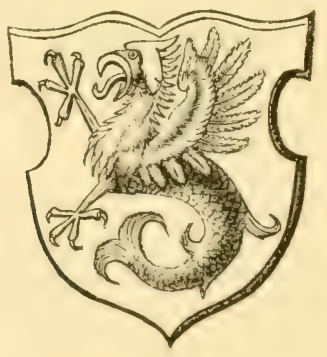




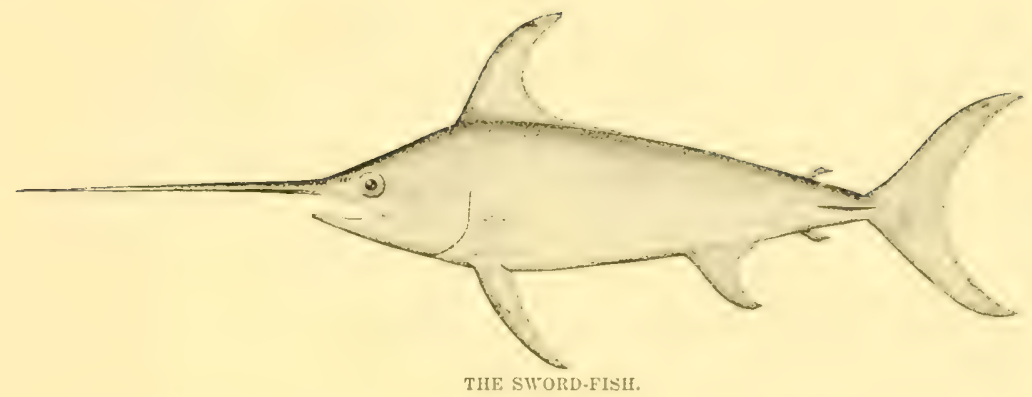

SWORD-FISH, SPEAR-FISH, AND CUTLASS-FISH.

\begin{abstract}
Toward the sea turning my troubled eye
I saw the fish, (if fish I may it cleepe)

That makes the sea before his face to flye

And with his flaggie finnes doth seeme to sweepe

The foamie waves out of the dreadful deep.

The huge Leviathan, dame Nature's wonder,

Making his sport, that manie makes to weepe;

A Sword-fish small, him from the rest did sunder,

That, in nis throat him prickingly softly under,

His wide abysse him forced forth to spewe,

That all the sea did roare like heavens thunder,

And all the waves were stained with filthie hewe.

Hereby I learned have not to despise

Whatever thing seems small in common eyes.
\end{abstract}

EDMUNd SPENER, The Visions of the World, I591.

THE Sword-fish, Xiphias gladius, ranges along the Atlantic coast of America from Jamaica, latitude $18^{\circ} \mathrm{N}$., Cuba, and the Bermudas, to Cape Breton, latitude $47^{\circ} \mathrm{N}$. It has not been seen at Greenland, Iceland, or Spitzbergen, but occurs, according to Collett, at the North Cape, latitude $7 \mathrm{I}^{\circ}$. It is abundant along the coasts of Western Europe, entering the Baltic and the Mediterranean. I can find no record of the species on the west coast of Africa, south of the Cape Verdes, though Lütken, who may. have access to facts unknown to me, states that they occur clear down to the Cape of Good Hope, South Atlantic in mid-ocean, to the west coast of South America and to Southern California, latitude $34^{\circ}$, New Zealand, and in the Indian Ocean, off Mauritius.

The names of the Sword-fish all have reference to that prominent feat ure, the prolonged snout. The "Sword-fish" of our own tongue, the "Zwaard-fis" of the Hollander, the Italian "Sofia" and "Pesce-spada," 
the Spaniards "Espada," and "Espadarte," varied by "Pes de spada" in Cuba; and the French "Espadon," "Dard" and "Epée de IIcr," are simply variations of one theme, repetitions of the "Gladius" of ancient Italy, and "Xiplizus," the name by which Aristotle the father of zoology, called the same fish twenty-three hundred years ago. The French "Empereur," and the "Impcrador," and "Ocean King-fish" of the Spanish and French West Indies, carry out the same idea, for the Roman emperor was always represented holding a drawn sword in his hand. The Portuguese names are "Agulha," "Agulhao," meaning "needle" or "neerlle-fish.,"

This species has been particularly fortunate in escaping the numerous redescriptions to which almost all widely distributed forms have been subjected. By the writers of antiquity, it was spoken of under its Aristotelian name, and in the tenth edition of his Systema Nature, at the very inception of binomial nomenclature, Linnæus called it Xiphias gladius. By this name it has been known ever since, and only one adiditional name is included in its synonymy, Xiphias Rondeletii of Leach.

The sword-fish has been so long and so well known that its right to its peculiar name has seldom been infringed upon. The various species of Tetrapturus have sometimes shared its title, and this is not to be wondered at, since they closely resemble Xiphias gladius, and the appellative has frequently been applied to the family Xiphiita - the Sword-fish familywhich includes them all.

The name "Bill-fish," usually applied to the Tetrafturus albidus, a fish of the Sword-fish family often taken on our coast, must be pronounced objectionable, since it is in many districts used for the various species of Belonida, the "gar-fishes" or "green-bones" (Bclone truncata and others), which are members of the same famas. "Spear-fish" is a much better name.

The "Sail-fish," Histiophorus americamus, is called by sailors in the south the "Boohoo" or "Woohoo." 'This is evidently a corrupted form of "Guebucu," a name, apparently of Indian origin, given to the same fish in Brazil. It is possible that the Tetrapturus is also called "Boohoo," since the two genera are not sufficiently unlike to impress sailors with their differences. Bleeker states that in Sumatra the Malays call the related species, H. glatius, by the name "Joohoo" (Juhu), a curious coincidence. The names may hare been carried from the Malay Archipelago, to South America, or aice z'ersa, by mariners. 
In Cuba, the Spear-fishes are called "Aguja" and "Aguja de Palada"; the Sail-fish, "Asuja Prieta" or "Aguja Voladora"; Tetrapturus albidus especially is known as the "Aguja Blanca," $T$. albidus as the "Aguja de Casto."

In the West Indies and Florida the scabbard-fish or silvery hair-tail, Trichiurus lcpturus, a form allied to the Xiphias, though not resembling it closely in external appearance, is often called "Sword-fish." The body of this fish is shaped like the blade of a saber, and its skin has a bright metallic lustre like that of polished steel; hence the name.

Sword-fish are most abundant on the shoals near the shore and on the banks during the months of July and August; that they make their appearance on the frequented cruising grounds between Montauk Point and the eastern part of George's Banks some time between the $25^{\text {th }}$ of May and the zoth of June, and that they remain until the approach of cold weather in October and November. The dates of the capture of the first fish on the cruising ground referred to are recorded for three years, and are reasonably reliable; in 1875 , June $20 ; 1877$, June Io; 1878 , June I 4 .

South of the cruising ground the dates of arrival and departure are doubtless further apart; the season being shorter north and east. There are no means of obtaining information, since the men engaged in this fishery are the only ones likely to remember the dates when the fish are seen.

The Sword-fish comes into our waters in pursuit of its food. At least this is the most probable explanation of their movements, since the duties of reproduction appear to be performed elsewhere. Like the tunny, the blue-fish, the bonito, and the squeteague, they pursue and prey upon the schools of menhaden and mackerel which are so abundant in the summer months. "When you see Sword-fish, you may know that mackerel are about," said an old fisherman to me. "Where you see the fin-back whale following food, there you may find Sword-fish," said another. The Sword-fish also feeds upon squid, which are at times abundant on our banks.

To what extent this fish is amenable to the influences of temperature is an unsolved problem. We are met at the outset by the fact that they are frequently taken on trawl-lines which are set at the depth of one hundred fathoms or more, on the off-shore banks. We know that the temperature 
of the water in those localities and at that depth is sure to be less than $40^{\circ} \mathrm{Fahr}$. How is this fact to be reconciled with the known habits of the fish, that it prefers the warmest weather of summer and swims at the surface in water of temperature ranging from $55^{\circ}$ to $70^{\circ}$, sinking when cool winds blow below? The case seemed clear enough until the inconvenient discovery was made, that Sword-fish are taken on bottom trawl-lines. In other respects their habits agree closely with those of the mackerel tribe, all the members of which seem sensitive to slight changes in temperature, and which, as a rule, prefer temperature in the neighborhood of $50^{\circ}$ or more.

The appearance of the fish at the surface depends apparently upon temperature. They are seen only upon quiet summer days, in the morning before ten or eleven o'clock, and in the afternoon about four o'clock. Old fishermen say that they rise when the mackerel rise, and when the mackerel go down they go down also.

Regarding the winter abode of the Sword-fish, conjecture is useless. I have already discussed this question at length with reference to the menhaden and mackerel. With the Sword-fish the conditions are very different. The former are known to spawn in our waters, and the schools of young ones follow the old ones in toward the shores. The latter do not spawn in our waters. We cannot well believe that they hibernate, nor is the hypothesis of a sojourn in the middle strata of mid-ocean exactly tenable. Perhaps they migrate to some distant region, where they spawn. But then the spawning time of this species in the Mediterranean, as is related in a subsequent paragraph, appears to occur in the summer months, at the very time when Sword-fish are most abundant in our own waters, apparently feeling no responsibility for the perpetuation of their species.

The Sword-fish when swimming at the surface, usually allows its dorsal fin and the upper lobe of its caudal fin to be visible, projecting out of the water several inches. It is this habit which enables the fisherman to detect the presence of the fish. It swims slowly along, and the fishing schooner with a light breeze finds no difficulty in overtaking it. When excited its motions are very rapid and nervous. Sword-fish are sometimes seen to leap entirely out of the water. Early writers attributed this habit to the tormenting presence of parasites, but this theory seems hardly necessary, knowing what we do of its violent exertions at other times. The pointed head, the fins of the back and abdomen snugly fitting into 
grooves, the absence of ventrals, the long, lithe, muscular body, sloping slowly to the tail, fit it for the most rapid and forcible movement through the water. Prof. Richard Owen, testifying in an England court in regard to its porrer, said :

"It strikes with the accumulated force of fifteen double-handed hammers. Its velocity is equal to that of a swivel-shot, and is as dangerous in its effects as a heavy artillery projectile."

Many very curious instances are on record of the encounters of this fish with other fishes, or of their attacks upon ships. What can be the inducement for it to attack objects so much larger than itself it is hard to surmise. We are all familiar with the couplet from Oppian :

Nature her bounty to his mouth confined,

Gave him a sword, but left unarmed his mind.

It surely seems as if a temporary insanity sometimes takes possession of the fish. It is not strange that, when harpooned, it should retaliate by attacking its assailant. An old sword-fish fisherman told Mr. Blackford that his vessel had been struck twenty times. There are, however, many instances of entirely unprovoked assault on vessels at sea. Many of these are recounted in a later portion of this memoir. Their movements when feeding are discussed below, as well as their alleged peculiarities of movement during the breeding season.

It is the universal testimony of our fishermen that two are never seen swimming close together. Capt. Ashby says that they are always distant from each other at least thirty or forty feet..

The pugnacity of the Sword-fish has become a by-word. Without any special effort on my part numerous instances of their attacks upon vessels have in the last ten years found their way into the pigeon-hole labeled "Sword-fish."

Aelian says (b. xxxii, c. 6) that the Sword-fish has a sharp-pointed snout, with which it is able to pierce the sides of a ship and send it to the bottom, instances of which have been known near a place in Mauritania known as Cotté, not far from the river Lixus, on the African side of the Mediterranean. He describes the sword as like the beak of the ship known as the trireme, which was rowed with three banks of oars.

The "London Daily News" of December II, r868, contained the following paragraph, which emanated, I suspect, from the pen of Prof. R. A. Proctor : 
"Last Wednesday the court of common pleas-rather a strange place, by-the-by, for inquiring into the natural history of fishes-was engaged for several hours in trying to determine under what circumstances a Sword-fish might be able to escape scot-free after thrusting his snout into the side of a ship. The gallant ship 'Dreadnought,' thoroughly repaired and classed A-I at Lloyd's, had been insured for $£_{3}, 000$ against all risks of the seas. She sailed on March io, I864, from Colombo, for London. Three days later the crew, while fishing, hooked a Sword-fish. Xiphias, however, broke the line, and a few moments after leaped half out of the water, with the object, it should seem, of taking a look at his persecutor, the 'Dreadnought.' Probably he satisfied himself that the enemy was some abnormally large cetacean, which it was his natural duty to attack forthwith. Be this as it may, the attack was made, and at four o'clock the next morning the captain was awakened with the unwelcome intelligence that the ship had sprung a leak. She was taken back to Colombo, and thence to Cochin, where she hove down. Near the keel was found a round hole, an inch in diameter, running completely through the copper sheathing and planking.

"As attacks by Sword-fish are included among sea-risks, the insurance company was willing to pay the damages claimed by the owners of the ship if only it could be proved that the hole had really been made by a Sword-fish. No instance had ever been recorded in which a Sword-fish had been able to withdraw his sword after attacking a ship. A defense was founded on the possibility that the hole had been made in some other way. Prof. Owen and Mr. Frank Buckland gave their evidence, but neither of them could state quite positively whether a Sword-fish which had passed its beak through three inches of stout planking could withdraw without the loss of its sword. Mr. Buckland said that fish have no power of 'backing,' and expressed his belief that he could hold a Sword-fish by the beak; but then he admitted that the fish had considerable lateral power, and might so 'wriggle its sword out of the hold.' And so the insurance company will have to pay nearly $£ 600$ because an ill-tempered fish objected to be hooked, and took its revenge by running full tilt against copper sheathing and oak planking."

The food of the Sword-fish is of a very mixed nature.

Dr. Fleming found the remains of Sepias in its stomach, and also small fishes. Oppian stated that it eagerly devours the Hippuris (probably Coryphana). A specimen taken off Seaconnet, July 22, IS 75 , had in its stomach the remains of small fish, perhaps Stromateus triacanthus, and jaws of a squid, perhaps Loligo Pealii. Their food in the Western Atlantic consists for the most part of the common schooling species of fishes. They feed on menhaden, mackerel, bonitoes, bluefish, and other species 
which swim in close schools. Their habits of feeding have often been described to me by old fishermen. They are said to rise beneath the school of small fish, striking to the right and left with their swords until they have killed a number, which they then proceed to devour. Menhaden have been seen floating at the surface which have been cut nearly in twain by a blow of a sword. Mr. John H. Thompson remarks that he has seen them apparently throw the fish in the air, catching them on the fall.

Capt. Benjamin Ashby says that they feed on mackerel, herring, whiting, and menhaden. He has found half a bucketful of small fish of these kinds in the stomach of one Sword-fish. He has seen them in the act of feeding. They rise perpendicular out of the water until the sword and two-thirds of the remainder of the body are exposed to view. He has seen a school of herring crowding together at the surface on George's Banks as closely as they could be packed. A Sword-fish came up through the dense mass and fell flat on its side, striking many fish with the sides of its sword. He has at one time picked up as much as a bushel of herrings thus killed by a Sword-fish on George's Banks.

But little is known regarding their time and place of breeding. They are said to deposit their eggs in large quantities on the coasts of Sicily, and European writers give their spawning time as occurring the latter part of spring and the beginning of summer. In the Mediterranean they occur of all sizes from four hundred pounds down, and the young are so plentiful as to become a common article of food. M. Raymond, who brought to Curier a specimen of Histiophoms four inches long, taken in January, IS29, in the Atlantic, between the Cape of Good Hope and France, reported that there were good numbers of young Sail-fish in the place where this was taken.

Meunier, quoting Spallanzani, states that the Sword-fish does not approach the coast of Sicily except in the season of reproduction; the males are then seen pursuing the females. It is a good time to capture them, for when the female has been taken the male lingers near and is easily approached. The fish are abundant in the Straits of Messina from the middle of April to the middle of September; early in the season they hug the Calabrian shore, approaching from the north; after the end of June they are most abundant on the Sicilian shore, approaching from the south. 
From other circumstances, it seems certain that there are spawning grounds in the sea near Sicily and Genoa, for from November to the ist of March young ones are taken in the Straits of Messina, ranging in weight from half a pound to twelve pounds.

In the Mediterranean, as has been already stated, the very young fish are found from November to March, and here from July to the middle of September the male fish are seen pursuing the female over the shoals, and at this time the males are easily taken. Old sword-fish fishermen, Capt. Ashby and Capt. Kirby, assure me that on our coast, out of thousands of specimens they have taken, they have never seen one containing eggs. I have myself dissected several males, none of which were near breeding time. In the European waters they are said often to be seen swimming in pairs, male and female. Many sentimental stories were current, especially among the old writers, concerning the conjugal affection and unselfish devotion of the Sword-fish, but these seem to have originated in the imaginative brain of the naturalist rather than in his perceptive faculties. It is said that when the female fish is taken the male seems devoid of fear, approaches the boat, and allows himself easily to be taken; but, if this be true, it appears to be the case only in the height of the breeding season, and easily understood. I cannot learn that two Sword-fish have ever been seen associated together in our waters, though I have made frequent and diligent inquiry.

There is no inherent improbability, however, in this story regarding the Sword-fish in Europe, for the same thing is stated by Prof. Poey as the result upon the habits of Tetraptums.

The only individual of which we have the exact measurements was taken off Seaconnet, R. I., July 23, I874. This was seven feet, seven inches long, weighing II 3 pounds. Another, taken off Noman's Land, July 20, I875, and cast in plaster for the collection of the National Museum, weighed 120 pounds, and measured about seven feet. Another, taken off Portland, August I5, I 878 , was 3,999 millimeters long, and weighed about 600 pounds. Many of these fish doubtless attain the weight of 400 and 500 pounds, and some, perhaps, grow to 600 ; but after this limit is reached, I am inclined to believe larger fish are exceptional. Newspapers are fond of recording the occurrence of giant fish, weighing $\mathrm{I}, 500$ pounds and upwards, and old sailors will in good faith describe the enormous fish which they saw at sea, but could not capture; but one well-authenticated 
instance of accurate weighing is much more valuable. The largest one ever taken by Capt. Benjamin Ashby, for twenty years a sword-fish fisherman, was killed on the shoals back of Edgartown, Mass. When salted it weighed 639 pounds. Its live weight must have been as much as 750 or Soo. Its sword measured nearly six feet. This was an extraordinary fish among the three hundred or more taken by Capt. Ashby in his long experience. He considers the average size to be about 250 pounds dressed, or 525 alive. Capt. Martin, of Gloucester, estimates the average size at 300 to 400 pounds. The largest known to Capt. Michaux weighed 625. The average about Block Island he considers to be 200 pounds.

The size of the smallest Sword-fishes taken on our coast is a subject of much deeper interest, for it throws light on the time and place of breeding. There is some difference of testimony regarding the average size, but all fishermen with whom I have talked agree that very small ones do not find their way into our shore waters. Numerous very small specimens have, however, been already taken by the Fish Commission at sea, off our middle and southern coast.

Capt. John Rowe has seen one which did not weigh more than 75 pounds when taken out of the water.

Capt. R. H. Hurlbert killed near Block Island, in July, IS 87 , one which weighed 50 pounds, and measured about two feet without its sword.

Capt. Ashby's smallest weighed about 25 pounds when dressed; this he killed off Noman's Land. He never killed another which weighed less than Ioo. He tells me that a Bridgeport smack had one weighing i6 pounds (or probably 24 when alive), and measuring eighteen inches without its sword.

In August, 1878 , a small specimen of the mackerel-shark, Lamna cormubica, was captured at the mouth of Gloncester Harbor. In its nostril was sticking the sword, about three inches long, of a young Sword-fish. When this was pulled out the blood flowed freely, indicating that the wound was recent. The fish to which this sword belonged cannot have exceeded ten or twelve inches in length. Whether the small Sword-fish met with its misfortune in our waters, or whether the shark brought this trophy from beyond the sea, is an unsolved problem.

Lutken speaks of a very young individual taken in the Atlantic, latitude $32^{\circ} 50^{\prime} \mathrm{N}$., longitude $74^{\circ} \mathrm{I} 9^{\prime} \mathrm{W}$. 'This must be about I 50 miles southeast of Cape Hatteras. 
For many years from three to six hundred of these fish have been taken annually on the New England coast. It is not unusual for twenty-five or more to be seen in the course of a single day's cruising, and sometimes as many as this are visible from the mast-head at one time. Capt. Ashby saw twenty at one time, in August, r 839, between George's Banks and the South shoals. One Gloucester schooner, the "Midnight," Capt. Alfred Wixom, took fourteen in one day on George's Banks, in 1877.

Capt. John Rowe obtained twenty barrels, or four thousand pounds, of salt fish on one trip to George's Banks; this amount represents twenty fish or more.

Capt. Ashby has killed one hundred and eight Sword-fish in one year; Capt. M. C. Tripp killed about ninety in $\mathbf{1} 874$.

Such instances as these indicate in a general way the abundance of the Sword-fish. A vessel cruising within fifty miles of our coast, between Cape May and Cape Sable, during the months of June, July, August, and September, cannot fail, on a favorable day, to come in sight of several of them. Mr. Earll states that the fishermen of Portland never knew them more abundant than in 879 . This is probably, in part, due to the fact that the fishery there is of very recent origin.

There is no evidence of any change in their abundance, either increase or decrease. Fishermen agree that they are as plenty as ever, nor can any change be anticipated. The present mode of fishing does not destroy them in any considerable numbers, each individual fish being the object of special pursuit. The solitary habits of the species will always protect them from wholesale capture, so destructive to schooling fish. Even if this were not the case, the evidence proves that spawning Sword-fish do not frequent our waters. When a female shad is killed, thousands of possible young die also. The Sword-fish taken by our fishermen carry no such precious burden.

"The small Sword-fish is very good meat," remarked Josselyn, in writing of the fishes of New England in the seventeenth century. Since Josselyn probably never saw a young Sword-fish, unless at some time he had visited the Mediterranean, it is fair to suppose that his information was derived from some Italian writer.

It is, however, a fact that the flesh of the Sword-fish, though somewhat oily, is a very acceptable article of food. Its texture is coarse ; the thick, fleshy, muscular layers cause it to resemble that of the halibut in consist- 
ency. Its flavor is by many considered fine, and is not unlike that of the bluefish. Its color is gray. The meat of the young fish is highly prized on the Mediterranean, and is said to be perfectly white, compact, and of delicate flavor. Sword-fish are usually cut up into steaks-thick slices across the body - and may be broiled or boiled.

The apparatus ordinarily employed for the capture of the Sword-fish is simple in the extreme. It is a harpoon with detachable head. When the fish is struck, the head of the harpoon remains in the body of the fish, and carries with it a light rope, which is either made fast or held by a man in a small boat, or is attached to some kind of a buoy, which is towed through the water by the struggling fish, and which marks its whereabouts after death.

The harpoon consists of a pole $5_{5}$ or 16 feet in length, usually of hickory or some other hard wood, upon which the bark has been left, so that the harpooner may have a firmer hand-grip. This pole is from an inch and a half to two inches in diameter, and at one end is provided with an iron rod, or "shank," about two feet long and five-eighths of an inch in diameter. This "shank" is fastened to the pole by means of a conical or elongated, cup-like expansion at one end, which fits over the sharpened end of the pole, to which it is secured by screws or spikes. A light line extends from one end of the pole to the point where it joins the "shank," and in this line is tied a loop, by which is made fast another short line which secures the pole to the vessel or boat, so that when it is thrown at the fish it cannot be lost.

Upon the end of the "shank" fits the head of the harpoon, known by the names Sword-fish iron, lily-iron, and Indian-dart. The form of this weapon has undergone much variation. The fundamental idea may very possibly have been derived from the Indian fish-dart, numerous specimens of which are in the National Museum, from various tribes of Indians of New England, British America, and the Pacific. However various the modifications may have been, the similarity of the different shapes is no less noteworthy from the fact that all are peculiarly American. In the enomous collection of fishery implements of all lands in the late exhibition at Berlin, nothing of the kind could be found. What is known to whalers as a toggleharpoon is a modification of the lily-iron, but so greatly changed by the addition of a pivot by which the head of the harpoon is fastened to the shank that it can hardly be regarded as the same weapon. The lily-iron is, in princi- 
ple, exactly what a whalemen would describe by the word "toggle." It consists of a two-pointed piece of metal, laving in the centre, at one side, a ring or socket, the axis of which is parallel with the long diameter of the implement. In this is inserted the end of the pole-shank, and to it or near it is also attached the harpoon-line. TVhen the iron has once been thrust point first through some solid substance, such as the side of a fish, and is released upon the other side by the withdrawal of the pole from the socket, it is free, and at once turns its long axis at right angles to the direction in which the harpoon-line is pulling, and thus is absolutely prevented from withdrawal. The principle of the whale-harpoon or toggle-iron is similar, except that the pole is not withdrawn, and the head, turning upon a pivot at its end, fastens the pole itself securely to the fish, the harpoon-line being attached to some part of the pole. The Sword-fish lily-iron head, as now ordinarily used, is about four inches in length, and consists of two lanceorate blades, each about an inch and a half long, connected by a central piece much thicker than they, in which, upon one side, and next to the flat side of the blade, is the socket for the insertion of the pole-plank. In this same central enlargement is forged an opening to which the harpoon-line is attached. The dart-head is usually made of steel; sometimes of iron, which is generally galvanized; sometimes of brass.

The entire weight of the harpoon-pole, shank, and head, should not exceed is pounds.

The harpoon-line is from 50 to $5^{\circ}$ fathoms long, and is ordinarily what is known as "fifteen-thread line." At the end is sometimes fastened $a$ buoy, and an ordinary mackerel keg is generally used for this purpose.

In addition to the harpoon, every Sword-fisherman carries a lance. This implement is precisely similar to a whaleman's lance, except that it is smaller, consisting of a lanceolate blade perhaps, one inch wide and two inches long, upon the end of a shank of five-eighths-inch iron, perhaps two or three feet in length, fastened in the ordinary way upon a pole $\mathbf{I} 5$ to $\mathbf{S}$ feet in length.

The Sword-fish are always harpooned from the end of the bowsprit of a sailing-vessel. It is next to impossible to approach them in a small boat. All vessels regularly engaged in this fishery are supplied with a special apparatus, called a "rest" or "pulpit," for the support of the harpooner 
as he stands on the bowsprit, and this is almost essential to success, although it is possible for an active man to harpoon a fish from this station without the aid of the ordinary frame-work. Not only the professional Sword-fishermen, but many mackerel schooners and packets are supplicd in this manner.

The Sword-fish never comes to the surface except in moderate, smooth weather. A vessel cruising in search of them, proceeds to the fishing ground, and cruises hither and thither wherever the abundance of small fish indicates that they ought to be found. Vessels which are met are hailed and asked whether any Sword-fish have been seen, and if tiding are thus obtained, the ship's course is at once laid for the locality where they were last noticed. A man is always stationed at the masthead, where, with the keen eye which practice has given him, he can easily descry the tell-tale dorsal fins at a distance of two or three miles. When a fish has once been sighted, the watch "sings out," and the vessel is steered directly towards it. The skipper takes his place in the "pulpit," holding the pole in both hands by the small end, and directing the man at the wheel by voice and gesture how to steer. There is no difficulty in approaching the fish with a large vessel, although, as has already been remarked, they will not suffer a small boat to come near them. The ressel plows and swashes through the water, plunging its bowsprit into the waves, without exciting their fears. Noises frighten them and drive them down. Although there would be no difficulty in bringing the end of the bowsprit directly over the fish, a skilful harpooner never waits for this. When the fish is from 6 to ro feet in front of the ressel it is struck. The harpoon is never thrown, the pole being too long. The strong arm of the harpooner punches the dart into the back of the fish, right at the side of the high dorsal fin, and the pole is withdrawn and fastened again to its place. When the dart has been fastened to the fish the line is allowed to run out as far as the fish will carry it, and is then passed in a small boat, which is towing at the stern. Two men jump into this, and pulling in upon the line until the fish is brought in alongside, it is then killed with a whale-lance or a whale-spade, which is stuck into the gills.

The fish having been killed, it is lifted upon the deck by a purchasetackle of two double blocks rigged in the shrouds.

The pursuit of the Sword-fish is much more exciting than ordinary fishing, for it resembles the hunting of large animals upon the land, and 
partakes more of the nature of the chase. There is no slow or careful baiting and patient waiting, and no disappointment caused by the accidental capture of worthless "bait-stealers." The game is seen and followed, and outwitted by wary tactics, and killed by strength of arm and skill. The Sword-fish is a powerful antagonist, sometimes, and sends his pursuers' vessel into harbor leaking, and almost sinking, from injuries which he has inflicted. I have known a vessel to be struck by wounded Sword-fish as many as twenty times in a season. There is even the spice of personal danger to give savor to the chase, for the men are occasionally injured by the infuriated fish. One of Capt. Ashby's crew was severely wounded by a Sword-fish which thrust his beak through the oak floor of a boat on which he was standing, and penetrated about two inches in his naked heel. The strange fascination draws men to this pursuit when they have once learned its charms. An old Swords-fisherman, who had followed the pursuit for twenty years, told me that when he was on the cruising ground, he fished all night in his dreams, and that many a time he has bruised his hands and rubbed the skin off his knuckles by striking them against the ceiling of his bunk when he raised his arms to thrust the harpoon into visionary monster Sword-fishes.

The Bill-fish or Spear-fish, Tetrapturus indicus (with various related forms, which may or may not be specifically identical) occurs in the Western Atlantic from the West Indies, latitude $10^{\circ}$ to $20^{\circ} \mathrm{N}$, to Southern New England, latitude $42^{\circ} \mathrm{N}$; in the Eastern Atlantic, from Gibralter, latitude $45^{\circ} \mathrm{N}$, to the Cape of Good Hope, latitude $30^{\circ} \mathrm{S}$; in the Indian Ocean, the Nalay Archipelago, New Zealand, latitude $40^{\circ} \mathrm{S}$., and on the west coast of Chila and Peru. In a general way, the range is between latitude $40^{\circ} \mathrm{N}$, and latitude $40^{\circ} \mathrm{S}$.

The species of Tetraptumus which we have been accustomed to call $T$. albidus, abundant about Cuba, is not very unusual on the coast of Southern New England. Several are taken every year by the Sword-fish fishermen. I have not known of their capture along the Southern Atlantic coast of the United States. All I have known about were taken between Sandy Hook and the eastern part of George's Banks.

The Mediterranean Spear-fish, Tetrapturus belone, appears to be a landlocked form, never passing west of the Straits of Gibraiter.

The Spear-fish in our waters is said by our fishermen to resemble the Sword-fish in its movements and manner of feeding. Prof. Poey narrates 
that both the Cuban species swim at a depth of one hundred fathoms, and they journey in pairs, shaping their course toward the Gulf of Mexico, the females being full of eggs. Only adults are taken. It is not known whence they come, or where they breed, or how the young return. It is not even known whether the adult fishes return by the same route. When the fish has swallowed the hook it rises to the surface, making prodigious leaps and plunges. At last it is dragged to the boat, secured with a boathook, and beaten to death before it is hauled on board. Such fishing is not without danger, for the Spear-fish sometimes rushes upon the boat, drowning the fisherman, or wounding him with its terrible weapon. The fish becomes furious at the appearance of sharks, which are its natural enemies. They engage in violent combats, and when the Spear-fish is attached to the fisherman's line it often received frightful wounds from these adversaries.

The Spear-fish strikes vessels in the same manner as the Sword-fish. I am indebted to Capt. William Spicer, of Noank, Conn., for this note:

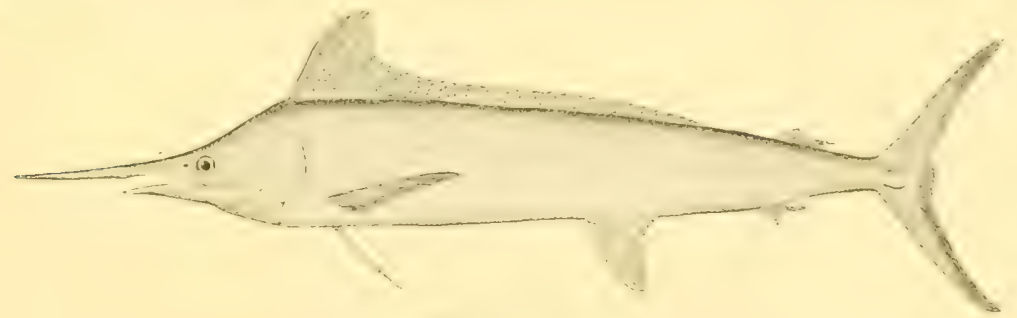

THE SPEAR-FISH.

"Mr. William Taylor, of Mystic, a man seventy-six years old, who was in the smack 'Evergreen,' Capt. John Appleman, tells me that they started from Mystic, October 3, I 8 32 , on a fishing voyage to Key West, in company with the smack 'Morning Star,' Capt. Rowland. On the I 2 th were off Cape Iatteras, the winel blowing heavily from the northeast, and the smack under double-reefed sails. At ro o'clock in the evening they were struck by a 'Woho' (sic), which shocked the vessel all over. The smack was leaking badly, and they male a signal to the 'Morning star' to keep close by them. The next morning they found the leak, and lowth smacks kept off to Charleston. On arrival they took out the ballast, hove her out, and found that the sword had gone through the planking, timber, and ceiling. The plank was two inches thick, the timber five inches, and 
the ceiling one and a half inches white oak. The sword projected two inches through the ceiling, on the inside of the 'after run.' It struck by a butt on the outside, which caused the leak. They took out and replaced a piece of the plank, and proceeded on their voyage."

The Sail-fish, Histiophorus gladius (with $H$. americanus and $H$. orientalis, questionable species, and $H$. pulchellus and $H$. immaculatus, young), occurs in the Red Sea, Indian Ocean, Malay Archipelago, and south at least as far as the Cape of Good Hope, latitude $35^{\circ} \mathrm{S}$; ; in the Atlantic on the coast of Brazil, latitude $30^{\circ} \mathrm{S}$, , to the Equator, and north to Southern New England, latitude $42^{\circ} \mathrm{N}$; in the Pacific to Southwestern Japan, latitude $30^{\circ}$ to $10^{\circ} \mathrm{N}$. In a general way the range may be said to be in tropical and temperate seas, between latitude $30^{\circ} \mathrm{S}$. and $40^{\circ} \mathrm{N}$, and in the western parts of those seas.

The first allusion to this genus occurs in Piso's "Historia Naturalis Brasiliæ," printed at Amsterdam in I 648. In this book may be found an identifiable though rough figure of the American species, accompanied by a few lines of description, which, though good, when the fact that they were written in the seventeenth century is brought to mind, are of no value for critical comparison.

The name given to the Brazilian Sail-fish by Narcgrave, the talented young German who described the fishes in the book referred to, and who afterwards sacrificed his life in exploring the unknown fields of American zooiogy, was Guebucu brasiliensibus. The use of the name Gucbucu is interesting, since it gives a clew to the derivation of the name "Boohoo," by which this fish, and probably the Spear-fishes, are known to Englishspeaking sailors in the tropical Atlantic.

Sail-fishes were observed in the East Indies by Renard and. Valentijn, explorers of that region from $\mathrm{i} 680$ to $\mathrm{I} 720$, and by other eastern voyagers. No species of the genus was, however, systematically described until i 786 , when a stuffed specimen from the Indian Ocean, eight feet long, was taken to London, where it still remains in the collections of the British Museum. From this specimen M. Broussonet prepared a description, giving it the name Scomber gladius, rightly regarding it as a species allied to the mackerel.

From the time of Marcgrave until 1872 it does not appear that any zoologist had any opportunity to study a Sail-fish from America, or even from the Atlantic; yet in Gunther's Catalogue, the name $H$. americamus 
is discarded and the species of America is assumed to be identical with that of the Indian Ocean.

The materials in the National Museum consist of a skeleton and a painted plaster cast of the specimen taken near Newport, R. I., in is72, and a drawing made from the same, while fresh, by Mr. J. H. Blake.

The occurrence of the Sail-fish is, as has been already stated, very unusual. Marcgrave saw it in Brazil as early as I648. Sagra and Poey mention that it has been seen about Cuba, and Schomburgk includes it in his Barbadoes list. 'The specimen in the United States National Museum was taken off Newport, R. I., in August, $\mathrm{I} \delta_{72}$, and given to Prof. Baird by Mr. Samuel Powell, of Newport. No others were observed in our waters until March, 1878 , when, according to Mr. Neyle Habersham, of Savannah, Ga., two were taken by a vessel between Savannah and Indian River, Fla., and were brought to Savannah, where they attracted much attention in the market. In I 873 , according to Mr. E. G. Blackford, a specimen in a very mutilated condition was brought from Key llest to New York City.

No observations have been made in this country, and recourse must be had to the statements of observers in the other hemisphere.

In the life of Sir Stamford Raffles, is printed a letter from Singapore, under date of November $30, \mathbf{1} 822$, with the following statement:

"The only amusing discovery we have recently made is that of a sailing fish, called by the natives, Ikan layer, of about ten or twelve feet long, which hoists a mainsail, and often sails in the manner of a native boat, and with considerable swiftness. I have sent a set of the sails home, as they are beautifully cut and form a model for a fast-sailing boat. When a school of these are under sail together they are frequently mistaken for a fleet of native boats."

The fish referred to is in all likelihood Histiophorus gladius, a species very closely related to, if not identical, with our own.

The Cutlass-fish, Trichiums lepturus, unfortunately known in Eastern Florida and at Pensacola as the "Sword-fish"; at New Orleans, in the St. John's River, and at Brunswick, Ga., it is known as the "Silver Eel," on the coast of Texas as "Sabre-fish," while in the Indian River region it is called the "Skipjack." No one of these names is particularly applicable, and the latter being pre-occupied, it would seem advantageous to use in this country the name "Cutlass-fish," which is current for the same species in the British West Indies. 
Its appearance is very remarkable on account of its long, compressed form and its glistening, silvery color. The name "Scabbard-fish," which has been given to an allied species in Europe, would be very proper also for this species, for in general shape and appearance it looks very like the metallic scabbard of the sword. It attains the length of four or five feet, though ordinarily not exceeding twenty-five or thirty inches. This species is found in the tropical Atlantic, on the coast of Brazil, in the Gulf of California, the West Indies, the Gulf of Mexico, and north to Wood's Holl, Mass., where, during the past ten years, specimens have occasionally been taken. In 1845 one was found at Wellfleet, Mass.; and in the Essex Institute is a specimen which is said to have been found in Salem Harbor. The species occurs also on the coast of Europe, two specimens having been found on the shores of the Moray Frith many years ago, and during the past decade it has become somewhat abundant in Southern England. It does not, however, enter the Mediterranean. Some writers believed the allied species, Trichiumus haumela, found in the Indian Ocean and Archipelago and in various parts of the Pacific, to be specifically the same.

The Cutlass-fish is abundant in the St. John's River, Fla., in the Indian River region, and in the Gulf of Mexico. Several instances were related to me in which these fish had thrown themselves from the water into rowboats, a feat which might be very easily performed by a lithe, active species like the Trichiurus. A small one fell into a boat crossing the mouth of the Arlington River, where the water is nearly fresh.

Many individuals of the same species are taken every year at the mouth of the St. John's River, at Mayport. Stearns states that they are caught in the deep waters of the bays about Pensacola, swimming nearly at the surface, but chiefly with hooks and lines from the wharves. He has known them to strike at the oars of the boat and at the end of the ropes that trailed in the water. At Pensacola they reach a length of twenty to thirty inches, and are considered good food-fish. Richard Hill states that in Jamaica this species is much esteemed, and is fished for assiduously in a "hole," as it is called, that is, a deep portion of the waters off Fort Augusta. This is the best fishing place for the Cutlass-fish, Trichiurus. The fishing takes place before day; all lines are pulled in as fast as they are thrown out, with the certainty that the Cutlass has been hooked. As many as ninety boats have been counted on this fishing ground at daybreak during the season. 




\title{
THE ROSE-FISH AND ITS ALLIES.
}

\author{
And there were crystal pools, peopled with fish, \\ Argent and gold; and some of Tyrian skin, \\ Some crimson-barred. And ever at a wish \\ They rose obsequious, till the wave grew thin \\ As glass upon their backs, aud then dived in, \\ Quenching their ardent scales in watery gloom, \\ Whilst others with fresh hues rowed forth to win \\ My changeable regard.
}

THOMAS HOOD.

A

LTHOL'GH mon the west coast of North America the fishes of the family Scorpanida are among the most important, there are only four species on the Atlantic coast of our continent; of these, two hare been discovered within the past decade, and the others, though well known and widely distributed, are not of great importance. The Rose-fish, Sebastes marinus, is conspicuous among cold-water fishes by its brilliant scarlet color; it is known as "Red Perch," * "Norway Haddock," "Hemdurgan," and "Snapper," as "Bream " in Gloucester, Mass, and "John Dory" at Halifax, Nova Scotia. It is found also in Northern Europe, where it has been recorded as far south as Newcastle, in Northern England, latitude $55^{\circ}$, + and it has been observed in Aberdeen and Berwick, and in Zetland, where it is called "Bergylt" and "Norway Haddock."

*In distinction from the "blue perch" or "cunner" (Ctcnolabrus adspirsus), which it resembles in form, though not in color.

† GUхтнек: Cat. Fishes Brit. MIus. 2, p. 26. 
On the eastern side of the North sea the species has not been seen south of Gothenborg, latitude $58^{\circ}$, but is said to be abundant along the entire western coast of Norway to North Cape and Varanger Fjord in East Finmark, while Malmgren records it from Baren Island, and Scoresby from Spitzbergen, in latitude $80^{\circ}$. In Iceland it is abundant, and in Davis' Straits, at least as far north as Disco, where it is found associated with the halibut, and is said to constitute a liberal share of its food. In Eastern Labrador, about Newfoundland, and in the Gulf of St. Lawrence, it is abundant, and also along the shores of Nova Scotia and in the Bay of Fundy. In these northern regions the Rose-fish prefers shallow water, and may be taken in the greatest abundance in the bays and around the wharves in company with the sculpins and the cunners or blue perch. On the coast of the United States, south of the Bay of Fundy, they are rarely seen near the shore, but have been found in deep water in all parts of the Gulf of Maine and Massachusetts Bay, and also abundantly south of Cape Cod. In the fall of 1880 the United States Fish Commission obtained great quantities of them, young and old. DeKay included this fish in his New York list, stating, however, that it was very rare in those waters. He remarks that " the coast of New York is probably its extreme southern limit."

Of late years none have been taken south of the locality already mentioned, which was in water from one to three hundred fathoms in depth, at the inner edge of the Gulf stream, from fifty to one hundred miles southwest of Newport, and about the same distance east of Sandy Hook. A hundred or two hundred miles farther south it is replaced by a fish resembling it somewhat in form and color, Scorpana dactyloptera, De la Roche, discovered by the Fish Commission during the past year, and by Scorpana Stearnsi, detected at Pensacola by Silas Stearns, and at Charleston by C. H. Gilbert.

It may fairly be said that the Rose-fish, as a shore species, is not known south of parallel $42^{\circ}$, which is $13^{\circ}$ south of its transatlantic limit. When the deep waters of Southern Europe have been as carefully explored as those of the United States, it is probable that the range of this fish will be extended considerably further to the south.

The temperature range of the Rose-fish corresponds closely to that of the halibut, and its limits will, on more careful study, probably be found included between $32^{\circ}$ and $50^{\circ}$. It is found everywhere on the shallow 
off-shore banks north of Cape Cod, where it attains its greatest size. $A$ specimen, brought in by one of the Gloucester halibut schooners, was about two feet in length and weighed about fourteen pounds. Along the Maine coast they are much smaller than this, rarely exceeding eight or ten inches and the weight of twelve ounces, though occasionally growing to the weight of one and a half pounds.

In Scandinavia there have been recognized two species; one, a large, orange-colored form, inhabiting deep water, known to the Norwegians as the "Red-fish" (Roed-fisk), and considered to be S. marimus (S. noracgicus); the other, a smaller species of much deeper color, called the "Lysanger," and described by Kroyer under the name "S. viviparus," and by Ekström as "S. regulus." After the most careful stucly of a'l the specimens in the National Museum, we have been unable to recognize more than one species on our coast, and recent Norwegian ichthyologists, among them especially Mr. Robert Collett, believe that the two Norwegian forms are not actually distinct species, but that the smaller one is simply a pigmy race which is especially adapted to live in the long, shallow fiords of that region. Dr. Lütken, always conservative, is inclined to believe the two forms distinct, regarding the large fish of the deep water as the primitive type from which the smaller littoral form has been derived by development. According to the last mentioned authority, the two forms have very different geographical distribution, $S$. viviparus inhabiting the shallows in the vicinity of the Faroe Islands, Southern Sweden, Norway, and New England, but unknown to Great Britain, Denmark, Finmark, Iceland, and Greenland; while S. marims is found in Greenland and Iceland and all the length of the Norwegian coast, in Spitzbergen, Baren Island, on the coasts of Denmark, and occasionally in the north of England and Ireland. Possibly, he suggests, it inhabits the deep waters at a distance from shore, off the Faroe Islands and North America, but that is not yet certainly known. S. viviparus, then, he declares, is a form less arctic as well as more littoral.

This subject is here referred to in the hope that additional observations may be drawn out tending to settle the question whether or not there are two forms of Sebastes on the American coast. It seems, however, improbable, since the physical conditions are so different from those under which they occur on the other side of the Atlantic.

The food of the Rose-fish consists, like that of its cousins, the sculpins, 
of small fish, crustaceans, and, to some extent, of mollusks, although its tecth are formed for crushing the thick-shelled species. In Greenland they are said to feed upon the pole-flounder. A specimen taken off Eastern Point, Gloucester, in July, 1878 , had its throat full of shrimp-like crustaceans (Mysis, sp.), and others, taken at Eastport, were feeding extensively on a larger crustacean (Thysanopoda, sp.), which is also a favorite food of the mackerel. They may be caught with almost any kind of bait, but are not, like their associates, the cunners, given to feeding upon refuse substances, and, being also more shy and watchful, cannot be captured in bag-nets. They breed in summer, from June to September, in deep holes in Massachusetts Bay and off the coast of Southern New England, where it has not been uncommon for the Fish Commission to obtain thousands of young ones, two and three inches long, at one set of the trawl-net, and also adults full of spawn. The young are lighter in color than the adults, and are conspicuously banded with reddish-brown upon a grayish ground. The young constitute a favorite food of the codfish, while, at all ages, they are preyed upon by the halibut and other large predaceous fishes of the cold-water districts.

Although the Rose-fish is much esteemed as an article of food, and is caught in considerable numbers all along the coast of Maine and the British Provinces in the season when it frequents the shallows near the shore, and in winter at Gloucester when flocking in large numbers into the harbor, the most extensive fisheries are probably on the coast of Greenland, where they are highly prized by the natives, who feed on the flesh and use the spines of fins for needles, and in Massachusetts Bay, where great quantities are taken by the Irish market-fishermen on trawling-lines. In winter they are occasionally found in the New York markets, and on one or two occasions have been brought in considerable numbers to New Haven, and even to Philadelphia. The flesh is firm, rich, and delicate in flavor; the young fish, fried crisp, make an excellent substitute for whitebait.

The naturalists on the "Albatross" sometimes have a famous dish of this sort set before them, when the trawl net has brought up bushels of the young Rose-fish from the ocean depths.

The writer once had the pleasure of testing the flavor of this species under peculiarly favorable circumstances. It was during the Fisheries Exhibition of $188_{3}$, and the occasion was thus described at the time in the London "Times." 
"On Thursday, May I 7 , the Prince of Wales entertained the Foreign and Colonial Commissioners at luncheon in the Royal Pavilion. Souches of trout and eels, Filets de Soles a la Normande, Wullets Barbés a la Genoise, Scotch Salmon, grilled Severn trout, eels fried in the manner designated as a l'Irlandaise, and White-bait constituted the fish department, as set down in print, but the greatest success was a well prepared impromptu, not on the card. It so happened that in the fish market was a consignment from Hull, of the Norwegian 'bergylt,' little known in Loudon, but quickly identified by the Earl of Ducie, a leading authority on the subject of Norway fishing. Being a rather dry fish, though the flakiness and the flavor are not unworthy of comparison with the red mullet, it was judged expedient by the clucf to deal with the bergylt, as a Continental artist might deal by the pike. So after being marinaded for three hours, with fine oil, this Norwegian fish was expertly treated with yolk of eggs and cream, fried in a light batter, and served at the moment of perfection. It remains to be said that nothing of the fish was left."

On the Pacific coast, as has already been stated, the fishes of this family, known as Rock-cod and Rockfish, are of great importance, and many of them are illustrated in the "The Food Fishes and Fishery Industries of the United States." For accurate identification it is necessary to resort to Jordan's "Synopsis." They have been discussed briefly by President Jordan, who writes as follows:

One of the most remarkable features of the California fish fauna is the enormous abundance both in individuals and in species of the group of Scorprnidx. All of them are excellent food-fishes, and scarcely a boat returns from any kind of fishing in which these fishes do not form a conspicuous part of the catch. In every fish market they are found, and from their large size and brilliant coloration they are everywhere the mos: conspicuous fishes on the stalls.

These fishes have so many traits in common, that a review of the group as a whole is desirable before we proceed to the consideration of the several species.

These fishes are universally known by the names of Rockfish and Rockcod. The latter name is the one most commonly heard, the other name being apparently a reaction against the obvious error of calling these fish "Cod." The name Rockfish is an appropriate one, and in time it will probably supplant that of Rock-cod. The name Corl or Codfish is never applied to them without the accompanying "Rock." In the southern part of California, the name "Garrupa" or "Grouper" is in common 
use, especially for the olivaceous species. This is a Portuguese word, and belonged originally to the species of Epinephelus and related genera. Different species have also special names, mostly given by the Portuguese fishermen. These are noticed below.

The average size of the species of the group is about fifteen inches in length, and a weight of two or three pounds. Some of them reach a length of nearly three feet, and a weight of twelve pounds. Nothing is known of their rate of growth.

The greatest abundance both of individuals and of species in this group is to be found from Santa Barbara to San Francisco, the maximum about Monterey. They occur from Cerros Island, where they are rather scarce, at least as far as Kodiak, and other species similar are found on the coasts of Japan and Chili. The individuals are extremely local. Most of the species are found about rocky reefs, often in considerable depths, and they probably stray but little from their abodes. In general, the red species inhabit greater depths than the brown or green ones, and the latter swim about more freely. Their abundance on certain reefs about Monterey and the Farallones is doubtless being diminished; elsewhere there has been little danger of over-fishing. All are predatory and voracious, feeding mainly upon other fishes, and sometimes on crustaceans.

All of the species are ovo-viviparous. The eggs are small and exceedingly numerous, and are hatched within the body. The eggs themselves are bright yellow. In the spring, at a season varying with the latitude, and perhaps with different species, these yellow eggs turn to a grayish color. If then examined, the two eyes of the young fish can be distinctly seen. Later a slender body appears, with traces of vertical fins, the length then being about one-fourth to one-third of an inch. They are probably extruded at about the length of one-third of an inch, and in a very slender and pellucid condition, as I have never seen them in any more advanced stage of development. Nothing is known of the modes of copulation, nor of the circumstances under which the young are excluded, but the time of breeding is probably for the most part in May. Young fishes of one and a half to two inches are common in August, and in the fall they are large enough (S. paucispinis, flavidus) to be taken with hook and line from the wharves. Individuals of less than six or eight inches are rare in the spring, and the fish of that length are probably a year old.

The enemies of these fishes are of course their predatory neighbors, and 
the larger individuals prey upon the smaller. The hag-fish (Polistrotrema) destroys considerable numbers. They are usually very free from internal parasites.

All the members of this family rank high as food-fishes. The flesh is firm and white, and, although not very delicate, is of a fair quality. That of Scorpena guttata is probably best; that of Scbastichthy's my'stimus brings the lowest price in market, but the prejudice against the latter species perhaps rests on its color.

The Scorpene, Scorpana guttata, is known also by the names "Scorpion" and "Sculpin." "Scorpene" (Scolpina), in common use among the Italian fishermen, is of course the name of Seorpcend porcus, S. scrof a, and other Mediterranean fishes, transferred to this very similar North American fish. The wound made by the dorsal spines of this fish is excessively painful, far more so than the sting of a bee, as though the spines had some venomous secretion. The name Scorpana is evidently derived from this. This species reaches a length of something over a foot and a weight of about two pounds. It is found only from Point Conception southward to Ascension Island, living about rocks and kelp, but often entering the bays. It is generally common, and takes the hook freely. It feeds upon crustacea and small fishes, and spawns in spring. Nothing distinctive is known of its breeding habits. As a food-fish it ranks with the best, being superior to the species of Sebastichthys, and it always is in good demand where known.

The Black-banded Rockfish, Scbastichthy's migrocinctus, has, so far as we know, received no distinctive name from the fishermen. It reaches a weight of about four pounds and a length of eighteen to twenty inches. It ranges from Monterey northward, being found only in deep water (ten to twenty fathoms). About San Francisco it is exceedingly rare, not half a dozen usually coming into the market in a year. In the Straits of Fuca and outside in the open ocean it is tolerably abundant. The food and the breeding habits, as far as known, differ little in this family, and the general remarks on the group apply to all the species of Scbastichthy's. As a food-fish this species sells readily on account of its brilliant and attractive colors, second only in brilliancy to those of the "Spanish Flag."

Sebastichthys serriceps, wherever this species receives a distinctive name, is known as the "Tree-fish," an appellation originating with the Portuguese at Monterey, and without obvious application. 
Southward it is confounded with other species as a Garrupa. Its size is rather less than that of $S$. nigrocinctus, which it much resembles. It ranges from San Martin Island to San Francisco, being found in rather deep water among rocks. It is most common about the Santa Barbara Islands, and is rare in the markets of San Francisco. It is a handsomely colored species, and therefore sells well in the markets.

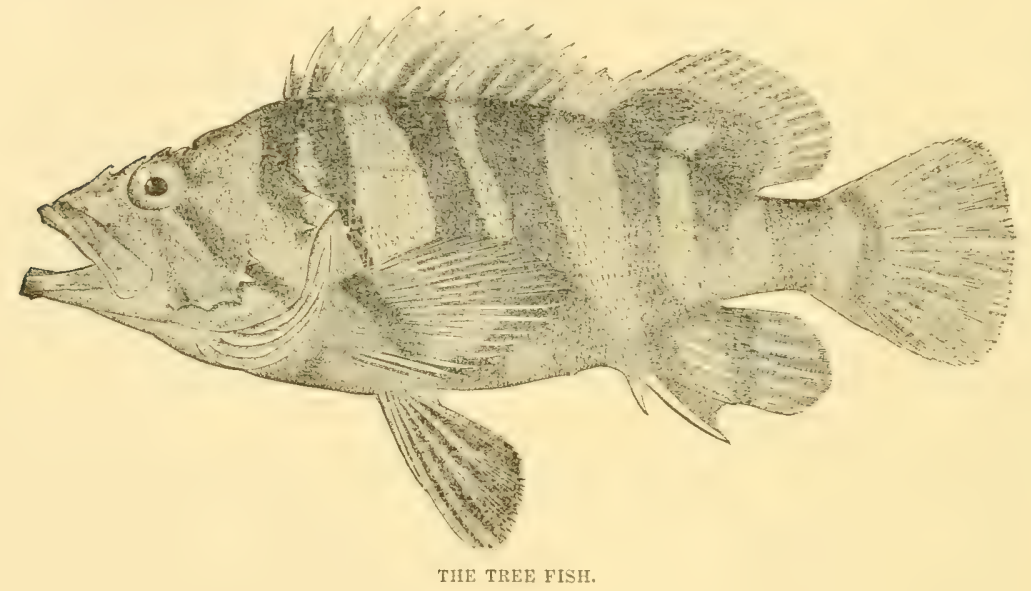

The Speckled Garruta, Sebastichthys nebulosus, is known as "Garrupa" and "Rock-cod," rarely receiving any distinctive name. It reaches a weight of three and one-half pounds. It ranges from Monterey to Puget Sound, being generally common at all points, and most abundant northward. It lives in water of moderate depth. It forms about two per cent. of the total rockfish catch, and is always readily salable. It is the most attractive in color of any of the dark-colored species.

The Black and Yellow Garrupa, Sebastichthy's chrysomelas, is also confounded under the names "Garrupa" and "Codfish." It is one of the smaller species, reaching a weight of about two pounds. It ranges from Sar Nicolas Island to San Francisco, and is generally common in water of moderate depth, although not one of the most abundant species. It is an attractive fish in color and therefore readily salable.

The Flesh-colored Garrupa, Schastichthy's carnatus, reaches a somewhat larger size than the last, and ranges from Santa Barbara to San Francisco. About San Francisco it is considerably more abundant, forming nearly seven per cent. of the total rockfish catch. 
The Vellow-backed Rockfish, Scbastichthy's maliger, seems to have no distinct name in common use. It ranges from Monterey to Puget Sound, in rather deep water. It is not very common about San Francisco, but many are caught in the Straits of Fuca. It is one of the largest of the species, reaching a weight of six or eight pounds. As a food-fish it is not so good as some of the others.

The Red Garrupa, Sebastichthy's caurinus and sub-species icxillaris, is known as "Garrupa," "Rockfish" and "Rock-cod." It reaches a length of twenty inches and a weight of six pounds. It ranges from San Nicolas to Puget Sound, being generally common in water of moderate depth. It is subject to greater variations than any other species in the different parts of its range. It forms about seven per cent. of the total rock-cod catch. Its flesh ranks as about arerage.

The Grass Rockfish, Sebastichthy's rastrelliger, like all those of dusky color, is known as "Garrupa." At San Francisco it is often called "Grass Rockfish," perhaps from its color. It reaches a weight of two to four pounds. It lives in water of moderate depth, and is rather common everywhere from San Nicolas to Humboldt Bay. Its abundance is greatest south of Point Conception. It is said to be the best of all the Rockfish for the table, and to be an especial favorite with the Jews.

The Brown Rockfish, Sebastichthys auriculatus, seldom receives a distinctive name from the fishermen. It reaches a weight of three or four pounds, although, as usually seen in the markets, it is smaller than any other of the species. This is owing to the fact that its young are caught in seines in the bay, while those of other species are less frequently taken, and then only in the open ocean. It ranges from San Martin Island to Puget Sound, living in shallow water and entering all the bays, and being taken with a hook from all the wharves. It is thus apparently more abundant than any other species, although in actual numbers probably many of the deep-water forms (S. flavidus, pimiser, rosaccus) far exceed it. As a food-fish it is held in lower esteem than most of the others.

The Pesce-Vermiglia, Scbastichthy's chlorostictus, is called "PesceVermiglia," or "Vermilion-fish," by the Portuguese fishermen at Monterey. It is known only from Monterey Bay and the Farallones, occurring about the rocks in considerable depths of water and being taken only with the hook. In its native haunts it is not a rare species. It reaches a weight of three or four pounds, and is excellent food. 
The inexplicable name of "Fly-fish" is given to one species, Sebastichthy's rhodochloris, by the fishermen at Monterey. Like the preceding, it is known only from very deep water about Monterey and the Farallones. It is one of the smallest species, rarely weighing more than a pound.

The Corsair, Sebastichthy's rosaceus, is known to the Portuguese fishermen at Monterey by the name "Corsair," a name of uncertain application transplanted from the Azores. It is one of the smallest species, rarely weighing more than a pound and a half. It ranges from Santa Barbara to San Francisco, in deep water, and where found, it is the most abundant of the red species. When the weather permits outside fishing with trawl-lines this is one of the most abundant species in the San Francisco markets. It ranks high as a food-fish.

The Spotted Corsair, Sebastichthys constellatus, in size, distribution, habits and value agrees with the "Corsair." It is, however, considerably less abundant, although not a rare fish in the markets of San Francisco.

Two specimens only of the Yellow Rockfish, Sebastichthys umbrosus, are known, both of which are from Santa Barbara.

At Monterey, the Spanish-Flag, Sebastichthys mubicinctus, is known by the very appropriate name of "Spanish Flag," from its broad bands of red, white, and red. It reaches a weight of about six pounds. It is found in very deep water on rocky reefs about Santa Barbara and Monterey. It is perhaps the least common in the markets of all the species, except $S$. $u m$ brosus. In coloration it is the most brilliant fish on the coast.

The Red Rockfish, Scbastichthys mucr, is usually the "Red Rockfish" par cxcellence. At Monterey it evidently attains a weight of twelve or more pounds, and is called by the Portuguese "Tambor." It ranges from Santa Barbara to Puget Sound, its abundance increasing to the northward. It lives in water of considerable depth. In the markets of San Francisco it is one of the most common species. Large specimens about Victoria, in the Straits of Fuca, had the skull above the brain infected by an encysted parasite worm. Great numbers of them were seen in the Straits of Fuca, according to Mr. Swan, swimming stupidly near the surface, so torpid that the Indians killed them with clubs. According to the Indians, they had been struck by the Thunder-bird, which, with its companion, the Lightning-fish, causes many of the phenomena in that region. The smaller specimens of this species rank well as food-fishes; the larger ones are likely to be coarse or tough. 
Sebastichthys miniatus is known to the Portuguese fishermen at Monterey as the "Rasher," a name of uncertain origin and othography. It ranges from Santa Barbara to San Francisco, living in water of moderate depth. It is comparatively common, and is frequently seen in the markets, though in much less numbers than $S$. ruber and S. pinnigcr. In size and quality it agrees closely with $S$. pimiger.

The Orange Rockfish, Sebastichthy's pinniger, is usually called simply "Red Rock-cod" or "Red Rockfish," and not distinguished from the two preceding. The Portuguese at Monterey know it by the name "Fliaum," a word of unknown origin. It is one of the largest species, reaching a weight of eight or ten pounds. It ranges from Monterey to Puget Sound, being generally very abundant in deep water, where it is taken on trawl-lines. This is probably the most abundant of the larger species. At San Francisco individuals are often found with black discolored areas, looking like ink-blotches, on their sides. No cause for this has been noticed, and if it be a disease it does not seem to discommode the fish. In the market this species grades with $S$. mber, and like it, is often split and salted.

The Green Garrupa, Sebastichthy's atrovirens, is commonly known as "Garrupa" and "Green Rockfish," being rarely distinguished from S. rastrclligcr." It reaches a weight of about three pounds. It ranges from San Diego to Monterey, being more southerly in its distribution than the other species. It lives in rocky places, in rather shallow water, and is generally common, especially south of Point Conception. It is considered excellent food.

Scbastichthy's clongatus is known as "Reina," or the Queen, at Ionterey. It is a small fish, reaching a weight of less than two pounds, and lives in deep water about Monterey and the Farallones. It is never very common in the markets, although frequently taken in considerable numbers.

The Red Rockfish of Alaska, Sebastichthys proriger, in habits, agrees with $S$. clongatus. It is usually still smaller, rarely weighing more than a pound. Its range extends northward to the Aleutian Islands, where it reaches a large size, and is of considerable importance as a food-fish.

Sebastichthy's ozalis is known at Monterey as "Viuva" or the Widow; the reason not evident. It reaches a weight of three or four pounds. It is found from Santa Barbara to Monterey, in deep water, and is seldom brought to market. 
Sebastichtly's sentomelas is very similar to the preceding in size and habits. Thus far it has been only found in deep water outsıde of Monterey Bay.

Scbastichthy's mystimus, is most generally called the "Black Rockfish," but in Puget Sound is known, with its more abundant relative, Sebastichthys mclanops, as the "Black Bass." The Portuguese at Monterey call it "Pesce Prétre," or Priest-fish, in allusion to its dark colors, so different from those of most of the other members of the family. It reaches a weight of five pounds, but as usually seen in the markets, varies from two to three. It ranges from Santa Barbara to Vancouver's Island, inhabiting waters of moderate depths. It is much more abundant about Monterey and San Francisco than either northward or southward, and large numbers are taken in Tomales Bay. In the markets of San Francisco it is found, taking the year through, in greater numbers than any other species. It sells at a lower price than the others, its color causing a prejudice against it, although the quality of the fish doubtless differs little from that of the rest.

Specimens of the Alaska Black Rockfish, Scbastichtlys ciliatis, from the Islands are in the National Museum. Nothing distinctive is known in regard to its habits, which probably agree with those of $S$. melanops.

The Spotted Black Rockfish, Sebastichthys melanops, is founded with S. mystinus by the fishermen, under the name of "Black Bass" in Puget Sound, "Black Rockfish" in San Francisco, and "Pesce Pretre" at Monterey. In size and value it agrees with $S$. mystimus. Its range is more northerly, from Monterey to Puget Sound, being not very common at San Francisco, and one of the most abundant species in Puget Sound.

The Yellow-Tail Rockfish, Sebastichthys flavidus, is occasionally called the "Green Rockfish" or "Rock-cod" at San Francisco. At Monterey" it is always known by the appropriate name of "Yellow-tail," the caudal fin being always distinctively yellow. To distinguish it from the Yellowtail of further south we may call it the Yellow-tail Rockfish. This species reaches a weight of six and seven pounds, but its usual weight is about two. It ranges from Santa Catalina Island to Cape Mendocino, and is taken both in deep water and near shore. About Monterey and San Francisco it is very abundant, and is one of the principal species in the markets. As a food-fish it is considered as one of the best in the group).

About Monterey and San Francisco, the Boccacio, Sebastodes paucispinis, 
is known as "Boccacio" or "Boccac" (bocatch) to the Italians, and as "Miérou" (maroo) to the Portuguese. American fishermen use the name "Jack," and those who fish for the young from the wharves call them "Tom-cod.", The name "Boccacio" (Big-mouthed) is very appropriate; "Mérou" is transferred from Atlantic species of Epincthelus; "Jack" comes from the species of Esox and Stizostedium, which in the Southern States are called by that name. This species is one of the largest of the group, reaching the weight of twelve to fifteen pounds. Its average size in the markets is greater than that of any of the others. It ranges from the Santa Barbara Islands to Cape Mendocino. It inhabits reefs in deep water, only the young coming near the shore. It is rather more abundant southward than about San Francisco. It is, however, a common market-fish, and its flesh is considered excellent. It is probably the most voracious of the family.

Five species of the genus Sebastichthy's, namely, S. melanops, S. caurimus, S. maliger, S. proriger, and $S$. ciliatus, attain to large size and considerable commercial importance in Alaska, and are discussed by Dr. Bean in his paper on the "Shore Fisheries of Alaska" in another section of this work. S. melanops is called "Black Bass" at Sitka.

The Rock Trouts, Chiridc, a family of fish of considerable importance on our Pacific coast, is that of the Chirida, or Rock Trouts, no representatives of which are known in the Atlantic. One or two species of the family occur in the sea of Japan.

The Boregata, Hexagrammus Stelleri, is known in Puget Sound by the Italian name of "Boregata" or "Boregat." The name "Starling" is applied to some fish, supposed by us to be this species, in the Straits of Fuca. It reaches a length of fifteen inches and a weight of three pounds. It ranges from Puget Sound to Kamtchatka. In Puget Sound it is comparatively abundant, living about rocks. It spawns in July. It feeds on crustaceans, worms, and fishes, and apparently gets its food on the bottom in deep water, as the animals taken from its stomach are often of a kind not seen near shore. Its intestines are very often full of long tænioid worms, supposed to be parasitic. As a food-fish, it ranks with the other Rock-trout, being of fair quality, but inferior to Ophiodon and Sebastichthy's.

The name "Boregata," is applied to the Green Rock Trout, Hexagrammus decagrammus, by the Italians on Puget Sound. The name "Rock Cod" is also given to it. From San Francisco southward, the 
names "Rock Trout" and "Sea Trout" are common. The Portuguese at Monterey call it "Bodieron." It reaches a length of fifteen inches and a weight of two or three pounds. It ranges from San Luis Obispo to Alaska, and is much more generally common than any of the other species, and large numbers are brought into the market of San Francisco. It lives in rocky places of no great depth. It feeds voraciously on crustaceans and worms. It spawns in July. It dies at once on being taken from the water, and the flesh becomes rigid and does not keep as well as that of the rock-fish. It is a food-fish of fair quality, but not of fine. The sexes are very unlike in color, and have been taken for distinct species.

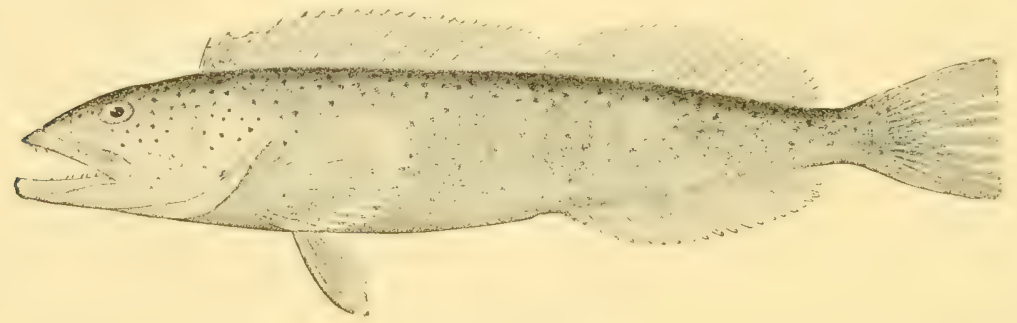

THE CULTUS COD.

The Cultus Cod, Ophiodon elongatus, is universally called "Cod-fish," where the true cod is unknown. About Puget Sound the English call it "Ling." Among the Americans the word "cod" is used with some distinctive adjective, as Cultus Cod ("cultus" in the Chinook jargon, meaning of little worth), "Bastard Cod," "Buffalo Cod," etc. The name "Blue Cod" is also given to it from the color of its flesh. The name "Rock Cod" applied to other Chiroids and to Schastichthy's, and thence even transferred to Serrams, comes from an appreciation of their affinity to Ophiodon, and not from any supposed resemblance to the true cod-fish. The Cultus Cod reaches a length of five feet, and a weight of fifty or sixty pounds, the largest specimens being taken in northern waters. Many very small ones come into the San Francisco market, being taken in the sweep-nets of the paranzelle. These weigh less than a pound; the average of the large ones is from six to ten pounds. It ranges from Santa Barbara to Alaska, being very abundant everywhere north of Point Conception. It lives about rocky places, and sometimes in considerable depths, and spawns in summer. It feeds upon fishes and crustacea and is cxcessively voracious. It often swallows a red rockfish when the latter is 
on the hook, and is thus taken. Like other large fishes, it is subject to the attacks of the hag-fish (Polistrotrema). As a food-fish it holds a high rank, being considered rather superior to the rockfish. From its great abundance, it is one of the most important fishes on the Pacific coast.

Zaniolepis latipinnis ranges from San Francisco northward in deep water. It reaches a length of about a foot, and is of no economic value.

'The bright-colored little fish, Oxylcbius pictus, ranges from Santa Barbara to Vancouver's Island, living among rocks near shore. It reaches a length of six inches, is rarely taken and is then used only for bait.

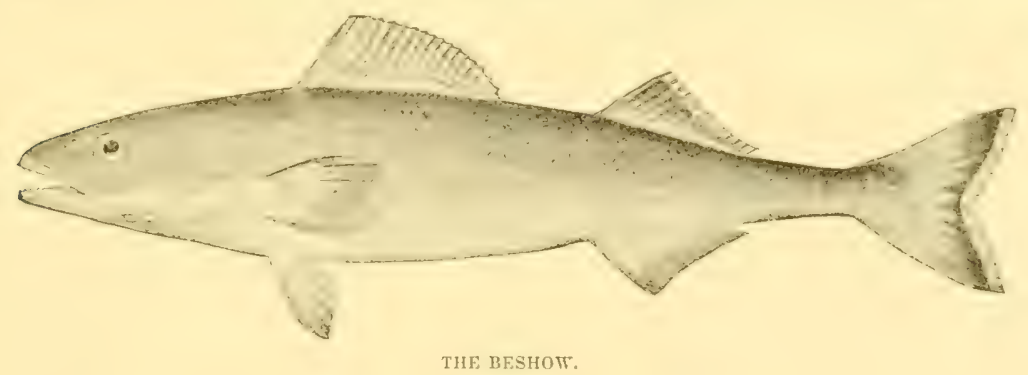

The Beshow, Anoplopoma fimbria, is generally known in Puget Sound by the name of "Horse-mackerel." At San Francisco it is usually called "Candle-fish." In the market it is sometimes fraudulently sold as Spanish mackerel. It reaches a length of twenty inches and a weight of five pounds. It ranges from Monterey northward to Sitka, in rather deep water, and is generally common, especially northward. At Seattle it is one of the most abundant fishes, but in the San Francisco market it is seldom seen in large numbers. It feeds on crustaceans, worms, and small fishes.

In the Straits of Fuca it reaches a much larger size tlian has been noticed elsewhere. It is here very highly valued by the Indians, according to Mr. Swan. It is called by the Indians "Beshow," and is the "Black-cod," of recent writers. Mr. James G. Swan has given a full report upon its habits in a recent Bulletin of the Fish Commission, * and has forwarded some of the salted fish for examination. The writer is not prepared to give to Anoplopoma a position as yet among the finest of American fishes, although it is no doubt an excellent kincl for local consumption.

*Vol. V. ISS5, pp, 225-34. 
In Alaska, according to Dr. Bean, the most important chiroid fishes are Ophiodon elongatus, Anoplopoma fimbria, Hexagrammus decagrammus, H. lagocephalus, H. ordinatus, H. asper, and the "Vellow-fish," "Striped Fish," or "Atka Mackerel," Plcurogrammus monopterygius (Pallas) Gill, which is the chief of them all. This fish is most abundant about the Aleutian chain and the Shumagins, its northern limit as now understood being about Kodiak, and its western limit at Atka. It congregates in immense schools, and can be taken in purse-seines like the mackerel, which it strongly resembles in taste after being salted in the same manner.

In this connection, not because of zoological affinities, but in order that a majority of the principal food-fishes of the Pacific slope may be discussed in one chapter, it seems appropriate to refer to the Embiotocoids or Surf-fishes. Full descriptions of the various members of this multiform genus are given by President Jordan in his "Synopsis" and in the great Fisheries quarto. Here I can only quote what the same authority has to say of the group as a whole:

"This remarkable group of fishes forms the most characteristic feature of the fauna of our Pacific coast. Of the nineteen species now known, all but one (Ditrema Temmincki of Japan) occur on the coast of California, and most of them in very great abundance. The species are most of them very similar in habits and economic value, and the following general remarks are proffered before proceeding to the discussion of the different species.

"The general name "Perch" is applied to these fishes everywhere along the coast. This unfortunate misnomer came about from their resemblance to the sun-fishes or "perch" of the Southern States, and to the "white perch," Roccus americams, of the East. On the coast of Oregon the larger species (especially Damalichthys argyrosomus) are called "Porgy" or "Porgee," in allusion to their undoubted resemblance to the scup or porgee of the East. The names "Minny," "Sparada" and "Moharra," are also applied to the smaller species northward. About San Francisco, the name "Perch" is given to them all, as well as to Archoplites intermptus, and separate names for the different species are seldom heard. From Monterey southward, the name "Surf-fish" is in common use, although the name "Perch" is still more common.

"The largest, Rhacochilus toxotes, reaches a weight of four pounds; the smallest, Abeona minima, a length of four or five inches. So far as we are able to juclge, the growth of the young are quite rapid, as the specimens are about half grown the first winter, and probably reach full size in two and a half to three winters-perhaps, in some cases, in the second year.

"The center of distribution of this group is from Santa Barbara to 
Tomales Bay. Northward the number of species decreases, while the number of individuals is perhaps, equally great as far as the Gulf of Gcorgia. Southward both individuals and species rapidly diminish in number.

" Their range probably extends from Cerros Island to Sitka ; certainly no further. Most of them live in shallow water, on a sandy bottom, both in the open sea and in sheltered bays. A seine drawn in the surf will often be filled with'the silvery species (Amphistichus; Holconotus), and a seine drawn in a bay may be equally full of Ditrema laterale, Ditrema Jacksoni, etc. One species is confined to the fresh waters. Nearly all of them feed chiefly on crustacea, together with such small fish as they can swallow. The species of Abcona are chiefly herbivorous, feeding on seaweed.

"The Embiotocoids are all oviparous. The young are fifteen to twenty in number, and are brought forth in summer: when born, the little fish are from three-fourths of an inch to two and a half inches in length, according to the species. They are closely packed together in the uterus, the inner surface of which forms folds partly separating the young from each other. The young are at first excessively compressed, with the soft parts of the vertical fins excessively elevated. As their development proceeds they resemble more and more the parent, and when born their form is quite similar, the body, however, more compressed, the fins higher, and the color usually red.

"Impregnation probably takes place in the fall. In January most of the species have the young half grown, as to length, and when the parent fish is caught the young readily slip out from the ovary. From January to func the fish-stalls where these fishes are sold are littered with these teetal fish. Little is known of the place of spawning, but I suppose that the young are simply extruded in the water just outside the breakers and left to shift for themselves. As to the mode of impregnation, we have made no observations. Dr. Blake thinks that the fleshy thickening on the anal fin of the male is to give the female something to hold to with the ventral fins, and that the two sexes approach each other, ventral surfaces together, and with their heads in opposite directions. They have no special enemies except the larger predatory fishes and the fishermen, who destroy great numbers at the breeding time. No diseases have been noticed.

"The species are all, with the exception of two or three of the smallest, used as food. Their flesh is watery, flavorless, and much inferior to that of the Scorprenoid, Scianoid and Percoid fishes. and only their abundance gives them value. Great quantities of them are consumed by the Chinese." 


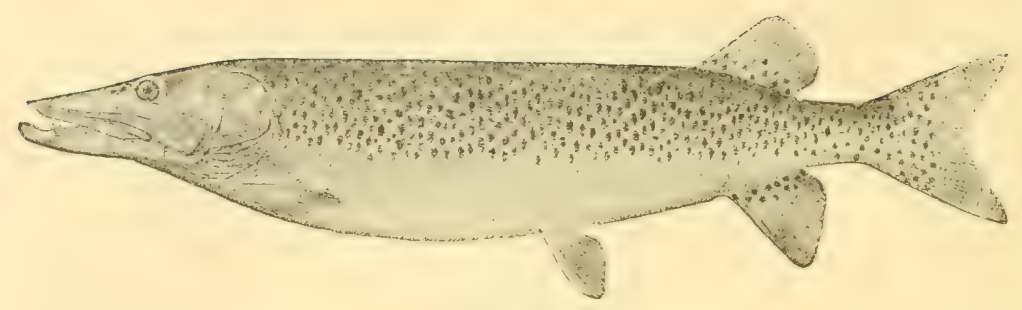

THE MUSKELLUYGE.

\title{
PIKE, MUSKELLUNGE AND PICKEREL。
}

\author{
I will give thee for thy food \\ No fish that useth in the mud, \\ But trout and pike, that love to swim \\ Where the gravel from the brim, \\ Through the pure streams may be seen.
}

Beaumont And Fletcher, The Faithful Shepherdess, 161 .

The goodly well-grown trout, I with my angle strike,

And with my bearded wire, I take the ravenous pike

Drayton, The Muses Elysium, Nymphal IV.

$\mathrm{O}$

NE of the most ancient among the families of fresh-water fishes, is that of the Pike-the Esocida-a group of physostomous fishes, closely related to the flying fishes, and the cyprinodonts, and not very distantly related to the Salmon tribe. This family contains only the genus Esox, which embraces five species, all natives of North America, one, the Pike, being a resident of the Old World, as well. Geologists tell us that remains of the Pike are found in abundance in the quartemary deposits of Europe, and that this, or closely related species,occur in the diluvial marl of Silesia, and in the chalks of the Eningen region. The wide distribution of the Pike throughout the northern regions of Europe, Asia and America, indicates that this species was in existence many centuries ago, before the three continents became so widely differentiated as they are at the present time.

The Pike being the oldest, the most widely distributed, and the best known member of its tribe, shall serve as the text for this chapter, and the type with which the related species shall be compared. So few, however, have been the observations in this country, and so much has Esox lucius been confused with the other species of the genus, that it 
seems impracticable to compile from American authorities a satisfactory account of its life history, and in default thereof, frequent references must be made to the studies of European observers.

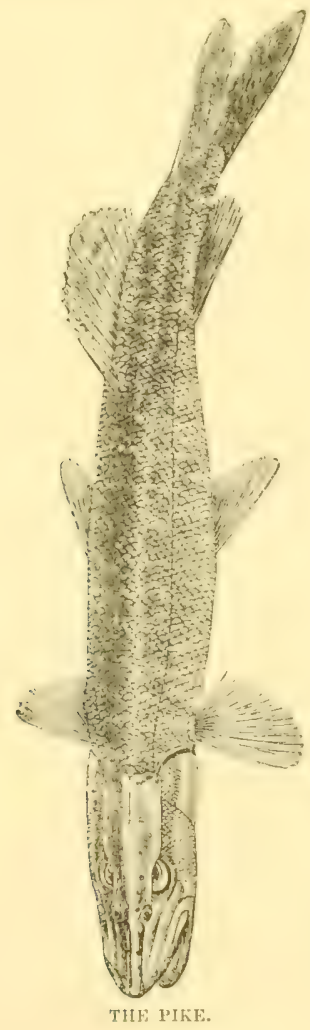

In Eastern America, the Pike is abundant as far south as Ohio; its northward range has not been determined, but since its existence on the Island of Kodiak, in Alaska, has been demonstrated by Dr. Bean, there is every reason to believe that it will be found pretty generally distributed throughout British America. It has not been recorded from Greeniand, or the islands of the Polar Sea. Its European range extends from Britain to Silesia, and doubtless east to Kamtchatka, throughout the Scandinavian peninsula, and north in Lapland, even beyond the limits of the birch-tree. It inhabits most of the rivers and lakes of European 
Russia and Siberia, but does not enter those of the Trans-Caucasus, and the Crimea. On the south it enters Roumania, and has been found in the Lake of St. Stefanos, near Constantinople, in the lagoons of Venice, in Switzerland and France, but not in the Iberian peninsula.

It is found in all parts of Germany, not only in the high mountain region, but along the sea-coast of Northern Germany, and even close to the shores of the Baltic. The highest vertical distribution on the northern side of the Alps, is in the Tyrolean Lake of Halden, 3,6r 8 feet. On the south, it occurs in certain lakes of the Tyrol, and in the Lake of Reschen, 4,637 feet, which is apparently the loftiest point of its distribution. In Switzerland, according to Tschudi, it ranges to 3,398 feet.

The climate of England and Germany seems suited to its best development, and its persistence in low latitudes will probably be found to be due to a special adaptability for hybernation.

The Muskellunge, Esox nobilior, is the rival of the Pike in size and vigor, but is very limited in its geographical range, occurring only in the Great Lake region of America, and in the St. Lawrence River.* It is very like the Pike, but has a head proportionally somewhat larger, and its color is markedly different. In general hue, it is dark grey, with silvery lustre, belly white, sides dotted with round, blackish and brownish blotches, and the fins flected with black. The Pike on the other hand has its markings white or yellowish, upon a darker background of green, dark grey or brown; in European examples the lighter markings are often confluent and band-like.

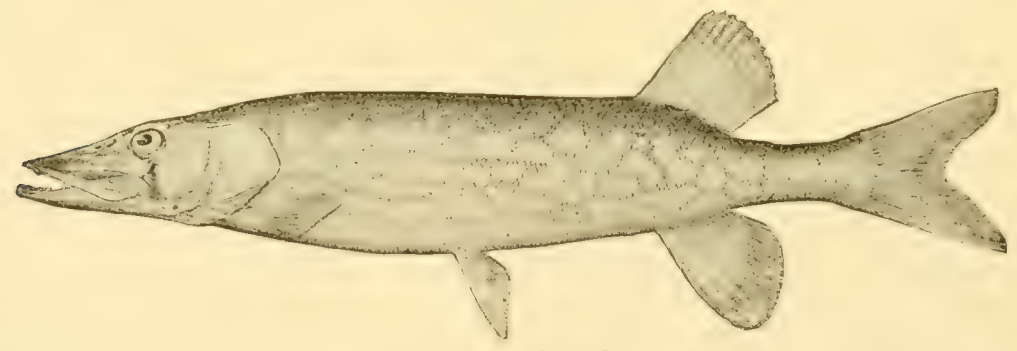

THF CHIIN PICKEREL,

The "Pickerels," of American nomenclature, are three in number, and

*It has frequently beensaid in print that Miskellunge were introduced into a pond near Rellow's Falls, Mass., in $183^{8}$, and that they have since escaped into the Connecticut, where they have become abundant. This is a great mistake. I have examined several of these would-be Muskellunge from the Connecticut, but all of them proved to be overgrown Pike. This species probably does not occur in the Comnecticut. 
are much smaller. Esox reticulatus, is usually known in the North by the name "Pickerel"'; in the Southern States it is the "Jack." It is found chiefly in the streams along the Atlantic coast, from Maine to Nlabama, and is generally abundant, especially in clear, grassy creeks and ponds. It is not found in the Lake region, nor west of the Alleghanies. It sometimes, though rarely, attains the weight of seven or eight pounds, and the length of three or four feet, and is much more slender in form, and graceful in motion than the Pike. It is yellow-green or brown in color, with an interlacing network of brown lines, covering the body. Its peculiar markings have given it the name of "Chain Pickerel," and patriotic Americans of early Federal days called it the "Federation Pike," an allusion to the chain of thirteen linked rays, symbolical of the Federal union, which was stamped upon certain copper coins used during the last century.

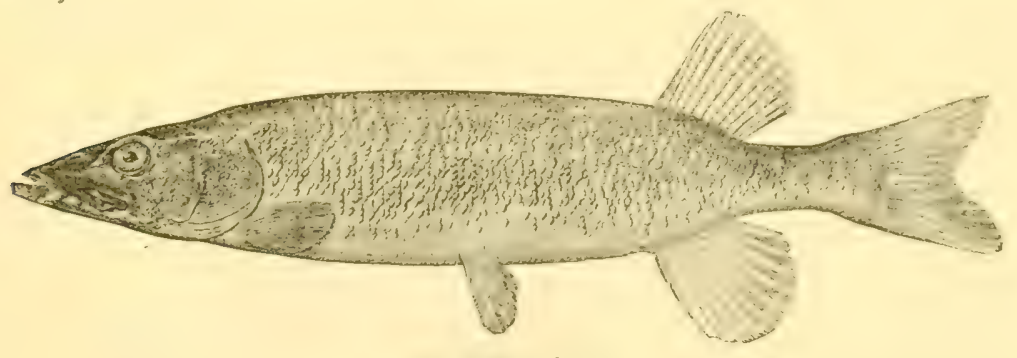

THE MROOK PICKEREL.

Esox americanus, the "Brook Pickerel," or "Banded Pickerel," sometimes also called the "Long Island Pickerel," "Trout Pickerel," and "Pond Pike," is comparatively small, rarely exceeding a foot in length, though occasionally reaching the weight of five to eight pounds. Its color is dark green, with about twenty blackish, lateral, transverse bands, usually curved, often obscure, but never net-like. There is a black line below the eye, and another through the eye and snout. The fins, especially in the breeding season, are bright red. This species occurs in the brooks on the Atlantic side of the Alleghanies, from Florida north to Massachusetts.

Another diminutive Pike, similar in form and color to the last, is Esox vermiculatus (Esox cypho) which is found in the Mississippi valley, especially in the small streams and bayous in the South and IVest. This species is also green, with numerous darker transverse bands or stripes, but 
they are usually arrayed in net-work, or in such manner as to produce a " marbled " effect." It has been called the "Hump-back Pickerel," anrl is of little value for food.

The common names of this group of fishes offer an opportunity for much curious research. The oldest name in literature is the Latin "Lucius," by which it was doubtless known to the gourmets of classic times, which was mentioned by the poet Ausonius, in the fourth century, $\uparrow$ and which lingered in the old French "Lus" and the names "Luccio" or "Luggo" by which Italians still know the species.

Although it is customarily stated that the Pike was unknown to the ancient Greeks, I see no reason to doubt that this is the fish which Athenæus, sixteen centuries ago, called Lycus, just as the Germans of to-day name it in familiar phrases the "Wasserwolf" (Water Wolf). Another vestige of this name, is the English "Luce," commonly applied to large individuals in the days of Chaucer, $f$ and not unfamiliar in later days, because of the extensive use of the fishes under this name as one of the symbols of heraldry. Shakespeare has immortalized the arms as well as the name of the name of the country squire, whom he hated, in his allusion to the escutcheon of the Lucys, and the blood-thirsty Sir Lucius O'Trigger in Sheridan's "Rivals," doubtless owed his prænomen to the savage Esox.

The name Pike, the philologist says, has been given to this fish, either from the likeness of its nose to a pike or spear, or because it moves itself

Since it is by no means a simple matter to discriminate between these species, especially when young, I depart from my usual custom. and present a key, in which some technical terms are used. This table is based upon Jordan's diagnosis.

Cheeks and opercula completely covered with scales.

Branchiostega!s, 12 in number. Colors obscure. About ros scales in lateral line,

Diameter of eye contained 5 times in length of head, and

neasly twice in snout, its posterior margin scarcely behind middle of head. E. annericanus.

Diameter of eye 6 in length of head, and less

than $\mathrm{B}$ in that of snout, the eye being exactly in middle of head. $\quad E$. vermiculatus.

Branchiostegals $14-16$. About 125 scales in lateral

- Diameter of eye, 8 in that of head, $31 / 2$

in snout. Snout prolonged, nearly half the length of the head. Colors bright, markings reticulate.

Cheeks scaly, lower half of opercula bare. Branchiostegals I4:16 Color:-light spots on a dark ground. E. lucius Lateral line 123.

Lower half of cheeks and opercula bare. Branchiostegals r6-rg.

Color :-Black spots on lighter ground. E. nobilior. Lateral line 150 .

† Lucrus obscurus ulva canoque lacunas

Obsidet: Hic nullos mensarum lectus ad usas

Fervet fumosis olido nidore popinis.

110sclle, 120-124.

$\ddagger$ Full many a fat partricke had he in mewe,

And many a Breme and many a Luce in stewe. Canterbury Tales. 
in the water like a spear thrown; and Pickerel is regarded as another form of the same word.* Jack, says the same authority is "perhaps from Jaculum, because like a Javelin, either in shape or motion." 'The French "Brochet," is of similar origin, and has reference to the resemblance of the fish to a spit or long needle, and "Lance", and "Lanceron," refer to its mode of motion.

In England, in the early days, when transportation was slow, and those who lived in castle and monasteries had the carp, and the bream, and the pike grown in their own fish-ponds for a sole dependence, Esóv lucius were more highly esteemed than at present, and this one species was honored with many names.

The fish, we learn from Halliwell's "Dictionary of Archaic IVords," was "first a Jack, then a Pickerel, thirdly a Pike, and last of all a Luce." This statement agrees with the prevailing idea that in England, "Pickerel" is used as a diminutive of Pike. Whether or not this was the usage in the fourteenth century seems a little doubtful, when we read what Chancer wrote:

"Bet is," quote he, "a pike than a pickerel,

And bet than old beef in the tender veal.'

I am assured by good authority, that Jack, rather than Pickerel, is at present the customary name in Britain for young Pike.

The word Pickerel is employed in America, to designate any small species of Pike, and since this name seems to have been almost abundant in England, this usage may perhaps be allowed to pass unchallenged. Confusion sometimes has arisen from the fact that in the West, the "Pike perch," Stizostedium, is alsu by many called "pickerel." (See American Angler, Feb. 25, I 882.$)$

Concerning the name Muskellunge, there have been many controversies. In a recent issue of "Forest and Stream," Mr. Fred Mather has given a very thorough history of the name in its various versions.

The predacious nature of the Pike is proverbial. It eats nearly all other linds of fishes, sparing not even its own species, and also devours frogs, mice, rats, and even young ducks. Although it is voracious in its attacks upon its prey, it remains generally in quiet and seems to prefer quiet and slow-flowing waters rather than swift streams.

:Skinner.

$\dagger$ Marchant's Tale, verse 9273. 
The Pikes have been well described as mere machines for the assimilation of animal matter. They are the wolves of the ponds, the blue-fish of the fresh waters, and nothing comes amiss to their ravenous maws. The habits of the European species are thus described by a recent writer:

"Shrouded from observation in his solitary retreat, he follows with his eye the motions of the shoals of fish that wander heedlessly along; he marks the water-rat, swimming to his burrow, the ducklings paddling among the waterweeds, the dabchicks and moorhens leisurely swimming on the surface, he selects his victim, and like the tiger springing from the jungle, he rushes forth, seldom indeed missing his aim ; there is a sudden rush, circle after circle forms on the surface of the water, and all is still again in an instant."

"No quadruped, bird or fish that the Pike can capture, seems to be secure from its voracity, and even the spiny perch is an acceptable prey to this water tyrant," wrote Richardson, speaking of its habits in British America.

The breeding habits of the Pike have been best described by my friend Prof. Benecke, of Königsberg, who writes:

"The Pike inhabits all the waters of Germany except shallow and rapid brooks. It prefers clear, quiet water with clean bottom; is usually active at night and quiet in the daytime; lurks among the plants in convenient corners, whence it rushes forth with arrow-like velocity. It lives a hermit life, only consorting in pairs during the spawning season. The pair of fish then resort to shallow places upon meadows and banks which have been overflowed, and, rubbing violently upon each other, deposit their spawn in the midst of powerful blows of their tails. The female deposits generally about 100,000 yellowish eggs, about three millimeters in diameter, out of which in the course of fourteen days the young, with their great umbilical sacs, escape."

In Germany, the spawning time of the Pike, as is shown in an elaborate table presented by Wittmack, often begins in the latter part of February, and lasts, depending somewhat on the temperature and the weather, into March and April, sometimes even into May.

In South Germany the spawning time is later than in -Prussia, while in Ireland and Sweden, it appears to be earlier. In Norway, according to Lloyd, there are three successive spawnings, which correspond to the disappearance of the winter ice, the pairing of the frogs, and the unfolding 
of the vernal leaves, the broods being known as "Ice-Pike," "FrogPike," and "Blossom-Pike."

Benecke's estimate of the number of eggs is undoubtedly too low. Buckland states that in a Pike of twenty-eight pounds, the roes weighed twenty-one ounces, and contained 292,320 eggs, while in one of thirty-two pounds, there were 595,000 eggs, weighing five pounds.

Benecke's period of incubation would be too short for more northern climates. In Great Britain and Sweden, they require from twenty-five to thirty days to come to maturity.

Seeley states that the young fish breed at the age of three years, and that the females are larger than the males.

The newly hatched Pikes grow rapidly when provided abundantly with food. A yearling fish in Prussia is often a foot in length, and according to Seeley a two-year-old may with exceptional feeding, weigh six or seven pounds.

Wittmack gives a number of statements from authorities in different parts of Germany, showing the annual rate of growth of the Pike, which appears to vary from two to three pounds, the maximum size attained being from forty-five to seventy pounds. He cites one instance in which, in two summers, a few individuals, liberated in a pond full of a species of carp, grew from the weight of one and three-quarters to that of about ten pounds.

As to the size to which a Pike may ultimately attain, there exist important differences of opinion. Frank Buckland naively remarks that " from the days of Gesner down, more lies, to put it in very plain language-have been told about the Pike than, any other fish in the world; and the greater the improbability of the story, the more particularly is it sure to be quoted." This savage thrust at Gesner and his commenters, has especial reference to the story of that enormous fish, nineteen feet in length, caught in the year 1497 , in a pool near Hailprun in Suabia, and which carried attached to its gills, a brass ring upon which was a Greek inscription, which said:_ "I am that fish that was first put into this lake by the hands of the Emperor Frederick II, on the fifth day of October, 1230. .' "The skeleton of this fish was said to have been preserved at Mannheim for many years, and there is a tradition that some inquiring anatomist discovered that it had been lengthened by the addition of several vertebrx. While it is true that "the legends of fishes with rings bearing ancient 
dates have not that quality of veracity which is required by science," it is also true that it was the practice in early days to fasten inscribed rings in the gill covers of fishes. Pennell states that in 16 Io, a Pike was taken in the Meuse, bearing a copper ring dating 1448 . It is very curious that no English writer on the Pike seems to have taken pains to investigate the German records which undoubtedly contain accurate and critical estimates of the value of this tradition.

Buckland seems disposed to doubt the existence of Pike larger than those which have come "under his own personal knowledge," a method sufficiently skeptical no doubt, but not necessarily scientific. Hesaw one forty-six and a half inches long, weighing thirty-five pounds, and ascertained to be about thirteen years old, another thirty inches long, weighing twenty-four pounds, another of forty-three inches, and twenty-eight pounds, and forty-four inches and thirty-two pounds, and two others, one forty-six and a half inches, and thirty-five pounds, and one forty-six inches, and thirty-six pounds, were taken by his friend Mr. Jardine. Daniell, in his "Rural Sports," speakes of a Scotch example, seventy-two pounds, and over seven feet in length. Pennell refers to others captured on the Continent, which weighed So, 97, and I45 pounds, the latter caught at Bregenty in $\mathbf{1} 862$.

There is no inherent improbability in these stories, since the Muskellunge often attains the weight of eighty pounds or more, as is attested by numerous witnesses.

No records of colossal Pike are found in the annals of American anglers-perhaps because the large Pike are usually pronounced by uncritical anglers to be in Muskellunge.

The western Pickerel, Esox vermiculatus, said to have been known to the Indians by the name Piccanau, has been known to attain the weight of twenty pounds, * but at the present day never exceeds seven or eight, and as usually seen, is not more than a foot in length. The eastern brook Pickerel is likewise diminutive.

In his census investigation of the Great Lakes, Mr. Kumlien obtained the following notes upon the abundance of the Pike and Muskellunge:

"On the western shore of Lake Michigan, Pike appear to be resident in those portions of the lake off Racine, and are very rarely taken in giilnets. At the west end of Lake Erie, individuals are at rare intervals taken 
in pound-nets set in the deepest water. About Sandusky and vicinity, like the Muskellunge, they are said to be rather rare, though a few taken in winter around Put-in-Bay Island are there regarded as residents of cold, deep water. Above Cleveiand they are not known to the fishermen, but in the vicinity of Ashtabula, considerable numbers are sometimes taken in spring-one or two hundred pounds at a haul of a pound-net. On the south shore of Lake Erie, very few are taken in pounds, and it is there thought that they keep constantly in deep water and seldom approach the shore. They are very salable and much sought after, but apparently nowhere abundant."

Among the Islands dotting the southwestern part of Lake Superior, including the Apostle Islands, Sand, York, and Rock Islands, and others, Muskellunge are caught in small quantities in the pound-nets. The Muskellunge is occasionally caught in the small bays indenting the shore south of Keweenaw Point as far as Huron Bay, and with it a large and much lighter-colored fish that may possibly be Esox lucius. This latter is not well known among the fishermen, but Mr. Edgarton says he has often noticed it, and has remarked that the general aspect was different from that of the Muskellunge. On the fishing grounds at the north end of Green Bay this is a rare fish, only half a dozen or so being taken each year. When it occurs it is found at any and at no particular point. Not a single specimen of this fish was taken by Mr. Nelson in ten year's fishing in the Cedar River district, and Mr. Everland in thirty-six years has not taken half a dozen. They are reported of occasional occurrence in the Monomonee River; but are not found in deep nets far out in the bay.

Lower down on the west coast of Green Bay, from Longtail Point to Peshtigo Point, this fish occurs everywhere, but nowhere in abundance. A specimen was taken at Washington Island in 1866 that weighed fortyfour pounds. The fishermen of this stretch of coast-line pronounce it Musk-ka-lone. At Green Bay City this fish is caught frequently weighing forty pounds. It is common at this point, $i$. $c$. the southern end of Green Bay. Ascending the eastern shore of Green Bay as far as St. Martin's Island the Muskellunge is very rare, being known by name only to a great many of the fishermen. Following the western shore of Lake Michigan southward from Port des Mortes on the north, as far south as Manitowoc, this fish is rare. At Jacksonport two have been taken in seven years. At 'Two Rivers only one has ever been recorded, viz., in i 878 . At Manito- 
woc it is less scarce, being caught sometimes in pound-nets, and more frequently in the River. At Milwaukee, the Muskellunge occurs in the lake but rarely; it is never caught in gill-nets. In I $868 \mathrm{Mr}$. Schultz took one in a small seine, in the old harbor, weighing one hundred pounds. This is believed by Mr. Kumlien to be a fact, having been testified to, as he says, "by so many reliable persons." He adds: "Formerly, fish of this kind weighing eighty pounds were far from rare."

On the 9th of April, a fish of this species four feet in length was taken at Racine; head to operculum, ten inches; to eye, four inches; greatest circumference, twenty and one-half inches; over eye, eighteen inches; at gills, eighteen inches; weight, forty-five pounds. These fish are never here taken in the gill-nets; they are resident in the lake about Racine in winter. A very few have been known to occur at Waukegan. On the southeastern shore of Lake Michigan, including the fisheries of Saugatuck, South Haven, and St. Joseph, this fish is reported as always being of a large size. At Ludington, farther north, only one instance of capture is on record; it is also said to be very rare at Grand Haven.

But little has been reported regarding the occurrence of the Muskellunge upon the numerous fishing grounds along the north shore of the southern peninsula of Michigan, between Little Traverse Bay and Thunder Bay. It is generally rare through the Straits of Mackinaw, only about half a dozen being taken each season; and most abundant of all at Les Cheneaux Islands. Capt. Coats caught one here, in $\mathrm{I} \delta_{74}$, weighing sixty-two pounds. These fish are rarely taken in pound-nets, and are chiefly caught with hook and line about the Les Cheneaux and Drummond Islands. Capt. Dingman has caught only one in his pound-net in the past fifteen years. All caught, of which he has heard, have been large. In Thunder Bay, about a dozen, on an average, are taken in twelve months. In Saginaw Bay, they are taken in about the same numbers as in Thunder Bay. Here too they are always large fish. A few are taken in seines along the coast between Port aux Barques and Port Huron. A few also are taken annually in the St. Clair River; perhaps a dozen or two altogether in this region during a year. Between Toledo and Detroit River, Lake Erie, a specimen of this fish is taken now and then in the poundnets. When taken, it is always large. The same remark will apply to the vicinity of 'Toledo and Maumee Bay.*

* Mr. Fred Alford states that he procured a Muskellunge from Maumee Bay, in I864, weighing cighthty-five pounds. 
About Locust Point a few are taken in the fall. Twenty years ago, in this region, including the fisheries of Ottawa, Port Clinton, Toussaint, and Locust Point, Muskellunge were taken weighing sixty or seventy pounds. In Sandusky Bay, specimens are caught of forty-five pounds weight, and at Kelley's Island one was caught weighing fifty-seven pounds, and another sixty-two pounds.

In connection with the Huron (Ohio) fisheries, it is reported that about one hundred and fifty fish of this species were taken in seventy-five nets during the year $\mathbf{1} 879$. They are here generally large, and are always taken in pairs. Three or four represent a year's catch of this fish at Vermillion, Ohio. About Black River, Lorain County, Ohio, Amherst, and Brownhelm Bay, it is very scarce, few being caught in nets; all that are taken are large. Of this fish, in connection with the Cleveland and Dover Bay fisheries, it may be said that it is very rare, and is becoming more so each year. Mr. Sadler says he took one weighing eighty pounds. The fishermen say they are always found in pairs.

The Muskellunge is taken at Conneaut, at the rate of half a dozen in ten years. Only one specimen was taken in the Painesville pounds in IS79. At Fairport and Willoughby, Ohio, no mention is made of its occurrence. Erie Bay, especially at Dunkirk and Barcelona, New York, Erie, Pennsylvania, and Mill's Grove, Ohio, is famous for its Muskellunge fishing; this past season, over sixty were caught, weighing from twenty to forty-five pounds. They are caught by trawling. Fancy prices are paid for them; about twenty-five cents per pound retail in the city, and twelve and a half cents when shipped. Nore were caught during the season of I 879 than ever before.

The following notes relate to the fishery in Lake Ontario: At Oswego, the fish is very rare on the American side; at Port Ontario, one is occasionally caught; at Cape Vincent, they are common, especially in the St. Lawrence. Nine have been brought in in one day, the smallest of which weighed thirty-two pounds. They are not now, howerer, so plentiful here as formerly. At Chaumont very few are caught. Seven years ago one was captured here weighing sixty-five pounds. At Sacket's Harbor, very few Muskellunge are caught.

The Pike is in Europe considered one of the most important of game fishes. Isaac Walton devotes to it an entire chapter, and Mr. Cholmondeley-Pennell, a well-known English writer on angling, has published a considerable work, entitled "The Book of the Pike." 
Buckiand, in his "History of British Fishes," devotes several pages to the exploits of Mr. Alfred Jardine, where he describes as "the most successful angler for Pike in modern times."

In this country, the Pike and the Pickerels have few friends, although the Muskellunge is not without admirers, among those who fish for sport. The opposition party is led chiefly by the angler-fish-culturists, who have good reason for their spite, since the hungry Esox is a sad foe to the proprietor of a fish preserve, and until it has been banished from a pond, no other species can be expected to thrive. In the days of the infancy of fish culture, Pike and Pickerel were frequently transplanted into our waters, and the results of this ill advised enterprise are by no means satisfactory to those who desire to propagate carp or trout in the same area. Only a few of these fish can live in one pond, and in the end the colony consists of a few patriarchs, strong, large and voracious.

The Pike is not without its uses in fish-culture however. One or two, kept in a pond, are believed by German carp-breeders to benefit the carp, by "keeping them lively," and thinning out the feeble.

The enemies of Esox in America denounce him vigorously, and declare that he is bony, flavorless, and of trifling value. He has his friends however. In the reign of Edward I., the value of Pike was higher than that of fresh salmon, and more than ten times greater than that of the best Turbot or cod, and in the time of Henry VIII, a large one sold for double the price of a lamb, and a Pickerel for more than a fat capon. Tough old Pike, and those taken from muddy, sluggish water, are of course not to be desired, but as a rule, any one of the American species is to be chosen as a delicate morsel for the table.

"Roast him when he is caught," said Isaac Walton, "and he is choicely good-too good for any but anglers and honest men." 


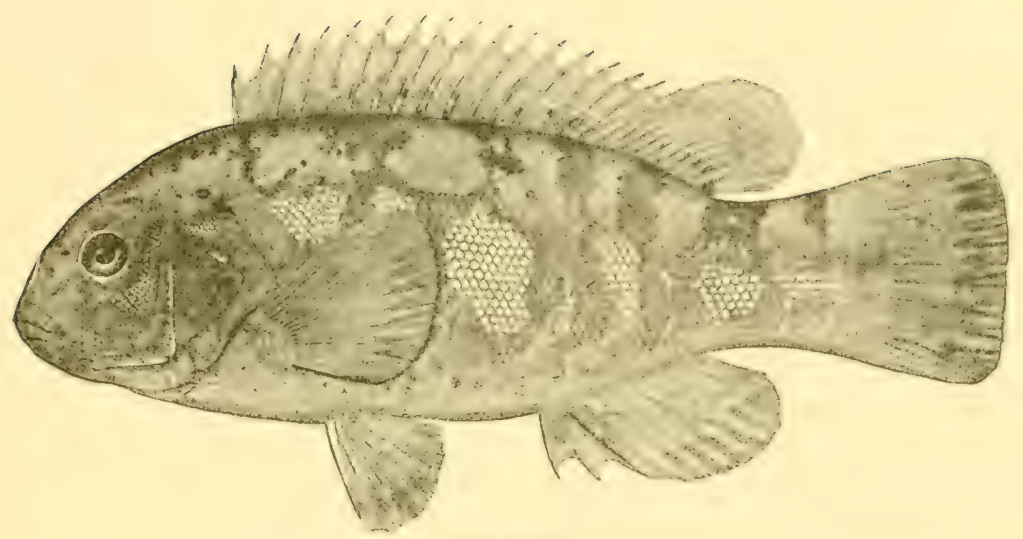

TIIF TAUTOG.

\title{
TAUTOG, CHOGSET AND PARROT-FISH.
}

\begin{abstract}
While blazing breast of humming-bird and Io's stiffen'd wing Are bright as when they first came forth new-painted in the spring. While speckled snake and spotted pard their markings still display, Though he who once embalm'd them both himself, be turn'd to clay, On fish a different fate attends, nor reach they long the shore Ere fade their hues like rain-bow tints, and soon their beauty's o'er. The eye that late in ocean's flood was large and round and full,

- Becomes on land a sunken orb, glaucomatous and dull ; The gills, like mushrooms, soon begin to turn from pink to black, The blood congeals in stasis thick, the scales upturn and crack; And those fair forms, a Veronese, in art's meridian power, With every varied tint at hand, and in his happiest hour, Could ne'er in equal beauty deck and bid the canvas live, Are now so colourless and cold, a Rembrand's touch might give.
\end{abstract}

BADHAM.

THE Wrasses and Parrot-fishes, are among the most gorgeously apparelled of the inhabitants of the waters. Nature has not conferred on the Labri, said Lacépède, either strength or power, but they have received instead, as their share of her favors, shapely proportions, and activity of fin, and are adorned with all the hues of the rainbow. "Le feu du diamant, du rubis, de la topaz, de l'cmeraukle, du saphir, de l'améthystes du grenat, scintille sur leurs écailles polies, il brille sur leur surface en goutte, croissans, en raies, en bandes, en anneaux, en ceintures, en zones, en ondes; il se mêle à l'éclat de l'or et de l'argent, qui y resplendit sur des grandes places, les teintes obscure, les aires pâles, et pour ainsi décolorées." 
These fishes were held in the highest esteem in classical days, for numerous species of the group frequent the waters of Italy and Greece.

"According to the Greeks," writes Badham, "s to do justice to their flesh was not easy, to speak of their trail as it deserved was impossible, and to throw away even its excrement was a sin. The frugal Numa would not allow these expensive 'brains of Jove' (Ccrebrum Jovis Supremi was a poetic name for the Scarus) to be imported for public entertainments, intimating thereby that parsimony was agreeable to the gods."

Aristotle considered the Scarus to be the only fish which slept at night.

"Scarus alone their folded eyelids close

In grateful intervals of soft repose

In some sequestered cell, removed from sight

They doze away the dangers of the night."

This ancient and aristocratic family is rather tropical in its tastes, but we have two worthy though not very highly appreciated representatives on our Eastern Atlantic coast, and others in our Gulf and Pacific waters.

One of the best known shore species on our Atlantic coast, is the Tautog or Black-fish, Tautoga onitis. This fish is now found in greater or less abundance about St. John, N. B., to Charleston, S. C. East of New York it is usually called Tautog, a name of Indian origin, which first occurs in Roger William's "Key to American Language," printed in I6 43 , in which this fish is enumerated among the edible species of Southern New England. "Tautog" would consequently seem to be a word from the dialect of the Narragansett Indians. On the coast of New York it is called "Black-fish"; in New Jersey also "Black-fish" and "Smooth Black-fish," "Tautog," or "Chub" ; on the eastern shore of Virginia "Moll," or "Will-George"; at the mouth of the Chesapeake "Saltwater Chub," and in North Carolina the "Oyster-fish." Of all these names, Tautog is by far the most desirable for general use. There are several other species along our coast called Black-fish, especially the seabass, which is often associated with the Tautog. The names Oyster-fish and Chub are also pre-engaged by other species.

Though the present geographical distribution of the Tautog is well understood, there is no reason to believe that its range has been very considerably extended in the present century by the agency of man. That the species was known in Rhode Island two hundred and thirty years ago is reasonably certain from the reference by Roger Williams, 
already referred to, and in 1776 it was stated by Schcepf that it was very abundant in summer at New York. It is in greatest abundance between the southern angle of Cape Cod and the Capes of Delaware, which would inclicate that within these limits, at least, the species has always existed. The waters of Long Island Sound and those immediately adjoining seem especially well adapted for its residence.

Mitchill, writing in ISI4, remarked: "The Tautog was not originally known in Massachusetts Bay; but within a few years he has been carried beyond Cape Cod, and has multiplied so abundantly that the Boston market has now a full supply without the necessity of importing from Newport and Provicence." This statement is confirmed, in a way, by Mr. Isaac Hinkley, of Philadelphia, who tells me that in $\mathrm{I} \$ 24$, he saw several indi viduals from Cohasset Rocks, Jerusalem Road, Mass., and that the fish was at that time said by the fishermen to be entirely new to them. Storer, writing about 1867 , remarked: "Although a few years only has passed since this species was brought into Massachusetts Bay, it is now taken along a large portion of the coast. At Plymouth, Nahant, and Lynn, at some seasons, it is found in considerable numbers, and is frequently caught from the bridges leading from Boston. The Boston market is for the most part supplied by Plymouth and Wellfleet." As early as I $S_{5} \mathrm{I}$, they had spread northward to the Bay of Fundy, and in that year it is stated that many were sold in the fish market at St. John, the largest of which weighed eight pounds; Mr. Lanman wrote that he obtained there in July and August specimens nineteen inches long, and weighing four pounds.

The rocky shores of Cape Ann seem particularly well adapted to its peculiar habits, and large numbers are annually obtained from the Rocks. So long has it been acclimated, and so well known is it, that the local authorities of that region are inclined to doubt that it is not native. The "Gloucester Telegraph", of May 5, I 860 , challenged the statement that the Tantog was a new fish, declaring that many years ago they were very plenty, and that after a period of scarcity they reappeared. So abundant had they become in $\delta_{3} 6$ in the harbor of Wellfleet, Mass., that three Connecticut smacks were accustomed summer after summer to devote their entire energies to their capture in this locality, and this fishery has continued up to the present day. In sandy localities, like the harbor of Provincetown, they have never secured a firm hold, thougl large specimens are sometimes taken under the wharves. 
As to the extension of the range of this species southward, we have the statement of Holbrook, quoted by DeKay, writing in 1842 : "Attempts have been made to introduce this fish farther south, but with limited success. I am informed by my friend, Dr. Holbrook, that Gen. Thomas Pinckney imported from Rhode Island a smack load of the Tautog and set them adrift in the harbor of Charleston, S. C., where they are to be found to this day. They are still occasionally caught, weighing from one to two pounds, but never in such quantities as to be brought to market." Mr. Earll obtained specimens at Charleston in January, r8So. Certain ichthyologists, among whom is Prof. Jordan, express skepticism as to the range having been thus artificially extended southward.

At Cape Lookout, S. C., Jordan records the species, under the name "Oyster-fish," as rather common, the young abundant about the wharves. About Norfolk and in the mouth of Chesapeake Bay they occur, and also on the coast of Southern New Jersey, where they are taken in the vicinity of Beasley's Point, in the channel ways, and along the shores, and they are said to be somewhat common on the banks off Sandy Hook, and in the southern bays of Long Island. These sandy regions, however, are not so much frequented by them as those abounding in rocky beaches and ledges.

Although the Tautog appear to thrive in cool water, as has been shown by the rapid extension of the northern range, they take refuge from too great cold, by retreating in winter to somewhat deeper water than that preferred in summer. Here they appear to seek shelter under the stones and in crevices of the rocks, if we may judge from their habits as observed in aquaria, their smooth, slimy skins, with scales protected from abrasion by a thick epidermis, enabling them to move about among the sharppointed rocks unharmed. They are on this account, also, especially well suited for confinement in the walls of smacks and in "live-cars," where it is customary to keep them living until required for market. They appear to enter upon an actual state of hibernation, ceasing to feed, and the vital functions partially suspended. It is the opinion of fishermen that during the hibernating season, the vent becomes entirely closed up, as is known to be the case with hibernating mammals. It is certain that they do not retreat far from the shore in winter, and that very cold weather, especially in connection with a run of low tides, often causes very remarkable fatalities. There are instances of their death in immense numbers. In February, I 857 , after a very cold season, hundreds of tons 
drifted upon the beach at Block Island, and along the southern shores of Massachusetts and Rhode Island, and a similar catastrople took place in I 84 I. In March, I875, it is stated that as much as a ton was thrown ashore in the drift ice at Cuttyhunk. They were seen floating by the Hen and Chickens light-ship for three successive days. In Southern New England they become torpid in November and December. It is stated that they are sometimes caught as late as Christmas. It is probal)le that many do not enter upon a state of complete torpidity, but remain in a partially active state in deep holes not far from the shore, and that it is these, rather than the hibernating individuals, which are especially liable to injury from the cold. A few are taken in Rhode Island in midwinter, both by line and in lobster-pots. North of Cape Cod they are rarely taken except in summer, ${ }^{*}$ while towards the southern limit of their range they are apparently as abundant in winter as at any other time. Mr. Nathan King, a Rhode Island fisherman, states that when the sun is very hot the Tautog leaves the clear spots for shelter among the weeds and rocks.

As may be inferred from its haunts and from the character of its strong, sharp teeth, the food of this consists of the hard-shelled mollusks and crustaceans, which are so abundant among the rocks. In their stomachs have been found, among other things, lobsters, crabs of various species, clams, mollusks, squids, scollops, barnacles, and sand-dollars. Many of the smaller mollusks they swallow, shells and all, ejecting the hard parts after the flesh has been digester. The common bait for Tautog in the spring is the clam, preferably the soft clam, for at this time the fishermen say they have tender mouths. In the fall, crabs and lobsters are used, the fiddler-crab and rock-crab being the favorites. They are sometimes taken with a bait of marine worms.

In Narragansett Bay and vicinity they spawn from the end of April until August.

The pound fishermen find them to be full of ripe eggs when they begin to approach the shore in early summer. Mr. Christopher E. Dyer, of New Bedford, has witnessed the operation of spawning in Buzzard's Bay in the middle of June, in water about two fathoms deep. This was in 1859 or I 860 , about two miles east of Seconnet Point. The number of eggs has not yet been determined, nor is it known how long the period of incuba-

* The first of the season were taken at Gloucester, May x3, IS3I. 
tion continues, but young fish are found abundantly in the eel-grass along the shore in August and September, and have been observed at various points from Cape Lookout to Monomoy. There can be no question, however, that there are breeding grounds near Charleston, S. C., and north to Cape Cod, since the species is very local in its habits, and does not make long journeys to select spawning beds. Little is known of their rate of growth, though it is probably slow. Capt. Benjamin Edwards, of Woods Holl, Mass., kept thousands of small Tautog confined in a pond for five years, and at the end of that time, when six years old, none weighed more than two and one-half pounds. A half-pound fish which he confined in a lobster-car, with plenty of room and plenty of food, increased from one-half to three-quarters of a pound in six months. The average weight of those sent to market does not exceed two or three pounds, though individuals weighing ten, twelve, and fourteen pounds are by no means unusual. The largest on record was obtained near New York in July, 1876 , and is preserved in the National Museum-its length thirty-six and one-half inches, its weight twenty-two and one-half pounds.

The abundance of this species past and present has been actively discussed and much interesting testimony on the subject may be found in the report of the United States Commissioner of fisheries. This was one of the fish regarding which the claim was made that it has been almost exterminated in Rhode Island by overfishing; upon this point, however, the opinions of fishermen and experts are much at variance. In 1870 , when, according to general opinion, Tautog had been almost exterminated in the waters of Narragansett Bay, the records of Newport fish-markets show that in one day, Norember 2, eleven men caught about 3,000 pounds of Tautog with hook and line, besides cod and other fish, while on the following day the catch of fifteen meen was 28,000 pounds, besides codfish caught to the amount of 600 pounds, being an average of over 2,600 pounds to each man. These catches compare very favorably with that recorded at Fir Rock Ledge, Wareham, ten years previous, when, on the gth of October, two men caught, in three hours, $27 \mathrm{I}$ pounds of Tautog, a catch which was pronounced by local authorities the greatest ever made in those waters.* Col. Lyman, Massachusetts commissioner, writing in $r 8_{72}$, remarked: "Great complaint is made of the scarcity of this valued species north and south of Cape Cod, but especially near the mouth of

\footnotetext{
* Barnstable Patriot, October 9 , I860.
} 
Narragansett Bay, where they are said to be not more than one-eighth as numerous as they were a score of years ago." Although much testimony" has been printed in the reports of the Fish Commissions of the United States and of Rhode Island, the general tendency of which is to show that old fishermen believe that Tautog and other fish are much less abundant than in the days of their youth, nothing definite has yet been proved.

The Tautog has always been a favorite table fish, especially in New York, its flesh being white, dry, and of a delicate flavor. Storer states that they are frequently pickled, and may be kept in weak brine for a long time, and in this state they are considered by epicures a delicacy.

The capture of Tautog is chiefly accomplished by the line fishermen of Southern Massachusetts and Rhode Island, and the weir fishermen of the same district. No one fishes for Tautog alone, and it is consequently more difficult to estimate the quantity taken. About 200,000 pounds were brought to the New York market last year. Local consumption is considerable, and the total amount annually taken may be estimated at from 400,000 to 450,000 pounds. At least two hundred fishermen are entirely or partly engaged in this business between Cape Cod and New York. The catch of such fishermen in Narragansett Bay is estimated at 6,000 pounds each annually. This gives in round numbers 100,000 pounds taken by hook and line along this stretch of coast. To this should be added 20,000 pounds estimated to be taken on the coast of New Jersey and southward, and 20,000 more north of Cape Cod. Tautog are also frequently taken in the weirs and pounds, and the catch of these for the year I 876 was estimated as is shown in the following table:

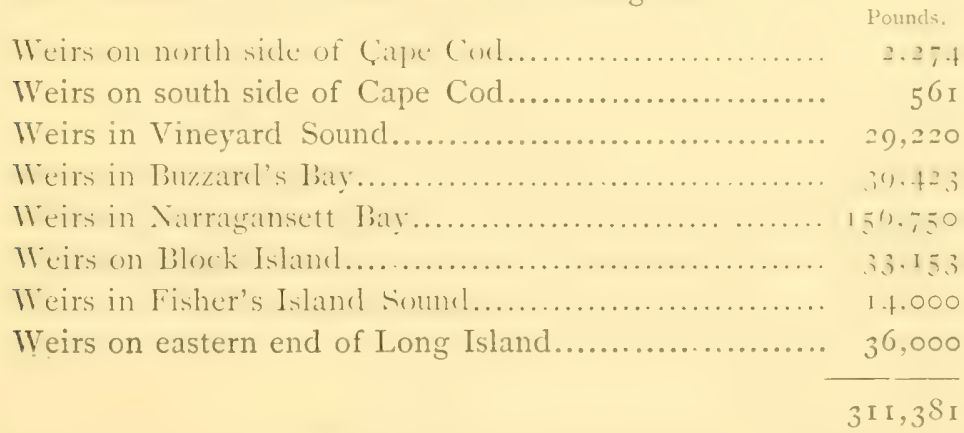

At Noank, Conn., there is in the fall a season of "black-fishing" which continues from the mitdle of October until the snow begins to fall, 
about the first of December. About twenty-five men are engaged in this fishery during the season specified, some of whom begin a month or two earlier. They fish in Fisher's Island Sound at a depth of six to eight fathoms, using crabs and lobsters for bait. The average catch of each man for the season is estimated by Capt. Ashby at one thousand pounds. The most northerly point where there is a regular fishery for them is, as has already been mentioned, in Wellfleet harbor. According to DeKay, three smacks were constantly employed from April to November. These smacks doubtless, then as now, hailed from Connecticut. In I879, these vessels were still upon the old ground, one of them hailing from Westport and one or two from New London. One of the skippers was said to have fished upon this ground every season for thirty years. I was told in Wellfleet that they ordinarily remained about three weeks to fill their wells, obtaining in that time from two to four thousand pounds.

Angling for Tautog from rocks is a favorite pursuit of amateur fishermen all along the coast, particularly about New York, where there are precipitous shores, the anglers standing upon the rocks. July I2, 1879, Capt. S. J. Martin caught in this way, at Eastern Point, Gloucester, seven, two of which weighed twenty-one and a half pounds. In Long Island Sound and other protected waters they are usually fished for from boats anchored among the reefs or near wrecked vessels. Mitchill, writing in I8r4, describes the methods of this fishery better than any other subsequent authority: "Rocky shores and bottoms are the haunts of Blackfish. Long experience is required to find all these places of resort. Nice observations on the landmarks in different directions are requisite to enable a fishing party to anchor on the proper spot. For example, when a certain rock and tree range one way, with a barn window appearing over a headland the other way, the boat lying at the point where two such lines intersect each other, is exactly over some famous rendezvous. At some places Blackfish bite best upon the flood. In others they are voracious during the ebb. Thunder accompanying a shower is an indication that no more of them can be caught. The appearance of a porpoise infallibly puts an end to the sport. Dull weather with an easterly wind is generally the omen of ill luck. Some persons who live contiguous to the shores where are situated the rocks which are frequented by Tautog, invite the fish there by baiting. By this is meant the throwing overboard broken clams or crabs to induce the Blackfish to renew their visits; and fine sport is procured." 
Mitchill also gives an interesting bit of folk lore in the following account of the botanical mnenonics of the fishermen in the vicinity of New York :

"The blossoming of the dogwood, Cormes florida, early in April is understood to denote the time of catching black-fish. As soon as these flowers unfold, the fishermen proceed with their hooks and lines to the favorite places. If there is no dogwood, a judgment is derived from the vegetation of the chesnut tree, Castanca vesca. The people express this sentiment in these coarse rhymes:

"When chesnut leaves are as big as thumb-nails

Then bite black-fish without fail,

But when chesnut leaves are as large as a span,

Then catch black-fish if you can ?"

As has been already stated, the Tautog on the coasts of the United States is extremely sensitive to cold, and at the approach of the time of hibernation, the vent becomes sealed, the fish thus becoming prepared for a minimum consumption of its own fat during its winter sleep.

In Brown's "American Angler's Guide," in the article on Tautog or Black-fish it is remarked:

"The Black-fish abounds in the vicinity of Long Island, and is a stationary inlrabitant of the salt water. He may be kept for a long time in ponds or cars, and even fatted there. When the cold of winter benumbs him he refuses to eat any more, and a membrane is observed to form over the vent and close it. He begins to regain appetite with the return of warmth in the spring.

"Now we know that Tautog hibernate among rocks near the coast and in our rivers, and it has been stated by Mr. L. Tallman or Mr. Daniel Church, that some years ago, after a very cold snap, not only many Tautog were washed ashore frozen stiff, but afterward quantities were also found dead among rocks off the coast. If, during the winter, they don't feed as stated above, and this membrane closes them up, the conclusion must be that they remain in a state of torpor or sleep during cold weather. Now it happens that the scup, when first taken by traps, are in a state of torpor; they neither eat nor have any passage. It is probably sealed up like the Tautog, and nothing in the shape of food is to be found within them. Some say they are blind, and they seem hardly able or willing to move.

"The inference, then is, that the scup have also been hibernating within a short distance from the coast, in the same state as the Tautog. This would account for the stray scup mentioned by Mr. Sonthwick as having been occasionally found in March. A warm day wakes him up, and he 
visits the shore for a day or so and then returns. To my mind this is a more reasonable way of accounting for his presence than to assume that he has been left behind. If these facts are as stated, it is to be presumed that scup are local fish, and do not have their localities any more than Tautog, about the propriety of classification of which as a local fish there is no question."

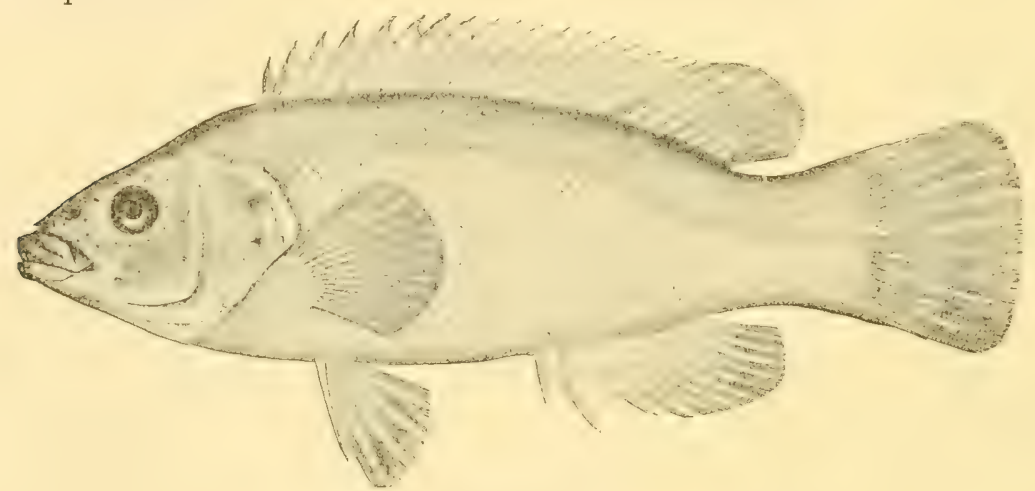

THE CHOGSET.

The Chogset, or Cunner, or Bergall, Ctenolabrus adspersus, is very similar in appearance to the Tautog, though much smaller and far less important. Its range is more northerly. I can find no record of its occurrence south of New Jersey. DeKay remarks: "I am not aware that it is found south of Delaware Bay." From New York to the Straits of Canso the species is exceedingly abundant, being found everywhere in harbors and bays, particularly in the vicinity of fish houses, where offal is thrown overboard. Cuvier had specimens from Newfoundland, but it abounds on the coast of Labrador. It is closely related to the "Goldsinny," Ctenolabrus mpestris, and the "Connor" or "Gilt-head," Crenilabrus melops, of Great Britain and adjoining Europe. It has numerous conmon names. In Southern New England it is called "Chogset," a name of Indian origin, sometimes pronounced Cachogset. 'This name appears to have been in occasional use as far west as New York, where, in Mitchill's time, it was also called "Bluefish." In Maine, the British Provinces, and in some parts of Massachusetts the name "Cunner" is in use, evidently having been brought over by the English colonists who remembered a very similar fish at home which has this name. In New York, the name "Burgall" has continued in use since the revo- 
lutionary times. This name also is of English origin, certain species of this family being called "Bergylt" in parts of England." This name appears to hold in Eastern Long Island at the present time. At P'rovincetown they are called "Sea-perch," and at the Isle of Shoals and occasionally on the adjoining mainland, "Blue-perch" and "Perch," this also being a reminiscence of English usage. At Salem they are called "Nippers," and occasionally here and elsewhere "Bait-stealers." About where Cunners are found at all, they are exceedingly abundant, and, though performing a useful duty as scavengers, are a pest of fishermen, from their habit of nibbling the bait from their hooks. They are the especial detestation of those who fish for Tautog, since the two species are ordinarily found together. Their food is very similar to that of the Tautog, except that they cannot swallow large shells. They feed also upon dead animal matter, and are among the most important scavengers of our harbors. Numbers of them may be taken by lowering a net containing a piece of meat or fish and quickly raising it to the surface. Like the Tautogs, Cunners are local in their habits, only moving from the shoal water in extreme cold weather, and, though adapted for living in colder water, rarely retreat except in the severest weather. In winter, however, they are rarely caught with the hook. The first of the season of ISSI at Gloucester, were caught May 8. A very cold season sometimes destroys them. It is recorded that in January, $\mathbf{1} 835$, great quantities were frozen and thrown up on the shore between Gloucester and Marblehead.* In June and July they spawn on therr feeding grounds in Southern New England, and in July and August fish three-quarters of an inch, or more, in length are taken abundantly along the shores. They appear to become adult and to breed when three inches long. The largest I have observed was taken at Woods Holl, in July, I875; its weight was twelve ounces, its length ten and a half inches, and it was spawning frecly. Storer claims to have seen them fourteen inches long, and I am assured that they sometimes attain a weight of two pounds.

From Eastport, Maine, to the vicinity of Boston, the Cunner is a favorite article of food. Elsewhere it is rarely eaten and is usually regarded with disgust-a foolish prejudice, for it is one. of the most agreeably flarored among the small fishes on our coast. Immense quantities are taken with the hook from the rocks, bridges, and boats, especially in the vicinity of

\footnotetext{
* Gloucester Telegraph, January 14, 1835.
} 
cities like Boston and Portland. They are also taken in immense quantities in nets. The Irish market-boats of Boston make a special business of catching them, using circular nets three or four feet in diameter which are baited and set among the rocks. Dr. Storer records that on the occasion of his visit to Labrador, in 1849 , he found them so plentiful in the Gut of Canso, that by sinking a basket with a salt fish tied therein for bait, he continually caught them by the score, and by putting a few hundreds in the well of his sloop, kept the crew well supplied with fish while at sea on the way to Labrador. The people of Nova Scotia, like those south of Cape Cod, rarely if ever eat the Cunner. Mr. J. Natthew Jones informs me that in the summer of $186_{3}$, when the French fleet was anchored in Halifax Harbor, the sailors caught them for food in great numbers. About St. Margaret's Bay, according to Mr. Ambrose, they are given as food to pigs; since, however, the pork of these fish-fed pigs always tastes oily, they are generally fed on some other food for a short time before being killed, and well dosed with sulphur. It was formerly customary in Boston to keep these fish alive for market in large cars, described by Storer as three feet deep, twelve to fifteen feet long, closerl beneath and latticed at the sides, and anchored in deep water. Storer states that sometimes as many as five thousand fish were kept in a single car, and that these cars were replenished every week or fortnight. It is impossible to estimate with any degree of accuracy the quantity of Cunners annually taken. The catch of the Irish market-boats of Boston cannot fall much short of 300,000 pounds, and that of the other towns and States on the coast of New England is certain to be from 200,000 to 250,000 pounds.

Several of the Parrot-fishes occur on the Florida coast, notably the Blue Parrot-fish, Platyglossus radiatus (Linn.) Goode, sometimes, according to Jordan, seen in Key West market, and $P$. bivattatus, known in Bermuda as "Slippery Dick," recorded by Jordan from Charleston market. They are gorgeous in color, but the flesh is so dry that they are held in slight esteem for table use.

The Red-fish, of California, Trochocopus pulcher, writes Jordan, is everywhere known as the "Red-fish": the name "Fat-head" is occasionally used, and it is very rarely called "Sheepshead." It reaches a weight of twelve to fifteen pounds. It is found from Point Conception southward to Cerros Island in enormous numbers, in the kelp. It is taken 
chiefly with hook and line. It feeds on crustaceans and mollusks. It is taken chiefly by the Chinese, who salt and dry it. It forms half of the total catch of the Chinese south of Point Conception. It does not rank high as food-fish, its flesh being coarse. The fat forehead is said to make excellent chowder.

The Senorita-fish, of Monterey, Pseudojulis modestus, is known as "Pescerey"; southward it is called "Senorita." It reaches a weight of less than half a pound. It is found in the kelp from Monterey southward to Cerros Island, and is generally common. It feeds chiefly on crustaceans, and is used, as a rule, only for bait, although the flesh is said to be of excellent quality.

The Kelp-fish, of California, Platyglossus semicinctus, bears in company with Heterostichus rostatus, and perhaps others, the name of "Kelp-fish." It reaches a pound in weight, and a length of nearly a foot. It is found in the kelp about Santa Catalina Island and southward, and is not very abundant. It feeds on crustacea, and spawns in July. Its flesh is said to be of good quality.

The Hog-fish, Lachnolamus falcatus, is, according to Mr. Stearns, abundant at Key West and along the Florida coral reefs, although he has not observed it north of the Gulf of Mexico. It there attains a considerable size, and a weight of twelve or fifteen pounds, although the average fish is not more than one-fourth that size. In the Key West market it appears almost daily, and is much esteemed for food. This species occurs throughout the West Indies, and is one of the favorite food-fishes of Cuba, although its sale is forlidden by law, on account of the supposed poisomous nature of its flesh. In the Bermudas it is one of the most important of the food-fishes, attaining sometimes the weight of twenty pounds. It is caught by the line fishermen among the reefs, at a depth of five to forty fathoms. Like the other members of this family, it feeds upon small fish, and upon bottom crustaceans and mollusks. Its brilliant red color renders it a conspicuous object in the markets. During the different stages of growth its species undergoes many changes of form, and has been described under several different names. The large adult male is remarkable on account of a heavy black blotch over the forehead and over the eyes. The name "Hog-fish" refers to the swine-like appearance of the head, jaws, and teeth. At the entrance to the Great Sound, in Bermuda, is a reef called Hog-fish shoal, which is surmounted by a beacon bearing an enormous effigy of a Hog-fish in metal. 
A family related to the Wrasses is that of the Demoiselles or Pomacentride.

Among the reefs of Florida two or three species of this family are abundant. Most prominent among them is the "Sergeant Major," Glyphidodon saxatilis (L.) C. \& V., called in Bermuda the "Cow-pilot," from an alleged habit of being always found in the society of the "Cow-fish," or Ostracion. This fish sometimes attains the length of ten inches and the weight of a pound or so, but is usually of a smaller size and is not highly esteemed for food. It is found throughout the tropical waters of the world.

There are several smaller species of this and of allied genera in the Gulf of Mexico, and on the western side of the Isthmus of Panama and in the Gulf of California. On the California coast occurs a species, Pomacentrus mubicundus, conspicuous by reason of its uniformly deep crimson or orange coloration, which is usually known as the "Garibaldi" among the Italians. The names "Gold-fish" and "Red Perch" are also used, all of them referring to its brilliant orange colorations. It reaches a weight of three pounds, and a length of less than a foot. It is found about the Santa Barbara Islands and southward to Lower California. It lives about rocky places, and is generally abundant. Its food is chiefly crustaceans. It is a food-fish of low grade, and has little economic importance. Another somewhat noteworthy species is known in California, on account of its dusky colors, as the "Blacksmith," Chromis punctipinnis, Cooper.

"This fish," writes Jordan, "is known as the "Blacksmith" from its dusky colors. It reaches a weight of about two pounds. It ranges from the Santa Barbara Islands southward, living about reefs of rock, and is lccally abundant. It feeds on shells and crustacea. It is considered as indifferent food."

The family Cichlide is large, and is composed chiefly of fresh-water fishes occurring in the tropical parts of Africa and America. Among its members is a South American species, Geophagns surinamensis, which is often mentioned by writers on the instincts of animals on account of a peculiar habit of the males which carry in their mouths the eggs until they are hatched, and which are even said to allow the young fish to seek refuge within their jaws. We have no representatives of this family on our Atlantic coast, though one or two species of the genus Heros occur in the brackish waters of Texas. 


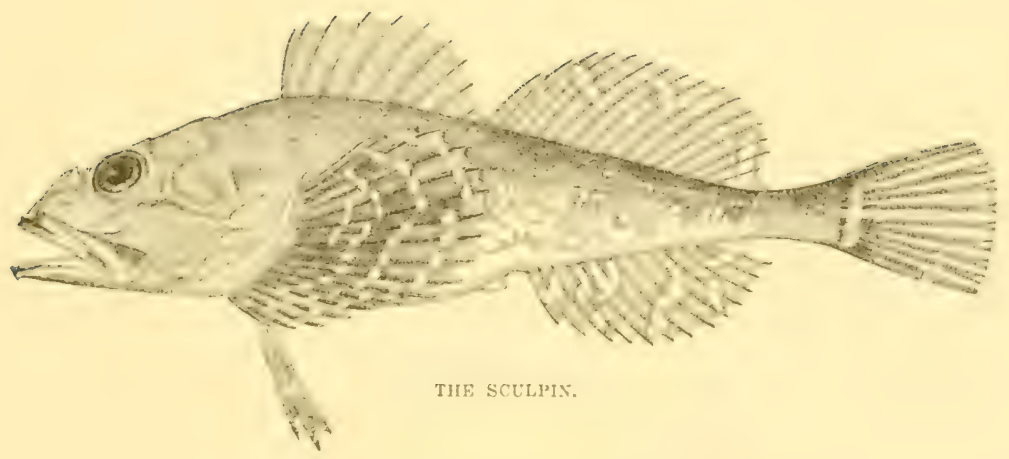

SCULPINS AND GURNARDS.

Now the Sculpin is a little water beast which pretends to consider itself a fish, and, under that pretext, h:ngs about the piles on which West Boston Bridge is built, swallowing the bait and hook intended for flourders. On being drawn from the water, it exposes an immense head, a diminutive bony carcass, and a surface so full of spines, ridges, rufles and frills that the naturalists have not been able to count them without quarreling about their number; and that the colored youth, whose sport they spoil do not like to touch them, and especially to tread on them unless they happen to have shoes on to cover the soles of their broad black feet.

Howies: The Professor at the Brcakfast Table.

$\mathrm{O}$ N our Atlantic coast are' found several species of this family: generally known by the name "Sculpin," and also by such titles as "Grubloy," "Puffing-grubby," " Daddy Sculpin," "Bullhead," "Sea-robin," "Seatoad," and "Pig-fish." Their economic value is little or none, but they are important as scavengers, and are used for lobster bait. They are often a source of great annoyance to the fishermen by cumbering their hooks and by stealing their bait. The most abundant species is the Eighteen-spined Sculpin, Cottus octodecimspinosus, which frequents shallow and moderately deep waters from Labrador to New York. It is usually associated with a smaller species, Cottus eneus, which may be called the "Pigmy Sculpin," and which ranges from the Bay of Fundy to New York.

Cottus scorpizus, of Europe, is represented on our coasts by C. scorpius sub-species granlandicus, which is abundant everywhere from New York to Greenland and Labrador. This sub-species has been found on the coast of Ireland,* and the typical Cottus scompius has been shown by Dr. Bean to occur in Maine. This is also, in addition to several insignificant species seldom seen except by naturalists, a large, brilliantly colored form, known

\footnotetext{
* Annals of Natural History, I84, P. 402.
} 
as the "Sea-raven," "Rock Toad fish," or "Deep-water Sculpin," which is found as far south as the entrance to Chesapeake Bay, is abundant throughout New England, and has been discovered off the coast of Nora Scotia. This fish, Hemitripterus hispidus, or $H$. amcricamus, attains the length of two feet, and is conspicuous by reason of its russet-orange or brick-red colors, its harlequin-like markings, its warted body, its grotesquely elongated fins, and above all, by its peculiar habit of swallowing air until its belly is inflated like a balloon.

These fishes feed upon all bottom animals, mollusks, crustaceans, seaurchins, and worms, and may also be found in the harbors devouring any refuse substances which may be lying upon the bottom. They breed for the most part in summer, and certain species, like the Sea-raven and the Greenland Sculpin, at that time assume very brilliant colors. They are not eaten by our people, although the Sea-raven is decidedly palatable. Those species which occur in Greenland, are said to be eaten by the natives. As has been remarked, they are a source of annoyance to fishermen, whose bait they steal and whose hooks, especially the hooks of their trawl-lines, they encumber. Boys delight to catch them and fix a piece of light wood between their teeth; they are then unable to swim and struggle vigorously at the top of the water.

About the fish-curing stations they are very abundant, and exceedingly useful as scavengers, gorging themselves with refuse thrown back into the sea; they care little for the presence of man, and can hardly be driven away, even when roughly punched with a boat-hook.

In the lakes and streams of the Northern States are numerous species of Tranidea and allied genera, known in some localities by the English name of "Miller's 'Thumb," also called "Bull-heads," "Goblins," "Blobs," and "Muffle-jaws.", They are small and of no importance except as the food for larger species.

The Cottidæ, according to Jordan, are represented on the Pacific coast by about eighteen separate species, known by such names as "Sculpin," "Drummer," "Salpa," "Johnny," "Biggy-head," and "Cabezon." Only one of these species, Scorpanichthy's marmoratus, has any sort of economic importance; the others may be considered collectively. The names applied to them may be briefly considered. The name Sculpin, of course, is derived from that in use for the Atlantic species of Cottus. "Drummer," comes from the quivering noise made by many species when 
taken alive out of the water. "Salpa" is a Spanish word for toad, and applied also to species of Batrachida. "Johnny" is applied only to very little Sculpins along the shore, notably Oligocottus maculosus. The same name is given in the Ohio Valley to fishes of precisely similar habits, the Etheostomatida. "Biggy-head" and its Spanish cognate "Cabezon" are used by the Italians and Spanish about Monterey, Santa Barbara, and elsewhere, for different Cottidx.

Most of the Cottidæe feed upon small fishes, and especially crustacea; one species, Enophry's bison, being a vegetable feeder. All take the hook readily. The flesh is poor, tough, and dry, and the waste by the removal of the head, viscera, and skin is so great that even the poorest people do not use them as food. Various sorts (notably Lcptocottus armatus) are dried by the Chinese, who consider them the poorest of all dried fishes.

The Sea-robin or Gurnard family, is represented on our Atlantic coast by several species, some of them being quite abundant. The most striking of them all is the Sea-bat or Flying Gurnard, Dactylopterus volitans, which is remarkable on account of its enormous spreading fins, larger than those of a flying-fish-wings which, however, are not sufficiently powerful to lift the body above the surface of the water, though useful in maintaining the equilibrium of the heavy-headed body swimming through the water. The colors of the body and of the fins are very brilliant, and the fish is often exhibited as a curiosity. It is found along our entire coast south of Cape Cod, and in the waters of Brazil; also in the Nediterranean and in the neighboring parts of the Eastern Atlantic.

The most important of the Pacific Sculpins, writes Jordan, is Scorpanichthy's marmoratus, a species which attains the weight of more than ten pounds, being by far the largest member of its family in those waters. It is found from San Diego on the south, to Victoria on the north, but is more abundant about Monterey and San Francisco, than either northward or southward. It inhabits moderate depths, and is taken in consiclerate numbers with gill-nets and hooks. It feeds upon crustacea and small fish. Its value is very slight, its flesh being tough and flavorless, and it is rarely sent to market when good fish are abundant.

The genus Prionotus, of which we have five species, resembles Dactylopterus in general form, but the wings are much smaller, while two or three of the lower rays of these fins are developed into finger-like appendages which are used in stirring up the weeds and sand to rout out 
the small animals upon which they feed. In Southern New England there are two species, $P$. palmipes and $P$. evolans, the latter distinguished by the presence of dark stripes upon its sides. These attain the length of fifteen to eighteen inches and a weight of one and a quarter to two pounds. They have excellent food qualities, but are eaten, so far as we have record, only in the vicinity of Hartford, Conn., where they are known as "Wing-fish." They are taken in great quantities in the pound-nets along the Vineyard Sound, especially the unstriped species, the habits of which are better understood than those of the allied species. It feeds upon crabs, shrimps, and small fishes.

In Vineyard Sound the Sea-robin spawns during the summer months. A specimen obtained at Woods Holl, August [2, I875, contained eggs nearly ripe. Another, observed at Noank, Conn., July I I, I874, was in precisely the same condition. Lyman states that in $\mathbf{I} 87 \mathbf{I}$ the eggs, which are bright orange, were thrown up in quantities during the last third of May on the beach on the inner parts of Waquoit Bay, and the females had well developed spawn in them.

The species just mentioned are found as far north as Cape Cod; the Web-fingered Sea-robin, $P$. palmipes, even north of the Cape, two or three specimens having been obtained in the vicinity of Salem and Lynn. These two species apparently do not occur much to the south of Cape Hatteras, and on our Southern coast they are replaced by others which are smaller, and at present, of no economic importance. The genus Prionotus does not occur in Europe, the family being there represented by a very similar form, genus Trigla, which, however, has still smaller wings. Its habits are much the same. A single specimen of the Red Gurnard of Europe, Trigla cuculus, is said to have been taken at New York. Euroje has nine species of Trigla, most of which are highly esteemed for food; some of these species have been known to attain the length of two feet, and the weight of eleven pounds. These fishes are held in high estimation, and are frequently seen in the markets.

Parnell writes: "The Red Gurnard occurs on the Devonshire coast in great numbers, and on some occasions thousands of them may be seen exposed for sale daily, especially in those small towns where the trawlboat fishing is carried on. The flesh is firm and well-flavored. The Tub-fish, $T$. himmdo, is of frequent occurrence on the west coast of Scotland, and is occasionally brought to the Edinburgh market. Its flesh is 
firm and wholesome, and is considered by some to be superior to the lasi species, but in general more dry. In the north of Europe it is salted for keeping. The Gray Gurnard, $T$. gurnardus, is considered by all fishermen richer and sweeter than any of the other Gurnards, although in the markets it is less sought after than the Red Gurnard, which is the drier and worse flavored of the two. It is taken generally with hooks baited with mussels." These fish are taken in very great numbers in the trawl-nets; they appear to be much more abundant on the European coast than their cousins, the Sea-robins, with us. These recommendations are yuoted here in order to (lraw attention to this neglected group of fishes, which are certainly worthy of greater consideration than they have hitherto received.

Mr. J. Carson Breroort has given the following testimony regarding the food qualities of the American species:

"Among the fish that may be classed as edible, but which are entirely neglected here, is the Sea-robin, Grunter, or Gurnard. This curious, but rather forbidding creature, is, in reality, one of the most delicate morsels that can be laid before an epicure, the flesh being snow-white, firm, and fully as good as that of the king-fish, or whiting. In fact it would be hard to distinguish them when placed on the table.

"In Europe every one of the kinds of the Trigla, or Gurnard family, is sought after eagerly, and finds a ready sale on the fish stalls. They have eight or ten kinds of the group there, and we have but six here; all but one different from the European kinds, though belonging to the same family. We shall not attempt to describe all these fish, which resemble each other very much in all but the color. They all have large heads, sheathed with rough, bony plates, and armed with many acute points, and their dorsal fin has also several sharp, thorny rays. 'These prickles are all erected by the fish when taken alive, and they inflict a painful, though not, as many say, a poisonous wound. The broad mouth is furnished with rough, but not sharp, teeth ; the pectoral fins in most of the species are very long, and can be expanded like a fan, whence they are sometimes called Flying-fish and Butterfly-fish. It is doubtful, howerer, whether they can actually fly like a flying-fish, but they have been said to skip from wave to wave, a peculiarity often alluded to by halieutic poets. They also emit a grunting sound, which can be distinctly heard in still weather while lying at anchor on a shallow, which they frequent. At such a time the sound resembles the distant lowing of kine. When freshly taken from the water they grunt quite loudly, whence their popular name of Grunter, or Cuckoo-fish.

"The Gurnards live on crabs and delicate fresh food, taking all such baits readily, on a clean bottom, and they sometimes anno" fishermen 
hugely by their voracity. They play well on the hook, and a large one tugging at a rod is often supposed to be a game fish and a prize, till the ugly Sea-robin, with his spiky helmet, shows himself at the surface.

"The Gurnards of our coasts do not reach a large size, at least we have but rarely seen any that weighed over a pound, while in Europe some of the species, such as the Tub-fish, Trigla hirundo, have been found weighing eleven pounds, and those of seven or eight are common. The Red Gurnard, or Rochet, T. cuculus, and the Piper, T. lyra, reach three or four pounds, averaging about two, while the other European kinds resembles ours as to size.

"Small as our species are; they are not the less delicate when cooked, and we have often verified this fact. They are sold in England by the number, and not by weight, for their large heads are inedible, while they add, perhaps, one-quarter to their weight. The English fishermen take them almost everywhere along the coast in large trawl-nets, constructed for their capture, though other bottom fish may find their way into the net. These trawls are generally twelve or sixteen feet wide at the mouth, while a bag proportioned to their beam, which has one or two labyrinths like a fyke-net inside. The Trawl is managed from a large sail-boat, with a block and tackle, and is hauled in water as deep as eight or ten fathoms. We do not recommend this special fishery to our coast fishermen, as our Gurnards are small, but wish only to call attention to the edible qualities of this generally despised fish.

"Piscator (the anonymous auther of the "Practical Angler), in his excellent little treatise entitled 'Fish ; How to Choose and How to Dress,' published in I 843 , says of the Gurnard that their flesh is "white, excellent, exceedingly firm, and shells out into snowy flakes, and is of a remarkably agreeable flavor,' and that 'they keep well.' He recommends them to be boiled-that is the large ones; while the small ones may be split and fried.

Having drawn attention to this first as one that deserves a place on our tables, we leave his fate hereafter to the tender care of a good cook and a discerning palate.

Another member of this family is the Peristedium miniatum, a brilliant red species recently discovered by the Fish Commission in the deep waters on the coast of Southern New England. 


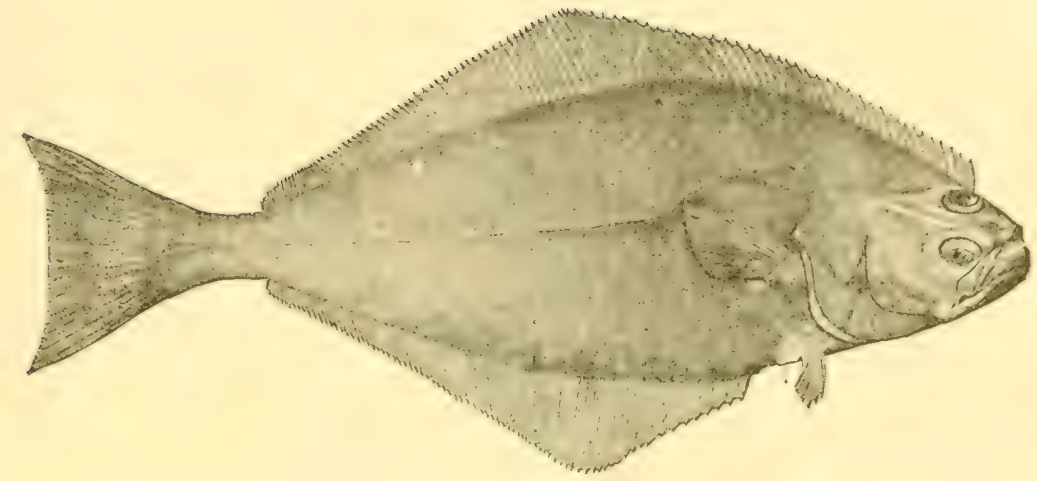

THE H.ALIBUT.

\section{HALIBUT, FLAT-FISH AND FLOUNDER.}

Flat fish, with eyes distorted, square, ovoid, rhomboid, long,

Some cased in mail, some slippery-backed, the feeble and the strong,

Sedan'd on poles, or dragg ${ }^{2} d$ on hooks, or poured from tubs like water,

Gasp side by side, together piled, in one promiscuous slaughter.

\section{BADHAM.}

THE Halibut is widely distributed through the North Atlantic and North Pacific, near the shores, in shallow water, as well as upon the off-shore banks and the edges of the continental slope down to a depth of two hundred and fifty fathoms or more. In the Western Atlantic the species has not been observed south of the fortieth parallel, stragglers having occasionally been taken off Sandy Hook, Block Island. and Montauk Point, while it ranges north at least to Cumberland Gulf, latitude $64^{\circ}$, and as far as Disko, Greenland, five or six degrees within the Arctic Circle. Along the entire west coast of Greenland they exist, abundant about Iceland and north to Spitzbergen, in latitude $80^{\circ}$. No one knows to what extent they are distributed aiong the European and Asiatic shores of the Arctic Ocean, but they have been observed on both sides of the North Cape, in East and West Demmark, and from the North Cape, latitude $7 \mathrm{I}^{\circ}$, south along the entire western line of the Scandinavian Peninsula, in the Skager Rack and Kattegat, but not, however in the Baltic. South of latitude $50^{\circ}$ their range in the Eastern Atlantic appears to cease.

On the Pacific coast the Halibut, which has been shown by Dr. Bean to 
be identical with that of the Atlantic, ranges from the Farallone Islands northward to Behring Straits, becoming more abundant northward. Its centre of abundance is in the Gulf of Alaska, particularly about Kodiak, the Alexander Archipelago, and the Shumagins. It is occasionally taken off San Francisco and about Humboldt Bay. In the Straits of Fuca and in the deeper channels about Puget Sound it is taken in considerable numbers.

The Halibut is emphatically a cold-water species. That it ranges nine or ten degrees further south on the American than on the European coast, is quite in accordance with the general law of the distribution of fish-life in the Atlantic; indeed, it is only in winter that Halibut are known to approach the shore to the south of Cape Cod, and it is safe to say that the temperature of the water in which they are at present most frequently taken is never, or rarely higher than $45^{\circ}$, and seldom higher than $35^{\circ}$, and often in the neighborhood of $32^{\circ}$. Its geographic range corresponds closely to that of the codfish, with which it is almost invariably associated, though the cod is less dependent upon the presence of very cold water, and in the Western Atlantic is found four or five degrees-in the Eastern Atlantic at least two-nearer the Equator, while the range of the two species to the north is probably, though not certainly, known to be limited relatively in about the same degree. In the same manner the Halibut appears to extend its wanderings further out to sea, and in deeper and colder water than the cod. Although observations on this point have necessarily been imperfect, it seems to be a fact, that while cod are very rarely found upon the edge of the continental slope of North America, beyond the 250 -fathom line, Halibut are present there in abundance.

The name of this species is quite uniform in the regions where it is known, though of course subject to certain variations in the languages of the different countries, and its characteristic features are so unmistakable that it is rarely confounded with other species, the only fish for which it is crer mistaken seeming to be the Turbot of the European coast, with which it sometimes interchanges names. In Scotland it is said that the Halibut is frequently called the Turbot, and Yarrell has expressed the opinion that in instances where it had been claimed that Halibut had been taken in the south of Ireland the Turbot was the species actually referred to.

"Halibut" and "Holibut" are words which are as old as the English language. In Germany it is called "Heilbutt" or "Heiligebutt"; in 
Sweden, "Hallefisk" "or "Hallefundra," while in Holland the name is "Heilbot."

In studying these names it should be borne in mind that "But" or "Bott" is another word for a flounder or flat fish, and that the English, Dutch, German, and Scandinavian prefixes to either this word, or the equivalent word Flounder, are presumably of the same meaning. A false derivation has been imagined for the name, which is exemplified in the German word "Heiligebutt" just mentioned, and also in the English orthography, which is sometimes encountered "Holybut." "This is without foundation, for the Halibut has never been mentioned more than any other species of flat fish, and the derivation is as fanciful as the New England one of "Haul-a-boat," which our fishermen have frequently assured me is the proper name, referring to the size and the strength of the fish. The true derivation of the word is best understood by a study of its Scandinavian names, from which it appears that the prefix has reference simply to the holes or deep places at sea in which the fish is found, and that the name simply means, "a deep-sea fish," or " a deep-sea flounder." The name "Flètan" which a species bears in France is not distinctive, the fish being almost unknown in that country.

Half a century ago Halibut were extremely abundant in Massachusetts Bay. Elsewhere in this essay are given several instances of their great plenty and voracity, as narrated by some of the early fishermen of Cape Ann. Of late years, however, few are found except in deep water on the off-shore banks.

The presence of so important a food-fish as the Halibut in America did not long escape the observations of the early English explorers. Capt. John Smith, in his "History of Virginia," wrote: "There is a large sized fish called Halibut, or Turbot; some are taken so bigg that two men hare much a doe to hall them into the boate; sut there is such plenty, that the fisher men onely eate the heads \& finnes, and throw away the bodies; such in Paris would yeeld 5. or 6. crownes a peece: and this is no discommodity."

The Halibut is surpassed in size by only three of our eastern speciesthe sword-fish, the tunny, and the tarpum. There is said, by experienced fishermen, to be a great difference in the size of the two sexes, the females being much the larger; the male is said rarely to exceed fifty pounds in weight, and to be, ordinarily, in poor condition and less desirable for 
food. The average size of a full-grown female is somewhat between one hundred and one hundred and fifty pounds, though they are sometimes much heavier. Capt. Collins, who has had many years' experience in the Gloucester Halibut fishery, assures me that he has never seen one which would weigh over two hundred and fifty pounds, and that one weighing over two hundred and fifty pounds is considered large. 'There are, however, well-authenticated instances of their attaining greater dimensions. Capt. Atwood, in a communication to the Boston Society of Natural History, in 1864 , stated that the largest he had ever taken weighed, when dressed, two hundred and thirty-seven pounds, and would probably have weighed three hundred pounds as taken from the water. In July, r 879 , however, the same reliable observer saw at Provincetown two individuals taken near Race Point, one of which weighed three hundred and fifty-nine pounds (three hundred and two pounds when dressed), the other, four hundred and one pounds (three hundred and twenty-two pounds when dressed).

There is a tradition in Boston that Mr. Anthony Holbrook, one of the early fish dealers of that city, had in his possession a Halibut, taken at New Ledge, sixty miles southeast of Portland, which weighed over six hundred pounds. This story, which is recorded by Storer in his "Fishes of Massachusetts," Capt. Atwood believes to be untrue. Halibut, weighing from three to four hundred pounds, though unusual in comparison with the ordinary size, are by no means rare. I have before me a record of ten or twelve such, captured on the New England coast during the past ten years. Nilsson, a Swedish ichthyologist, has mentioned the capture of a Halibut on that coast which weighed seven hundred and twenty pounds. There are stories of Halibut ten feet in length: a fish weighing three hundred and fifty pounds is between seven and eight feet long and nearly four feet in width. The largest individuals are not considered nearly so good for table use as those of less than one hundred pounds' weight. A fat female of eighty pounds, is by good judges, considered to be in the highest state of perfection. Males are not, however, so highly esteemed. Small Halibut, known as "Chicken Halibut," ranging from ten to twenty pounds, are much sought after by epicures, and bring a high price in the New York and Boston markets. They are comparatively rare however, and a Halibut weighing ten pounds or less is rarely seen; the smallest recorded on our coast was about five inches in length and was: taken by Prof. Verrill in a dredge-net in the Stralts of Canso. 
The Halibut of the Pacific are apparently similar in dimensions to those of New England. Mr. Anderson, inspector of fisheries for British Columbia, states that they there attain a weight of 200 pounds.

The wholesale dealers of Gloucester, in buying fresh Halibut from the fishermen, recognize two grades; one, which they call "Grey Halibut," they consicler to be of inferior value, and pay a lower price for. The Grey Halibut are distinguished by dark cloudings or blotches upon the under side, which in the most remarkable fishes are pure white. Almost all the largest Halibut are classed among the Greys. Fishermen claim that there is no actual difference between the grey and the white fish, and it is a fair question whether they are not right.

They are large-mouthed, sharp-toothed, voracious, although adapted for life upon the bottom, and doubtless feed largely upon crabs and mollusks; they are particularly fond of fish of all kinds; these they waylay, lying upon the bottom, invisible by reason of their flat bodies, colored to correspond with the general color of the sand or mud upon which they rest. When in pursuit of their prey they are active, and often come quite to the surface, especially when in the summer they follow the capelin to the shoal water near the land. They feed upon skate, cod, haddock, menhaden, mackerel, herring, lobsters, flounders, sculpins, grenadiers, turbot, Norway haddock, bank clams, and anything else that is eatable and can be found in the same waters. Capt. Ashby tells me that common flounders and flat-fish are among their most favorite food; they follow them up the shoals of George's and Nantucket; they lie in wait for them on the sand-rips and catch them as they swim over. He has seen a half bushel of flat-fish in the stomach of one; they stow them away very tightly. He has often seen Halibut chasing flat-fish over the surface of the water. About Cape Sable their favorite food seems to be haddock and rusk. He has seen eight or ten pounds of haddock and cod taken out of one of them. When they are on the shoals they are sometimes filled with flat-fish, haddock, cusk, sculpin and herring, but when in deep water he has found very little food in them. They eat crabs and other crustaceans, but shells are rarely found in their stomachs, except those of clams and mussels.

Capt. Hurlbert tells me that when the ressels are dressing codfish on the Grand Banks, and the back-bones and head are thrown overboard, these are frequently found in the stomachs of Halibut taken in the same locality. 
At the meeting of the Boston Society of Natural History, in $18_{52}$, Dr. IV. O. Ayres stated that he had seen a block of wood, a cubic foot in dimension, taken from the stomach of a Halibut, where it had apparently lain for a long time. Capt. George A. Johnson found an accordion key in one of them. Olafson, in $\delta_{3} I$, studying them on the coast of Greenland, found not only pieces of iron and wood in them, but in the stomach of one individual a large piece of floe ice. Capt. Collins has observed that they often kill their prey by blows of the tail, a fact which is quite novel and interesting. He described to me an instance which occurred on a voyage home from Sable Island in $\mathrm{I} 877$ : "The man at the wheel sang out that he saw a Halibut flapping its tail about a quarter of a mile off our starboard quarter. I looked through the spy-glass, and his statement was soon verified by the second appearance of the tail. We hove out a dory, and two men went in her, taking with them a pair of gaffhooks. They soon returned bringing not only the Halibut, which was a fine one, of about seventy pounds' weight, but a small codfish which it had been trying to kill by striking it with its tail. The codfish was quite exhausted by the repeated blows, and did not attempt to escape after his enemy had been captured. The Halibut was so completely engaged in the pursuit of the codfish that it paid no attention to the dory, and was easily captured."

The Halibut, in its turn, is the prey of seals, of the white whale, and of the various large sharks, especially the ground shark, or sleeping shark, in the stomachs of which they have sometimes been found; their sides, I am told by Copt. Collins, are often deeply scarred, probably by the teeth of the sharks, or in their early lives by mouths of larger individuals of their own kind.

There is diversity of opinion regarding their spawning. Some fishermen say that they breed at Christmas time, in the month of January, when they are on the shoals. Others declare that it is in summer, at the end of June. Capt. George A. Johnson, of the Schooner "Augusta H. Johnson," of Gloucester, assures me that Halibut "spawn, just like the human race, at any time of the year." In April, I 878 , he was fishing on Quereau Bank, and found large and small Halibut, the large ones full of spawn. In May he was on the Le Have Bank, where he found only small male fish full of milt; in June he was on Le Have again, fishing in shallow water, where he found plenty of "small bull fish, with their pockets full of milt"; in 
July he was again on Quereau Bank, where he found a school of small and big male and female fish, all, apparently, spawning, or ready to spawn, "with milt and pees soft"; in August he was on the outer part of Sable Island, where he found females full of spawn.

Capt. Ashby, speaking of the Halibut on George's Banks, states that roe is always found in them in May and June. The roes of a large Halibut caught by him in $8_{4} 8$ on the southwest part of George's, and which weighed $35^{6}$ pounds, after it had been dressed and its head removed, weighed 44 pounds. He states that the Halibut in this region have spawn in them as long as Connecticut vessels continue to catch them, or until September. He has seen eggs in Halibut of twenty pounds' weight, and thinks that they begin to breed at that size. The spawn of the Halibut is a favorite food of the fishermen of Southern New England, though never eaten by those of Cape Ann.

Capt. Hurlbert, of Gloucester, tells me that on the Grand Banks of Newfoundland the Halibut school used to come up in shoal water, in forty or fifty fathoms, in summer and that the spawn was ripest about a fortnight later. In August, i $\delta 78$, he found many with the spawn already run out. At that time several Gloucester fishermen reported that the Halibut on Le Have and Quereau Banks were full of spawn. Capt. Collins told me that in July and August, and up to the first of September, they are found here with the ovaries very large, and are often seen with the ova and milt exuding. The ovaries of a large fish are too heavy to be lifted by a man, without considerable exertion, being often two feet or more in length. At this time very little food is found in their stomachs. In September, I878, the Fish Commission obtained from Capt. Collins the roes of a fish weighing from 190 to 200 pounds, taken by the schooner "Marion" on the I $3^{\text {th }}$ of the month on Quereau Bank. This fish was taken at the depth of 200 fathoms, and the temperature of the water was roughly recorded at $36^{\circ} \mathrm{F}$. These ovaries were put into a basket with ice and brought to the laboratory of the Fish Commission, where they were found to weigh seventeen pounds, two ounces. Part of the eggs were nearly ripe, and separated readily, while others were immature and closely adherent to each other. A portion of the roe, representing a fair average of the size of the eggs, was weighed and was found to contain $2, \mathrm{I}_{5}$ eggs; the weight of this portion was two drams. The total number of eggs was from this estimated to be $2,182,773$. It is not yet known whether the eggs float or 
rest upon the bottom, nor is it known how long is the period of incubation, nor what is the rate of growth of the fish. As has already been mentioned, young fish are very unusual; the smallest ever seen by Capt. Ashby in Southern New England was taken on Nantucket Shoals, and weighed two and a half pounds after it had been eviscerated.

"Left-handed" Halibut are sometimes taken. Perhaps one out of five thousand is thus abnormal in its form, having the eyes upon the left rather than upon the right hand side of the head.

Halibut with dark spots or patches on the under side of the same dark color as the back are occasionally taken. These are called by the fishermen "Circus Halibut." They are generally of medium size, and thick, well-fed fish.

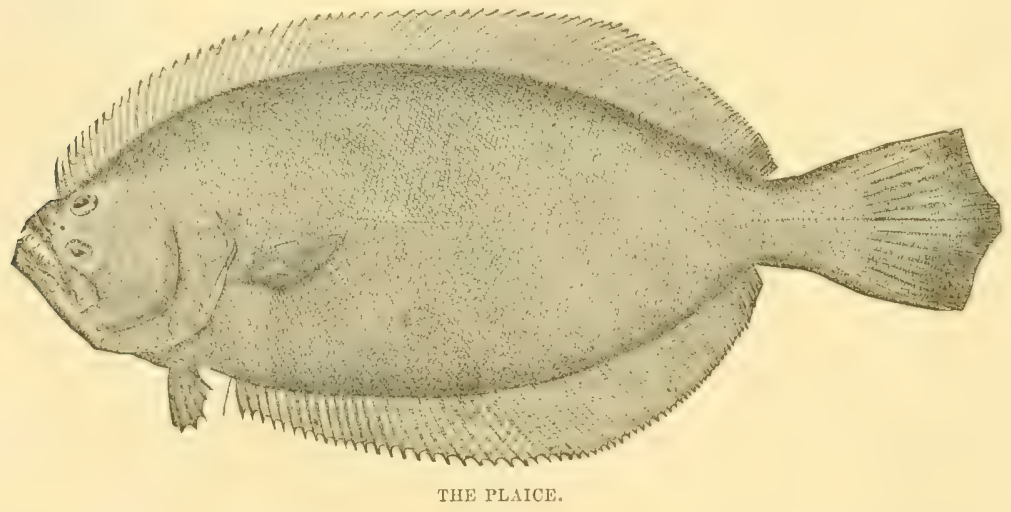

The Plaice, Summer Flounder, or Turbot Flounder, Paralichthys denatus, is, next to the Halibut, the most important flat fish on the eastern coast. It is a member of a genus not existing in Europe, though represented on our own Pacific coast, in China and Japan, and in the Indian Ocean. Its affinities are with the Halibut, which it much resembles in form, and to which it is more similar in flavor than to the Turbot and Brill, so well known in transatlantic fish markets. Our common species was first brought to notice in I 766 , when Linnæus received specimens from South Carolina, sent him by Dr. Garden. It seems at that time to have been of recognized commercial importance, since it was one of the few received by Linnæus from Garden which had a common name. In South Carolina at this time it was called Plaice, and this is a name which is now accepted 
in the New York market and about Cape Cod, although it has never been recognized by those who have written books on American fishes. The fishermen of the St. John's River also use the name Plaice, but whether for this species has not been determined. In Connecticut, North Carolina, and in Florida, east and west, as well as on other parts of the coast, the names Flounder and Common Flounder are current. In New York and New England the name Summer Flounder is also frequently heard. In Rhode Island the names "Brail" and "Puckermouth" are used, the former doubtless a modification of the English name "Brill," while on the bills of fare in Boston and New York hotels it is often called the "Deep-sea Flounder," especially since the Pole Flounder has been brought to notice by the Fish Commission, and has obtained a reputation as a delicious table fish. Fishermen sometimes mistake them for young Halibut, and they doubtless at times are sold under the name of "Chicken Halibut." Turbot: Flounder is another name which has been suggested, but, upon the whole, Plaice seems most desirable for general adoption.

This fish is abundant upon the eastern coast of the United States from Cape Cod to Cape Florida, and according to Mr. Stearn's report is also found along the entire Gulf coast. Southward, its range extends at least as far as Paraguay. To the northward it barely rounds Cape Cod. Capt. Atwood remembers that in the first half of the present century great quantities of Plaice were found inside the Point at Provincetown. They were so numerous that in one afternoon he caught two thousand pounds. They are now only occasionally taken, and have not recently been seen north of Provincetown, though Storer has recorded their occurrence at Wellfleet. Capt. Atwood attributes their disappearance, which was nearly simultaneous with the advent of the blue fish, to the fact that blue fish destroyed their favorite food, the squid, and rendered it impossible for them to live longer in these waters. The Plaice has been much less abundant in Cape Cod Bay within the last thirty years, but there is no evidence of considerable diminution in numbers elsewhere. On the eastern coast of Connecticut and Long Island, where the Plaice fishery is most extensively prosecuted, it is the opinion of experienced fishermen that no change in numbers has been perceptible within the last thirty years. The Connecticut fishermen say that they are frequently so abundant that they have only to throw out and pull in their lines, catching "all they choose," while the bottom seems to be carpeted with them. 
Like others of its tribe, the Plaice habitually lie upon the bottom, where their peculiar shape and color protect them from observation and give them excellent opportunities to capture their prey. In the north they are usually found at a depth of two to twenty fathoms, and in winter move off into deeper water. In New Jersey they occur at lesser depths. Prof. Baird records that they are sometimes taken in large numbers by means of nets in the deep slues along the beach. In winter they do not run out so far into deep water, and "at times," says Prof. Baird, "seem to be quite torpid on the shallow grounds, suffering themselves to be taken up with oyster-tongs without making any attempt to escape." Still further south they are found in the shallowest water. The fishermen of St. John's River seine them in the grass along the shores at a depth of three or four feet. Mr. Stearns writes, speaking of the eastern part of the Gulf of Mexico: "They are found mostly in the bays and bayous where the bottom is muddy or grassy, but it is not unusual to find them in shoal water along the sand beaches of the coast and bays. Very shoal water seems to be particularly attractive, and they are often found at the water's edge embedded in the sand, with only their eyes in view. When alarmed or in pursuit of prey their movements are very swift, and the quickness with which they bury themselves in the sand is quite wonderful."

Their habit of ascending Southern rivers is remarkable. They are said to occur in Lake George and the other lakes at the headwaters of the St. John's and the Ocklawaha Rivers. At Jacksonville they are commonly taken in company with bream, black bass, and other fresh-water fish, in winter as well as summer.

Although present in the shoal waters of Florida throughout the year, Mr. Stearns states that they are most abundant in summer. On the Connecticut coast, however, their habit of migrating seaward is much more pronounced. The Noank fishermen never find them until May. They say that they never catch them until after they have fished awhile for seabass. As early as the first of October they begin to grow scarce, and none are ordinarily caught after the middle of the month. I cannot find that they have ever been seen moving in schools, though fish taken in the same locality at the same time are usually quite uniform in size. They shift their position, probably in search of food, and where any are found they are plenty. This indicates that they are gregarious in habit. The abundance of food in special localities sufficiently explains this fact. 
The Plaice feed upon small fish, shrimps, crabs, and lermit cralss, squid, small species of shell-bearing mollusks, and certain rarliates, such as sand-clollars. They are frequently seen at the surface, rapidly swimming, and even jumping out of the water, in pursuit of schools of sand-eels and sand-smelts. They also feed upon dead fish thrown out from the fish-houses. Little is known of their breeding habits. All the large females observed in July and August, r874, upon the Connecticut coast contained spawn, but it was, evidently, far from maturity. The Fish Commission has obtained no very small specimens; in fact, none less than eight or mine inches in length, though the fishermen speak of capturing six-inch individuals. Their average length is from sixteen to thirty inches, and the weight about two and a half pounds, though it is not unusual to take individuals weighing seven or eight pounds. At Noank about eighty fish are ordinarily packed in a barrel, weighing from 160 to 175 pounds. The largest ever brought to Noank weighed twenty-six pounds. Others, of whose capture I have known, weighed twenty, seventeen and a half, and fifteen pounds. In Florida and at Provincetown I have seen them three feet in length. A one-pound fish measures about fifteen inches; a one and a quarter pound fish, sixteen or serenteen; a two-pound fish, seventeen or eighteen; a three-pound fish, about twenty; a four-pound fish, about twenty-two; an eight-pound fish, about twenty-seven, and a tenpound fish, about thirty inches. These proportions are taken from notes relating to a large number weighed and measured at Noank, Conn. The Winter Flounder or Flat Fish spawns in late winter and early spring near the shore, and it is possible that the Plaice breeds at about the same period.

The most extensive fishery for the Plaice is in the waters of Southern New England. Favorite fishing grounds are on sandy bottoms, at a depth of ten to twenty fathoms, along the Atlantic side of Block Island, Martha's Vineyard, and Eastern Long Island, where they are most plentiful. They are obtained in smaller numbers in the harbors and bays along the south shore of New England, on Skagwam and Middle Ground Reefs, in Fisher's Island Sound and Long Island Sound, and outside of Fisher's Island. They are also taken in considerable numbers in the pounds of this region, occasionally five or six hundred at a time. The quantity taken in the weirs of New England in I 876 was estimated as follows: 
Pounds.

Weirs on north side of Cape Cod...................... $43^{6}$

WVeirs on south side of Cape Cod...................... 3,600

Weirs in Vineyard Sound............................. 326,620

Treirs in Buzzard's Bay............................. I $5,7+9$

VVeirs on Block Island, (estimated)................. 94,500

WVeirs in Fisher's Island Sound, (estimated)........... 4,000

Weirs on eastern end of Long Island................... I 4,000

Weirs on Rhode Island................................ I $72,25^{\circ}$

$66_{3}, 555$

From other localities.............................. 50, 000

7 I 3,555

Estimated annual catch of Flat Fish.............. 600,000

I, 3 I 3,555

Value of the above, at four cents a pound, $\$ 52,542.00$.

These statistics of the catch in pound-nets include Plaice and Flat Fish, and in the statement of the total catch no distinction will be made between these two species.

Immense numbers of them are sometimes taken in large seines hauled up on the beach. In I 876 , E. Cleveland seined I 28,000 pounds at Menemsha Bight, Mass. By far the greater quantity, however, is taken by small fishing smacks belonging to and hailing from Noank, Mystic, and New London, which pursue this special business from May until October. These vessels are usually absent frum port four or five days, and spend two days in fishing. The fish are shipped in ice from Noank and New Londor principally to New York, and also to inland cities in the vicinity. A single smack, with a crew of a man and two boys, usually will obtain and ship to New York, on an average, about I 2 barrels a week, about i 60 barrels a year, or 25,000 to 28,000 pounds. Capt. Palmer, of Noank, in I 873 , caught on one trip of two days about $\mathbf{I}, 000$ fish, weighing, perhaps, 2, 000 pounds. On this trip he used four lines. A good fisherman is able to manage two lines, each carrying two hooks. Menhaden bait is always used by professional fishermen, though I have caught Plaice to good advantage with lobster bait. A vessel usually consumes one barrel of menhaden on each trip. The fish strike the hook sharply as soon as it approaches 
the bottom, giving little opportunity to the skates, which very seldom get a chance at a Plaice's hook. In this respect they are very different from the cod. When the fish have been hauled to the surface, they are quickly transferred, with as little injury as possible, to the well of the smack, which is amply large enough to hold the results of two or three days' fishing. They are thus brought alive to the place of shipment and reach the markets in excellent condition, a fact which partially explains their popularity compared with that of other fish of the same family.

In 1877 there were seven smacks engaged in this fishery-one from Mystic, one from New London, and five from Noank. It was estimated by the owner of one of the vessels that each vessel made on an average fifteen trips during the summer, and that each trip averaged Soo fish, weighing $\mathrm{I} 3 / 4$ pounds each, making a total of $I, 400$ pounds to a trip, or $2 \mathrm{I}, 000$ pounds to the season, thus giving an aggregate of $\mathrm{I}_{47,000}$ pounds as the result of this branch of the fishery.

Capt. Atwood states that in I 846 he began catching Plaice for the Boston market, in Provincetown Harbor, anchoring where the keel of the smack would just clear the bottom, and anywhere near Race Point he could catch them in great numbers, the largest weighing from ten to fifteen pounds each. In one afternoon he caught two thousand pounds. These he carried to Boston in the well of his smack and tried to sell, but was unsuccessful, though they were offered under the name of "Turbot," local prejudice being against them. In 1879 there were seven or eight boats engaged in the Plaice fishery during the month of June, this month being the best for Plaice fishing. In the latter part of July, when I made my observations, all of the winter boats had stopped fishing for the year.

The method in use here is somewhat peculiar, and merits description. The fishermen call it "drailing for Plaice." The boat used is an ordinary cat-boat, managed by one person, and is allowed to drift with free sheet before the wind, while the fisherman stands in the stern dragging the line over the bottom, baited with a bit of squid or clam. The boat is kept as nearly as possible over the places where the flats are deepening most abruptly into the basin of the harbor, and where the water is from eight to eighteen fathoms deep. Only very large fish, weighing ten, fifteen, sometimes even twenty pounds, are taken in this manner. The average catch is from eight to twenty a day. In one day one man reported eight, one fourteen, and one twenty-three. Some of these fish are sold in Province- 
town, but the greater portion is sent iced to New York, where a price of twelve cents a pound wholesale, is easily obtained. In Boston there is no market for them.

On the coast of New Jersey Prof. Baird states that in 1854 they were taken in large numbers, by means of nets, in the deep slues along the beach. Along the southern coast they are occasionally taken by the line fishermen, and a considerable quantity is seined by the river fishermen.

In the Gulf of Mexico they are rarely taken by hook and line, and are usually speared or jigged at night, by torchlight.

The Plaice has always been the most popular of our in-shore flat fishes, being exempt in a certain degree from the prejudice attaching to the fishes of this family. It seems to have been a common food-fish in South Carolina as early as I 760 , and Schoepf mentions it as one of the food-fishes of New York in 1776 . In 1856 , according to Gill, it was found in the New York market in autumn, but seems to have been less in favor than the Flat Fish. At present the Plaice is growing in favor in New York, and is upon the lists of all good restaurants, though perhaps not so generally consumed as the Flat Fish, which comes in the winter, when the market is less lavishly supplied.

In Boston, and indeed throughout the greater part of New England, this, with all other Flounders, is considered unfit to eat, and it is by no means generally popular along the Southern coast, though in Florida its flesh is highly prized. The Connecticut fishermen esteem it greatly, and when preparing it for their own use are accustomed to hang it in the open air for a day or two "to dry," as they say. The wholesale price in New York varies from one and a half to six cents, but is usually three cents a pound.

Another species of Flounder, closely related to the Plasce, is the common Four-spotted Flounder, Paralichthys oblongus, which occasionally finds its way to market in company with the Plaice, and is doubtless sold under the same name. It is a small species, rarely attaining a greater length than twelve inches and a weight of one pound. It may be readily distinguished by the presence upon the back of four large, dark spots, elliptical in form, but these soon fade out after death.

Its distribution is much more restricted than that of the Plaice: it is most abundant, at a depth of ten to twenty fathoms, off the southern coast of New England; it rarely occurs north of Cape Cod, though one 
individual was taken by the Fish Commission at the mouth of Salem Harbor, nor has it been recorded south of New York. There are two smaller species upon the Southern coast-one, Paralichthy's quadrocellatus, broader than Paralichthys oblongus, also marked with four dorsal spots, and known in the South as the Four-spotted Flounder. 'This species has been observed as far north as Charleston and Fort Macon, while its western record of limit is Pensacola. Stearns records it as common from Cedar Keys south to Key West, and pronounces it an excellent food-fish. It cannot at present, howerer, be considered very important. The other species, Paralichthy's stigmatias, occurs in deep water (seventy-five fathoms) off the coast of South Carolina, and may be distinguished by the presence of three conspicuous spots upon the upper side of the body.

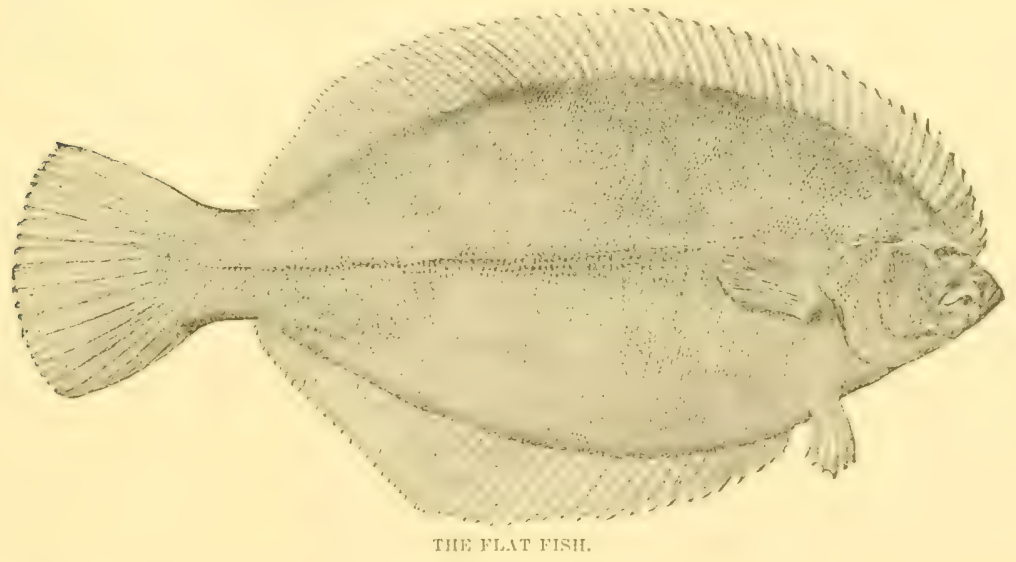

Next in importance to the Plaice, comes the Flat Fish, Pscudoplcuronectcs amcricamus, or Common Flounder, sometimes called the "Winter Flounder," said to be known in Massachusetts May as the "MInd-dab," and in New York as the "Flounder." New lork anglers call it the "Nigger Fish." This fish, like the I'laice, belongs to a genus unknown to Europe, but is closely related to the common Flounder, or Fluke, of the British coast. Its range is somewhat extensive, and in a certain degree it replaces the Plaice along our northern coast. It has not been observed south of Chesapeake Bay, but northward its range extends to the Bay of Fundy, to the eastern shores of Nora Scotia, the Gulf of St. Lawrence, and even to the coast of Labrador. 
Flat Fish are always upon the bottom, feeding chiefly upon minute shells, such as Nucula and Bulla, upon young crabs, or whatever they can find among the stones in the mud. Their mouths are very small, and since they would be unable to seize and kill other fish, they never come to the surface in pursuit of prey, as do the large-mouthed Flounders. They prefer sheltered bays and harbors, and appear to be equally abundant on the bottoms of the sand, mud, or rock; when at rest, they are usually partially embedded in the mud or sand at the bottom. I have observed that, when they come to a stop, they always settle themselves by convulsive motions of the fins and body, which has the effect of pushing them down into the soft bottom. This species is perhaps a more permanent resident of the localities which it inhabits than any other on our coast, unless it be the sculpins. There is very little evidence of a tendency to move to and from the shore with a change of season. Winter and summer, they appear to be equally abundant from New York to the Bay of Chaleur, where, in the tide-way of Miramichi River, they are caught in winter through holes in the ice. In Labrador they are described as exceedingly abundant in summer, but nothing is known of their winter habits. Prof. Baird found them scarce in Southern New Jersey in summer, but learned that they were very abundant in the bays in winter. Small quantities are brought to Washington in winter from the mouth of the Chesapeake.

The spawning season occurs early in spring, in February and March on the Connecticut coast, and is thought to be closed by the first part of April. Young fish of half an inch in length are found in July in the deeper parts of the bays and sounds, and in August and September, having attained the length of one and one-half to five inches, occur in great abundance in the coves and along the sandy shores of the Southern New England coast, in very shallow water. Their growth is probably rapid, though it would seem most likely that the five-incli specimens just referred to were eighteen months rather than six months old. The largest that have been discovered were fifteen inches long, and would weigh from one to one and a half pounds.

The flesh of the Flat Fish is solid, white, and of excellent flavor, and cleserves a more general popularity than it has yet attained. It is, and has been for the last century, largely consumed in New York in winter. Schoepf, writing in 1776 , mentions it as occurring in the market in spring ; 
later, writing in $\mathrm{I} S \mathrm{I} S$, he states that small numbers were found in the stalls in January and February, taken with spears while searching for eels. These were not very inviting, owing to their mangled appearance and frozen state, but, with the disappearance of ice and the approach of spring, their numbers increased, and in March the stalls were well filled with them, cheap and fresh and good. They were only used as pan-fish. Gill wrote, in 1856 : "This is the most common species of flounder that is brought to the city markets in the winter and spring months; it is seldom sold at a higher price than eight to ten cents per pound. Flounders are chiefly sold by the weight; occasionaily they are strung through the bronchial apertures on twigs and nominally sold by the bunch."

The Smooth Flounder, or Christmas Flounder, Plcuronectes slaber, is very similar in habits and appearance to the Flat Fish, and is still closer to the Flounder of Europe, being a member of the same genus. It may be distinguished from the former by its smooth skin, which has given to the species, in some localities, the name "Eel-back." Its distribution is extremely limited, it having been recorded as only found in Salem, Massachusetts, Portland and Belfast, Maine, or within the limits of two degrees of latitude. Its range may in the future be extended farther to the north, but it is certain that at present none occur south of Salem. In Casco Bay they are very abundant in summer, and the Fish Commission secured great quantities of them in water three or four fathoms deep in Bluelight Cove. They have never elsewhere been observed, except in winter, about Christmas time, when they come into the harbors to spawn. At Salem they are, on this account, called the Christmas Fish. Considerable quantities are caught every year by spearing them upon the sand. At this place they are also called "Fool Fish," because, in their anxiety for food, they will bite at any kind of bait, even at a rag. The spawning season is short, and they soon retire into deeper water. At Portland, and in the vicinity, considerable numbers are taken in the winter fishery in company with the Flat Fish, and with them are sent to New York and neighboring markets. In one instance a quantity were offered for sale in the markets of Washington. The spawning season on the coast of Maine is slightly earlier than that of Massachusetts, beginning as early as the middle of December, while in Penobscot Bay they are taken at the very beginning of the month, full of spawn. In Penobscot Bay they are taken in traps, or "fliers," as the fishermen call them, shaped something like lobster-traps and baited. The 
young Smooth Flounder may be taken in summer on the beaches. The largest females observed weighed twenty-three ounces, the weight of the spawn being seven ounces. Too little attention has hitherto been paid to this fish, but it seems more than probable that in the future it will greatly increase in faror.

The Greenland Turbot, Platysomatichthys hippoglossoides, though never occurring in our inshore waters, is found on the off-shore banks, as far south as George's Bank, and a certain quantity of them is usually brought to New York in winter. It is emphatically an arctic species, being abundant on the coast of Greenland, often found at Holsteinborg and beyond, and along this entire coast very eagerly sought by the natives. The Eskimo name is "Kalleraglik," and the fish is also known as "Little Halibut." In Gunther's work on "The Fishes of the British Museum," he has confused this species with the true Halibut, making it appear that only the former is to be found on the coast of North America. In Northern Greenland the Turbot is found only at very great depths, and is fished for, in water of three hundred and fifty to three hundred and eighty fathoms, through holes in the ice, over certain banks in Omenak Fiord and at the mouth of the Jacob's-Haven ice-fiord which is also packed with great ice-floes. It is said to be found only in the ice-fiords and between the great ice-fields, and there only in the coldest months of the year.

In South Greenland they are taken on the oceanic banks at a depth of sixty to one hundred and eighty fathoms, though there considered to be not so abundant as in North Greenland. In Fortune Bay, Newfoundland, according to Captains G. Johnson and $\Lambda$. Leighton, of Gloucester, they are very abundant in sixty to three hundred fathoms, and are caught chiefly in winter. They are also obtained by the Gloucester halibut fleet on the outer edge of the oceanic banks, in two hundred and fifty to three hundred fathoms of water.

Their habits are not at all well understood, but it would appear from the statement of several experienced fisherman, whom I have questioned, that they occur on the very edge of the continental slope in deeper water than the true Halibut, in fact in places where the slope is so nearly perpendicular that the Halibut can hardly hold their places on the bottom. This species is more symmetrical than any other of the family on our coast, and, moreover, is colored upon both sides of the body - a fact which indicates that its movements are more like those of the ordinary symmetrical fishes and that it can rest with the body in a vertical attitude. 
It would seem probable that its chosen haunts are along the declivities of the outer slope of the continental plateau, where abundance of fool is known to occur, and where other fishes are not so well adapted to live. Many hundreds of pounds are caught, every year, on the halibut trawls, and the fish are frequently iced and brought to market with the Halibut, and frequently eaten by the fishermen themselves. The greater portion of those brought to New York in winter are, however, taken on trawl lines at the mouth of Fortune Bay, and brought down by the ressels which go there to secure cargoes of frozen herring. It is impossible to obtain statistics of the quantities thus brought in, because the market returns do not discriminate between the different species of flounders and flat fishes.

The Greenland Turbot is an exceedingly palatable fish, its flesh being firm, white, and less dry and more delicate in flavor than that of the Halibut. The average weight is from ten to twenty-five pounds. In Greenland they are perhaps more highly esteemed than any other fish. The Greenlanders begin fishing as soon as the fiords are frozen and the white whales; which prey greedily upon this fish, have left the entrances open. They fish through holes in the ice, and attach little threads at intervals to lines, so that they may better see the motion which the nibbling fish makes. Under favorable circumstances a man may take ten to eighteen of these fishes daily.- 'The fishery continues from January to the middle of March, sometimes, however, only a week or two, and usually only about a month. The fish are cut into strips and dried for the consumption of the Danish colonists. It it said that a very fine oil can be made out of their fat, so that in hard times the fish serves to warm and light the houses as well as feed their occupants. In South Greenland they are not so numerous, but are constantly sought for, being taken in company with the sea perch, or red fish.

Glyptocephalus cynoglossus, a fish often known as the Deep-sea Flounder, was first observed on this coast in $\mathbf{I} S 77$, when numerous specimens were obtained by the United States Fish Commission, in the deepest part of Massachusetts Bay. Specimens have since been obtained south of Cape Cod, at a depth of one hundred fathoms or more, by the Fish Commission, and by Prof. Agassiz, off the entrance to Delaware Bay, at a depth of three hundred and ninety-five fathoms. 'The l'ole Flounder appears to be a permanent resident, throughout the whole year, in the deep basins of Massachusetts Bay and on the edge of the continental slope, and 
is found abundant in Bedford Basin, the inner expansion of Halifax Harbor, at a depth of thirty-seven fathoms. It ranges nearly to Greenland, and is also found on the coast of Northern Europe, where it is found in the Trondhjem Fjord, in latitude $65^{\circ}$, and south to the coast of Ireland. Its. thermal range appears to be confined by the limits $34^{\circ}$ and $45^{\circ}$.

It breeds abundantly in our waters in summer time, numerous individuals, full of spawn, and young from half an inch upward, having been taken, from July to October, in various localities.

The Pole Flounder has been pronounced, by all who have tasted it, a most delicious food-fish, resembling more closely than any other species on our coast the English Sole, having a great quantity of peculiarly flavored mucilaginous tissue about the base of the fins; it has never been taken by our fishermen, because, on account of its exceedingly small and weak mouth, it could not hold fast to an ordinary hook and line; and, should it ever come into demand, it will be necessary for our fisherman to introduce the English trawl-net.

The Turbot, or Steinbutt, Rhombus maximus, and the Brill, or Glattbutt, do not occur in our waters, although many attempts have been made to prove that they do. The nearest representative of the Turbot is the Spotted Sand Flounder, Lophopsetta maculata, a species found from Bucksport, Maine, to Fort Macon, North Carolina, variously known along the coast as Water Flounder, Windorv-pane, and Daylight; the latter name refers to the remarkable thinness of the fish, its flesh being so transparent that, when held to the light, the shadow of an object on the other side can be seen. Its flavor is good, but the amount of flesh is so small that it is of no consequence as a food-fish. There are other smaller representatives of the family on the southern coast, and in deep water from Cape Cod southward, belonging to the genus Citharichthys, which, although edible, are never eaten.

The Sand Dab, or rough Dab, Hippoglossoiles platessoides, also sometimes known as the Rusty Flounder, is taken in winter by the line fishermen of New England, and small quantities are doubtless brought to market and sold with other flat fishes without discrimination as to species. It often attains the length of twenty to twenty-four inches, and the weight of two to five pounds, and is, in all respects, a desirable food-fish, being highly esteemed on the other side of the Atlantic. In summer, individuals of this species are to be found only in very deep water, thirty fathoms 
or more, on the New England coast, and, though never very abundant in any one locality, might be taken in consideralsle quantities, in company with the l'ole Flounder, by the use of a trawl-net, or even by specialiy derised trawl-lines.

The Rough Dab has not been observed south of Woods Holl, irassachusetts, but ranges north to Greenland, is abundant on the English coast, and is a well-known food-fish of Scandinavia. Its breeding habits in our waters have not been observed, but in Southern Sweden the spawning time is in April and May. It is a large-mouthed species, feeding upon fish as well as upon large invertebrates, such as crustaceans and annelids, and mention has been made of it more on account of its possible value in the future than for its importance at the present time.

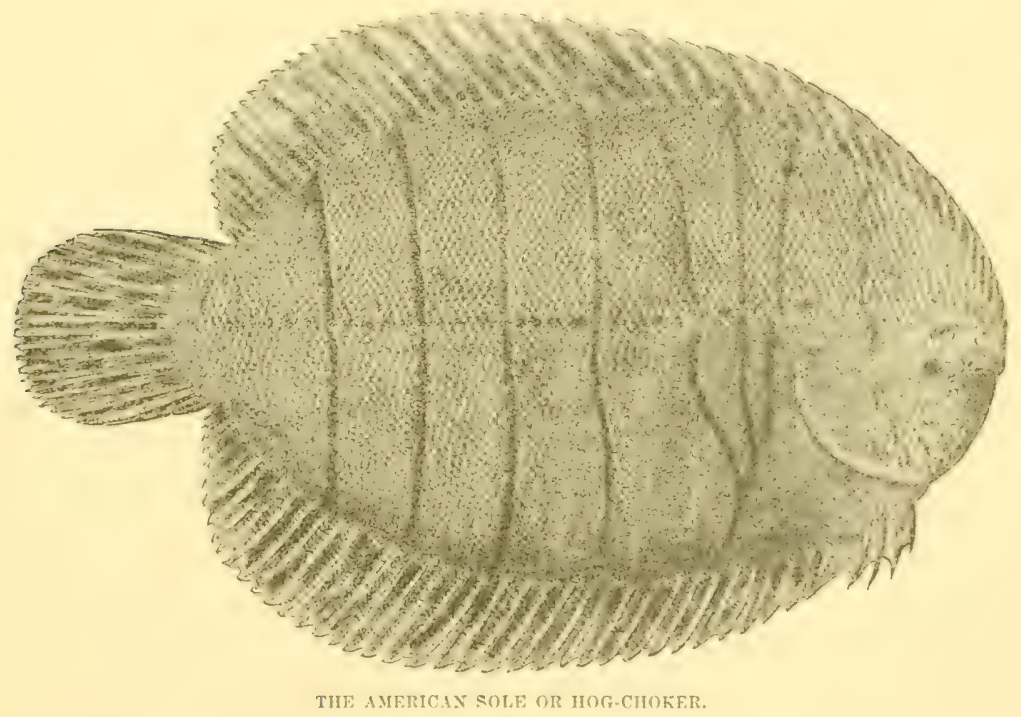

The much-prized Sole of Europe, Solea vulgaris, does not occur in the Western Atlantic, although attempts are being made to introduce it, and individuals have been set free in Massachusetts Bay, at Woods Holl, and off Coney Island. Its nearest representative, the American Sole, is found along our coast from Boston and Nahant to the mouth of the Mississippi River. It occurs in all of the rivers south of the Susquehanna, and is taken in great numbers in the shad seines. It rarely attains 
a greater length than six inches, and, though edible, is never eaten, and it must be regarded as of extremely small importance. There are also two or three other fishes belonging to this family in our Southern waters which are insignificant in size and of no importance whatever.

Aphoristia atricauda is a very small species of Sole, the only genuine representative of the European Sole on our Pacific coast. It reaches a length of six inches, and is occasionally taken in San Diego Bay. It has no economic value.

Turbot and Sole in America. - A Philadelphia writer has lately tried in the newspapers to revive the long-obsolete belief that the Turbot and Sole of Europe occur on our coast. Although he has never seen them himself, and fails to bring forward evidence that any one else has seen them, he insists that they occur in the greatest abundance in New Jersey, particularly in the vicinity of Atlantic, "and doubtless all along the Atlantic coast from Portsmouth, N. H., to Wilmington, S. C." (sic) He upbraids the American public for their incredulity, though this does not surprise him so much when he calls to mind that "our Government Fish Commissoner has actually contemplated sending a steamer to English waters to procure turbot-seed to plant along our shores." He would not be surprised if incredulity were to continue longer " under such official indorsement." He accounts for the ignorance regarding them by the theory that the English trawl-net is unknown in America, and that our fishermen would not know how to catch such fish if they were aware of their presence, and have not become aware of their presence because they have no means of catching them. He intimates that he is preparing to form a company for the purpose of developing a turbot fishery upon our coast; an enterprise "in which but little will be risked, and the results will be a surprise to all." He closed one of his letters to a New York journal with the appeal: "I trust that you will not let this question subside, but persist in callng attention to it until we do away with the extraordinary anomaly of this enlightened nation being within reach of treasure that for more than a century they have been unaware of and have remaned persistently blind to."

All this is very entertaining, and furnishes a neat text for a few remarks on the history of this belief, as well as an opportunity for demonstrating to the public a fact which has for forty years or more been known to ichthyologists, that the Turbot and the Sole never have been seen on the 
western side of the Atlantic, and never will be, unless they are introduced by artificial means.

From the beginning to the end we encounter the well-known sources of contusion-the giving of old-world names to species which resemble in a general way the old-world species which bear them, and the unquestioning acceptance of these names as authoritative, by persons who are not trained to close discrimination.

When Boston was occupied by the British during the Revolutionary war, the officers of the fleet are said to have been bountifully supplied with Turbot, which was caught in the neighborhood of an outer harbor. This fact is recorded by Dr. J. V. C. Smith, in his "Natural History of the Fishes of Massachusetts" (Boston, I $8_{33}$ ), on the authority of William Ladd, esq., of Maine. He also mentions "a statement of Mr. Parker, the conductor of the marine telegraph," who told him that "many years before, Admirable Sir Isaac Coffin brought out to this country a trawl-net, such as is used on the coast of Holland, for taking Sole for the Lonclon markets, with which he succeeded in capturing that delightful fish in Ipswich Bay, which was not before supposed to exist here." The fishes found in this manner were no doubt the common Flat Fishes of Massachusetts Bay. The common Flounder, Paralichthys dentatus, taken in Provincetown water, where it is usually called "Plaice," was in ISSo sold in Boston under the name "Turbot." Captain Mackinnon, of the Royal Nary, who visited this country in $I_{5}$, conceived the idea that Turbot ought to be found on the shores of the United States, and took pains to search for them with a trawl-net. The nets which he used had been imported ten years before by Mr. Nathan Smith, an American gentleman, who had hoped to introduce them, but had never used them. Captain Mackinnon tried one net at Newport, Rhode Island, and succeeded in taking a number of different kinds of Flat Fish. He carefully refrained, however, from pronouncing any one of them to be identical with the Turbot or Sole, though from the vagueness of his language it is evident that his ichthyological knowledge was very scanty, and that he was not accustomed to observe the differences between the different species of fishes which somewhat resemble each other. His experiences are described at length in his book of travels, entitled "Atlantic and Trans-Atlantic Sketches, Afloat and Ashore" (Harper \& Bros., New York, I $8_{52}$, pp. I66I70). Capt. C. C. Churchill, U.S.A., who saw the results of Capt. 
Mackinnon's experiment, tells me that the fish taken were the common species of New England flat-fishes and flounders.

We fancy that the inspiration of the new advocate of the turbot-inAmerica question, as well as the information upon which he bases his conclusion, was drawn from this very same book of Capt. Mackinnon, for he uses many of the same phrases, and he repeats, in almost the same words, Captain Mackinnon's statement: "The fish markets in America are not all in keeping with the size and wealth of the States," a statement which, however true it may have been thirty years ago, will be amusing to any one who has recently had opportunity to compare the fish markets of America and Europe. This ingenious Philadelphia savant sums up his evidence as follows:

"The Turbot, Sole, and Plaice are, however, in abundance in your deep-water sand banks. They were caught there in I 8 I 2 by English sailors, and in I880 Turbot have been obtained off Atlantic City, if the 'Baltimore American' is any authority."

The notion that the introduction of the English trawl in America would be novel and would at once open up a field for a fishery industry of boundless extent, deserves a word. The trawl has been assiduously used by the summer collecting party of the United States Fish Commission for ten years past, and also by Prof. Agassiz upon various exploring trips. The steamers of the Fish Commission have used it on every portion of the coast, from Yucatan to Halifax. Prof. Agassiz has used it in the Gulf of Mexico and on the coast of Florida, and has employed it in running five lines of research at right angles to the coast from Cape Hatteras, at points nearly equidistant between Charleston and Cape Cod, one of them directly out from the entrance to Delaware Bay. The dredgings of the Fish Commission were carried from near the shore to a depth of nearly five miles in the open sea, and covered a very wide area of the ocean bottom.

In $\mathrm{I} \$_{54}$ Prof. Baird made a careful exploration of the coast of New Jersey with especial reference to the fishes, and since that time every stretch of coast line from Brownsville, Texas, to Eastport, Me., has been thoroughly investigated by the naturalists of the United States Fish Commission. It is true that a new species of fish is occasionally discovered, but the new fishes always belong to one of two classes. They are either swift-swimming species, members of the West Indian fauna, which come 
upon our northern shores in summer, or they are inhabitants of waters more than six hundred feet deep, which have never previously been explored. The Turbot and the Sole are shallow-water species, and, had they occurred in our waters, would have been discovered many years ago.

There are twenty-six species of flat fishes on the east coast of the United States. Four of these belong to the same family with the Sole, but are utterly worthless as articles of food. The nearest relative of the sole is often called the American Sole, Achirus lineatus, and is known on the coast of New Jersey as the Hog-choker, Cover-clip, or Cover. Of the flat fishes only two are positively unfit for food, and these two, strangely enough, are the representatives of the sub-family Rhombina, to which belong the Turbot aud Brill of Europe. One of these Lophopsetta maculatta, is sometimes called the Spotted Turbot, and in New Jersey is called IVindow-pane, or Daylight, because it is so thin that when held to the light the sun can be seen through its translucent flesh.

The most important Flat Fish is the Halibut, which is identical with that of Europe. 'This species, and the Pole Flounder, which has recently been brought to light in our waters by the Fish Commission, are the only two of the number referred to that are found on both sides of the Atlantic. We have in our waters abundance of flat fishes, some of which, for instance, the common Flounrler of the New York market, Paralichtliys dentatus, are probabiy fully equal to the turbot for food uses. In fact, it may be had in the New York restaurants and hotels under this name. Another fish, Platysomatichthy's hippoglossoides, resembling the Turbot in flavor, is sometimes brought to New York in winter. It is found at great depths on the coast of Newfoundland, and is often called the American or the Newfoundland turbot. The Pole Flounder is very similar to the sole in flavor and in the texture of its flesh, but it unfortmately inhabits somewhat inaccessible localities at great depths, and it is hardly to be expected that, with the present supply of excellent food-fish to be obtained at so much smaller expense, our fishermen will take the pains to go in search of it. That the popular taste for flat fish is already cultivated is shown by the fact that, in $1879,1,796,000$ pounds were sold in New York alone.

It is needless to refer to the efforts of the United States Fish Commission to introduce Sole; they are lamiliar to all who are interested in the subject. The introduction of the trawl-net has been for many years 
under consideration, but this expensive mode of fishing does not seem to be required at present, since the supply of fine-flavored food-fishes is more than equal to the demand. With an eye to the interest of the American fishermen, Prof. Baird some years ago detailed Capt. J. W. Collins, of the Fish Commission, one of the most experienced fishermen of Massachusetts, to study the trawl fishery of the German Ocean, and his report which is in press, will soon be published.

Finally, it may not be amiss to state that Mr. E. G. Blackford, of Fulton Market, New York, has for some time been authorized by the Commissioner of Fisheries to pay twenty-five dollars to any one who should present a true Turbot or a true Sole, caught on the coast. This offer is still standing.

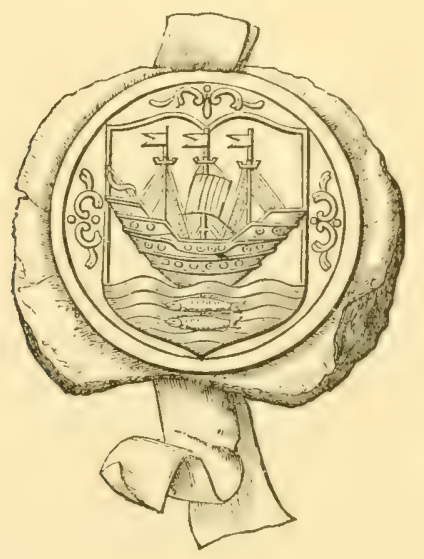




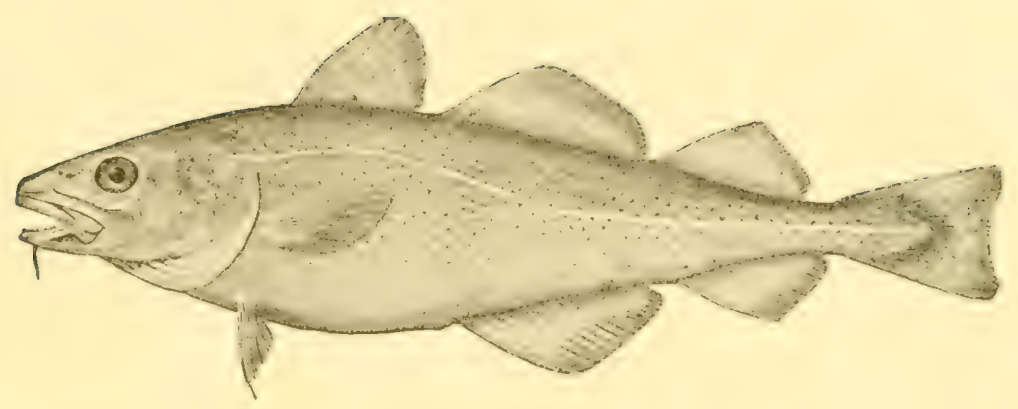

THE COD OR BACC.ILAO.

\section{COD, POLLOCK, HADDOCK AND HAKE.}

\section{'I'was merry, when}

You wager'd on your angling; when your diver

Did hang a salt fish on his hook, which he

With fervency drew up. Anthony and Cleopatra, Act in Scene v.

Within this twenty years

Westward be found new lands,

Fish they have so great plenty,

That in havens take and slane they be

With staves, withouten fail,

Now Frenchmen and others have found the trade

That yearly of fish there they lade

Above a hundred sail.

Experiens, The Four Elements, 1519 .

$\mathrm{T}$

HE Codfish and its allies constitute, from an economical point of view, the most important of all the families of fishes, containing, as it does, a large number of species, most of them of considerable size, distributed throughout all parts of the northern hemisphere, usually found together in great numbers, readily captured, and easily preserved for future use.

The codfish is usually found in the North Atlantic, in the North Pacific, and in the Polar Ocean, its range extending far beyond the Arctic Circle. It seems unnecessary to enumerate all the localities in which it has been observed, for its geographical range may be defined with sufficient accuracy by a much more comprehensive statement. In the Western Atlantic the species occurs in the winter in considerable abundance as far south as the mouth of the Chesapeake Bay, lat. $37^{\circ}$, and stragglers 
have been observed about Ocracoke Inlet. The southern limit of this species may safely be considered to be Cape Hatteras, in lat. $35^{\circ}$, ro'. Along the coast of the Middle States, New England, and British North America, and upon all the off-shore banks of this region, Cod are found ustially in great abundance during part of the year at least. They have been observed also in the Gulf of Boothia, lat. $70^{\circ}$ to $75^{\circ}$, and in the southeastern part of Baffin's Land to the northward of Cumberland Sound, and it is more than probable that they occur in the waters of the Arctic Sea to the north of the American continent, or away round to Behring's Straits.

The Cod has been observed on the Western coast of Greenland. In the North Atlantic the range of the species extends to Iceland and Spitzbergen, lat. $80^{\circ}$; along the arctic coast of Europe, as far as Eastern Finmark, and probably round to Siberia; while southward it ranges at least to Brittany. Its southern limit is probably near the Bay of Biscay, lat. $40^{\circ}$, although Yarrell states that it is found south to Gibraltar. It does not enter the Mediterranean, but penetrates into the Baltic to the coast of Western Russia. Its distribution in the North Pacific is not so well understood, though it appears to occur in the same abundance on all the off-shore banks of this region, and also close to the coasts to the north of the Straits of Fuca. According to Jordan, there is said to be a cod bank outside of the mouth of the Columbia, but the species at present is of no economic importance south of Alaska.

The Cod, like most other species which migrate to and from the shore instead of northward and southward, is, doubtless, more dependent upon temperature conditions than fishes like the menharlen and the blue-fish, and, Mr. Earll has suggested, the abundance of food doubtless has much more influence upon its movements. We cannot doubt, however, that the Cod moves periodically to and from the shore as a direct result of the seasonal changes of temperature. The Cod prefers a temperature of from $35^{\circ}$ to $42^{\circ}$ Fahr., approximately, and this it secures in a temperate climate, such as that of Southern New England, by remaining on the offshore banks in fifteen to thirty fathoms of water, coming into the shallows in winter. On the coasts of Labrador, Newfoundland, Nova Scotia, and Eastern Maine, moving to and from the shore from deeper to shallower water and vice versa to secure at different seasons of the year a temperature environment best suited to their needs, they are near the shore in summer and in deep water in winter. 
I have before me the statements of nearly a hundred observers which I hope to discuss more fully at some future time. Their opinions confirm, in a very striking manner, the generalization just stated. They show that while on the coast of Maine the Cod leave the immediate shores in the autumn, not reappearing in any considerable numbers until late in the following spring, south of Cape Cod they approach the shore only in the winter season, while during the summer they keep out in the cold Labrabor current, which extends south to the inside of the current of the Gulf stream. In Vineyard Sound, Buzzard's Bay, and off the shores of Connecticut, New York, Delaware, New Jersey, and even in Eastern Virginia, there is excellent fishing during the winter season. "A wise provision of nature," remarks Prof. Baird, "in the absence of so many species that supply food during the summer."

It will probably be found that fishing in deeper wate: in these same regions in summer will bring to light an abundance of Cod.

In Norway they are caught, to some extent, in the fiords in the summer season, though more are caught in winter, while in summer great numbers of them still remain on the off-shore banks.

From Prof. Hind's pen the following paragraphs are taken:

"When the coasts of Finmark are thronged with fishermen catching their fares of the "Lodde,' or summer Cod, the shores of Northeast Newfoundland and the shore of the Gulf of St. Lawrence are alive with fishermen successfully capturing the same variety of fish in British American waters; and when the Russian on the Murmanian coast is laying in his winter stock of Cod, and accumulating a large overplus for a foreign market, the New Foundlander and the Labradorian are securing their fares at the Moravian missionary stations, Okak and Nain. So, also, in the North Sea and on the coast of the British Isles, around the Faroe Islands, all along the Icelandic shores, on the south coast of Greenland, - off Arksut Fiord, away up north to Torske Banks, and down the Atlantic coast of America to over the Grand Banks, and as far as, and even beyond, St. George's Shoal, the Cod is taken simultaneously and in great abundance.

"Local variations of days, and even weeks, occur in a coast line or stretch of shallow sea of not more than one hundred miles in length; but these arise from the one great leading cause which guides the Cod in its approach to known feeding grounds on the coast or known banks at sea. This leading cause is temperature, which determines the movement towards the coast of the various forms of marine life on which the Cod, inhabiting different waters, is accustomed to feed. . . The Cod, caught on 
each stretch of coast line within variable but tolerably well-defined limits, are indigenous to the sea area adjacent to the sea-coast which they frequent.

"Thus the winter haunts of the Codfish on the Northern Labrador coast are slopes of the great range of outside banks on that coast. The summer haunts of the 'Winter Cod' caught on the coast of Norway during the winter season, are on the slope of the 'Storegg' and its continuations which lie seawards from the Norwegian coast, following the edge of the barrier separating the 'polar deeps' from the shallower costal seas. The seasonal movements of the Cod are reversed in this case, purposely introduced, but have afforded a beautiful illustration of the principles adopted and confirmed by Prof. Baird and the influence of marine climate on fish-life."

The depth at which Codfish are found varies greatly with the season and locality. It is stated by Mr. Earll that they seem to prefer water less than seventy fathoms deep, and that by far the greater numbers are caught in from eight to forty fathoms. This generalization will doubtless hold true for the whole coast of North America. Many of our correspondents state that they are occasionally seen in the water two or three feet in depth. In the course of some recent explorations by Prof. Agassiz, Cod were found three hundred fathoms below the surface.

In February, 1879 , there was good fishing in three fathoms of water, within a few rods of the shore in Ipswich Bay, while in May of the same year large numbers were taken in one hundred and ten fathoms in the channel near Clarke's Bank.

It would be extremely interesting to know the extent of the migrations of Codfish, from deep to shallow water and back again, on different parts of the coast. This, however, varies with local conditions. There have already been many observations made, the study of which will doubtless aid in the solution of this problem, but it is exceedingly important that there should be systematic exploration at a distance from the shore both in winter and summer. This is one of the tasks proposed for the Fish Commission schooner "Grampus," recently constructed. Mr. Marcus A. Hanna, of Bowery Beach, Me., states that he knows certain places on the coast of Maine where Cod are found in mid-summer not more than two miles from land, in water from forty to fifty fathoms deep, and upon soft bottom. A portion of the Gloucester George's Bank fleet continues fishing through the winter months, though at this season the vessels do not, as in spring and summer, fish upon the shallow parts of the bank, 
but rather seck the deep waters around its edge. The fish make their appearance, however, on the bank early in February.

Cod may be found in greater or less number within reach of the land from Block Island to Newfoundland, and perhaps to Labrador, at all seasons of the year. South of Block Island, Codfish are very rarely noticed in summer, even in the deepest water frequented by the fishermen, though a few remain on the grounds in the vicinity of the islands cluring the whole summer.

In the waters from Cape Cod to Cape Ann, and perhaps a little further to the north, we find the district in which the bathic migrations of the Codfish are least apparent, the periodical changes in depth being but slight from winter to summer-the fish being within easy reach of the fishermen at all seasons of the year. Even here, however, there is a great increment in their numbers in winter.

The statements which have been made regarding the periodical movements or the Cod I do not by any means consider satisfactory or final. These movements are the results of many influences, and no one yet understands how much weight to attach to the relative importance of these three influences, $i . e .$, (1) the direct effect of temperature upon the fish themselves; (2) the abundance of food, as affected by temperature and other causes; and (3) the immediate relations between temperature and the reproductive habits of the fish. There is no more difficult problem in ichthyological science.

Mr. J. Carson Brevoort, of New York, contributes the following interesting sketch of the names applied to the cod family by the different nations of Europe :

"The appellations under which the weather-dried Codfish, split and stretched on a short stick, is known throughout the civilized world can all be traced to one common root, based upon the mode of preparation for the market.

"Among the Greeks the large Codfish were called Baccht, from Bacchus, a rod. By the Latins the fish was named Gadus, from a Sandscrit root cad or gad, a rod. We find this root in English in 'goad,' and perhaps, in 'cat-o'-nine-tail'; in Gaelic gad and godan, signifying a small rod. By the Iberians the dried Cod were called Bacalaos, from Baculeum, a small stick.* This points also to the root of the French Baguette, a rod, Bilboquet, the toy known as cup and ball, really a stick

*The rod held by Mercury was called a Baculeum. 
and ball, and other words. By the Anglo-Saxons it was called the Cod, from the word gad or goad, a rod. By the Germans it was known as the Stockfisch, from Stock, a stick.

"The Hollanders varied a little from this, and as far back as the year I 400 called it the Kabeljaaum, which seems to be from the Dutch gabcl, a fork. They also called it the Bakkeljanue.

"The French Morue is not from the above root. It may be from the Celtic 1 15or, the sea. The French, however, never prepared the Cod by drying it on a stick, but salted it as the Morue verte, or green Cod. The French Molue is merely a change in the liquid consonants.

"When the Cod is dried on the downs it is called Dunfish, from the Gaelic root Duin, a hill. If dried on the rocks it becomes the Rock Cod, or the Klippfisk of the Norwegians. Among these last the Cod is called the Dorset, or Torsk, in English Tusk, from the Gothic Durren, to dry.

"The English 'Aberdeen fish,' or French Laberdan, is from the Gaelic abar, the mouth; dan, a river, or fish caught near the river's mouth."

These remarks are suggestive in the extreme, since they explain the origin of almost all of the names now applied to this species both in its fresh and cured condition.*

The name by which this species was known among the Narragansett Indians is indicated by the following sentence from Roger William's " Key into the Languages of America" :

"Panganaut, tamwock. Cod, which is the first that comes a little before the Spring."

In the vicinity of Cape Ann the young Cod, too small to swallow a bait, are sometimes known to the fishermen as "Pickers," and throughout all Eastern Massachusetts the name "Scrod," or "Scrode," is in common use. In its primary meaning it seems to refer to these small fish slightly corned, in which condition they are a favorite article of food, but the name is also transferred to the young fish themselves. The fishermen recognize several varieties of Cod for which they have different names. Rock Cod are those which are found in shoal water among the reefs and ledges, and which usually are of a dark color; these fish are often brilliant red in color, owing to the fact that the small animals upon which they live feed upon the red algre, abundant in those localities, and

*Skeat in his Etymological Dictionary, recently published, does not confirm the views advanced by Mr. Brevoort, remarking: "I suppose that this word cod must be the same as the Middle English codite or cod, a husk, bag, bolster; though the resemblance of the fish to a bolster is but fanciful. It is obvious that Shakes. peare knew nothing of the Linnatan name gadus (Greck rados), nor is the derivation of cod from gadus at all satisfactory, 
from them they have absorbed the red coloring matter into their tissues. "Rockling" are probably young Rock Cod. In the vicinity of Scituate, Mass., Rock Cod are also called "Native Cod."

Another class of names appears to apply to those fish which live near the shores, but which are less closely limited to the reefs. These are called "Shoal-water Cod," Shore Cod," "Inshore Cod," " Worm-cod," "Clam-Cod," "Black Snappers," "Black Biters,", "Brown Cod," "Ground Keepers," and "Ground 'Tenders", or "Groupers."

Still another class of fish is known by such names as "Deep-water Cod," "Bank Cod," and "School Cod.

There are also certain local schools of fish which have names of their own; for instance, the "Herring Fish" or "Herring Cod" of Southeastern Maine, and the "Squid School" of Nantucket and other parts of the coast, the "Pasture School" of Cape Ann, and the so-called "Shad School" which frequented Massachusetts Bay between I $\delta_{1} 5$ and ${ }_{3} \delta_{3}$.

In Southeastern Maine the name "Pine-tree Cod" is also in use. It is difficult at present to determine exactly to what extent these mames are used and what their precise meaning may be, but it is almost certain that each community of fishermen has its own peculiar names by which to designate local peculiarities of habit and movement.

In the markets, the Cod from George's Bank are usually classed as "George's Fish," and are considered to be of superior value. George's fish are very fat fish with white "napes." This name is becoming a commercial term to describe Codfish of the finest quality. No one of these names, excepting Rock Cod, or Red Cod, appears to be in use in Great Britain, although there, as here, there are various names of local significance, which are of little interest, however, to Americans.

"Bank Cod" and "Shore Cod" are commercial names, used in the same manner as the name "George's Cod."

As early as I 4 I $_{5} \mathrm{~A}$. D., English vessels frequented the fishing grounds near Iceland, and it is claimed by some authorities that the Banks of Newfoundland were known to the Basques centuries before the discovery of the American continent. The Banks of Newfoundland were among the principal inducements which led the English to establish colonies in this country, and in the records of early royages are many allusions to the abundance of Cod along our shores.

A Nova Scotia coin or bank-token has upon it the figure of a Codfish. 
Upon the obverse is a plow with the legend "Speed the Plough," upon the reverse a salted Codfish with the words, "Success to the Fisheries."

Codfish feed upon all marine animals smaller than themselves which are found in the same waters with them and are digestible. For a long period of years, before our naturalists learned to use the hand-dredge, a favorite place in which to search for the rare invertebrates of the deep water was the fish-dealer's stall, and from the stomachs of Codfish scores of shells new to science have been taken. Since the introduction of improved methods of deep-sea research the mode of collecting has been somewhat less prosperous, but even at the present time many important additions to zoology are yearly made by the aid of this omnivorous animal.

Codfish swallow bivalve shells of the largest size, like the great sea clams, which are a favorite article of food on certain portions of the coast ; for instance, in Ipswich Bay great beds of empty shells of the sea-clam, Mactra ovalis, may be found upon the bottom. These shells are "nested," the smaller inside of the larger, sometimes six or seven in a set, having been packed together in this compact manner in the stomachs of the Codfish after the soft parts have been digested out. Some of them had shreds of the mussels remaining in them and were quite fresh, having evidently been but recently ejected by the fish. In Dana's "Geology" are mentioned great banks of dead shells off the island of Grand Manan, which doubtless originated in the same manner. Mr. W. H. Dall found some similar beds on the coast of Alaska which he attributed to the walrus, but which are more probably the remains of mollusks eaten by the Codfish. They feed also upon crabs of all kinds, lobsters and star fish, and have been seen at the surface catching the potato beetles and "June-bugs" which have drifted out from the shore. It is said that they succeed occasionally in capturing a duck, * and that they vary their diet by browsing upon carrageen, or Irish moss, which grows on the ledges near the shore. In searching at the bottom for shells and worms, Codfish often pick up objects which can hardly be regarded as nutritious. A very amusing catalogue of such objects might be included in this chapter, in which would be enumerated articles such as scissors, brass oil-cans, potato parings, corn cobs, and head of a rubber doll. The finding of fingerrings and fragments of oil-clothing, and the heel of a boot, inside of a

* 'The Vineyard Gazette says that Mr. James Osborne took a Codfish on Wednesday, at the "South Side," which weighed over sixty pounds. On dressing it, two full-grown ducks (old squaws) were found it its entrails. They were quite fresh, having most of their feathers,-Gloucester 'Telegraph, May $6, x 857$. 
large Codfish has suggested the idea that sometimes they swallow the fishermen.

A wedding ring which belonged to Pauline Burnam, an English lady who was lost in the steamship "Anglo Saxon," wrecked off Chance Cove, N. F., in I 86 r, was lately restored to her relations by a St. Johns (N. F.) fisherman, who found the ring in the entrails of a Codfish. The lucky' fisherman received a present of $\mathfrak{f}_{50}$ for restoring the highly prized memento to the lady's son.*

Stones of considerable size are often found in their stomachs, and fishermen have a theory that this is a sign of an approaching storm and that the fish thus take in ballast to enable them to remain at the bottom when the waters are troubled. It is more likely that these stones are swallowed on account of sea-anemones or other edible substances which may be attached to them, in just the same manner that the shells of mollusks are taken in for the sake of the nutritious parts which they, contain.

It is believed that certain schools of Codfish feed slmost entirely at the bottom, while others prey upon fish. The fishermen claim to be able to distinguish these two classes by their general appearance, the first being heavier, with shorter heads, blunter noses, and smaller fins, and frequently known as "grubbers" or "ground-keepers," while fish belonging to what are known as the squid school, the herring school, and the lant school, which are probably the same fish at different seasons of the year, are brighter-eyed, slenderer in form, with sharper head, and in every way better adapted for swift locomotion. On the coast of Labrador, as well as in Scandinavia, Codfish follow the schools of spawning capelin in to the shore and prey greedily upon them, and elsewhere, at other seasons, they feed with no less roracity upon other species of fish which may be schooling, and of which they destroy vast numbers, such as mackerel, menhaden, herring, alewife, salmon, sculpin, flounders, cunners, and haddock.

On the Grand Banks, especially in shallow water about the Virgin Rocks, I have been told that they follow the lant to the surface, pursuing them with great fierceness. Along our northern coasts they replace, to some extent, the voracious bluefish and bonito of the South. Capt. Atwood remarks that the amount of food which they consume is enormous, when the size of the fish is taken into account. He has seen them on the coast of Labrador, where the capelin were in great numbers, with their

\footnotetext{
$\therefore$ Boston Journal, July 9, is 7 .
} 
stomachs filled to the greatest possible extent, and capelin in their mouths which they were unable to swallow for want of room, and in this condition they were still biting at the hook. They even feed upon the young of their own kind. They are said to feed largely upon herring spawn, though they are not seen in great numbers, about the spawning grounds until the schools of parent fish have departed. The herring, also, is a favorite article of food, and when these fish approach the shores or are seen on the banks, it is a very good sign that Cod will soon be abundant. Mr. Earll remarks :

"I am told that in the spring of $\mathbf{1} 879$ an immense school of herring moved closely across George's Bank, and that with them came the largest school of Cod that has been seen in that locality for a long time. The Cod remained constantly among the herring, so that when the lattter had passed the fishing fleet, the vessels were obliged to weigh anchor and follow them in order to secure the Cod.

"About Provincetown the common squid sometimes appear in great numbers, and they are most vigorously preyed upon by the Corl."

The same accurate observer gives the following notes concerning their food while breeding :

"During the spawning season the Codfish cease to search for food, and give less attention to feeding than at other times, though they will usually take the bait when placed before them. That they do not search for food is shown by the fact that the pasture school remained within a few miles of a large school of sperling without being drawn after them; and that the Ipswich Bay school was largest after the sperling had left the coast, and remained for a number of months on sandy wastes which supported only three species of invertebrates, Buccimum undatum, Fusus species, and Asterias vulgaris, in any considerable abundance. The examination of the stomachs of several hundred individuals showed fourfifths of all to be entirely empty, while a greater part of the remainder contained only bait picked trom the trawls of the fishermen. A small number contained fish of one or more species that had probably been captured in the locality, while a few scattering invertebrates were found. Of the species mentioned as abundant on the grounds, not a star-fish and but two shells of one species and one of the other are found. But it was clearly shown that the fish would not refuse food, for often the stomachs were well filled with bait picked from the trawl before the fish were hooked. From ten to fifteen pieces were frequently found, and in one case eighteen were counted.

"The females when fully ripe seemed less willing to feed than at other times, and few were caught with the moring hand-lines; but when the 
trawl was used, thus leaving the bait motionless on the bottom for hours at a time, they were induced to bite, and many were taken with the eggs running from them. Ripe males seemed to bite readily at any time.

"The young fish, as has been remarked, seems to spend the first three or four years of its life in shoal water, among the rocks and algre. Here its food consists at first of the minutest forms, and later principally of small crustacea, though it often picks up mollusks and worms, and even enters the harbors in summer, where it remains about the wharves, picking up bits of refuse thrown from the fish-houses."

Capt. R. H. Hurlbert tells me that sometimes a school of Codfish will bite at night; these the fishermen call "Night Cod.",

In I 860 the schooner "C. C. Davis" caught one entire trip of fish on George's Bank all in the night, and there are other instances on record, though, as a rule, these fish feed only in the daytime.

The Cod is one of the most prolific of the ocean fishes, and we find not only thousands but millions of eggs in a single female. All members of this family contain large number of eggs, but the Codfish is the most prolific of all. Mr. Earll writes as follows:

"The exact number of eggs in a female varies greatly with the individual, being dependent largely upon its size and age. To ascertain the number for the different sizes, a series of six fish, representing various stages of growth from twenty-one to seventy-five pounds, was taken, and the eggs were estimated. Care was exercised that the series should contain only immature females, so that no egg should have been lost, and that all might be of nearly equal size. The ovaries were taken from the fish and their weight accurately ascertaincd; after which small quantities were taken from different parts of each and weighed on delicately adjusted scales, the eggs in these portions being carefully counted. The number contained in a given weight being known, it was easy to determine approximately the entire number for each fish."

"The results obtained are given in a table, quoted below, showing a twenty-one pound fish to have 2,700,000, and a seventy-five pound one, 9, I00,000. The largest number of egrgs found in the Pollock was 4,029200 , and in the Haddock, $1, \$_{40,000 .}$

"When the eggs are first seen in the fish they are so small as to be hardly clistinguishable, but they continue to increase in size until maturity, and, after impregnation, have a diameter, depending upon the size of the parent, varying from one-nineteenth to one-seventeenth of an incls. A 
five to eight pound fish has eggs of the smaller size, while a twenty-five pound one has them between an eighteenth and a seventeenth.

"From weighing and measuring known quantities it is found that one pound avoirdupois will contain 190,000 of the smaller size, or that r, $, 00,000$ eggs well drained will weigh about five pounds. Again, by assuming one-nineteenth of an inch as the standard, or by precipitating a known quantity in chronic acid and measuring, we find one quart, or fifty-seven cubic inches, and three-quarters to contain a little less than 400,000 , or that $\mathrm{I}, 000,000$ will measure between two and a half and three quarts."

With these facts in mind, it will be an easy matter to estimate the quantity of eggs taken for hatching purposes during any given season.

"When the little fish breaks through the shell of the egg," says Earll, " the fotal curve or crook is still quite noticeable, but it soon straightens, and is then about five-sixteenths of an inch in length. At this time the yelk-sack, situated well forward, is quite large, but so transparent as to escape the notice of the ordinary observer. This is gradually absorbed, disappearing wholly in about ten to fifteen days, and the little fish begins to move about with a peculiar serpentine motion, at .times darting quite rapidly, and then remaining motionless, as if resting from its evolutions. It now begins its independent existence, and moves about more frequently, apparently in search of food. From this date it is impossible to follow the Cod, for none have been confined, and it is only by catching large numbers at different seasons and carefully recording their weights and measurements that one is enabled to judge of their growth. The habits of the species, that cause them to live near the shore for the first few years, furnish excellent opportunities for such observations, and many were examined during our stay at Cape Ann.

"Evidence is not wanting to show that a Cod spawns every year, and that it deposits the entire number of eggs in the ovaries each season. We have examined hundreds of specimens and have failed to find a single instance where the condition of the ovaries did not clearly indicate that such was the case. During the first of the season no mature fish were found in which eggs were not present, though they often varied greatly in development from very small to nearly ripe Again, later in the season, no spent fish were seen with any eggs remaining in the ovaries; and no fish were found during the spawning period in which the condition of the 
ovaries did not indicate that the eggs were gradually maturing, and would be deposited before the close of the season.

"The schools of Cod move about but little during the spawning season, except when driven away by enemies or by violent storms. After they reach the waters of Cape Ann, fishing continues best in the same localities, and even upon the same spots, until they leave. The individuals, too, seem to move about but little among themselves. When the female becomes ripe she remains quietly near the bottom, while the male, a little more active, often swims high up. This is indicated by the fact that greater numbers of spawning females are taken with the trawl, which lies directly on the bottom, than with the hand-line a little way above it, while the males are taken on one as readily as on the other.

"It may not be impossible that the eggs are fertilized while floating about in the water some minutes after exclusion, and that the strong tides usually found on the spawning grounds play an important part in distributing the germs, thus making the chances of impregnation more favorable. Incleed it may be possible, and, if the spawning goes on gradually for sereral months, seems not improbable, that the immediate presence of the opposite sexes during the act of spawning is not necessary, but rather that the eggs are fertilized mainly by accidental contact. Observations would seem to strengthen the probabilities of this theory; for, if the fish went in pairs, they would often be taken on adjoining hooks of the trawl, or one on either hook of the hand-line. Such is not usually the case, however; but, on the contrary, several of the same sex are more frequently taken together.

"The eggs have a specific gravity of $\mathbf{I . 0 2 0}$ to $\mathrm{I} .025$, as inclicated by the fact that they float in salt water and sink rapidly in fresh. They may be found at the surface in common with eggs of the Pollock, Haddock, and probably other species of the cod family, when the sea is smooth; but when the water becomes rough they are carried to a depth of several fathoms by the current, though the tendency is to remain near the surface.

"There are many ways in which the eggs may be destroyed. The principal loss is probably the result of non-impregnation, for unless they come in contact with the milt of the male very soon after being thrown from the parent, they lose their vitality. Again, being drifted about by the winds and tides, they are often carried long distances from the spawning grounds into the little bays and coves, and are driven in immense num- 
bers upon the shores, or are left dry by the tides, where they soon die from exposure to the atmosphere, or during the cold winter weather are instantly destroyed by freezing. Ipswich Bay, the most extensive spawning ground in the locality, is especially unfortunate in this particular, for the heavy storms from the north and east sweep with unbroken force across its surface, and each breaker as it rolls in upon the beach must carry with it many millions of eggs.

"But such impregnated eggs as escape destruction upon the shores are subjected to the ravages of the myriads of hungry anımals living about the rocks and coves. One day in January we placed a jelly-fish or medusid, having a diameter of but one and a half inches, into a tray of eggs in the hatching-room, and in less than five minutes it had fastened seventy eggs to its tentacles, loading some of them so heavily that they were severed from the body by the weight or resistance of the eggs as they were dragged through the water."

In addition to his other observations, Mr. Earll computed the number of eggs in Codfish of different sizes. The results of his observations are shown in the following tables:

\section{Table showing the number of eggs in Codfish of different sizes:}

\begin{tabular}{|c|c|c|c|c|c|c|c|c|c|}
\hline Number. & 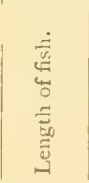 & 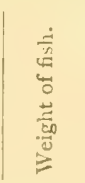 & 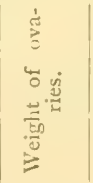 &  & 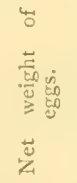 & 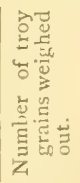 & 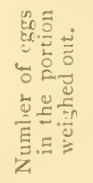 & 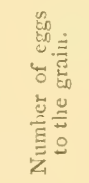 & 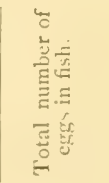 \\
\hline т.... & $\begin{array}{c}\text { Ft. in. } \\
\ldots \ldots \ldots \ldots \ldots\end{array}$ & $\underset{70-75}{L b s}$ & $\mid \begin{array}{c}\text { Lbs.oz. } \\
88\end{array}$ & $\underset{6}{\mathrm{Oz}}$ & $\begin{array}{c}\text { Lbs.oz. } \\
82\end{array}$ & 7 & $\mathrm{I}, 108$ & & \\
\hline$I(a)$. & ............. & $70-75$ & 88 & 6 & 82 & 7 & $I, I_{32}$ & 160 & $9,100,000$ \\
\hline 2..... & $+2 \frac{1}{2}$ & | $5 \mathrm{I}$ & 72 & 5 & 813 & 6 & $I, I 3 I$ & 188.5 & $8,988,094$ \\
\hline 3. & 38 & 30 & $283 / 4$ & $23 / 4$ & 26 & 6 & $\mathrm{x}, 34 \mathrm{I}$ & 023.6 & $3,7 \times 5,687$ \\
\hline 4. & 35 & 37 & $29^{3 / 3}$ & $23 / 3$ & 26 & 7 & 1,680 & 240 & $4,095,000$ \\
\hline $5 \ldots \ldots \ldots$ & $34 \frac{\pi}{2}$ & $223 / 4$ & $223 / 3$ & 2 & $203 / 3$ & 6 & $x, 368$ & 228 & $3,229 \cdot 3$ SS \\
\hline$\therefore$ & 33 & $2 I$ & $\begin{array}{ll}1 & 153 / 4\end{array}$ & $13 / 4$ & I I4 & 6 & I, 249 & 208.17 & $2,732,237$ \\
\hline
\end{tabular}

It is interesting to compare these with the observations made during the last century, references to which may be found in all the standard works on natural history. Leuwenhoek is said to have found in a Cod of middling size $38_{4}, 000$ eggs. Harmer found, in one weighing eighteen or twenty pounds, between $3,000,000$ and $4,000,000$ eggs. It was examined 
December 23 , and was estimated to have $29+\mathrm{eggs}$ to the grain, the ovaries weighing I 2,540 grains; the total number, according to this calculation, is $3,686,760$.

The result of Mr. Earll's observations indicates that in June the fish hatched the previous winter, or about six months old, range from one and a half to three inches in length; while those from nine to thirteen inches long, and weighing seven or eight ounces, were eighteen months old; those seventeen to eighteen inches long, and weighing two to two and a quarter pounds, were supposed to be two years and a half old; those of about twenty-two inches, which weighed four to five pounds, were three years and a half old. He also concludes that the male reaches maturity at the age of three, and female at the age of four years, for the smallest ripe male noticed during the season of $1878-79$ weighed three and one-half pounds, and the smallest ripe female five pounds.*

I have before me memoranda relating to a large number of enormous Codfish, taken along the New England coast at rarious times from i $S_{3}$ o to 1879 . It seems unnecessary to refer to them, excepting the cases of a few which exceed one hundred pounds in weight. Capt. King Harding, of Swampscott, tells me that he once caught, on the eastern side of Cape Cod, a fish weighing Ior pounds as it came from the water. On the $22 \mathrm{~d}$ of July, I 873 , Miss Fannie Belis, of St. Louis, while on a fishing excursion off Eastern Point, on board the yacht "United States," caught a Cod which weighed 130 pounds. Capt. G. H. Martin caught, off Chatham, a Codfish which weighed, dressed, III pounds. Capt. Stephen Mar, of Gloucester, saw a Codfish taken on George's Banks in ${ }^{8} \delta_{3} S$, which, after having been eviscerated, weighed ${ }^{3} 6$ pounds. Capt. Atwood says, on the coast of Cape Cod he has never seen a male Codfish, with one exception, which weighed more than 60 pounds; he once saw one, however, which weighed I 60 pounds. This fish was not much larger than an ordinary fish weighing 75 pounds, but was very thick.

Capt. Atwood remarks: "In regard to size, the Cod differs very widely in different localities. When taken on the Grand Banks it usually requires from thirty to forty to make a quintal when dried. Those caught in the Gulf of St. Lawrence with hand-lines are smaller, requiring seventy or

:On pages 733-734 of Mr. Earll's report may be found the measurements of a large number of Codfish of different weights, and with the ovaries and spermaries in different stages of development. These measurements are interesting, since they show the relation between the length and weight of individual fish. 
eighty per quintal; in the same locality, however, Cod caught on trawl lines require only twenty to twenty-five per quintal, while on the coast of Labrador they are small, and it requires about one hundred to one hundred and ten to make a quintal.

Writing in the summer of 1877 , Capt. Atwood expressed the opinion that the average weight of the fish taken about Cape Cod was in the neighborhood of ten pounds; but he informed me that in the winter of 1877 , in two days, thirty thousand pounds of Codfish were landed from the boats, and that there was not a fish among them small enough to. be classed as a market Cod, a market Cod weighing from six to ten or twelve pounds.

In conclusion, it may not be amiss to quote the remarks of Prof. Baird concerning the decrease of Codfish along our coast, and its probable causes :

"Of all the various fisheries formerly prosecuted directly off the coast of New England, north of Cape Cod, the depreciation in that of the Cod appears to be of the greatest economical importance. Formerly the waters abounded in this fish to such an extent that a large supply could be taken throughout almost the entire year along the banks, especialiy in the vicinity of the large rivers. At that time the tidal streams were almost choked up with the alewives, shad, and salnon that were struggling for entrance in the spring, and which filled the adjacent waters throughout a great part of the year.

"As is well known, the erection of impassable dams across the streams, by preventing the ascent of the species just mentioned to their spawning grounds, produced a very great diminution, and almost the extermination of their numbers; so that whereas in former years a large trade could be carried on during the proper season, now nothing would be gained by the effort.

"Of late the attention of the legislatures of the New England States has been called to this fact, and to the importance of restoring their fisheries, and a great deal has been already accomplished toward that end. Unfortunately, however, the lumbering interest in Maine, and the manufacturing in New Hampshire and Massachusetts, are so powerful as to render it extremely difficult to carry out any measures which in any way interfere with their convenience or profits; and notwithstanding the passage of laws requiring the construction of fishways through the dams, these have either been neglected altogether, or are of such a character as not to answer their purpose. The reform, therefore, however imperatively required, has been very slow in its progress, and many years will probably elapse before efficient measures will be taken to remedy the evil referred to.

"It would, therefore, appear that while the river fisheries have been 
depreciated or destroyed by means of dams or by exhaustive fishing, the Codfish have disappeared in equal ratio. This is not, however, for the same reason, as they are taken only with the line, at a rate more than compensated by the natural fecundity of the fish. I am well satisfied, however, that there is a relation of cause and effect between the present and past condition of the two series of fish; and in this I am supported by the opinion of Capt. U. S. Treat, of Eastport, by whom, indeed, the idea was first suggested to me. Capt. 'Treat is a successful fisherman and dealer in fish on a very large scale, and at the same time a gentleman of very great intelligence and knowledge of the many details connected with the natural history of our coast fishes, in this respect worthily representing Capt. Atwood, of Provincetown. It is to Capt. Treat that we owe'many experiments on the reproduction of alewifes in ponds, and the possibility of keeping salmon in fresh waters for a period of years. The general conclusions which have been reached, as the result of repeated conversations with Capt. Treat and other fishermen on the coast, incline me to believe that the reduction in the Cod and other fisheries, so as to become practically a failure, is due to the decrease off our coast in the quantity, primarily, of alewives; and, secondarily, of shad and salmon, more than to any other cause.

"It is well known to the old residents of Eastport that from thirty to fifty years ago Cod could be taken in abundance in Passamaquoddy Bay, and off Eastport, where only stragglers are now to be caught. The same is the case at the mouth of the Penobscot River and at other points along the coasts of Massachusetts, a much more weighty reason than that of merely enalling a few salmon to enter the streams in order to permit their capture while on their way.

"Whatever may be the importance of increasing the supply of salmon, it is trifling compared with the restoration of our exhausted Cod fisheries; and should these be brought back to their original condition, we shall find, within a short time, an increase of wealth on our shores, the amount of which it would be difficult to calculate. Not only would the general prosperity of the adjacent States be enhanced, but in the increased number of vessels built, in the larger number of men induced to devote themseives to maritime pursuits, and in the general stimulus to everything connected with the business of the seatfaring profession, we should be recovering, in a great measure, from that loss which has been the source of so much lamentation to political economists and well-wishers of the country."

The Atlantic Tom Cod, Microgadus tomcod, is found only in the Western Atlantic, ranging from New York at the south, to Cape Sable at the north. It is ordinarily known as the Tom Cod, but in the Bay of Fundy, and in various places south of Cod, it is called the "Frost 
Fish," owing to the fact that it becomes most abundant in the early part of the winter, when it approaches the shore and even ascends the rivers and creeks for the purpose of spawning. Dr. DeKay states, on the authority of Dr. Yates, that Tom Cods sometimes appear at Albany in abundance, while I am informed by the Rev. Dr. Gardiner that they are taken in winter in the Kennebec, sixty miles from its mouth, and far above the reach of the tide. They ascend the Charles River to Watertown, where they are taken in dip-nets and by the hook from the wharves and bridges. Although most abundant near the shores and in the streams in early winter, they are found along the coast at all seasons of the year.

In form the Tom Cod is the miniature of the Codfish, rarely exceeding ten or twelve inches in length, and there is much difficulty in distinguishing the young of the two species. The Tom Cod, however, varies even more in its color than the Cod, and several varieties have been described under different names. When these fish approach the shores in winter they are taken in great quantities in nets, and are esteemed in many localities as a great delicacy. It is said that they are sometimes sold in the markets under the captivating name of "London Trout."

The Tom Cod feeds upon numerous species of crustaceans and mollusks, and also upon the young of many other kinds of fishes.

The Pacific Tom Cod, Microgadus proximus, is thus described by Prof. Jordan :

"The English at Victoria know this species by the name 'Whiting.' Elsewhere on the coast the name of 'Tom Cod' is universally applied to it. In the restaurants at San Francisco it is usually served under the name of smelt. It reaches the length of a foot and a weight of about half a pound. It ranges from Monterey to Puget Sound and northward, being everywhere very abundant, and taken in great numbers in seines and sweep-nets, both outside and in the bays. Its food is small fishes. Nothing special is known of its breeding habits; it is apparently abundant at all seasons. It is one of the important food fishes of the coast, always abundant and always meeting a ready sale. Its flesh is, however, watery and tasteless, and cannot be rated high."

The Pollock, Pollachius carbonarius, which is the Coalfish of England, the Könler of Germany, and the Sei of Norway and Sweden, is closely related to the Pollock of Great Britian, Pollachins virens, from which, however, it is specifically different. It is one of the best-known fishes of Northern Europe, as may be inferred from the abundance of its common 
names. The following names are in use in different parts of England: Baddioch, Billet, Billard, Black-Pollock, Black-Jack, Black-Coalsey; Blockan, Blockin, Coal, Coal-fish, Coalsay, Coalsey, Coal-whiting, Colemie, Colmey, Cooth, Cudden, Cuddy, Dargie, Gilpin, Glassock, Glashan, Glossan, Glossin, Green-cod, Green Pollock, Grey-lord, Gullfish, Harbin, Kuth, Lob, Lob-keling, Naulrush, Parr, Pitock, Podley, Poddlie, Podling, Pollack, Prinkle, Rauning Pollack, Rawlin Pollack, Rock Salmon, Raw Pollock, Saithe, Sethe, Sey, Sey Pollack, Sillock, Skrae-fish, Stenlock, Tibre.

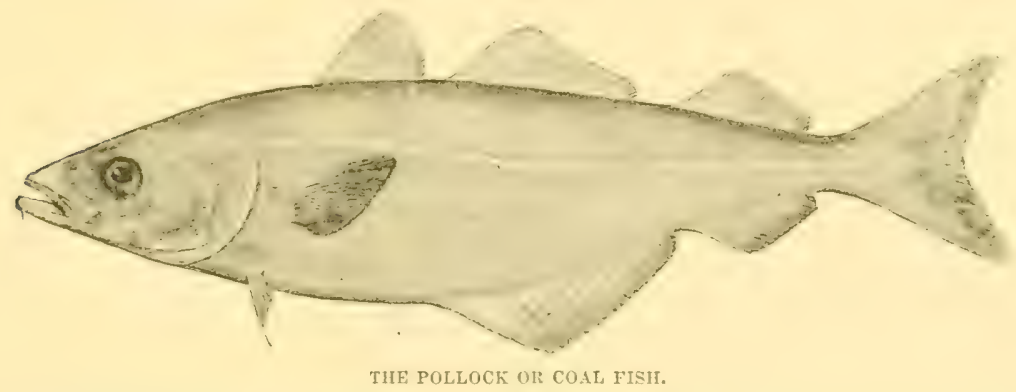

Its geographical distribution is quite different from that of either the Cor or Haddock, its northern range, at least in the Eastern Atlantic, being fully as wide as that of the Cod, the species having been found in the northern part of Spitzbergen, beyond the parallel of $50^{\circ}$, and on the arctic coast of Europe. It rarely enters the Baltic. Bloch records a specimen from Lubeck, and it is said to occur on the coast of Pomerania.

Concerning the limits of its southern range authorities differ. Gunther places this at latitude $46^{\circ}$ in the Bay of Biscay, while others claim that it enters the Mediterranean. Canestrini states that it has been observed at Taranto. It does not appear, however, that the species is abundant south of the English channel. It occurs about Iceland and on the west coast of Davis Straits, where specimens were obtained by Sir Edward Parry on his first voyage. North of Newfoundland it does not seem to be rery abundant, while to the south the limit appears to be in the vicinity of Nantucket Shoals, where specimens are occasionally taken by the cod smacks.

In Perley's "Catalogue of the Fishes of Nova Scotia," he states that he had never seen the fish in the Gulf of St. Lawrence, nor heard of it except near the Straits of Canso. although it was found rery alumelant in the 
Bay of Fundy and everywhere except in the muddy waters, such as those of Cumberland Bay and the Basin of Minas.

I have seen large individuals taken in midsummer in the pounds in Vineyard Sound, and the capture of small individuals in these waters is not unusual. They are often taken, according to De Kay, off New York, in company with the Cod. In June, I88I, the schooner "Edward E. Webster," of Gloucester, Solomon Jacobs, captain, returning from a southern mackerel trip, fell in with a school of Pollock and captured sixty thousand pounds of them in her purse seine. Its range, as now understood, is in the Eastern Atlantic between the paralleis $46^{\circ}$ and $80^{\circ}$, in the Western Atlantic between $40^{\circ}$ and $70^{\circ}$. That its southeastern limit is as near the equator as the parallel of $36^{\circ}$ seems quite improbable.

Unlike the Cod and the Haddock, the Pollock is, to a great extent, a surface-swimming species. The fishes of this species congregate together in large schools, roaming from place to place in search of food. To a certain extent they feed at the bottom, like Cod, but are more often seen at the surface of the water, where they prey upon young fish of all kinds.

Prof. Sars gives the following account of the manner in which they prey upon little Codfish:

"I was much interested to see how the Pollock caught the young Cod. fish. It looked like a systematic chase, and it certainly looked as if the Pollock were acting with a common and well-defined purpose. As far as I could observe, the schools of Pollock surrounded the little Codfish on all sides, making the circle constantly narrower until all the Codfish were gathered in one lump, which they then, by a quick movement, chased up to the surface of the water. The poor little fish now found themselves attacked on all sides; below, the voracious Pollock, which in their eagerness often leaped above the water; and above, hundreds of screeching sea-gulls, which, with wonderful voracity and precision, pounced down upon the places where the Pollock showed themselves, to share the spoils with them. The whole chase is carried on so rapidly, and the young fish stay only so short a time at the surface of the water before they are scattered in all directions with lightning-like rapidity, that it was not even possible for me to see any, much less to catch any with my insufficient implements." *

On the coast of New England they are much disliked by the fishermen, who claim that they consume great quantities of other fish much more

\footnotetext{
* Report of the United States Fish Commission, Part 5, 1870, p. 593. Another vivid description of the manner in which the Pollock feed upon the sand-eels, or lant, may be found on pp. 619 and 620.
} 
valuable than themselves; in consequence of this the fishermen have a great prejudice against them and refuse to eat them.

Capt. Atwood states that about Cape Cod they do not take to the hook frecly; that in other localities they are exeeedingly voracious, ancl great numbers of them may be caught in Massachusetts Bay with a surface bait.

When the United States Fish Commission steamer has been stationed north of Cape Cod, a favorite amusement of the officers has been to catch young Pollock with a fly. The older fish are less active and remain more at the bottom.

Concerning this species, Capt. Atwood states that they appear about Cape Cod in schools in early May, frequently passing Race Point so close to the shore as to be caught with the seine among the "tide-rips."

Capt. E. W. Merchant, of Gloucester, tells me that the Pollock were very abundant in Massachusetts Bay early in this century-before the war of isr2. They were especially abundant on Middle Bank. They were at that time chiefly caught with bait of herring, taken in seines from the beaches. The fishing boats were of about thirty tons, and carried three men and a boy. Fishing was carried on chiefly at night. When the vessels would all "fleet up," and the bait on their hooks would toll the schools of fish together. The vessels would take about fifty quintals in a night. There were about thirty fish to the quintal. This abunclance of Pollock lasted until about $x \& 20$. These Pollock were salted, and consumed at home or carried to Maine. They sold for about two dollars a quintal. The oil of their livers was tried out in kettles on the shore. Their roe was exported largely in those days, It was sold by the bushel, at the rate of about sixty cents.

Mr. Earll writes: "Large Pollock are absent from the waters of Caje Ann from the middle of January till early in May, the small ones leaving earlier, in the fall, and returning in April.* The young may be taken almost anywhere along the shore, but the large fish seem to confine themselves to definite localities; and though not particularly abundant during the summer at Cape Ann, it is a favorite spawning ground for the species, and during this period large schools visit this shore.

"They begin to grow plenty about the first of October, and by the last of the month are so numerous as to greatly annoy the cod-fishermen by taking the hook before it can get to the bottom. 
"During this season some of the small vessels fish exclusively for Pollock, 'seizing up' their lines a number of fathoms from the bottom, and at times the fish bite as fast as the fishermen can haul them. Early in in November a crew of four men landed Io, 420 pounds, or about I, I OO fish, the result of less than two days' fishing. Owing to a foolish prejudice, the price is always low, at times being less than thirty cents per one hundred pounds. The average weight of the fish is about nine or ten pounds, and during the spawning season the sexes are taken in about equal numbers."

In the Bay of Fundy and along the coast of Maine the capture of young Pollock from the rocks is a favorite amusement. At Eastport these fish are often called "Quoddy Salmon." Hinds states that in the Gulf of St. Lawrence they are known as "Sea Salmon ;" this name may refer both to their active and voracious habits, and to the excellence of their flesh in those localities.

The spawning of the Pollock occurs in the German Ocean, according to Wittmack, from December to February; in Scotland, according to Parnell, in February, after which it remains out of condition until May.

About the Loffodens, as indicated by the observations of Sars, the breeding time corresponds with that of the Codfish, the young Pollock being found in early summer in company with the young Cod, swimming under the protection of the jelly-fishes.

The Pollock is one of those species whose value as an article of food is very much underestimated. Many persons who have investigated the subject accurately prefer salted Pollock to salted Codfish, although the flesh is not so white. Its value for use in the fresh state, we think, deserves the highest commendation.

Pollock are more highly prized in New Brunswick than anywhere else on the Western Atlantic coast, and the pollock fishery was in $185^{\circ}$ prononnced by Perley the most valuable and extensive of the deep-sea fisheries of the Bay of Fundy. It is stated by this authority that directly after the spawning season the fish is lank and almost worthless, but that it becomes in good condition again in August and improves as the season advances.

The liver of the Pollock yields a great quantity of oil, proportionaliy much more than that of the Cod. It is probable that most of the cod-liver oil in the market is more or less adulterated with pollock-liver oil. No one has yet demonstrated that its medicinal properties are inferior. The eggs of the Pollock are very large, and great quantities of them have been in past years salted and exported to France. 
The Alaska Pollock, Pollachius chalcogrammus (Pallas) J. \& G., is thus described by Prof. Jordan: "This species is known as Pollack to those who have seen the Atlantic species. It is possibly iclentical with the 'Beshow' of the Makah Indians, the 'Coal-fish' of the English settlers northward, a deep-water fish noted for its rich, fat flesh. It reaches a length of about two feet. It ranges from Monterey to Behring's Straits. It is taken with hook and line in deep water, and is never plentiful south of Cape Flattery. It feeds upon anchovies and the like. Nothing is known of its breeding habits, enemies or diseases, and, unless it be the 'Beshow' abore noticed, it is not sufficiently abundant to attract any notice as an article of food.

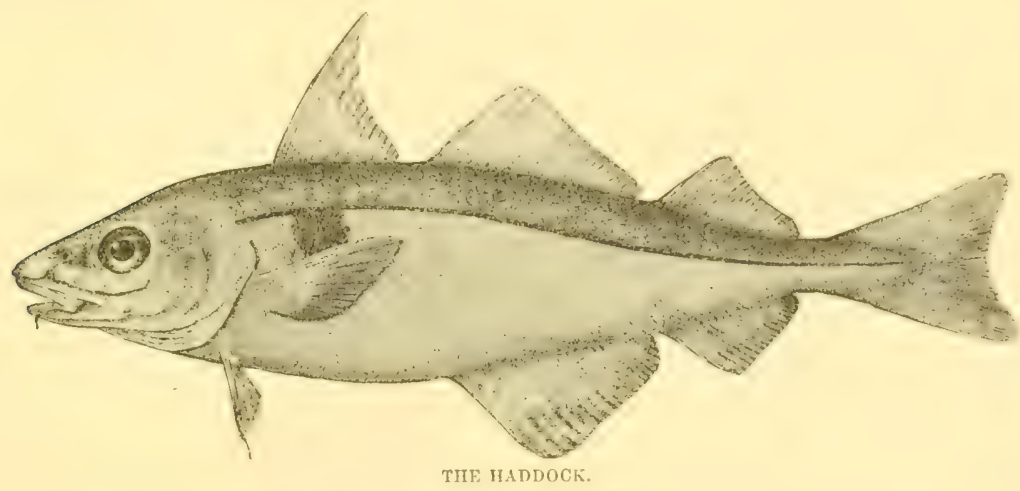

The Haddock, Melanogrammus aglefinus, is found only in the Atlantic. Hadot and Hadou are old French names for the same fish, though the species is now usually known by the name Egrefin. In Scotland the name is said to be pronounced almost in the same way as in France, and is often varied to Haddie. It is the Schellfish of Germany. Concerning this fish many of our fishermen entertain the idea, which with them can hardly be called a superstition, that the black spots upon their side are due to the impression of the thumb and finger of St. Peter when the apostle took the tribute money out of the mouth of a fish supposed to be of this species, the fisherman's mark having been continued among its descendants ever since. This notion is prevalent also in England, and in Southern Europe is attached to other fishes, particularly to the John Dory, Zcus fabcr. It is needless to say that no member of this family occurs in the Sea of Galilee. 
Its wanderings are more limited than those of the Cod. It is not found nearly as far to the north, while its southern range is no wider. Haddock are probably found in company with Codfish on all the northern fishing grounds, as far south, at least, as the Capes of Delaware, though concerning their occurrence in southern waters there is dearth of information. In winter and spring they are taken in Fisher's Island Sound and outside of Fisher's Island, on the coast of Eastarn Connecticut ; and also in great quantities on Nantucket Shoals by the smacks, and are carried thence with Cod into New York market. In I $_{7}$ I it was estimated that the catch of Haddock here was nearly equal to that of Cod, although the latter usually predominates. They abound north of Cape Cod, in the Gulf of Maine, and in the Bay of Fundy, in the Basin of Minas, on the coast of Nova Scotia, in the Gulf of St. Lawrence, and in the Bay of Chaleur. In the Gulf of St. Lawrence, according to Capt. Atwood, they are not very abundant, but the individuals taken are very large. They are taken on the western coast of Newfoundland in winter; their northern limit appears to be marked by the Straits of Belle Isle, latitude $52^{\circ} \mathrm{N}$. In $186_{3}$ and 1864 they were found in abundance on the southern border of the Grand Bank. They are not so frequent on the Grand Bank as on the Western Bank, and, in turn, less common there than on George's Bank.

In the Eastern Atlantic the range of the Haddock is somewhat wider, for they are found in the seas of Iceland, the whole length of the Scandinavian coast to East Finmark and Varanger Fjord, and on all the shores of Great Britain, and in the North Sea, where they are particularly abundant, though rarely or never entering the Baltic. There is no evidence that they are found to the south of the English Channel. De La Blanchere states that they are caught in considerable numbers on the coast of Manche. In the Eastern Atlantic, then, they are found between the parallels $48^{\circ}$ and $66^{\circ}$; in the Western Atlantic between parallels $3^{\circ}$ and 53

Haddock are not so active and powerful as the Cod. Dr. Gilpin has expressed the opinion that on the coast of Nova Scotia they do not retreat so far from the shore in winter as the Cod, but this does not appear to be true in Massachusetts Bay.

Remarkable variations in the abundance of this fish are upon record; at certain times they have been exceedingly rare, at others abundant in the extreme. 
Capt. Atwood states that in $S_{34}$ Haddock were very scarce on the Grand Bank, and few were caught anywhere on the coast, but in is 40 they became so numerous about Cape Cod as to interfere seriously with the Cod fishery, devouring the bait before the Cod could reach it, and about $S_{5}$ o they had increased so rapidly that the markets were glutted. In $186+$ they were caught in great numbers and were still on the increase. In $\mathbf{I} 870$ the same observer related to the Massachusetts senate the story of another period of scarcity and abundance. His statements may be found in the report of the United States Commission of Fish and Fisheries, Part I, I 873 , p: I I 9 .

The food of the Haddock resembles that of the Cod, except that they are, if possible, more omnivorous; their diet consists, however, largely of invertebrates. They are rarely seen feeding at the surface, though they devour the spawn of other fishes, particularly that of the herring, with great eagerness. They devour great quantities of shells, many of them of the burrowing species. Prof. Verrill has well said that a complete list of the animals devoured by the Haddock would doubtless include all the mollusks belonging to the fauna of New England.

The Haddock are said to be particularly abundant on clam-banks. From this habit of feeding on shells has originated the German name for the fish. The difference between the habits of the Haddock and the Cod is illustrated by the remark of Capt. Atwood that Haddock will take a baited hook as it rests upon the ground, while the Cod will only notice it when it is raised a short distance from the bottom. Salted menhaden is a favorite bait for Haddock, but not desirable for Cod, while both Cod and Haddock will readily take stale clams, which are much better for bait than fresh ones.

On the German coast the Haddock spawn on rocky bottoms in February and early March at a depth of twenty-two to twenty-five fathoms; and according to Yarrow the spawning period is the same on the British coast, the young growing to a length of six or seven inches before the beginning of September. At the Loffoden Isles, according to Sars, the spawning season of the Haddock takes place a little later, beginning toward the end of February and being at its height late in March. At Cape Ann the season is in late April, May and June.

The average size of the Haddock is probably not far from three or four pounds; many twelve-pound fish are brought to market, and individuals weighing seventeen pounds are on record. 
In I 879 Haddock were successfully hatched, under the supervision of Mr. Earll, at the Gloucester station of the United States Fish Commission.

The Haddock is now very highly esteemed as a food fish, having grown in favor during the last twenty years. It is especially desirable for boiling or for making chowders, and is a great favorite in Boston, while in Philadelphia enormous quantities are yearly consumed. Being well adapted for preservation in ice, great numbers of them are distributed through the interior of the country, together with the Codfish. The success with which the Scotch method of smoking Haddock has been introduced into this country has also greatly increased the demand for them, and "Finnan Haddies" are manufactured in enormous quantities in Portland and Boston. At Provincetown a Haddock salted and dried after being split is called by the name "Skulljoe," or "Scoodled Skulljoe."

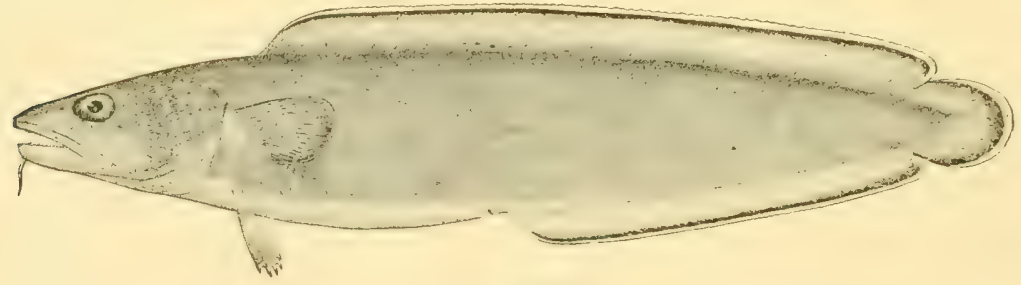

THE BURBOT.

The Cusk, Brosmius brosme, is a deep-water species, inhabiting rocky ledges in the North Atlantic. It has not been observed south of Cape Cod, but ranges northward to the banks of Newfoundland and of Greenland. It occurs in Iceland and Spitzbergen and along the entire length of the Scandinavian Peninsula, but is not known on the coast of Germany, while Faber states that it just touches the most northern part of Denmark at the Scaw in Jutland, and that it is occasionally taken in the Frith of Forth and brought to the Edinburgh market. It is also plentiful about the Faroe Islands. Its range in the Western Atlantic is from latitude $42^{\circ}$ to latitude $65^{\circ}$, or beyond; in the Northeastern Atlantic to latitude $80^{\circ}$, and south to latitude $55^{\circ}$.

The Massachusetts fishermen tell me that these fish are usually found in considerable abundance on newly-discovered ledges, and that great numbers may be taken for a year or two, but that they are soon all caught. Sometimes, after a lapse of years, they may be found again abundant on a recently-deserted ground. From these facts it has been reasoned that the 
Cusk is very local in its habits and rarely changes from one locality to another.

The food of the Cusk doubtless consist chiefly of mollusks and small crustaceans.

Concerning its spawning habits nothing is known, except that, accorcling to Faber, it breeds in April and May on the coast of West and South Ireland.

The Cusk is considered a very excellent fish, especially for boiling, but there is a very limited demand for it, and most of those which are taken are salted. On account of their low prices fishermen shun them, and they are hardly in better favor than dogfish. In the spring of 1878 they were worth in Gloucester from twenty to fifty cents per hundred, and in August of the same year about one dollar per hundred. One of the peculiar habits of the Cusks renders their capture difficult, and frequently causes the destruction of the fishing-tackle; it is said that after they have taken the hook they curl their tails round the angles of the rock and cling to them with such strength that it is impossible to dislodge them. Fishermen say that when they are brought to the surface the skin rises from the borly in great blisters. This they regard as a favorable sign, as showing that the fish are "thrifty," or healthy. The name "Tusk," used for this fish in Newfoundland, is now never used in the United States, although it seems to have been in use a century ago, a well-known fishing ground in the Gulf of Maine being known as the "Tusk Rock."

The two species which have commercial value being $P$. chuss and $P$. tenuis. These species are very similar in appearance, and it is with difficulty that they can be distinguished from each other by the trained eye of the zoologist. The most tangible distinction may be found in the number of scales, which are much smaller in $P$. tenuis, there being from one hundred and thirty-five to one hundred and forty oblique rows between the bronchial opening and the root of the caudal fin, while there are about twelve rows between the lateral line and the region of the first dorsal. In $P$. chuss there are only one hundred rows in the lateral line and nine rows above the lateral line; in the former the ventral does not ordinarily reach quite to the vent, in the latter it extends beyond the vent. This character, however, cannot always be relied upon.

Our Hakes are all different from the Forked Beard, P. blemioides, of Great Britain, sometimes called the Hake's Dame, which is a member of 
the same genus.* Owing to their great similarity, Phycis chuss and $P$. tenuis, are usually known indifferently by the name "Hake ;" the former, however, is sometimes called the Old English Hake, and the other, Phycis tenuis, the Squirrel Hake or White Hake. In the Gulf of St. Lawrence and the Bay of Chaleur, and also south of Cape Cod, they are invariably called Ling. There has been much confusion both in the names and descriptions applied to them by fishermen and ichthyologists. Their geographical range appears to be essentially the same. The young of one or both species are frequently taken swimming at the surface, on the southern coast of New England, in midsummer, and numerous individuals have been found off Block Island and Watch Hill, seeking shelter between the valves of a large species of scallop, Pecten temicostatus; the majority appear to belong to the species of $P$. chuss.

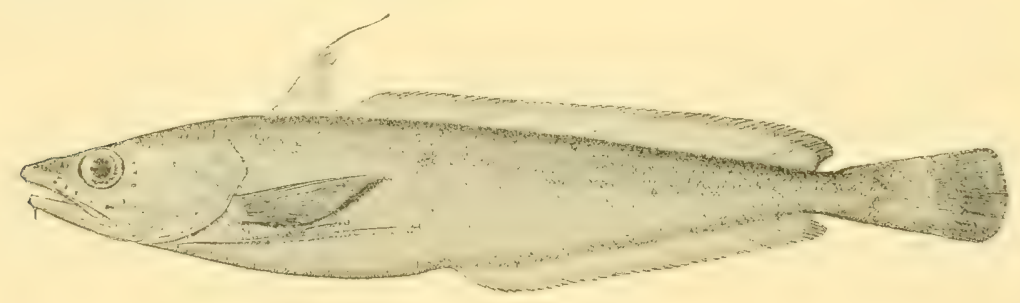

THE $11.1 \mathrm{KF}$.

The two species are frequently taken by the cod-fishermen, on the shoals south of Cape Cod, but they are there considered to be of but little value. They are more or less abundant in Massachusetts Bay, in the Bay of Fundy and in the Gulf of St. Lawrence. Large specimens of one or both species have been taken at a depth of three hundred fathoms as far south as Virginia.

The Hakes appear to be bottom-loring fishes, and rarely change locality. They feed on crustaceans, and occasionally indulge in a fish diet. One taken at Gloucester in July, 1878 , had a menhaden in its stomach.

It is believed that they spawn throughout the summer, for the young fish are found during all the summer months, while specimens taken at the depth of thirty-seven fathoms August i 8 , i 878 , off Ipswich, at a temperature of $4 \mathrm{~T}^{\circ} \mathrm{F}$, contained well-developed ova, and were apparently ready to spawn.

The Hake of Europe is a different fish, more closely related to the Silver Hake or Whiting of the New England coast, Alerlucius bilincaris. 
An extensive fishery is carried on from Cape Ann for these fish in winter, and there are sometimes as many as fifty ressels engaged. It was estimated in $S_{7} S$ that the total quantity landed at Gloucester was not far from 5,000,000 pounds. 'The fishing is carried on almost entirely at night with the use of trawls, which are about the size of those used in the capture of Haddock.

Hake are salted and dried in the same manner as Codfish, and are often sold under the name of Codfish. Before the introduction of boneless fish it was sometimes difficult to sell them on account of the difference in appearance, Lut at the present time great quantities of Hake are put up) in boxes uncier the tracle name of "boneless fish," the qualifying word "Cod" being usually cmitted from the brands and labels. The Hake is not often eaten except when salted.

The air-bladder, or sound, of the Hake is of great commercial value, being used extensively in the manufacture of isinglass; great quantities of sounds are sent from the British Provinces to the United States annually. sounds from the Gulf of St. Lawrence being considered much better than those from farther south. In ISSo New England produced 255,69S pounds of dried sounds, worth $\$$ I $7 \delta, S \circ S$. Massachusetts had eight isinglass and glue factories, employing one hundred and eighty-two men and a capital of $\$ 3 \bar{T}, 5,000$, and producing $\$ 450,000$ worth of ribbon-isinglass and glue in $S_{79}$. These sounds were for the most part derived from the Hake.

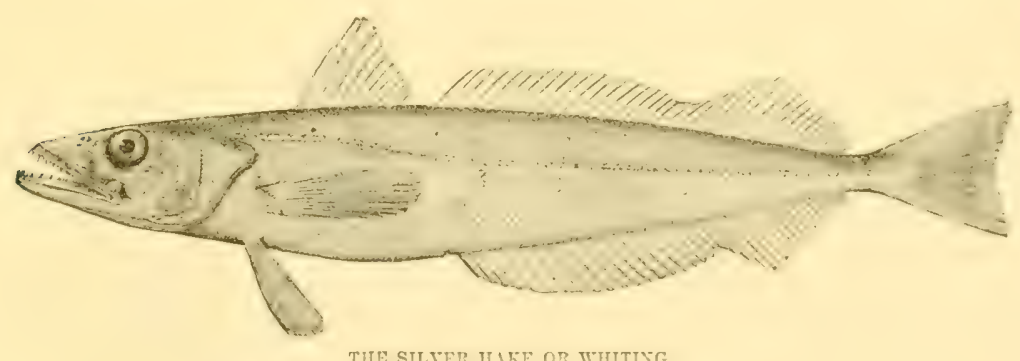

TIE SILVER II.IKE OR WHITIN,

It is the opinion of certain writers, among whom Dr. Gunther is leader, that the Hake of Europe, Mcrlucius merlus (or M. imlgaris of recent authors), is identical with the species of Mcrlucius occurring in the Western Atlantic. This is, however, a mistake; the American form may easily be distinguished from that of Europe by the greater number of 
rays in the first dorsal (Io to I I in $M$. merlus, I 2 to I $3_{3}$ in $M$. bilinearis), and by the larger size of the scales (the number in the lateral line being about 150 in $M$. merlus, roo to I 10 in $M$. bilinearis).

The general appearance of the two species is very similar, and it requires careful study to separate them. It is probable that at no very remote period they diverged from a common stock. The clistribution of the two species upon the opposite sides of the Atlantic coincides very closely with that of other Gadoid fishes, which are specifically identical in Europe and America. The Hake of Europe is found along the coast from Trondhjem Fjord, latitude $65^{\circ}$, south to $36^{\circ}$, being very abundant in the Mediterranean ; also found on the coast of Portugal and in Western France. In the English Channel, however, and in the waters of Holland and Germany, it is considered very unusual. On our coast it ranges from New York to the Gulf of St. Lawrence, where it is common-especially in the Bay of Chaleur-but it has rarely been observed as far north as the Straits of Belle Isle. Dr. Packard was told by fishermen that during a period of forty summers spent on the coast of Labrador they had taken but one specimen of this fish. This fish has been found at great depths as far south as latitude $36^{\circ}$ and $37^{\circ}$.

The name Silver Hake, by which this fish is known in the Bay of Fundy, is much more appropriate than that of Whiting, though the latter is more frequently heard in New England; its similarity to the European Hake is very great; while the name Whiting, which is in Europe applied to a species (Merlangus vulgaris), somewhat resembling the Pollock, has been appropriated in this country for a fish which frequents our southern coast and belongs to the drum family.

The Silver Hake commonly inhabits the middle depths of the ocean, or the outer edge of the continental slope, and comes to the surface to feed. Like the Pollock, it is a fish of prey; its teeth are sharp, its mouth large and powerful, and its form lithe, muscular, and adapted to rapid locomotion. It comes to the surface to prey upon the schools of herring and other small fish, and is frequently caught in the mackerel and bluefish nets. Its appearance in our waters is irregular, and when seen it is usually swimming in schools in considerable numbers.

They average one foot in length. They are of roving habits, following the shoals of herring, which they devour in great quantities. Until r 880 little was known concerning the breeding habits of the Silver Hake; but, 
in exploring the bottom, at a clepth of from one hundred and fifty to three hundred fathoms, off Newport and in the edge of the Gulf Stream, immense numbers of young fish, from half an inch to three inches in length, were found at the bottom, and with them were many adults, twelve to eighteen inches in length, apparently in the act of spawning; some of them with the ova ripe, or nearly ripe, but not yet shed; others evidently spent-fish. This discovery was exceedingly interesting, since it may serve as a clew to the spawning habits of other species, like the bluefish and menhaden, which have been supposed to spawn at a distance from the shore, but have never been detected in the act. The spawning period doubtless extends over a consicierable space of time; some of the eggs from which the largest of the young were hatched off Newport must have been laid as early as July. In September an adult, obtained at Halifax, Nova Scotia, had the ova well developed and nearly ready for deposition. It is not known whether the eggs of the Silver Hake float or sink. Couch states that the spawning season of the European Hake is from January to April, at which time the fish are caught near the bottom, and lose the great voracity by which they are characterized at other times, so that multitudes are caught in trawls, and a few with lines. When pilchards approach the shore the Hake follow them, continuing in incalculable numbers throughout the winter.

The Hake of Europe is always considered a coarse fish, and though great quantities are annually salted and dried it is not held in very high esteem. Many of the salted fish are sent to Spain. They are said to be quite common on the northern shore of the Mediterranean, where consiclerable traffic is carried on with them; they are packed with aromatic plants and sent to the towns remote from the coast.

Storer remarks: "Occasionally this species is brought to market, and when perfectly fresh is a very.sweet fish, boiled, broiled or fried. It soon becomes soft and is preserved with difficulty. As it does not appear to be known abroad, and the fishermen consequently have no call for it, it is not cured, but is considered worthless. In the months of September and October the Whiting is used somewhat for bait for the dogfish and answers a good purpose."

The California Hake, Mcrlucius productus, writes Prof. Jordan, is most commonly known along the coast by its Italian name, "Merluccio," pronounced merlooch. At Soquel and elsewhere it goes by the name of 
Horse-mackerel, a name used on our coasts with the greatest carelessness, being applied to Elops saums, Anoplopoma fimbria, and Mcrlucius productus, as well as to various scombroids and carangoid fishes. It reaches a length of about thirty inches and a weight of ten pounds, its average weight being five or six. It is found from the Island of Santa Cruz to Alaska, being very irregular in its appearance, some years very abundant and at other times wanting altogether. It is exceedingly voracious, feeding on all sorts of small fishes and squids. The stomach is always filled almost to bursting.

It spawns in the spring, and its arrival near the coast always precedes the deposition of the spawn. It probably then retires to deeper water.

Its value as a food-fish is very little. It is scarcely salable in the market of San Francisco. Its flesh is very soft, and it is always ragged-looking when shipped. Nothing was learned as to the quality of its flesh, but it probably differs little from the Atlantic form Merlucius bilinearis.

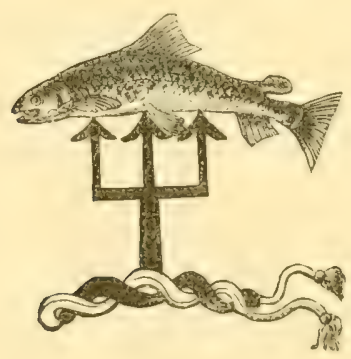




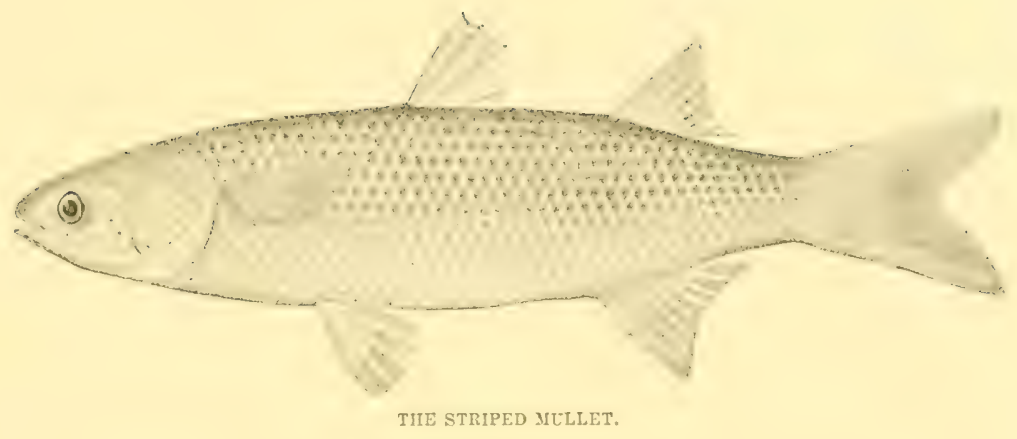

THE MULLETS.

Still shall be heard the loons lone cry

Upon the stream, and to their rest Long troops of curlews seaward fly, At sunset to their sandy nest.

Still joyous from the sparkling tide W'ith silver sides shall Mullets leap The eagle soar in wonted pride, And by their eyrie strong and wide On the dry oak beside the deep, Their watch shall busy ospreys keep.

Willian J. Grayson: The River Coosa.

$\mathrm{O}$ $\mathrm{N}$ our eastern coast there are two species of Mugil, the differences between which are sometimes, though not always recognized by fishermen. The most familiar is the Striped Nullet, Mugil albula; the other is the so-called "White Mullet," Mugil brasilicnsis. The former is the larger, and has eight instead of nine rays in the anal fin, and forty-two instead of thirty-eight scales between the gill openings and the base of the caudal fin. There has been so much confusion among writers regarding the species of this family upon our coast that it has until very recently been impossible to define precisely their geographical range. The Striped Mullet occurs in the West Indies, the Gulf, and from Lower California to Peru. A single specimen of $M$. brasilicnsis, was taken at Provincetown, in November, IS5I. North of New Jersey the capture of a large individual is very unusual. In July great numbers of them, about an inch in length, have been observed on the Connecticut coast, especially in the vicinity of Noank; the fishermen there call them by the name of 
"Bluefish Mummichog." On various parts of the coast they have special names, which, however, do not appear to refer to special peculiarities. About Cape Hatteras the names "Jumping Mullet" and "Sand Mullet" occur ; in Northampton County, Va., "Fat-back," and in Southeastern Florida "Silver Mullet" and "Big-eyed Mullet." The name "Fatback" is also in use, but whether this name is used for Mullets in general, or simply for those in particularly good condition, I have been unable to learn. In the Gulf of Mexico the Striped Mullet is known simply as the "Mullet"; the other species as the "Silver Mullet."

There are seventy or more species of Mullets, some of which are found on every stretch of coast line in the world in the temperate and tropical zones. They live in the sea, and in the brackish waters near the mouths of rivers. They, like the menhaden, though indeed to a still greater degree, subsist on the organic substances which are mingled with the mud and sand on the bottom.

In order to prevent the larger bodies from passing into the stomach, or substances from passing through the gill openings, they have the organs of the pharynx modified into a filtering apparatus. They take in a quantity of sand and mud, and after having worked it for some time between the pharyngeal bones, they eject the roughest and most indigestible portion of it. Each bronchial arch is provided on each side, in its whole length, with a series of closely set gill-rakers, which are laterally bent downward, each series closely fitting into the series of the adjoining arch; these constitute together a sieve, admirably adapted to permit a transit for the water, retaining, at the same time, every other substance in the cavity of the pharynx. The intestinal tract is no less peculiar, and the stomach, like that of the menhaden, resembles the gizzard of a bird. The intestines make a great number of circumvolutions, and are seven feet long in a specimen thirteen inches in length.

Although Mullets are abundant almost everywhere, it is probable that no stretches of sea-coast in the world are so bountifully supplied with them as those of our own Southern Atlantic and Gulf States, with their broad margin of partially or entirely land-locked brackish water and the numerous estuaries and broad river mouths. The mullet is probably the most generally popular and the most abundant fish of our own whole southern seaboard. Like the menhaden, it utilizes food inaccessible to other fishes, groping in the bottom mud, which it swallows in large quantities. Like 
the menhaden, it is not only caught extensively by man, but is the main article of food for all the larger fishes, and is the best bait fish of the regions in which it occurs. In the discussion of the habits of the Mullet, when it is not otherwise stated, the Striped Mullet, which is in our waters by far the most important species, is kept chiefly in mind.

Since the time of Capt. John Smith every observer has remarked upon the great abundance of Mullets. Numerous correspondents of the Fish Commission, from Wilmington south, agree that the Nullet is far more abundant than any other species, except Mr. Simpson, who thinks that at Cape Hatteras they are less numerous than the tailors or blue-fish, and about as numerous as the fat-backs or menhaden.

In $S_{75}$ circulars were sent out by the United States Fish Commission, asking information concerning the habits of the Mullet. The replies, although suggestive, were not sufficiently numerous to afford the data necessary for a complete biography of this species. In fact its habits are so peculiar that in order to understand them it will be necessary for some naturalist to devote a considerable period of time to study them throughout the whole extent of their range. At present, therefore, I propose to present first the results of my own observations upon this fish, as it occurs in Eastern Florida, supplementing them with the excellent study of the Gulf Mullet from the pen of Mr. Stearns.

Mullets abound in the St. John's River, sometimes running up to the lakes, and along the coast in all the inland bays, or "salt-water rivers." It is probably incorrect to call them anadromous. They appear to ascend the rivers to feed, and the relative saltness of the water is a matter of small importance. Small mullet are abundant all the year round, and so are scattered individuals of a larger size. Cast-nets at Mayport take them throughout the year. I have taken quantities of small fish, from one to five inches long, in the St. John's near Arlington. They begin to assemble in schools in midsummer. This is probably preparatory to spawning, for at this time the ova are beginning to mature. In midsummer they swim at the surface, pursued by enemies in the water and the air, and are an easy prey to the fishermen. They prefer to swim against the wind, and, I am told, school best with a northeast wind. They also prefer to run against the tide. The spawning season appears to continue from the middle of November to the middle of January, and the weight of evidence tends to show that they spawn in brackish or salt water. 
Some of the fishermen say that they go on the mud-flats and oyster-beds at the mouth of the river to deposit their eggs. What becomes of them after this no one seems to know, but it is probable that they spread themselves throughout all the adjacent rivers, bays, and sounds, in such a manner as not to be perceptible to the fishermen, who make no effort at this time to secure the spent, lean fish. Many of them probably find their way to the lakes, and others remain wherever they find good feeding ground, gathering flesh and recruiting strength for the great strain of the next spawning season. There is no evidence of any northern or southern coastwise migrations, the habits of the species apparently being very local.

The fisherman recognizes three distinct periods of schooling or separate runs of mullet. To what extent these are founded on tradition, or upon the necessity of change in the size of the mesh of their nets, it is impossible to say. The "June Mullet" average about five to the pound; the "Fat Mullet," which are taken from August 20 to October I, weigh about two pounds; these have, the fishermen say, a "roe of fat" on each sicle as thick as a man's thumb. The "Roe Mullet" weigh about two and a half pounds, and are caught in November and until Christmas. Between the seasons of "Fat Mullet" and "Roe Mullet" there is an intermission of two or three weeks in the fishing. How to interpret these curious statements is surely a difficult problem, and one which can be solved only by careful study of the fishes themselves at these seasons. The fishermen insist that these schools come successively down the river and proceed directly out to sea. They will not believe that the "Fat MIullet" and the "Roe Mullet" are the same schools under different circumstances. I would hazard the suggestion that the "Fat Mullet" of September are the breeding fish of Norember, with roes in an immature state, the ova not having become fully differentiated.

The largest fish appear rarely to exceed six pounds. This is exceptional, however. Mr. W. H. Tate, of Melton \& Co., Jacksonville, tells me that he never saw one exceeding seren pounds, though he had heard of one weighing fourteen. He showed me on the floor of the fish-market a line indicating the length of a very large one; this measured twenty-nine inches. At Mayport none had been seen exceeding six pounds in weight. At the mouth of the St. John's cast-nets ten feet in diameter are used, but most Mullet are taken in gill-nets, which are swept around the schools, the fish being easily visible at the surface. These nets are from 
seventy to ninety fathoms long and forty meshes deep. The size of the mesh varies with the season. Very few are used from December to July, but where they are used the mesh two and one-half to two and threequarters inches is preferred ; from August $\mathrm{x}$ to October $\mathrm{I}$, for "Fat Mullet," the mesh is three and one-half to three and three-quarters inches, and in late October, November, and December, for "Roe Nullet," four inches-at least so said my informant, an intelligent negro fisherman. At Mayport there were in $\mathrm{I} \$ 85$ two sweep-seines, seventy-five fathoms long and thirty feet deep, belonging to Kemp, Mead \& Smith, used in the Mullet fishery.

There is a large trade in fresh Mullet iced, of the extent of which I could gain but little idea; they are shipped chiefly to Central Florida and Georgia. Some have been sent in ice to Atlanta. About twenty thousand are shipped from Yellow Bluffs, by way of Jacksonville.

It is the general opinion of the fishermen that the Mullet have greatly diminished in abundance of late years, and that they are not one-third as plenty as they were ten years ago. This falling off is attributed to the presence of steamers, to the changes of the season, and, most of all, to the use of small-meshed seines, which catch the young fish in great numbers, and to the constant fishing by numerous nets, which destroys a large proportion of the mother-fish from year to year. Mr. Isaac Calsam, of New Berlin, told me that ten or twelve years ago a man with a cast-net could easily take four or five hundred Mullet in a day, while now it is difficult to get any; this is due in part to their shyness. Mullet were comparatively scarce in the St. John's in $\mathrm{I} 877$, though plenty in $\mathrm{r} 876$. The fishermen with whom I have talked favor the passage of laws prohibiting the use of gill-nets with a smaller mesh than three inches, and thus to allow the escape of the young fish, and of a close time during which fishing shall cease-for instance from Saturday night to Monday morning. And then they say, with a regretful shake of the head, that the Nullet always run best on Sunday. There are probably one hundred or more Mullet nets on the St. John's, yielding an average of perhaps five thousand Mullet each annually. The fisheries are chiefly carried on by negroes in small boats, dug-outs, and skiffs, although every resident fishes for Mullet in summer when there is nothing else to do, and when the Mullet is the best food and the easiest obtained. There is no salting business of commercial importance in East Florida, though considerable 
quantities are put up for domestic consumption. Salt Mullet sell at the rate of eight or ten dollars a barrel, or five or six fish for twenty-five cents. I had an opportunity of tasting some salted by a negro at Mill Cove, and can bear testimony to their excellence. Their flavor is more like that of salted salmon than of mackerel, and they are hard, toothsome, and not at all "muddy" in taste, this last being the usual charge made against the Mullet. Usually only the "Fat Mullet" are salted, the "Roe Mullet" being caught later in the season, when they can easily be shipped.

To prepare a Mullet for salting, the head is first cut off, then a cut is made on each side of the back-bone, down the back, and the bone is removed; the fish may then be spread out flat, and packed in a barrel. In packing, the flesh side is carefully placed up, the skin down. The fish are spread out flat upon the skin side and are laid in tiers across the bottom of the barrel, each tier being covered with salt. Care is taken to have the direction of the bodies in the different tiers at right angles to each other. When the Mullet are scaled before packing they command a somewhat higher price. Mullet roes, though usually eaten fresh, are sometimes salted and dried in the sun. In this condition they are eaten raw, like dried beef, or are fried. Large ones sell for ten cents a pair. Fishermen often boil the heads to extract the oil, which they use to lubricate their guns.

Mr. Silas Stearns has prepared a most valuable study of the habits of the Mullet, and writes as follows:

"The Mullet is one of the most abundant and valuable food-fishes of the Gulf coast. It is present on the coast and in the estuaries of the Gulf throughout the year, and in most places is pursued by fishermen at all seasons, yet, for so common and important a fish, its habits seem to be but little known or understood. Intelligent fishermen of long experience at particular points have learned many details regarding their local movements, which may disagree in many respects with those at some other point a hundred miles or so away. A few months spent on the southern part of the Florida coast has led me to believe that there is a less migratory movement of Mullet in that section than along the northern Gulf coast. It is probable that in each bay or section or coast Mullet have peculiar habits as to time and manner of arrival, time and place of spawning, and the general habits of old fish after spawning and young 
after hatching. It is also likely that their manner of spawning and feeding is the same everywhere. My own observations have been chiefly made in Pensacola and Choctowhatchee Bays and Santa Rosa Sound, which take in fifty miles of coast line. In this section, which I have called the Pensacola region, there is a spring "run' of Mullet composed of various sizes of young which are in part, no doubt, of the previous year's hatching. The first school of this run appears on the coast in April or in the first part of May, and they continue to come for two or three weeks, when they are all inside and scattered about the bay shores. These fish are very thin on their arrival, but rapidly fatten and grow on the feeding grounds. Some of these contain spawn at first, and in some it is developed during the summer.

"In September and October there is a "run" of large fish, which comes, as usual from the eastward, the fish swimming at the surface of the water and making considerable commotion. Some years there is but one large school in the 'run' and at others many small schools, and it is thought that the fish are more abundant when they come in the latter form. At Chotawhatchee Inlet, when the spawning grounds are near by, the fish come in with the flood tide and go out again with the ebb tide; and at the Pensacola Inlet, when the spawning grounds are far away, they come into the bay and stay until the operation of spawning is orer. The spawn in this fall 'run' is fully developed, and is deposited in October and Norember. The spawning grounds are in fresh or brackish water at the heads of bayous, in rivers or heads of bays. The many bayous of Choctawhatchee Bay are almost blocked up with spawning Mullet in October, and they are very abundant at the head of Pensacola Bay near the mouths of fresh-water rivers at that time. Although I have been in the bayous when Mullet were supposed to be spawning, I have not witnessed the operation, nor seen any person who has. In such places the bottom is grassy, sandy, and muddy, the water varying with the tide from fresh to brackish, and of a temperature varying from $70^{\circ}$ to $75^{\circ} \mathrm{F}$. It is supposed that the spawn is deposited upon the bottom. If they hare been spawning at the times when I have been present, I would say that the operation was a general one. That they do spawn at or near these places is quite certain, for they go to them with spawn and come away without it, and the young fry first appear near the same places. Crabs and alligators are abundant in such places, and they doubtless destroy many 
of the eggs and fry. Before spawning Mullet are very fat, but after the operation are extremely thin and worthless for food. Their colors also undergo some changes, at sea being bright blue on the back, which deepens to a light brown in the bays and to a dark brown in fresh water. By these characteristics it is not difficult to determine the locality where a lot of Mullet are caught.

"Some persons of this coast agree that Mullet, or any other sea-fish, will not bear sudden change from salt to fresh water, and to meet this argument I made an experiment with Mullet in I879. I took a dozen or more medium-sized Mullet from the warm shoal water of the bay and placed them in cool, fresh spring water. They swam around very rapidly for about half an hour, then sank to the bottom of the spring, where they remained, apparently comfortable, for twelve hours. Before leaving the spring I returned them to their native waters, seemingly in as good condition as when first caught. The bay water was at that time $77^{\circ} \mathrm{F}$. and the spring water $71^{\circ} \mathrm{F}$, a difference of $6^{\circ}$ and a change from pure salt to pure fresh water.

"After spawning, in October and November, the Mullet leaves these bays in small schools, going directly to deep water if the weather is stormy, and following the beach along if there is not much surf. Those that have been in the bays all the summer leave also at about this time, many of them having spawned at the same time with the full 'run.' A few of these, having just reached maturity, are found with spawn nearly all winter; also, some young stragglers. In February, March, and April young Mullet, varying from one to two and a half inches long, are found in great abundance along the bay shores. Mullet grow to about eight inches in length the first year, to twelve or thirteen inches the second year, when they are mature. The average size of adults is twelve inches in length, weightabout one and a quarter pounds. The largest I have seen measured twenty inches long and weighed four and a half pounds. It was caught at Charlotte Harbor, Fla. Mullet of that size are extremely rare in West Florida. Those of South Florida are much larger, as a rule, than those found further north. There they are also far more abundant than on the coasts of West Florida, Alabama, Mississippi, Louisiana, and Texas.

"In October, Charlotte Harbor, Sarasota and Palmasola Bays, seem to be the headquarters of all the Mullet of the Gulf. Tampa Bay, Anclote 
River, Homosassa River and ricinity, are also favorite spawning places. During the fall they move in such immense schools that the noise of their splashing in the water resembles distant thunder; and to persons living near the river or bay, their noise, kept up day and night, becoming very annoying. These schools are followed by large numbers of sharks, porpoises, and other destructive fishes, as well as pelicans and like sea-birds, all of which eat of the Muliet until they can eat no more, and have to make way for fresh arrivals. In spite of these enemies and those of the eggs and fry, Mullet are as plentiful as formerly, according to the general opinion of the fishermen of the coast."

The Mullet is a bottom-feeding fish, and prefers still, shoal water with grassy and sandy bottom. It swims along the bottom, head down, now and then taking a mouthful of earth, which is partially culled over in the mouth, the microscopic particles of animal matter or vegetable matter retained, and the refuse expelled. When one fish finds a spot rich in their desired food, its companions immediately flock around in a manner that reminds one of barn-yard fowls feeding from one dish. The Mullet eats rery little compared with other fish of its size. It preys on no other fish, and is preyed upon by nearly all other common fishes larger than itself. It does not readily take the hook, but can sometimes be caught with a bait of banana, or one manufactured from cotton and flour. It is the most widely distributed fish of the Gulf of Mexico, being found on the seabeach everywhere, in all the bays and sound, and even far up fresh-water rivers and in fresh-water lakes that have outlets.

Concerning the other species of Mullet, Mugil brasilicusis, as occurring in the Gulf, Mr. Stearns writes:

"It is common, and is found in company with the Mugil albula and usually considered with it, and the old fishermen of Pensacola clistinguished it and have given it the above name. I have found spawn in them in May and June. On the southern coast they are very abundant, and appear in Key West almost daily in the fall and winter."

"On the California coast occurs IIJugil albula," writes Prof. Jordan, "which is commonly known as the 'Mullet.' It reaches a length of about fifteen inches. It is very abundant about San Diego, and thence south to Mazatlan, and it ranges occasionally northward as far as Monterey. It enters creeks and lagoons, ascending as far as the brackish water extends, in the winter, and thus is often land-locked in great numbers, which are then destroyed by the sea-birds, especially by the pelicans, and a few are taken in seines. It swims in schools in the bays, 
and its presence is made known by its frequent leaps from the water. It is said that the Mullet has long been known at San Diego, but that it first made its appearance at San Pedro in 1877 . It is not well known either at Santa Barbara or Soquel, although occasionally taken at both places. Those fishermen who have given the matter any attention assert that the Mullet is gradually extending its range northward. It feeds on mud and minute organisms contained in it. It is considered a good food-fish when taken from the ocean. In the muddy lagoons it acquires in summer a rank flavor."

The Mullet of America compared to the Grey Mullet of Europe, must be carefully distinguished from the Mullus of classical literature.

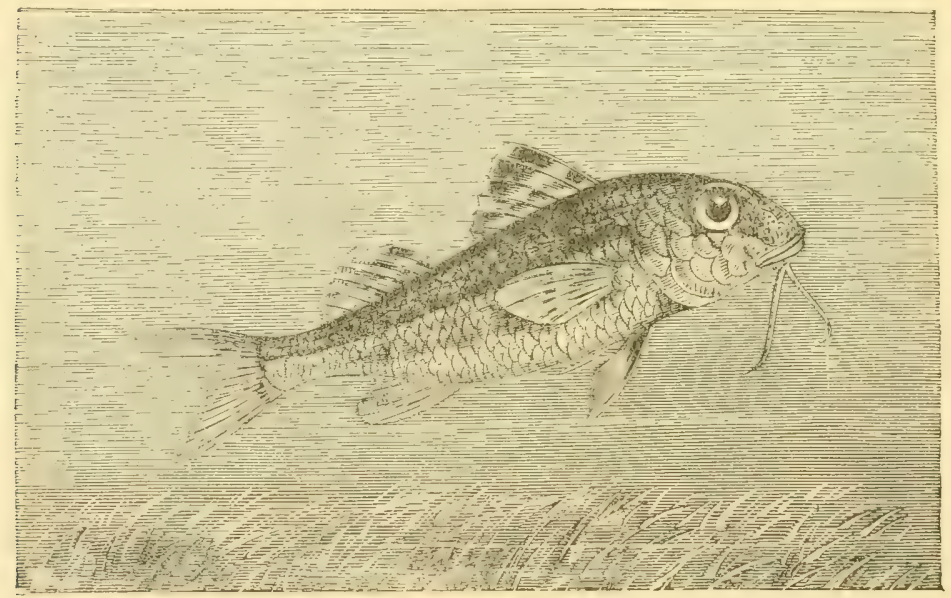

THE RED MULLET OF EUROPE.

This fish, the Red Mullet or Surmullet of modern nornenclature was the favorite of the gourmets of ancient Athens and Rome. It was brought living into the banquet hall, that the guests might admire the brilliant change of color exhibited in its expiring struggles. There are two or three related species in our waters, one of which Upencus flavovittatus, the Croatfish, is occasionally captured in New England. 


\title{
THE STURGEONS.
}

\author{
On the white sand of the bottor. \\ Lay the monster Mishe-Nahma \\ Lay the sturgeon, King of Fishes.
}

LONGFELIOW: Hiaziatha's Fishing.

WO species of Sturgeon are supposed to exist on our Atlantic coast.
The most abundant of these, Acipenser oxyrhynchus, is now generally supposed to be identical with the common Sturgeon of Europe, $A$. sturio. The other, A. Urevirostris, which is distinguished from A. oxyrluynchus by its shorter and blunter nose, has not yet been found north of Cape Cod, and appears to be comparatively less abundant, although both species are found in great numbers in the larger rivers and estuaries during the si.m. mer season, and are frequently seen leaping from the water, especially at dusk. A leaping Sturgeon is a striking object, the whole length of the fish appearing above the surface before it falls back with a splash into the water.

The Sturgeon attains the length of five to twelve feet. In Europe, individuals of the common Sturgeon eighteen feet long have been observed. They spawn in spring and early summer, in the lower stretches of the rivers, and perhaps also at their mouths, in brackish water.

The mouth is situated upon the under surface of the head, and is not provided with teeth, but is surrounded with a cup-shaped organ composed of powerful muscular tissue, by means of which it grubs for its food in the mud. Its stomach resembles that of the menhaden and mullet, though comparatively more muscular, since, like the gizzard of a fowl, one of its uses is to triturate the food which has been swallowed, and which consists largely of mollusks, and crustaceans. Around the mouth is a group of large and sensitive tentacles, which aid the fish in its search for food.

No one has yet made a careful study of the habits of the Sturgeon in our waters, and in fact European zoologists have made little progress in the study of the species of the Old World.

Within the past few years the capture of the Sturgeon for smoking and for the manufacture of caviare from its eggs has attained considerable importance on the Atlantic coast. The most satisfactory discussion of this fish is that published by Milner in Part II, of the Report of the United States Fish Commission, pages 67 to 75 . 




THE CATFISH OR BLLL-HEAD.

Don't talk to me o' bacon fat

Or taters, coon or 'possum,

Fo' when I'se hooked a yaller cat

I'se got a meal to boss 'em.

The Darky and the Catfish.

THE Catfish is somewhat like paté de foie gras or pickled olives. 1 Those who do not very much like it detest it. The metropolis of its popularity is Philadelphia, but whenever taken from clear, cool water it is palatable, and when properly cooked even delicious, its texture and flavor resembling that of the eel. Since every small boy begins his angling experiences with Catfish, instructions for its capture would be superfluous. Its appetite is always good, and its palate, or whatever stands for palate in fish architecture, by no means delicate. A spice of danger attends its capture, and perhaps the excitement of taking one of them off the hook, atones in part for its lack of gameness in the water, for a well constituted catfish always gorges the hook, and its spines, always erected, inflict painful wounds. Certain anglers I belicre, essay the capture of catfish with fly and fancy tackle. It would be cruel to deprive ingenious tyros of the privilege of learning this method for themselves.

I am assured that salt mackerel is almost as good a bait as angle-worms or live minnows-a secret of great economic importance to small boys. Another secret is this, that the catfish never bites when an east wind is blowing. 
I am indebted to President Jordan of Indiana University, for the following remarks upon this group:

"The Catfishes abound in all the fresh waters of the United States east of the Rocky Mountains. The species of the three genera, Ictalurus, Amiums, and Leptops, which constitute the bulk of the family as represented in North America, all reach a length of from one to five feet, and are all food-fishes of more or less importance. One of the Catfishes, Ictalurus ponderosus, is our largest fresh-water fish, weighing upwards of one hundred and fifty pounds, and two of the others, Leptops olivaris and Ictalurus nigricans, reach a very considerable size.

"The Catfishes are voracious and indiscriminate feeders, any kind of animal substance, living or dead, being greedily swallowed by them. They are also (especially the species of Amiums) extremely tenacious of life, living for a long time out of water, and being able to resist impurities in the water better than any other of our food-fishes. They spawn in spring, and the female fish keeps a watch over the school of young, much as a hen takes care of chickens. The Catfishes are especially adapted for stocking ponds and sluggish streams with muddy bottoms, which become partly dry in summer, bodies of water not suited for the more aristocratic trout and bass.

"The species of the genus Ictalurus-known as "Channel Cats" are much less hardy than the other Catfishes, and do not thrive wall exicept in river channels. Any water which does not dry up absolutely to the bottom in summer will suffice to nurture the common small Catfishes.

"The flesh of all the Catfishes is of fair quality, not delicate nor tender, but of good flavor. The Channel Cats have whiter meat than the ordinary small Catfish, but the flesh is drier, and the latter are usually preferred."

The Channel Cat or Blue Cat, Ictalumus punctatus, abounds in all the larger Western and Southern streams, living in the river channels. It reaches a weight of five to ten pounds and is readily salable, but its flesh is not better than that of its less attractive relatives. It takes the hook readily. This species is abundant in the St. John's River, Florida. In I878 many were taken near the bar at Mayport in brackish water. For table use they are much more highly esteemed than the Mud Catfish.

The Great Mississippi Cat, Ictalums ponderosus, the largest of our Catfish, is found in the Mississippi, and probably in its larger tributaries, where it reaches a weight of about one hundred and fifty pounds. Little distinctive is known of its habits, which probably agree with those of the next species.

The Great Lake Catfish, Ictalums nigricans, the most abundant of the large Catfishes, abounds in the Great Lakes and in the larger streams of 
the West and South as far as Florida. It reaches a weight of fifty to one hundred pounds, perhaps more. In all the markets of the region where found it is one of the most important species, and its flesh, which can be cut in "steaks" like Halibut, is generally esteemed. Nothing distinctive is known of its breeding habits or rate of growth. Prof. Goode remarks : "I have observed frequently enormous specimens of this species in the St. John's River, where they are called Mud Cats. The young are sometimes called "Flannel-Mouth Cats."

The White Catfish, the Channel Cat of the Potomac, Ictalumus albidus, of the tributaries of the Chesapeake Bay, is very abundant in the Susquehamna and Potomac Rivers, and forms an important part of the fish supply of the Washington market. It reaches a weight of two to five pounds, being much smaller than the preceding species, which it resembles.

Aminus nebulosus, the common "Horned Pout," "Bull-head," "Bullpout," or "Minister" of the Northern and Eastern States is the most generally abundant and familiar representatives of this family. It reaches a length of about eighteen inches and rarely exceeds three or four pounds in weight, while the majority of those seen in the markets are still smaller. It is probably the hardiest of all our fresh-water fishes, thriving in any waters, but preferring those which are quiet and shaded. Numerous other species very similar to this occur in our fresh waters.

The Bull-head has been introduced from the Schuylkill into the Sacramento and San Joaquin Rivers in California. It has there very rapidly multiplied, and is now common in all the sloughs and bayous of the lower courses of these rivers. As a food-fish it is not very highly valued by the Californians, most of those brought to market being taken by the Chinese. Leptops olivaris, the "Mud Cat," "Yellow Cat," "Goujon," or "Bashaw" is found in all the large rivers of the West and South. It reaches a weight of at least fifty pounds. It is found only in the larger streams, swimming near the bottom. It is less attractive in its appearance than the other Catfishes, but we are not aware that its flesh is inferior to that of the others. This species, and other of the larger Catfishes, are often caught by "jugging," the bait being attached to a jug filled with air, which will in time tire out the fish and bring it to the surface.

'The Stone Cat, Notumus flazus, reaches a length of about a foot; the other Stone Cats (Noturus) are still smaller, and none of them can be considered as food-fishes. 
The Gaff-topsail Catfish, Elurichthy's marimus, which ranges from Cape Cod to Florida, is found chiefly in brackish water. It is not uncommonly taken at Arlington, Florida, and Empire Point. It is known here and at Pensacola as the "Sea Cat," and at Brunswick, Ga., as "Gaff-topsail," in allusion to the shape of the first dorsal fin. According to Mr. H. S. Williams, it is abundant in the Indian River. It is common also along the Gulf coast, but is nowhere valued as food. Many of the fishermen believe this species to be viviparous. Mr. S. C. Clarke, writing from New Smyrna, Narch 3I, I874, remarks: "They have eggs in them as large as cherrics."

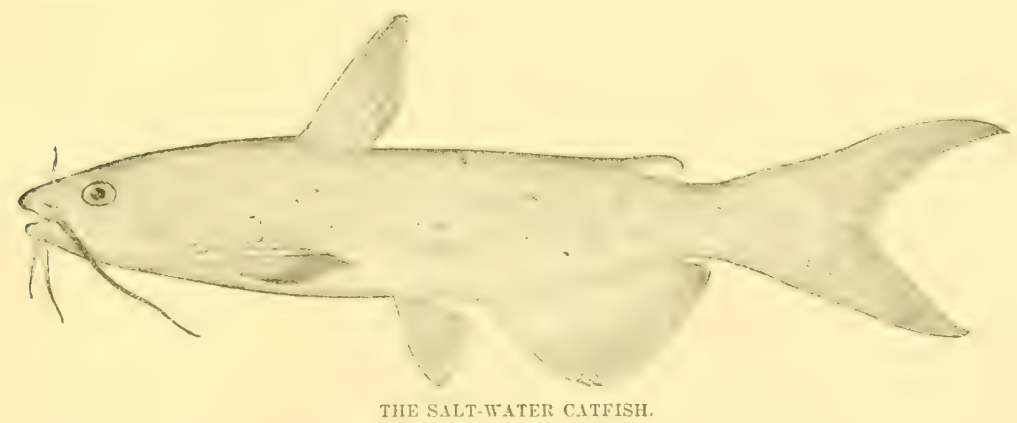

The Salt-water Catfish, Arius felis, is found along the coasis of the Gulf of Mexico to as far north as Cape Hatteras. In the first volume of the Proceedings of the United States National MIuseum, p. 278 , is an interesting account of its breeding habits, as observed by Prof. N. 'T. Lupton. The species spawns there in July, and the parent (sex not stated) carrics the eggs in its mouth. Silas Stearns says of this fish :

"The Salt-water Catfish is very abundant everywhere on the Gulf coast. It is found on the sea-beaches, the shores and bottoms of bays and bayous, and even some distance up fresh-water streams. It is a bottom-loving fish, feeding upon worms and small crustaceans chiefly, but will readily eat anything else-fish, flesh, or fowl, dead or alive, As the pest of these waters, it is ever present and never welcome. It breeds in the summer, in June, July, and August. The spawn is deposited in the depression in the sand and impregnated with the milt. One of the parent fish then takes the eggs in his mouth and by some morement fixes them against the gills, or between the leaves of the gills. 'The eggs are carried in this position until the embyro fish are hatched and have become perfect and able to care for themselves. The eggs when full size resemble white grapes; they are large and clear. Sometimes the parent fish's jaws are much distended by the eggs and young inside, and its appearance is comical. 
The Catfish has been introduced in Europe, and in Belgium is already fairly well acclimated. Attempts have been made to introduce it into England - an act of international courtesy which might perhaps offset in a slight degree our debt to our motherland for the gift of the English Sparrow. Punch in this connection has made his only contribution to the literature of fish culture under the caption :-

\section{NO CATFISH, PLEASE!}

Oh do not bring the Catfish here!

The Catfish is a name of fear.

$\mathrm{Oh}$, spare each stream and spring.

The Kennet Sivift, the Wandle clear,

The lake, the loch, the broad, the mere,

From that detested thing !

The Catfish is a hideous beast,

A bottom-feeder that doth feast

Upon unholy bait :

He's no addition to your meal.

He's rather richer than the eel;

And ranker than the skate.

His face is broad, and flat, and glum ;

He's like some monstrous miller's thumb;

He's bearded like the pard.

Beholding him the grayling flee,

The trout take refuge in the sea,

The gudgeons go on guard!

He grows into a startling size ;

The British matron 'twould surprise.

And raise her burning blush.

To see white catfish, large as man,

Through what the bards call "water wan"

Come with an ugly rush!

They say the catfish climbs the trees,

And robs the roosts, and, down the breeze,

Prolongs his catterwaul.

Ah, leave him in his western flood,

Where Mississippi churns the mud;

Don't bring him here at all! 


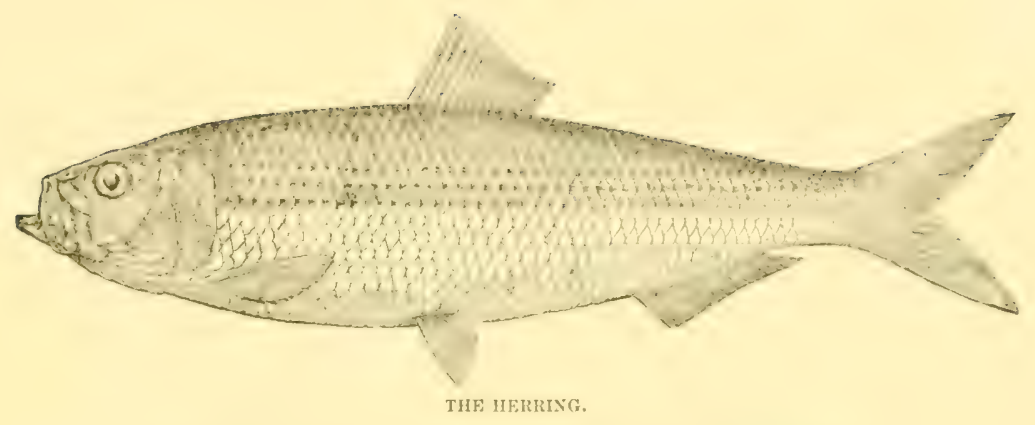

THE HERRING AND ITS ALLIES.

\begin{abstract}
But why, good fisherman,
Am I thought meat for you, that never yet

Had angling rod cast towards me?

Between dark hills on either side

The salt sea-loch runs for a mile, And now, sun-charmed to a smile, Gleams bright its flowing frothing tide.

But lo! each wave to silver turns

In dazzling fire the whole loch burns, Millions of Herring dart and splash.

Each one a living lightning flash.
\end{abstract}

Mrdoleton and Dekkar: Moll Cut Purse, i6ri.

William Sharp: A Herring Stzoal, i8S4.

\begin{abstract}
THE Herring family contributes more generously than any other group of aquatic animals to the support of man, and the Herring is beyond question the most important of food-fishes. Distributed throughout the whole of the North Atlantic, it affords occupation for immense fleets of fishing boats, and, according to Huxley, the number taken every year out of the North Sea and Atlantic is at least 3,000,000,000 with a weight of at least $\mathrm{I}, 500,000,000$ pounds. According to Dambeck, the average yield in Norway from I 860 to 1870 amounted to $\mathrm{I}, 45^{2,000,000}$ pounds. Holdsworth placed the yield of Scotland in i 873 at i $\$ 8,000,000$ pounds, their capture requiring 15,095 boats with crews of 45,494 men. In the

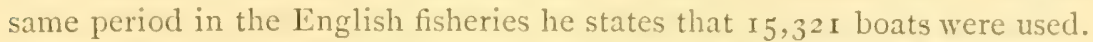
France, Ireland and belgim have also Herring fisheries of considerable extent, and Germany in less degree. In $\mathrm{I}_{7} 74$, according to compilations and estimates of Prof. Hind, 200,000,000 pounds of Herring were taken
\end{abstract}


in the waters of British North America, and in I 880 nearly 43,000,000 pounds were obtained on the east coast of the United States. Summing up the aggregate of these statements and estimates, and allowing to Ireland, Belgium, Germany and France, a product equal to that cited for Scotland, we have an aggregate of $250,000,000$ pounds.

Commenting upon the supposed injurious effect of the fisheries upon the abundance of this fish, Prof. Huxley in his well-known lecture upon the Herring, delivered at the International Fishery Exhibition at Norwich in I $88 \mathrm{I}$, remarked as follows:

"It is said that $2,500,000,000$, or thereabout, of Herrings are every year taken out of the North Sea and the Atlantic. Suppose we assume the number to be $3,000,000,000$, so as to be quite safe. It is a large number, undoubtedly, but what does it come to? Not more than that of the Herrings which may be contained in one shoal, if it covers half a dozen square miles, and shoals of much larger size are on record. It is safe to say that scattered through the North Sea and the Atlantic, at one and the same time, there must be scores of shoals, any one of which would go a long way toward supplying the whole of man's consumption of Herrings." ",

So well known was the Herring, from the earliest days, to the inhabitants of Northern Europe and to their descendants who migrated to the western shores of the Atlantic, that one name serves to designate the fish in the languages of a majority of the peoples to whom it is known. Its name in English, German. and Dutch, though differently spelled, is pronounced in exactly the same way. To the Scandinavians it is known by the name "Sill." France in the name Clupèe employs a form of the Latin for fishes of this group by which the same fish is known to these nations when described in the language of their men of science. There are also local names to designate certain conditions and ages. To this class belongs the name "Sperling," employed by our own fishermen of Cape Ann to denote the young Herrings. Corresponding to this name the word "Stromming" is used in Sweden.

The Herring is found in the temperate and colder parts of the North Atlantic. On the west, its range extends south to Sandy Hook, at the entrance of New York Harbor, where it is found occasionally in midwinter, and on the north as far as Northern Labrador, diminishing in numbers perhaps toward the northern extreme. On the east its southern limit is in the vicinity of the Bay of Biscay, while northward it is found in the White Sea and on the southern shores of Spitzbergen. It of course 
does not enter the Mediterranean, though it is abundant in the North Sea and in the Baltic.

The temperature preferred by the Herring has been more carefully determined in Europe than here. The observations of the Scotch and Dutch meteorological societies have demonstrated that the temperature of the water most favorable to the summer Herring fisheries of their respective countries is about $55^{\circ} .4 \mathrm{~F}$, though during the Scotch winter fisheries the temperature ranges from $40^{\circ}$. I F, and during the Norwegian spring Herring fisheries it ranges from $37^{\circ} \cdot 4 \mathrm{~F}$. to $39^{\circ} .2 \mathrm{~F}$.

Discussing the causes of the movements of the Herring schools, Prof. Baird in $\mathrm{s} 877$ wrote as follows.

"Although the movements of the Herring appear to be very capricious, they are doubtless governed as much by well-defined laws as any other portion of creation, although we are yet far from understanding fully the conditions which control their actions. They sometimes frequent a portion of the European coast for many successive years, and then abandon it gradually or suddenly, presenting themselves usually at the same season in some far remote locality. Sometimes a wind blowing on shore will favor their inward migration; at other times it appears to have a directly opposite effect. Eren when they reach the portion of the coast for which they are bound, the facilities of their capture depend upon meteorological conditions: and the Scottish Meteorological Society has been engaged for several years in ascertaining what these are, and how they may be best applied by the fishermen.'"

So far as is known, the abundance of Herrings in the Western Atlantic has been constant during the past two centuries; at the same time so little is our fishing population dependent on the Herring fisheries when compared with that of Northern Europe that variations in abundance not being regarded as national disasters would, except perhaps, in the case of Newfoundland, scarcely have been placed definitely upon record.

Prof. Baird's remarks concerning the periodicity of the Herring supply in Northern Europe, may be found in the Quarto Fisheries Report.

There are several interesting series of observations upon the spawning habits of the Herring, the hatching of the egg, and the development of the young; all of which may be found in the later volumes of the Report of the United States Commissioner of Fisheries, and in Prof. Huxley's lecture on the Herring.

In the spring of $x S_{7} S$ the first successful experiments in the artificial 
propagation of Herring were carried on in Germany by Dr. H. A. Meyer, of the Commission for Scientific Investigation of the German Seas, at Kiel, and in the fall of the same year by Mr. R. E. Earll, of the United States Fish Commission, at Gloucester. A translation of Dr. Meyer's paper may be found in the United States Fish Commission Report, part vi, pp. 629$6_{3} 8$, and a brief summation of Mr. Earll's experiments in the same volume, Pp. 727-729.

Much has been written upon the food of the Herring, and the translation from an article in "Die Natur," No. 47, 1869, printed in the quarto Report of the U.S. Fish Commission, expounds in a very satisfactory manner recent views of European authorities upon the subject.

The methods of capture of the Herring are fully described in the publications of the Fish Commission, but being always of a commercial character will not be referred to here. The Herring fishery is as yet of comparatively small importance in America, but is constantly increasing, and in time will without doubt, approximate in extent that of Northern Europe, especially after our countrymen shall have begun to pay attention to the now multiplying resources of our Pacific coast, where there are at least two species sufficiently abundant to be of value to fishermen.

"One of these, Clupea mirabilis, is universally known as the Herring," writes Prof. Jordan. It indeed scarcely differs in size, appearance, or qualities from the Herring of the Atlantic. It reaches a length of about a foot. It is found for the entire length of the coast, being exceedingly abundant northward. All the bay sand outlets of Puget Sound are filled with them in the summer. South of Point Conception they are seldom seen except in winter. At San Diego they spawn in the bay in January. Farther north their spawning season comes later. They are so abundant in San Franciscu Bay in the spring that eighty pounds can often be bought for twenty cents. They are fattest and bring the best price in early winter. The Herrings are smoked and dried, or salted, or sent fresh to the markets. Sometimes herring oil is expressed from them. The principal herring-curing establishment is at Port Madison, on Puget Sound."

Prof. Huxley, in his Norwich address, expressed belief that the true Herring probably occurs in the Pacific, but there is no reason to believe that his supposition was correct.

Still another is the California Sardine, Chupa sagax. "This species," writes Prof. Jordan, "is everywhere known as the Sardine, or by the 
Italians as 'Sardina.' It is, in fact, almost exactly identical with the Sardine of Europe. It reaches a length of a little less than a foot. It ranges from Cape Mendocino to Chili, and is extremely abundant southward, especially in the winter, when it fills all the bays. In the summer it is generally scarce southward, although still taken northward. The young are, however, seen in San Diego in the summer. It is probably to. some extent migratory along the coast, but as little attention is paid to it, no definite data can be given. It is brought into the markets when taken, and is sold with the Herring. The question of the possibility of canning it in oil, like the Sardine, has been considerably discussed. It would probably prove unprofitable, from the high price of labor and the uncertain supply of fish."

Far more abundant than the Herring, and occurring at times on all parts of our Atlantic coast, is the Menhaden, Brevoortic tyrannus. This species has at least thirty popular names, most of them limited in their use within narrow geographical boundaries. To this circumstance may be attributed the prevailing ignorance regarding its habits and migrations, among our fishermen, which has perhaps prevented the more extensive utilization of this fish, particularly in the South.

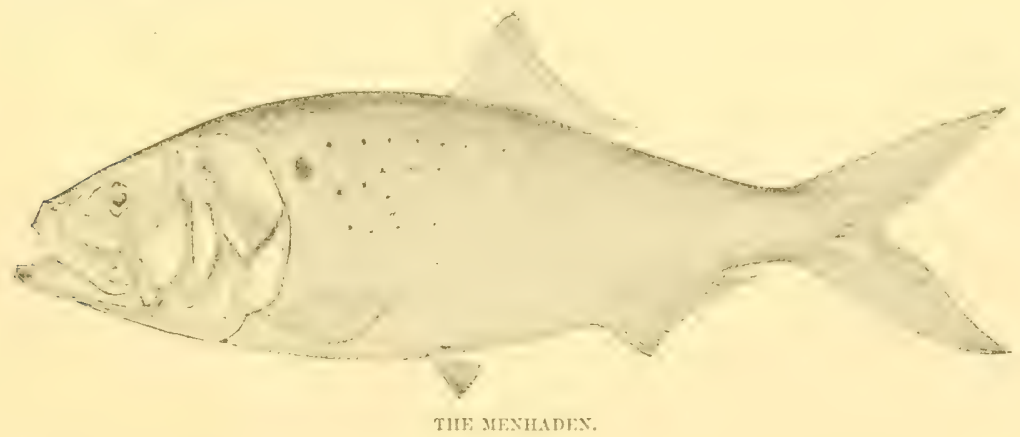

North of Cape Cod the name "Pogy" is almost universally in use, while in Southern New England the fish is known only as the "Menhaden." These two names are derived from two Indian words of the same meaning; the first being the Abnaki name "Pookagan," or "Pogharlen," which means "fertilizer," while the latter is the modification of a word which in the Narragansett dialect meant "that which enriches the earth." About Cape Ann, "Pogy" is partially replaced by "Hard-head" or 
"Hard-head Shad," and in Eastern Connecticut "Bony Fish." In Western Connecticut the species is usually known as the "White-fish," while in New York the usage of two centuries is in favor of "Mossbunker." This name is a relic of the Dutch colony of New Amsterdam, having evidently been transferred from the "Scad," or "Horse Mackerel," Trachums lacerta, a fish which visits the shores of Northern Europe in immense schools, swimming at the surface in much the same manner as our Menhaden, and known to the Hollanders as the "Marsbanker." New Jersey uses the New York name with its local variations, such as "Bunker" and "Marshbanker." In Delaware Bay, the Potomac and the Chesapeake, we meet with the "Alewife," "Bay Alewife," "Pilcher" (Pilchard), and "Green-tail." Virginia gives us "Bug-fish," "Bughead" and "Bug-shad," referring to the parasitic crustacean found in the mouths of all Southern Menliaden. In North Carolina occurs the name "Fat-back," which prevails as far south as Florida, and refers to the oiliness of the flesh. In this vicinity, too, the names "Yellow-tail" and "Yellow-tail Shad" are occasionally heard, while in Southern Florida the fish is called "Shiner" and "Herring." In South America, among the Portuguese, the name "Savega" is in use. On the St. John's River, and wherever Northern fishermen are found, "Menhaden" is preferred, and it is to be hoped that this name will in time be generally adopted. A number of trade names are employed by the manufacturers in New Jersey who can this fish for food ; these are "American Sardine," "American Club-fish," "Shadine" and "Ocean Trout."

The geographical range of Brevoortia tyramus varies from year to year. In 1877 it was, so far as it is definable in words, as follows: The wanderings of the species are bounded by the parallels of north latitude $25^{\circ}$ and $45^{\circ}$; on the continental side by the line of brackish water; on the east by the inner boundary of the Gulf Stream. In the summer it occurs in the coastal waters of all the Atlantic States from Maine to Florida, in winter only south of Cape Hatteras. The limits of its winter migration oceanwards cannot be defined, though it is demonstrated that the species does not occur about the Bermudas or Cuba, nor presumably in the Caribbean Sea.

With the advance of spring, Menhaden appear near our coasts in company with, and usually slightly in advance of, the other non-resident species, such as the Shad, Alewife, bluefish and squeteague. The follow- 
ing general conclusions regarding their movements are deduced from the statements of about two hundred observers at different points on the coasts from Florida to Nova Scotia.

At the approach of settled warm weather they make their appearance in the inshore waters. It is manifestly impracticable to indicate the periods of their movements except in an approximate way. The comparison of two localities distant apart one or two hundred miles will indicate very little. When wider ranges are compared there becomes perceptible a certain proportion in the relations of the general averages. There is always a balance in favor of earlier arrivals in the more southern localities; thus it becomes apparent that the first schools appear in Chesapeake Bay in March and April ; on the coast of New Jersey in April and early May; on the coast of New England in late April and Nay ; off Cape Ann about the middle of May, and in the Gulf of Maine in the latter part of May and the first of June. Returning, they leave Maine late in September or in October; Massachusetts in October, November and December, the latest departures being those of fish which have been detained in the narrow bays and Creeks; Long Island Sound and vicinity in November and December; Chesapeake Bay in December, and Cape Hatteras in January. Farther to the south they appear to remain more or iess constantly throughout the year.

The arrival of the Menhaden schools is closely synchronous with the period at which the weekly average of the surface temperatures of the harbors rises to $51^{\circ} \mathrm{F}$., that they do not enter waters in which, as about Eastport Me., the midsummer surface temperatures, as indicated by monthly averages, fall below $5 \mathrm{I}^{\circ} \mathrm{F}$, and that their departure in the autumn is closely connected with the fall of the thermometer to $5 \mathrm{I}^{\circ} \mathrm{F}$. and below.

The arrival of the Menhaden is announced by their appearance at the top of the water. Theyswim in immense schools, their heads close to the surface, packed side by side, and often tier above tier, almost as closely as sardines in a box. A gentle ripple indicates their position, and this may be seen at a distance of nearly a mile by the lookout at the masthead of a fishing vessel, and is of great assistance to the seiners in setting their nets. At the slightest alarm the school sinks toward the bottom, often escaping its pursuers. Sailing over a body of Menhacien swimming at a short distance below the surface, one may see their glittering backs 
beneath, and the boat seems to be gliding over a floor inlaid with blocks of silver. At night they are phosphorescent. Their motions seem capricious and without a definite purpose; at times they swim around and around in circles; at other times they sink and rise. While they remain thus at the surface, after the appearance of a vanguard they rapidly increase in abundance until the sea appears to be alive with them. They delight to play in inlets and bays, such as the Chesapeake, Peconic and Narragansett Bays, and in former years frequented the narrow fiords of Maine. They seem particularly fond of shallow waters protected from the wind, in which, if not molested, they will remain throughout the season, drifting in and out with the tide. Brackish water attracts them, and they abound at the mouth of streams, especially on the Southern coast.

Why the schools swim at the surface so conspicuous a prey to men, birds and other fishes is not known. It does not appear to be for the purpose of feeding; perhaps the fisherman is right when he declares that they are playing.

An old mackerel fisherman thus describes the difference in the habits of the mackerel and Menhaden: "Pogies school differently from mackerel; the Pogy slaps with his tail, and in moderate weather you can hear the sound of a school of them, as first one and then another strikes the water. The mackerel go along "gilling," that is, putting the sides of their heads out of the water as they swim. The Pogies make a flapping sound; the mackerel a rushing sound. Sometimes in calm and foggy weather you can hear a school of mackerel miles away." They do not attract small birds as do the schools of predaceous fish. The fish-hawk often hovers above them, and some of the larger gulls occasionally follow them in quest of a meal.

Their winter habitat, like that of the other cold-water absentees, has never been determined. The most plausible hypothesis supposes that instead of migrating towards the tropics or hibernating near the shore, as has been claimed by many, they swim out to sea until they find a stratum of water corresponding to that frequented by them during their summer sojourn on the coast.

As indicated by the testimony of many observers, whose statements are elsewhere reviewed at length, the Menladen is by far the most abundant species of fish on the eastern coast of the United States. Several hundred thousands are frequently taken in a single draft of a purse-seine. A firm 
in Milford, Conn., captured in $1870,8,800,000$; in $\mathrm{r} 87 \mathrm{r}, 8,000,000$; in i 872, I $0,000,000 ;$ in $1873, \mathrm{I} 2,000,000$. In $\mathrm{I} 877$ three sloops from $\mathrm{New}$ London seined I $3,000,000$. In i 877 , an unprofitable year, the Pemaquid Oil Company took 20,000,000, and the town of Booth Bay alone 50,000,000. There is no evidence whatever of any decrease in their numbers, though there can be in the nature of the case absolutely no data for comparison of their abundance in successive years. Since spawning Menhaden are never taken in the nets, no one can reasonably predict a decrease in the future.

The nature of their food has been closely investigated. Hundreds of specimens have been dissected, and every stomach examined by me has been found full of dark greenish or brownish mud or silt, such as occurs near the mouths of rivers and on the bottoms of still bays and estuaries. When this mud is allowed to stand for a time in clear water, this becomes slightly tinged with green, indicating the presence of chlorophyl, perhaps derived from the algr, so common on muddy bottoms. In addition to particles of fine mud the microscope reveals a few common forms of diatoms.

There are no teeth in the mouth of the Menhaden, their place being supplied by about fifteen hundred thread-like bristles, from one-third to three-quarters of an inch long, which are attached to the gill-arches, and may be so adjusted as to form a very effective strainer. The stomach is globular, pear-shaped, with thick, muscular walls, resembling the gizzard of a fowl, while the length of the coiled intestine is five or six times that of the body of the fish. The plain inference from these facts, taken in connection with what is known of the habits of the Menhaden, seems to be that their food consists in large part of the sediment, containing much organic matter, which gathers upon the bottoms of still, protected bays, and also of the regetation that grows in such localities. They also, as was demonstrated by M[r. Rathbun in I $8 S 0$, feed rery extensively upon the minute crustaceans, Copcpoda, \&c., which are found in great quantities swimming near the surface in the summer months all along our coast.

Their rapid increase in size and fatness, which commences as soon as they approach our shores, indicates that they find an abundant supply of some kind of food. The oil manufacturers report that in the spring a barrel of fish often yields less than three quarts of oil, while late in the fall it is not uncommon to obtain five or six gallons. 
There is a mystery about their breeding. Thousands of specimens have been dissected since $\mathrm{I} 87 \mathrm{I}$ without the discovery of mature ova. In early summer the genitalia are quite undeveloped, but as the season advances they slowly increase in size and vascularity. Among the October fish a few ovaries were noticed in which the eggs could be seen with the naked eye. A school of large fish driven ashore in November, in Delaware Bay, by the bluefish, contained spawn nearly ripe, and others taken at Christmas time, in Provincetown harbor, evidently stragglers accidentally delayed, contained eggs quite mature. Young Menhaden from one to three inches in length and upward are common in summer south of New York, and those of five to eight inches in late summer and autumn in the southern part of New England. These are in schools, and make their appearance suddenly from the open ocean like the adult fish. Menhaden have never been observed spawning on the Southern coast, and the egg-bearing individuals when observed are always heading out to sea. These considerations appear to warrant the theory that their breeding grounds are on the off-shore shoals which skirt the coast from George's Banks to the Florida Keys. There are indications, too, that a small school of Menhaden possibly spawn at the east $\epsilon$ nd of Long Island in the very early spring.

The fecundity of the Menhaden is very great, much surpassing that of the Shad and Herring. The ovaries of a fish taken in Narragansett Bay, November I, i 879 , contained at least 150,000 eggs.

Among its enemies may be counted every predaceous animal which swims in the same waters. Whales and dolphins follow the schools and consume them by the hogshead. Sharks of all kinds prey upon them largely; one hundred have been taken from the stomach of one shark. All the large carnivorous fishes feed upon them. The tunny is the most destructive. "I have often," writes a Maine observer, "watched their antics from the masthead of my vessel-rushing and thrashing like demons among a school of fish; darting with almost lightning swiftness, scattering them in every direction, and throwing hundreds of them in the air with their tails." The pollock, the whiting, the striped bass, the cod, the squeteague, and the gar-fish are savage foes. The sword-fish and the bayonet-fish destroy many, rushing through the schools and striking right and left with their powerful swords. The blue-fish and bonito are, however, their most destructive enemies, not even excepting man ; these corsairs of the sea, not content with what they eat, which is of itself an enormous 
quantity, rush ravenously through the closely-crowded schools, cutting and tearing the living fish as they go, and leaving in their wake the mangled fragments. Traces of their carnage remain for weeks in the great "slicks" of oil so commonly seen on smooth water in summer. Prof. Baird, in his well-known and often-quoted estimates of food annually consumed by the blue-fish, states that probably ten thousand million fish, or twenty-five million pounds, daily, or twelve hundred million million fish and three hundred thousand million pounds are much below the real figures. This estimate is for the period of four months in the middle of summer and fall, and for the coast of New England only.

Such estimates are professedly only approximations, but are legitimate in their way, since they enable us to appreciate more clearly the luxuriance of marine life. Applying similar methods of calculation to the Menhaden, I estimate the total number destroyed annually on our coast by predaceous animals at a million million of millions; in comparison with which the quantities destroyed by man, yearly, sink into insignificance.

It is not hard to define the place of Menhaden in nature. Swarming in our waters in countless myriads, swimming in closely packed, unwieldy masses, helpless as flocks of sheep, near to the surface and at the mercy of every enemy, destitute of means of defense and offense, their mission is unmistakably to be eaten.

In the economy of nature certain orders of terrestrial animals, feeding entirely upon vegetable substances, seem intended for one purpose-to elaborate simple materials into the nitrogenous tissues necessary for the food of other animals, which are wholly or in part carnivorous in their diet; so the Menhaden feeding upon otherwise unutilized organic matter is pre-eminently a meat-producing agent. Man takes from the water every year eight or nine hundred millions of these fish, weighing from two hundred to three hundred thousand tons, but his indebtedness does not end here; when he brings upon his table bluefish, bonitoes, weak-fish, swordfish, or bass, he has before him usually Menhaden flesh in another form.

The commercial importance of the Menhaden has only lately been rightly appreciated. Thirty years ago and before, it was thought to be of very small value. A few millions were taken every year in Massachusetts Bay, Long Island Sound, and the inlets of New Jersey. A small portion of these were used for bait; a few barrels occasionally salted in Massachusetts to be exported to the West Indies. Large quantities were plowed 
into the soil of the farms along the shores, stimulating the crops for a time, but in the end filling the soil with oil, parching it and making it unfit for tillage. Since that time manifold uses have been found. As a bait-fish this excels all others; for many years much the greater share of our mackerel was caught by its aid, while the cod and halibut fleet use it rather than any other fish when it can be procured. The total consumption of Menhaden for bait in 1877 did not fall below 80,000 barrels, or $26,000,000$ fish, valued at $\$ 500,000$. Ten years before, when the entire mackerel fleet was fishing with hooks, the consumption was much greater. The Dominion mackerel fleet buy Menhaden bait in quantity, and its value has been thought an important element in framing treaties between our government and that of Great Britain.

As a food resource it is found to have great possibilities. Many hundreds of barrels are sold in the West Indies, while thousands of barrels are salted down for domestic use by families living near the shore. In many sections they are sold fresh in the market. Within six years there has sprung up an important industry, which consists in packing these fish in oil, after the manner of sardines, for home and foreign consumption. In I 874 the production of canned fish did not fall below 500,000 boxes.

The discovery made by Mr. S. L. Goodale, that from these fish may be extracted, for the cost of carefully boiling them, a substance possessing all the properties of Liebig's "Extract of beef," opens up a vast field for future development. As a food for the domestic animals in the form of "fish meat," there seems also to be a broad opening. As a source of oil, the Menhaden is of more importance than any other marine animal. Its annual yield usually exceeds that of the whale (from the American fisheries) by about 200,000 gallons, and in I 874 did not fall far short of the aggregate of all the whale, seal, and cod oil made in America. In 1878 the menhaden oil and guano industry employed capital to the amount of $\$ 2,350,000,3,337 \mathrm{men}, 64$ steamers, 279 sailing ressels, and consumed $777,000,000$ fish; there were $5^{6}$ factories, which produced $1,392,644$ gallons of oil, valued at $\$ 45^{\circ}, 000$, and $55, \mathrm{I} 5 .+$ tons of crude guano, valued at $\$ 600,0>0$; this was a poor year. In $187+$ the number of gallons produced was $3,373,000$; in $1875,2,681,000$; in $1876,2,992,000$ : in 1877 , $2,427,000$. In 1878 the total value of manufactured products was $\$ 1,050$, 000 ; in 1874 this was $\$ 1,809,000$; in $1875, \$ 1,582,000$; in $1876, \$ 1,671,-$ 000 ; in $1877, \$ 1,608,000$. It should be stated that in these reports only 
four-fifths of the whole number of factories were included. In isso the number of persons employed in the entire industry was placed at 3,635 , the amount of capital invested, $\$ 2,362,8+1$, the value of products, $\$ 2,116$, 787 , including $2,066,396$ gallons of oil, worth $\$ 733,424$, and 68,904 tons of guano, worth $\$ \mathbf{I}, 301,217$. The refuse of the oil factories supplies a material of much value for manures. As a base for nitrogen it enters largely into the composition of most of the manufactured fertilizers. The amount of nitrogen derived from this source in 1875 was estimated to be equivalent to that contained in $60,000,000$ pounds of Peruvian guano, the gold value of which would not have been far from \$1,920,000. The yield of the menhaden fishery in pounds is probably triple that of any other carried on by the fishermen of the United States.

In estimating the importance of the Menhaden to the United States, it should be borne in mind that its absence from our waters would probably reduce all our other sea-fisheries to at least one-fourth their present extent. It is therefore of great importance to anglers as well as fishermen.

In addition to the common Menhaden, a second North American species, Brevoortic patronus, has recently been discovered. This species has been reported only from the Gulf of Mexico.

The commercial representatives of the Herring in America are perhaps the River Herrings and the Shad, which ascend our streams in the spring, and, fresh, pickled and smoked, enter very largely into the food resources of the Atlantic region.

Early writers on American fishes, especially Mitchill and De Kay, seem to have experienced great difficulty in differentiating into species the various forms of River Herrings or Alewives in our waters. These early writers were, however, apparently more discriminating than some of their successors, for they recognized differences which have been ignored by subsequent writers. They were as much at fault, however, in making too many species, as were Storer and Gill in uniting all the forms under one specific name.

The attention of the zoologists of the Fish Commission was first called to the probable existence of two species by the persistent opinions of the fishermen of the Potomac, who recognizerl two forms-differing in habit and in general appearance-which they called the "Branch Herring" and the "Glut Herring" respectively.

The announcement of the discovery of the two species and a definition 
of their characters were first published in the report of the Virginia Fish Commission for 1879 . These species may easily be distinguished from each other by the following characters: C. astivalis is more elongate in form, has a lower body, less elevated fins, and smaller eyes than $C$. vernalis. The proportions of the bones of the head in C. astivalis differ from those in $C$. vernalis, as also does the coloration of the lining of the abdomen, which in $C$. astivalis is black and in $C$. vernalis, gray.

The popular names applied to these fishes differ in almost every river along the coast. C. vernalis is known along the Potomac River as the "Branch Herring"; on the Albemarle River as the "Big-eyed Herring" and the "Wall-eyed Herring" ; in Canada it is known as the "Gaspereau " or "Gasperôt." It is pre-eminently the "Alewife" of New England; the "Ellwife" or "Ellwhop" of the Connecticut River. The other species, C'. astivalis, undoubtedly occurs occasionally in its company, but is probably not common in the Connecticut and Housatonic Rivers, and in many parts of Massachusetts is distinguished by another name.

The C. astivalis is the "Glut Herring" of the Albemarle and the Chesapeake, and the "English Herring" of the Ogeechee River. In the St. John's River, Florida, it is known simply as the "Herring." On the coast of Massachusetts it is called the "Blue-back," a name which is common to the late runs of the same species of the Rappahannock. Around the Gulf of Maine this species is also known by the names "Kyack" or "Kyauk," "Saw-belly," and "Cat-thrasher." Although the coast fishermen of Massachusetts and Maine claim to distinguish the two species, the "Blue-backs" and the "Alewives," their judgment is by no means infallible, for I have frequently had them sort out into two piles the fishes which they distinguish under these names, and found that their discrimination was not at all reliable. The features to which they mainly trusted in the determination of $C$. cestivalis are the bluer color of the back and the greater serration upon the ventral-ridge. The other species, when the scales on its back are rubbed off, is as blue as this, and the serration of the belly is dependent entirely upon the extent to which the back has become stiffened in the death struggle and the consequent degree of arching of the ventral ridge. The young of one or both species are sold in the Boston markets under the name "Sprats," and in New York they make up a large proportion of the so-called "Whitebait." 
"The Alewife," writes Col. MacDonald, "is by far the most abundant of our river fishes, and throughout the whole Southern region where they are caught, together with the Shad, the number of individuals is not far from ten to twenty times as great as that of the Shad. For instance, in the Albemarle region, in $\mathrm{I} S 79,75^{\circ}, 000$ Shad were taken and upwards of $20,000,000$ Alewives. Again, in $\mathbf{I} \$ 80$, about 600,000 Shad were taken from the Potomac and I $1,000,000$ Alewives. By far the greatest number of the Alewives thus taken were "Glut Herring," C. astivalis; but, since the two species are sold together, without discrimination, no accurate statement of proportional numbers can be made.

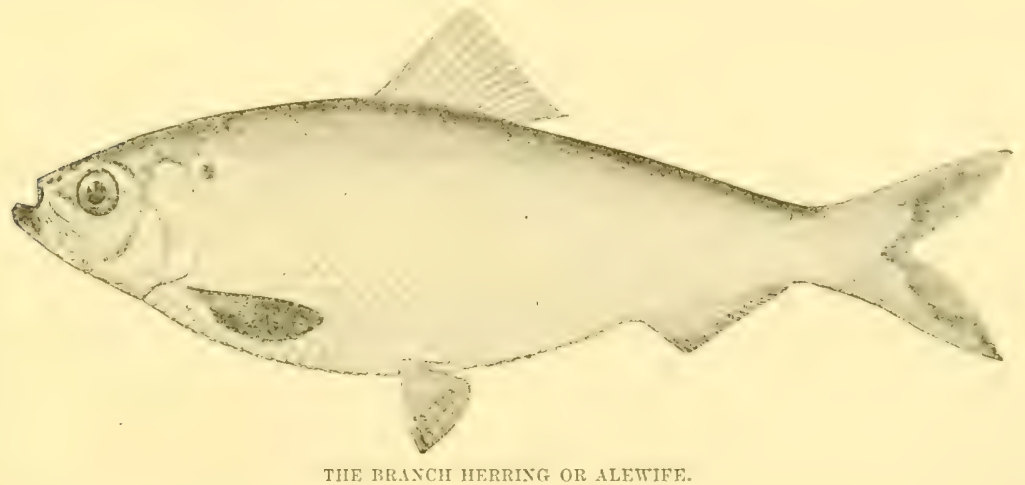

There is on Cape Cod an extensive Alewife fishery. This has for more than a century been regulated by law, and the fish are allowed cluring stated periods to swim without interruption to their spawning beds. The streams in which they are taken are so small, and the fish in their ascent so crowded together, that they appear to be extremely abundant, although the aggregate catch for the entire Cape is not perhaps much greater than the yield of many single seines in the South. Here, however, there has been no great decrease in abundance, while in the South the herring fishery is much less productive than in former years.

A very remarkable phenomenon, recently observed, has been the appearance of this species in immense numbers in Lake Ontario and lakes of New York. This has been only in waters in which shad fry had previously been placed by fish culturists.

Like the Shad, the Alewives are anadromous in habit. The dates of their first appearance in any given river may be very closely determined 
by an examination of the tables which show the movements of the Shad. The Gaspereau or "Spring Herring" usually precedes the Shad by a period of several weeks, while the run of the "Blue-back" or "Glut Herring" occurs in the middle of the Shad season.

One of the earliest American observers thus spoke of their habits :

At the end of March begins the spring by Sol's new elevation,

Stealing away the Earth's white robe, dropping with sweat's vexation.

The Codfish, Holybut and Barse do sport the rivers in,

And Allwives, with their crowdy sholes in every creek do swim. Good Newes from New England, i678.

Little is known concerning the food of the river Alewives in their saltwater habitat. It is, however, supposed that they, like the Shad, exist largely upon swimming crustaceans. When in the rivers they do not feed to any considerable extent, although they have been known in a few instances to take the fly.

The eggs of the Alewife are adhesive, like those of the sea Herring, though to a much less degree. The number of eggs varies from sixty thousand to one hundred thousand, in accordance with the size of the individual. They are deposited upon the bottom in shoal water, or on whatever object they may come in contact with. The time for spawning, after the fish have entered the river, depends, as in the case of the Shad, entirely on the temperature of the water. The spawning of the "Glut Herring" takes place under ordinary conditions at a temperature of $70^{\circ}$ to $70^{\circ} \mathrm{F}$.; that of the "Branch Herring," when the water is as low as $55^{\circ}$ to $60^{\circ} \mathrm{F}$. The period of development varies directly with the temperature.

"During past years," writes McDonald, "the Alewife has frequently been artificially introduced into new waters or over dams by the transportation of fish of considerable size. This is constantly done on Cape Cod in the restocking of the herring streams which have been exhausted, and was successfully accomplished by Gen. N. L. Lincoln, in Maine, as long ago as $175^{\circ} . "$

"Herring eggs have frequently been artificially impregnated by men engaged in shad culture. The young fish artificially hatched have in some instances been transported. In $\mathrm{I} 882$, two million were sent to Texas by the United States Fish Commission and deposited in the Colorado River. Artificial hatching would seem less necessary in the case of the Alewife 
than in that of the Shad, since with the former, owing to its peculiar spawning habits, the eggs stand a better chance of hatching out, and very slight protection of the fish during spawning season will be sufficient to keep up the supply.',

Prof. Baird, in his second report as Commissioner of Fisheries, spoke as follows upon the uses and importance of this fish:

"I am inclined to think, for various reasons, that too little has been done in our waters toward the restoration to their primitive abundance of the Alewife.

"The Alewife in many respects is superior, in commercial and economical value, to the Herring, being a much larger and sweeter fish, and more like the true Shad in this respect. Of all American fish none are so easily propagated as the Alewife, and waters from which it has been driven by the erection of impassable dams can be fully restocked in the course of a few years, simply by transporting a sufficient number of the mature fish taken at the mouth of the stream to a point above the dams, or placing them in ponds or lakes. Here they will spawn and return to the sea after a short interval, making their way over dams which carry any flow. The young Alewives, after a season, descend and return, if not prevented, at the end of their period of immaturity, to the place where they were spawned.

"In addition to the value of the Alewife as an article of food, it is of much service in ponds and rivers as nutriment for trout, salmon and other valuable fishes. 'The young derive their sustenance from minute crustaceans and other objects too diminutive for the larger fish, and in their great abundance are greedily devoured by the other species around them. In waters inhabited by both pickerel and trout these fish find in the young Alewives sufficient food to prevent their preying upon each other. 'They are also, for the same reason, serviceable in ponds containing black bass.

"As a cheap and very abundant food for other fishes, the young Alewives can be placed in waters that have no connection with the sea by merely transferring from any convenient locality a sufficient number of the living mature parents, taken at the approach of the spawning season; they will remain for several months, and indeed can often be easily penned up by a suitable dam and kept throughout the year.

"It is in another still more important connection that we should consider the Alewife. It is well known that within the last thirty or forty years the fisheries of cod, haddock and hake along our coast have measurably diminished, and in some places ceased entirely. Enough may be taken for local consumption, but localities which formerly furnished the material for an extensive commerce in dried fish have been entirely abandoned. Various causes have been assigned for this condition of things, and among others the alleged diminution of the sea Herring. After a careful consideration of the subject, however, I am strongly in- 
clined to believe that it is due to the diminution, and in many instances to the extermination, of the Alewives. As already remarked, before the construction of dams in the tidal rivers the Alewife was found in incredible numbers along our coast, probably remaining not far from shore, excepting when moving up into the fresh water, and at any rate spending a considerable interval off the mouths of the rivers either at the time of their journey upward or on their return. The young, too, after returning from the ocean, usually swarmed in the same localities, and thus furnished for the larger species a bait such as is not supplied at present by any other fish, the sea Herring not excepted. We know that the Alewife is particularly attractive as a bait to other fishes, especially for cod and mackerel. Alewives enter the streams on the south coast of New England before the arrival of the bluefish ; but the latter devote, themselves with great assiduity to the capture of the young as they come out from their breeding ponds. The outlet of an alewife pond is always a capital place for the bluefish, and, as they come very near the shore in such localities, they can be caught there with the line by what is called 'heaving and hauling,' or throwing a squid from the shore and hauling it in with the utmost rapidity.

"The coincidence, at least, in the erection of the dams, and the enormous diminution in the number of the Alewives, and the decadence of the inshore Cod fishery, is certainly very remarkable. It is probable, also, that the mackerel fisheries have suffered in the same way, as these fish find in the young Menhaden and Alewives an attraccive bait.

"The same remarks as to the agency of the Alewife in attracting the deep-sea fishes to the shores, and especially near the mouths of rivers, apply in a proportional degree to the Shad and salmon."

The Inland Alewife or Skipjack, Chupea chrysochloris, which is found in many parts of the Mississippi Valley, has recently been found by Mr. Silas Stearns in the salt water off Pensacola- a surprising circumstance, since the species was thought to be an inhabitant of fresh water exclusively. " It is known to most inland fishermen as the "Skipjack," " writes Prof. Jordan, "in allusion to its habit of leaping from the water. It is also sometimes called 'Shad' and 'Herring.' It is abundant throughout the Mississippi Valley in all the larger streams. In the neighborhood of the ocean it descends to the Gulf, but in the upper courses it is permanently resident. It has also entered Lake Michigan and Lake Erie since the construction of the canals. It reaches a length of a little more than a foot. It feeds on small crustaceans, worms, and the like, rarely taking the hook. As a food-fish it is regarded as wholly worthless, its flesh being poor and dry and full of innumerable small bones."

The Shad appears to inave been considered by early American writers 
on fish identical with the Shad of England, Clupea finta. The first to give to it a distinctive name was Alexander Wilson in the American edition of Rees' Encyclopadia.

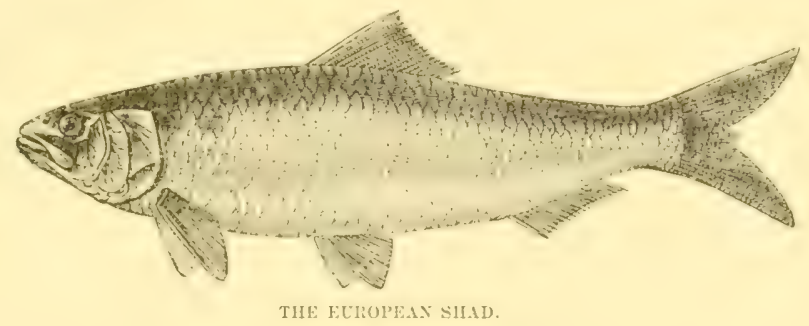

It is very closely allied to the European species, but is a much finer fish. The English care little for their shad, though in France the same species is highly esteemed.

The following account of our Shad is from the pen of Col. Marshall MacDonald, who has made it a subject of special study for many years:

The Shad is found along the whole Atlantic coast of the United States, and its capture constitutes one of the most important fisheries in all the streams draining into the Atlantic between the Gulf of St. Lawrence and the St. John's River, Florida.

It is but rarely seen on the Atlantic coast of Nova Scotia, but occurs in the Gulf of St. Lawrence, the various rivers of which it ascends as far north as the Mramichi, which seems to be its limit in that rlirection, none having been seen in the Bay of Chaleur.

Throughout its entire range the Shad is found in sufficient quantities to give rise to fisheries of great commercial value. There is no run of Shad in any of the rivers draining into the Gulf of Mexico, although the capture of isolated individuals of this species has been reported from the Alabama River and from several tributaries of the Mississippi prior to any steps towards the artificial propagation of Shad in these waters by the United States Fish Commission.

The geographical range of the Shad then was confined to the Atlantic coast of the United States until, by the operations of the United States Fish Commission, its limits were vastly extended. Runs of Shad, sufficiently large to be of commercial value, have been established in several of the tributaries of the Mississippi River, notably the Ohio River; and the several plants made from time to time in the Sacramento River, on the 
Pacific coast, have resulted in the colonization of this species in all the rivers of the Pacific slope, from the Sacramento to Puget Sound.

The Shad make their first appearance in the St. John's River about the middle of November, the height of their spawning season in that river being about the ist of April. In the Savannah River they appear early in January, and in the Neuse River at a period not much later than in the Savannah. In the Albemarle the important Shad seine-fisheries begin early in March, but doubtless the fish are in the Sound some time before that date; not, however, in numbers sufficient to justify the great expenses attendant upon the operation of these large seines. In the Chesapeake Bay they make their appearance in February, although the height of the fishing season in its waters is during April and May, and at a date somewhat later in the more northern tributaries. In the Delaware, Connecticut, Merrimac, and St. John (Nova Scotia) Rivers, Shad are first seen at periods successively later as we proceed farther north. The date of their first appearance in any of these waters, however, varies from season to season, the limit of such variation being from three to four weeks.

These irregularities in the time of the run into our rivers, which cause so much perplexity and discouragement to the fishermen, are, however, readily explained by the influence of temperature.

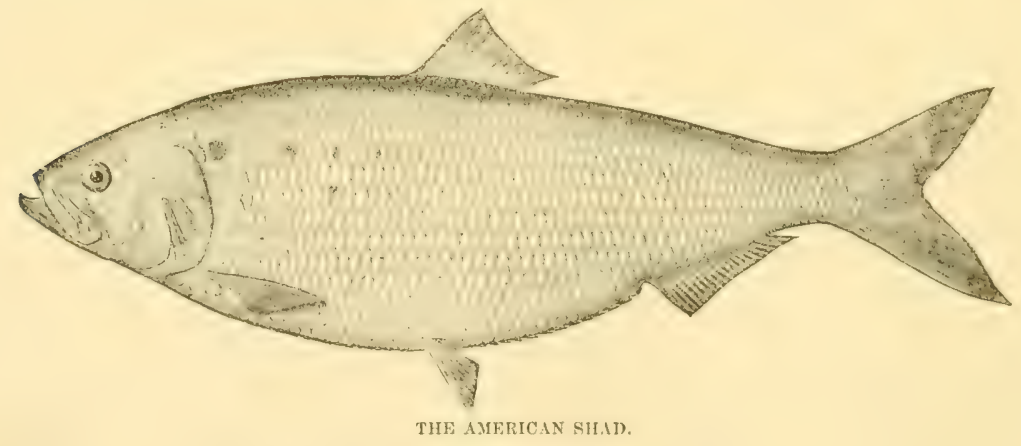

It is doubtful whether there is any general coastwise movement of the Shad. That there is an occasional migration of this kind is evidenced by the following facts: The Shad of the rivers of the South Atlantic coast, as a rule, have black-tipped caudal and dorsal fins, which distinctive marks of coloration are absent in the Shad of more northern rivers; and yet occasionally these southern Shad are caught as far north as the tribu- 
taries of the Chesapeake and Delaware Bays. These fish have undoubtedly been born and bred in southern waters, and their appearance so far north would indicate that occasionally this southern variety strays beyond its normal range. At one time it was imagined that the whole body of American Shad, having wintered in the south, started northward with the new year, and as each river mouth was reached a detachment would leave the entire mass for the purpose of ascending the river, the last remaining portion of the immense school entering the Gulf of St. Lawrence.

At a later date it was thought more reasonable to suppose that the young fish, hatched out in any particular stream, went out into the sea and remained within a moderate distance of the coast until the period again occurred for their upward river migration. Their appearance, first in the extreme southern river of the coast, the St. John's, and at later dates successively in the more northern rivers, was thought to confirm this view. It will be seen, in the discussions of the relation of the movements of the Shad to the water temperature, published in the reports of the United States Fish Commission, that this order of appearance when preserved may be reasonably accounted for; there are, however, exceptions. For instance, the Edisto River is many miles north of the Savannah, and yet the run of Shad in the former is usually coincident with that in the latter. This -leads us to believe that the Shad are generally distributed along the coast at all times, entering the rivers as soon as the temperature of the water is suitable. It is but natural that the waters of a creek or short stream, not having its source in the mountains, should in the spring become warm long before those of a large river whose headwaters are far up among the mountains; for which reason we may expect to find, in the case of two rivers, the most southerly of which has a longer water-course than the other, that the Shad will first enter the more northerly, yet shorter, and consequently, at a given date, warmer stream. The question, therefore, appears to be rather one of temperature than of geographical location.

The greater portion of the life of the Shad being spent in salt water, the possibility of close observation as to their food, habits, or precise habitat is precluded. The young fry, hatched out in the rivers in spring and early summer, remain there until the following fall, when, the temperature of the waters having fallen below $60^{\circ}$, they leave for the ocean. Nothing more is seen of them until they return to the rivers as mature fish for the 
purpose of spawning. In these upward migrations the schools of mature fish ascend the rivers either until obstructed by impassable falls or dams, or until the volume of water becomes very inconsiderable. Before artificial impediments were placed in the rivers, the limit of this movement was the natural and insurmountable falls to be found at the head of almost all of our principal streams. For example, in the Savannah River the Shad used to ascend to the Falls of Tallula, at the very source of the river in the northern part of Georgia. In the Potomac they ascend as high as the Great Falls. In the Susquehanna River, in which there exist no natural obstructions, their migration extended up into the State of New York, a distance of several hundred nilles above the present limit. On the Hudson River they ascended to Glens Falls. On the Connecticut at one time they went as high as Bellows Falls, but recent obstructions in this river have materially reduced the extent of their range.

The age at which the Shad reaches maturity and becomes capable of reproducing is not definitely determined; it is generally held by fish culturists, however, that the female Shad attains this condition when three or four years old. 'The favorite spawning grounds, or "Shad Wallows," as they are termed by the fishermen, are on the sandy flats which border the streams, and the sand-bars which are found at intervals higher up the river. When the fish have reached suitable spawning grounds and are ready to cast their eggs, they move up to the flats seemingly in pairs. The time of this movement is usually between sundown and I I p. $m$. When in the act of coition they swim close together and near the surface, their back fins projecting above the water. The rapid, vigorous, spasmodic movements which accompany this operation produce a splashing in the water which can be plainly heard from the shore, and which the fishermen characterize as "washing."

The number of eggs in the ovary of a Shad, as in all other fish, bears a certain relation to the size and weight of the fish. As the result of experience in the artificial propagation of the Shad we conclude that a ripe roe Shad weighing four or five pounds contains from 20,000 to 40,000 eggs, the average number being about 25,000. A much larger number, however, has been obtained from some individuals. In the season of ISSI we obtained from a single Shad, weighing about six pounds, over 60,000 impregnated eggs; again, in $\mathbf{I} S 80$, on the Potomac River, the yield of eggs from a single Shad was over 100,000 . These were full-sized, 
thoroughly impregnated, and were hatched out with a loss of hardly one per cent.

Shad ready to deposit their spawn seem to prefer waters of a warmer temperature than $60^{\circ} \mathrm{F}$. Therefore, when the mature Shad, intent on reproduction, leave the hydrothermal area of $60^{\circ} \mathrm{F}$. and ascend the rivers into waters of $65^{\circ}$ to $70^{\circ} \mathrm{F}$. and upwards, they are unaccompanied by the half-grown Shad, the latter ceasing to ascend as soon as they encounter a temperature of more than $60^{\circ} \mathrm{F}$. In I 882 , however, when the temperature of the water was below $60^{\circ} \mathrm{F}$. for the greater portion of the season, the spawning had to take place in water colder than the fish would have preferred, and therefore mature and young Shad were found together on the spawning grounds.

The shad-fry, which spend the first six months in our rivers, must of necessity find their food therein. From examinations made of the stomachs of these young fish, they have been found to feed upon certain species of crustacea and insect larve, common to the fresh waters of our rivers. During the spring of $\mathrm{r} 882$ some young fry, which were hatched out at Central station, were confined by Dr. John A. Ryder in a glass aquarium, through which the circulation of the water was maintained, and fed with Copepooda, obtained in large quantities from the United States carp ponds. In about seren days after hatching some of the young fry were observed to eat, and a few days later they were all vigorously engaged in pursuit of food. While the ratio of mortality was large, some of the fish survived for six weeks, the last specimen having attained a length of considerably more than an inch, and a weight many times greater than that at birth.

From these experiments we deem it altogether probable that under natural conditions the Copepoda, which are abundant in the Potomac in places frequented by the young Shad, are their natural food during the early stages of their existence.

It is probable that Shad in their early lives vary their food with minnows and the young of other species of fish. Indeed, from the stomach of a Shad, taken in one of the pounds at Saybrook, I found an undigested minnow two or three inches in length. In the fresh-water life of the mature Shad, the fish do not seem to take food at all. Repeated observations of the contents of the stomach show no food whatever. Occasionally, however, they can be induced to rise to a fly dexterously cast on the water. This fact is presumptive evidence that the desire for food, although sub- 
ordinated to the impulse of reproduction (which brings them into the river), is not wholly lost.

A female Shad of a certain age is always larger than a male of corresponding age. A general average for both sexes along the whole coast would be about four pounds, the extremes-for males-being from one and a half to six pounds, and for females from three and a half to eight pounds, the latter representing a maximum weight for Shad at the present time; although, in the early history of the fisheries, there are records of the capture of fish weighing eleven, twelve and as much as fourteen pounds.

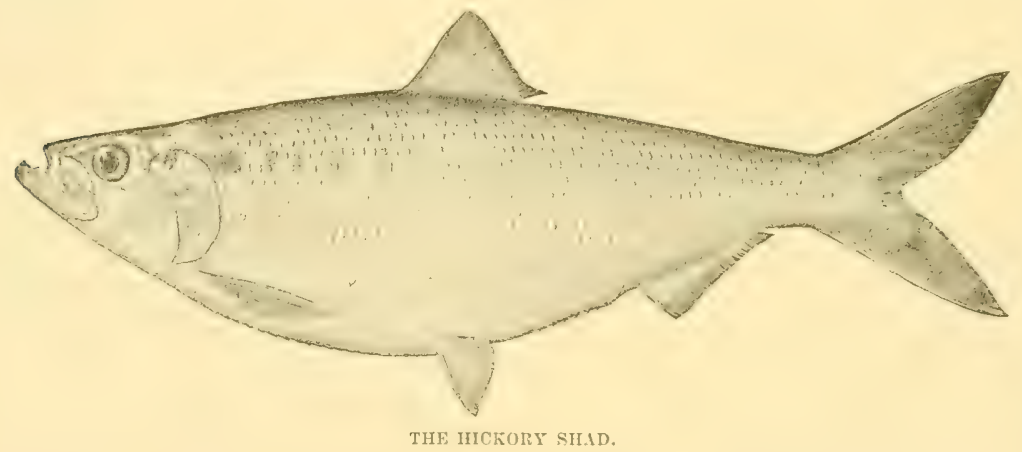

The Hickory Shad, or Mattowacca, Clupea mediocris, was first brought to notice in I $\delta_{5} 5$ in Mitchill's paper on the fishes of New York, wherein it was described under two names, being called the "Staten Island" Herring, C. mediocris, and the "Long Island" Herring, C. mattozacca. The latter name was adopted by Storer for the species, but more recent authorities, guided by a rather questionable interpretation of the rules of priority, have substituted the name $C$. mediocris, because it was printed on the page preceding the other. Mitchill stated that the "Long Island " Herring occupied a middle station between the Shad and the "Staten Island " Herring, but it seems strange that so accomplished an ichthyologist should not have at once perceived the identity of the two. The name "maliocris" was founded upon small specimens. The names given this species are as varied as those of the river Herrings. The name "Mattowacca" is of Indian origin, and is said to have been derived from the Indian name for Long Island, Mattowaka or Mattozuax.

The name "Hickory Shad" is applied to this species on all parts of the 
coast from Cape Cod to Florida. It is used in the Chesapeake and in the Albemarle regions, and on the Ogeechee, Savannah, and Altamaha Rivers, where it is familiarly called "Hicks." In the St. John's River and Alabama River the name "Hickory" Shad is also used. The derivation of the name "Hickory" Shad cannot easily be traced. It may be that the word "Hickory" is used in a derogatory sense, but a more reasonable explanation is that it refers to the striped markings on the fish, which resemble those upon the coarse cotton fabric known in the South as "Hickory," and frequently used by the fishermen.

In the Potomac the species is called the "Tailor Shad," or the "Freshwater Tailor," in contradistinction to the bluefish, which is called the "Salt-water Tailor." The comparison between the bluefish and this species is doubtless due to a fancied resemblance between their jaws, those of the "Tailor Shad " being very long and strong. "The "Tailor Sharl" may be distinguished from the common Shad and from the river Herrings by the extreme projection and thickness of the lower jaw. This species is in some rivers called a "Forerunner," from the fact that it makes its appearance shortly before the Shad.

Col. McDonald writes as follows concerning this species: "The 'Hickory Shad' is most abundant in the region between the Chesapeake Bay and Altamaha River and intermediate waters, ascending the rivers as high as the Shad. In the St. John's River it is somewhat abundant, making its appearance the first or second week in November, and shortly before the Shad. North of New York it has not been observed to enter the rivers in any great numbers, and there is no record north of Cape Cod of its having been seen in fresh water. In the fall small schools of them occasionally enter the brackish estuaries and tideways of Cape Cod.",

In the Altamaha River, Georgia, the catch of "Hickory" Shad is equal to that of "Common" or "White Shad," and in the markets they sell for more than one-half as much. In the St. John's River they are not exceedingly abundant, and two "Hickory Shad " are equal in value to one "White Shad." In the Ogeechee and Savannah Rivers the proportion of the catch of the "Hickory" to that of "White Shad" is about one to four. All taken here are used for local consumption, and are sold at prices equal to about one-half of the White Shad. In the Albemarle they are less abundant than farther south and are of less value. Here they are sold with the herring for local consumption, two of them counting for one 
herring, or are used for manure. In the Chesapeake region they are not highly esteemed, although great quantities are sold by hawkers, especially in the cities, where people are not well informed, under the name of "Shad." At the beginning of the season hundreds of men may be seen going about the city of Washington with strings of these fish, which they cry for Shad, and which with great insolence they press upon such wouldbe purchasers as are inclined to question their genuineness. In the poundnets of the Chesapeake in the beginning of the season they are caught in immense numbers, and are shipped to the markets with the true Shad until their price falls below three cents apiece, after which they are sold with the Herring, one counting as two Herrings.

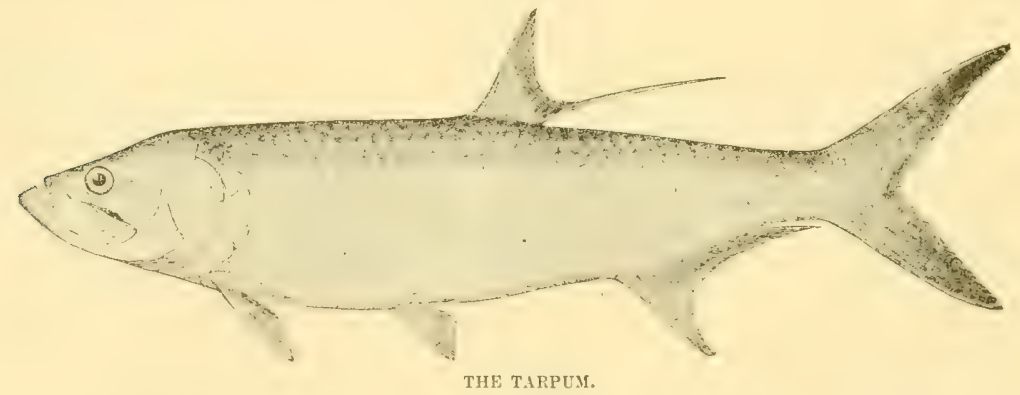

In our waters the most important member of this family is the Tarpum, Megalops thrissoides, an immense herring-like fish, which occurs in the Western Atlantic and in the Gulf of Mexico, ranging north to Cape Cod and south at least to Northern Brazil. It is somewhat abundant in the West Indies, and stragglers have been taken as far to the eastward as the Bermudas. This species attains the length of five or six feet, and is covered with enormous circular scales of one inch to two inches and a half in diameter, the exposed portions of which are covered with a silvery epidermis. The fish, when alive, presents a very brilliant metallic appearance, and the scales are much prized by curiosity hunters and for fancy work in the Florida curiosity shops. They are a staple article of trade, selling for from ten to twenty-five cents each, the price paid to the fishermen being about fifty cents per dozen.

The sailors' name for this fish, by which same name it is also known at Key West, Bermuda, Brunswick, Georgia and elsewhere, is "Tarpum " or "Tarpon." In Georgia and Florida it is commonly called the "Jew-fish." 
a name also applied by the fishermen of South Florida to a species of percoid which has already been discussed. It is the "Silver-fish" of Pensacola, the "Grande-Ecaille" (Large-scale fish), or "Grandyky'e," as it is pronounced and sometimes spelled, and the "Savanilla" of Texas.

The species can hardly be said to be common on our Atlantic coasts, though from fifty to one hundred specimens are doubtless taken erery year between Florida and Cape Cod. In I 874 and $S_{75}$ none were caught in the St. John's River, though several had been brought in during the previous winter. In the Indian River region these fish are sometimes harpooned.

Mr. Stearns contributes the following notes upon the fish, as observed by him :

"The Silver fish, or Grande Ecaille, is common everywhere on the Gulf coast. It is an immense and active fish, preying eagerly upon schools of young fry, or any small fish that it is able to receive into its mouth, and in pursuit of which it ascends fresh-water rivers quite a long distance. During September, I879, I saw large numbers of Silver-fish eight or ten miles up the Apalachicola River, and am told that that was not an unusual occurrence. They go up the Homosassa River in Florida, and several of the Texas rivers, so I have subsequently learned. The Tarpum will take a baited hook, but it is difficult to handle and seldom landed. The Pensacola seine fishermen dread it while dragging their seines, for they have known of persons having been killed or severely injured by its leaping against them from the seine in which it was inclosed. Even when it does not jump over the cork-line of a seine, it is quite likely to break through the netting before landed. I have secured several specimens, the smallest of which weighed thirty pounds and the largest about seventy-five pounds. The Tarpum is said to be palatable and well flavored."

Dr. C. J. Kenworthy, of Jacksonville, Fla., known in the literature of American angling as "Al. Fresco," is the great apostle of Tarpum, and by his enthusiastic advocacy has won it a place among game fishes.

The "Big-eyed Herring" or "Ten-pounder," Elops scurus, was described by Linnæus from a Carolina specimen sent to him by Garden. It occurs all along the coast from Martha's Vineyard southward, but only in the summer in the northern part of its range. It is cosmopolitan in its distribution, occurring throughout the West Indies, on the coast of South America, on both coasts of Mexico, at the Cape of Good Hope, in East Africa, Arabia and China. At Fort Macon it is known as the "Horse Mackerel." It is rarely or never eaten in the United States, its flesh being said to be dry and bony. 
A species of Anchovy, Stolephorus Browni, is extremely common about Fort Macon, where it is known as the "Sardine" and occurs in large schools. Specimens of this and of an allied species, S. Mitchilli, are occasionally taken in the vicinity of Woods Holl, Mass., and in greater abundance in New Jersey.

The presence of a true Anchovy in America was first announced by Prof. Baird in 1854 . A species was noticed by Mitchill, but its relations to the Anchovy of Europe were not recognized. In his report on the Fish of the New Jersey Coast, Prof. Baird remarked of S. Brozoni: "The Anchovy made its appearance early in August in the shallow waters along the beach, though of very small size; it subsequently became more abundant, and towards the end of the month, while hauling a large net in the surf, many were taken, measuring over six inches in length; as the meshes of the net were large, a great portion escaped, but with a seine properly constructed enough could be secured to supply the American market. I procured several specimens of this fish in 1847 at the residence of Mr. Audubon, on the Hudson River above New York."

There is little reason to doubt that this species of Anchovy might be prepared in salt or in paste, like that of Europe, and that the results would be equally satisfactory; as an actual fact, however, most of the Anchovies put up in Europe do not belong to this genus at all, but are simply pilchards or sprats preserved in a peculiar manner, the name "Anchovy" having come to be descriptive of a peculiar method of preparation rather than of the fish which is prepared. Our Anchory has recently been sold in considerable numbers in New York under the name "Whitebait," although the fishermen distinguish it from the true "Whitebait," the young of the herring, calling it "Spearing."

The Anchovy of the Pacific coast is reported by Jordan to be of little economic value. The commonest form is what he calls the California Anchovy, Stolephorus ringens, and which is thus described by him:

" 'This species is everywhere known as the Anchovy. It reaches a length of about six inches. It ranges from British Columbia to Chili, and is probably found on the coast of Asia also. It is found in sheltered bays, and is everywhere extremely common, but rather more abundant south of San Francisco than northward. It serves as food for the larger species to a greater extent than any other single species. The salmon, bonito, mackerel of all sorts, barracuda, sea-bass, the larger flounders, and, in fact, a majority of the larger fishes make a large percentage of their food 
of Anchory. At San Francisco it is occasionally brought into the market. Some attempts have been made to pickle them with spices for the trade, but this amounts to little as yet. A great many are salted by the Chinese, who use them as bait for the flounders and rock-fish. Two other species of Anchovies, Stolcphorus compressus and Stolcplorus delicatissimus abound south of Point Concepcion. They have no economic value."

The family Dorosomatide is represented on our Atlantic coast by a single species, the "Mud-Shad," Dorosoma Cepediamum, which is abundant in brackish waters along the coast from Delaware Bay southward to Mexico. In the Chesapeake region it is known as the "Mud-Shad," "Winter-Shad," or "Stink Shad;" in North Carolina as the "Hairyback" or the "Thread Herring ;" in the St. John's River as the "Gizzard Shad," "Stink Shad," or "White-eyed Shad."

The names "Gizzard Shad" or "Hickory Shad" refer to the peculiar muscular stomach, which is of about the size of a hickory-nut and is shaped like the gizzard of a fowl. The fish is found in brackish waters, or in the sea, for the whole length of our coast. It enters all streams after becoming land-locked in ponds, and throughout the whole Mississippi Valley it is permanently resident in large numbers in the larger streams and reservoirs. Since the construction of the canals it has appeared in force in Lake Erie and Lake Michigan.

This fish is extremely abundant in many localities, particularly in the St. John's River, Florida, where it becomes an annoyance to the fishermen by getting into their nets, several hundred bushels being sometimes taken in a shad net. They are also sometimes annoying to fishermen using gillnets for catching mullet. In the Potomac they are abundant and attain a maximum size and weight. Their flesh is coarse and not delicate in flaror, but they are by no means unpalatable, and on the tributaries of the Chesapeake they are extensively eaten by the negroes. In the St. John's Rirer they are made into guano. A factory for this purpose was in existence in I $S_{74}$ at Black Point, above Palatha. They breed in summer, and are supposed to feed, like the Menhaden, to a great extent upon the bottom mud.

In the Great Lake regions the Gizzard Shad is sometimes split and salted as "Lake Shad," but it probably meets with little sale, owing to the inferior quality of the flesh and the presence of the vast number of small bones that make up the skeleton. It is usually thrown away by the fishermen, and when brought to market it is only bought by the poor or the ignorant. It is not infrequently seen in the markets of Washington in 
spring. In the WVest it is sometimes seined by farmers in winter in still places in the rivers and peddled about the towns.

The Moon-eye, Hyodon tergisus, is a handsome fish, taking the hook readily and feeding on minnows, crustaceans and insects. It reaches a weight of one to two pounds. "In Lake Pepin," writes Dr. D. C. Estes, "in some seasons they seem to be quite plenty, and at others but very few are seen. On the whole, I have always regarded it as a rare fish. They are vigorous biters, and are as gamy as the striped bass (Roccus saxatilis). They take freely the minnow or fly, and are one of the smartest of fishes. They will come up, taste of a fly, let go and be gone before the angler has time to strike. Therefore, to be a Moon-eye fly-fisher one must be very sharp and not read a book while casting, as I once knew a man to do. As to his being a food-fish there is not a single doubt. I ate one this very morning for my breakfast, and it was excellent, the bones being far less in number and of larger size than in the herring."

The Lady-fish, Albula vulpes, occurs in the West Indies, in the Gulf of Mexico, on the Atlantic and Pacific coasts of North and South America, and sparingly along our Atlantic shores as far north as Cape Cod. It is also found about the Bermudas and Cape Verde Islands, in the Indian Ocean, the Red Sea, and on the coast of Japan. With us it is usually called the "Lady-fish ;" in the Bermudas the "Bone-fish," or "Grubber." At the Bermudas large schools are taken, and it is there considered a most excellent food-fish. From personal observation I can testify that its reputation is by no means a false one.

Henshall found it in the Indian River inlet, and gives it a fine character as a game-fish. Describing winter angling experiences, he writes: "In the course of an hour, and in quick succession, I took several more saltwater trout, a few red-fish or channel-bass, some ravallia or snooks of from three to ten pounds, some crevalle of three or four, and finally a Bone-fish of about three pounds, which gave more real sport than any of the others. The Bone-fish or Lady-fish, as it is sometimes called, is a siender, silvery fish, and fights in the water and in the air like the black-bass, but mostly in the air-a Silver Shuttle.",*

The species is found in some numbers in San Diego Bay, on the coast of California, where it is taken with the mullet: On account of its beautiful color it sells readily, but is not especially esteemed as a table fish.

\footnotetext{
* Turf, Field and Farm, Dec. 1884.
} 


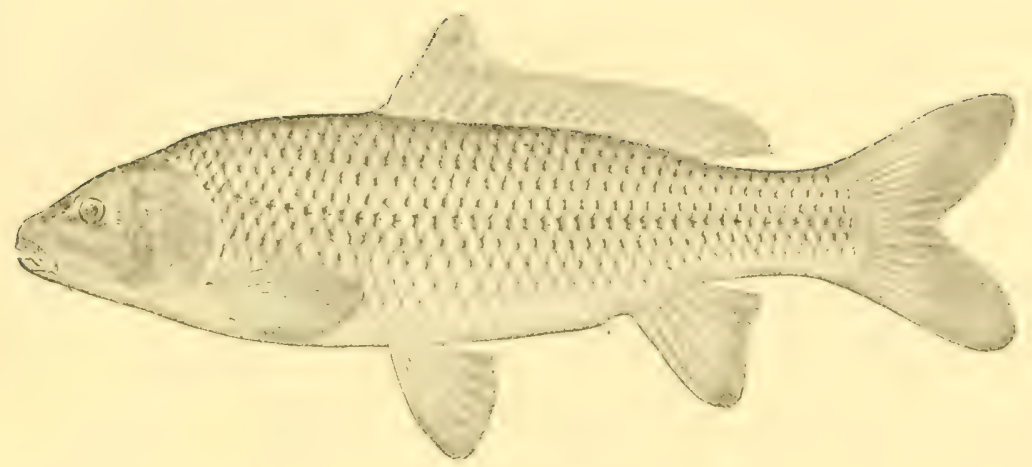

THE ASI.ITIC C.ARP,

CARP, DACE AND MINNOW.

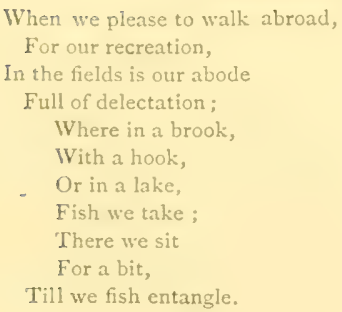

If the sun's excessive heat
Make our bodies swelter,
To an osier hedge we get
For a friendly shelter;
Where in a dyke,
Perch or pike,
Roach or dace,
We do chase
Bleak or gudgeon,
Without grudging;
We are still contented.

Piscator's Song.

ATHOEGII the fishes of the Carp family have recived lut slight com-
sideration from American writers upon angling, I am convinced that
they deserve a chapter in this book, on account of their growing popularity
among the great angling-democracy of the nation. They are the favorite
fishes of hundreds of thousands of modest fresh-water fishermen, and when
this continent shall have become more densely populated, and the oppor-
tunities for field sports more restricted, it is hoped that the inhabitants of
our cities, through the intervention of law and fish culture, may have
opportunities for fishing equal to those now enjoyed by the people of
Southern England. When that day comes the Cyprinidx must be counted
upon for the principal contribution to their pleasures.
Our cyprinoids are known to us, for the most part, by old English
names-names which are duar to luvers of Waltunian literature. and which 
are embalmed in the dramas, essays and poems of the old masters. Instead of grouping these fishes in accordance with systematic relations, they shall be taken up under their popular names and much in the same order in which Piscator introduced them, or their representatives, to his pupil Venator, two hundred and thirty-five years ago.

There is a kind of pleasure known to English anglers which is cultivated by but few of those who are called by the same name in America-the quiet, peaceful delight of brook-fishing in the midst of the restful scenery of the woods and the meadows. It is difficult to imagine a thorough disciple of Walton chumming for striped-bass in the surf at Newport or trolling for Muskellunge among the Thousand Islands, drailing for Blue-fish in the Vineyard Sound, or tugging at a tarpum-line in the Gulf of Mexico. The muscular exertion, the excitement, the flurry and noise, make such sports more akin to the fiercer pursuits of hunting than to the contemplative man's recreation. The wisest, best and gentlest of anglers, those who have made the literature of angling akin to poetry, have not, as a rule, preferred to make a violent exercise of their fishing.

In his charming essay on " Roach-fishing as a Fine Art," Edward Senior makes some pertinent remarks upon this topic. "Notwithstanding," says he, "the Philistine sneer at the assertion that the beauties of nature are a strong attraction for the angler, the fact remains. The meadows, woods, birds, bees, dragon-flies, forget-me-nots, meadow-sweet, and even the water-vole and the moorhen, enter into the vision which tempts the angler to the water-side. A little angling with a good deal of the sweet sights and sounds which it brings, is a boon to tens of thousands, who ought to be ever grateful to the roach, which is their excuse and opportunity."

This is the true Waltonian spirit, and the very same which inspired the angler's songs of old:

Of Recreation there is none

So free as Fishing is alone ;

All other Pastimes do no less

Than Mind and Body both possess;

My Hand alone my WVork can do,

So I can fish and study too.

I love not Angling (rude) on Seas-

Fresh Streams my Inclination please,

Whose sweet calm Course to Thought I call,

And seek in Life to copy all ;

In Bounds (like them) I fain would keep,

Like them, would (when I break them) weep. 
And when the timorous 'Trout I wait

To take, and he devours my Bait.

How small, how poor a thing I find

IVill captivate a greedy Mind ;

And when none bite, the IVise I praise,

Whom false Allurements ne'er betrays.

If (too intent on Sport) I fast,

Good Fortune gives me repast ;

My Friend it serves me to invite,

In whom I more than that delight ;

IVho comes more welcome to my Dish

Than to my Angle was my Fish.

Not only must we recognize their claim to a place in our esteem, but we must, in our far-reaching plans for the preservation of life in our waters, provide for them, not only for themselves, but for the sake of the common species which are dependent upon them for food.

These fishes are of importance also for bait, and an excellent essay upon the use of minnows for bait, written by Mr. D. W. Cross, was printed in the American Angler for April, I $88_{3}$.

The Asiatic Carp is the king of the Cyprinoids. The tribe takes its name in fact from the genus Cyprimus, of which the Carp is the best known form. Linne thus described it in $175^{8}$ in his "System of Nature:" Nobilis piscis sepius piscinis educatus, circa anno I600 in Angliam introductus. We all have heard the old saying, that turkies, carp, hops, pickerel and beer came into England all in one year, which is by no means a statement of fact. It was known in England as early as 1606 , when it was alluded to in the "Boke of St. Albans" as "a dayntous fysshe, but there ben but few in England." It came to Denmark in 1660, and to Sweden in 1560, and was cultivated in Germany and France as early as $125 \mathrm{~S}$, in Austria in $\mathbf{2 2 7}$. Cassiodorus in the sixtin century spoke of the Carpa of the Danube as a costly fish of delicate flavor, and supplied to the tables of princes. No one knows when or how it came to Europe from its original homes in Persia, China and the far east, but it seems probable that it mored by slow stages, from pond to pond, and from tribe to tribe, the beginning of the movement dating back beyond the beginning of the Christian era.

The acclimation of the Asiatic Carp in America has been wonderfully successful. As it often happens, the conditions here seem to be more favorable than in Europe, and in our southern waters, color, activity and growth continue throughout the entire year, the fishes soon attain a remarkable size. 
The following table from Cholmondeley-Pennell's "Fishing " will be generally useful to students of the Carp:

Comparative Weights and Lengths of Carp.

\begin{tabular}{|c|c|c|c|c|}
\hline Length. & IVeight. & Length. & IVe & ight. \\
\hline $\begin{array}{c}\text { inches } \\
9 \\
\text { I0 } \\
\text { II } \\
\text { I2 } \\
\text { I3 } \\
\text { I4 } \\
\text { I5 } \\
\text { I6 } \\
\text { I7 } \\
\text { IS } \\
\text { I9 }\end{array}$ & $\begin{array}{cc}\text { lbs. } & 0 . z s, \\
& 73 / 4 \\
& \text { II } \\
& \text { I } 43 / 4 \\
\text { I } & 21 / 2 \\
\text { I } & 81 / 4 \\
\text { I } & 141 / 2 \\
2 & 4 \\
2 & 111 / 2 \\
3 & 41 / 2 \\
3 & 141 / 2 \\
4 & 9\end{array}$ & $\begin{array}{c}\text { inches } \\
20 \\
21 \\
22 \\
23 \\
24 \\
25 \\
26 \\
27 \\
28 \\
29 \\
30\end{array}$ & $\begin{array}{c}\text { lbs. } \\
5 \\
6 \\
7 \\
8 \\
9 \\
\text { IO } \\
\text { II } \\
\text { I3 } \\
\text { I4 } \\
\text { I5 } \\
\text { I6 }\end{array}$ & $\begin{array}{l}\text { ozs. } \\
51 / 4 \\
23 / 4 \\
11 / 2 \\
13 / 4 \\
31 / 2 \\
63 / 4 \\
\text { II } \\
2 \\
10 \\
4 \\
0\end{array}$ \\
\hline
\end{tabular}

I shall not attempt to speak of Carp culture or to give statistics of the work of the Fish Commission. All these matters are discussed in the angling journals and the Government reports. It is equally useless to speak of the value of Carp for food. Every one will soon put this to a personal test, and those who experiment with badly coolied or badly kept fish will ever after denounce all Carp as worthless. The place of the Carp as a fish for sportsmen has not been discussed very fully, and since they are now growing abundant in all our streams, it is proper to quote the words of Pennell as to the manner of catching them.

"Early in the morning, and, occasionally, late in the evening, are the best times for fishing; but, as observed, the catching of Carp with the rod and line is always a difficult and uncertain operation, particularly if the fish are large. The smaller the pond, the better the chance I have always found of catching Carp and Tench, though, of course, they are not so large as in bigger waters. I once caught half a bucketful of Carp before breakfast, in a pond by the side of a road between Weybridge and Byfleet, which was not bigger than an ordinary sized ball-room. The biggest of these Carp did not, however, exceed two pounds in weight.

"The following is the method of Carp fishing in stagnant waters which I have found most successful :

"Let the line be entirely of medium sized or fine round gut-clouded, if possible-with a very light quill float, say No. 4, and one good-sized shot, about six inches or so from the hook, which should be No. 5 or 6 and baited with a brandling or red worm. Plumb the depth accurately ; 
and arrange the distance between the float and the shot, so that the latter may exactly rest on the bottom, weighing down the point of the float to about 'half-cock,' and letting the gut below the shot and the bait lie on ground. Fix the rod in the bank and keep perfectly quiet. When a bite is perceived, do not strike until the float begins to move away.

"It constantly happens, however, that the Carp will not be taken either by this or any other mode of fishing with which I am acquainted; but if he is to be caught at all it is thus.

"The baits are, worms (first), gentles, greaves, grains and various sorts of pastes, of which latter, however, I believe, the plain white bread crumb paste is the best, as well as the most easily made. Prof. Owen, who had a good deal of Carp fishing experience in Virginia water, gave me the results of his practice which concur in a great measure with my own, except that he fished with his bait paste made of soft herring roe worked up with bread crumbs and wool, a favorable substitute sometimes for the brandling."

In Germany the Carp season is in July, August and Septemter. The angler usually prepares for his sport by "ground-baiting" with a thousand or more angle-worms, twenty-four hours before he expects to fish, and while fishing he throws worms into the water. He uses Nottingham tackle, and baits his hook with the tail of an angle worm, or with grains of barley or wheat, a maggot or a wasp-larva, or with balls of dough. The bait rests on the ground, and the fish is allowed to rise toward the surface before striking. The young Carp of two pounds or less bite the best.

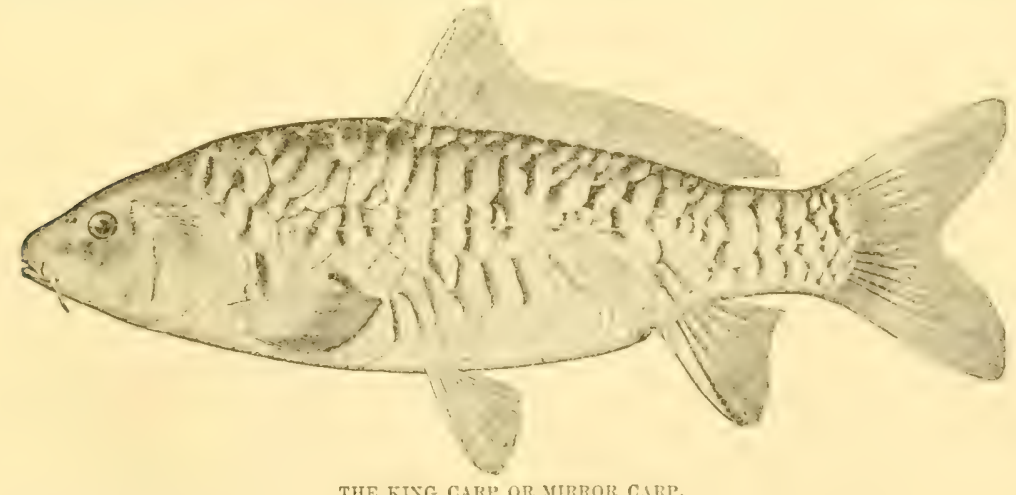

The natural result of so many centuries of pond culture has been the differentiation of varieties as well marked as those among poultry or domestic animals. The most important of these for the fish culturist are 
those which have been introduced into America by the Fish Commission. These are (I) the "Scale Carp;" with regular, concentrically arranged scales, being in fact the original species improved. A picture of this form stands at the head of the chapter.

(2.) The "King Carp" or "Mirror Carp," thus named on account of the extraordinarily large scales which run along the sides of the body in three or four rows, the rest of the body being bare. When there is a row of large scales down the back it is called the "Saddle Carp."



(3.) The "Leather Carp," which has on the back either only a few scales or none at all, and possesses a thick, soft skin, which feels velvety to the touch.

In addition to these somewhat interchangeable varieties of the typical Carp there are certain other local forms which have been described as definite species, such as the Danube Carp, C. acuminatus, the Lake Carp, C. hungaricus, abundant in the Lakes of Platten and Neusiedler, an Italian form, C. regina and C. Nordmanni, from Southern Russia.

Another Carp, Carassus aulgaris, the Karausche of Germany, often called the Crucian Carp or German Carp, is as protean in its forms as Cyprinus carpio itself, and probably found its way from the far East in much the same manner: a large-headed form, C. gibclio, is often called the Prussian Carp, and a specially differentiated type, C. buccphalus, lives only in the warm springs of Macedonia. The Gold Carp or Gold-fish is believed by some competent ichthyologists to be simply a variety of the Karausche, and when it escapes from domestication, quickly reverts to its ancestral form and color. The Karausche hybridizes freely with the Carp, 
and numerous curious and perplexing forms have resulted from such intermixturing.

The so-called Carp of the Hudson appears to be either escaped Goldfish or some inferior hybrich form of the "Karausche" type. Those introduced into California a few years ago by Mr. Poppe were an inferior strain of Scale Carp. The "Carp" of Virginia is a sucker, Carpiodes cyprinus.

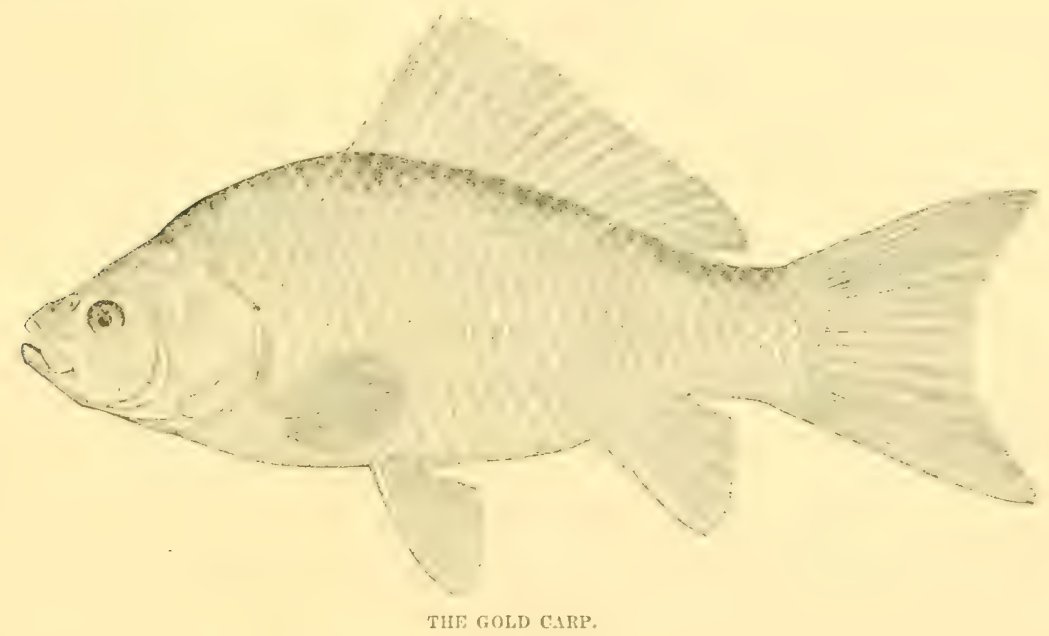

The Gold-Carp, the favorite of aquarium-keepers, is constantly becoming more popular, and many thousands have been distributed by the United States Fish Commission within the past few years, incidentaily, in connection with the work on food-fishes. It frequently escapes from domestication, reverts to the natural hue of olive-bronze, and is taken in nets and brought to market. The graceful long-tailed and triple-tailed varieties from Japan are reared by the Fish Commission as well as the silvery and the parti-colored forms, silver and gold. Mr. Seal has by artificial selection produced some grotesque forms, surpassing even them of Japan.

"The Gold-fish and its Culture," by Hugo Mulertt, of Cincinnati, is a book worthy of a place by the side of every aquarium. Henry W. Elliott, of Cleveland, has had fine success in hatching then in open, ornamental ponds, and has described his experience in the Bulletin of the United States Fish Commission. 
It is very interesting to a fish culturist to visit the sites of mediaval abbeys in England and trace out the remains of the immense stews or ponds in which the provident monks of old were wont to rear Carp and Tench and eels. The pond culture of England in the Middle Ages was very extensive, but has not been resumed in later days. On the continent, especially in Germany, however, it has been continued, and there are many excellent treatises on "Teichwirthschaft."

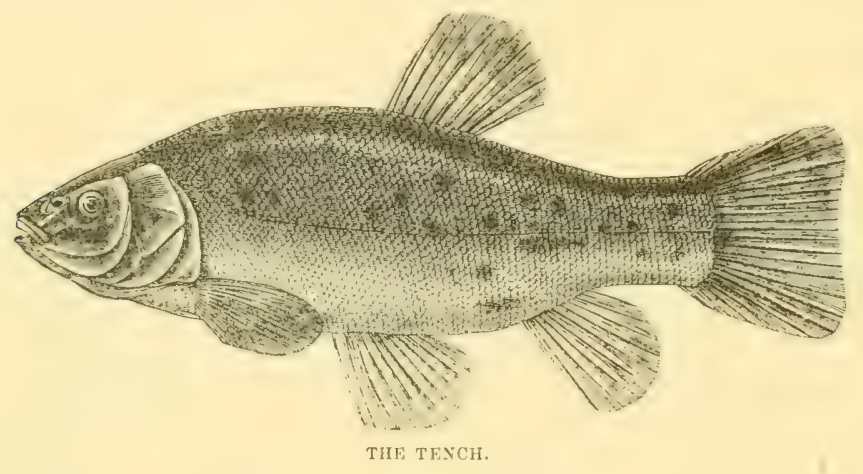

The Tench, Tinca vulgaris, the Schleihe of Germany, and the Tanche of France has already become acclimated in our waters, particularly in the Potomac, and will soon be available for the uses of anglers. It frequents streams and ponds with muddy bottoms, and is partial to weedy places. It is exceedingly tenacious of life, and even when grown in foul water has delicate white flesh, which many prefer to that of the Carp. Both Tench and Carp are better if kept in clear, cool water for a few days, and the slime should be washed off their scales with warm water before they are. cooked. I have eaten the Schlei in Bremen, and can speak well of it for in flavor and texture it resembles the American bluefish. My praise is, however, but feeble compared with that of Badham, who writes:

"In spite of the prejudice entertained by some Italian doctors, and all the old women of Italy, who believe this fish to be so impregnated with marsh malaria as necessarily to engender ague.

Nessuno mangia tenca

Che febre non senta.

At Florence it is held superior to any fishy food which enters the market, and in the Neapolitan pescheria yields to very few finer marine species. A 
Florentine noble once had the hardihood to assert at Leo X.'s table that there was nothing which swam the sea, to his mind, comparable to a good Tuscan Tench; which declaration, though it convulsed the native Romans assembled at the board with laughter at the simplicity of so poor a connoisseur, we should certainly have sided with, and been willing to back an Agnano or Thrasymene "T'enca' against the whole of the Mediterranean ichthyarchy." **

The season for Tench fishing in Germany is from July to October. The waters are ground-baited on the day before with angle-worms or washlarræx, and the method of angling is the same as for the Carp.

The Tench is an animal, which, like the owl and the weasel, was in former days looked upon with veneration and eren awe, and 15 an important accession to our fauna if only by reason of the wealth of fable which it brings in its wake.

"The Tench, said Piscator, "is the physician of fishes, and loves ponds better than rivers.

"In every Tench's head there are two little stones, which foreign physicians make great use of, but is not commended for wholesome meat, though there be very much use made of them for outward applications. Rondeletius says that, at his being at Rome, he saw a great cure done by applying a Tench to the feet of a very sick man. This, he says, was done after an unusual manner, by certain Jews.

"The Tench is the physician of fishes, for the pike especially ; and that the pike, being either sick or hurt, is cured by the touch of the Tench. And it is observed, that the tyrant pike will not be a wolf to his physician, but forbears to devour him, though he be never so hungry."

The Minnow or Penk, which Piscator used as a bait in fishing for trout, and the manner of impaling which he so minutely described to his scholar, was Phoximus lacvis Ag., a species widely distributed over Europe-the Vairon of France, the Pfrille of Germany, the Fregarolo of Italy.

Our Saxon ancestors knew it many hundreds of years ago as the "Menawe," and admired its graceful form and many hues. We have four species of Phoxinus in North America; one in the Tennessee, one in the Upper Missouri, one in the Beaver River, Utah, and one sparingly represented in Michigan, Wisconsin and Iowa. We have, besides, numerous forms sufficiently similar to be known by the same name, which, as a matter of fact, is applied indiscriminately to all small cyprinoids, and indeed to all small fresh-water fishes. "Minnow bait" is used by all live-

Prose Halieutics, p. 274. 
bait fishermen, and we have "artificial minnows" of multifarious forms for salt-water as well as for inland angling.

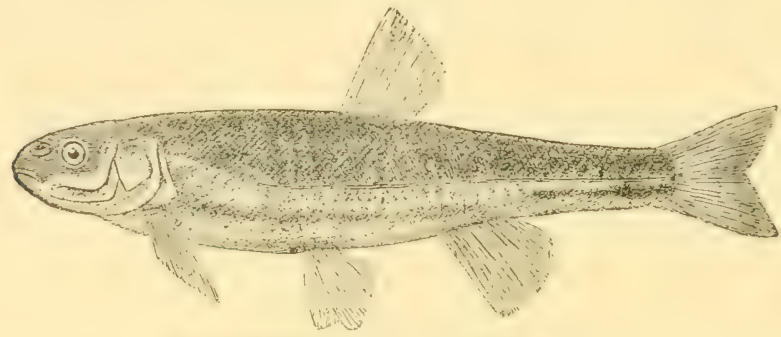

THE SUROPEAN HiXNOW-PHOXINUS LAETIS.

One of the most beautiful of our species is the "Black-striped Minnow," Rhinichthys atronasus, also abundant in clear brooks and mountain streams from Ohio and Virginia to New England, and one of the choicest of aquarium pets.

The Minnow is artificially propagated in France for the benefit of carnivorous fishes in ponds. Since it is an exceedingly prolific species, it is possible that its introduction into America might be beneficial.

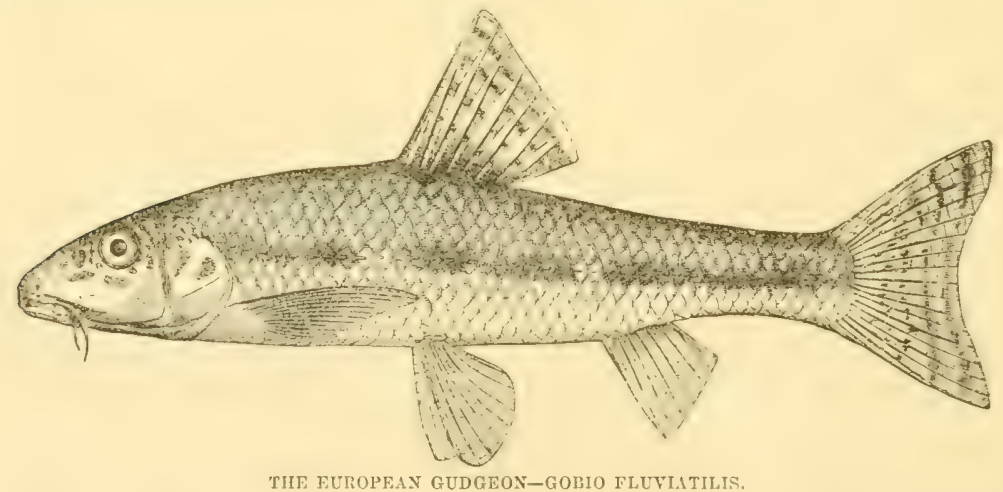

"The Gudgeon," said Piscator, "is reputed a fish of excellent taste, and to be very wholesome; he is of a fine shape, of a silver color, and beautified with black spots both on his body and tail. He breeds two or three times in the year, and always in summer. He is commended for a fish of excellent nourishment; the Germans call him Groundling, by reason of his feeding on the ground, and he there feasts himself in sharp streams and on the gravel. He is a most excellent fish to enter a young angler, being easy to be taken with a small red worm, on or near to the ground. He is 
one of those leather-mouthed flsh that has his teeth in his throat, and will hardly be lost off from the hook if he be once strucken."

We have no true Gudgeons in America, but the name is familiar to every American. It is a curious illustration of the persistence and vitality of popular sayings-that any man of English descent, be he of the East, West or South, if in fishing his hook brings up a worthless object, a stick, a tin-can or a rusty crinoline, will remark that he has "caught a gudgeon." And this is simply a manner of speech handed down to him through several generations, from his English forefathers. The dramas current in England at the time when America was first colonized were full of allusions to Gudgeon catching, which seem to have been a part of the slang language of the day, and in which the man who fished for Gudgeon seems to have been considered as contemptible as the Gudgeon itself.

In I 533, three hundred and fifty years ago, Holinshed in his "Chronicle of Ireland" asked: "Do you think that James was so mad as to gape for gogions?" and Butler in "Hudibras", said :

"Make fools believe in their foreseeing

Of things before they are in being

To swallow gudgeons 'ere they're catched

- And count their chickens 'ere they're hatched."

Webster in his drama, "The Devil's Law-Case," in I6 3, made Romelio to say :

"I would wish my noble venturer take heed,

It may be that while he hopes to catch a gilt-head

He may draw up a gudgeon." [Act I, Sc. I.]

Barry in his "Ram-Alley ; or, Merry Tricks," in I $6 \mathrm{I}$, made use of this dialogue:

Adriana: "I took you for a novice, and I must think

You know not the inwards of a woman.

Do you not know that women are like fish,

Which must be struck when they are brave to bite,

Or all your labor's lost."

Sinall-Shanks: Has the gudgeon bit?

Frances: He has been nibbling.

[Act 2, Sc. I. $]$

Ben Jonson and Richard Duke also alluded to the gudgeon, and we all are familiar with the advice of Gratiano in "The Merchant of Venice:"

"But fish not with his melancholly baite,

For this fool gudgeon, this opinion. [Act I, Sc. I.] 
It would seem that before England came to America this word had become associated with an idea to such a degree that the fish, the little "gojone" of the English middle ages, had been almost lost sight of, and this will account for the curious fact that the Gudgeon was almost the only common fish of the motherland whose name was not given to several smaller forms in different parts of Colonial America.

It was only in Virgina, which was the most English of all the colonies, and at the head of the Chesapeake, that the name was adopted. The Gudgeons of the Tuckahoes are the little cyprinodents, known as "mummichogs" in New England and "killifish" in the Middle States, belonging to Fundulus, Hydrargyra and related genera. The Crudgeon of the Patapsco and the lower Susquehannah is a cyprinoid fish, Hybognathus resius.

Gudgeon fishing at Relay House and in that vicinity is a favorite sport of the Baltimore people in April. The Gudgeons then ascend the Patapsco, to spawn and are taken in vast numbers with the finest of tackles and worms or maggots for bait.*

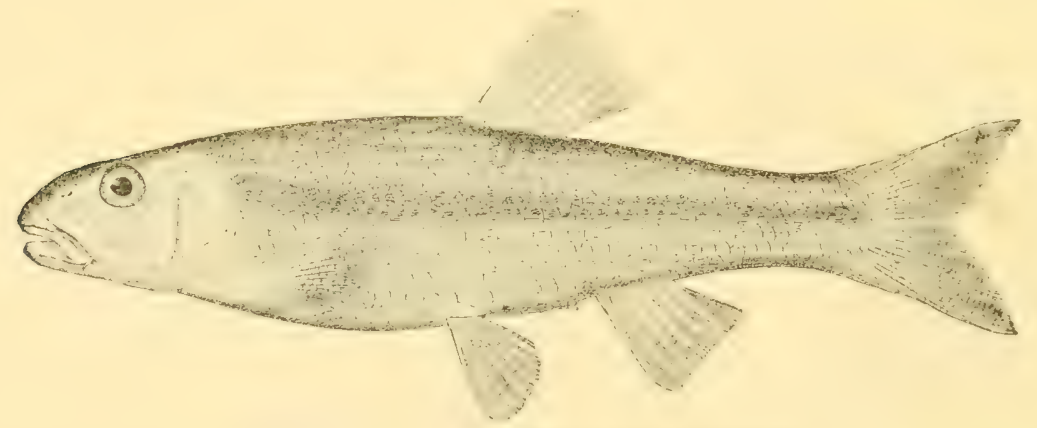

THF AMERICAN RIVER CHUB-CFRATICHTITS BigUtTATUS.

Zoologically speaking, the nearest kindred of the Gudgeon on this sideof the Atlantic are the members of the genus Ceratichthy's, (or Nocomis), of which we have at least twenty species, the best known of which is our "Horny Head" or River Chub, Ceratichthy's biguttatus, which is one of the most widely diffused of fresh-water fishes, occurring from New York to Utah and Alabama. It reaches a length of ten or twelve inches. It inhabits larger streams than the Horned Dace, which delights in little brooks. It takes the hook readily, and throughout the southwest is a great 
source of satisfaction to the angler. The flesh of this and other small Cyprinidae is very palatable when fried crisp soon after being taken from the water. Toward the northwest another Chub, Platygobio gracilis, takes the place of the preceding, and reaches a somewhat larger size.

The English Chub is also closely allied to its American namesake.

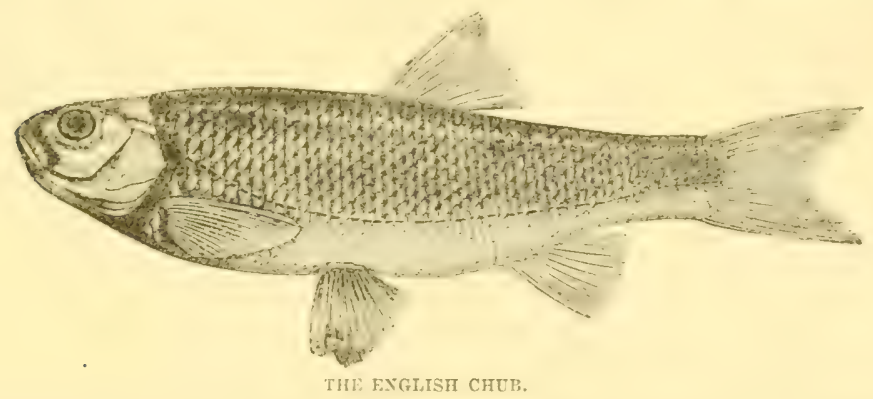

The English Chub, "Chevin" or Chavender, Squalius cophalus, the Chevaine or Dobule of France, the Altel or Dobel of Germany is widely distributed over Europe and Asia Minor.

Frank Buckland compares it to the Yorkshireman's horse-very bad to catch and no good when he is caught-but many old-school anglers will not ratify his judgment.

Pennell says of the Chub that, though not so mettlesome or gamesome as the Dace, it grows to far greater size, and has the merit of taking the artificial fly kindly.

The Chub is believed by many etymologists to have derived its English name from an old Saxon word meaning "head," and its French name also from chcf, a word of similar significance. It is also often called the "Loggerhead," and in Germany the "Dickkopf," and in France the $\therefore$ ( illiot.

The word "chubby" we owe, perhaps, to this plump little Leuciscus. Marston, in I602, in his play called "Antonio's Revenge," used this simile :

\section{"I never saw a fool lean; the chub-faced fop \\ Shines sleek with full-cramm'd fat of happiness."}

It attains a length of two feet and a weight of eight or ten pounds, lives in clear, swift waters, and is found in the mountains of Central Europe to a height of 3,000 feet or more, as well as in the brackish waters of North 
Germany, Finland and the lower reaches of the Thames and other English rivers. Somewhat gregarious in habits, it occurs in schools about bridge piers and mills, or in deep holes with hard bottoms, or in midsummer lies near the surface in shady places. It was at this season that Walton taught his scholars to catch Chubs.

"Look here, sir, do you see? said Piscator, there lie upon the top of the water, in this very hole, twenty Chubs. I'll catch only one, and that shall be the biggest of them all, and that I will do so, I'll do so, I'll hold you twenty to one, and you shall see it done."

Piscator was a skillful angler, for, notwithstanding the fact that he considered the Chub "the fearfullest of fishes," he landed his choice. And then, when it was cooked, Venator, who had called the Chub "the worst fish that swims, confessed that 'twas as good meat as he had ever tasted," and forthwith became the master's scholar.*

The food of Squalius is miscellaneous, like that of the Carp, and includes among other things frogs, mice and even rats. Cunning anglers tempt its appetite with red cherries, strawberries and raspberries.

The spawning time is in April, May and June, when the back of the male becomes covered with a fine white granulation. The eggs number 100,000 or more, and are deposited in gravel or weeds in shallow water.

Its shyness, its strength and its size make it a favorite among anglers, and there are many who make its pursuit a specialty.

"The Chub of all fish in his silver Trent

Invites the angler to the tournament."

\section{Trench in his "Northern Memoirs."}

In England its popularity seems to be increasing. Pennell protests against the old fashion of painting the Chub as a sort of water donkey, and Wheeldon speaks of it when in condition as an exceptionally handsome fish, while Senior writes thus in its favor:

"Fly-fishing for Chub answers best in the hot summer months, and along the willow and alder-lined reaches payable sport is obtained. It is a great boon for the man, in the big city pent, to be able to get away from lunsiness, and by an afternoon train arrive at any portion of the Thames below Oxford an time to have three or four of the he'st hours' fly-fishing which the day affords. The Chub is not fastidious in its choice of flies. So long as the lure is large and hairy; so long as it bears some passing resemblance to a caterpillar or beetle or large-winged moth, the anglers" chances of big fish are good. $\nmid$ "'

" Dame Juliana Berners said that "the chevyn is a stately fysshe, and his heed is a deynty morsell."

+ IVilliam Senior ("Red-spinner") Angling in Great Britain, p. 4 . 
The Dace of England, Squalius leuciscus, belongs to the same genus, which is one of the largest in this group of fishes, abundantly represented in the Palæartic region, and by at least fifty species in North America.

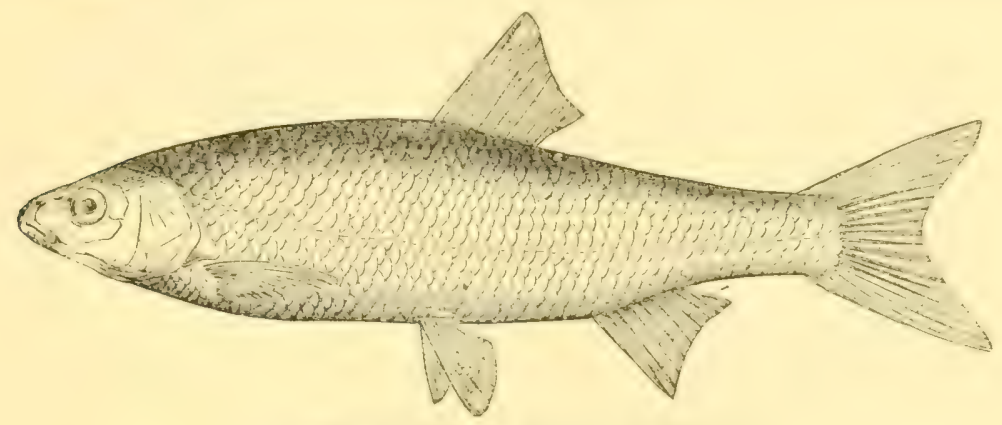

THE EUROPEAN DACE. SQUALIUS LEUCISCUS.

It is the Vandoise of France, the Hasel of Austria, the Häseling of North Germany.

The name Dace seems to be a modification of the word meaning a dart or javelin. Hundreds of years ago, according to Skat, it was called "Darce" and "Dare" (pronounced dahr) by our English forefathers, names clearly related to the old French dard and the Latin dardus. The Bretons call this species the "Darz," and in parts of England it is still known by the name "Dart."

Pennell tells us that it is "a bright, graceful fish, glancing about in the clear, and quiet streams which are often barren of trout or salmon," and is in full season from October to January when these are spawning, "and thus," he continues, " a red-letter day's sport is often to be obtained which would otherwise have had to be left blank in the angler's diary." It readily rises to an artificial fly, as does also the Chub, and Pennell's instructions are worth the consideration of American brook anglers.*

The German anglers, who fish for the Häseling from July to October, ground-bait with several hundred angle worms, about twenty hours before they intend to fish. They use the same tackle and bait as in carp fishing, and occasionally, in the latter part of July and August, employ an artificial fly, which they find more tempting if a maggot is added at the top of the hook.

It is said that the Jews consume great quantities of Dace in theirseasons

\footnotetext{
*See "The Badminton Library."
} 
of fishing; otherwise the fish is not now in especial favor for food. Its scales are so silvery and bright, however, that it makes the best of livebaits for pike or perch fishing, and has been used for this purpose from times immemorial.

"If the young dace be a bait for the old pike," said Falstaff, "I see no reason in the law of nature, but I may snap at him."

There are many species of Squalius in the streams and lakes of the far West and Southwest which must in time be highly prized by our people. At present, however, it is only in localities which are thickly populated that the native cyprinoids and catostomoids are known and appreciated.

Two species, Squalius rhomaleus and $S$. atrarius, are excessively abundant in Utah Lake. The latter, as it ascends the streams to spawn almost simultaneously with the trout (Salmo purpuratus), is extremely destructive to the young salmonoids. It is taken in considerable numbers in seines, and is sold in the markets of Salt Lake City and other towns. It reaches a length of nearly a foot. These species are known as Mullets and Chubs.

Numerous others, similar in size and habits, abound in the region between the Rocky Mountains and the Sierra Nevada, and are used as food by the Indians and by the white settlers. Among these are $S$. niger, $S$. purpureus, S. obesus, S. pandora, the "Pescadito" of the Rio Grande region, S. tinia, the "Leather-sided Minnow" of the Provo River and Salt Lake Basin, and S. elongata, the "Red-sided Shiner" of the Upper Missouri and the great lakes.

President Jordan speaks briefly as follows of various other American forms :

The "Chub" or "Mullet" of San Francisco, Squalius gibbosus, abounds in the Sacramento River, and is taken in great numbers. It reaches a length of about a foot, and is eaten chiefly by the Chinese.

The various species of Gila abound in the basin of the Rio Colorado and Rio Gila, and are used as food in New Mexico and Arizona. They reach a length of about eighteen inches. Gila clegans, robusta and Grahamiare the principal species.

Ptychochilus oregonensis abounds in the Columbia and Sacramento and their tributaries, where it is known as "Shepawl" and "Pike." It reaches a length of three or four feet at least, a size much greater than that of any other of our representatives of this family. A great many are brought into the markets of San Francisco in the winter. A second species (Ptychochilus Harfordi) accompanies $P$. oregonensis in the Sacramento, and is brought 
with it to the markets. A third species (Ptychochilus lucius) occurs in the lower course of the Rio Colorado, and is said to reach a still larger sizea length of five or six feet.

Mylopharodon conocephalus occurs with Piychochilus oresonensis in the Sacramento, and is brought with it into the markets. It reaches a size scarcely less than that of $P$. oreconcnsis, but is less plentiful.

Mylochilus caurinus abounds from California to l'uget Sound in all the streams of Oregon, Washington and Idaho, and often enters the sea. It reaches a length of little more than a foot, and is used for food where trout and other better fishes abound. Its great numbers, however, give it a special claim to notice.

The Split-tail, Pogonichthy's macrolepidotus, is very common in the Sacramento, and is brought in consiclerable numbers to the San Francisco market. It reaches a length of about eighteen inches.

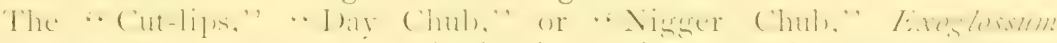
maxillingua, has but a narrow distribution, being found in abundance only in the basin of the Susquehanna. It reaches a length of six or eightinches, and has no economic importance.

Lavinia cxilicauda is found in some abundance in most streams of Califormia, and comes occasionally into the market. It reaches a length of about fifteen inches.

Orthodon microlcpidotus occurs in most streams of California in considerable abundance. A good many are sent to the market of San Francisco, where they are eaten by the Chinese. It reaches a length of about eighteen inches.

The Hard-mouth Chub, Acrochilus alutaceus, is found in the rivers of Washington and Oregon. It reaches a length of about a foot, but is only rarely eaten.

The name Dace in the Eastern states has been appropriated by a species perhaps more strictly entitled to be called a chub, but which is not likely ever to relinquish its time-honored appellation. 'This is the Dace or Horned Dace, Scmotilus corporalis, a fish which abounds in all small streams and ponds from Western Massachusetts to Nebraska and southward. It reaches the length of about a foot, and is beautiful, active and gamy, rising to the fly almost like a brook trout, though usually taken with worm-bait. The "horns" to this and other Minnows and Chubs are dermalexcrescences developed on the males in the breeding season, but absent at other times.

The name Corporal seems to have been derived from the Dutch or German settlers of the Middle States. "Corporaalen" is one of its common names in that region.

Very closely allied to the Eastern Dace is the "Fall-fish," Semotilus 
bullaris, of Virginia, also often called "Roach " or "Dace," is abundant in the Eastern and Middle States east of the Alleghanies. It reaches a

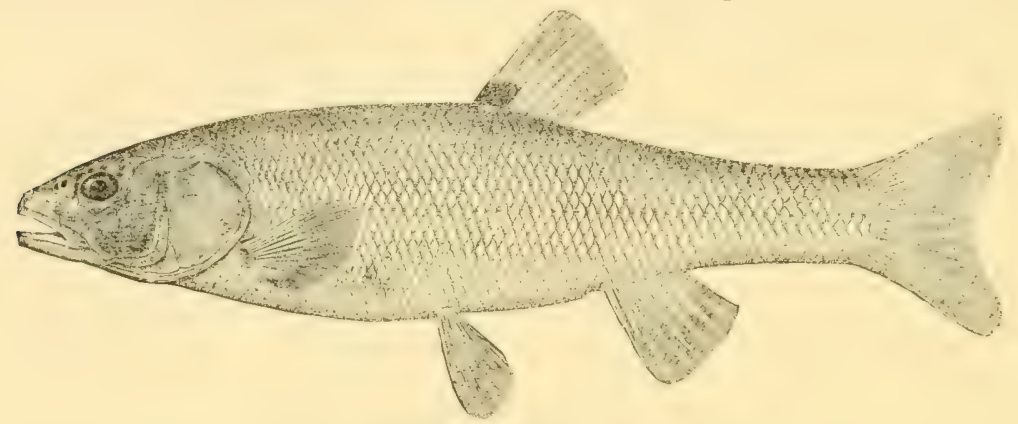

THE EASTERY DACE-SEMOTILUS CORPORALIS.

length of eighteen inches, being the largest of the Cyprinidæe east of the Rocky Mountains.

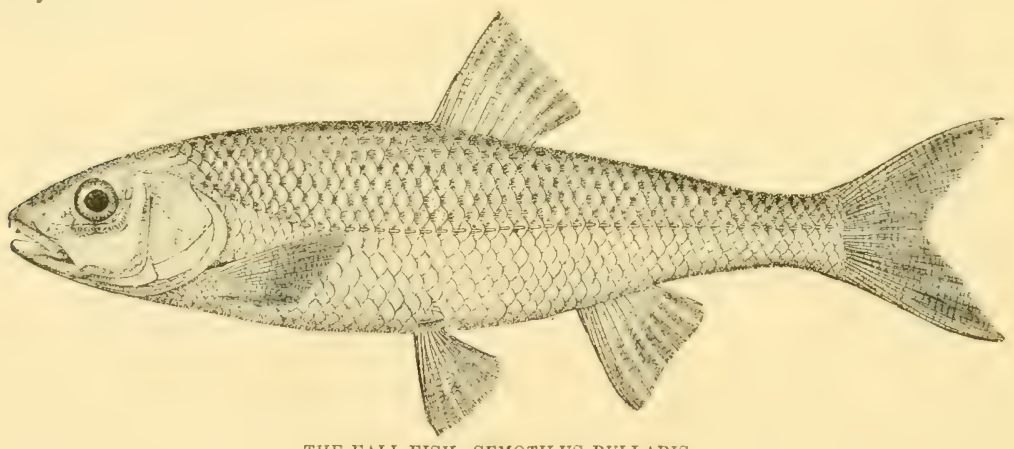

THE FALL-FISH-SEMOTILUS BULLARIS,

It is very common in the Delaware Basin, more so, perhaps, in the Susquehanna, but a common form in the head waters of the Atlantic-flowing streams of Virginia and the Carolinas. Hallock says that it has been caught weighing four pounds, that it is much esteemed as food, and affords good sport for the angler. I have myself taken them with light tackle and found them as gamy as brook trout in preserved streams. In Massachusetts it is often called the "Cousin Trout" in allusion to its trout-like habits, and also the "Chiven" from its resemblance to the English Chub or Cheven.

The mention of the American "Roach" brings us to the consideration of the Old World species, which it much resembles in habits. This is 
Lenciscus mutilus, the Plotze of the Germans, and the Rosse of the French.

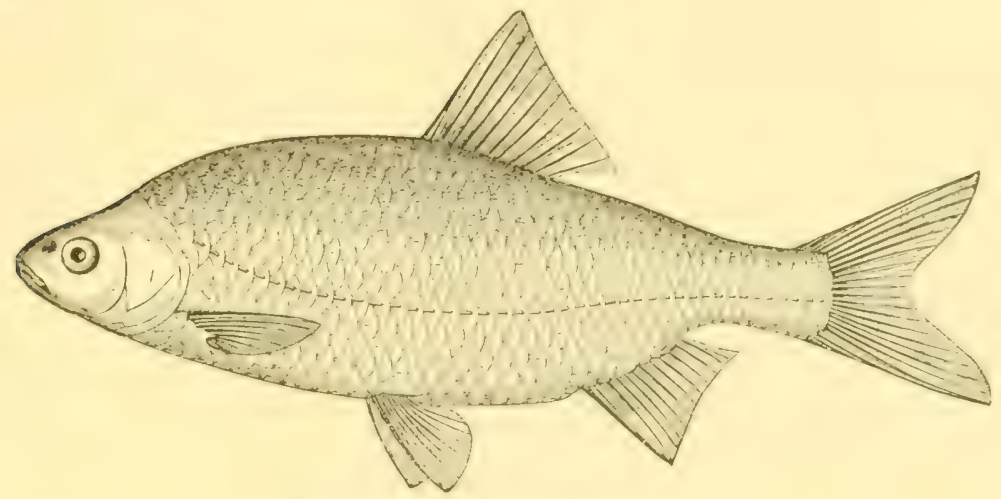

THY EUROPEAN ROACII OR RED D.ICE,

"The Roach," said Piscator, "is a fish of no great reputation for his dainty taste; and his spawn is accounted much better than any part of him. And you may take notice, that as the Carp is accounted the waterfox for his cunning, so the Roach is accounted the water-sheep for his simplicity or foolishness."

It has, however, gained in popularity in England since the days of Walton. "The Book of the Roach," by Greville Fennell, is one of the standard works, and William Senior ("Red-spinner") has written an essay upon "Roach-fishing as a Fine Art," * which is commended to all who go-a-fishing for cyprinoids in American waters, for the methods described by him will apply to many of our fishes.

Senior thinks that Roach-fishing requires special qualifications of mind and heart. "I am acquainted," writes he, "with many rich and poor, learned and ignorant, somebodies and nobodies, who have a passionate attachment for the pursuit. The higher kinds of rod-and-line work have no joys for them. Give them their camp-stool and Roach rod over the dark waters that move slowly above a clear bed, and they ask no more."

The "Rudd or Red-eye" of England, Scardinius erythrophthatmus, the Rothatige or Rotengle, is a rather important fish, resembling the Roach in its habits, and used by English pond culturists to stock new-made waters with bait for pike, and by those of Germany in feeding trout and pike perch.

\footnotetext{
* See "The Eadminton Library," p. $3+3$.
} 
The Bream is highly prized by many European anglers, but is perhaps less in favor than it was two hundred years ago, when this proverb was current : "Qui a brême, peut bramer ses amis," or as Walton translated it, missing the pun: "He that hath bream in his pond may bid his friend

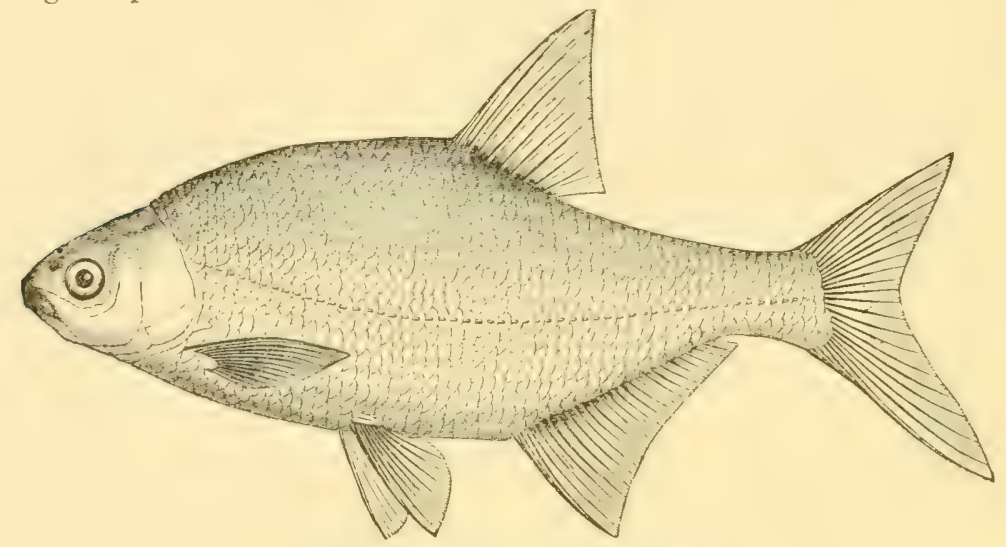

THE FUROPEAN BREAM. ABR.MMS BRAMA.

welcome." In Chaucer's day the Bream was apparently cultivated in ponds in England, but now is somewhat neglected, even by anglers, though Wheeldon devotes a chapter to Bream fishing in his "Practical Lessons in the Gentle Art." In. Germany the Brasse is in high favor, and is by some preferred to the Carp, especially for winter eating.* Great quantities are brought to the markets.

The American Bream, or Golden Shiner, Notemigomus chrysoleucus, is a better fish than its English namesake, and as an angler's fish, more like the Roach. It is in fact, often called Roach and Shiner in the Middle and Eastern States, Dakota and Texas, while an allied species, N. amcricanus, inhabits the rivers of the South Atlantic States, and others occur in limited areas elsewhere.

$N$. chrysolcucus abounds in most rivers east of the Great Plains, frequenting ponds, bayous, canals and ditches, and is the most abundant of all cyprinoids in the tide-water region, preferring waters in which the bottom is covered with aquatic plants. It reaches the length of nearly a foot, and the weight of a pound and a half, and is sometimes brought to mar-

To COOK Bream.-Cleanse him and lay him in salt and water one hour ; stuff with a rich veal stufting, and bake him--plentifully anointed with good butter-in a slow oven, until the meat comes off easily from the Lones. Serve him up, hol and hot, with cayenme pepper and lemon juice.-WHEELDoN. 
ket, though usually consumed by its captors. When eaten fresh, as a panfish, it is by no means despicable, and to my own taste, as palatable as black-bass or flounder.

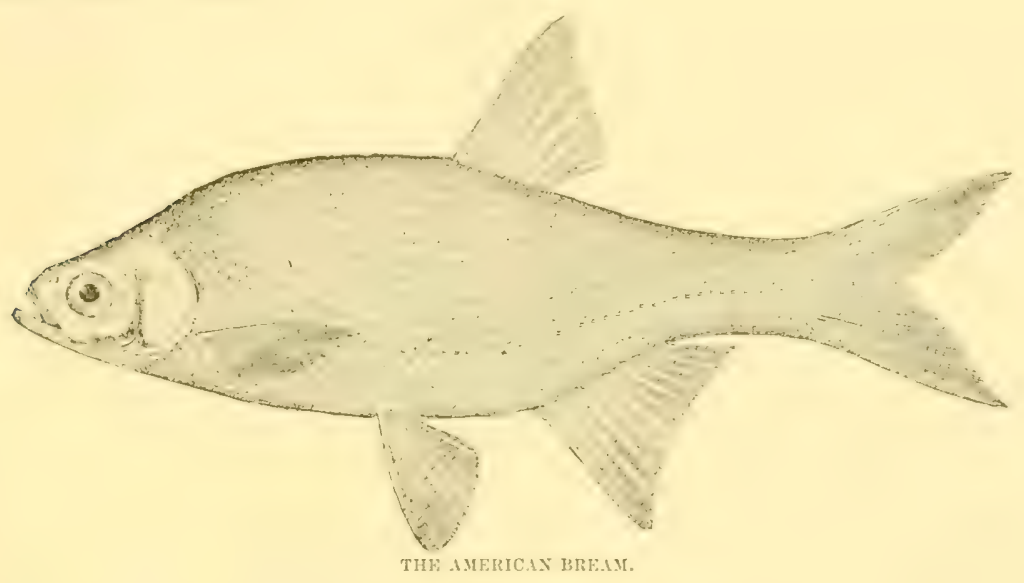

The early American angling authorities prized this fish more than those of to-day. Brown bursts into rhyme when he speaks of it:

"A capricious little fish

That swims in pond and stream, And a dainty on the dish

Is the cautious, cunning Bream."

"Being possessed," he continues, in a very sober vein "of a large amount of caution, they require all the skill and patience of the angler and the finest kind of tackle. A trout fish rod with a fine line and a good-sized trout hook baited with a grub angle-worm, cricket or grasshopper, if cautiously used, will generally tempt him from his element. He is good on the platter."

Scott and Norris also approve its claims to consideration as a game fish, and it is said by those who know, to rise readily to an artificial fly.

The Shiner, Mimilus or Luxilus cormutus, also called "Red-fin" or "Red Dace," abounds in ali streams from New England to Kansas and Alabama, being in most waters more numerous than any other species. In clear, cool lakes it is often found in great schools. At the mouths of small rivers in Lake Michigan hundreds of them can be taken in a short time on a small hook baited with worms or flies. This species reaches a length of 
about ten inches. It assists to swell the urchin's string, but has no tangible importance as a food-fish. Its flesh spoils very quickly after the fish is taken from the water, hence the name " Rot-gut Ninnow," applied to it in Alabama. A large part of the food of the black bass, trout and other predatory fish is contributed by the Shiner and by its numerous congeners.

Minmulus rubricroceus, a species inhabiting the headwaters of the Tennessee and Savannah Rivers is a very lovely species found by Cope and Jordan in rock brooks at the foot of cascades-a species well adapted for acquarium culture in the north.

Album the Bleak, Ablette or Uckelei of Europe, called by Walton the "fresh-water sprat," is represented in America by two species of the genus Richardsonius, which occurs in the Columbia River and northward. The Bleak is chiefly of interest as the source of the pearly matter, or Essence d'Orient, which is prepared from its scales and used in the manufacture of false pearls. In Pomerania one hundred and ten pounds of Uchelei yield about two and one-fifth pounds of scales, worth about three dollars in commerce. In other words, 10,000 fish are destroyed to make one pound of pearl material. Is not this worse than killing birds for feathers? This industry has been carried on in France for over two hundred years. The product of the Moselle in 1860 was worth 5,000 francs. The scales of the Roach and Dace are also used.

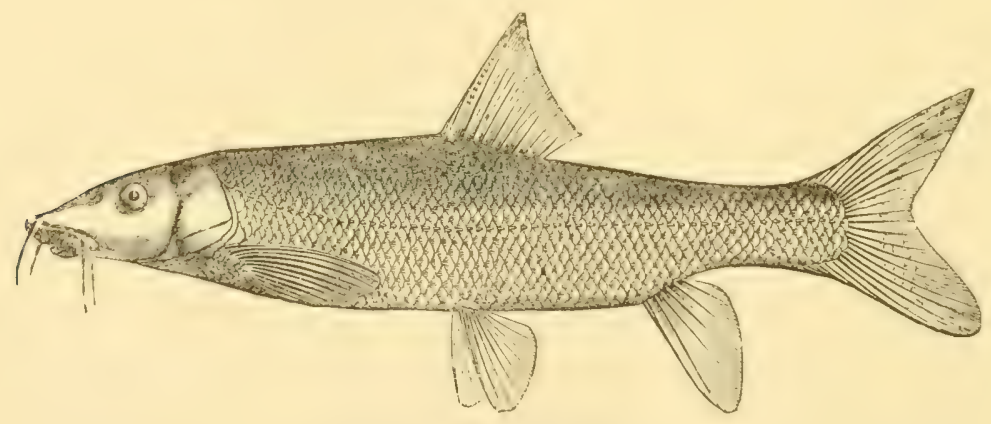

THE BARBEL OF' EUROPE.

The Barbel is somewhat like our Tarpum, since it is pursued by fishermen and caught chiefly for the pleasure of catching it.

"This fish," says Walton," is of a fine cast and handsome shape, with small scales, which are placed after a most exact and curious manner, and, as I told you, may be rather said not to be ill than to be good meat; the 
chub and he, have, I think, both lost part of their creclit by ill cookery. they being reputed the worst or coarsest of fresh-water fish. But the barluel affords an angler choice sport, being a lusty and a cumning fish-so lusty and cumning as to enclanger the breaking of the angler's line, by running his head forcibly towards any covert or hole or bank, and then striking at the line, to break it off with his tail, as is observed by Plutarch in his book "De Inclustriâ Animalium," and also so cunning, to nibble and suck off your worm close to the hook, and yet aroid letting the hook come into his mouth."

The Barbel, Barbus fluviatilis, the Barbe of Germany, the Barbeau of France, has no representative in America, though Günther recognizes over two hundred species in the tropical and temperate parts of the Old World, some of which are of consiclerable economic importance. The "Mahaseer," Bar-fus tor, which inhabits the mountain streans of India, attains sometimes the weight of one hundred pounds and the length of six feet, and has scales as large as the palm of a man's hancl. It is the largest of all cyprinoids and its introduction into the United States might be adrantageous, since when under twenty pounds in weight this and other Inclian forms are said to be excellent food.

The English IBarbel is one of the coarsest of their "coarse fish," and is not needed in America. It is, howerer, quite as highly esteemed in Ensland as our chubs and suckers are on this side of the Atlantic. Its habits are indeed not unlike those of our suckers or catostomoid fishes, and the methods of Barbel angling may yet be adopted in America for the fishes of this group. From the angler's standpoint, also, the Barbel is perhaps more like our "suckers" or Catostomide than any other Luropean species. The Catostomide are, howerer, not represented in the Old World, although they are so numerous in North America that no stream or river is without them.

The suckers, like the American representatives of the carp family; have suffered unjustly at the hands of Prof. Jordan, who is the principal authority as to their scientific affinities, and who, in the midst of his discussions of fin-formula and pharyngeals, never loses an opportunity to denounce them as unfit to eat. I can only account for his hatred of these fishes by the fact that he has handled so many thousands of specimens badly kept in alcohol, that he has acquired a loathing for them in any condition. Conceding to him a thorough knowledge of cyprinology and 
catostomology, I impeach him as a gastronomist. If he ever is a randidate for election to the Ichthyophagous Club, I hope I may have the privilege of casting a black-ball. He does not know what fish are good to eat, or, at any rate, is a bigoted disciple of the Salmonida.

For the benefit of our river fishermen I quote two recipes in favor in England for preparing the drier cyprinoids for table use.

"After being scaled and cleaned, they should be cut open like haddocks, well peppered all over, and then a good handful of salt rubbed in; let them lie in this all night. In the morning hang them up in the sun all day, to let them dry; fry them in the evening, with as little lard or butter as practicable, and eat them cold for breakfast. If you try it, I thin $\mathrm{k}$ you will say they are an excellent relish for breakfast, and nearly as good as anchovies. The secret lies in well drying them in the sun, and eating them cold.

"Although the Chub is generally a much despised fish, he is capable during the days of winter, the colder and more frosty the weather the better, of being elevated to a dish by no means despicable. At a dinner recently I was 'helped twice' from a plat of this fish, not knowing what it was composed of, and being induced by its delicious flavor to commit this solecism. When told that I had been regaling so earnestly upon chub from a neighboring stream, and expressing my desire for the recipe, my hostess very kindly upon my quitting gave me the following, telling me at the same time, she had received it while residing in Italy, from a Jewish family: "Take four or five large onions, boil them until they give to the pressure of the spoon, slice them: take the back bone out of the fish, and cut it, if large, into pieces of 3 inches or 4 inches; strew equally over the bottom of a stew-pan a little ginger in powder, salt and pepper; place the fish on these, and almost cover the fish with fresh water, then the sliced onions over all; put the lid on close, and let it simmer gently till all is done. While this is proceeding beat up the yolks of four eggs, with a good quantity of parsley chopped very fine, and a little of the liquor from the stew-pan, and while it is amalgamating, squeeze the juice from two lemons into it, very gradually, or the juice will curdle the eggs. Take up the fish with the onions upon it in a deep dish, and pour the mixture over it.' I ought to add that I tasted the dish again when cold next morning at breakfast, and that it had lost nothing of its relish, and I do not think that many who sat down before it without prejudice would come to any other than such a favorable conclusion. Perhaps vinegar instead of lemon might cheapen the dish, but as the recipe is given, it may be classed as economical.'

The common "Brook Sucker," Catostomus Commersoni, or the "White Sucker," is the most familiar and generally abundant of the group. It 
inhabits all bodies of water, large and small, from New England to Coloraclo. In the great lakes it reaches a length of two feet or more. In small brooks it is mature at eight or ten inches. It varies much in size, color and form in the different streams. It bites freely, and is one of the fishes with which the unambitious brook angler is well contented. When taken out of clear water, properly cared for and well washed, it is an excellent pan-fish, like most of its kind.

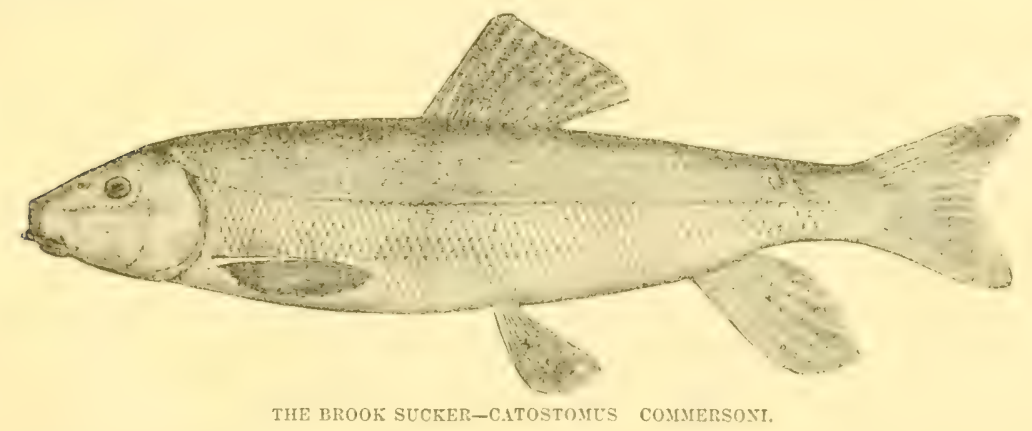

All the lakes and rivers of the Rocky Mountains and the Pacific slope, "says Jordan, are inhabited by species of this genus, or of the allied genera Chasmistes and Pantostcus. In Utah Lake, said to be the "greatest Sucker-pond in the world," are found Catostomus fecundus and ardens, Chasmistes liorus and Pantosteus platyrhynchus, all in abundance. In Lake Tahoe Catostomus tahoensis; in the Sacramento C. occidentalis; in the Columbia C. macrochilus; in Klamath Lake Chasmistes luwatus and Ch. brevirostris, abound, while in the great lakes and all waters thence to Alaska and Arctic Ocean C. longirostris is an important food-fish.

The "Stone-roller," "Hog Sucker," "Stone Toter " or "Hammerhead Sucker," Catostomus nigricans, abounds in most waters from the great lakes southward. The Stone-roller is extremely abundant in every running stream in the North and West, where its singular, almost comical form is familiar to every school-boy. It delights in rapids and shoals, preferring cold and clear water. Its powerful pectorals render it a swifter swimmer than any other of its family. Its habit is to rest motionless on the bottom, where its mottled colors render it difficult to distinguish from the stones among which it lies. When disturbed it darts away very quickly, after the manner of the etheostomoids. They often go in small schools. 
I have never found this fish in really muddy water. Although called the "Mud Sucker" in the brooks, it is most characteristically a fish of the running streams. This species reaches a length of about two feet, and is often caught in its spawning season by means of a spear or snare. It is, like C. commersoni, a "boy's fish," and not worth the eating.

It is hardy in the aquarium, and like its handsome cousin, Catostomus melanops, the Striped Sucker is recommended for domestication by Cope.

The suckers afford sport of an exciting kind to those who know how to capture them with snares of horse-hair or fine wire. I have thus caught them in Dutchess County, N. Y., where this method is greatly in favor.

Vast quantities are taken in the sluiceways of dams, and by spearing by" torch-light or "weequashing."

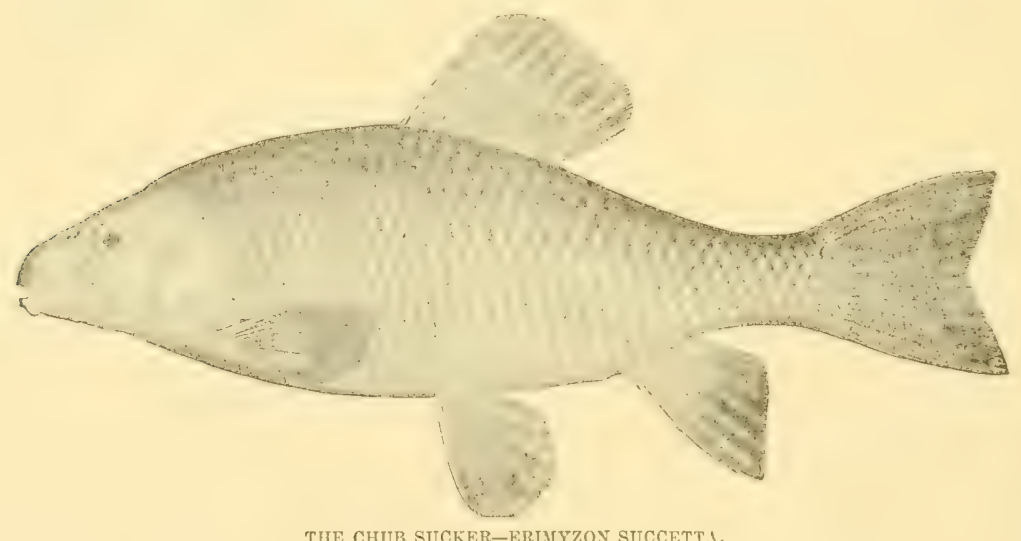

The "Chub Sucker," Erimyzon succetta, the "Sweet Sucker" or "Creek-fish," is one of the most abundant and wirlely diffused of the Suckers, being found from Maine to Texas. It is one of the smallest species, reaching a length of little more than a foot. A closely related species abounds in Florida, where it was first collected by the author, and has been named by Jordan Erimy'an Goodci. Hallock says that the "Chub-sucker" is often called the "Barbel."

"The Black Horse, Cycleptus clongatus, also called "Missouri Sucker," "Gourd-seed Sucker," "Suckerel" and "Shoenaher" is found in the river channels of the Ohio and Mississippi. It reaches a considerable size, weighing sometimes fifteen pounds, and is said to be a much finer 
fish in fesh than any other of its family. It is common in the Pittsurg market.

The different species of the genus Carpiodes abound in all the larger bodies of water south and west of New York as far as the Rio Grande. They reach a weight of four or five pounds. In Virginia and elsewhere they go by the name of "Carp," as they have done from the earliest days of the English occupation. Though fairly eatable, they are not equal to the Carp, and are less prolific, less rapid in growth, and most of all, not accustomed to domestication. The term American Carp should be abandoned, and when characteristic local names are not in use, the name "Carp-sucker" is recommended for adoption.

Carpiodes velifer, the "Spear-fish," "Sail-fish," "Quill-back" or "Skim-back" of the Ohio River, is a fish often seen in the markets.

Carpiodes cyprimus, the "Carp" of the Susquehannah, is abundant east of the Alleghanies from New York to Alabama. It is a common and acceptable food-fish in Pennsylvania, attaining a weight of two or three pounds. It is the "Carp" that is abundant in the Mattapony and Pamunky Rivers in Virginia.

The "Red Horses" belong to the genus MFoxostoma and the related Minytrema and Placopharynx, and ustally have their lower fins bright recl. They are useful and palatable food-fishes, although our writers have persistently underrated their value.

They are spring spawners, and when dams and other obstructions do not forbid run up to the head-waters to breed. It is of the utmost importance that fish-ways should be built over every dam on the continent, for already the streams have been drained, not only of the game fishes, local and anadromous, but of most of the humbler forms, which supply food to the carnivorous water-aristocrats, and render trout and bass culture possible.

The most familiar member of this group is the "Brook Nullet," Moxostoma macrolcfidotum, also called "Red Horse" in Pennsylvania, and elsewhere, and pretty generally distributed east of the Rocky Mlountains, except in Eastern New England. The form which occurs in the Ohio and Missouri has a larger head and larger mouth, and is generally catalogued as a variety or sub-species Duquesnii. This form is shown in the cut, which represents a specimen from Ecorse, Michigan.

The eastern form occurs in the Great Lakes, together with the allied 
M. aurcolus, and is common in the markets. Philadelphia receives a large supply from the Susquehanna and the Delaware. It is sometimes: called the "Lake Shad." There are four species of good size in the Catawba and other streams of the Southern Alleghanies. The Mullets and the Red Horses sometimes grow to the weight of four pounds.

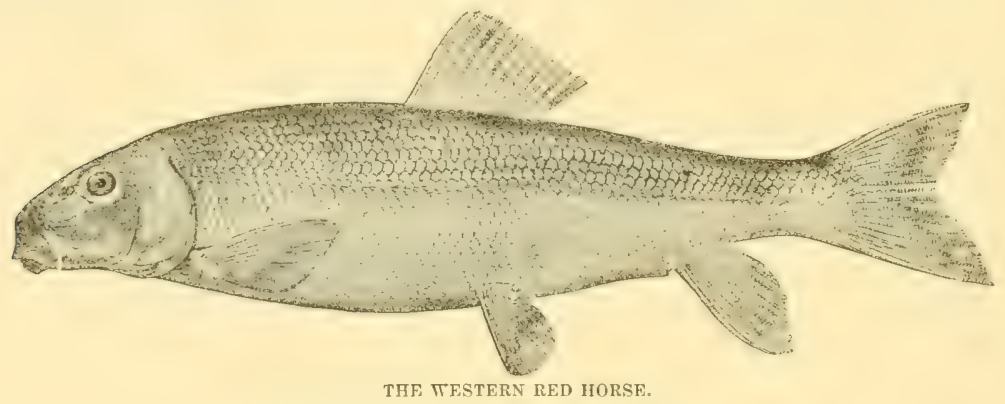

The "Buffalo-fish," Bubalicthyina, so called from the bull-like humpon the nape, are found mainly in the river channels of the Mississippi and its tributaries. They are the largest of the Suckers, reaching a weight of fifteen pounds or more. In the Mississippi and Obio Valleys they form a large percentage of the food-fish consumed. They usually bring a betterprice than the smaller Suckers, excepting the Black Horse. The Buffalofishes are found by Prof. Forbes to feed on small crustaceans more than do the other Suckers, and less on mollusks.

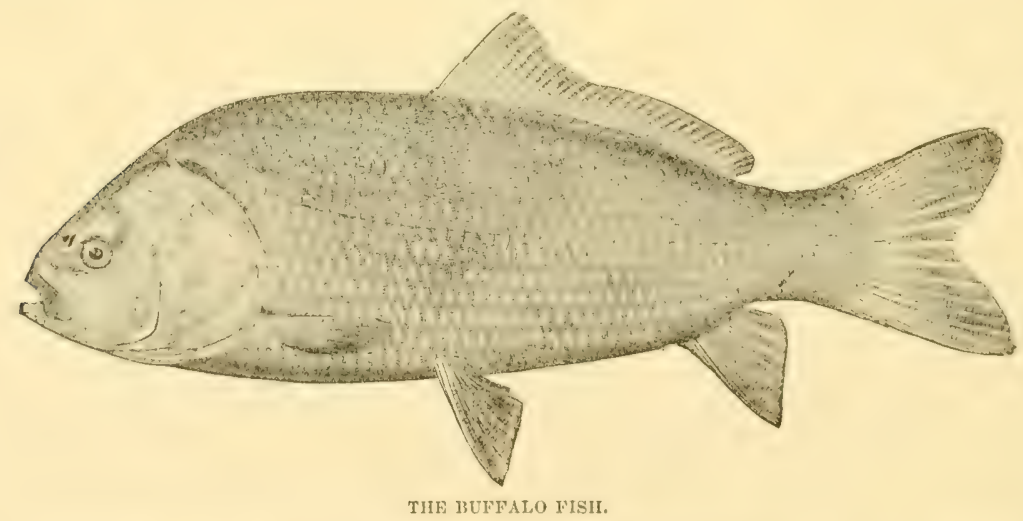

Icthyolus liululus, is abundant in the larger streams of the Mississippi 
Valley, growing to a weight of twenty or thirty pounds and a length of three feet.

Bubalichthys urus, of Agassiz, occurs in the same waters, and is called the Big-mouth Buffalo. In the Ohio and Mississippi Basins it is used very extensively for food, and grow's to weigh fifty pounds or more.

Bubalichthy's altus, which, like $I$. bubalus, is a small-mouth species, is distinguished by its smaller head and other characteristics. (Sce Jordan's ".sunopisis." 1. I (1).)

The name "Gaspergou" is shared by these fishes with the fresh-water Drum.

The only angling book which tells how to catch Buffaloes is a very old one, that of Brown. A bottom line of good strength and heavily leaded is used, and the bait prescribed is a wad of soft cheese and raw cotton.

The "Rabbit-mouth Sucker," Quassilabia lacera, "Hare-lip," "Splitmouth" or "May-sucker" is found in abundance in many rivers of Tennessee and in some streams in Ohio. It reaches a length of about eighteen inches, being one of the smaller species, but its qualities as a food-fish are said to be better than usual in this family.

The name "Sucker" has acquired a special and by no means complete significance in the colloquial language of the United States, being applied to worthless fellows, and especially to topers. The allusion is doubtless to the slow, greedy habits of the fishes of this family. 


\section{THE SALMONID Æ IN GENERAL.}

N Europe there is but one Salmon, but in this country they are many, and in a book on American Fishes all must needs be mentioned. Since the characters by which they are separated are rather minute, it will be necessary to employ the technical language of ichthyology.

The family Salmonida includes not only the Salmons and Trouts, but also the graylings, smelts, whitefishes, capelins, oulachans and certain other less familiar forms. The most prominent characteristic of the fishes of this group is the little fleshy appendage on the posterior part of the back, known as the soft, or adipose dorsal. This is found in many fishes belonging not to the Salmonida, but to allied groups, but none of these inhabit our coasts or inland waters, except the Catfishes, which are not likely to be mistaken for members of the salmon tribe.

The following table, prepared by Dr. Bean, will enable any one to determine at once to which genus any salmonoid fish belongs.

THE GENERA OF SALMONIDÆ.

\section{[Key prepared by Dr. T. H. BEAN.]}

A. Pyloric coeca many ; stomach siphonal.

a. Dentition strong and complete; conical teeth in jaws, vomer, and palatines; scales many more than I00; largely anadromous.

6. Anal rays g to ix.

c. Vomer flat, its toothed surface plane; teeth on its shaft in pairs or in a zigzag row ; species blackspotted.

d. Sea-salmon, anadromous.

di. River-salmon, not anadromous,

cc. Vomer boat shaped.

Subgenus Salmo. (The Sea Salmon.)

$e$. Vomer with a raised crest, head and crest both toothed ; species gray-spotted

CRistivomer. (The Lake Trouts.)

$e e$. Vomer without raised crest, its shaft strongly depressed; teeth on chevron only;

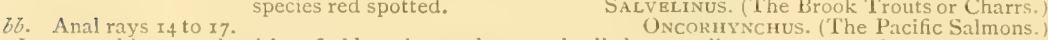
aa. Jaws toothless, or dentition feeble or incomplete; scales little exceeding roo; not anadromous.

$f$. Dorsal fin long and high. of about 20 rays.

Thymallus. (The Graylings.)

ff. Dorsal fin not elevated, ray's about ro to $x_{3}$.

g. Mouth small; jaws toothless, or with a tew weak tecth. Coregonus. (The Lake White-fishes.)

$\mathrm{sg}$. Nouth large; vomer, palatines and tongue with bands of minute villiform teeth.

AA. Pyloric cœca few or none; stomach cœcal

Stenodus, (The Inconnu.)

h. Branchiostegals 6 to 8 ; body compressed.

i. Month large; ventrals in front of middle of dorsal.

i. P'ectoral rays $x 6$ to 20 : scales very small: males with strong lateral ridges covered by modified scales.

kik. Pectoral rays ro to 1 ? ; scales larger, similar in both sexes.

d. Teeth feeble, especially on tongue. scales small, adherent.

Trazeichtriys. (The Oulachans.)

dd. Teeth stronger, lingual teeth enlarged; scales moderate, deciduous.

i. Mouth moderate or small; ventrals under or behind midelle of dorsal.

1h. Jaws with minute teeth; maxillary reaching past front of cye. Hrponesus. (The Surf-Smelts.) 


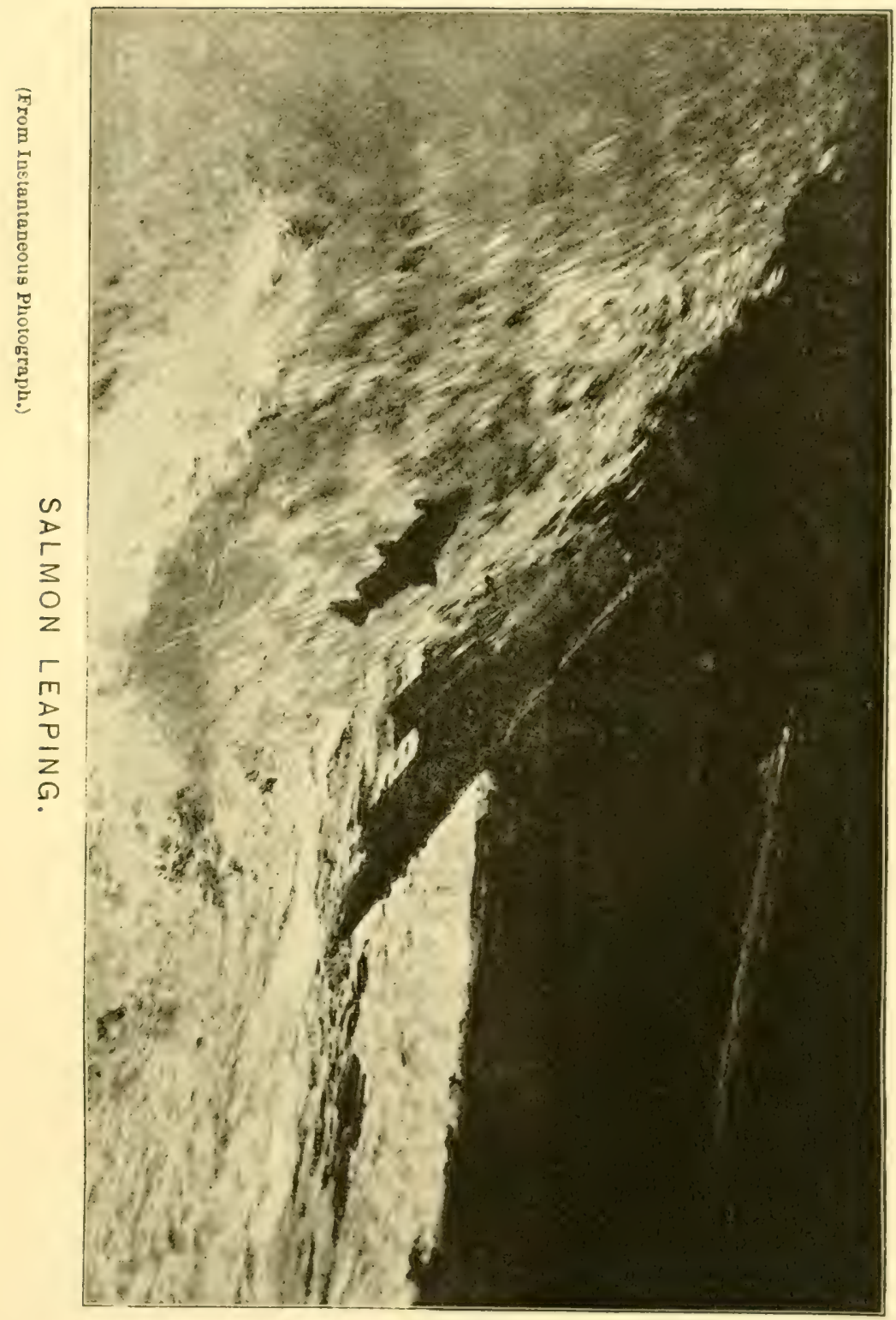





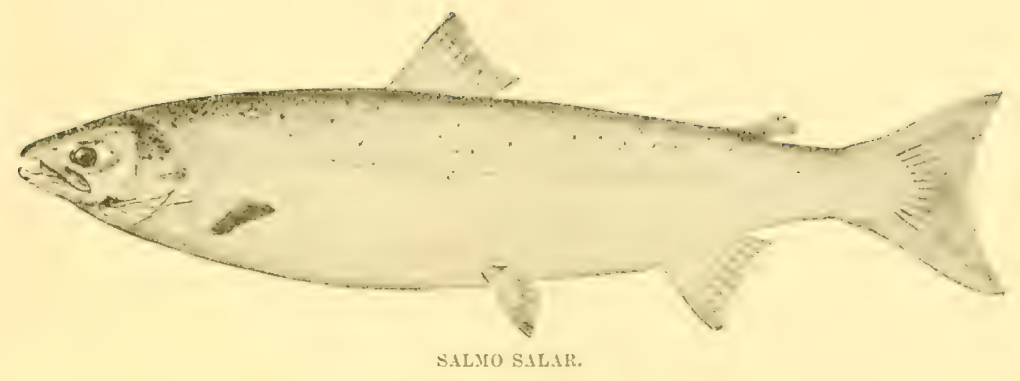

THE S.ILMON.

Nec te puniceo rutilantem viscere, Salmo Transierim, lata cujus vaga verbera caudx Gurgite de medio summas referuntur in undas, Occultus placido cum proditur aquore pulsus. Tu loricato squamosus pectore, frontem Lubricus et dubix facturus fercula cœenæ T'empora longarum fers incorrupta morarum, Præsignis maculis capitis, cui prodiga nutat Alvus, opimatoque fluens abdomine venter. *

Ausonius: The hoselle, 97-105.

66 TN the countrey of Aquitaine or Guienne in Fraunce, the River Salmon passeth all other sea fishes whatsoever." So wrote Pliny eighteen hundred years ago, and his was the first allusion in literature to Salmo salar. Hundreds of members of the family are now known to science, but this one species still stands preëminent, like a Highland chieftain, needing no name save that of his clan. The Salmon streams of ancient Britain and Gaul were known to the Romans, who appreciated fully the worth of their scaled treasures, and our early British ancestors were equally familiar with the Salmon, as we know from the Saxon names which were applied to it, many of which still survive both in England and Americaparr, peal, penk, smolt, grilse, kipper, bagget, and a dozen more. 'The reader will recall Walter Scott's generalization, that while our names for animals as served upon the table,-beef, veal, mutton, pork, - are of Norman origin, the names of the anmals themselves are still those by" which they

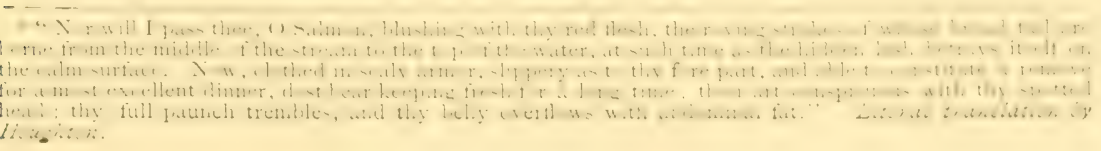


were known to the English, who after the conquest became their keepers. In a similar way, the word Salmon, the name of the adult fish ready for the banquet, was brought in by the Norman invaders. The Magna Charta recognized property rights in Salmon-fisheries, and protective laws have been enforced in England for at least six centuries.

How did the Salmon get its name? Fuller in his "Worthies," says, "from its strange leaping (or flying rather) so that some will have theirs termed salmones a saliendo," and later etymologists have found no better theory. Skeat calls attention to the fact that the introduction of the $l$ is due to our knowledge of the Latin form, since we do not pronounce it. The Middle English name was Saumoun, very close to the Old French Sammon. Salm is the German version and one of the tributaries of the Moselle is called the River Salm.

There are other names by the score used in Europe, but scarcely known in this country, where Salmon and Grilse are the only titles in common use. A Grilse is a Salmon of less than five pounds weight on its first return from the sea.

"Grilse" is believed by Houghton to be a corruption of the Swedish graclax or "gray lax," $i$. e. a gray salmon.

The Salmon inhabits the North Atlantic and its tributary waters. No one knows how far beyond the arctic circle it ranges, though its occurrence in northern Scandinavia, Iceland, Greenland, and middle Labrador is well established. It occurs in all parts of northwestern Europe, and is especially abundant in the British Islands, and is more or less plenty in France, Belgium, Holland and Prussia, entering the Baltic,-according to some authorities, the White Sea,-and ascending the Rhine as far as Basle. The southern limit of range is in Galicia, the most northern province of Spain, in latitude $43^{\circ}$. " "There is a river in Macedon," says Fluellen, in King Henry the Fifth, "and there is also a river in Monmouth; it is called Wye at Monmouth; but it is out of my brains what is the name of the other; but ' $t$ is all one, 't is alike as my fingers is to my fingers, and there is salmons in both." Fluellen was wrong, and so was Shakespeare, if he shared the belief of his hero, for there are no Salmon in any portion of the Mediterranean basin.

On this side of the Atlantic the species ranges more to the southward. The Connecticut River once teemed with them, and stragglers have been captured in the Housatonic and the Hudson. The southern limit is 
marked approximately by lat. $40 \% 2^{\circ}$, but they may be regarded as partially acclimated, through the efforts of the Fish Commission, in the Delaware and in the Susquehanna, which flows into the Atlantic in lat. $37^{\circ}$, and individuals have even been taken in the Potomac and in North Carolina. 'The Merrimac river was once full of these fish, and there are Salmon streams in Maine, New Brunswick, Nova Scotia, Newfoundland, Canada. and Labrador. They occur in all the tributaries of the St. Lawrence to Niagara Falls, and probably are found in Hudson's Bay and on the arctic coast of the continent.

Wonderful things are said about their abundance in colonial days. Every one has heard of the epicurean apprentices of Connecticut who would eat Salmon no oftener than twice in the week. "The shad, bass, and Salmon more than half support the province. From the number of seines employed to catch the fish passing up the locks one might be led to suppose that the whole must be stopped, yet in six months' time they return to the sea with such multitudes of young ones as to fill the Connecticut River for many days, and no finite being can number them." These are the words of Peters in $I_{7} 8_{3}$, in his "History of Connecticut."

Like many other good ones, this tale seems to be prehistoric, and was doubtless told of some other fish in the times when our Aryan ancestors dwelt on the plains of Central Asia. You may find it in Fuller's "Worthies of England," where it has the archaic and indefinite flaror which is so evident now, two centuries later. "Plenty of them in this country," wrote Fuller, "though not in such abundance as in Scotland, where servants (they say) indent with their masters not to be fed therewith above twice a week."

Day has pointed out, the frequent eating of Salmon, and especially of kelts was thought conducive to leprosy which after the Crusades in the Middle Ages, was a formidable disease in Europe. Capt. Franks writing of Stirling in the time of Cromwell, remarked that "the burgomasters, as in many parts of Scotland, are compelled to reinforce an ancient statute that commands all masters, and others not to force or compel any servant or apprentice to feed upon. Salmon more than once a week."

Nova Scotia, New Brunswick, and Maine have many Salmon rivers; New Hampshire, Massachusetts and Connecticut, a few very good ones. The natural limit of the southward range of the Salmon appears to be in lat. $4 \mathrm{I}^{\circ}$, near the Connecticut River, where they were once extremely 
abundant, but many stragglers have been taken in the Housatonic and Hudson. Much effort has been put forth in trying to prove that the Salmon, of which Hendrick Hudson saw "great store" in 1609 , when sailing up the river which bears his name, were weak-fish, or some equally remote species. Surely weak-fish do not go up the river to the Highlands. Salmon nave from time to time been seen in the Delaware, it is said, and, if this be true, it renders the story of Hudson still more credible.

There can be no doubt that one hundred years ago the Salmon fishery was an important industry in Southern New England. Many Connecticut people remember hearing their grandfathers say that when they went to the river to buy shad, the fishermen used to stipulate that they should also buy a specified number of Salmon. There is a tradition of a farmer's wife in New Hampshire who used to spear Salmon with a pitchfork to provide food for the farm hands. At the beginning of this century they began rapidly to diminish. Mitchill stated, in I 8 I 4 , that in former days the supply to the New York market usually came from Connecticut River, but of late years from the Kennebec, covered with ice. Rev. David Dudley Field, writing in $\mathbf{s} 8 \mathrm{I} 9$, stated that Salmon had scarcely-been seen in the Connecticut for fifteen or twenty years. The circumstances of their extermination in the Connecticut are well known, and the same story, names and date changed, serves equally well for other rivers.

In 1798 a corporation, known as the "Upper Locks and Canals Company," built a dam, sixteen feet high, at Miller's River, one hundred miles from the mouth of the Connecticut. For two or three years fish were observed in great abundance below the dam, and for perhaps ten years they continued to appear, vainly striving to reach their spawning grounds; but soon the work of extermination was complete. When, in IS 72 , a solitary Salmon made its appearance, the Saybrook fishermen could not give it a name.

In 1878 , at least five hundred large fish were caught in these wates, the direct result of the labors of the State commissioners of fisheries in 1874 . This story of destruction, with a change of names and dates, may be repeated for the Merrimac and many other rivers. Mr. C. G. Atkins recorded, in $8_{72}$, twenty-eight Salmon rivers lying wholly or in part in the United States, in only eight of which Salmon were at that time regular visitors. The story of restoration will, it is hoped, soon be applicable to these, and perhaps to others to which the species is not native. Thack- 
eray, in "The Virginians," made George Esmond claim Salmon, shad, and rock-fish among the game creatures of Westmoreland county, Va., and nearly permitted him to profane Nadame Esmond's hospitable mansion by quarrelling over the matter with young Colonel Washington, her guest.

Was the great novelist a prophet? In Nay, I878, several fine Salmon were taken in the Susquehanna, after having coasted along more than one hundred miles of the Old Dominion shore.

At least half of the Salmon's life is spent in the ocean. "He is ever bred in the fresh rivers," said Walton, "and never grows big but in the sea." "He has (like some persons of honor and riches, which have both their winter and summer houses) this fresh water for summer and the salt water for winter to spend his life in." Mlost of his tribe, however, are peculiarly fresh-water fishes, though several share his sea-dwelling habit, and others, like the Brook-trout, descend into salt water, when not prerented by barriers of temperature. All of the family run into very shoal water, and usually to the sources of streams, to deposit their eggs, and all of them seek food and cool temperatures in the largest and deepest bodies of water accessible. I am inclined to the view that the natural habitat of the Salmon is in the fresh waters, the more so since there are so many instances-such as that of the Stormontfield Ponds in England-where it has been confined for years in lakes without apparent detriment. The "Landlocked" or "Fresh-water" Salmon, known also in the Saguenay region as "Wimninish," in the Shubenacadie and other rivers of Western Nova Scotia as the "Grayling," and in different parts of Maine as "Schoodic Trout," "Sebago Trout," or "Dwarf Salmon," probably never visit salt water, finding ample food and exercise in the lakes and large rivers. In certain regions in Maine and New Brunswick their access to salt water is cut off by dams, and some investigators have claimed that Land-locked Salmon did not exist there until these obstructions were built, some fifty years ago. This hypothesis, however, is not necessary, for in the Saguenay the Winninish has easy, unobstructed access to the sea. The Salmon of Lake Ontario and its tributaries are not thought to enter salt water, and there are similar instances of land-locking in the lakes of Northern Sweden. In the Maine lakes Salmon feed on minnows and other small fishes. The Salmon while it remains in the sea or in the brackish estuaries takes particular delight in feeding on crustaceans and their eggs, small shrimps, and young crabs. When in the rivers they eat but little, though they are 
at times eager enough for food, as is shown by their eager rushes at the angler's fly-hook. The absenteeism of the Salmon is due principally to the dearth of desirable food in the rivers. The young fish stay in fresh water for one, or frequently, two years. When they pass down to the sea they weigh but a few ounces. They find congenial food and begin to grow rapidly. The broad world of ocean affords them new opportunities for adventure and self-advancement, and it is only when summoned by the duties of family life that they return within the narrow limits of the old home. When Salmon live in the lakes they prey upon minnows and other small fishes, but those of the sea delight also in small crustaceans and their eggs, to which they owe the vivid color of their flesh. The habits of successive generations become hereditary traits, and the differences in their life-histories seem to justify the claim of the Land-locked Salmon to be regarded as a variety of Salmo salar, though it is hardly to be distinguished except by its lesser size and some slight peculiarities in coloration. It has been designated Salmo salar, variety sebago.* Although both originated in the same primitive stock, it is not probable that one changes to the other except after many generations, under the influence of forced changes in their environment.

The leaping of the Salmon is one of the most marvellous of feats, and has been the theme of many writers.

"Here, when the labouring fish doth at the foot arrive,

And knows that by his strength but vainly doth he strive,

His tail takes in his teeth; and bending like a bow

That's to the compass drawn, aloft himself doth throw ;

Then springing with his tail, as doth a little wand

That bended, end to end. and flirted from the hand,

Far off itself doth cast ; so doth the Salmon vaut.

And if at first he fail. his second somersaut

He instantly assays, and from his nimble ring

Still yesting, never leaves until himself he fling

Above the streamful top of the surrounded heap."

This was once the idea of the mechanism of the leap of the Salmon. A modern English writer thus describes the actual feat: "I watched the fish with a raceglass for some ten minutes before disturbing them. There is a very deep pool at the point where the waterfall joins the lower level of the water. The fish came out of this pool with the velocity of an

'Sec H. H. Thompson's essay in The American Angler, r, 296. 
arrow; they gave no warning of their intentions, but up they came, and darted out of the surface of the water with a sudden rush like rockets let loose from the darkness of the night into the space above. When they first appeared their tails were going with the velocity of a watch-spring just broken, and the whole body, sparkling as though they had been enameled, was quivering with the exertion. They looked as much like flying fish as ever I saw anything in my life."

Observations have recently been made by Dr. A. Landmark, of Norway, on the extent of Salmon leaps. He thinks that the jump depends as much on the height of the fall as on the currents below it. If there be a deep pool right under the fall, where the water is comparatively quict, a Salmon may jump I 6 feet perpendicularly: but such jumps are rare, and he can only state that it has taken place at the Hellefos, in the Drams River, at Haugsend, where two great masts have been placed across the river for the study of the habits of the Salmon, so that exact measurements may be effected. The height of the water in the river of course varies, but it is, as a rule, when the Salmon is running up stream, I 6 feet below these masts. The distance between the two is $3 \mathrm{I} / 2$ feet, and the professor states that he has seen Salmon jump from the river below across both masts. Landmark states that when a Salmon jumps a fall nearly perpendicular, it is sometimes able to remain in the fall, even if the jump is a foot or two short of the actual height. This has been proved by overwhelming evidence. The fish may be seen trembling, and then rest for a minute or two a foot or so below the edge or the fall, with a smart twitch of itstail, the rest of the fall is cleared. Only fish which strike straight with the snout are able to remain in the falling mass of water; if they strike obliquely, they are carried back into the stream below. This, Landmark believes to be the explanation of Salmon passing falls with a clear descent of 16 feet.

Aithough, like trout, and unlike shad, Salmon spawn with a falling temperature, not depositing their eggs until the water is at least as cold as $50^{\circ}$, yet they seem to enter the rivers on a rising temperature. Yarrell remarked that English rivers issung from large lakes afford carly salmon, while rivers swoilen by melting snows in the spring months are later in their season of producing fish, and yield their supply when the lake rivers are beginning to fail. In America the Southern streams seem to yield the earliest fish. In the Connecticut they appear in April and May, in the 
Merrimac in May and June, in the Penobscot most abundantly in June and July, though some come as early as April, and in the Miramichi, from the middle of June to October. I can only account for this seeming paradox by the theory that, while Salmon are not harmed by extreme variation of temperature, they may be arerse to sudden changes, and though strongly impelled to seek the spawning grounds are prevented by the cold. I have ascertained that the cod possesses very little animal warmth. The temperature of the blood of a number of individuals caught in twenty-five fathoms of water was $47^{\circ}, \mathrm{F}$, precisely that of the water at the bottom whence they were lifted. Mackerel swimming at the surface registered $59^{\circ}$ or $60^{\circ}$, while the temperature of the water was $5^{8^{\circ}}$, thus indicating that they possess a triflung amount of animal heat. The Salmon unquestionably changes its temperature with that of the surrounding water in much the same way, and if, as is probable, rivers rising in the mountains are colder in early spring than the ocean strata frequented by the Salmon, here is a possible solution of the problem. It is stated that in the English rivers, which are always open, there are no regular seasons of ascent, the fish constantly passing in and out; indeed, Mr. Atkins thinks it pretty certain that large Salmon in prime condition are running into the Penobscot from the sea every month in the year. It is likely, also, that the warmth of the rivers is an important factor in accelerating the vegetative growth of the eggs in the ovaries of the mother fish.

The movements of the Salmon are not so intimately related to the temperature of the water as those of many other species. They are not sensitive to sudden changes, and are capable of enduring a range of at least forty-five degrees. In this they resemble less the migratory fishes than the permanent residents of our fresh waters; indeed, it is quite allowable to speak of them as resident, for a large proportion of the whole colony belonging in one river may be found in it at any season. This proportion cannot fall much below two-thirds, if we consider that the fish less than a year old would make up at least half its number, and that the breeding fish are in the rivers six or seven months after the breeding. The breeding fish remain during the season of greatest heat and greatest cold, though their stay after they have deposited their eggs is no doubt chiefly because their vitality is diminished and their circulation retarded by the falling temperature, depriving them alike of the craving for food and the power to seek it. Those which spawn early are believed 
to return at once to the sea; the more tardy ones often remain all winter, and are carried out by the spring freshets. Salmon eggs are not injured by freezing, and the fish are unquestionably quite as hardy. English fish-culturists claim that their Salmon will not thrive where the water is warmer than $60^{\circ}$, or at most $65^{\circ}$ in the summer, but Mr. Atkins kept fish in his ponds at Bucksport, Maine, with the water at the bottom as warm as $74^{\circ}$ at midday, the means of bottom and surface temperature for June, July, August, September, and October, 1872 , being $60^{\circ} .6,65^{\circ} .9,69^{\circ} .8$, $59^{\circ}, 50^{\circ} \cdot 3$, and $72^{\circ} \cdot 9,73^{\circ} \cdot 1,73^{\circ} \cdot 6,62^{\circ} \cdot 2,54^{\circ} \cdot 3 \cdot$, respectively. In the Gaspé Salmon streams, where the fish are in the perfection of activity, the temperature of the pools in July ranges from $30 \mathrm{I} / \mathrm{2}^{\circ}$ to $59^{\circ}$.

Leaving the open ocean they enter the bays, where they remain for several weeks, becoming inured to brackish water, feeding liberally on the small estuary fishes, such as smelts, capelins, and the fry of the herring tribe. When they begin to ascend the rivers they seldom pause even to feed. Sometimes they rest in the quiet pools, and it is then that they condescend to notice the fly-hook of the anglers. It is the dryest season of the year, and they are often obliged to wait until the streams are raised by rain, and then they bravely struggle onward, springing with agility over falls of considerable height. Most of them proceed at once to the vicinity of the spawning ground, which is near the source of some cool stream. On the Penobscot, the earliest reach the limits of upward migration before midsummer. Spawning begins here during the last week in October, and continues into November, while in the Gaspé region it is a week or two earlier, though everywhere the season is in late autumn.

At the approach of the pairing season their trim shapes and bright colors disappear. They grow lank and misshapen, the fins are thick and fleshy, and the skin, which becomes thick and slimy, is blotched and mottled with brown, green or blue, and vermilion or scarlet. These changes are chiefly apparent in the males, whose jaws now become curved so that they touch only at the tips, the lower one developing a large, powerful hook, which is his weapon in the savage combats with his rivals in which he at this period engages. When in this condition, and after spawning, when they retrace their source to the sea, they are known as "Kelts."

The earliest arrive on the headwaters two or three months before spawning time. As soon as the water is cool enough they proceed to 
deposit their eggs in deep furrows which they plow up in the sandy or gravelly bottom of the stream, usually near the verge of a rapid. European observers state that the furrows are shaped by the noses of the two parent fish, every nest being filled with eggs before the next one is made, and the first covered up by the sand which is loosened in digging the second, chiefly by the action of the current. Mr. Atkins observed a female Land-locked Salmon excavating a nest by turning on her side and flopping violently against the bottom with her tail, while the male was engaged in driving away rivals and predaceous foes. Spawning is not accomplished at once, but the eggs, are deposited by installments, as fast as they mature, during a period of from five to twelve days. "When the furrow is made, the male and the female retire to a little distance, one to the one side, the other to the other side of the furrow; they then throw themselves on their sides, again come together, and rubbing together both shed their spawn into the furrow at the same time." 'This is the observation of Mr. Ellis on the European Salmon, and a similar habit has been observed by Mr. Whitcher in Canada. In the tributaries of the St. Lawrence, spawning begins by the middle of October; in Maine, with both Land-locked and Sea Salmon, a week or two later, and it is presumable that in the Connecticut it will be found to occur well along towards December. In Great Britain and in the Rhine the season begins in October or November, continuing in some rivers till February.



A YOUNG SALMON.

Salmon eggs are about one-quarter of an inch in diameter, and of a bright reddish or yellowish hue. English fish-culturists estimate the number of eggs yielded by a large fish at I, 000 to each pound of her weight; 
experiments in the Penobscot indicate a yield of not more than 5,000 or 6,000 for a fish of eight pounds, and about 15,000 for one of forty pounds. In the Scotch streams the eggs come to maturity in one hundred to one hundred and forty days, but in our colder waters, at a temperature of $33^{\circ}$ through winter and spring, the period of incubation is supposed to extend over six or seven months, the young fish not appearing until May. In the hatching-house the period varies greatly, eggs having been hatched in fifty-four days with a temperature of $55^{\circ}$, and in one hundred and fourteen at $36^{\circ}$.

The newly hatched Salmon measures about three-quarters of an inch, and has the yolk-sac adherent from four to six weeks. When this is absorbed it begins to feed, rising greedily to seize any minute floating object. In two months the fry has grown to an inch and a half, and begins to assume the vermilion spots and transverse bars or finger marks which entitle it to be called a "Parr," and which it retains while remaining in fresh water, sometimes until it is seven or eight inches long. It continues a "Parr" until the second or third spring, when, in preparation for, or perhaps in consequence of, a descent toward the sea, a uniform bright silvery coat is assumed, and the Parr becomes a "Smolt." After remaining from four to twenty-eight months in the salt water it again seeks its native river, having become either a "Grilse" or a "Salmon." The "Grilse" is the adolescent Salmon; it weighs from two to six pounds, and is more slender and graceful than the mature fish, with smaller head, thinner scales, more forked tail, and spots rounder, more numerous, and bluish rather than jetty black. The two may easily be distinguished even though both should be of the same size, as not unfrequently happens. The male Grilse is sexually mature, but not the female, in America; in Europe the same is claimed for the male Parr and the female Grilse.

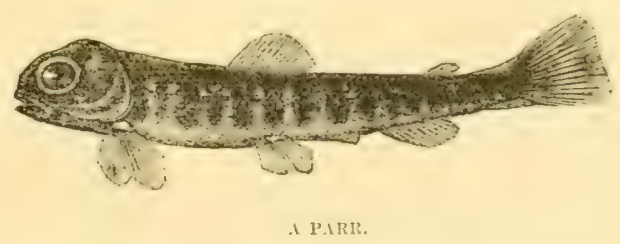

"There is nothing in the water," says Norris, "that surpasses a Grilse 
in its symmetrical beauty, its brilliancy, its agility, and its pluck. I have had one of four pounds to leap from the water ten times, and higher and further than a Salmon. Woe to the angler who attempts, without giving line, to hold one even of three pounds; he does it at the risk of his casting line, or his agile opponent tears a piece from its jaw or snout in its desperate effort to escape."

Mr. Atkins calls attention to the fact that the great run of Grilse which is so prominent a feature in Canada and Europe is almost entirely absent in the rivers of the United States, the fish not returning until they have become adult. In rivers where Grilse are found, the Salmon always precede them in their ascent, for the former do not enter fresh water until toward the end of summer.



Who can wonder at the angler's enthusiasm over "a Salmon fresh run in love and glory from the sea?" Hear Christopher North's praise of a perfect fish :

"She has literally no head; but her snout is in her shoulders. That is the beauty of a fish, high and round shoulders, short waisted, no loins, but all body and not long of terminating-the shorter still the better-in a tail sharp and pointed as Diana's, when she is crescent in the sky."

Mr. Kilbourne's painting in Scribner's " Game Fishes of North America" represents a thirty-pound fish drawn to a scale of one-fourth, The largest on record was one of eighty-three pounds, brought to London in I 82 I ; the Scotch fish rarely exceed twenty-five pounds. Periey speaks of a sixty-pounder taken long ago in the Restigouche; in ${ } \delta_{52}$ many of forty, and one of forty-seven pounds, were caught in the Cascapediac. Mr. Frederick Curtis's score for York River, Canada, July 7, I 87 I, shows nine fish ranging from seventeen to thirty-four and averaging twenty-six and a quarter pounds. Another, for the same locality, July, i 876 , shows 
one hundred and ten fish, averaging more than twenty-two pounds. This was by Mr. Thomas Reynolds, who caught in the same river a fish of forty-seven pounds, the largest ever killed in Gaspé with a fly. In the Penobscot forty-pounders have occasionally been taken, but not more than one out of a thousand weighs thirty, and the common size is from ten to twelve pounds. A fish two feet long would weigh about six pounds; one of thirty inches, nine or ten ; one of three feet, sixteen to seventeen ; and one four feet long, nearly fifty. A score of twenty-two day's fishing, witl four rods, in the Godbout, in June and July, I $86_{5}$, foots up four hundred and seventy-eight fish, averaging nine and three-quarters pounds.

In Great Britain, by systematic culture and protection, the salmon fishery has been made one of the most important aquatic industries. The rental of the privileges on three salmon rivers, the Tay, the Spey, and the Tweed, amounted in 1873 to nearly $\$ 200,000$; and in this year $3,800,000$ pounds of salmon, worth at least \$I,350,000 were brought to London markets, $2,580,000$ pounds coming from Scotland alone.

The salmon rivers of North America may be made to yield a harvest much richer than this; those of Maine alone are probably as numerous and well adapted for the purpose as those of Scotland, which are valued at $£ 250,000$ a year, those of England being placed at $£$ I00,000, and of Ireland at $£ 400,000$.

Walton and all his disciples have called the Salmon the "King of Fresh Water Fishes." Whole libraries have been written, about his Majesty, and the adventures of the regicides who show their admiration of him by killing him as often as they can. Salmon fishery, from the technical standpoint, may not here be discussed, and the reader is respectfully referred to the writings of Hallock, Scrope Roosevelt, Harris, Dawson, Herbert, Iennell. Francis and Buckland, and others. mighty with the roxl and facile with the pen. 


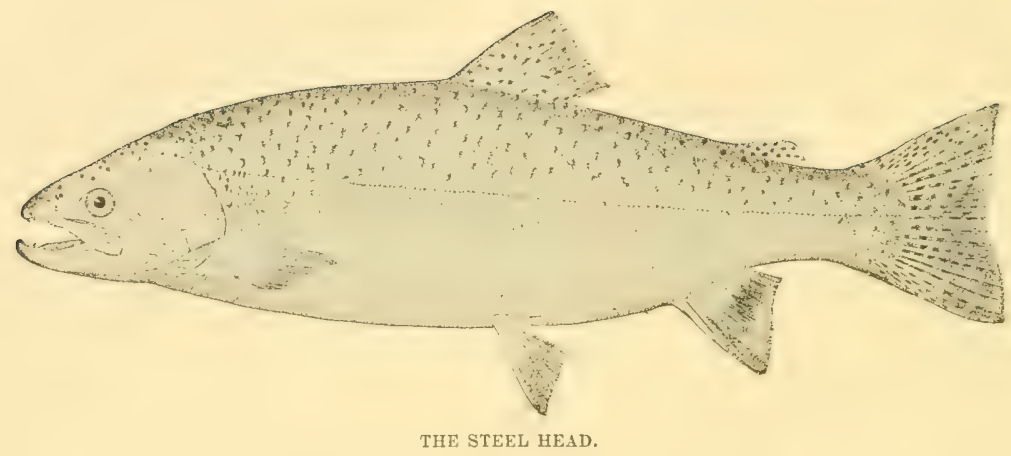

\section{THE SALMON TROUTS.}

The glad trout is roaming in every clear stream And the grilse and the Salmon now drink the May flood,

Then anglers be up with the sun's early beam,

Let your flies be in trim and your tackle be good.

Снатто: The North County Angler, 1883.

\section{T}

HE near allies of Salmo salar, which occurs on the Pacific slope, are set aside by Jordan in subgenus to be called either Salar or Fario, which is distinguished from the typical Salmo by an exaggerated development of the teeth upon the vomer or plough-share bone in the roof of the mouth, and also by a much less pronounced difference between the males and females in the breeding season.

These fishes are so closely allied, and are likely to be of so much interest in the near future, that $I$ think it proper to print a table of their affinities prepared by Dr. Bean :

\section{SPECIES OF SALMON.}

A. Sea salmon, anadromous.

Subgenus SALMO.

No hyoid teeth; vomerines little developed, sometimes deciduous; scales large ; caudal forked except in the old; lower jaw of breeding males hooked upward and received into or through upper jaw; gill-rakers short, 19 ; vertebræ 27-31.

1. A. River salmon, not anadromous. Silmo salar. The Atlantic Salmon.

b. No hyoid teeth.

c. Scales large, fewer than $x_{40 .}$

d. American species : silvery, with usually small black spots; a broad median crimson band in breeding males ; opercles with few spots or none.

c. Anal rays 12 ; depth of body equals length of head in young gill-rakers 7 -ro-r2-13; coeca $50-62$.

S. Gairdneri. 'Fue Sterliead Salmon.

ce. Anal rays to; depth of body much exceeds length of head in young; gill-rakers 8-42 : cœca 45-70

S. irideus. THe. Raniow Trout. 
di. European species; brown, with large brown or black, sometimes red, spots; opercles with rather numerous dark spots.

$f$. Body rather stout; maxilla very strong and dilated; vomerine teeth in a double series. gill-rakers $8-12$; ceca $4 \mathbf{I}-42$; vertebræ $57-58$, persistent.

S. fario. The Brown Thout or Europe.

if. Body rather slender; maxilla narrow and feeble; vomerine teeth caca 60-80; vertebrx 59, uniserial, persistent. S. levenensis. THE Loch-Livey Trour.

cc. Scales small, about 770 , gill-rakers 8-9-13; cæca 40-50. S. spilurus. THE Rio Girande 'irout. cb. Hyoid teeth.

s. Back and sides cverywhere black spotted, silvery in sea run examples.

12. Head short; scales not more than 170 , gill-rakers $8-12 ; \operatorname{cocca} 20$.

S. pupuratus. THe Rocky Mountain Trout.

hh. Head long, conical; scales sometimes $x 8$, gill-rakers $9 . x+4$; coeca 50.60 .

S. Henshavii. THe Lake TaHoe Trout.

5S. Sides anteriorly with few black spots; scales about 200.

i. Head long, with medium keel; gill-rakers 7-12. S. pleuriticus.

ii. Head shorter, without keel.

S. stomias. THE KANSAS RIVER Trout.

The Salmo Gairdneri, of Richardson, is usually known as the "Steelhead." The name "Hard-head" is sometimes applied to it, and it is known to the Russians as "Seomga. The name "Mykiss" is said to have been in former years in use in Kamtchatka. Large individuals are often called "Salmon Trout." The Indian name "Humaana" is said to be given to it on the Upper Columbia. It reaches the weight of twentytwo pounds, the average weight when fully grown being about sixteen. Young specimens have not very often been captured. It is found always, from the Sacramento river northward at least to Kodiak, Alaska, close to the coast. In the Columbia and Frazer Rivers it occurs in abundance in the spring at the time of the Salmon run. Gravid females were taken by Bean at Sitka in June. The species sometimes exceeds 25 pounds in weight. None have yet been noticed to the eastward of the Cascade Range, and as far as appearances go it is a permanent inhabitant of river mouths. It probably spawns late in the fall or in the winter, as many of those taken at the first run of the Salmon are spent fish, with the flesh white and worthless.

Its history, writes Jordan, is still obscure. According to Pallas, it migrates singly, from June to September; some remaining all the year in the rivers, returning to the sea in May. It feeds in the fresh waters, on any living thing. Hence, unlike the other Trout, which during the ascent of the rivers grow lean with fasting, breeding, and exertion, this species is plump and well fed, and, with Salvelimus malma only, does not perish in the winter. Elsewhere than in the Columbia this species is highly valued as a food-fish. When taken in the Columbia, in spring, little or no 
use is made of it. Its flesh is pale, and its bones too firm for it to be used in canning, while old individuals taken in the canning season are usually spent and worthless. In the Sacramento it is not very common.

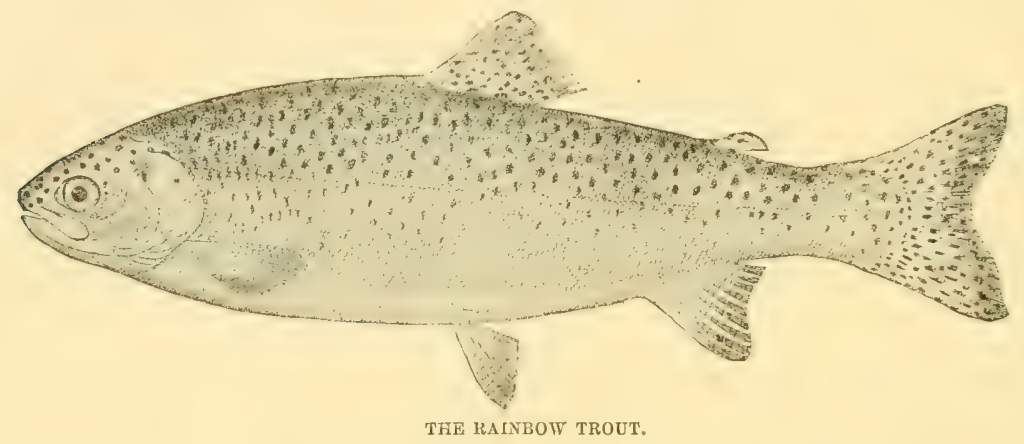

Salmo irideus, is called the "Rainbow Trout," "Brook Trout," " Mountain Trout," "Speckled Trout," "Golden Trout," and by various other names. It does not reach a weight of more than five or six pounds, so far as we know, and most of them, as taken, are fingerlings ranging from four inches to a foot in length. It is found in streams west of the Sierra Nevada, from near the Mexican line to Oregon, and is said to occur in the northern part of Lower California. The southernmost seen by Jordan were from San Luis Rey River. Few have been observed in salt water. It may probably run into the sea from streams in which the lower waters are clear. It feeds on worms, larvæ, and the like. It is a fish of little gameness or activity, which has not often been brought into the markets of San Francisco, and at present has little economic importance, although of course a good table-fish. It has been rather extensively introduced into the waters of the Eastern United States, and has been reared artificially in large numbers by the U. S. Fish Commission on the McCloud river in California, and thence distributed eastward and across the Pacific. The growth of the species at Northville, Mich., Verona, Mo., Wytheville, Va., Cold Spring, N. Y., and in Japan, is very gratifying. Specimens have been obtained from North Carolina. The South Side club at Oakdale, Long Island, recently sent to the National Museum a fine example taken in salt water.

The Rio Grande Trout, Salmo spilums, (Cope) is abundant in the headwaters of the Rio Grande, Rio Colorado, and their tributaries, being 
the finest food-fish in New Mexico and Western Colorado. It has also been taken in Bear River, and probably is found in most of the mountain streams of Utah, being in general rather southern in its distribution. It probably inhabits all streams within the circle of its distribution, without regard to the direction in which they may flow. Little distinctive is known of its habits. It is probably a comparatively recent off-shoot from S. purpuratus. As in other species, considerable variation is shown in specimens from different localities. Its usual size is larger than that of S. purpuratus.

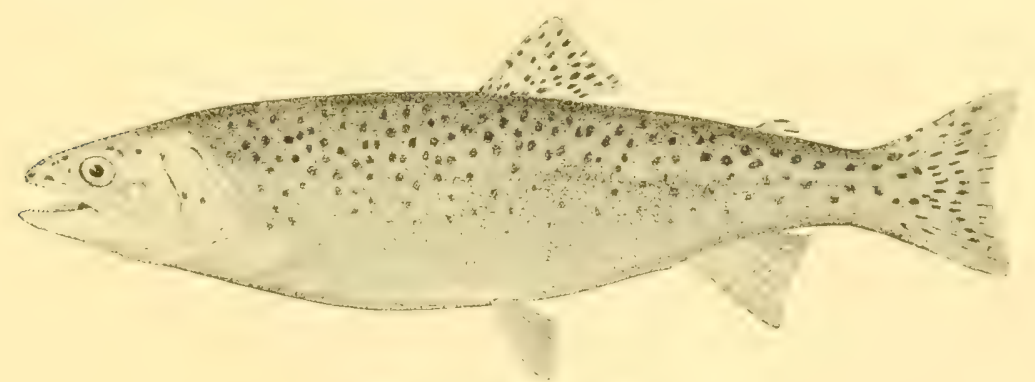

THE DLACE SPOTTED TROTT.

The Black Spotted Trout, the Salmo purpuratus of Pallas, is universally distributed through the Rocky Mountain region, chiefly east of the Sierra southward, but reaching the sea from Mount Shasta, northward. It occurs in every lake of New Mexico, Utah, Western Colorado, Wyoming, Montana, Idaho, Oregon, and Washington. All the streams in this region are filled with them, and in Puget Sound the young of every size occur in abundance in the salt water. Individuals are occasionally taken along the California coast.

This fish is known as the "Trout," "Mountain Trout," "Spotted Trout," "Black Trout," and "Silver Trout," in the mountains, but when in the ocean, full grown, as "Salmon Trout" or "Steel-head." Hallock and other recent writers have applied to it the horrible name "Cut Throat Trout," which it is hoped will never be sanctioned in literature. The Indian name "Preestl" is also ascribed to it on the Upper Columbia. It reaches a weight of thirty pounds under the most favorable circumstances, but may be found in any stream or lake of its habitat, of lengths varying from two inches to two or three feet. 
It feeds on any living thing it finds near it. In the mountain lakes it spawns in the spring, running into the rivers for that purpose. Unlike $S$. Gairdneri, its young are very common, and it probably begins breeding in mountain streams at a length of less than a foot. Local variations occur in abundance. Specimens from Seattle have the scales notably larger than those from Victoria and Astoria, which agree with Utah Lake specimens in this respect. Those that live in the depths of shady lakes are almost black, while others are pale. Those in the sea are silvery and only faintly spotted. In the opinion of Prof. Jordan this species is likely to prove much more valuable for introduction into Eastern waters than the Rainbow Trout. It is more active, more gamy, reaches a large size, and thrives in a greater variety of waters.

The Lake Tahoe 'Trout, Salmo Henshazi, named in honor of the well-known explorer and naturalist Henry IV. Henshaw, and known also as the "Silver Trout" and the "Black Trout," occurs not only in Tahoe, but in Pyramid Lake and the streams of the Sierra Nevarla. This form, which has a longer and more conical head than S. spilums, is a remarkably fine fish, many the weight of fifteen pounds, and is supplied abundantly to the California city markets. Its ordinary weight is five or six pounds, but it often weighs eighteen or twenty.

A small hatchery has been established at Tahoe City for the purpose of stocking a small branch of the lake for the benefit of summer visitors. Bean is inclined to consider this a form of $S$. purpuratus.

The Black-spotted Trout, Salmo pleuriticus, is closely allied to a form which is found chiefly in the Utah Basin. Bean calls attention to the fact that the types of this species have well developed hyoid teeth and must be placed in the same group with purpuratus, and not with spilurus, as has hitherto been done by good authorities.

The Waha Lake Trout, S. purpuratus Bouvieri, was discovered by Capt. Charles Bendire,U. S. A., in Waha Lake, a landlocked mountain tarn in Washington Territory. It is a curiously colored local form of S. purpuratus, with dark spots only on the dorsal, caudal and adipose fins, and on the tail behind the anal where the spots are very dark and comparatively small. It is characterized by other minute differences catalogued by Jordan.

The Kansas River Trout, $S$. stomias, is a form with a broad, flat head, distributed from the Kansas river to the Upper Missouri, - the characteristics 
of which have not yet been well defined. Bean states that it reaches twenty-four inches in length, is believed to be one of the numerous varieties of Salmo pumpuratus.

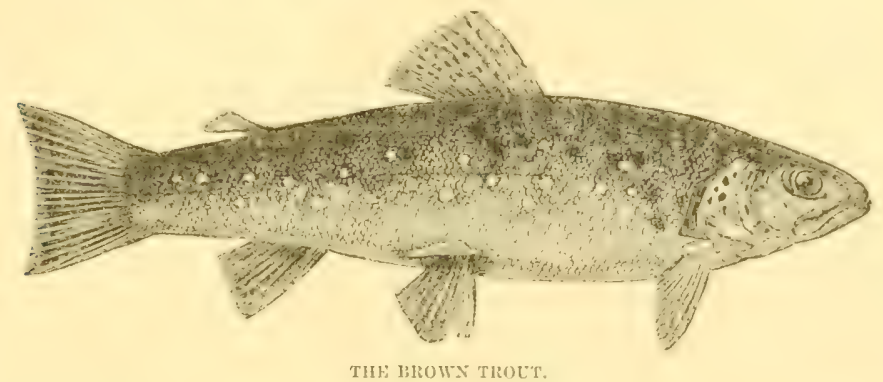

The Brown Trout of Europe, Salmo fario, has been successfully introduced into our waters by the U. S. Fish Commission.

Eggs were first received from Herr Von Behr, the President of the Deutsche Fischerei-Verein, in the winter of $\mathbf{1} 88_{2}-' 8_{3}$, and were sent directly from. New York to the station at Northville, where they arrived February i 8 . These were successfully hatched out by Mr. Clark by the miclde of March, and early in April were planted by him in a branch of the Pere Marquette River of Northern Michigan.

Early in $188_{3}$ another lot of eggs was sent to $\mathrm{M}[\mathrm{r}$. Mather as a personal present by Herr Von Behr. Most of those kept at this station died, but those sent to the Northville Station and to the station of the New York Fish Commission at Caledonia were reported as doing well. In $\mathrm{I}_{8} 8_{4}$ Herr Von Behr sent an additional gift, this time to the U. S. Fish Commission, in care of Mr. Mather, and a lot of 10,000 was received from England. These did better than those of $188_{3}$, and many were distributed to various New York waters.

On the 2 Ist of February Mr. Nather forwarded to Washington 2, 000 of the large kind of Salmo fario, and 9,000 of the small variety. These were transferred to the Wytheville Station, and were hatched with fair success, but all died before beginning to eat.

A few of the German trout reared at the Northville Station spawned in December, $\mathrm{I} \mathrm{S}_{5}$, and $8,000 \mathrm{eggs}$ were obtained. Two lots of eggs, 23,000 in number, were forwarded from the Cold Spring Harbor Station, the second lot of which $(13,000)$ arrived in poor condition. From these 31,000 eggs, 20,000 fry were hatched, which were retained at the station. 
In February, $\mathrm{I} 885$, a box containing 40,000 eggs in very good order was received at Cold Spring, from the German Fischerei-Verein. The fry from these eggs, which when hatched and ready for distribution amounted to about 28,000 , were mostly planted on Long Island and near the Hudson.

In I $88_{5}$, eggs were taken by several other persons, as well as at the Cold Spring Harbor Station, from fish which had been bred from eggs sent over from Germany two or three years before. The average number of eggs taken in one case (the fish being three-year-olds) was 540, and there are indications that this yield will increase. This valuable fish has thus been successfully acclimatized in this country, and their cultivation may to good advantage be greatly extended, as they are considered superior in many respects to our native brook trout.

The Brown Trout is an excellent table fish and attains a much larger growth than the species found in the United States, a weight of from ro to 20 pounds being not unusual. Prof. Baird, in introducing it, hoped that it might be available for some localities not so well fitted for the brook trout, where, by its rapid growth and the size to which it attains, it may constitute an important article of food.

The Loch Leven Trout, Salmo levenensis, has also been introduced within the past few years. One hundred thousand eggs were received in excellent condition on January 7, I885, from Scotland, having been sent by Sir James Gibson Maitland, of the Howietoun fishery, Stirlingshire, and repacked by Mr. Fred Mather, of Cold Spring Harbor, N. Y., by whom all shipments of eggs to and from Europe were skilfully and successfully handled. Fifty-five thousand of the eggs were distributed to the commissioners of New Hampshire, Iowa, Minnesota, and Maine, including to the Bisby Club, in Herkimer Co., N. Y. The loss of the eggs in hatching was very slight, and only a few of the fry died in the tanks. Of the 43,500 that were hatched at Northville, 36,500 were planted in various streams in Michigan, and 7,000 were retained at the hatchery for breeding purposes.

Of the 10,000 eggs which were sent to Bucksport, about 3,000 were lost, and the remaining 7,000 fry were planted in May, in Branch Pond and its tributary brooks, near Ainsworth, Maine.

"There is some difference of opinion," remarks Bean, "as to the distinctness of the Loch Leven Trout from the Brown Trout; for the present we may use the characters mentioned by Dr. Günther and stated in the key to the species, on page 455 . 
The Sea Trout of Europe, Salmo trutta, has not yet been introduced, but I see no reason why it might not be a very desirable addition to the fauna of New England and British North America.

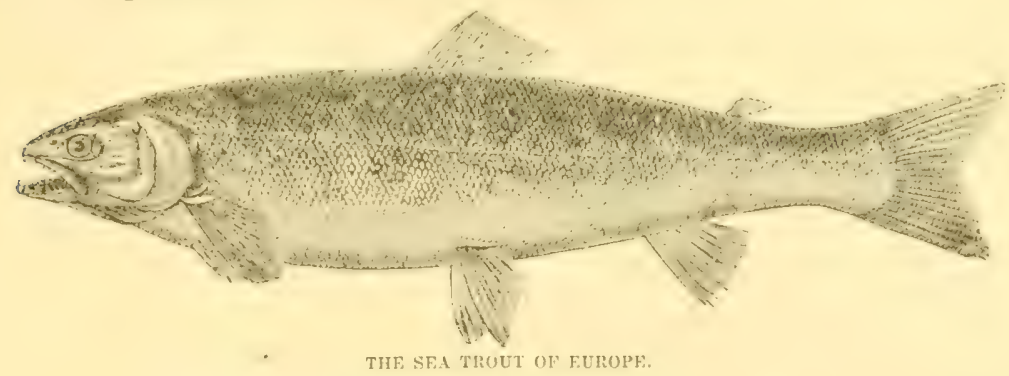

It is variously known as the Salmon Trout, the Bull Trout, the Savern, the Gwyniad and the Peal. It occurs in the rivers which fall into the Baltic, the North Sea, and the seas surrounding the British Isles, and in France, in the Seine and Loire, where it is known as Truite de Mer. Its habits correspond to those of the Salmon, and its life history is very similar, since it passes through the parr smolt and grilse stages. It hybridizes with the other salmonoid fishes, and the resulting intermediate forms have always been a great source of perplexity to ichthyologists as well as to anglers.

The anglers of this country have had little opportunity to practice upon the various species of Salmon Trout, but the general opinion seems to be that they are inferior as game fishes to our Red Spotted Trouts, like Salvelinus fontinalis. I have taken the Rainbow Trout with a fly, but found it as undemonstrative as a Carp. The Brown Trout is more of an angler's fish, and if our streams should be protected so as to permit its thoruugh acclimation, we doubtless have glorious fishing before us. 


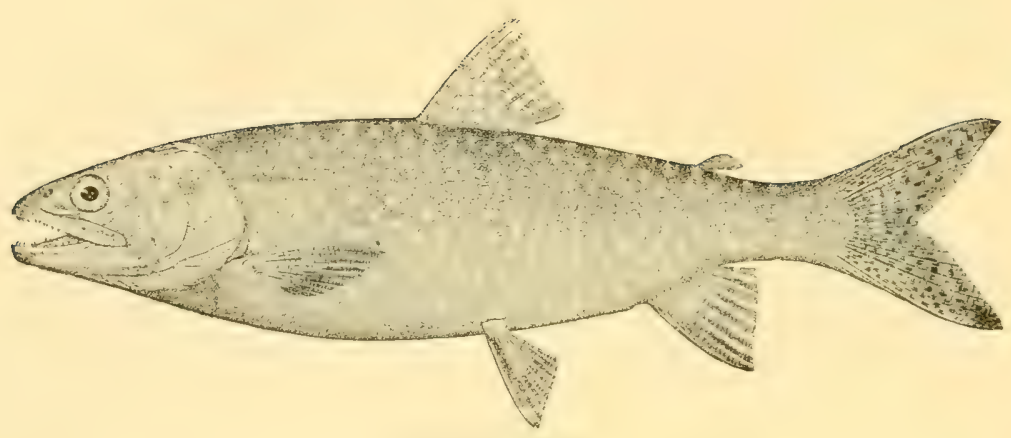

THE NAMAYCUSH.

\title{
THE LAKE TROUTS.
}

\section{Namaycush, Togue and Siscowet.}

\author{
The generous gushing of the springs, \\ When the angler goes a-trolling, \\ The stir of song and summer wings, \\ The line which shines, and life which sings \\ Make earth replete with happy things \\ When the angler goes a-trolling."
}

Tromas TOD STODDART.

THE Mackinaw Trout, or Namaycush, is a non-migratory species inhahiting the chain of Great Lakes from Superior to Ontario, as well as Lake Champlain and many other smaller lakes of the United States and of British America, occurring also to the Northeastward, in Mackinaw River and in the Knowall River, Alaska.

"The Lake Trout is," remarks Bean, " a species remarkable for its great size, reaching 3 feet and sometimes weighing 40 pounds; varying greatly in coloration, the extremes noteworthy in Maine and Alaska. It seem to have no parallel in Europe and is well separated from American species by its peculiar vomer and its large number of pyloric caca (about I 50)."

Every lake of Northern New York and New England has its own variety, which the local angler stoutly maintains to be a different species from that found in the next township. Some are as black as a tautog, some brown with crimson spots, some gray, with delicate reticulations like those of a pickerel. The usual type to be found in the Great Lakes is brown or gray, dappled with lighter shades of the same general tints. 
Naturalists have been saclly misled by their protean modifications. The "Namaycush" of the North, the "Togue" or "Tuladi" of the Maine and New Brunswick Indians and lumbermen, the "Siscowet" or "Siskawitz" of Lake Superior, the "Trout" of Winnipiseogee, and that of the Adirondack lakes, have each been honored with a distinct binomial.

The angling authorities still refuse to admit that the Lake Trout of the East is identical with the Mackinaw Trout, or Namaycush, supporting their views by accounts of their very different habits. A careful study of the dead fish is sufficient, however, to convince a trained observer that there are no structural characters by which these different forms may be separated into species. The local variations should, undoubtedly, be taken into consideration, and when these are better understood it is probable that zoologists and anglers will compromise by agreeing to consider the most strongly marked types as races, or breeds, such as are now recognized among dogs, pigeons, and other domesticated animals.

The Namaycush reaches its greatest perfection in the northern parts of Lakes Huron, Michigan and Superior, where it is quite generally known as the "Mackinaw Trout." In the lakes of Northern New York the same species occurs, being known by the names "Lake Salmon," "Lake Trout," and "Salmon Trout." This form, which is considerably smaller than that of the northern lakes, was described by DeKay under the name Salmo confinis, and was observed by this author as far south as Silver Lake, in Northern Pennsylvania. Still another form is recognized by sportsmen, which, although undoubtedly specifically identical with that of the Great Lakes, has been described under various names, such as Salmo toma and Salmo symmetrica.

"This fish," writes Lanman, "is found in all the great lakes of New Brunswick, and in very many of those of Maine, but it is believed not to exist in the lakes of Nova Scotia. It is called by the lumbermen the 'Togue ;' the Indians designate it by a name equivalent to 'Fresh-water Cod.' It is found in great numbers and of large size in the Eagle Lakes, at the head of Fish River, in the St. Francis lakes, from which it follows the river of that name, and in the Matapediac Lake, which discharges itself into the Restigouche, and in the Miramichi Lake, at the head of the river. In Lake Temiscouata this fish has been taken of the weight of twenty-one pounds. It is there called the "Tuladi.' It is often taken of the weight of twelve pounds and upwards in the Cheputnecticook lakes, at the head of the eastern branch of the St. Croix. It has been found of late years that this species of fish exists in considerable numbers in Loch Lomond, twelve miles from the city of St. Tohn.'" 
Hamlin writes: "This Trout inhabits many of the great lakes and deep mountain torrents of Maine and New Brunswick, but it is believed not to exist in those of Eastern New Brunswick, which singular hiatus in its distribution, perhaps, may be explained by the absence of deep waters in that country. It haunts the deepest waters, where the cold, or the repose to which it leads, favors that development and conservation of fat which is indeed a characteristic, and it steals forth in quiet at the approach of twilight or at early morn to the shoals and the shores in quest of its prey."

The Winnipiseogee Trout, somewhat abundant in Lake Winnipiseogee and supposed to occur in Lake George, is also a form of this species, closely related to the Togue.

The popular and scientific names which have been given to this species are due to the wonderful tendency of variation in size, shape, and coloration which this species, like the Brook Trout, exhibits. Every lake in which they occur has its own varieties, which local authorities believe to be quite peculiar. Some are black, some brown, with crimson spots, some gray, with delicate reticulations like those of a pickerèl. The usual type to be found in the Great Lakes is brown or gray dappled with lighter shades of the same general tint. Throughout Lakes Superior, Michigan, and Huron, the fishermen are generally of the opinion that there are at least two kinds of Lake Trout. It seems probable, however, that these observers have been misled by superficial characters.

The best study of the habits of the Namaycush, as an inhabitant of the Great Lakes, was that made by Milner, in $187 \mathrm{r}$. He observed that in Lake Michigan, except in the spawning season, they remain in the deepest parts of the lake. In their autumnal migrations they do not ascend the rivers, and although they are known to exist in a few small inland lakes, connected with the main lakes by rapids, there is no knowledge that they have ever been seen or taken in the outlets. In the northern parts of Lake Michigan they are caught in depths of fifteen fathoms in small numbers by the gill-nets, and more plentifully through the ice in winter, chiefly at a depth of more than thirty fathoms.

They are ravenous feeders. In Lake Michigan, where a careful investigation into the nature of their food was made, it was found that they were preying upon the cisco, Coregonus Hoyi, a well-known fish closely resembling the white-fish. MIr. Milner was inclined to combat the generally accepted theory of the fishermen that they are large consumers 
of young white-fish, stating that for a great part of the year they live in much deeper water than is resorted to by the young white-fish, though Irout straying into shoal water, or migrating upon shallow spawning grounds, would undoubtedly prey upon the smaller white-fish as readily as they would upon any other.

It is not uncommon for a Trout to swallow a fish nearly as large as itself. One measuring twenty-three inches was brought ashore at Two Rivers, Wis, from the mouth of which some three inches of the tail of a fish (Lota maculosa) projected. The "lawyer," when taken from the Trout, measured about seventeen inches. " Their exceeding voracity," writes Mr. Milner, "induces them to fill their maws with singular articles of food. Where the steamers or vessels pass, the refuse of the table is eagerly seized upon, and I have taken from the stomach a raw peeled potato and a piece of sliced liver, and it is not unusual to find pieces of corn-cobs, in the green-corn season."

Neither the Mackinaw Trout nor the Siscowet is a game fish in high esteem, though the latter is taken by trolling with a bright-colored fly, with a minnow bait, or a spoon-hook. It does not rise like the Brook Trout, and its play is likely to be sluggish and sulky. It is also taken with a bottom line on grounds which have been previously baited. The Indians of the Sault Ste. Marie display great skill in spearing the Nackinaw Trout through the ice, luring them within reach by means of decoy fishes of wood and lead. By far the largest quantities are taken in pounds and gill-nets in the Great Lakes.

In Lake Superior Trout are caught principally in September, October, and November in pounds and gill-nets. Formerly they were fished for with hooks only, but of late years this practice has been abandoned by professional fishermen. In the Green Bay region large 'Irout are caught principally with hooks, though in the western part of the bay and in Oconto Bay many are taken in gill and pound nets in deep water. Those captured in the gill-nets are thought by the fishermen to be meshed, for the most part, while these nets are being lifted; the Trout dart after the other fish which have been gilled and thus become entangled. In Lake Huron they are caught entirely with gill-nets. They may be taken with hooks baited in the ordinary way, but can hardly be said to afford sport to the angler, since they allow themselves to be pulled to the surface as easily and unresistingly as codfish. 
The Togue or Lunge of our northeastern boundary is held in much higher favor by the angler. Hallock states that the young fish rise freely to trout-flies in rapid water, while the adults are extremely voracious, particularly in May and June, when they can be taken near the surface.

Prof. Arthur L. Adams, in "Field and Forest Rambles," gives a vivid picture of the habits of this peculiar type: "It repairs to shallows to feed on Trouts, smelts, and the like; indeed, the last named fish would appear to constitute its farnorite winter subsistence. It preys extensively, also. on eels and cyprinoids, and is in fact a tyrant with an appetite so roracious that quantities of twigs, leaves, and fragments of wood are constantly found in its stomach. The great monster will sometimes rise to spinning taclile, but in su sluggish and undemonstrative a manner that the troller may fancy he has caught a water-logged pine or stone. In this way I had my line checked in schoodic Lake, when, striking gently, I found I hard missed a large Togue, whose trenchant teeth had made a series of deep furrows in the chub with which the hook was baited. It is naturally sluggish and inert, and apparently much of a bottom feeder. As we glided along the shore of one of the islets, composed more or less of granitic bowlders, our attention was directed by the guide to a large black olject on the bottom, among a mass of stones. This he asserted was a monster Togue, which, if such was the case, must have exceeded three feet in length; moreover, he showed us two notches on the side of his canoe, representing the dmensions of an enomous individual which an Indian had speared in the same waters during the spawning season, the admeasurement being no less than four feet five inches."

The Siscowet, or "Siskawitz," is a form of Lake Trout which, according to many authorities, is a distinct species, and which has been observed only in Lake Superior. Having never seen the fish in a fresh condition, I cannot express an opinion as to its distinctness from the Lake Trout, but good ichthyologists assure me that its peculiarities are very slight, consisting chiefly in its wider head, its thicker skin, and its stouter body. Since, however, it is always distinguished from the Lake Trout by the Indians and fishermen of Lake Superior, who often see them side by side, it seems possible that it may claim a sub-specific rank. It was first described in $\mathrm{x} 85^{\circ}$, in Agassiz's "Lake Superior," under the name Salmo siscorcet. Herbert, in his "Fish and Fishing," p. I 7 , gives the following description of its peculiarities:

"This fish, like the former species, came frequently under my eye during my late northern tour; and I rejoice in the possession of a birrel of him 
in his pickled state, which I procured at the Sault Ste. Narie, on the strength of which I can recommend him to all lovers of good eating as the very best salt fish that exists in the world. He is so fat and rich that when eaten fresh he is unsufferably rank and oily, but when salted and broiled, after being steeped for forty-eight hours in cold water, he is not surpassed or equaled by any fish with which I am acquainted. Since my return he has been tasted by very many gentlemen of my acquaintance, and by no one of them has he been pronounced anything less than superlative. His habits closely resemble those of the 'Namaycush,' and, like him, I cannot learn that he ever takes the fly or is ever taken by trolling. I do not, however, believe that either of these methods is often resorted to for his capture, although there are many scientific fly-fishers about the Sault, and the Brook 'Trout of those waters are principally taken with large and gaudy lake-flies. The average weight of the 'Siskawitz' does not exceed four or five pounds, though he is taken up to seventeen. His excellence is so perfectly understood and acknowledged in the lake country that he fetches double the price per barrel of his coarser big brother, the 'Namaycush'; and he is so greedily sought for there that it is difficult to procure him, even at Detroit, and impossible almost, at Buffalo."

Milner states that the Siscowet lives at depths greater than forty fathoms, and feeds chiefly upon a species of fresh-water sculpin. It spawns in September in deep water. The average size is about four and one-half pounds. Two five-pound fish yielded respectively 2,796 and 3,120 eggs. This species, like the Lake Trout, is for the most part taken in gill-nets.

Mr. George Barnston, of Montreal, Canada, formerly of the Hudson Bay Company, who made an extensive natural history collection on Lake Superior, claims that there is a third species of Lake Trout, different from the Siscowet, on the south shore of Lake Superior, called the "Mucqua" or "Bear Trout."

Mr. Robert Ormsby Sweeny, chairman of the Minnesota fish commission, in a letter dated Saint Paul, Minnesota, October I9, ISSo, conveys the following information concerning the Siscowet, which is more precise and comprehensive than anything hitherto published:

"I have not only examined the Siskowet carefully myself and compared them with Agassiz's formulas, but asked and consulted with traders, royagers, Indians and half-bloods, and fishermen, in regard to their habits, size, color, weight, etc., and all come to the same conclusion. They are not possibly a 'Namaycush' and should never be considered the same fish. The name 'Sis-ko-wet' is an Ojibewa word, and means literally 'cooks itself.' The fish when fresh is most deliciously rich, tasting like the belly 
of a mackerel. The 'Namaycush' is dry and lacks delicacy, and cannot be even fried without pork-fat or lard.

"The amateur is likely to confound the Namaycush with the Siscowet, but when the differences are once pointed out, no confusion of the two again arises. The fisherman recognize them before taken trom the water when hauling in the nets; even the Indian children know them at a glance. The head of the Siscowet is shorter and broader in proportion, eyes nearer the end of nose and are wider apart; the whole osseous structure of the head lighter, more delicate and flexible, particularly the sub-maxillaries, which in the Namaycush are heavy, rigid, and rounded. The coloring varies in different specimens according to locality whence taken. The spots or markings are unlike those of the Namaycush, more even in size and shape, and more decided and stronger in color, and I can clearly see in some specimens that the spots are compound or an indistinct quincunx arrangement. The Namaycush spawn only in the fall, beginning in October. We have just taken half a million eggs. The Siscowet, I am told by the fisherman and Indians, are always spawning, or that ripe females are taken at all times of the year. At first I thought this an exaggeration, but I find it so very universally reported and by reliable men that I give it credence. They are very rarely found at the lower parts of the lake. They begin to be more plentiful as La Pointe is reached and most plentiful along the north shores and Isle Roydle, but still they are a rare fish, comparatively. If one barrel of Siscowet to fifteen Namaycush are caught, they are said to be very abundant. They are so much prized that they bring a higher price, and it is rare that we get them here unless in winter time, when they are frozen and brought down fresh. A peculiarity I have noticed is, in winter when pulled out on the ice they puff up like a pouter pigeon full of air around the pectoral region, and when frozen can be instantly distinguished at a glance. They rarely exceed thirty pounds in weight and thirty-six inches in length, I am told by those very familiar with the fishes of the lake. On the same authority I learn that Namaycush reach ninety pounds in weight and six feet in length." 


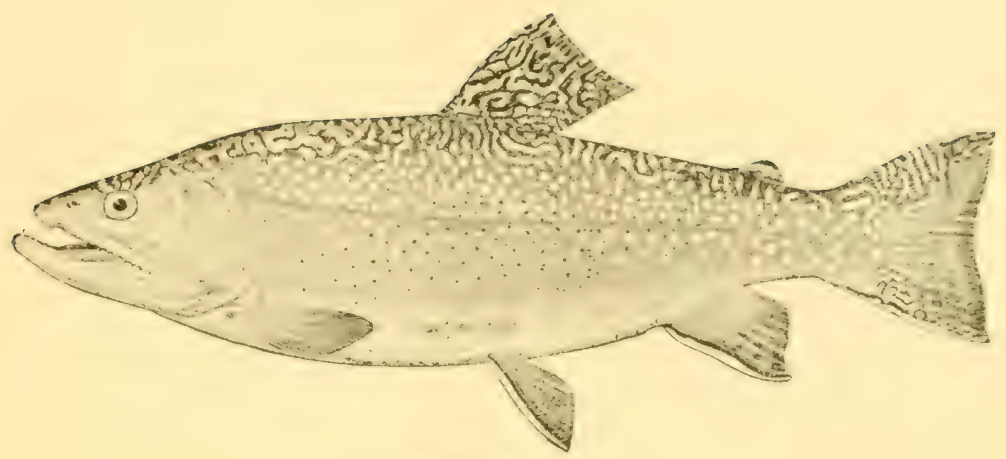

THF E.LSTERN BROOK TROCT.

\section{THE BROOK TROUTS OR CHARS.}

Here comes another trout that I must tickle, and tickle daintily. I've lost my end clse.

Beaumont and Fletciter.

OUR Brook Trouts belong to the division of the Salmon family known to the English as "Chars," a group confined, for the most part to freshwater lakes and streams, and distinguished from the true Salmons by a peculiar arrangement of teeth on the vomer, and also by their very small scales, and usually by numerous crimson or orange-colored spots, which are especially conspicuous in the breeding season. The Chars of Europe are, as a rule, lake fishes like the Saibling. On the other hand, the Chars of North America are usually found in streams and rivers.

There is probably no group of fishes in which individual specimens and communities inhabiting certain areas of water show more tendency to variations in color and form than they do in the salmon family. Dr. Ginther has very justly remarked: "We know of no other group of fishes which offers so many difficulties to the ichthyologist with regard to the distinction of the species as well as to certain points in their life-history. Although this may be partly due to the unusual attention which has been given to their study, it has revealed rather a greater amount of unexplained fact than a satisfactory solution of the questions raised. The almost infinite variations of these fishes are dependent upon the age, sex, and sexual development, food, and the properties of the water."

The tendency of modern ichthyology, with its more exact methods, and 
with access to better and more comprehensive material for research than was formerly available, has led to the rejection of many of the nominal species formerly recognized. Out of the forty-three species of Salmon ten years ago believed to exist in North America, only thirteen or fourteen are now recognized. In Günther's catalogue of "The Fishes in the British Museum," published in I886, thirty-one species of Chars were mentioned, while in his lately published "Study of Fishes" the same author ventures to enumerate only thirteen, all others being regarded as insufficiently characterized. In his treatment of the Chars of Europe, Günther is, notwithstanding, one of the most conservative writers, for he catalogues eight species of these fish, while most other European students, following the lead of the great German ichthyologists, Von Siebold, regard them as menbers of one polymorphic species. The sympathies of most American ichthyologists are, naturally, with the school of Von Siebold. It is difficult to believe, in the light of our own observations upon the salmon family in America, that every little lake or group of lakes in Europe possesses a well-characterized species of fish, and for the present it seems safer to consider the Chars of Europe to be of a single well-marked species which undergoes numerous variations under the influence of changes in temperature, elevation, food, and light, and that the Saibling of Bavaria and Austria is one and the same thing with the "Ombre Chevalier" of France and Switzerland, "Salmario" of Northern Italy, the "Torgoch" of Wales, the fresh-water "Herring" of Ireland, the "Char" of England and Scotland, the "Röding" of Sweden, and the "Kulmund" of Norway.

\section{SPECIES OF SALVELINUS.}

A. Hyoid teeth; back never mottled.

a. Subopercle nearly as deep as long, without conspicuous striations.

b. Gill-rakers fewer than 20; habitat Western America ; migratory. cœeca 25-46.

83. Gill-rakers more than 20; habitat Eastern America,

c. II Iratory; species very large; usually spawning in large streams and then going to sea.

gill-rakers 9-15; creca 30-35,
cc. Land-locked; species medium size or small.

d. Back blue; caudal not tipped with white in young; size very small; gill-rakers 9-15; cœen 38 .

it. Caudal tipped with white in youug; size medium or large.

e. Introduced species; 19 gill-rakers below angle; stomach slender; hyoids in a very narrow band; coeca $40-42$. S. ALPINUS.

ee. Native species, it gill-rakers below angle: stomach stout; hyoids in a broad band; young with clouded parr-marks; gill-rakers 7-10-9-14; coeca 49.

$a \alpha$. Subopercle twice as long as deep, conspicuously striated.

S. IGASSIZII.

$f$. Red spotted; size very large; gill-rakers, in young, $8-12$; $\operatorname{cocca} 36$.

ff. No red spots; size small; coeca $3 I-44$.

1.1. Hyoids absent (usually); back mottled, except in sea-run examples.

s. Gill-rakers to below angle; stomach very stout; cocea 44.

S. ROSSII.

S. ARCTURUS.

S. FONTINALIS.

Salvelinus fontinalis, the best known of our Red Spotted Trouts, the 
Speckled Trout or Brook Trout of the East. Its home is between latitudes $32 \mathrm{I} / 2^{\circ}$ and $55^{\circ}$, in the lakes and streams of the Atlantic watershed, near the sources of a few rivers flowing into the Mississippi and the Gulf of Mexico, and in some of the southern affuents of Hulson Bay. Its range is limited by the western foot-hills of the Alleghanies, and nowhere extends more than three hundred miles from the coast, except about the Great Lakes, in the northern tributaries of which Trout abound. At the South it inhabits the headwaters of the Chattahoochee, in the southern spurs of the Georgia Alleghanies, and tributaries of the Catawb in Nortl Carolina. It also occurs in the great islands in the Gulf of St. LawrenceAnticosti, Prince Edward, Cape Breton and Newfoundland.

Bean calls attention to the fact that although this species usually has no trace of hyoid teeth, he has seen specimens from Labrador, about io per cent of which possessed a few (never more than three) weak tecth on the hyoid bone, while occasional examples from New York and Massachusetts show the same abnormality, and farther to the southward the normal condition is permanent.

Temperature is a prime factor in determining the distribution of this species, and since few observations have been made in the field, our conclusions must needs rest on a study of the species in domestication, an instructive though not entirely reliable method. The experience of Messrs. Green, Stone and Ainsworth, indicates that Trout cannot thrive in water warmer than $68^{\circ}$ Fahrenheit, though they have been known to live in swift-running water at $75^{\circ}$. Fishes hatched in artificial ponds may probably be inured to greater warmth than wild fishes can endure, and it is doubtful whether the latter are often found in water warmer than $60^{\circ}$ or $65^{\circ}$. At the Oquossoc and Cold Spring hatching establishments the water ranges from $45^{\circ}$ to $49^{\circ}$ throughout the year. Below $36^{\circ}$ Trout are torpid and refuse to feed, and instances are on record of their reviving after being frozen stiff. The remarkable variations in the habits of Trout in different regions are easier to understand in the light of these facts. In the Long Island region Trout live in salt water in the coldest months, when its temperature is below $50^{\circ}$. North of the Bay of Fundy, at the entrance of which the water barely registers $50^{\circ}$ in midsummer, they inhabit the ocean abundantly, except at the spawning time. South of New York the coast-reaches of the rivers appear to present a barrier of warm water which the Salmon do not seek to penetrate from without, and 
which immures the Trout in their homes in the hill country as closely as would a mountain wall. Difficult Run, a few miles above Washington, is a natural Trout stream, and the species occurs in other streams near Baltimore and Washington.

When Trout have no access to the sea they still contrive to avoid a change of temperature with the seasons. In midsummer they lie in the bottoms of lakes cooled by springs, in the channels of streams, or in deep pools, lurking behind rocks and among roots. In spring and early summer they feed industriously among the rapids. At the approach of cold weather in autumn they hasten to the clear shallow water near the heads of the streamlets. It is at this time that they deposit their eggs in little nests in the gravel which the mother-fish have shaped with careful industry, fanning out the finer particles with their tails, and carrying the large ones in their mouths. After the eggs are laid, the parent fish covers them with gravel, and proceeds to excavate another nest. The same nests are said to be revisited by the schools year after year.

The spawning season begins in New England in October, continuing from three to six months, and during this period the fish should be protected by stringent laws. Mr. Livingston Stone observed that in his ponds at Charlestown, N. H., spawning began October $\mathrm{I} 2$ and ended carly in December; at Seth Green's establishment, near Rochester, N. Y., it began on the same day, and continued until March. At the former station spring water, with a uniform temperature of $47^{\circ}$, was in use, while at Caledonia the eggs were kept in brook water, which is colder in midwinter, retarding development.

Trout eggs are usually three-sixteenths of an inch in diameter, although varying greatly, and are colorless, red or orange-hued. The quantity yielded by a fish is in direct proportion to its size, the average being from four to six hundred. Mr. Stone took sixty from a half-ounce fish, and eightéen hundred from one which weighed a pound. The eggs having been laid, their time of development depends strictly on the temperature of the water. According to Mr. Ainsworth, they will hatch in one hundred and sixty-five days with the mercury at $37^{\circ}$, one hundred and three at $41^{\circ}$, eighty-one at $44^{\circ}$, fifty-six at $48^{\circ}$, forty-seven at $50^{\circ}$, thirty-two at $54^{\circ}$, \&c. Seth Green's rule is that at $50^{\circ}$ they hatch in fifty days, every degree warmer or colder making a difference of five days. After the eggs are hatched the yolk sac is absorbed in from thirty to eighty 
days, and the young fish begin to lead an independent life. Now the rate of growth is determined by the amount of food consumed. Some two-year-old fish weigh a pound, some half an ounce, as Mr. Stone's experience show. In domestication growth is more even. Mr. Ainsworth's estimate allows an average of two ounces for yearlings, a quarter of a pound for two-year-olds, half a pound for three-year-olds, and a pound for four-year-olds. Wild fish often grow much faster. One of a large number of Rangely Trout, tagged by Mr. George Shepard Page in I87 I, and caught in $\mathbf{I} 873$, was found to have grown in two years from half a pound to two pounds and one-quarter. All two-year-old Trout and some yearlings can reproduce their kind.

The best description of the spawning habits is that by James $\mathrm{W}$. Miles:

"His whole wooing is the most polite attention and the gentlest of persuasions. He moves continually to and fro before his mate, parading his bright colors, while she rests quietly, with her head up stream, vibrating her fins just sufficiently to keep her from floating down. At Waterrille, Wis., I had the opportunity of watching their habits. A pair of large Trout had selected a spot near the bank of the stream, where the water was about ten inches deep. The female had fanned the gravel with her tail and anal fin until it was clean and white, and had succeeded in excavating a cavity. They were frightened away as I came to the edge of the bank. Concealing myself behind a willow bush, I watched their movements. The male returned first, reconnoitering the vicinity, and, satisfying himself that the coast was clear, spent a half hour in endearoring to coax the female to enter the nest. She, resting half concealed in the weeds, a few feet away, seemed unwilling to be convinced that the danger was gone; and he, in his full, bright colors, sailed backward and forward from the nest to his mate, rubbing himself against her, and swimming off again in a wide circle close along the bank, as if to show her how far he could renture without finding danger. She finally entered the nest."

Brook Trout seldom exceed two or three pounds, and a five-pounder is thought a monster. St. Lawrence Sea Trout usually weigh two and onehalf pounds, though they are not seldom caught weighing six or eight. A famous locality for large fish is the headwaters of the Androscoggin River in Northwestern Maine. Prof. Agassiz, in IS60, obtained one of them which weighed eleven pounds. The well-known specimen taken by MIr. George Shepard Page in 1867 , in Rangely Lake, weighed ten 
pounds after three days' captivity, and was thought by experts to have lost a pound and a half in transit from Maine to New Jersey, where it died. Its length was thirty inches, and its circumference eighteen. Another, from Mooselucmaguntic, weighed eight and one-half pounds, and measured twenty-five inches. The Nepigon River claims still heavier fish. Hallock mentions one said to have weighed seventeen pounds.

There are many local races of Trout; the same stream often contains dissimilar forms, and those bred in different hatcheries may easily be distinguished. Whoever has seen the display at the April opening of the trout season at Mr. Blackford's, in Fulton Market, N. Y., can understand the possibility of almost infinite variety in form and tint within the limits of one species. Fish inhabiting swift streams have lithe, trim bodies and long, powerful fins; those in quiet lakes are stout, shortfinned, and often overgrown. In cool, limpid brooks, with sunlight, much oxygen, and stimulating food, their skins are transparent and their hues vivid; in dark, sluggish pools they are somber and slimy, and are called "Black Trout." Agassiz noticed that those of the same river varied accordingly as they haunted its sunny or shady side. They have the power of changing their tint at will. 'The influence of the nerves over color was neatly demonstrated by M. Pouchet, who produced a white side in a Trout by destroying the eye of that side. In the sea, for reasons unexplained, both Trout and Salmon lose their gay colors and become uniform silvery gray, with black spots. In the sea, too, the flesh assumes a reddish color, due no doubt to the absorption of the pigments of crabs and shrimps eaten by the fish. Red flesh is also found in some inland races.

Our Trout are strong feeders, but are dainty rather than greedy. They consume moderate quantities of food, and it suits their capricious appetites to seize their prey while living. They take objects at the surface with an upward leap, instead of downward from above like the Salmon. Of all foods they prefer the worms washed out of the bank, then gayly colored flies, water insects, little fishes, larva and the eggs of fishes. Those in domestication are usually fed on the heart, liver and lungs of animals killed for the market.

Their daintiness, shyness, cunning and mettle render them favorites of the angler, who lures them into his creel by many sly devices. The most skillful fisherman is he who places before them least obtrusively the bait 
which their momentary whims demand, or a clever imitation thereof. Trout are always in season from April to August, and in some States for a longer period.

The Eastern Brook Trout must have been discovered by the first settlers of North America soon after their coming to the New World; yet, strange to say, the only allusion to it in colonial times is in the "Remonstrance of New Netherland," addressed by that colony to the States General in $\mathbf{1} 649$. It was first brought before the world of science in $\mathbf{s}$ I 4 , when Dr. Mitchill named it Salmo fontinalis, a name which has become almost classical. Our ichthyologists having recently decided that its technical name shall be Salvelinus, a wail has arisen from our anglers, and the ever witty Charles Hallock has voiced the general discontent in his rhythmical protest, beginning "I am Salmo fontinalis," * which concludes as follows:

"No fulsome titles do I covet,

Science holds no bribe for me.

Slavery for those who love it.

From nomenclature leave me free,

Yet they call me Salvelinus.

Can you fancy sin more heinous."

They have always been the pets of fish-culturists; indeed, the experiments of Dr. Garlick and Prof. Ackley, who inaugurated in 1853 the practice of pisciculture in America, were made with this fish. They become thoroughly domesticated, and are as much under the control of their owner as his horses and cattle. They have been acclimatized in England since IS68, and are always on exhibition in the aquaria of the museum of fish-culture at South Kensington.

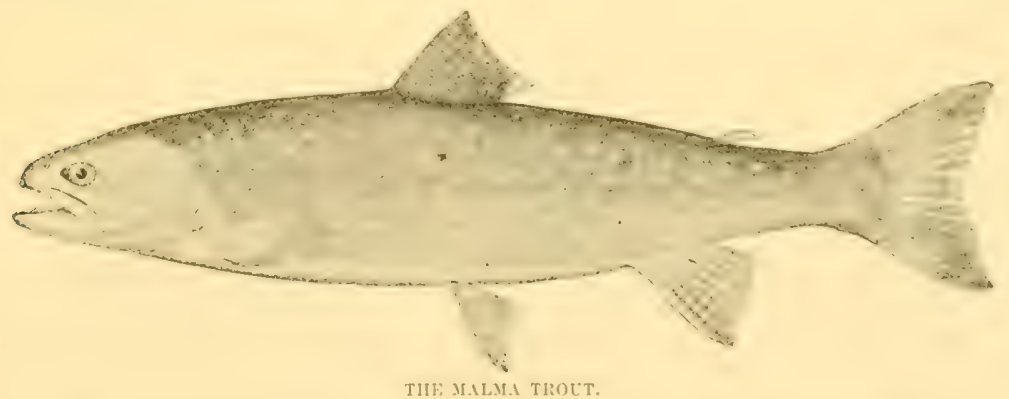

The Malma Trout, Salielinus malma, is the most important of our 
chars, next to the Eastern Brook Trout. It occurs in Northern California, west of the Cascade Range, is abundant throughout the Aleutian Islands, and northward to Colville River in Alaska, and has been found at Behring Island by Stejreger, and at Plover Bay, Siberia, by Bean.

It is known as the "Lake Trout," "Bull Trout," "Speckled Trout," and "Red-spotted 'Trout." In the ocean, where it is found in large numbers, it is the "Salmon Trout." In the Sacramento Valley the ridiculous and inappropriate name "Dolly Varden," is still retained. In Siberia it was formerly known as the "Malma" or "Golet." The Indian name "Chewagh" is ascribed to it in British Columbia. In size this species reaches a weight of fourteen pounds. The largest seen by Jordan weighed twelve pounds, a weight which is not uncommon in the ocean. "In the lakes," writes Jordan, "it averages smaller, and in the mountain streams it breeds at a length of six or eight inches. In all these peculiarities it agrees with its near relative, the common Brook Trout of the Atlantic coast. It ranges from the upper waters of the Sacramento to Kamtchatka on the west side of the Rocky Mountain chain, and for the most part in and west of the Cascade range. From Puget Sound northward it is generally abundant. It feeds voraciously in the salt water on smelt of various sorts, young Trout, sand lances, shrimps, anchovies, herrings and even sticklebacks. In fresh water it probably eats whatever living thing it can get. Nothing is certainly known of their breeding habits. They probably spawn late in the fall in the river, and therefore those which are in the sea must be to some extent migratory. They are taken in Frazer River at the time of the eulachon run, but they probably then ascend the river to feed upon the eulachon, and not for spawning purposes. As a food-fish this beautiful species ranks high."

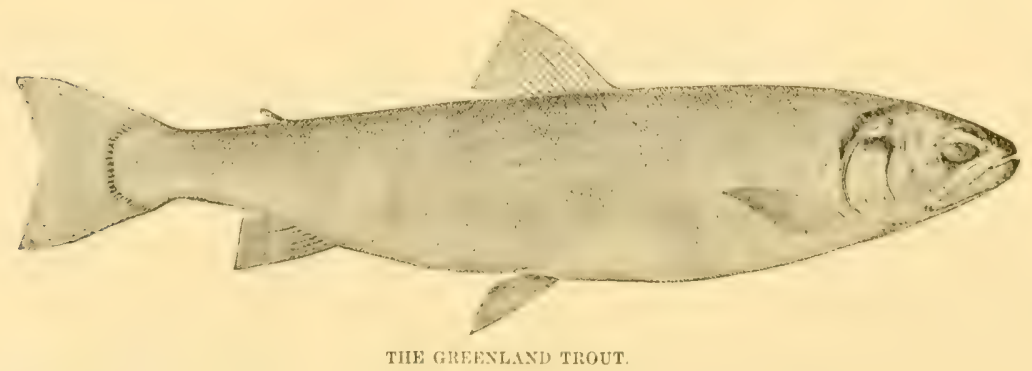

Bean adds that this Trout reaches its greatest size northward; it is 
extensively salted at Kodiak in the sea-run condition under the name of Salmon Trout. Examples of twenty-four inches in length are known. The Greenland Trout, Salvelimus stagnalis, a native of ArcticAmerica, is believed by Bean to be, with litule doubt, the "Sea Trout" of Labrador, and of Canada. It rivals the Atlantic Salmon in size, and has no near connection with the "Sea 'Irout" of Europe. It is interesting to know that the anglers have probably been in the right and the ichthyologists wrong in regard to this interesting species, concerning which as yet we know very little. Hallock and others of our anglers have described its qualities as an angling fish very fully. S. stagnalis occurs in the lakes of Greenland. The National Museum has specimens from Disko, taken by Ensign Dresel; and from Labrador, obtained by liuncr.

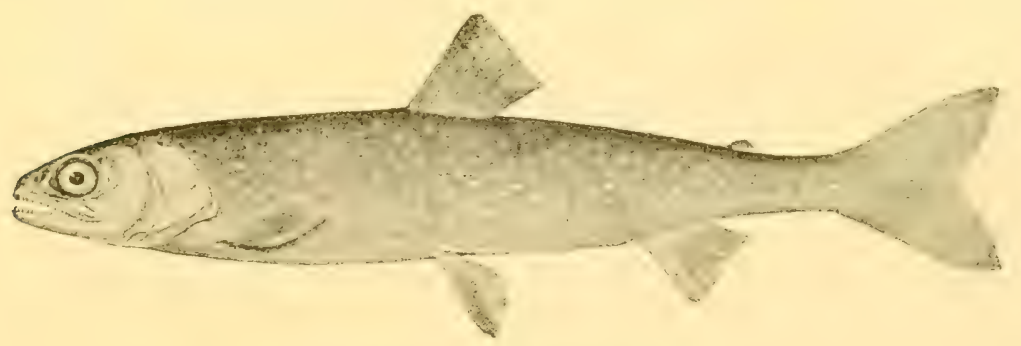

THE OQUASSA OR BLLEE BACK THOLT.

Salvetimus oquassa, inhabits the lakes in Western Maine; thence introduced into New York and New Hampshire. 'This is, says Bean, a small species, not known to exceed ten inches in length from existing collections. It is probably a land-locked form of $S$. stagnalis, and specimens of much larger size may be expected. Its distribution, also, will be found to be more extensive.

Closely related to the Oquassa is the Saibling, introduced into Massachusetts, New York, New Hampshire and Wisconsin, which, according to Bean, closely resembling some of our native Chars as to make its recognition difficult. A hybrid between the Saibling and our common Brook Trout has further increased the trouble of identification.

This form, whether it be regarded as a single species or several related species, is distributed over all of Northwestern Europe, and possibly also over a portion of Asia, although, since the Asiatic representatives of the 
genus have not been sufficiently studied, it is impossible yet to make this generalization. They are, emphatically, cold water fishes, thriving at a temperature little above the freezing point, and in their period of greatest vigor and perfection at the approach of winter, as is indicated by the fact that at this time their spawning takes place. No fish of any kind has ever been found nearer to the North Pole than the Char, a species, Salvelimus arcturus, having been discovered by the last English polar expedition in I $2^{\circ}$ north of the Arctic Circle. In the South of Europe its range is limited by the Alps, and in this region its study has brought to light a very curious fact which confirms still more strongly the idea just spoken of, that the fish thrive the best in a very cold climate. In the extreme north and in the extreme south this fish reaches its greatest perfection.



The Saibling has been propagated by German fish-culturists for a period of ten years or more, and thrive magnificently in captivity. The hatchery at Oussee, in Germany, produces yearly three or four hundred thousand of artificially-brooded Saibling, and plants them in the neighboring lakes. In the tanks at the late International Fishery Exhibition in Berlin were exhibited many superb specimens of this fish, some of them over two feet in length, and one of these was sent to the National Museum by Herr von Behr, president of the Deutscher Fischeri Verein.

In selecting a place in which to deposit the Saibling eggs received in January, I887, the Commissioner of Fisheries has endeavored to find a lake as similar as possible in depth and temperature to the larger Swiss lakes, and he has, therefore, sent them to Lake Winnipseugee, N. H. Here the whole sixty thousand were planted, with the hope that placing so large a number together in a lake of moderate size the experiment of intro- 
duction may be a success, and this hope was realized, for they proved satisfactorily hardy, and on December 3, I88 3 , about 600 eggs were taken by Commissioner Hodge.

There are three other little known fishes of this group, now under study by Dr. Bean.

Salvelinus Rossii, which occurs in the Arctic Ocean about Boothia Felix, has recently been detected by him in the province of Leubec, Canada. It is a very large species, reaching more than two feet in length, according to Richardson. The best distinguishing character is the shape and striation of the opercular bones.

Another is Saluelimus arcturus, which has been taken in Victoria Lake, and Flocking Beach, Arctic America, and is the northernmost salmonoid known. This he remarked may be one of the forms of stagnalis, but specimens with red spots are still unknown. Last of all is the Stmapee Trout, S. Agrassizii, a form little understood, occurring in Sunapee Lake, N. H., which is being investigated by Prof. Quackenbos, Col. Hodges and Dr. Bean. 


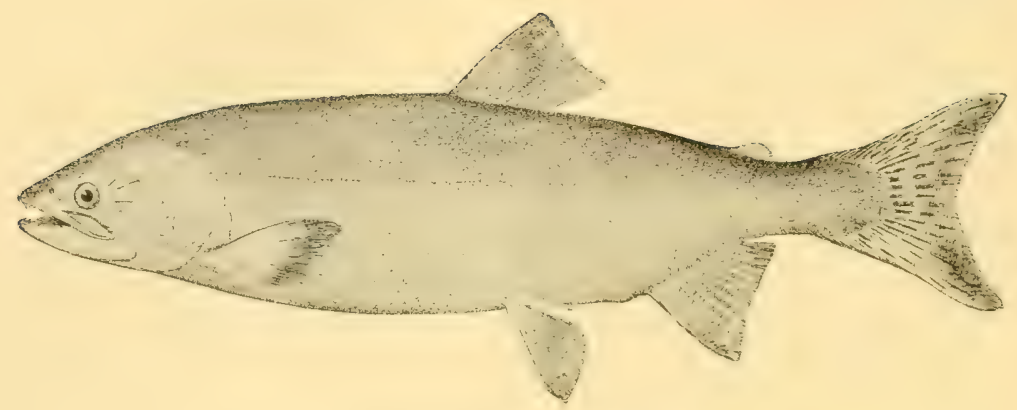

THE GORBCSCHA SALMON.

\section{THE PACIFIC SALMON.}

So dainty Salmons, chevins thunder-scar'd, Feast-famous sturgeons, lampreys speckled-star'd In the spring season the rough sea forsake And in the rivers thousand pleasures take.

Du Bartas : The Divine IVeek.

WE have upon our Pacific coast four species of the genus Oncorhlnchus, which is also abundant in the waters of Northwestern Asia. Having never seen one of them, except in bottles of spirits, I shall quote literally from the writings of Jordan, and from the notes furnished me by Dr. Bean, who has tabulated the principal characters as follows:

\section{SPECIES OF ONCORHYNCHUS.}

A. Scales small, lateral line more than 200 .

O. GURBUSCHA. AA. Scales large, I25 to 155 .

a. Gill-rakers long, 30 to 40.

aa. Gill-rakers short, 20 to 25 .

O. NERKA.

b. Pyloric coeca 50 to 80 .

O. KISUTCH.

66. Pyloric cœeca $x_{40}$ or more.

c. Anal rays I 3 to $x_{4}$ : branchiostegals $I_{3}$ to $x_{4}$.

cc. Anal rays 16 : branchiostegals 15 to 19 .

O. KETA.

O. CHOUICHA.

The Gorbuscha, Oncorlynchus gorbuscha, is still known to the Russians as in the time of Pennant and Pallas by the name of "Gorbuscha," gorb meaning hump. The English-speaking people call it generally the "Hump-back Salmon," and often the "Dog Salmon." On Frazer River it is known as "Holia" or "Hone" Salmon, and on Puget Sound as the "Haddoh." This is one of the smallest Salmons, not averaging over 
four or five pounds, and probably never exceeding ten. It ranges from the Sacramento River to Alaska, Behring Island and Kamtchatka. In the Sacramento and Columbia it is only an estray, on the latter river being. sometimes called "Lost Salmon." In Puget Sound it runs in large numbers in late summer and fall, like the Keta or Dog Salmon, ascending every little stream. Its run in Puget Sound takes place on alternate years, a fact which seems to be well established. It was very plenty in I 879 . None were noticed in I880, but stragglers are occasionally taken during the year of scarcity. A few were seen by us on the Columbia and Sacramento. We are told that this species runs every year in Alaska. During its run in Puget Sound the females are canned, and the males are thrown away or given to the Indians. The flesh is then pale, and the canned product is inferior in quality. In economic value the Hump-back Salmon is far inferior to the Quinnat, the Blue-back and the Silver Salmon, and, like the Dog Salmon, is mainly useful in furnishing a winter supply of food to the Indians.

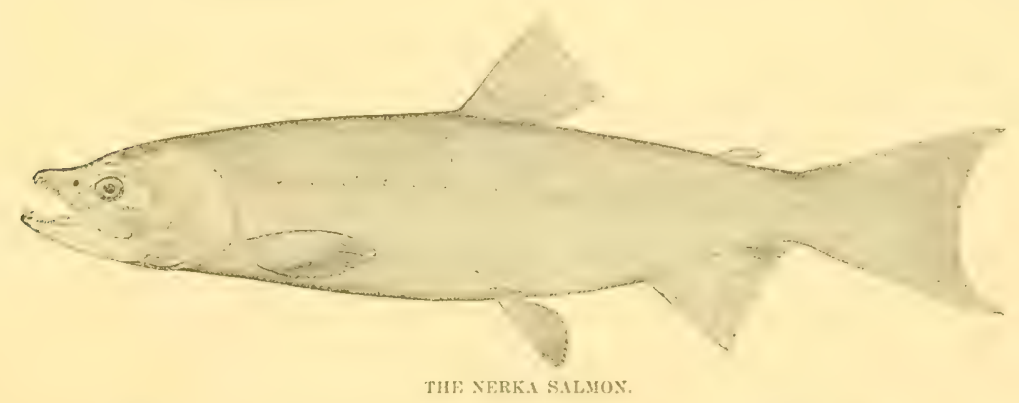

The Nerka or Blue-back Salmon, Oncorhynchus nerke, writes Jordan, known as the "Red-fish" to the English-speaking inhabitants of Alaska and Kamtchatka, and to the Russians, now as in the time of Pennant and Pallas, as "Krasnaya Ryba," which signifies red-fish, the name having reference to the color of the flesh. It is not unlikely that other species are occasionally confounded under this name, but there is little doubt that the present species is the one to which it is chiefly applied. On Frazer River, where this species is the most important. Salmon, it is known as the "Suk-kegh," "Saw-quai" or "Suck-eye." Elsewhere in Puget Sound it is rarely seen. In the Lower Columbia it is known by the appropriate name of "Blue-back ;" in the Upper Columbia as "Red-fish." 
Its average weight does not cxceed eight pounds and its extreme weight is probably not above fifteen. Its range is from the Columbia River, the Yukon and Behring Island to Japan and Kamtchatka. It runs in considerable numbers in the Columbia, and in much greater abundance in Frazer River, where it is the principal spring Salmon. We have no information as to its occurrence in California, or as to its entrance into any of the streams south of the Columbia. Like the Quinnat Salmon, it is attracted in early spring into all those streams which are fed by the melting snows, and into no others. Its run in spring on the Columbia is, so far as we know, contemporaneous with that of the Quinnat Salmon. The numbers are, however, much less, and I think that its run is over, earlier in the fall. On Frazer River it runs with the Quinnat, or a little earlier in the spring, the run mostly ceasing in midsummer, while that of the Quinnat continues on through the fall months. This species and the Quinnat run early and go far up the streams, where, after spawning, they all die. In Puget Sound this species is not known to the fishermen, only stray individuals being taken there. It does not accompany the Silver Salmon and Dog Salmon in their ascent of the Dwamish, Puyallup and other small streams; neither is it caught near the shore when out of the spawning season, as the other species are. In Alaska and Kamtchatka we are told that the Red-fish (ncrka) and King Salmon (chazoycha) run in spring and early summer, while the other species run in late summer and fall, the Silver Salmon last.

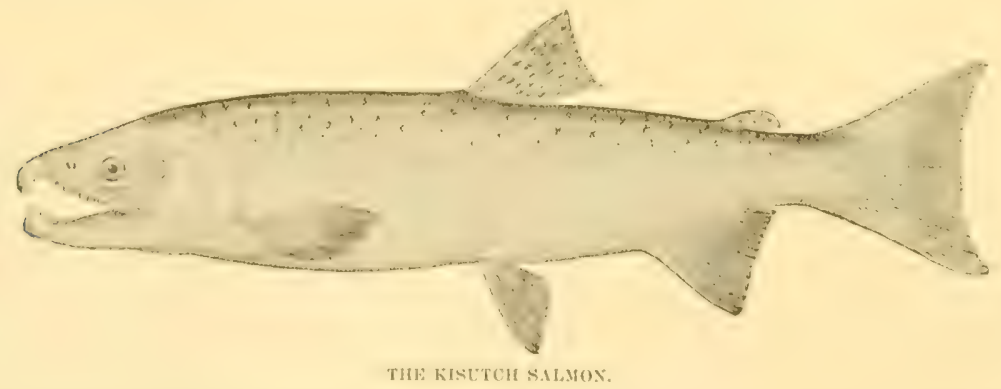

The Blue-back is the most graceful of the Salmons and the most elegant in color. Its flesh is very similar to that of the Quinnat, but less firm and more watery, and it is not quite so rich when canned, though in favor because of its red color. Next to the Quinnat, it is the most 
valuable of the different species, and its inferiority is mainly that of size. It has been artificially propagated by the Canadian government.

The Kisutch, or Silver Salmon, Oncorhynchus kisutch, writes Jordan, is almost everywhere known by the name of "Silver Salmon." It has also a series of local names. In Kamtchatka it is still known by the name "Kisutch," in use in Pennant's time; a hundred years ago. The name "Bielaya Ryba," or "White-fish," is also ascribed to it. On Frazer River it is known by the Nusquaw name of "Coho ;" at Seattle, by the Nisqually name of "Skowitz;" about Cape Flattery by the Makah name of "Hoopid ;" on the Columbia it is called "Silver Salmon" or "White Salmon," and southward the same names prevail. It reaches a weight of twenty pounds, the usual range being from seven to ten. The Silver Salmon enters all the rivers from Sacramento to Behring Island and Kamtchatka. In the fall it is abundant in probably all the rivers. Few or none, however, are seen in the spring. They are often taken with seines in Puget Sound at all seasons. Like the other fall-running Salmon, they seldom ascend the rivers to any great distance.

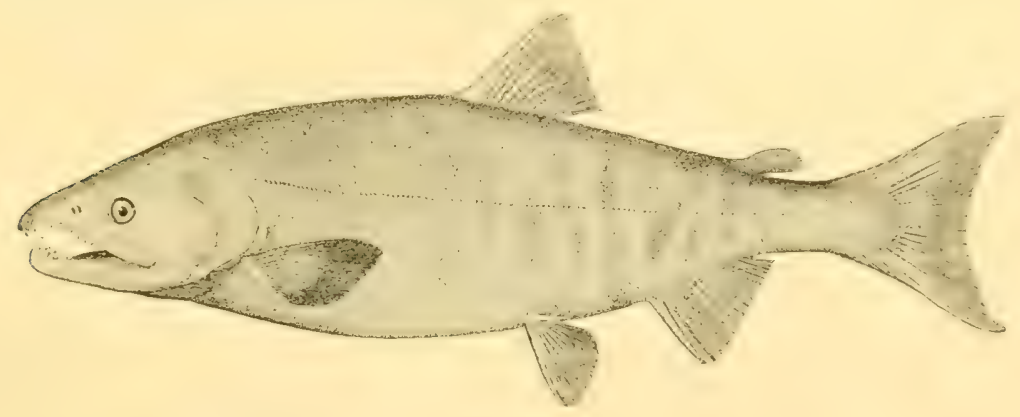

THE KET.

The Keta, Oncorhynchus keta (Walb.), Gill and Jordan, occurs on the Pacific coast from San Francisco northward to Hotham Inlet, Alaska. This species, during the period of its run in the fall, generally goes by the name of "Dog Salmon," under which name the males of the Silver Salmon, and even of the Quinnat, are often confounded with it. The Russians now, as in the time of Pennant, Pallas and Walbaum, call it "Kayko," the name "Keta" (whale) being no longer in use. On Frazer River the name (Musquaw) is now "Qualoch," at Seattle (Nisqually) "Ktla-why," and in the Chinnook jargon "Le-Kai." This 
species is rery uniform in its size, and arerages ten to twelve pounds. It is seldom or never seen in the rivers in spring.

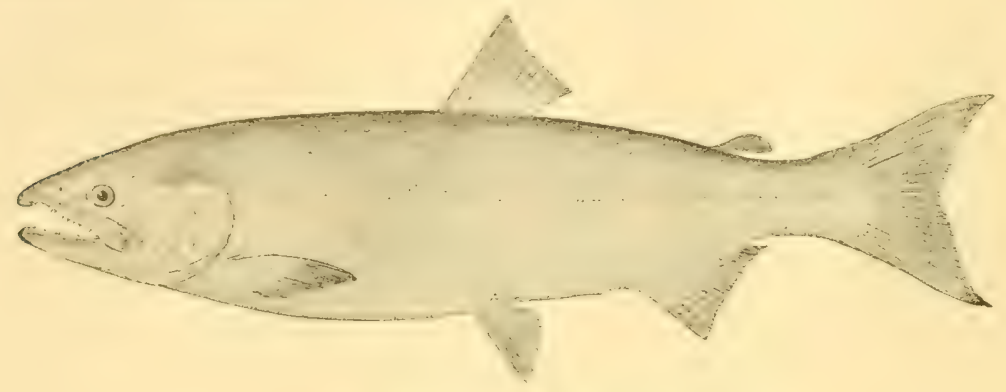

THE CHOUICHA OR QUIXIIT S.ILYON.

The Quinnat Salmon, Oncorhynchus chouicha, ascends the large rivers of California and occurs northward to the Yukon in Alaska.

This is the largest and most important species of the genus, it is said to reach one hundred pounds in weight. It is easily caught with hook and line in the fresh-waters, where it goes to deposit its eggs. It does not readily take a fly, but becomes an easy victim when tempted with salmon roe, which is the most effective of all baits for catching this fish. When prime it very much resembles in appearance the well known Atlantic Salmon (Salmo salar) in the same condition, with this exception, that it has on its back and sides nearly black, star-like spots, while the Alantic Salmon, when fresh from the ocean has none.

The California Salmon is a remarkable fish, and has an extraordinary career. Fifty years ago it was hardly known, except to students of natural history. Now it is known and eaten almost all over the world, for there is hardly a port in the world where ships have not carried the canned Salmon of the Columbia, which is the same fish under a different name; and not only has this fish, in the form of food, traveled nearly all over the work, but the living embryos of the Califorma Salmon have been transported to England, France, Germany, Belgium, Denmark, Russia, Australia, and New /ealand, so that there is probably no one fish inhabiting a limited locality which is known over the world in so many different places as the California Salmon. An admirable biography of this species by Mr. Livingston Stone, may be found in the Quarto Fishery Report. 


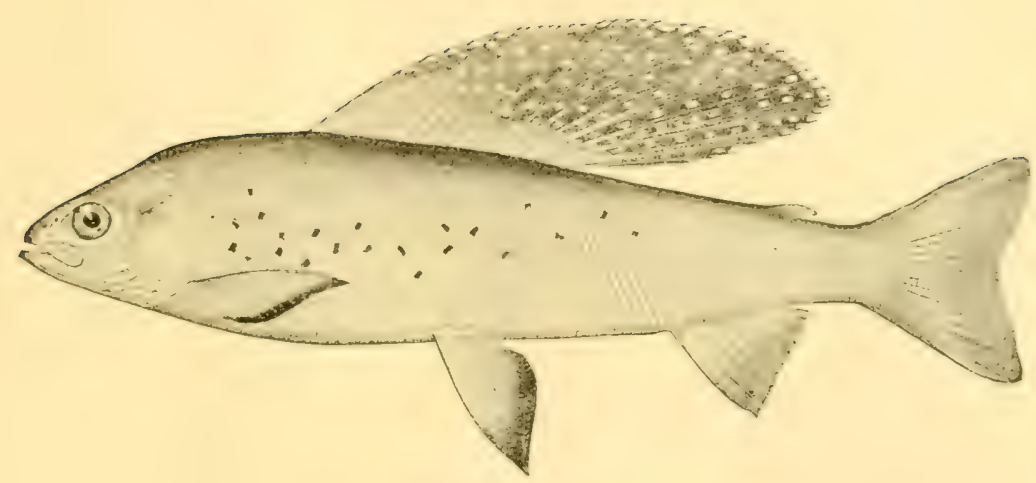

THE AICTIC GRAYLIXG

\section{THE GRAYLINGS.}

Effigiens oculis celeri umbra natatı.

Ausonius; The Moselle.

\section{WWO species of the genus Thymallus occur in North America, one, the} Aretic Grayling $T$. simifor, the other the Michigan Grayline $T$. tricalor, the diagnostic characters of which are thus defined by Bean:

\section{SPECIES OF GRAYLING.}

A. Gill-rakers 22 ; pyloric coeca 19 ; maxilla $1 / 3$ head; mandible equal to anal base ; eye nearly equal to interorbital space; dorsal when laid back not reaching adipose fin. (iill-rakers 18 ; nyloric cnecn
at. interorbital space; dorsal when laid back reaching end of adipose fin.
T. SIGNIFER.

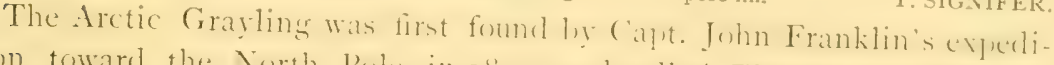
tion toward the North loule, in rsig, and called Thymallus sirnifir. ly. Sir John Richardson, who thus describes its discovery :

"This very beautiful fish alomunds in the rockl strams that thew through the primitive comtry lying north of the sixty-second paralled lectweres

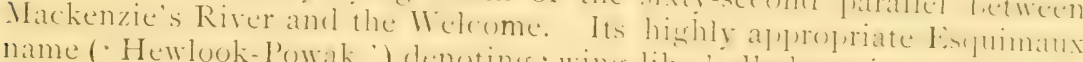
name ('Hewlook-Powak. ) denoting - wing-like, allukes to its magnitio ent clorsal, and it was in reference to the same feature that I lestow wen it the

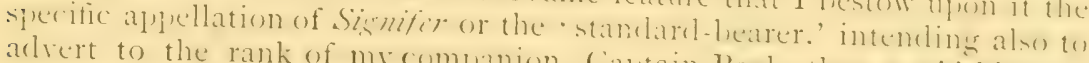

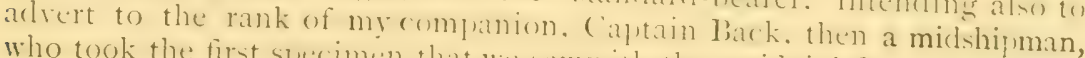
who took the first specimen that we salw with the artific ial fly. It is fomnel only in clear waters. and secms a de dight in the most rapicl parts of the mountann streams." As is implicel in these remarks this speries in res markalule for its immense doral fin, which is nearly wiec as high as tive
body of the fish. 
It is found generally in British America and Alaska, abundant northward, and extending to the extremity of the territory.

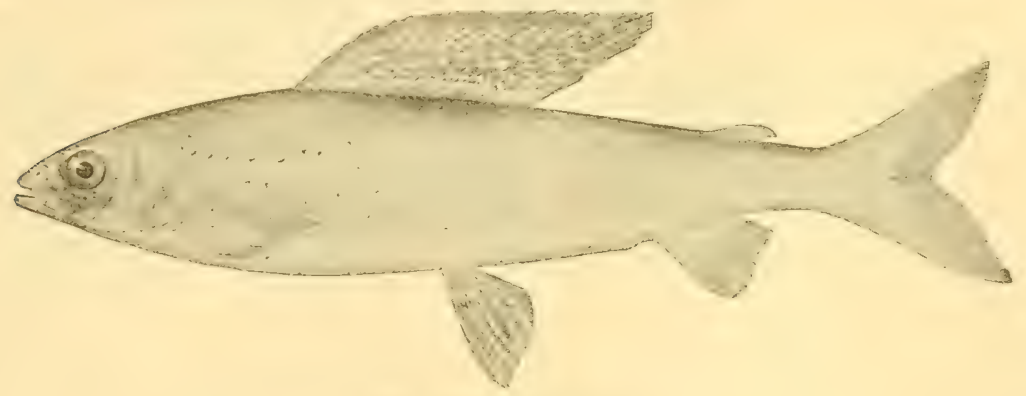

THE TRICOLOR GR.TLING.

Thymallus tricolor occurs in the streams of the southern peninsula of Michigan, and is abundant in Ausable River, and in the headwaters of the Missouri in Montana.

It was described by Cope in I $S 6_{5}$, but his notice, having been published in the proceedings of a scientific society not generally read by sportsmen, attracted but little attention. Popular interest was first excited in 1873 , by the discussions in "Forest and Stream," and by a letter from Professor Agassiz, published extensively in the daily papers, acknowledging the receipt of two specimens sent to him from New York through the agency of Mr. Hallock, who had received them from Michigan. The subject was then taken up by the newspapers, and the Grayling was soon well known. A name closely associated with the study of the Grayling is the honored one of the late James W. Nilner. In IS7r, Mr. Miliner, in company with Mr. D. H. Fitzhugh, of Bay City, Mich., risited the Jordan River for the purpose of procuring specimens of this fish; but, although many were seen in the clear cold waters, they could not be induced to take the hook during the day spent on the river. In I 873 he again risited this region, and subsequently published several popular articles on the subject of "Graylings of North America," which constitute a considerable portion of the very few essays finished by him, out of the many which were planned, and interrupted by his untimely death.

MiIner's description of the habitat of the Grayling is excellent:

"In the center of the Lower Peninsula of Michigan is an elevated plateau, a sancly region, with a soil containing a very small per cent. of organic 
matter, and covered with a forest of pines, generally the Norway pine, Pimus resinosa, Linm, growing in grand dimensions, the long, limbless shafts making wide boards, free from knots, yet but little utilized, while immense forests of the favorite lumber material, white pine, Pinus strolus, are yet uncut. From this plateau arise several large streams and rivers, flowing each way into Lakes Huron and Michigan. Among these are three rivers of note, the Muskegon, the Manistee, emjtying into Lake Alichigan, and the Ausable, entering into Lake Huron. Among the minor streams are the Cheboygan, Thunder Bay, and Rifle, tributary to Lake Huron, and the Jordan, empyting through Pine Lake into the Traverse Bays of Lake Michigan. A few branches and streams, spring-ferl, are formed, in which the water has a uniform degree of coldness throughout the summer, seldom rising above $52^{\circ}$. The rivers Rifle, Ausable, Jordan, Mersey, branch of the Muskegon, and the headwaters of Manistee, all have this character, and in all of these, and only in this limited locality, short of the Yelluwstone region, is found the already famous Michigan Grayling."

The town of Grayling, Mich., formerly called Crawford, is in the midst of this district. and the headquarters of Grayling fishermen. The Grayling is said to live also in Portage Lake, in the extreme northern part of the State. These streams seem to be remarkably cold, being fed by numerous springs. Nilner found the Ausable to vary between $45^{\circ}$ and $49^{\circ}$ morning and evening, in September; and Mr. Fitzhugh has remarked that the south branch of this river, which rises in a swampy lake, contains no Grayling except near its mouth, where its volume is swelled by large springs, and its water becomes clear and cold.

The Grayling of Europe, Thymallus vulgaris, is also restricted to cold streams, and appears to be found within limited areas. It is found in Norway, Sweden, Lapland, and the Oreades, in Switzerland and Hungary, and southward to lakes Constance and Leman, in Bavaria. A Grayling, possibly of different species, occurs in Lake Maggiore, and others have been recognized from Russia and Siberia. It is constantly being discorered in new localities. In England the species was formerly known as the "Umber." "And in this river be Umbers, otherwise called Grailings," wrote Holinshed, in "The Description of Britaine," A. D. I577. The German name, "Aesche," has been thought to refer, like "Grayling," to its color. The European and American fishes are so similar that only a trained ichthyologist can distinguish them, and their habits are very much the same. Our Grayling spawns in April in the Ausable, that of 
Europe in March and April, and sometimes, it is said, in May. Ours rarely grows to the length of sixteen inches, and the largest Milner could find weighed less than two pounds, the arerage length being ten or eleven inches, with a weight of half a pound. The European fish is said to grow to eighteen inches long, and the weight of four pounds and one-half.

Milner remarks: "Like the Brook Trout, their natural food consists of the insects that light or fall upon the surface of the stream. Their stomachs were found to contain broken and partially digested specimens of coleoptera, neuroptera, as well as the larva of species of the dragon-flies. There were also found in their stomachs the leaves of the white cedar, Thuja occidentalis, which drop continually on the surface of the stream, and are probably taken because the fish in their quick darts to the surface mistake them for insects falling upon the water." In France they are said also to devour little mollusks and the eggs of fishes.

The propagation of the Michigan Grayling was attempted as soon as its existence was known. Mr. Fred. Mather and Mr. Seth Green, always pioneers in such enterprises, were the first to attempt it, and they were soon followed by others, and the Grayling is now to be found in many fish-cultural establishments. I saw two hundred fine yearlings at Wytheville $\mathrm{Va}$., in $\mathrm{I} 887$.

There has been much discussion over the claims of the Grayling as a game-fish, and also its excellence for food. It has many ardent admirers and detractors. The enthusiasm with which it was greeted ten years ago has somewhat subsided, and it seems doubtful whether a vote of the guild of American anglers would now place it in the first rank of noble fishes.

"There is no species sought for by anglers," writes Mather, "that surpasses the Grayling in beauty. They are more elegantly formed and more sraceful than the Trout, and their great dorsal fin is a superb mark of loveliness. When the well-lids were lifted, and the sun's rays admitted, lighting up the delicate nlive-brown tints of the back and sides, the bluish-white of the abdomen, and the mingling of tints of rose, pale blue, and purplishpink on the fins, they displayed a combination of colors equaled by no fish outside of the tropics." 




THE LAKE THITE FISH.

\title{
THE LAKE WHITE FISHES, AND THE SIIELTS.
}

\author{
Of venison Goldsmith may wittily sing, \\ A very fine haunch is a very fine thing; \\ And Burns, in his tuneful and exquisite way, \\ The charms of a smoky Szotch haggis display ; \\ But 'tis often much harder to eat than descant, \\ And a poet may praise what a poet may want; \\ Less doubt there sha!1 be 'twixt my Muse and my' dish \\ While her powers, I invoke in the praise of White Fish.
}

HeNRy R. SchOOLCRAFt.

$\mathrm{T}$ HE White-fish of the Great Lakes, Coregonus clupciformis is a well known fish which has numerous representatives in the lakes of the Great West, all of which will necessarily come into prominence as the country becomes more densely populated, and all of which will doubtless in time come under the attention of the fish culturist, though none of them are of any especial interest to the angler.

Corcgonus clupeiformis (Mitchill) Milner, as has been said, is the most important of its family. It inhabits the Great Lakes and British America, and is replaced in Alaska by $C$. Richardsonii. This species has been artificially reared, and widely distributed beyond seas, and is one of the most important market fishes of the Upper Mississippi Valley.

Next in rank is the Coregoneus Artedi almost universally known as the "Lake Herring." "The name "Cisco" is also often applied to it, especially about the smaller lakes, and in many regions also the name 
"Michigan Herring." The Lake Herring is one of the most abundant fishes of the Great Lake region, probably second only to the White-fish in importance as a food-fish. It goes in large schools, and is taken in great numbers in comparatively shallow waters. It ranges northeastward to Labrador, the eye becoming larger eastward. The sub-species sisco of Jordan is a form modified by residence in small deep lakes in Wisconsin and Indiana, and probably in Northern New England and New York. Its usual length is little more than a foot. Its mouth is much larger than that of the White-fish, and its range of food is doubtless greater. It usually remains in deep water until in November and December, when great numbers come near shore to spawn in the shallow waters. As a food-fish the Lake Herring ranks well, and although it is considerably inferior to Coregonus clupeiformis, it is sent to market in immense quantities.

Coregomus Hoji, occurs in Lakes Michigan and Ontario, in deep water; in the lakes of Western New York (particularly Geneva Lake) where it sometimes dies in great numbers. It is known as "Frost fish" in some parts of New York.

The Mongrel White-fish, Coregonus tullibee, is a species occasionally taken in the Upper Great Lakes, where it is generally considered a hybrid between a White-fish and a Lake Herring, hence the name of "MIongrel White-fish." It is a rare fish in collections, and nothing distinctive is known of its habits. Its range extends northward, to Alaska, where young have recently been taken in the Kowah River.

The Menomonee White-fish, Corcgomus quadrilateralis, inhabits the Lakes of New England, Upper Great Lakes, and is found northwestward to Alaska; occurring at Kodiak Island in the Gulf of Alaska. It is replaced in the Rocky Mountain, and Sierra Nevada regions by C. Filliamsonii. "The name of "Round-fish" is given to it by Richardson, and that of "Shad Waiter" (Winnipiseogee Lake) by Prescott. In the Great Lakes it is much less abundant than the common White-fish, and its size is less than that of the White-fish.

Rocky Mountain White-fish, Coregomus Milliamsonit, occurs in the upper tributaries of the Missouri and streams flowing into the Columbia; also in clear lakes from the Rocky Nountains to the Pacific; it is abundant in the Sierra Nevadia. This species is ustally known as the White-fish; in Utah as the "Mountain Herring." It reaches a length of a little more 
than a foot, and a weight of about a pound. It is common in the market of Salt Lake City, and sometimes comes into the San Francisco market. - It spawns in October and November, running from the lakes into the small streams for this purpose. As a food-fish it ranks well, being similar to its Eastern relative, $C$. quadrilateralis.

The "Blue-fin" or "Black-fin," Coregonus nigripinnis, has thus far been taken only in the deeper waters of Lake. Michigan, and in deep lakes near Madison, Wis. At times it comes in considerable numbers to the Chicago market, but it is in general a rare species. It reaches a much larger size than the Lake Herring, which it very closely resembles in general appearance.

"The "Inconnu" of the French trappers and voyageurs of the far north, is the Stenodus Mackenzii, which inhabits the Mackenzie river and its tributaries, Yoken and Kowak rivers, Alaska. It is a food-fish of great value, said to reach forty pounds in weight.

The habits of the Coregoni are little understood. The publications of the Fish Commission will give all that is of record, and also a fuil history of what has been done in their artificial propagation.

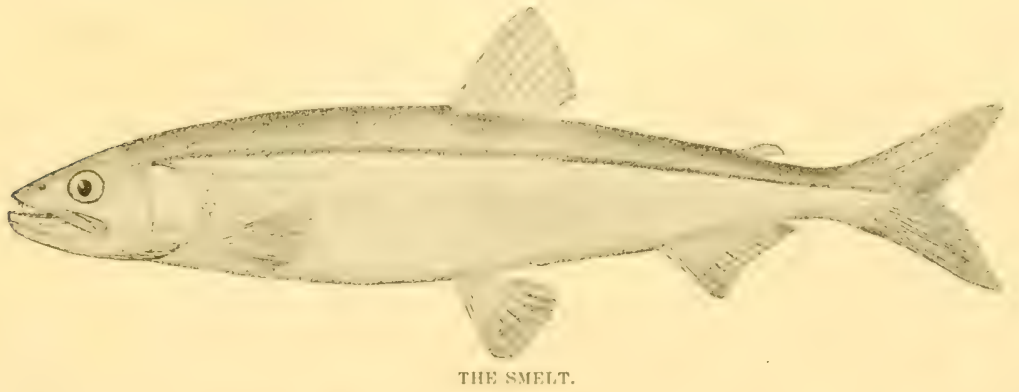

The Smelt, Osmerns mordax, is found along our Atlantic coast from Virginia to the Gulf of Saint Lawrence. The northern limit of its range has not been precisely defined, although it is known to be extremely abundant along the northern shores of New Brunswick. It is also found in many of the fresh-water lakes of Maine, New Brunswick, and Nova Scotia, where they have become land-locked, and in some instances, as in Belgrade Lake, Naine, seem to have rather been improved in size and flavor by the change from salt to fresh water.

The Wilton Smelt of Wilton Pond, Kennebec County, Maine, and the 
Cobessicontic Smelt are two of the land-locked forms which have received specific names.

The European Smelt, O. eperlamus, which, though very similar in form to our own, differs from it in the size of its scales, is found in Southern Sweden, as far north as Christiania Fjord district, lat. $62^{\circ}$, and south as the entrance to the river Loire, lat. $47^{\circ}$, ascending the Seine as high as Rouen. It is the "Stint" and the "Spearling" of Germany, the "Smelt" or "Sparling" of England, and the "Spiering" or "Spearling " of Holland. It is found in the Baltic, and, entering the Gulf of Finland, becomes a member of the fauna of Russia, and is found landlocked in cool lakes, especially those of Norway, and also in many of the lakes of Northern Germany, and even as far south as Bavaria.

The Smelt enters our rivers and brackish bays during the winter months for the purpose of spawning, and at this period is caught in immense quantities in nets and by hook and line.

It is to be regretted that no one has made careful observations upon the beginning and close of the breeding season of this species at different points along the coast, but the spawn appears to be deposited, generally, late in the winter and early in the spring. The smelt fishery is increasing yearly in importance, owing to the greater facilities for the transportation of fish in ice. As long ago as 1853 , Storer stated that in Watertown, Mass., alone, about 750,000 dozen were annually taken in scoop-nets from the first of March to the first of June. Perley, stated in $1 S_{52}$, that on the Gulf coast of New Brunswick large quantities were used every season as manure, while at the fishing stations in the Bay of Chaleur it was taken in the seine, and used as bait for cod. At the present time, however, there is an enormous shipment of Smelts from this region to the United States, forty car-loads sometimes being received in New York in the course of one winter. As early as IS64, according to a note from Mr. J. Matthew Jones, quantities of Smelts were packed at Halifax for shipment to the United States.

Although on account of its great abunclance it sells in the markets at a low price, it is among the very choicest of all our food-fishes.

'The "Green" Smelts, as they are called, or those which have never been frozen, are much the more highly esteemed, especially those which come from the Raritan Bay and other points in the vicinity of New York. 


\section{N D EX.}

\begin{tabular}{|c|c|c|c|}
\hline & & & \\
\hline …. : & 386 & ail. & \\
\hline 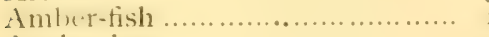 & 232 & ream, 1 & \\
\hline ........................ & 408 & ater, or Sea....... & \\
\hline ............................ & 146 & ighead ........... & \\
\hline$\ldots \ldots \ldots \ldots \ldots \ldots \ldots \ldots \ldots$ & $7 \mathrm{I}$ & 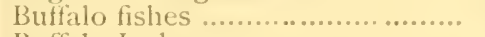 & \\
\hline ............. & 123 &  & \\
\hline …...............34 & 4,69 & l'ull P'out......... & \\
\hline n.................. & 223 & $\ldots \ldots \ldots \ldots \ldots \ldots \ldots \ldots \ldots$ & \\
\hline (no, & & ga & \\
\hline (.......... & & …..............22I & \\
\hline ...... & & ..................... & \\
\hline ...... & & 다. & \\
\hline or Red Drum & 102 & ,............... & \\
\hline ....... & 99 & .......... & \\
\hline ........ & 5 & ................... & \\
\hline ................. & 55 & (n................... & \\
\hline (.......... & & ..... & \\
\hline & 48 & .. & \\
\hline me for Red Drum...... & Io & ................... & \\
\hline$\ldots \ldots \ldots \ldots \ldots \ldots \ldots \ldots, 50,52$ & & ........ & \\
\hline ................ & 56 & , & \\
\hline$\ldots \ldots \ldots \ldots \ldots \ldots \ldots \ldots \ldots \ldots \ldots, 32,39$ & & 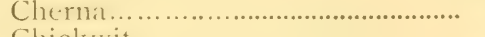 & \\
\hline$\ldots \ldots \ldots \vdots \quad, \ldots \ldots \ldots \ldots \ldots \ldots$ & 3 , & 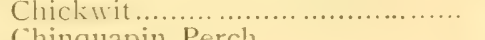 & \\
\hline , n.......... & & n............. & \\
\hline$\ldots \ldots \ldots \ldots \ldots$ & te & $\ldots \ldots \ldots \ldots \ldots \ldots \ldots$ & \\
\hline (........... & 22 & ( & \\
\hline$\ldots$ & & ;.............. & \\
\hline$\ldots$ & & I4 & \\
\hline …................... & 8.4 & (2......................... & \\
\hline .................27I & 3 & dred..................... & \\
\hline & i & ................. & \\
\hline ..... & 47 & . & \\
\hline & 24 & . & \\
\hline .... & 6 & & \\
\hline .... & 54 & & \\
\hline ...... & 3 & ................209 & \\
\hline ...............398, & . & I 33 & \\
\hline ..................... & 39 & (n.............. & \\
\hline & & & \\
\hline ....... & 276 & (…........ & \\
\hline (.... : & $3^{61}$ & & \\
\hline$\cdots \cdot$ & 30 & & \\
\hline & & & \\
\hline n........... & & 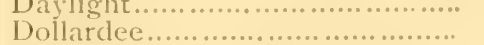 & \\
\hline ….... 4 & & & \\
\hline & & & \\
\hline & 386 & & \\
\hline
\end{tabular}


Drum, Red..

I.

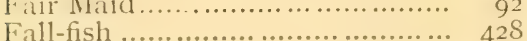

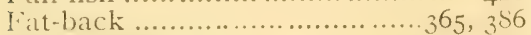

Flimnel Mouth..................... 79

Flounders and Flukes............. 314, $3^{2}$

Frigate Mackerel .................. 213

Frost fish.......................... $49^{1}$

Garrupa, various kinds ...........26 26 -73

Gaspereau........................... 393

Gaspergou.......................... I43

(ilass-cye......................... It

Goggle-eye.................67, 68, 69, 7 I

(ii)grgle-ejed Jack.................... 228

Gioggler ........................... 22S

Gold-fish .......................... 417

Goody .............................. I 129

Grand Fcaille....................... 406

Grayling .......................... $48_{5}$

ireen-fish ......................... I5I

Green-head .......................... 22

Green-tail............................ $3^{86}$

Grilse ........................... 45 I

Grouper..................47, 51, 52, I 48

Grunt ............................. $79, \mathrm{~S}_{2}$

Guasa ................................. 49

Gurnard........................... 305

Haddock ............................ 355

Hake .......................... I 23, 359

Half-moon .......................... 100

Halibut ............................ 307

Hitrd-headd ............................ ${ }_{3} S_{5}$

Hard-tail ............................. 228

Harvest-fish ...................... 22 I

Hendurgan ....................... 257

Herrings ......................... $3_{3} S_{I}$

Hickory Shad........................ 404

Hind, Spotted ....................... 50

Hog-choker......................... 337

Hogfish ............................ 2I, $\mathrm{S}$ I

Horned Dace............................ 427

Horn Pout ........................... 378

Horse-eyed Jack.................... 228

Horse-fish .......................... 232

Horst-htad ....................... 1 132

Horse-mackerel.................... 2 I 5

Jack .................................. 269

Jew-fish ............................49, 406

jewel-head........................ 173

Jinh Dory ......................... 257

Jorobado ............................ 232



firel ............................. I 28

Killifish............................. 422

King Cero......................... I86
King-fish ......................... I 23

Kipper.............................. $4+1 \mathrm{I}$

Kisutch............................ $4 S_{2}$

Krasnaya Ryba ..................... $4{ }_{4}$ I

Kyack.............................. 394

Lady-fish ........................... 410

Lafavette ........................... $\quad 129$

Lamplighter ........................ 69

Leather-jacket ..................... 234

Ling................................ I45, 270

Log-fish ............................. 2I 3

Log-Perch ......................... 2 I

Look-down ........................ 232

Lunge .............................. $46_{3}$

Mackerel .................................. 163

Bull ............................. I I

Chub ....................................... I I 77

Easter......................... I 79

Frigate ........................ $2 \mathrm{I}_{3}$

Horst................................... 2 I 5

Horse (Anoplopoma)........... 27

Monterey ....................... I I $7_{7}$

Spanish ............................... I 84

Thimble-eye........................... $\quad 177$

Tinker ................................ $\quad 177$

Mackinaw Trout........................... 463

Mademoiselle................................. I33

Maigre ............................................... I0

Malashaganay......................... It

Mangrove Snapper................ 52

Margate fish ........................ So

Marsh Bass .......................... $\quad 5_{56}$

Mattowacca............................. 404

Medialuna .......................... T0

Medregal.............................. 234

Menhaden ............................ $3^{S_{5}}$

Minnows ............................... 420

Moharra............................ 272

Moon-eye.......................... I $S_{7}$

Moon-fish ..........................232, I 46

Mossbunker........................... ${ }_{3} 8_{5}$

Mullets.......................... I 23, 363

Muskellunge...................... 276

Namaycush.......................... $46_{3}$

New Licht ........................ 7 I

Norway II addock.................. 257

Ombre Chevalier.................... 478

Oswego Bass........................ 55

Otsego Bass ....................... 459

Perch of Alaska.................... 272 name for Black Bass........... $\quad 5^{6}$

Chogset............... 273

Drum ................ I4 2

Sunfish .............. 66

Black.......................... $\quad 5^{6}$ 
l'renth

Black.

Blue ....

Bitid....

Chincuapin $\ldots \ldots \ldots \ldots \ldots \ldots . . . . . . . . .$.

Goggle-eye.......................

Gray, name for I rum.

(i. i, in

$1 \cdot \cdots$

liil.

Red

Red bellied........................

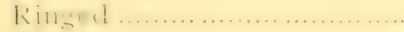

River

Sacramento..............................

Speckled .......

Silver.

sinile.

Strawberry

stripuel.

Sun

Ilhite

name for Driun

Iellow

name for Hlack Bass.

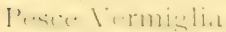

Per Colorado

Pickerel

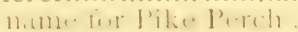

Pig-fishes........................... 79 , Si

Pike....

name for Pike Perch ............. J.

Wrall-eved, name for l'ike l'r.r.h ........................ 1 ,

I'ili: Perell, ...................... I.

Pilut-tish ............................. $2: 5$

l'in-tish ............................, .,

l'luice ............................... 31;

Pogy ................................. ${ }_{3} S_{5}$

Poision Rutrige ....................... is

Pollerk .............................. $3=$

Pompanoes ............................ ig

Porgy .................................. 99, I00

Three-tail........................ 146

Porgy, flamel Mouth............... So

Pork-li-h .............................. st

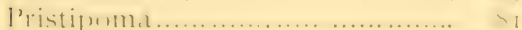

P'riest Fish ........................... . 268

Pumpkin-seed .......................64, 221

Gmaluch ............................. It

(jutentish ......................... 124

Quill-back ................................. 437

Quinnat ................................ 454

Rainbow Trout....................... 456

Ravalga or Ravallia.................. I 40
Kevi Live+t In

Recl-I rwum ......................... in?



ReUthii

Recl-tishl .............................. the

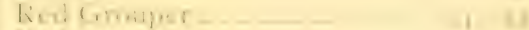

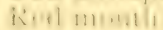

Rn, P., I.!

Red-Snapper.

Reinit

kn, h $_{1}$

Robialo

ki... I.

kock-Bass

kuck-col ................................. भiा

of the l'acific......... 20

li... I. H I. I

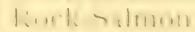



Round Robin

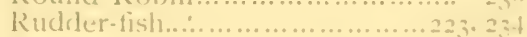

Runner............................... 237

Sac-atlait, name for Crappic......... it

Sah- quai..................................... ISi

.

Sail-tish .................................... 2.40

Sailor's Choice.................so, s1, S4, g5, 99

Salmon ...................................... +1.

Bluebatck ............................... Jis

California........................... . . 4.4

Chimnook.......................... 45it

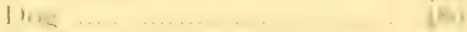

Hardhead......................... 4.. 45,5

Humplack ....................... tisi

Kelp................................. 52

Kietal ...............................

Kink ....................

ki -41, h ...............

Land-locked ...................... $\$ 45$

Nerka ................................ . Sit

(uinnat ............................. tist

Silver a.

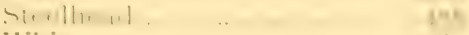

White ...................... I 4. 23,3, 153

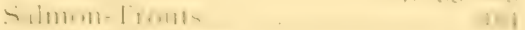

Sardine, Califormia............................. 394

Sargo ...................................................... Sil

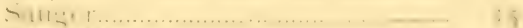

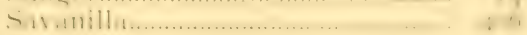

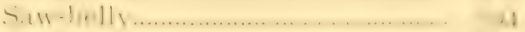

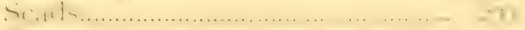

xim . . . . . .

Scrod ............................................

sculpin................................ \$or 
Scup

Sea Bass

Sea-robin

Sirreant-fish

Shad

Sheepshead... name for Butter................... Lake

Shiner.

Shoemaker

Silver Bass

Silver-fish.....................

Skip Mackerel, name for Bluefish

Skipjack............................

Skowitz ....................................... 47

Simclt ............................. 49 I

Smolt ..................................... $45^{2}$

Snapper ................................ 73

name for Rose-fish ............. 257

Bastard .......................... 78,84

Black ............................ 78

Brown, name for Red Grouper 47

Gray ............................ $7^{8,79}$

Mangrove ........................5 52,78

Pensacola .......................... ${ }_{7} 8$

Red.................................... 78

Snooks ................................ I $\quad$ I 49

name for Cobia.................. I 145

Sole ................................. 327

Spade-fish ........................... 146

Spanish Flag ......................... 266

Nackiel ......................... IS4

Sparad, name for Bonito .......... 209

Sipot ................................. I I 9

Spot, name for Red-fish ............. IO2

Siprat ................................ 39.4

Sifucteague .......................... I10

Squirrel-fish ....................46, 79, 99

Sipuit or sipuitee ................... I I I

Star-fish, name for Butter-fish..... 22 I

Ste.l-huad ......................... 47.4

Strawberry Bass........................ 68

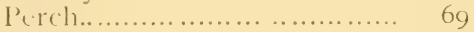

Striped Bass....................... 22

Suckers ............................. 433

Suk-kegh.......................... $4 \mathrm{~S}_{\mathrm{I}}$

Sun-fish .........................6. 64 et seq. name for Blunt-nosed Shiner. 232
Sword-fish ......................... 239

Tailor Shad .......................... 405

Tarpum ............................. 406

Talutog .............................. $2 \mathrm{~S}_{7}$

Thunder-pumper .................... 142

Tin Mouth......................... $7 \mathrm{I}$

Togue ................................ 463

Tom-cod, name for King-fish...123, 269, 349

Tree-fish .......................... 263

Triple-tail ........................... I48

Trout, name for Black Bass......... 55

Black .......................... $45^{8}$

Black-spotted..................4457-8

Brook ........................456, 459

Cut-throat ..................... 457

Dolly Varden.................... 475

Golden .......................... 456

Greenland ..................... 476

Grey, name for Squeteague... II I

Lake ............................. 462

Lake Tabor........................ $45^{8}$

Loch Leven ....................... 459

Mackinaw ...................... 462

Malma.......................... 475

Mountain .......................... $45^{\circ}$

Rainbow ....................... 456

Rio Grande..................... 456

Sta ........................... 46 I name for Squeteague.... II I

Silver .............................457-8

Speckled ....................... 469

Tuladi...................................... 486

Tunny ................................ 215

Turbot .......................... 319, 324

il all-eye ............................. I,

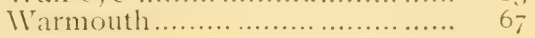

IVarsaw ..............................49, 50

IVeak-tish ........................... II

White-fish ....................... I 5 I, 386, 489

Ithite P'erch.......................... 35

Whiting.................... 8I, I23, I25, 223

IVinninish ........................ $4+45$

Yellow Bass ......................... 32

Yellow Fin ............................. II

Yellow-tail ................99, I31, 233, 368

Zander .............................. I4, 16 





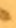

ivi.-

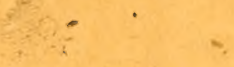

3:

$\checkmark$

4

2

$\infty$ 



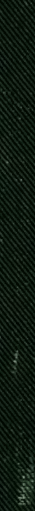

in 